\title{
《蕉風》創刊初期（1955-1960）的文學觀遞變 \\ The Evolution of literary views in the early years of the Chao Foon's literary Journal (1955-1960)
}

\section{HO SOK FONG}

\section{賀淑芳}

School of Humanities and Social ciences

A thesis submitted to the Nanyang Technological University in fulfilment of the requirement for the degree of Doctor of Philosophy 



\section{感言}

「習以為常的事情, 要另眼相待。即使常規也要視之為不明不白。」

一一布萊希特《例外與常規》，轉引自布朗肖《無畫的談話》

文學是這樣另一隻眼睛。可以批判, 可以讚嘆, 可以旁觀與疼痛。縱使日常安穩平 庸, 文學仍能鏊穿表象, 轉化深刻。寫這份論文, 嘗試巡梭於那歷史時刻, 知道一切 所予, 猶如來自廢墟。文學語言與美學所求為何物? 不同於歷史遺跡、諸如碑石古 蹟, 文學之銘刻, 卻總意味著無穿盡的閱讀與創造之可能。這一切自非理所當然。因 你在此處, 為此處生態所塑, 雖有所蝕亦有所養; 復為流入眼裡的文學所吸引。文學 的語言美學, 便猶如從中冒現的參雜髧藤鱗片, 即便並不固常, 無真理無答案, 卻反 而能對此局限中仍持續變化、創造與燃燒之可能，寓予信任。

許多師友的建議, 不克處理, 默感於心。研究《蕉風》, 補充非左翼馬華文學史的拼 圖, 最初來自黃錦樹老師的建議, 感謝他扶持提攜我多年。也想謝謝張錦忠、林春美 和莊華興老師在這期間曾經給予的指點, 還有兩位指導老師衣若芬和郭淑雲教授的督 促與包容, 以及眾位審查老師的批閱意見。寫論文期間, 偶與師友切磋, 也謝謝友人 傅向紅、歷史系的老師陳聰榮和我先生關志華, 僅將他們的意見以註腳方式補充文 內。

對於此處所予, 以及這段時間, 我很感激, 無以言表。 



\section{目錄}

頁

摘要

第一章 緒論

一、歷史的劇場 1

二、美援文化與《蕉風》的創刊背景 3

三、左翼、右翼、非左翼和同路人 22

四、概述《蕉風》南來文人的多元風格 26

五、從流亡、離散到安居 31

六、文獻回顧綜述 41

七、問題意識與章節架構 50

第二章 《蕉風》的本土認同與家園想像

一、快速的認同 53

二、二戰前後的 $「$ 馬來亞化」主張 56

三、《蕉風》的「純馬來亞化」主張 67

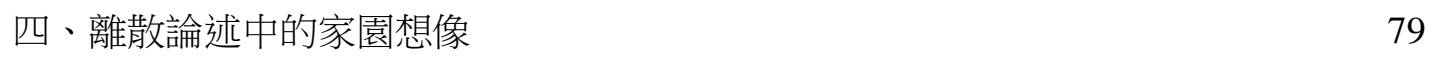

五、「馬來亞化」的樂土想像 80

六、小結：未能平撫的焦慮 87

第三章 方天在《蕉風》的寫實主義書寫

一、一個國籍 90

二、方天的生平資料 92

三、在地書寫的方言與混雜的語彙 95

四、方天的寫實主義書寫：本土化與社會主義傾向 101

五、非共的社會主義寫實主義 110

六、小結：一點輕微的剥離 121

第四章 馬摩西的旅行、搬遷與本土書寫

一、搬遷南來

123 
二、馬摩西：從外交官至宗教官

四、散文中的「沒有」：宗教官身分的經驗及故鄉敘述

五、從病體到痊癒／遷移

六、緊急狀態時期的旅途上

七、小結：國族的濾斗

第五章「人文主義」與「自由主義」一姚拓時代的《蕉風》

一、南來經歷

157

二、姚拓的編輯方針

159

三、人文主義的定調

164

四、越境之後的「自由主義」

176

五、論述轉向：寫實主義的創作論與小說美學

178

六、姚拓的小說：一九四九之後

180

七、小結：在地屬性與文化異子

第六章 現代主義白忹紀：白圭的反叛、局限與待續

一、開端 197

二、盜火者白圭與現代詩起點

198

三、文藝的個體主義

199

四、與集體的政治話語疏離

203

五、現代主義的序幕

206

六、詩心突變，抒情重寫

222

七、小結 : 詩語和場域的啟示一空無與意義

附錄表 1.1 ：方天刊於《蕉風》的作品列表（從 1955 至 1960 年間） 



\section{摘要}

過往對《蕉風》的研究多集中於一九六 $\bigcirc$ 年代或以後的現代主義, 但對於現代主 義之前的歷史卻甚少論及。這份論文以《蕉風》為主要的研究文本, 並以一九五 五年至一九六 $\mathrm{O}$ 年間來到馬來亞的非左翼南來文人為研究對象。《蕉風》的創刊 與主張緣由, 可溯自一九四九年在中國政治易權之後, 一系列從東亞捲動掀起、 冷戰時期匯聚各方勢力的政治意向。友聯出版社當時接受美援資助, 局負反共任 務, 在亞洲自由協會與英殖民政府協調的安排之下, 來到馬來亞。由此成為馬來 亞緊急時期的剿共計畫的一部份, 也構成釀嵌權力、跨越區域的文學網絡。根據 Stuart Hall 的文化研究理論, 文本總是與其他文本和場域資源, 形成相互勾連的 關係。本文除開以「反共」和 $「$ 馬來亞化」的本土認同宗旨為詮釋核心之外, 在 閱讀個別作者的書寫與文學觀點時, 也點出那從 $「$ 宗旨」剝離歧忿開來的旁支與 裂隙。冷戰局勢的編碼, 把個體縛於權力網絡裡。通過析讀四位南來文人的書 寫, 這份論文想要探討, 以《蕉風》南來文人當時堪稱簡樸的書寫方式, 是否也 有可能啟動一道逸離政治宗旨的路徑?

關鍵字：非左翼 南來文人 冷戰 在地 逸離 


\begin{abstract}
The available studies on Chao Foon were mostly focused on modernism writings during and after 1960s but fewer on the history of 'pre-modernism' period. This thesis is aim to study on the earlier foundation years of Chao Foon and concentrates on the south-bound non-left wing writers who came to Malaya from Hong Kong and affiliated with Chao Foon between 1955 and the 1960s. The launching of Chao Foon and the objective of the publication can be traced back on the altering of the political power in China in 1949. The shifting of ruling regime in China, the cold-war atmosphere spreading across South East Asia and the fighting on the Communist uprising during the emergency period in Malaya, had greatly influenced the power strategies and the power embedded webs of various entities across the region. The Union Press had received the financial aid from the Committee of a Free Asia, covering their activities in Malaya. They had came to Malaya as part of the anti-communist program to reduce the influence of communist ideology, with the coordination together with the British colonial government. According to the cultural studies discourse of Stuart Hall, a particular text always articulates itself with other texts as well as with the sources within the production field. However, beside than the articulation effect of the texts with the cold war and Malayanization discourse, this thesis also wish to studies the possibility of the writings to obtain an escape route away from the power coding. Even though this study is focus on the themes of 'anti-Communism' and 'local identity' of the writings by the selected four south-bound non-left writers, it also discussed whether the simple and unadorned writing style applied by the south-bound writers, provided a way for them to escape from the above public concerned themes and political interpretation discourse .
\end{abstract}

Keyword: Non-left wing South-bound literati Cold war Local identity Escape 


\section{第一章}

\section{緒論}

\section{一、歷史的劇場}

沒有意義的題材，當然不值得寫，比較有意義的題材，往往又因環境的關係不能 寫，所以就索性不寫了，若從歷史上去找些適當的題材來寫些有價值的歷史劇， 既不與目前環境發生正面的衝突，又有相當的意義，也是一條暫時可走的路。1 在這個㓣造的過程中，馬華文藝工作者是負有隻重使命的。作為一個馬來亞人， 便應該設法沖淡頽廢傷感和偏激詛咒的舊有氣息，創造新生檑發的文藝，給一個 新興的國家鋪好稳固的心理基礎。作為一個馬來亞華人，一方面要有選擇地保留 中華文化傳統; 另一方面還要積極主動地去融合其他民族文化。2

以我的私見來說, 以往的各種形式固然有值得借爁的地方, 但我們並不是一定要 依循那固有的形式，我們盡可以大膽的打破舊有的小說形式的成規，好像曼殊斐 兒創造新體裁的小說一樣，努力發揮自己的天才，隨著時代的進化，自由地創造 新的形式。 ${ }^{3}$

以上引文來自趙戎編《新馬華文文學大系》所整合的一系列座談會或會議資料。這些座談 會所關心的, 包括馬華文藝應如何面對建國的諸多政治問題、本土認同、馬華文學的主體 特性和未來走向。這一切, 正如羅普寫在一九六 $\mathrm{O}$ 年的〈砂勞越的文藝運動〉中所引用

1 常夫的發言, 〈劇本的創作與戲劇批評〉, 參見蕉風, 〈再談馬華文藝〉, 《蕉風》1955 年第 22 期, 頁 5 。

2 申青，〈雙重使命〉，《蕉風》1957年第 29 期，頁 3 。

3 逸人, 〈創造新的形式〉, 參見蕉風, 〈論小說創作問題一一文藝座談之六〉, 《蕉風》1957 年第 31 期, 頁 6 。 
的、中國左翼現實主義作家于潮寫於一九四五年《方生未死之間》的名言：「我們正處在 方生與未死之間, 我們的任務是, 叫未死的快死, 叫方生的快生。」 ${ }^{4}$ 排除與新生, 不僅 只是發生於一九四五年的中國, 亦延伸到因國共内戰以至認同分裂的馬華文學場域中。經 過一九四八年的馬華文藝論爭之後, 在地認同為群體共識, 幾成塵埃落定, 當時表明在地 認同與愛國，已成爲政治與文學上意識正確的抉擇。

從一九四八年六月十八日開始，英殖民政府實施緊急法令戒嚴鼍共，緊急狀態延續 到馬來亞獨立後, 至到一九六 $\bigcirc$ 年七月三十一日才正式宣告結束。5從一九四八年至一九 四九年, 是剿共措施最激烈的時期。當時有大批左翼文人被遣返中國或遭到扣留, 使得馬 來亞華社遽然面臨書刊、教材乃至文教人材方面的短缺。政府也禁止從中國人口中文書 籍, 在地的多家傾左報刊與雜誌遭到查禁, 中文書刊便轉往從香港輸入。一九五五年,

《蕉風》與《學生周報》就在這種情勢複雜的政治氛圍中創刊。

這份論文主要是研究一九五 $\bigcirc$ 年代抵達馬來亞的非左翼南來文人, 以《蕉風》的作 者群體為主。時間範圍定在《蕉風》創刊初期的五年内。過往對《蕉風》的研究多集中於 現代主義運動, 但對於現代主義產生之前的狀況卻甚少論及。這份論文以《蕉風》為主要 的研究文本, 並以一九五五年至一九六 $\bigcirc$ 年期間來到馬來亞的非左翼南來文人為研究對 象，為馬華文學史上仍欠缺的非左翼文學史補充拼圖。

《蕉風》向來被一九五 $\bigcirc$ 年代反英殖民的學潮視爲反共文學的陣地, 尤其因為它是 香港友聯出版社在新加坡分社子公司旗下的刊物。從五 $\bigcirc$ 至六 $\bigcirc$ 年代, 香港美國新聞處在 香港開始資助右翼與反共的出版社, 當中也包括香港友聯出版社。美國新聞處雖然大量資 助反共刊物, 但耗時頗長, 才突破當時華文媒體為左翼勢力壟斷的局面。6 非左翼的寫實 主義以及現代主義文學, 之所以能獲得成長的空間, 可說是冷戰形勢的產物。

《蕉風》的創刊與其宗旨, 可溯自一九四九年的中國政治易權之後, 一系列從東亞 捲動、遷移南來的文化資源與冷戰中拉鋸周旋的政治意向。在香港有其母公司「友聯出版 社」的出版宗旨, 扶植第三勢力的美援文化, 以及新亞書院主張的中華文化傳承與人文精 神; 臺灣因反共國策, 亦被編入冷戰體系, 官方的政治意識致力於塑造以漢族傳統文化為

\footnotetext{
4 羅普, 〈砂勞越的文藝運動〉, 趙戎編, 《新馬華文文学大系》, 新加坡：教育, 1971, 頁 297-299。

${ }^{5}$ Karl Hack, “The Malayan Emergency as counter-insurgency paradigm”, Journal of Strategic Studies, 2009, vol.32(3), p. 383-414.

6 趙綺娜, 〈一九五 $\bigcirc$ 年代的香港美國新聞處 : 美國在亞洲之反共宣傳政策研究〉, 行政院國家科學委員會 專題研究計劃, 2005。
} 
中心的體制格局, 以及反共文藝政策帶來的限制, 使得文學副刊傾向於憶鄉故里、抒情與 純文學路綫。五○年代, 臺灣的現代主義詩社相繼創立, 其後爆發的現代主義詩歌論爭, 對當時的文學語境帶來更複雜的變化, 稍後經由在臺灣留學的白圭引線, 《蕉風》在五○ 年代末開始刊登臺灣現代詩作品。在馬來亞, 英殖民政府的剿共計畫(Briggs Plan)、馬華 公會的邀請, 華人的政治認同與聯盟政府的協商策略; 非左翼南來文人在抵達之後, 不得 不面對在地左翼學潮與學運的杯葛對歭。各方權力拉鋸和文化觀念的起伏湧現, 相繼護 持、啟迪、加劇、抑制或改變刊物的主張與文化定調。

這群南來文人的文學書寫作風都不一致。這一特殊的群體，形成了一個可說是以協 商 (Negotiation)來解決歧異的合作方式。這對於友聯出版社南來遷移, 或繼續離散到全球 生存相當有利, 因能多元吸收在地的資源, 而後進行散播、連結與互動。他們之間各有分 歧的文學觀念，也可以在 $「 反$ 共」與 $\ulcorner$ 維護中華文化」這兩個宗旨底下共存。與之相關的 人文報導, 也多突顯出那在全球流動、更具有現代化優勢、同時也繼承或發揚了傳統文化 的主體典範。

根據 Stuart Hall 的文化研究理論, 文本總是與其他文本和場域資源形成相互勾連 (articulation)的關係, 為了真正發揮實質效用, 意識形態必須能夠與政治和社會資源勾 連。7這篇論文分別從區域流動和文學觀遞變這兩個軸向來梳理幾個問題。前者包括美援 文化、南來文人的流動定義（離散或流亡）、在地認同的複雜因素, 後者則從刊物的聲明

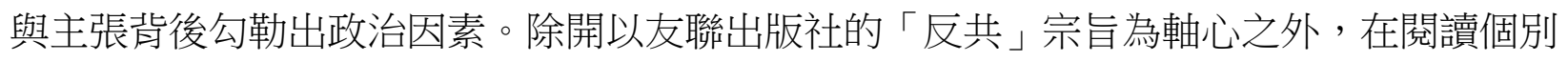
作者的書寫與文學觀點時，也著重於點出那從「宗旨」軸心歧岔開來的旁支與路徑。

\section{二、美援文化與《蕉風》的創刊背景}

在此先約略介紹《蕉風》的背景。它在一九五五年十一月十日創刊於新加坡，在草 創時期以「馬來亞化」為其定位。《蕉風》的創刊人和編輯都是南來文人, 第一任社長, 亦為創刊者之一的申青（原名余德寬），原為香港《中國學生周報》的社長。 ${ }^{8}$ 申青在一 九五四年到新加坡做考察, 一九五五年開始在新加坡出版《蕉風》月刊。9 稍後《學生周

\footnotetext{
${ }^{7}$ Stuart Hall 1996, "The Problem of ideology: marxism without guarantees", David Morley and Kuan-Hsing Chen (eds.),Critical Dialogues in Cultural Studies, London \& New York: Routledge, p.43

8 姚拓, 《雪泥鴻爪一一姚拓說自己》, 吉隆坡 : 紅蜻蜓, 2005, 頁 570 。

9 謝詩堅, 《中國革命文學影響下的馬華左翼文學 (1926-1976)》，檳城：韓江，2009，頁 195。
} 
報》也於一九五五年十二月在新加坡創刊。 ${ }^{10}$ 隨同申青一起南來的, 還有第一任《蕉風》 的編輯方天, 原名張海威, 是前中共領導張國壽之子。 ${ }^{11}$ 他和稍後在一九五七年抵達的姚 拓, 都曾參與香港《中國學生周報》的編輯工作, 《中國學生周報》也是香港友聯出版社 旗下的刊物。12

根據姚拓的追憶, 申青最初是與已經在星馬居留數年的作家, 包括李汝琳（李宏 賁）、陳振亞（白蒂、江陵）、范經（常夫）、馬摩西（原名馬俊武）和曾鐵枕一起成立 了《蕉風》出版社, 他們以非社員的方式, 包括方天在內, 共同組成了編輯委員會。 ${ }^{13}$ 根 據雜誌封底內頁的出版說明, 這份雜誌最初由《蕉風》出版社出版及發行, 由中國學生周 報星馬辦事處代理。自一九五六年六月第十六期開始, 才改成由新嘉坡友聯書報發行社發 行。文壇上咸以爲, 新嘉坡友聯書報發行社是從香港友聯社脫胎而來, 是香港的友聯出版 社在新馬設立的分行。1 ${ }^{14}$ 馬漢的一篇文章〈老照片說舊事 : 申青一一友聯的先鋒隊長〉有 較詳細的説明，新加坡友聯出版社是香港友聯社在一九五五年前後，到星馬擴展業務開辦 的分公司，最初由申青率領南來視察，與陳思明、王安娜與燕歸來（燕雲）一起創立，其 行政、發行與出版業務由申青、其夫人劉波、王安娜、陳稚農與彭子敦共同負責。 ${ }^{15}$ 這與 新加坡檔案局內所收的註冊資料，亦相當吻合，惟遺漏了王兆麟，此外還有一名外籍合夥 人。據註冊表格所載, 「中國學生周報星馬辦事處」的負責人為余德寬與 John Paul（合 夥人）。16「友聯出版社」的註冊負責人則有陳思明、丘西紅（即燕歸來）、余德寬和王 兆麟。 ${ }^{17}$ 王兆麟是後來留在馬來西亞, 友聯出版社的財務負責人。

\footnotetext{
10 謝詩堅, 《中國革命文學影響下的馬華左翼文學 $(1926-1976) 》 ，$ 頁 194 。

11 姚拓, 《雪泥鴻爪一一姚拓說自己》, 頁 570 。

12 謝詩堅, 同上註。

13 姚拓, 《雪泥鴻爪》, 頁 570 。參見盧瑋鑾、熊志琴編, 《香港文化眾聲道 第 1 冊》, 香港: 三聯, 2014 , 頁 278。《蕉風》文學誌網頁, https://chaofoon.wordpress.com/about/。目前資料所列, 把范經和常 夫當成兩個人。但是常夫其實是范經的筆名, 范經還有另一筆名為范提摩。

14 潘碧華, 〈五、六十年代香港文學對馬華文學傳播的影響 $(1949-1975)\rangle$, 載黃維樑編, 《活潑紛繁 的香港文學一一九九九年香港文學國際研討會論文集》（下冊）, 香港 : 香港中文大學、香港中文大學 新亞書院, 2000 , 頁 758 。

15 馬漢, 〈老照片說舊事 : 申青——友聯的先鋒隊長〉, 《南洋商報》, 2011 年 7 月 20 日。
}

${ }^{16}$ ROB 043, Record reference 27812： The Chinese Student Weekly (Malaya Office).

${ }^{17}$ ROB 048, Record reference 30700 : Union Press Organisation. 
一九五九年, 《蕉風》的編輯隊伍又加入從香港南來的黃思騁, 黃思騁曾和力匡、 夏侯無忌、齊桓一起在香港編《人人文學》（刊行時期為一九五二年五月二十日至一九五 四年六月一日）。《人人文學》由香港的人人出版社所出版。人人與友聯這兩家出版社, 皆為當時在香港接受美援資助的出版社。18

《蕉風》出版社最初在一九五五年十一月於新加坡加律路(Kellock Road)設置辦公 室。要至一九五九年一月, 才逐漸把印刷與出版業務移往八打靈。根據新加坡檔案局的註 冊資料, 「中國學生周報星馬辦事處」的註冊日期終結於一九五六年五月。19「友聯出版 社」在新加坡的業務則終結於一九五九年六月二十七日。 ${ }^{20}$ 由於謝詩堅的論文和姚拓自身 的記敘, 有關《蕉風》出版社遷往馬來亞的日期都有所出入, 故在此根據《蕉風》雜誌上 註明的地址, 把它在獨立後遷往馬來亞的相關業務與其營址更動, 列表如下, 以方便稍後 討論：

\begin{tabular}{|l|l|l|l|}
\hline 日期 & 期數 & 相關業務 & 地址 \\
\hline 1959 年 1月 & 75 & $\begin{array}{l}\text { 承印 (即馬來亞出版印務 } \\
\text { 公司) }\end{array}$ & $\begin{array}{l}\text { 八打靈再也(Petaling Jaya)13 號 } \\
201 \text { 路 }\end{array}$ \\
\cline { 3 - 4 } & & 出版社仍在新加坡 & $\begin{array}{l}\text { 新加坡錫 安 路 (Zion Road)53-A } \\
\text { 號 }\end{array}$ \\
\hline 1959 年月 4 月 & 78 & 承印與出版社 & 八打靈再也 13 號 201 路 \\
\hline 1959 年 12月 & 86 & 承印與出版社 & 八打靈再也 2 號 217 路 \\
\hline 1961 年 8 月 & 106 & 承印與出版社 & 八打靈再也 10 號 217 路 \\
\hline
\end{tabular}

\section{（一）冷戰形勢，美援文化與第三勢力}

18 鄭樹森, 〈「遺忘的歷史, 歷史的遺忘」一五、六 $\bigcirc$ 年代的香港文學〉, 載黃繼持、盧瑋鑾、鄭樹森 編, 《香港文學大事年表 1948-1969》, 香港: 香港中文大學、人文學科研究所、香港文化研究計劃, 1996, 頁 1-8。

${ }^{19}$ ROB 043, Record reference 27812 : The Chinese Student Weekly (Malaya Office).

${ }^{20}$ ROB 048, Record reference 30700 : Union Press Organisation. 
由於這層與香港友聯出版社的關係, 《蕉風》曾被視為接受美援的右翼刊物, 遭受 當時認同左翼的讀者所杯暮。然而, 直到這群創刊的編輯隊伍逝世, 實際狀況始終未能證 實。二 $\bigcirc$ 一四年出版的《香港文化眾聲道（第 1 冊）》, 是盧瑋鍠教授（小思）, 和浸會 大學的熊志琴博士, 以十數年時間, 遍訪多位香港的前友聯文人和香港文化界前輩, 收集 的口述歷史。其中包括何振亞、奚會暲、古梅和王建武的訪問篇章, 都講述了友聯與美援 文化之間的密切關聯, 尤其是與亞洲基金的合作方式, 以及雙方建立關係的來龍去脈。

根據《香港文化眾聲道》第一篇何振亞的訪問, 已經點明了當時友聯出版社成立的 宗旨，即為推促自由民主以及反共任務：21

「友聯」的宗旨理念就是一些年輕人在一起, 我們每個人的興趣、熱枕不一樣, 方 向不一樣, 但基本上都很純, 都是剛㣚大學畢業, 主要就是為了「政治民主、經濟 公平、社會自由」, 就是這三大口號, 然後就出了這三本書。22

「辦《中國掌生周邦》是為青年辦一份刊物, 所買編輯政策是沒有的, 反共是有 的。 $\rfloor^{23}$ 。

其反共意識, 亦跟知識分子意識到自身承擔的文化責任有關, 如林悅恆的口述：「這種政 治敏感主要關乎『友聯』基本的思想。『友聯』基本上是反共的, 因為它政策上對中國文 化有所摧殘。」 24 踓然反共, 卻不支持臺灣國民黨政府的蔣介石, 而臺灣政府亦不接受友 聯旗下《兒童樂園》之外的其他刊物; 25 儘管最初創辦時, 香港的友聯出版社有不少成員 來自臺灣, 「很多都有國民黨背景, 不是黨團代表就是黨員。」 26

根據高全之的一篇採訪稿, 前香港的美國新聞處處長麥卡錫認為, 香港的友聯出版社 其實是「由一群熱中『第三勢力』的年輕人組成。他們不喜歡國共兩黨。」 27 麥卡錫此處

21 友聯出版社的宗旨, 可見其手冊, 題爲「友聯出版社一一個追求真理的青年團體」的影本, 《香港文化 眾聲道 第 1 冊》, 頁 12 。參見何振亞的口述回憶, 友聯最初出版的刊物, 相當偏重反共, 頁 24 , 他也認 為友聯的立場該是「反共不反華」，頁 44-45。亦參見林悅恆的口述訪問，頁 184 。

22 何振亞口述, 《香港文化眾聲道第 1 冊》, 頁 10 。

23 何振亞口述, 《香港文化眾聲道 第 1 冊》, 頁 20 。

24 林悅恆口述，《香港文化眾聲道第 1 冊》，頁 184 。

25 奚會暲口述, 《香港文化眾聲道 第 1 冊》, 頁 62-63。

26 何振亞口述, 《香港文化眾聲道 第 1 冊》, 頁 16 。

27 高全之, 《張愛玲學》, 臺北: 麥田, 2008 , 頁 254 。 
所言的第三勢力, 乃是美國在冷戰局勢下, 在香港培育反共與反蔣的第三股政治勢力。2 8 在五 $\bigcirc$ 年代, 這「第三勢力」在香港曾經有過一段熱鬧喧嘩的時期。

一九四九年, 美國在發表嚴批蔣介石的《美中關係白皮書》之後, 當時意欲從香港培 植另一股反共的力量。在這股勢力裡頭, 有許多大大小小反共、反蔣的團體。成員最初包 括前國民黨人張發奎和曾經隸屬汪精衛派系的顧孟餘, 也包括前中國共產黨幹部張國壽和 前民社黨人張君歷。29 根據港英政府的觀察, 他們認為儘管第三勢力的團體與人數眾多, 其中卻有不少人打著反共的幌子, 招搖撞騙。此外, 他們也發現第三勢力的合作相當勉 強, 「雖然他們極力減少彼此之間的分歧, 但卻不乏在臺底下暗中過招, 且斤斤計較於瑣 細事務的忌妒心理, 也使得第三勢力難有進展」。英殖民政府認為, 第三勢力難成氣候, 不太可能取代當時持有軍隊與佔據台灣的蔣介石。尤其在美國開始表態支持台灣國民黨政 府之後, 第三勢力所能扮演的角色, 漸顯疲弱。30

最初為了壯大第三勢力的聲勢, 這批大部分自國共體制退出的舊派軍政人士，接受美 援, 延攬了不少年輕的知識分子。其中有年輕黨人左舜生、謝澄平創辦《自由陣線》與自 由出版社, 後來也吸引燕歸來（邱然）、陳思明（陳濯生、陳維瑲）、胡越、許冠三、徐 速等年輕文化人加入。31稍後, 由於第三勢力內部新舊兩代人之間的分歧, 導致這批後來 加人的年輕人脫離《自由陣線》, 自立門戶。他們過後也另外再申請美援, 創立文化機 構，如由燕歸來與陳思明（陳濯生）創辦的友聯出版社。32

大約在一九四九或五 $\bigcirc$ 年間, 香港 $「$ 友聯社」成立，其成員有陳思明、燕歸來、許冠 三、史誠之、余德寬, 徐東濱、胡越 (司馬長風) 和史誠之等等。繼後, 於一九五一年

28 陳正茂, 〈五○年代香港第三勢力的主要團體：「中國自由民主戰鬥同盟」始末（1952-1955）〉, 《北 臺灣學報》第 34 期 6 月，2011，頁 442-460。

29 陳正茂, 《逝去的虹影》, 臺北 : 秀威, 2011, 頁 179 。

${ }^{30}$ FCO 141/14536, Governor Hong Kong to Singapore, A Report on the State of "Third Forces" in Hong Kong as on the $10^{\text {th }}$ September, Hong Kong: Special Branch, 1951.

31 陳正茂, 《逝去的虹影》, 頁 179 。程思遠, 《政海秘辛》, 香港 : 南粵, 1988, 頁 236 。

32 陳正茂, 《逝去的虹影》, 頁 208 。陳正茂, 《五 $\bigcirc$ 年代香港第三勢力運動史料蒐秘》, 臺北：威秀, 2011, 頁 92-93。

33 綜合何振亞與奚會暲的口述, 《香港文化眾聲道 第 1 冊》, 頁 14 、頁 54 。 
四月, 再成立友聯出版社。 ${ }^{34}$ 一九五二年七月二十五日, 創刊《中國學生周報》, 一九五 五年一月十六日創刊《兒童樂園》。35

根據程思遠的回憶, 這群文化人原先加入 《自由陣線》, 脫離之後, 成立了友聯研究 所, 目的是為了能有充分的資料, 研究、揭露中國在共產主義統治下的狀況, 專門 $\ulcorner$ 收集 和分析中華人民共和國的資料, 提供予美國參考」36, 當時美國的學者難以進入中國做研 究, 友聯研究所的資料因此便十分寶貴。據林悅恆回憶, 韓戰爆發以後, 友聯研究社始獲 美國資助。37那麼, 之前的資金源自何處? 實仍存疑。程思遠曾引美國《亞洲研究學術評 論》的評語, 以表明在美國培植第三勢力計畫失敗之後, 友聯出版社與友聯研究所可説是 $\ulcorner$ 唯一真正留下價值的文化產物」。它所儲存的大量微縮膠卷, 後來提供予全球多家圖書 館, 也是「香港藏有研究當代中國最完整的研究材料的研究所」。38

早在一九五二年，新加坡英政府已經開始在觀察，香港的「第三勢力」活動是否有 擴及新加坡。這起於一九五一年年底, 他們發現一些來自香港的第三勢力人士, 包括前國 民黨的高職軍人政要, 開始和新加坡本地的華人領袖展開初步接觸, 甚至一起在新加坡合 作創立一家漁業公司。自一九五一年, 第三勢力就開始涉足婆羅洲, 惟要到一九五二年 初, 才開始接觸新加坡的華人圈子。當時, 英政府留意到, 有一些第三勢力人士曾藉由其 他身份掩護, 來到新加坡, 或者嘗試要在新加坡與檳城的報館找工作（如丘禹言）, 也有 者想要獲得在新加坡的居留權（如翁照桓）。不過, 由於當時殖民地尚未有人顯示出足夠 的能力與興趣去資助、參與第三勢力的活動, 故英政府相信, 新加坡還稱不上有第三勢力 的活動。惟來自香港的刊物銷量卻顯著增加。截至一九五一年底, 香港數家接受美援成立 的出版社, 包括《自由陣線》、《中國之聲》和《天文台》, 大量運銷其刊物到新加坡, 這些刊物有的直接從香港郵寄給訂戶個體或團體, 有的則以頗為低廉的成本, 傳送到當地 報刊的經銷商手中。 ${ }^{39}$ 這些在一九五 $\bigcirc$ 年代初接受美援資助的第三勢力出版社, 早在友聯 出版社之前，就已經建立影響擴及東南亞的刊物銷售網絡。

34 鄭樹森、黃繼持、盧瑋鑾編, 《香港新文學年表 (一九五○一一九六九) 》, 香港 : 天地, 2000 , 頁 17 。

35 何振亞口述, 《香港文化眾聲道第 1 冊》, 頁 32 。

36 程思遠, 《政海秘辛》, 頁 236 。

37 林悅恆口述, 《香港文化眾聲道第 1 冊》, 頁 179-183。

38 程思遠, 《政海秘辛》, 頁 236 。

${ }^{39}$ FCO 141/14536, Ag. Director of Special Branch Singapore to Secretary for Defence and Internal Security Singapore, Third Forces, Singapore: Special Branch, July 28, 1952. 
當時中共在大陸掌權，國民黨退守臺灣，國共分裂已成定局，然而對許多年輕知識 分子來說, 他們仍然期望能夠在國共體制之外繼續追求現代化, 對民主自由抱有期盼, 雖 然反共, 卻也無法苟同於蔣介石政府, 故此才加入第三勢力。其中也有後來創辦友聯出版 社的年輕文人。可以說, 正是第三勢力與美援文化帶來的契機, 才促成後來友聯社的人際 網絡。

美援文化, 亦稱爲綠背文化, 「綠背」之稱, 源於美元鈔票。美援文化的目的, 是 為了圍堵共產意識, 而製作、發行、促進反共的文化產品, 涵蓋出版社、刊物發行乃至到 電影製作。在美國新聞處與自由亞洲自由協會資助下出版的文學刊物、文學作品，尤其從 五 $\bigcirc$ 年代至六 $\bigcirc$ 年代中葉, 也常被等同於反共之作, 並籠統稱爲「美援文學」或「綠背文 學」。王梅香的研究認爲, 美援文化或綠背文化, 除了文學, 也包括因美援影響, 而相應 發展起來的流行文化、影劇與電影。 ${ }^{40}$ 王晉民認為, 美援文化乃出於美國為了在全球華文 讀者心目中產生反共甚至 $「$ 恐共」的論述效果。 ${ }^{41}$ 一九四九年以後, 美國相繼以設立在香 港的美國新聞處為運作據點, 通過幾個單位, 包括亞洲基金（Asia Foundation, 舊稱亞洲 自由協會, Committee for a Free Asia）, 資助、延攬不滿國共兩黨的作家、譯者、學人、 藝術家與前朝軍政人士等, 創立出版社、著書寫作。這些香港出版的中文書刊, 不僅輸送 至馬來亞、汶萊、菲律賓等東南亞國家, 亦遠至印度的唐人街。 ${ }^{42}$ 此外, 根據單德興的研 究, 美國新聞處也出資設立了兩家出版社機構, 今日世界社與今日世界出版社, 除了出版 雜誌, 也招攬人才, 精心翻譯大量美國文學, 從藝術、人文哲學、文化乃至到科學領域等 各方面, 大量傳播輸送至全球各地的華人讀者群體。43

然而「反共」詞彙攜帶的偏見, 常致貶義, 以爲這些作品僅僅只是為了美方服務的 工具, 而忽略其他複雜的層面。從美方資助的目的來看, 固然作品的内容、意識形態與形 式, 均須加以控制以符合其反共宗旨, 因而文本可能吸收美國的個體、自由主義等價值 觀, 然而文學文本在吸收美國價值觀之餘, 亦吸收其他藝術文化的觀點。那經由翻譯引入

40 王梅香, 《蕭殺歲月的美麗／美力：戰後美援文化與五、六十年代反共文學、現代主義思潮發展之關 係》, 臺南：國立成功大學臺灣文學研究所碩士論文, 2005 。王梅香, 《隱蔽權力：美援文藝體制下的台 港文學 (1950-1962)》，臺北：國立清華大學社會學研究所博士論文，2005。

41 王晉民，〈香港「綠背文化」思潮評介〉，《廣東社会科學》1998 年第 2 期，頁 87-91。

42 Amconsul Hong Kong to Department of State, "Hong Kong- Influnce of Hong Kong Publication in Southeast Asia."Jul 24, 1962.

43 單德興, 〈冷戰時代的美國文學中譯——今日世界出版社之文學翻譯與文化政治〉, 《翻譯與脈絡》, 臺北：書林, 2009。 
的外國文學, 所開拓的文學藝術視野, 不必然就苟同於美國政治籠罩區域的政治權力。現 代主義與現代性之間, 兩者互有參照, 但亦有分裂、剥離, 現代主義甚至是批判、反思現 代性最為深刻落力的藝術, 這使得它的藝術探索路徑, 異常曲折複雜。在馬來亞, 與美援 文化有著輾轉、或者間接關聯的《蕉風》, 固然也可能延續國共分裂、冷戰局勢的文化編 碼, 而有此自由主義意識形態的吸收。但是, 南來星馬之後, 在地政治與文化氛圍, 尤其 在新加坡友聯出版社創辦之時, 正好是終結英殖民地統治, 到迎來國家獨立的緊急法令時 期，當時的政治因素與反共話語，對於《蕉風》的影響與牽制，應當更爲切身。

\section{（二 ）友聯南來馬來亞的過程}

一九五 $\bigcirc$ 年代中旬, 友聯的業務擴展到新加坡與馬來亞。除開創刊出版《蕉風》與 《學生周報》之外, 還辦報與出版教科書, 在短短數年之內, 友聯掌握在地的商業與人脈 資源, 出奇迅速。一九五九年, 友聯與胡清德合作創辦華文報《虎報》, 不過《虎報》只 經營到一九六一年便告結束。 ${ }^{44}$ 當時多位友聯出版社的南來文人包括姚拓、楊際光、彭松 濤、黃崖、黃思騁都曾任職《虎報》, 如楊際光一九五九年南來後, 就先到《虎報》就任 副總編輯。 ${ }^{45}$ 在地文人也有曾經就職《虎報》者, 如曾經勤於投稿《蕉風》的林風。林風 中學期間曾參加《學生周報》, 中學畢業後即在《虎報》任職駐檳城記者, 直到一九六一 年報社停刊為止。 ${ }^{46}$ 另外, 在一九五九年, 友聯亦與胡家健合作成立馬來亞文化事業有限 公司, 出版教科書, 營業至今。 ${ }^{47}$ 友聯的業務在馬來亞, 曾經擴展至印刷、報界與教科 書, 資源與設施裝備都不弱, 雖然這些業務並非都能成功突破局面, 但其中數家公司的盈 利，已足以支撑《蕉風》至到它於一九九八年停刊。48

\footnotetext{
${ }^{44}$ 王建武口述, 《香港文化眾聲道 第 1 冊》, 頁 170 。

${ }^{45}$ 白圭，〈何物千年怒若潮〉，《縷雲起於綠草》，八打靈：大夢書房，2007，頁 78 。

46 他在一篇文章裡追憶：「當年獲得記者工作, 與我在中學參加《學生週報》相識友聯出版社中人有 關。」林風〈追憶《虎報》到《南洋商報》歷程〉, 《東方日報》電子版, 2011.11.08。

http://www2.orientaldaily.com.my/fread/27sC0J5M11OZ1HfC1b551SrG0zD68126

47 王建武口述, 《香港文化眾聲道 第 1 冊》，頁 155 。

48 姚拓, 《雪泥鴻爪》, 頁 570-574。
} 
據奚會暲的追憶, 當香港友聯在一九五六年決定發展新馬事務之後, 最初來到新馬 的, 有余德寬、陳濯生、邱然和他本人, 而後又有王健武、張海威（方天）、姚天平（姚 拓）、古梅、黃崖、黎永振等等。49

邱然, 又名丘西紅, 筆名燕歸來, 北大外文系學生, 青年黨人邱椿之女。陳濯生（陳 思明、陳維瑲）, 是中央大學政治系學生, 丁挺標女婿。他們都是友聯出辦社的創辦人, 燕歸來是創辦人, 也最早和亞洲基金建立與聯繫業務的負責人 ${ }^{50}$; 根據林悦恆與陳正茂的 口述, 陳思明是創辦友聯以及負責把業務擴至新馬的主要負責人。由於陳思明有相當重要 的人脈關係, 故能把重要的人事連結起來, 形成友聯社 ${ }^{51}$, 後來他也把業務擴展至新加 坡。52 方天稍後也加入友聯, 於一九五五年來到新加坡擔任《蕉風》的第一任主編。

根據《香港文化眾聲道》裡何振亞的訪問, 友聯的事務之所以會發展到馬來亞, 從一 開始就是出於馬來亞政府剿共計畫的一環, 他們實際上是受邀而來。當時馬來亞需要找一 些非左翼的文人，進行跟左翼不同的文化工作：

那麼新馬的《周郝》呢? 我們㣚去的時候, 馬來西亞還在䣋共, 他們那時候希望在 香港找一、雨個人先去搞一些青年的文化活動、停媒上的活動。53

何振亞也談到, 當時是一九五 $\bigcirc$ 年代中期, 從馬來亞負責找人的, 正是後來成為馬六甲州 長的梁宇摹, 他是 「汪精衛的連襟, 在那邊很有聲望」 ${ }^{54}$, 除了找到何振亞之外, 也找了 香港文化人逑寶倫, 但最初只有何振亞獨自來馬視察。何振亞回到香港以後, 便會合其他 人一起把友聯的文化工作擴展到馬來亞：

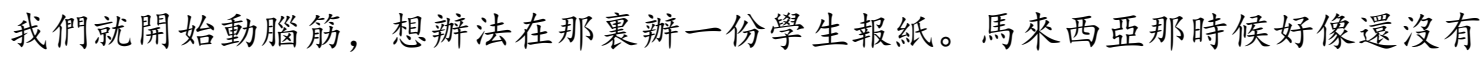
獨立, 新馬還在一起, 在吉隆坡辦邦比較困難, 所以就先在新加坡辦, 甚麼時候

\footnotetext{
49 奚會暲口述, 《香港文化眾聲道 第 1 冊》, 頁 60 。

50 奚會暲口述, 《香港文化眾聲道 第 1 冊》, 頁 63、65、66。

51 林悅恆口述, 《香港文化眾聲道第 1 冊》, 頁 176-178。

52 陳正茂, 《50 年代香港第 3 勢力運動史料蒐秘》, 頁 92 。

53 何振亞口述, 《香港文化眾聲道》, 頁 20 。

54 何振亞口述, 《香港文化眾聲道》, 頁 20 。
} 
搬到吉隆坡去我不記得了。我們當時辦《學生周報》是想讓年輕一代認識這個社 會、華文教育，同時我們增加活動。55

何振亞的敘述, 也許省略了最關鍵的原因。在日殖戰後初期至獨立以前, 右傾報刊很難突 破左翼掌控的局面。 ${ }^{56}$ 當文人陳振亞在《光華日報》任職主筆時, 該報曾被打成右傾報 紙, 影響銷路。許多小報以左傾報導、內幕報導以及情色路線來撐起銷路。左傾的報紙雖 屢遭查封，但依然有後來者陸續辦報，可見當時左傾意識之盛。57

根據以上何振亞的受訪篇來看, 表面上似乎是梁宇㚖從馬來亞主動往外找尋非共的 文人, 來經營不同於左翼的華文刊物。梁宇臬曾在一九三○年代, 受汪精衛之邀, 在國民 黨執政期間，到中國服務。 ${ }^{58}$ 二戰期間出任雲南省富海縣的縣长，富田省立銀行的經理， 其他職位還包括鐵道部參事、外交部視察員、僑委會常務委員等職。二戰結束後, 梁回到 馬來亞怡保重操律師業務。一九四七年梁任霹靂邦官委議員, 一九四九年二月梁成為馬華 公會十六位發起人之一, 並擔任霹靂州馬華公會主席至到一九五二年。一九五五年他參加 聯邦議會的選舉, 當選為怡保萬隆選區的聯邦立法議員。梁曾經相當深入地參與剿共計 畫, 曾被委任為聯邦戰爭理事會(Federal War Council)和霹靂戰爭理事會的成員之一。59

“Federal War Council” 是緊急法令行動理事會(Emergency Operation Council)的舊稱, 是一 九五 $\bigcirc$ 年代初期由畢禮斯將軍為魝共計畫而成立的戰爭行動理事會 (War Executive Committee) 的指揮委員會。 ${ }^{60}$ 戰爭行動理事會是個宛如金字塔般結構的組織, 從聯邦、州 級乃至縣區地方上都有設立委員會, 成員涵蓋平民與文職行政官員, 由此得以把警察、行 政和地方平民都納入整體獣共的團隊裡。 ${ }^{61}$ 惟梁宇臬作為曾經邀請友聯南來的關鍵人物， 近數十年來, 鮮見有論文提起。梁宇臬自從於一九六○年參與《拉曼達立報告書》以來,

55 何振亞口述，《香港文化眾聲道》，頁 22。

56 葉觀仕《馬來西亞華文報業史》, 吉隆坡：名人，2010，頁 102 。

57 葉觀仕，《馬來西亞華文報業史》，頁 93、116。

58 梁當時曾任中緬勘界工作, 後又任銀行經理等職位。〈梁宇臬抵成都將轉赴雲南重開中緬勘界工作〉, 《南洋商报》1936 年 11 月 21 日, 頁 2 。

59 陳中和, 〈梁宇臮〉, 何啟良主編, 《馬來西亞華人人物誌》, 八打靈：拉曼大學中華研究中心, 2014 , 頁 754-757。

${ }^{60}$ Riley Sunderland, Organizing Counterinsurgency In Malaya, 1947-1960, Memorandum RM-4171-ISA, Santa Monica: Rand Corporation, 1964, p.69.

${ }^{61}$ Riley Sunderland, ibid. p vii. Leon Comber, Templer and the Road to Malayan Independence: The Man and His Time, Singapore: Institute of Southeast Asian Studies, 2015, p.44. Karl Hack, “The Malayan Emergency as counter-insurgency paradigm", p. 386. 
在華語源流的華社群中, 可謂惡名昭著。6 2 僅在近年出版的《香港文化眾聲道》與白圭 《縷雲前書》這兩本書裡，才交代他們當時往來密切的關係。

根據王建武與奚會暲的訪問, 他們與在地的政府要員都有良好關係, 尤其與梁宇摹 的關係非常好。據王建武的追憶, 當時還與其他在馬來亞的友聯負責人, 余德寬、張海威 等人一起幫助梁宇臮競選：

他們以國內學生運動的那一套幫忙，結果幫我們所認識的梁宇臮成功當選議員。這 個政黨聯盟執政後，梁宇臮便當了衛生部長，後來馬來西亞獨立之後，便當了馬六 甲的州長。……當時十一個州, 只有馬六甲州長是華人, 就是梁宇摹, 「友聯」跟 他的關係非常好。「友聯」在那邊發展後, 我們慢慢在馬來亞、新加坡開書店、做 書報發行，在馬來亞辦印刷廠，慢慢發展起來。63

此外, 亦曾幫忙給梁宇㚖的政治演講翻譯, 「他做衛生部長的時候經常要到新村演講, 宣 揚政府的政策, 他有時要找翻譯, 請『友聯』的朋友幫忙翻譯, 有時他也要講國語, 他就 指明要黎永振教他國語」 ${ }^{64}$ 。奚會暲的口述篇亦提及梁宇臮, 言之甚敬, 「是馬來西亞僑 領，對『友聯』的一些年輕朋友很欣賞」 ${ }^{65}$, 奚與梁的交情, 又可從一九五九年左右為之 借款奔波之事顯見, 為幫助梁州長因家庭原因出現的財務困難, 奚會暲乘火車南下新加坡 找新加坡電影檚業有限公司借錢。 ${ }^{66}$ 以當時緊急時期的嚴厲查禁情況而言, 這些關係都有 利於友聯在馬來亞的業務發展, 包括需要長期居留批准 :

那時候陳濯生叫我坐飛機去, 因為我們跟內政部長有一個很重要的會議一一要求他 們批准我們「友聯」長期居留, 馬來西亞整個機構因此稳定下來。亞洲協會在馬來 西亞成立辦公室，展開工作都必須獲得外交及內政部同意，他們與「友聯」的關

62 自一九六 $\bigcirc$ 年代開始, 梁與中文源流的華社與華教人士關係惡劣, 起於一九六 $\bigcirc$ 年梁參與《拉曼達立報 告書》，他同意將所有中學整合為國民型中學或國民中學，甚至主張華文媒介的教育制度不合時宜，應該 轉向以英文學習數理。陳中和，〈梁宇臬〉，頁 757 。

${ }^{63}$ 王建武口述, 《香港文化眾聲道》，頁 147-148。

${ }^{64}$ 王建武口述, 《香港文化眾聲道》，頁 152 。

65 奚會暲口述, 《香港文化眾聲道》, 頁 60 。

66 奚會暲口述, 《香港文化眾聲道》, 頁 60 。 
係，政府都有資料，雨個機構都是很正派而做對馬來西亞文化教育有益的工作。其 實，有些與馬來西亞政府要員的關係是我們自己逐漸建立的。67

奚會暲所強調的「正派」與「有益」, 言下之意可圈可點，那實是經過媒體與資源配置， 而後生成的詮釋與定義。從友聯諸人的口述訪問來看，那些受到亞洲基金會資助的項目， 大都以香港的項目為主, 包括友聯研究所、 《大學生活》和《周報》（即《中國學生周 報》) ${ }^{68}$, 至於在馬來亞的業務, 據其所敘, 仍未能確知是哪個項目由亞洲基金（舊稱亞 洲自由協會）所資助。在奚會暲的口述訪問裡, 他認為「亞洲協會」提供了友聯主要的資 金來源，包括最後一次一九六七年資助香港的辦公室與廠房（香港新蒲利森大廈） ${ }^{69}$ 以及 $\left\ulcorner\right.$ 在馬來西亞買地」, 但何時與何處購地不詳。 ${ }^{70}$ 但奚會暲與王建武的說法互有出入, 《蕉風》的編輯與印刷廠房在一九六七年後並未再見更動。 ${ }^{71}$ 根據受訪諸人相當一致的說 法, 友聯開始從事反共的文化事業之後, 才收到亞洲自由協會的資金補助, 且根據特定項 目與刊物, 以及每年定期報帳, 才獲得撥款。根據口述, 友聯的業務在馬來西亞發展得相 當全面, 出版的教科書包括《友聯活葉文選》和英文教科書, 尤其後來的中小學課本因與 教育監圖配合, 頗有利潤。根據一九九九年《蕉風》休刊號第四八八期編委的告白書, 姚 拓陳述《蕉風》的經營熯難, 每期的虧損由友聯文化事業有限公司和其他姊妹公司來補 貼。72

雖然《香港文化眾聲道》書中所受訪諸位, 對於友聯出版社在馬來亞的活動, 是否 有受到亞洲基金會所資助這個問題, 都缄口不提。不過, 根據近年來美國情報局釋出的檔

67 奚會暲口述, 《香港文化眾聲道》, 頁 70 。在此「馬來西亞」是奚會暲 $\square$ 誤, 一九五七年應作馬來亞。

68 林悅恆口述, 《香港文化眾聲道》, 頁 188 。

69 王建武口述, 《香港文化眾聲道 第 1 冊》，頁 165 。

70 奚會暲口述, 《香港文化眾聲道 第 1 冊》, 頁 70 。

71 王建武提及他在新馬期間（1955-1965）, 曾在吉隆坡郊區買了兩英畧地, 建印刷廠與寫字樓, 但他的說 法是當時通過馬來亞文化公司出版社的教科書, 接了大筆生意。王建武口述, 《香港文化眾聲道 第 1 冊》, 頁 155 。根據白圭追憶, 一九六 $\bigcirc$ 年, 友聯始遷入自置廠房 $「 八$ 打靈再也二一七路十號」。但查 《蕉風》, 這地址是在一九六一年八月號第一○六期才開始啟用, 從原先的 $\ulcorner$ 八打靈再也第十三路二號」 （始自一九五九年十二月第八十六期）搬過來。搬過來以後, 印刷與出版業務就在該址運作多年。故應與 亞洲基金於一九六七年的最後一筆資助無關。亦參見白圭, 〈何物千年怒若潮〉, 《縷雲起於綠草》, 頁 76 。

72 姚拓, 《蕉風》1999 年第 488 期, 頁 1-3。其他共同補貼的公司還有馬來亞圖書公司、馬來亞印刷公司、 新加坡友聯書局、怡和書局等等, 依姚拓所言, 是「本諸『取之社會, 用之社會』的原則, 將利潤補貼 《蕉風》」。 
案資料來看, 友聯出版社在馬來亞的活動, 顯然是接受了亞洲自由協會的資助。當時友聯 出版社所積極開拓的中學華文教科書市場, 正是亞洲自由協會所資助的重點項目之一。。13

\section{（一）亞洲自由協會成立的背景}

以下略述亞洲自由協會的成立背景。一九五一年三月十二日, 亞洲自由協會創立於美 國加州舊金山。至到一九五四年十月, 才更名為亞洲基金會。74根據趙綺娜的研究, 亞洲 自由協會的組織概念, 實際上是脱胎自「援知會」底下那用以拉撤中國知識分子菁英的 $\ulcorner$ 中美編譯社」。75亞洲自由協會的組織宗旨, 是以促進反共或抗衡共產主義為目標, 其 角色可說是代替美國政府, 去涉入、推動、影響那些美國政府認為不宜出面介入的領域。 做為一個「私人組織」(private organization), 亞洲自由協會理當能夠「接觸那些在遠東地 區不願與美國政府扯上關係的團體」, 或者去接觸那些「美國政府無法直接聯繫的團 體」, 後者包括極端的愛國主義者與左翼份子。 ${ }^{76}$ 換言之, 為了有效滲透多個文化團體, 亞洲自由協會必須把它與美國國府的關係加以隱蔽化, 雖然對外表現為民間組織, 但實際 上卻是能夠獲得大量美國國內籌款與注資的機構。除了香港設立分部, 在菲律賓和馬來亞 亦有辦事處。亞洲自由協會在亞洲活動的項目遍及多國, 包括促進菲律賓的選舉、接觸東 南亞的佛教領袖, 以便能夠培育具有民主自由思想的現代化佛教教育。起初他們在亞洲想

73 以下將處理的這批檔案, 隸屬於美國政府情報局旗下設立的反共計畫, 這計畫稱之為 DTPILLAR, 創設 於一九五一年, 主要目的是資助那能夠代替美國政府、以民間形式出面的組織, 在亞洲區域進行反共的活 動。亞洲自由協會即為這個計劃底下最重要的組織之一。

${ }^{74}$ Record Reference 7/55. Public Relation Office(PRO), The Asia Foundation: A Statement of the Foundation's purposes and activities. 1954-1955. Singapore: Singapore National Archive reading room.

75 趙綺娜也將之譯為自由亞洲委員會。「援知會」為美國在一九五 $\bigcirc$ 年代初的一個民間團體, 成員為美籍 華人與美國的反共人士, 他們關心當時滯留香港的中國難民, 尤其集中於援助知識分子階層, 比美國政府 更早意識到這些逃離中共的知識分子，對於華文讀者所具的影響力。由於「援知會」被批評為國民黨人士 所參與、滲透, 故美國政府才以「亞洲自由協會」取代「中美編譯社」。趙綺娜, 〈冷戰與難民援助：美 國「援助中國知識人士協會」, 一九五二年至一九五九年 $\rangle,$ 《歐美研究》 1994 年第 27 卷第 2 期, 頁 $65-108$ 。

76 Jone Devine, James L. Meader, "Consensus of Opinion of PAO Conference, Baguio, Regarding Committee for a Free Asia.” DTPILLAR VOL.1_0083, Jan 15, 1952. Database: The CIA Records Search Tool (CIA CREST). https://archive.org/details/DTPILLAR 
涉入的國家也包括了印尼。 ${ }^{77}$ 但在一九五六年十二月八號, 印尼政府要求亞洲自由協會終 止他們在境內的活動。78

\section{（二）以培養本土意識來抗衡共產主義}

亞洲自由協會的宗旨列明, 活動目標首重華人。79他們認為, 為了圍堵共產主義, 應 該借助東南亞華人之力。基於過往東南亞華人與中國大陸在經濟與政治上的深刻紐結歷 史, 故反共運動也該從東南亞華人著手。他們認為, 由於東南亞華人已經長期形成中產階 層, 中共的理念對於東南亞華社未必能行得通。他們也留意到, 在馬來亞, 有一些國民黨 的活動場合相當獲得華人支持, 同時左翼勢力漸現衰弱之跡。他們認為, 由於東南亞華人 能夠接觸到中共之外的 $\ulcorner$ 自由世界」，應當能夠從中國大陸的政治變化，看出鐵幕國家背 後的問題。 80 這些觀察, 使得他們相信, 應以新馬華人社會為影響對象, 滲透、接觸, 使 之再受「教育」。

其中培養在地華人對在地文化與國族體系的認同, 可說是意味深遠。這種鼓吹華人產 生本土認同的意識, 早在一九五一年就開始浮現, 他們認為讓東南亞華人培養在地認同意 識, 能減少共產主義的影響。他們留意到, 東南亞各國政府都在面臨華人的效忠問題。81 故而, 保存、維護東南亞華人的在地認同, 便成為極重要的原則。譬如, 在一九五三年 間, 美方曾有意見, 提醒亞洲基金會在引導東南亞華人支持台灣的時候, 得注意東南亞華

人可能會因此產生與本土疏離的危機。82到了一九五八年, 計劃書就進一步把這個項目的 陳述修正為：「對海外華人推介較受歡迎的台灣形象, 同時也增進華人對所在國的認

77 一九五九年, 亞洲基金會資助印尼日惹的蘇丹，「一個在印尼很有影響力的公眾人物與前外防部長」，進 行訪問美國之旅。DTPILLAR International Organisation, “Request For PP Project Renewal Dividence Project Clearance Sheet." DTPILLAR VOL.2_OO03, Dec 1, 1958, p.4.

${ }^{78}$ PP/OPS/C/PR, “The Asia Foundation in Indonesia.” DTPILLAR VOL.2_0008, Feb 21, 1958, p.1.

${ }^{79}$ John Devine, “The committee for a Free Asia.” DTPILLAR VOL.1_0084, Dec. 1, 1951.

${ }^{80}$ FE Plans, "Project DTPILLAR." DTPILLAR VOL.2_0052, June 26, 1951, p.2.

${ }^{81}$ Memorandum for CFE, “Consideration with respect to RFA.” DTPILLAR VOL.1_0041, Sept 27, 1951.譬如早在 一九五一年, 談到亞洲自由電台的廣播效用時, 就曾論及其節目可能幫助當地政府解決部分問題, 譬如 $\ulcorner$ 鼓勵印尼華人效忠在地國家以便抗衡左翼的共產主義思想」，當時美方意識到，催促或促使華人產生在 地文化與國族意識, 是削減共產主義影響力的辦法。

${ }^{82}$ Memorandum for the record, "Meeting with Mr. Strong and MacKnight of the Department of State." DTPILLAR VOL.2_0043, May 22, 1953, p.1. 
同」。83從中可見, 《蕉風》創刊後推行的本土意識, 除了與馬來亞的官方國族話語有呼 應之外, 亦與冷戰時期的反共策略, 有密切關聯。

美國文化界對華人的問題與意見, 也並非只有單一看法, 打從運作初期, 就已有不 同的意見提出, 得留意美國與亞洲雙方冷戰中的視域差距, 尤其亞洲人的反應可能與美國 的期望有落差。這些意見包括針對當時冷戰傳播內容裡, 那流於把左右兩翼二元對立化的 呈現模式, 以及過度宣傳「美國是多麼好」, 可能有反效果, 使亞洲人聽得相當厭煩, 尤 其「亞洲人感受到美國所宣揚的改革條件, 無法在他們自己的環境裡複製、產生」; 此 外, 東南亞多國政府「對於強大的中國總有忌諱, 不管那是中共政府, 抑或是國民黨的政 府」。 ${ }^{84}$ 也有意見強調, 亞洲自由協會應努力去除以美國為中心的觀點, 其操作結構與人 力部署也應該從舊金山總部挪移到亞洲, 以俾更能接近目標群體, 即亞洲人的觀點。85經 過這些觀念的調整, 稍後於一九五一年, 亞洲自由協會遂建議於菲律賓馬尼拉設置總部, 將美裔職員限制到一至兩位, 其餘為東南亞多元各族, 包括菲律賓人、印尼人、印度支 那、泰國人與緬甸人。 86

\section{（三）友聯出版社在新馬的活動成果與其評估}

多份報告強調在亞洲教育領域的進展。在香港, 到一九五四年時, 亞洲基金會已經資 助八所大學院校, 可讓流亡香港的中國難民就讀。87不僅香港, 也涵蓋日本、緬甸、新加 坡, 亞洲基金會投入相當大量資源到遠東與東南亞各國的教育領域, 且視創設教育空間與 改變教材意識形態為其重點, 甚至亦包括和新加坡南大的學生建立聯繫, 培訓其學生成為 活動聯誼領袖。 ${ }^{88}$ 在國際之間, 它積極推介臺灣作為自由中國予東南亞華人, 也提供獎學

\footnotetext{
${ }^{83}$ DTPILLAR International Organisation, "Request For PP Project Renewal Dividence Project Clearance Sheet." DTPILLAR VOL.2_0003, Dec 1, 1958, p.2.

84 這意見參考一份來自媒體從業員致於亞洲自由協會的信件。From the Assistant Editor of the Reporter, Phillip Horton to Allan. No Title. DTPILLAR VOL.1_0069, June 6, 1951.

${ }^{85}$ John Devine, “The committee for a Free Asia.” DTPILLAR VOL.1_0084, Dec. 1, 1951, p.4.

${ }^{86}$ Mr. George H. Greane, Jr. No title. DTPILLAR VOL.1_0093, Nov. 2, 1951, p.1.

${ }^{87}$ Frank G. Wisner, "Memorandum for Project Review Committee." DTPILLAR VOL.2_0034, June 25, 1954, p.2.

${ }^{88}$ DTPILLAR International Organisations, "Request for PP Project Renewal.” DTPILLAR VOL.2_0003, Dec 1, 1958, p.5.
} 
金給各地華裔學生到美國和臺灣留學。89一九五四年秋季開學時, 就有數百名東南亞華裔 學生, 獲得獎學金與各種資助, 赴臺留學。90

在馬來亞, 針對華社的教育工作, 可說是通過友聯出版社(Union Press)完成的, 對於 友聯出版社在馬來亞推行的工作, 他們予以高度讚賞。關於友聯的資助, 最初始於友聯研 究所(Union Research Institute), 經過數年資助後, 他們仍讚其為「提供中共資料的最佳來 源」。根據一九五五年的彙報, 當時接受美國資助的反共文學, 在香港出版的已達八十五 部, 全都行銷東南亞。其他成果包括香港出版的六份雜誌, 讀者群涵蓋知識分子、兒童、 學生和電影觀眾, 在一九五五年第三季, 總共有十四萬八千五百零八本發行到東南亞。此 外, 也特別強調, 香港出版接受資助的一家 $\ulcorner$ 中文學生報刊」（當是指《中國學生周 報》）, 成功聯結了香港、馬來亞、新加坡、印尼和緬甸的華裔青少年，「但凡在刊物發 售所至之處，均成青少年的焦點」。91

多份文件證明, 亞洲基金會的資助, 也涵蓋友聯出版社在馬來亞的活動。在一九六一 年的匯報與計畫書裡, 特別備註友聯出版社在馬來亞的成就, 包括「成功鎖定馬來亞的教 科書市場」，成功打破過往由左翼主導的華文教材局面。92不過亞洲基金會也留意到友聯 出版社有一些不遵守合約的狀況, 他們曾私下挪用部分援助金來出版華文小學教材, 惟據 合約, 友聯只該負責出版華文中學的教材。9 3 顯然亞洲基金會與友聯之間, 實有合約明確 規定後者可及的範圍, 惟若友聯行事有益於整體反共目標, 亞洲基金會似乎也不甚嚴厲約 束。

顯然, 這些教材, 對於改變在地華人的意識形態, 在亞洲基金會看來極為關鍵, 比起 馬華文學更為重要。DTPILLAR 計畫執行者對於臺灣和日本方面的文學關注, 也遠遠超 過馬華文學。對於臺灣, 評估者認為, 「臺灣文學創作表現出極佳天賦潛能, 比起那些低 層次的政治宣導戰鬥, 更能俾益亞洲」。9 ${ }^{9}$ 對於日本, 他們大力資助那有別於馬克思唯物

\footnotetext{
${ }^{89}$ Andrew Defty, Britain, America and anti-communist propaganda, 1945-53: the Information Research Department, London, New York: Routledge, 2004, p.214.

${ }^{90}$ Frank G. Wisner,, "Memorandum for Project Review Committee.” DTPILLAR VOL.2_0034, June 25, 1954, p.4.

${ }^{91}$ International Organisation Division, "Project DTPILLAR FY 1955 Renewal.” DTPILLAR VOL.2_0029, Apr 8, 1955, p.3-4.

92 International Organisation Division,, "Request for Project Renewal.” DTPILLAR VOL.3_0031, Dec 1, 1961, p.2.

${ }^{93}$ From Peat Marwich Mitchell \& Co to the President of The Asia Foundation, Mr. Robert Blum. No Title. DTPILLAR VOL.3_0032, Sept 30, 1960, p.8.

${ }^{94}$ Chief International Organisations, "Memorandum for the record Meeting with Mr. Strong and MacKnight of the Department of State.” DTPILLAR VOL.2_0043, May 22, 1953, p.1.
} 
觀的現當代中國文學研究。95至於馬來亞, 卻完全沒提到馬華文學。也許他們認為, 以馬 華社會當時的條件，馬華文學實在是無甚可期待的。

除開教材之外, 也讚揚友聯出版社跟官方在反共方面的合作成果, 尤其是, 特別標註 友聯出版社透過新加坡的分公司(outlet), 幫忙英國政府蒐集文件, 以出版一份白皮書, 這 本白皮書揭露共產黨份子滲透新加坡的政治與出版機制的路徑與方式。此書應為一九五七 年出版的《新加坡境内之共黨威脅》(The communist threat in Singapore)白皮書, 中文譯本 也在該年面市。96此書出版後, 新加坡國會會議針對此書展開激烈討論, 人民行動黨首當 其沖, 它被認為已受共產黨滲透及掌控。97對於亞洲基金會而言, 這樣的出版結果亦為他 們所樂見。顯然, 在一九五 $\bigcirc$ 年代的冷戰背景下, 友聯出版社在新馬一帶涉入反共計畫以 及所扮演的角色, 比起過去所想像的, 更為深入。

有關在馬來亞的援助成果與呈報計畫, 中央情報局大致注重反共報章和教育這兩大領 域。一九五四年後, 才加上友聯出版社開拓的華語教材市場。這些在馬來亞的活動計畫, 都強調以華人社群為目標, 而這對英國人而言, 也是極為敏感的議題。在友聯南來之前, 早在一九五四年六月, 亞洲自由協會就已經開始慎重評估, 跟英殖民政府合作的可能性。 英殖民政府曾經表示, 友聯出版社應該能為馬來亞帶來「重要的成功」, 美國將之詮釋 為, 這意思顯然是指 $「$ (可以幫助) 英國當局獲得成功」。基於英國在新馬殖民地有顯著 的經濟利益, 在等待協調期間, 曾使得亞洲自由協會的計畫, 被逼拖延好些時候, 當時, $\ulcorner$ 除非有證據顯示英國願意支持這項計畫, 否則亞洲自由協會必須削減在馬來亞活動的經 費預算」，他們也得在六個月內評估應該留下、或撤退這兩個抉擇的得益與損失。 ${ }^{98}$ 故 此, 友聯出版社南來新馬的計畫, 本來應該比一九五四年底來得更早。

友聯出版社南來新馬, 實是英美聯盟合作協議的結果。其協調方式, 主要由亞洲自由 協會（亞洲基金會）代表, 而且得與英國代表在新加坡定期會面。99透過亞洲基金會與英

\footnotetext{
${ }^{95}$ International Organisations, "Request for Project Renewal." DTPILLAR VOL.3_0031, Dec 1, 1961, p.2.

${ }^{96}$ Singapore, The communist threat in Singapore, Singapore: Legislative Assembly, 1957. 相關中文譯本的報導,

見〈「新加坡境内之共黨威脅」白皮書中文譯本出版〉, 《南洋商報》, 1957 年 8 月 29 日，頁 5 。

97 〈新加坡境內之共黨威脅」白皮書將於今晨討論〉，《南洋商报》，1957 年 9 月 12 日，頁 5 。〈立院 整日激烈爭讋後表决大整肅白皮書不錯誤李光耀動議三票比二十二票被推翻〉，《南洋商報》，1957 年 9 月 13 日, 頁 5 。

${ }^{98}$ Frank G. Wisner, "Memorandum for Project Review Committee CFA budget for FY-1955." DTPILLAR VOL.2_0034, June 25, 1954, p.4.

${ }^{99}$ International Organisations, "Request for Project Renewal." DTPILLAR VOL.3_0033, Oct 25, 1960, p.4.
} 
殖民政府的協調, 友聯出版社的文化工作才能夠在馬來亞順利展開。然而, 從這些資料 裡, 可以發現, 美國亞洲自由協會最初予以友聯出版社在新馬的資助, 是以突破反共意識 形態為主要目的。在這些項目中, 最受重視與最常提到的, 是教科書與青少年的聯誼活 動。從這系列的檔案來看, 亞洲自由協會其實並不看重馬華文學的表現。故而, 《蕉風》 所著力打拓的文學空間, 可能確實很大部分是出於南來文人本身, 對文學所懷抱的理想所 致。100

曾到馬來亞參與編輯工作的奚會暲、古梅和王建武，也追憶當時在馬來亞推動《蕉 風》和《學生周報》的情況, 講述了初期五十年代期間, 友聯出版社在馬來亞推動、發 行、發展業務的過程與方式。據奚會暲敘述, 一九五六年開始, 友聯出版社在政策上決定 發展新馬的事務。 ${ }^{101}$ 也正是該年六月開始, 在《蕉風》每期雜誌封底內頁的說明, 也由蕉 風出版社出版及發行, 改成註明由新嘉坡友聯書報發行社發行。根據古梅的說法, 比起香 港, 友聯在馬來亞搞的活動「用力很大」, 除了新馬地理範圍比香港大之外, 也因為得開 闢新市場。除了反共, 他們也「推廣華文教育, 華文教科書這方面的需要就不小。」 ${ }^{102}$ 奚 會暲的說法則是「那邊的工作主要還是對華僑青年宣揚民主思想與保存中華文化」。103

古梅、奚會暲等當時皆為新亞書院的在籍學生，深受香港新亞書院的老師，如錢穆 主張傳承古典人文知識的精神感召。從一九五八年開始, 時值中共大躍進, 中國大陸加強 推行「薄古厚今」的文藝政策 ${ }^{104}$, 從教學、文學到戲劇, 以工農兵無產階級的作品與接受 為重, 而削減、排除資產階級知識分子較能專長的古典文學, 調整控制 $\ulcorner$ 古」與 $\ulcorner$ 今在 教學、評論與刊物內容的比例, 乃至於批判知識分子的 $\ulcorner$ 厚古」習性, 這類報導在《蕉 風》的文訊版裡屢見不鮮。 ${ }^{105}$ 友聯突顯自身致力於保留、編彙中華文化知識與典籍的使 命, 雖然主張推翻陳舊文學, 但仍極力強調保留、延續古典文學, 由此切分出兩者運作的

\footnotetext{
100 惟這需要更多檔案, 以進一步證實。到目前為止, 本論文主要根據新加坡國家檔案局的檔案資料, 以及 部分在網路上公開的資料做推論。論文在審查與口試時, 曾受評審提醒, 倘能依據與《蕉風》文學表現更 顯直接關係的解密檔案來做分析, 會更具有辯證性。

${ }^{101}$ 奚會暲口述, 《香港文化眾聲道第 1 冊》, 頁 60 。

102 古梅口述, 《香港文化眾聲道 第 1 冊》, 頁 98 。

103 奚會暲口述, 《香港文化眾聲道 第 1 冊》, 頁 60 。

$104\ulcorner$ 厚古薄今」作為大躍進時期的口號, 參見李方祥, 〈五十年代理論界關於 「厚今薄古」的論辯與馬克 思主義教條化〉，《黨史研究與教學》2007 年第 1 期，頁 37-44。

105 舉例有《蕉風》1958 年第 67 期、70 期、71期的文訊版。
} 
文化話語是何等的逕渭分明。南來文人白圭在《縷雲前書》裡, 也流露出他對於海外華人 社會, 在本土認同之餘亦能保留中華文化底罝的活力, 相當寄以厚望。白圭這本自傳性意 味頗濃的「小說」, 全書追憶他參與友聯往事為核心。其中有個段落寫及主角南來以後, 觀察在地華校取名具有豐蘊的古籍出處, 對比中共準備以數字符號來取代校名, 筆下不無 嘲諷中共無知之意。10即便是深受英文教育洗禮而疏於中文的梁宇摹, 當時亦曾隨口朗朗

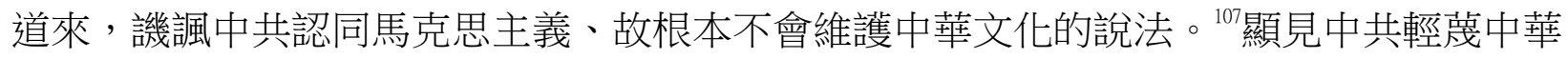
傳統文化, 當時在非共圈子中, 幾乎是深人人心的觀念, 幾可宣之於口的反共話語之一。

友聯能夠把業務擴展至馬來亞, 且為殖民地政府與馬來亞政府所接受, 和反共立場 的「正當」性亦不無關係。108在友聯的宗旨裡, 「反共」、「推行民主思想」與「宣揚中 華文化」連成一體。根據《香港文化眾聲道》的訪問稿, 曾經提到此處的年輕學生亂用成 語, 一般在地僑民的中文水平都相當差, 自有必要在此地推廣中文教育。對此, 莊華興曾 問, 當時馬來亞已有不少寫作人具有自身的著作出版, 但為何《蕉風》仍將此地視為「文 化沙漠」? 並質詢他們對文化性質的理解如何? $?^{109}$ 莊華興認為, 這是因為「播種與文化傳 薪」才是這些南來文人的正事與終極目標。他們當時播下的文化傳薪, 後來就改變了馬華 文學的體質, 尤其在七十年代至八十年代, 從溫任平、何啟良、潘碧華等人的書寫裡顯現 為懷舊的、極崇尚古典，但同時也與當前現實政治脫節，浪漫化的憂族情懷。

回溯至五 $\bigcirc$ 年代南來之初, 友聯從新亞研究院物色來幫忙活動的學生, 越洋南來, 他們實際上僅在傳承文化中國的遺產上, 才有這可摧帶的「精神家園」, 藉此延續那已失 的家園, 進而形成友聯、新亞的精神核心, 也形成這個群體記憶與感情紐結的共同核心。

《蕉風》的「純文藝」可能也不無隱含持續追尋這股繼承與發揚「純粹的」文化與文學的 理念。

相對於英殖民地與馬來統治者對於中文的禁忌與偏見, 友聯出版社在其反共宗旨 下, 獲得美援支撑以及英美協調賦予的各式資源, 因而得以在此建立不同於中共左翼的文 化耕地。透過聲明「馬來亞化」, 這份最初是由香港外來的雜誌與編輯團隊, 持續獲得其 合法性的介人、參與、關懷在地文化的發言位置。

\footnotetext{
106 白圭《縷雲前書》（下冊），八打靈：有人，2016，頁 305 。

107 白圭《縷雲前書》（下冊），頁 301 。

108 奚會暲口述, 《香港文化眾聲道第 1 冊》, 頁 60-61 ; 古梅口述, 頁 94 ; 王建武口述, 頁 146-155。 109 莊華興, 〈語言、文體、精神基調 : 思考馬華文學〉, 《思想 : 大馬華人與族群政治》2015 年第 28 期，頁 199-220，頁 206。
} 
因此，對於《蕉風》這份刊物的文學史論述，除了視它為冷戰局勢中發展的一環之 外, 那短期內在地化的實踐, 也因此注入了不同於香港、臺灣或其他地區的現代華文文學 的地域特性。無可否認, 如此快速的策略化安排的在地經歷, 缺乏了感性的過程。110從 異鄉到在地的感性變化過程, 則要在創刊數年後, 當時 $\ulcorner$ 馬來亞化」的熱度稍退, 才另有 不同的發展。

\section{三、左翼、右翼、非左翼和同路人}

在此, 本論文以「非左翼」文學來概括新加坡友聯旗下《蕉風》的文學路線, 這比起 $\ulcorner$ 右翼」更能容納觀點多元的群體, 也更符合《蕉風》的編輯隊伍裡, 雜無多樣的文學觀 點, 並不是非左即右。

根據《牛津辭典》，「右翼」在政治意識上的定義, 包括了持有資本者, 以及在宗 教、哲學、社會、文化各方面的態度保守者。在歐洲大陸的立法會議裏, 右翼會員被分配 坐在主席右手邊的席位; 一般上, 在右翼的譜系裡, 還可分爲中右、極右。要到一七八九 年的法國大革命之後, 兩派在實踐革命成果方面, 出現了鮮明的分歧, 但要到第十九世紀 的工業國革命時期，左、右翼等才分別被賦予激進、保守的意義。111

關於左翼的定義, 包括主張公平的資源分配、照顧勞工階層的社會主義立場, 而右 翼則傾向於保障那些從原有秩序獲得利益者。112 到二十世紀時, 才又從政治施政理念的 層面上, 是依循社會民主抑或馬克思主義的意識形態來做判斷。然而這樣的區分方式仍然 存在不少問題, 如方維保所言, 根據上述定義來判定「激進」仍是困難的, 尤其在進行實 踐改革時, 「手段與目的可能並不一致」。113在思潮與文化的判定上, 方維保也把馬克思 主義、無政府主義列爲左翼的標誌, 而右翼則為不認同左翼的馬克思主義作為改革的方 針。

110 馬來亞化的在地書寫, 是出於勸諭而非感性書寫, 採納林春美的說法, 見〈非左翼的本邦: 《蕉風》及 其「馬来亞化」主張 $\rangle,$ 《世界華文文學論壇》2016 年第 1 期, 頁 71-79。

${ }^{111}$ David McKnight, Beyond right and left: new politics and the culture wars, Crows Nest, N.S.W. : Allen \& Unwin, 2005, p.3.

${ }^{112}$ David McKnight, Beyond right and left: new politics and the culture wars, p.4.

113 方維保, 《紅色意義的生成—-20世紀中國左翼文學研究》, 2004 , 合肥: 安徽。 
在文學上，卻不必然可依據左與右的相互對立來定義右翼文學。在左翼與馬克思主義 思潮之外, 存在諸多擇項, 包括對待民主、憲法或立法、人道權益、個體主義甚至也可能 關懷階層, 由於多種不同思考方式的組合, 亦會因為各種思潮的流動而呈現不同的政治光 譜。

在共產主義文學運動發展的過程中，「右翼」曾經以在左翼定義下的「反動」負面意 義之文化產物出現 ${ }^{114} ， 「$ 右翼文學」的定義因此相當困難，從「極右的政治團體或資源」 到「為右翼政體或資源所支持贊助的文學或文化群體」, 雙方對於這場域空間與不同條件 下的創作, 並不具有政治上的共識。前者的視域常以抑制敵方的意識形態為其出發點, 後 者則有更多因其文化觀點與政治立場認同而來的各種細微差異。文化群體之內可能具有不 同層次的思考方式, 無論是對於全球性現代政治思潮與各種主義（如自由主義、民主、個 體主義、人本主義) 的吸收, 對當時當地政治意識的參與、認同（在地認同、民族主義等 等），乃至到寫作個體所持的文學觀點與創作實踐，疊合展延成多重差異的譜系，職是之 故, 其群體的精神面貌, 具有遠比左右兩翼之間更為多元複雜的界線。

盡管在一九五 $\bigcirc$ 年代以來的冷戰期間，臺灣國民黨的「戰鬥文藝」可能是華語文學 裡, 進行反共最為不譴餘力的文藝政策, 但即便是在這面旗幟下刊登的作品, 論者如婣阿 勤亦不作「右翼文學」論。115 這時期具有批判意味的現實主義被打壓, 抒情、懷鄉的寫 作大行其道, 左翼幾無立足之地。至到一九六 $\bigcirc$ 年代開始湧現的現代主義, 即使「不願意 為當時的政府的權威主義背書」, 卻也是 $「$ 堅決反共」的。116臺灣文壇少稱右翼文學的原 因, 主要在於當六十年代現代主義崛起時, 現代主義作家在文學美學上的探索和論爭, 應 當比左右二元對立的政治模態本身更為突出; 同時也波取自過去鄉土論戰中的教訓, 不再 將現代主義/鄉土文學, 直接對應於左右兩翼的二元對立比對, 轉而趨向更細緻複雜的差 異論述。今天在討論二十年代至三十年代期間的左右兩翼知識分子時, 那些錯綜複雜的認 同, 以及彼時歷史場景中的場域形構, 更是備受關注, 如趙勳達對臺灣一九三十年代的左 右翼知識分子研究, 王梅香關注戰後美援文化對現代主義興起, 以及研究那經過權力配置

${ }^{114}$ 王思睿, 〈主動右派中的修正主義者〉, 《二十一世紀雙月刊》2007 年總第 102 期, 頁 46-56。指出一 九五九年大陸的反右運動, 奠立於一場全然荒謬的命名, 即把受俄國修正主義左翼思想分子, 指派為右翼 分子進行打壓。

115 蕭阿勤, 《重構臺灣：當代民族主義的文化政治》, 臺北：聯經, 2012, 頁 140。

116 張誦聖, 《現代主義・當代臺灣：文學典範的軌跡》, 臺北：聯經, 2015, 頁 44。 
引導反共文學的隱蔽性質。1 17 論者雖或有稱其群體為右翼作家、右翼聯盟等, 但都謹慎 地避免直接將他們的寫作統稱為右翼文學。

在香港，一九四九年後，相繼創立多家接受美援資助的「右翼」出版社與文化機構， 人人出版社、亞洲出版社、自由出版社乃至到友聯出版社, 都出版反共意識的文學刊物, 包括鄭樹森和黃萬華在內, 皆直接以右翼文學稱之, 但收錄於《香港文學大事年表, 1948-1969》的訪談, 也闡明稍後的發展, 對於文學創作空間的追求, 當超越左右政治對 壘。118 香港、臺灣兩地左右翼對歭的形勢不同, 部分基於港英殖民政府當時不欲與中共 敵對, 再加上美國新聞處在香港的活動, 形成了左右兩翼在香港各自佔據地位、競逐、各 取立場，因而有迴旋的餘地。119

香港的右翼陣營與右翼文學, 據黃萬華的論著所言, 除開受到西方資本主義陣營的影 響, 其機構多數接受美援資助, 重要的右翼刊物如《中國學生周報》的編輯方式, 體現出 兼容並蓄、自由主義的態度，在文藝創作上多數吸收西方的現代主義。120

為了能更好涵蓋一九五 $\bigcirc$ 年至一九六 $\bigcirc$ 年之間《蕉風》南來文人的作者與編輯群體， 本論文使用「非左翼」來指稱所研究的對象。《蕉風》的文學立場誠然是反共的, 在創刊 初期, 也遭到認同毛澤東文藝觀的學運團體所杯葛。閱讀刊物內的文藝評論與創作, 可說 除了那「反共」意識之外, 亦顯見文藝面貌的多元特質與存異求同, 這點可能亦為出自反 共宗旨，以及自由主義的貫徹，以及那似乎總與反共任務相隨的中華文化使命。

根據古梅和王建武的追憶, 當時在馬來亞, 他們從當地中學生的華文寫作, 意識到有 更基礎的工作需要推行，包括推廣華文教育。 ${ }^{121}$ 在此，「非左翼」比「反共」、「右翼」 更適合概括那多向培育的文學空間。就其字面義而言, 「非左翼」所涵蓋的對象從右翼、

117 趙勳達, 《「文藝大眾化」的三線糾葛 : 一九三 $\bigcirc$ 年代臺灣左、右翼知識份子與新傳統主義者的文化思 維及其角力》, 臺南: 國立成功大學臺灣文學系博士論文, 2008, 頁 1-7。趙勳達的博士論文在重構當時 左右兩翼的思想光譜時, 指出這兩個群體雖然在政治實踐、寫作與表述, 各顯分歧, 但其實都有相同思維 ( 啟蒙之現代性) 。王梅香的碩士論文與博士論文, 見前述。

118 黃繼持, 盧瑋鑾, 鄭樹森主編, 《香港文學大事年表, 1948-1969》, 頁 11、13、19、23。黃萬華〈左 右翼政治對峙中的戰後香港文學“主體性”建設〉，《學術月刊》第 9期，2007，頁 98-103。

119英殖民者意欲在中美之間保持平衡的關係, 使得香港具有同時讓左右翼文人活動、交匯的獨特空間。鄭 樹森《從諾貝爾到張愛玲》, 臺北 : 印刻, 2007, 頁 178 。單德興〈冷戰時代的美國文學中譯—今日世 界出版社之文學翻譯與文化政治〉，《翻譯與脈絡》，同前注。

120 黃萬華，〈左右翼政治對峙中的戰後香港文學『主體性』建設〉，同上註。

121 古梅和王建武的口述, 《香港文化眾聲道 第 1 冊》, 頁 94 , 頁 154-155。 
傾右、自由主義、人本主義, 甚至也可能包括不必然支持左翼政權的社會主義意識。在一 九五九年第七十八期的《蕉風》有一篇魯文撰寫的〈文藝的個體主義〉, 提出揚棄社會功 效論的文藝觀, 其文學觀卻不止於反共, 同時亦為擺脫過去使文學背負社會改革義務的功 能論, 後者近可溯自五四文學, 遠者有儒家的文以載道, 故以文學承擔社會功能的要求, 實際上不限於左翼。

除了上述美國新聞處所培育的「第三勢力」之外, 過往與左翼文學立場迥異, 但又非 為「右翼」的, 尚有在一九三 $\bigcirc$ 年代革命早期出現的 $\ulcorner$ 同路人」, 又被稱為 $「$ 第三種 人」，他們曾出現在蘇聯一九二 $\bigcirc$ 年代中旬的馬克思文藝論爭裡, 是游離於左右兩翼之 外, 奉行文藝自由創作的群體。蘇聯於一九二○年代中旬掀起的馬克思文藝論爭, 曾把不 少成就斐然的作家劃入同路人群體中, 他們與左翼文學陣營之間的交流甚是密切, 對左翼 的革命意識, 或是同情或表認同。托洛茨基曾認為, 在無產階級能夠產生自己的藝術創作 之前, 這群「同路人」作家是必然的過渡階段。稍後在中國, 一九三○年代初, 在同路人 和左聯之間也曾掀起一場漫長的論爭, 後來因為有左翼文人的文章出版審查時, 遭到刪 裁, 故而傳聞有同路人或第三種人為國民黨服務, 在魯迅與「第三種人」蘇汶的論爭之 中, 魯迅也認為蘇汶批評寫實主義的立場與分辨權力脈絡的事理含糊不明, 這些事件種 種，導致「第三種人」的名聲不佳，當時頗受人詬病。122

${ }^{122}$ 早在二 $\bigcirc$ 年代中後期開始, 魯迅通過翻譯引入蘇聯的馬克思主義文藝觀時, 同時也引入蘇維埃政權時期 無產階級作家和 $「$ 同路人」作家的論爭。「同路人」出自托洛斯基筆下, 他於一九二○年代中旬的論戰中 提出這個概念。同路人是蘇聯一九二 $\bigcirc$ 年代主要的作家群體, 他們可說是從舊政權時期遺留的文化遺產, 在革命過後仍然保持各自的藝術個性, 表現卓越。被劃入的包括高爾基、馬雅可夫斯基等人。十月革命的 領袖托洛茨基在《文學與革命》一書中稱之爲「文學革命的同路人」, 認爲在無產階級作家的藝術誕生之 前, 同路人的文學乃是必然的過渡階段, 故主張吸引這群作家加入到革命陣營裏。當時同路人與無產階級 作家的陣營爆發論戰, 而後雖然不少同路人作家也加入革命陣綫, 但兩者之間的矛盾分歧從未消失過, 并 在三十年代持續形成左翼文學的内在張力。稍後 $\ulcorner$ 同路人」的概念也出現於日本的藏原惟人筆下, 以及中 國左聯一九三 $\bigcirc$ 年代初的論爭中。趙歌東, 〈横站的 $\ulcorner$ 同路人」一一魯迅與左翼文藝運動的内在關係及其 姿態〉, 載文史哲編輯部編, 《左翼文學研究》, 北京: 商務, 2015, 頁 149-183。黃悅, 〈階級革命與 知識分子人格——重論魯迅「第三種人」觀〉, 《左翼文學研究》, 2015, 頁 184-210。方維保, 《紅色 意義的生成：20世紀中國左翼文學研究》, 合肥 : 安傲教育出版社, 2004 , 頁 27-35。趙勳達, 《「文藝 大眾化」的三線紤葛 : 一九三 $\bigcirc$ 年代臺灣左、右翼知識份子與新傳統主義者的文化思維及其角力》, 頁 164-166。蘇敏逸《文學、政治與意識形態的多重敘述：中國三○年代左翼文藝理論及作品研究—以胡 風、馮雪峰、丁玲為中心》97 年度國科會結案報告 NSC 97-2410-H-006-080，2008, 頁 13-14, 敘及馮雪 峰與胡秋原和蘇汶的論爭。http://ir.lib.ncku.edu.tw/retrieve/132671/1010111008-000002.pdf 
在中共建國之前, 中國的左翼文學陣營也長期與「游離者」或「創作自由者」有所交 流, 試圖透過交流來改變這些游離者的觀點, 使之加入陣營。從這些長期的交流中, 經常 提出的一些老生常談的文學觀點, 諸如對於左翼文藝觀教條性的批評, 在五 $\bigcirc$ 年代時期, 亦出現在《蕉風》的藝評中, 只是隱去姓名, 所批評的對象（即左翼）更加隱晦。

由於馬來亞友聯是香港友聯出版社的分行, 與美援文化的關係密切, 故對於馬來亞的 左翼運動者而言, 《蕉風》僅能是敵而非友, 無法成為同路人。

\section{四、概述《蕉風》南來文人的多元風格}

根據《蕉風》的創刊詞, 僅能說明它最初的文藝立場乃是以「馬來亞化」為主, 卻並 不因此圊限於以浪漫主義或現實主義為其定位。從《蕉風》創刊初期五年內的編輯與作者 群體來看, 當中勤於供稿者, 包括方天、馬摩西、姚拓、黃思騁、力匡和白圭, 這些文人 雖都先後聚於《蕉風》, 但綜觀其寫作特性, 可謂「和而不同」。方天來到馬來亞後, 全 力投入開發在地化的寫實主義。馬摩西進行各種記敘文體的地方書寫, 包括地方報導與散 文。姚拓在最初幾年裡仍然以昔日在大陸從軍抗日和故鄉的往事, 為其小說材料。力匡的 散文與詩作極富個人的抒情特色, 寫實主義在力匡的寫作裏並不顯著。白圭則從一九五九 年開始，便在詩歌裏嶄露抒情現代主義風格。

其中方天、力匡和白圭均有大學學歷，馬摩西有碩士學歷。在一九五 $\mathrm{O}$ 年代，大部分 具有高學歷的文人, 幾乎都來自中國、香港, 或經臺灣留學而後南來, 高等學歷對於在地 的文人並不普遍。 ${ }^{123}$ 在地的大學中文教育, 包括馬大與南大的中文系, 要至到一九五三年

123有關獨立前在地華文高等教育仍未設立, 以及大部分支持左翼的勞工與群眾, 普遍上教育水平較低的情 況, 這點也受到友人傅向紅所提醒。在一九五 $\bigcirc$ 年代期間, 尚在馬來亞文壇上活躍創作的文人, 有大學學 歷者皆來自中國, 在那個時期, 之前積極抗日、反殖而政治立場明顯左翼、支持中共的文人, 不少遣回大 陸。與此同時, 仍有不少文人在一九四五年後南來, 他們多數是因爲中國大陸國共内戰的變化、或逃避鎮 壓而離開中國南下, 不少非左翼的南來文人具有大學學歷, 如一九四八年南來新加坡的黃潤岳 (重慶國立 政治大學畢業）、一九四五年南來的曹兮（南京金陵大學畢業）、一九四八年南來新加坡的茀特（西南聯 合大學畢業）、黃晚香（廣州大學畢業）、一九四七年南來的李汝琳（北大畢業）、一九五八年南來馬來 亞文冬的邢濟眾（上海暨南大學畢業）、一九四五年後抵新的李星可（北大和中法大學畢業）、一九四七 年南來新加坡的連士升 (北平燕京大學畢業) 、一九五三年受聘至馬來亞檳城鍾靈執教定居的蕭遙天（上 海藝術大學畢業）、一九四九年南來的芝青（上海復旦大學畢業後負笈日本）、一九四五年南來的杏影 
才開始。 ${ }^{124}$ 大部分中文刊物的讀者, 無論是出身學歷, 抑或自身階級為勞工者, 比較起純 文藝的觀念, 他們更能接受左翼的文藝觀, 以及支持群眾與階層同情的社會主義文學。至 於在地出生的文人, 彼時仍然年輕, 且大部分奉行寫實主義寫作。125 這群非左翼的文 人, 帶來了「另類」的寫作方式, 其中如方天、姚拓, 提供了迥異於左翼的寫實主義; 力 匡以另具風格的詩與散文, 以及白圭後來的現代主義, 則在寫實主義與浪漫主義之外, 打 開了不同的文學視野。他們也通過《學生周報》吸納在籍學生, 培育年輕一代的馬華寫作 人, 如憂草（余榮坤 1940-2011）與山芭仔（溫祥英）。

自《蕉風》創刊以來，在相當長的一段時間內，其文學定位，究竟該歸為寫實主義、 浪漫主義、現代主義, 其實難以定調。尤其這份刊物, 從小說、詩歌、散文乃至到藝評論 述, 或有寫實、或有抒情, 各呈差異, 作者的美學路線都不同。唯一明顯的, 乃為「馬來 亞化」以及強調異於左翼文學的「純文藝」定位。

早期在《蕉風》發表小説的作者, 主要有方天、陳振亞和絮絮等, 他們都致力於創作 具有在地特質的寫實主義小說。後來加入的姚拓與黃思騁，他們的小說可說是流亡境外的 民國遺民文學，或以故鄉或以反戰為主題的寫實主義路綫。到一九五九年以後，詩歌才開 始轉向現代主義。從一九五 $\bigcirc$ 到一九六 $\bigcirc$ 年代, 馬華文學的小説與詩歌的美學典範, 各自 發展，雖然詩歌已經開始走向現代主義，但小説卻幾乎仍由現實主義獨挑大梁。雖然馬華

（早稻田大學畢業）以及一九五二年南來新馬任報章編輯數年的劉以眓（上海聖約翰大學畢業）。他們抵 達新加坡之後, 多數在學院如義安學院、中學如中正中學、華僑中學執教。

124 一九五三年, 當時僅有兩家大學開辦中文系, 然而, 馬大收生稀少, 因為當時入學資格要求的英文劍 試, 對大部分華校生而言可說是過於苛刻。人們普遍對當時仍在籌備中、那可容許華校生入學的南大寄 予更多厚望。可見金榜居士，「馬大中文學系門庭冷落」《南洋商報》1953 年 10 月 17 日, 商餘版。文 中抱怨當時的入學英文門檻之高, 包括劍試英文科目優等、兩年先修班才能參加入學考試。另一篇語氣較 爲恭迎的頌文, 也提到這點, 參見: 康如也, 「祝馬大中文系」《南洋商報》1953 年 10 月 19 日, 商餘 版。王芝祿, 「我願為南大義演」《南洋商報》1953 年 10 月 12 日, 商餘版。王氏為香港獅子山的犬訓 練師, 五十年代曾受邀為電影《風塵義犬》訓練狗群。1953 年來新加坡時, 為回應另一文章大毛君「向 王芝祿君進一言」, 因而公開發表聲明他願意為南大義演而更動赴聯邦的日期。由此可見它如何吸引了跨 區域華裔社群的認同。參見許雲樵〈南洋華僑與大學教育〉, 《南洋學報》1953 年第 9 卷, 頁 12-18。

${ }^{125}$ 其時大學教育仍未普遍, 大部分的文人 (可能同時為版位或刊物編輯、編書出版或寫評論者) 如趙戎、 陳雪風、方北方、方修、崇漢、戴丁、丁之屏、白寒、駝鈴、原上草、雲里風皆無大學文憑, 有者如趙戎 自學成才。當時馬華文壇仍是現實主義為主流的時期, 少數例外者如姚紫（其小說吸納上海新感覺派的美 學), 以及剛開始寫詩的憂草 (余榮坤, 他被認為搖擺於現實主義和形式主義之間)。憂草在新加坡育英 中學念高中期間, 就開始創作, 惟其結集到六 $\bigcirc$ 年代才出版。 
文學的現代主義旗杆, 乃是由友聯旗下的刊物《學生周報》與《蕉風》所引領, 但一九五 ○年代第一波現代主義的改革, 幾乎只集中於詩歌, 而小説仍舊依從文壇主流的現實主 義。然而《蕉風》的特殊之處, 就在於它提供了有別於延安文藝觀的寫實主義敍述, 包括 方天那精於考察的在地化寫實主義, 以及姚拓熱衷於表達個體而非愛國主義的抗戰小說, 都將在稍後分章討論。

故而, 在綜述撰寫這群南來文人的群體圖像之時, 必須彰顯他們彼此在寫作上的差 異。在此，僅梳理幾個從一九五五至一九六 $\bigcirc$ 這段期間概括《蕉風》的關鍵詞：

一、「在地」：雖是《蕉風》創刊詞強調的特點, 然而, 若讀姚拓與黃思駎的小説, 卻不見得都能以「在地化」為其寫實原則。在方天之後, 姚拓繼任《蕉風》主編, 從那時 開始《蕉風》的「在地化」熱度稍斂, 各種以在地爲主題的策劃雖然不少, 可是不再僅以 在地為創作（尤其是小説）的刊登標準。在姚拓擔任主編期間, 他邀請更多港臺兩地的文 人助陣, 當時刊登的小説因此紛呈各個區域的特色。但在那些在地居留多年的作家稿件 裡, 仍能見到「本土特色」流露筆端; 惟真正徹底執行在地化的寫實主義者, 幾乎僅見於 方天擔任編輯的時期。

二、「非左翼」：若與「寫實」和「在地」相比，「非左翼」似乎更能概括他們之間 共有的寫作特色。在一九五九年之前, 《蕉風》的特色, 在小說方面, 依然是寫實主義路 線, 然而在評論方面, 在批評左翼的文學觀之餘, 《蕉風》的一些作者, 卻也不免挪用了 一些社會功能文學觀的語彙與觀念。若仔細閲讀刊於《蕉風》的評論, 不難發現到, 即便 是非左翼陣營的藝評, 早期仍不免有夾帶當時主張文學當用於社會功能論的功利觀點。那 視文學為「器用」、「反映現實」或主張文學可帶來社會改進的社會功能思維模式, 其實 雙方都有，不若他們以為的截然分明。這點將在第三章再作闡述。

《蕉風》在馬來亞創刊時, 緊急法令已實行七年, 左翼的文學空間已大量萎縮, 但 左翼在馬華文學的讀者群中依然有影響力, 尤其因捍衛華教之故, 華校生掀起反殖運動, 即便在嚴厲查禁之中, 仍然崇尚左翼與文藝與思想, 同時也杯葛《學生周報》與美國出版 的刊物。126 但是, 若從當時的報刊副刊來看, 其實也不乏小資意味的小塊文章, 《蕉

126 鄭文波、楊景水《二十世紀五十年代學生運動史料匯編》, 全馬華文中學生捍衛華教運動五十周年工委 會, 2009, 頁 166-167。 
風》也不是當時在地出版的唯一非左翼刊物, 非左翼的文學, 亦並不等到友聯出版社創辦 才出現。127 然而, 非左翼文學真正開始有系統的出版、栽植文學園地, 卻要始於友聯。 除了創辦《蕉風》和《學生周報》之外, 友聯也引入旗下出版的其他書刊, 包括《兒童樂 園》、古典典籍參考書, 兼具出版學校教材。此外, 也在各州設立分會, 組辦學生活動、 文學座談會、聯誼會等等。

《蕉風》從專題策劃、欄目設計、稿件蒐集, 以十六開頁, 從每周改至每二周一 期, 持續地出版, 這份雜誌提出了一個有別於左翼傳統的文學實踐。《蕉風》執行雜誌功 能, 作爲一個聚合寫作群體的平臺, 從而有了把非左翼書寫集聚成可見的印刷、閲評、刊 行、出版的機制。128 基於創刊早期, 在地的寫作人尚待拉㨢, 而文學觀也仍在切碰摸索 的階段, 《蕉風》初期的稿件與藝評, 不免良莠參差, 特色雜無。

為了建立、塑造真正有別於左翼文學觀的文學立論與文學典範, 《蕉風》花了好幾年 的時間使這些文學聲明的區別、差異(distinct), 從模糊到明晰。如前所述, 一開始友聯諸 人南來時, 實際上也抱著推廣延續中華文化的精神, 其反共意識實際上與培植中華文化的 理念相連。此外, 雖然強調是純文藝刊物, 然而《蕉風》自創辦以來, 除了少數作者如方 天、羅紫、重陽、吕朗等人的小說寫得特別精細以外, 刊物整體上的文學表現仍舊乏善可 陳, 馬來亞化的呼籲佔據相當大部分的篇幅。惟至五 $\bigcirc$ 年代末第一波現代主義引入, 始為 其文學自覺萌芽的分水嶺。尤其是《蕉風》在一九五九第七十八期的改版宣言中提出的人 文思潮 $\ulcorner$ 人本主義」，以及同期刊出魯文〈文藝的個體主義〉為文學意識萌芽的重要標 誌。但是, 人本主義如何涉入當時華文文學的場域, 成爲推動改革的觀點, 而後是否又有 實質的延續，尚需還原到當時的歷史情境與人文思潮脈絡裏，再加以嶅清。

在《蕉風》創辦初期, 反共宗旨尚且模糊, 但到了姚拓掌編時期, 開始變得明顯, 當 時姚拓推出文壇雜話版, 以及報導新馬、臺灣與中國大陸三地文化動態的文訊版。文訊版 有時會增加報導世界各地的欄目。尤其文訊版以涵蓋三地的社會近況對比, 益發突顯出中

127 包括星洲日報、南洋商報、益世報的副刊, 可看到包羅萬象的文章。讀者來稿頗多提出反黃的觀點。當 時可獨當一面的左翼作家如姚紫, 在報上刊登連載小説。同時也有一些以奇情取勝的單篇小説, 亦有信箱 專家討論婚姻、男女兩性關係的專欄。

128 在此, 關於文學雜誌作爲一種社會行爲的功能, 採用了羅蘭巴特的説法, 他認爲搞文學雜誌本身並非是 文學行爲, 而是社會行爲。文學創作本身不會提供任何「現時性」, 但文學雜誌卻是在對世界提供一個現 時性的建議, 同時也在決定把其建議的現時性給「機制化」。羅蘭巴特著, 懷宇譯《文藝批評文集》, 北 京：中國人民大學, 2010, 頁 188 。 
共對文化與藝術的極大破壞。但是除了友聯社的反共宗旨之外, 當時東南亞區域尚有其他 的政治思潮, 影響在地的文化群體。譬如自從一九五五年亞非國家出席的萬隆會議過後, 東南亞區域也開始形成不支持美、蘇任何一方陣營的外交路線, 以及主張人權與獨立反殖 的國家主體意識。像這樣的區域意識, 可能也對《蕉風》的立場有些影響。這點將在稍後 第五章討論。

《蕉風》第七十九期提出的自由主義與個體主義, 可溯至二十世紀初期中國知識分子 引入的西方思潮。文學觀念會因為場域中, 經由相互對立的勢力、否定作用與詮釋的競 爭, 而有所消長起落, 譬如, 在布迪厄的舉例論述裡, 藝術之純與「創造」之觀念, 脫胎 自西方神學, 經由多方論述塑造而成。129論述與觀念演變的過程, 總牽涉到場域裡幾股勢 力的運作。

另一方面, 經由南來文人遷移到此地, 因流亡離散, 與此地特殊的政治因素對應, 包 括在地的左翼文學陣營提出不同立場。譬如在白圭的追憶敘述裡, 可以看得出《蕉風》編 輯的策略, 以建構他我特性對比的方式, 達到與彼方 (左翼陣營) 標明分界目的。譬如以 $\ulcorner$ 南洋視野」對比左翼的「北京情結」、以友聯的「志在文化教育」來與左翼的「志在政 治權勢」作出區別。130

在閱讀《蕉風》裡的評論時, 那反共的政治意識, 時或以隱藏起指涉對象, 但卻能讀 來會意的方式表達, 譬如在高峰一片論述詩歌美學的稿件裡, 仍有以左翼文學觀為參照的 句子：「一派是主張為文藝而文藝，一派是為主張文藝應為政治服務」「把文藝當作政治 的工具, 是我們所一向反對的」 131 。如此含糊道來的原因, 似乎也在於指稱對方命名上的 含糊與困難。那些大部分為延安文藝的支持者, 包含了學潮的學生、劇團等不同團體, 白 圭曾稱之為鏡子旗子派。有時候, 對於彼方的批評, 也透過比喻的方式, 諷刺地傳達。譬 如在一九五七年第三十六期, 申青曾從馬摩西的文章〈雞的幻想曲〉, 借題發揮, 補充成 另一個宛如喬治歐威爾《動物農莊》般的寓言故事, 「從今天起每隻雞都要勒緊腰帶, 加

129 布迪厄(Pierre Bourdie) 曾以「創造」這一概念, 如何經由場域裡具有不同功能的參與者, 動用不同理論 系統的思路, 發展成觀照藝術之創造「另一個世界」的純美學理論。「藝術家具有天賦神權即『想像 力』」及其生活方式, 這樣的觀點經常賦予藝術家以極其魅力的幻象, 卻制止人們去追問, 因而導致產生 相關觀念的途經軌跡與運作方式, 被懸置與隱蔽起來。布迪厄主張去探索這樣觀點, 以理解這些觀念, 是 如何經由生產場域中各方參與者的關係與其系統所產生的。皮埃爾 - 布迪厄著, 劉暉譯, 《藝術的法則一 一文學場的生成和結構》, 北京：中央編譯，2001，頁 204-352。

130 參見白圭, 《縷雲前書》(上), 八打靈：有人, 2016 , 頁 215 。

131 高峰, 〈酒逢知已千杯少——謹以此文作為本刊二周年的賀禮〉, 《蕉風》1 957 年第 48 期, 頁 4 。 
緊生產, 一定要完成一天一蛋的光榮任務」, 藉此嘲諷中共以鎮壓方式鼓吹劃一的生產制 度。 ${ }^{132}$ 這段借題發揮, 可能超出馬摩西的本意, 比較像是申青本身為了盡其反共任務而 寫。

從立意反共到採取非左翼的「中立」姿態，以及表明收稿「不分派系」的編輯宣言， 誠然, 這或如王梅香所言的, 反共在這些美援刊物總是採取隱蔽的運作方式, 但從另一方 面來說, 經由翻譯外國文學與引入現代主義, 結果卻打開了讀者的文學視野, 宛如接枝般 栽植、帶來開拓文學空間的效果, 不復止於美援而來的反共目的。與此同時, 為了應對更 複雜的在地政治語境, 部分作家如方天的寫實主義實踐, 甚且生成了具有在地特質的文學 觀點。而在稍後由黃崖、姚拓、徐東濱、白圭等帶領的評論（或文學觀點）論述中, 從寫 作的佈局、節奏、文字、隱喻、形式、結構, 乃至到後來白圭掀起的現代詩改革, 才使 《蕉風》真正開始䞤向「純文學」的意向。

\section{五、從流亡、離散到安居}

一九四九年中共掌權後, 有大量精英與國民黨軍人逃亡至香港。除了馬摩西之外, 這群南來文人都經歷了從中國逃到香港、再從香港遷至馬來亞、或經臺灣留學才至馬來 亞, 至少有兩段地理跨境的流動歷程。

馬摩西是被國民黨政府派駐馬來亞領事館服務的外交官。在國民黨敗戰之後，從一 九四九年到一九五。年之間, 在星馬一帶的國民黨領事館官員, 曾要求英殖民政府, 勿遣 送回中國。在國民黨敗戰、中國易權之後, 馬摩西選擇留在馬來亞, 轉職教書乃直到成爲 宗教官。

其他人則都在國共内戰結束先後, 紛紛離開中國, 曾群聚香港, 過後因新加坡友聯 分社創立才南來。如方天（原名張海威）, 其父張國壽原是中國共產黨創始人之一。在一 九三八年與國民黨交戰的長征過程中, 張國壽與毛澤東決裂。在一九四九年冬天, 舉家從 臺灣遷至香港。在港時, 張國壽曾任《中國之聲》社長, 後來也參與美援的計畫, 籌設第 三勢力人事。133 方天稍後加入陳思明與燕歸來創辦的友聯出版社, 在《中國學生周報》 擔任編輯。

132 申青, 〈人不如雞〉, 《蕉風》1957 年第 36 期, 頁 23 。

133 盧瑋鑾、熊志琴編, 《香港文化眾聲道》, 頁 120 。路海江, 《張國濤傳記和年譜》, 北京 : 中共, 2003 , 頁 76 。 
姚拓曾經是國民黨軍人, 據他在《雪泥鴻爪》裡的敘述, 一九四九年國民黨戰敗 後, 因共產黨的重農政策, 無法在家鄉覓得教職, 於一九五 $\bigcirc$ 年流浪到香港, 在香港成為 難民, 直到一九五二年始在《中國學生周報》任職, 一九五七年二月來到新加坡編輯《學 生周報》。134 此外, 白圭亦是在一九四九年到達香港。

大批南來文人都是在一九四九年後離開中國到達香港, 這亦包括後來應聘至檳城鍾 靈執教的蕭遙天 (一九五 $\bigcirc$ 年抵港), 以及後來定居在新加坡的詩人力匡。力匡原名鄭健 柏, 據自述是在一九五一或一九五二年抵港, 但張詠梅將這抵港年份提早, 根據力匡詩裡 有「來港已三年」或流動島上「已三年」之語, 當可推早至一九五 $\bigcirc$ 年或一九四九年。135 在香港, 力匡曾參與人人出版社的編輯工作, 一九五八年才離開香港到新加坡。136

在姚拓〈破屋更遭連夜雨〉這篇文章裏, 寫及當年在香港街上所見, 不少難民都像 是 $\ulcorner$ 大陸來的潰軍敗卒」; 在香港摩星嶺一帶, 常遇到過去的軍中熟人。137當時香港群集 了不少前國民黨軍政要人。一九五 $\bigcirc$ 年, 韓戰觸發中共抗美援朝, 從該年三月開始, 中共 把前國民黨黨員劃為反動分子, 開始鎮壓。138大量前國民黨人、年輕精英、知識份子逃來 香港。他們在香港創立文化機構, 其中如自由出版社、友聯出版社、人人出版社, 獲得美 援支持, 從提供研究成果、發行書刊到電影製作, 傳播至東南亞, 漸漸形成一股在海外華 人社會中圍堵左翼的文化勢力。羅永生(Law Wing Sang)的論文以「離散民族」概括這場 冷戰歷史中, 為左右兩翼意識形態所分裂的華人社群, 從美援綠背文化的影響、南渡文人 的文化使命、文化機構的創立乃至到為臺灣與中國分裂, 塑成極複雜的華人身份認同與想 象。139

\footnotetext{
134 姚拓, 《雪泥鴻爪》, 頁 475-503, 頁 527-530。

135 轉引自張詠梅《力匡作品研究》, 香港: 香港中文大學, 中國語言及文學碩士論文, 1996, 頁 2 。

136 力匡, 另有筆名百木, 一九二七年在中國出生一九五 $\bigcirc$ 年從中山大學歷史系畢業, 其生平亦參見選集所 附小傳, 包括烈浦、莫河編, 《力匡 散文·詩歌·遺作選》, 新加坡 : 錫山文藝, 2003 。莫河編, 《力匡散 文選集》，新加坡：新加坡海南會館，2009。

137 姚拓, 《雪泥鴻爪》, 頁 484 。

138 這鎮壓最早的指示當始於一九五 $\bigcirc$ 年三月, 中央政府發佈《關於嚴厲鎮壓反革命分子活動的指示》。楊 奎松的論文研究這場新中國第一次發動的鎮壓, 中共認爲當時中國境内仍然有不少國民黨分子以各種暴力 行動破壞社會安寧, 從一九五○至一九五三年, 大量「反動分子」遭到處決。Yang Kuisong, "Reconsidering the Campaign to Suppress Counterrevolutionaries" The China Quarterly, 2008, vol.193, p.102121.

${ }^{139}$ Law Wing Sang, "Cultural Cold War and the Diasporic Nation" Collaborative Colonial Power: The Making of the Hong Kong Chinese, Hong Kong: Hong Kong University Press, 2009, p. 131-148.
} 
這群隨著新加坡友聯分行創立, 從香港南來至馬來亞, 抵達後極明確表達在地認同 的南來文人, 本論文將之歸入離散的群體。若根據離散最普遍的定義, 離散意味著存在一 個歸返中心的、境外的家園, 它想象著有一真正的家鄉位於祖宗國或遙遠的出生地。

誠然, 如王賡武的憂慮, 他認為「離散」的政治弦外之音, 如同「華僑」這詞彙, 忽略了華人當地的公民身分, 這種以中國為中心的稱謂, 會引起當地其他民族對於華人效 忠本土的懷疑問題。 ${ }^{140}$ 由於這遙遠他鄉情感上的寄縛, 可能造成「本土」與「離散」被詮 釋為二元對立的兩個觀念之間。

這些南來文人的群體, 幾乎都在很短的時間內, 就發出在地認同的聲明。故將他們 歸為離散, 似乎仍難合乎現有普遍的離散定義。至今幾成傳統的離散理論, 仍以猶太人的 流亡及二十世紀以後黑人被奴販史為主。141根據希臘語詞源, diasporá, 派生自複合動詞 dia- 和 speírein, 意為「散射, 擴散, 分散, 分離」 142 , 都含有從中心往外輻射之意。

但是, 由於近年來的全球流動與政治局勢的變化, 使得離散理論有必要調整以闡述 各種各樣繁複的流動情境。這包括對於以色列的復國與巴勒斯坦人的流亡, 使學界對猶太 人離散論述的家園觀點, 出現了不同於傳統的詮釋; 亦使得族群與個體有去中心化的詮 釋, 如 Barkan 和 Shelton 所合編的《邊界、流亡、離散》一書, 便演譯過往那離散中心化 的思路 , 如何從歷史複述的預設框架中, 把猶太人的想像鎖牢在一個幾可喻為「模擬」 (mimesis) 猶太人的概念裡。143此外, 在有關華人的離散流動敘述裡, 亦有大量從香港涌向

140 出自王賡武的演講詞, “A Single Chinese Diaspora”。參見李有成, 〈緒論：離散與家國想象〉, 載李有 成、張錦忠編，《離散與家國想象：文學與文化研究集稿》，臺北：允成，2010，頁 $21 。$

141 李有成, 〈緒論：離散與家國想象〉, 頁 16 。

${ }^{142}$ Martin Baumann, "Exile" in Kim Knott and Seán McLoughlin(eds.), Diaspora: Concept, Intersections, Identities, New York: Zed Books, 2010, p. 20.

143 有不少學者對以色列復國主義抱持保留或批判的意見。譬如 Paul Allatson 與 Jo McCarmack 便提出, 即便 以色列立國, 依然有大量的猶太人繼續選擇離散在以色列外, 由於如今散佈全球各地的離散猶太人, 所獲 得的成就, 已經是非常顯著的事實, 故認為離散的處境對猶太人來說, 並不見得就遜於回歸應許之地。

Barkan 和 Shelton 從近代關於猶太人的討論, 包括對於二戰中遭到納粹滅族的歷史記憶, 指出這些論述已 經形成了不言自明的預設, 甚至強化了「模擬」的、作爲概念化的離散與現代性的猶太人想像。Joan Brandt 對猶太人放逐論述的反省, 也提出同樣的觀點, 在復國主義放逐論中想像的猶太人, 不僅僅只是作 爲種族的「猶太人」而已, 這樣的想像也延續復國主義論述中、那種以尊崇傳統來凝聚族人的、「模仿」 (mimesis) 的猶太人, 這樣的論述焵顧過去那些在漫長離散歷史中, 曾經在各個人文與文學領域促成現代 性成就的猶太學者, 他們恐怕都會被批評為背叛了這值得「模仿」的猶太人典範。Elazar Barkan and Marie-Denise Shelton, "Introduction" in Elazar Barkan and Marie-Denise Shelton (eds.) Border, Exiles, Diasporas, Stanford: Stanford University Press, 1998, p. 9. John Brandt, "Sharing the Unshareable: Jabés, Deconstruction, 
歐美各地的中產階級移民, 以及在世界華文文學中出現的跨語言與跨域流動等現象, 都在 挑戰過去傳統上以中國為中心的觀點。

這些去除中心的離散論述，都具有重新審視「主體認同」產生的用意。按照拉康的 精神分析學, 認為主體性認同本身乃是心靈匱乏而來的病徵, 主體認同當中就有他者化的 問題存在。也因此, 通過梳理歷史複述中的預設框架, 就帶有除魅之意。主體表達的兩 難, 恰如 Stuart Hall 指出:

我們每個人都必須從某個特定的時間和地方，從一個特定具體的歷史與文化中來開 始鴧與說。144

由於過往乃是不完整而且破碎的未完過程, 故而一個主體的訴說, 那敘述一開始就置身於 一個充滿碎片且未完的文本脈絡中。145 如周蕾引 Etienne Balibar 之語, 正是以人類學視野 之名, 文化表述才弗詭地在去殖民之後設置新的界線, 竟然使得文化霸權如同生物基因的 自然屬性那般，再度形成不遜於種族主義的偏見，把個體的聲音鎖牢。146

近年來在有關中國性或華人性的論著裏, 從在美華裔的文學研究, 到東南亞的華文 文學, 到跨語言的華人文學的討論, 或藉世界主義、或從華語語系的脈絡, 展開去中心化 的離散論述, 尤其近年移民條件的要求, 使得全球性的華人移民多以中產階級或高等教育 菁英為主，於是階級帶來的流動性、跨語言等都備受焦注，如 Chan Kwok-Bun 曾提出一 個在跨國性的以中產階級為主的世界主義移民觀點中，華人的身分認同因此更多選擇，不 復跟隨傳統的華人觀念。 ${ }^{147}$ 此外, 基於移民的多代或隔代的大量流動, 在落腳定居之後,

and the thoughts of the "Jews"' in Elazar Barkan and Marie-Denise Shelton (eds.) Border, Exiles, Diasporas. Stanford: Stanford University Press, 1998, p. 134-147. Paul Allatson and Jo McCarmack, "Introduction" in Paul Allatson and Jo McCarmack (eds.) Exile Cultures, Misplaced Identities, New York: Rodopi, 2008, p.13.

${ }^{144}$ Stuart Hall, “Cultural Identity and Diaspora” in Jonathan Rutherford (ed.) Identity:community, culture, difference, London: Lawrence \& Wishart, 1990, p.222.

145 Stuart Hall, "Cultural Identity and Diaspora”, p. 227.

146 Rey Chow, "Introduction: On Chineseness as a Theoretical Problem”, Modern Chinese Literary and Cultural Studies in the Age of Theory: Reimaging a Field, Durham and London: Duke University Press, 2000, p.5 \& 12 . 周 蕾在此呼應 Ian Ang（洪宜安）那著名的文章，關於「為何不說中文」。

${ }^{147}$ Chan Kwok-Bun, Chinese Identities, Ethnicity and Cosmopolitanism, London \& New York: Routledge, 2005, p.111. 
可能在同一個世代或隔上幾個世代再度移民, John Rex 甚至建議不宜再稱之為離散, 改稱 為「跨國移民社群」(transnational communities of migrants)。148

在 Emma J. Teng 一篇題為〈甚麼是離散華文文學中的華人〉論文裡，根據各種跨越 地理邊界與跨語言的離散文學研究, 打破以中國文學為中心的觀點, 使華文文學不再是由 中國內部的視角來定義, 因此能構成一個跨越地理邊界, 與更多華人文化重疊組成的多元 場域。149周蕾在一篇序文裡, 也認為這去中心化的離散論述, 重新賦予再想像場域的觀 點, 使華文文學因此不再是一個以中國大陸為中心的單軌音調, 盡管如此, 在各個文學和 文化理論的思路裡, 仍可見到中國性是如何被潛在地想像。150 洪宜安曾對杜維明與李歐 梵的離散論述, 提供辯證與反論的挑戰, 她提出杜維明的離散論述設置了對於文化中國的 想像, 也從李歐梵關於中國作家陷入迷戀家園與跨越邊境的想像裡, 反證 $「$ 文化中國」的 位置可能根本並不邊緣。151

不過, 上述這些去中心的離散研究, 所探索的, 仍多以二戰之後的近代狀況為主。 在四十年代末開始到五十年代期間, 因政局變動, 而不得不大量南渡至香港的文人, 雖然 不能說是在無國籍的情況下逃亡, 惟當時中國人與華人的國籍狀況, 全然迴異於近代東南 亞各國獨立以後的國籍狀況。

如何看待這群南來文人從港遷移到馬來亞這個過程的流動呢？是否可稱之為「自願放 逐」(voluntary exile)? ${ }^{152}$ 李歐梵曾如此自況, 以「自願放逐」來稱謂身在美國的旅居生 涯。 ${ }^{153}$ 但在一九四九年以後，從中國大陸，或因自身、或因家世的國民黨背景，或因個人 在自由與文化發展上的追求, 而大量逃到香港, 後又因參與新馬友聯出版社的工作, 南來

\footnotetext{
${ }^{148}$ John Rex, "Foreword" in Chan Kwok-Bun, Chinese Identities, Ethnicity and Cosmopolitanism, 2005.

${ }^{149}$ Emma J. Teng, "What's Chinese in Chinese Diasporic Literature" in Charles A. Laughlin(eds.) Contested Modernities in Chinese Literature, New York: Palgrave, 2005, p.61-80.

${ }^{150}$ Rey Chow, "Introduction: On Chineseness as a Theoretical Problem." Modern Chinese Literary and Cultural Studies in the Age of Theory: Reimaging a Field, Durham and London: Duke University Press, 2000, p 1- 24.

${ }^{151}$ Ien Ang, "Can One Say No to Chineseness? Pushing the Limits of the Diasporic Paradigm", in Rey Chow (ed.), Modern Chinese Literary and Cultural Studies in the Age of Theory: Reimaging a Field, 2000, p. 281-300.

152「自願放逐」, 來自於本人的論文〈安居在馬來亞：馬摩西的旅行、搬遷與家居物語〉投稿國立暨南國 際大學《臺灣東南亞學刊》，當時其中一位匿名審查委員給予的建議。

153 李歐梵曾以「自願放逐在中國的邊緣」來描敘自身從臺灣來到美國旅居, 他認為正是這樣的放逐, 才能 維持個人忠實面對邊緣處境的獨立精神, 因為對原鄉的過度迷戀, 已經剥奪了中國作者原可從忠實面對自 身邊緣處境, 而體驗到的罕有優勢。李歐梵, 〈在中國話語的邊緣〉, 《現代性的追求 : 李歐梵文化評論 精選集》，臺北：麥田出版股份有限公司，1996，頁 475-497。
} 
馬來亞, 且可能因此順利獲得居留權的文人, 是否也可以稱之為 $\ulcorner$ 自願放逐」? 盡管是否 因此獲得維持精神的獨立性, 這結果因人而異, 但是, 按照牛津英文辭典上的解釋, 放逐 或流放(exile)這個詞彙，本身就包含「被強迫」或出於「抉擇」的動機。若根據英王欽定 本聖經辭典, 「自願放逐」(voluntary exile)則是因為出於恐懼或擔憂、厭惡、不滿或被區 隔孤立的原因, 導致一個人拋棄家園, 移居國外定居。Exile 源出拉丁文 exilium 和 exul, 意指暫時的驅逐, 這詞彙亦曾在某個時候指「避難所」。154 若依據希臘的語彙與傳統上 按照猶太人離境、那具有中心化本質意義的離散(diaspora)脈絡來解釋, 便會得出離散與 放逐兩者之間, 極為明顯的區別意義, 即流亡總是發生於政治排擠、壓迫、戰爭等而來的 $\ulcorner$ 別無選擇」的狀態, 有負面的「折磨受苦」痛楚之意, 「喚起錯置、難民狀態」以及可 以回歸家園的想像; 與此相對, 離散則是在地理與身分方面, 有較多選擇餘地。 ${ }^{155}$ 在 Schlesinger 研究德語作家 W.G. Sebald 異鄉書寫的一篇論文裡, 他深刻地寫道, 流亡也使 一個人被迫處於「無國籍的等待與中間過度(Liminal space)的狀態」, 由於分離, 邊緣, 失去公民的身分與國籍, 使一個人宛如處於「無國籍的等候室」內。在放逐的狀態中, 個 體的身分也可能會發生更換, 轉移, 包括可能會獲得國籍, 從「放逐者」變成「移民」。 156

那麼, 當這群非左翼文人南來馬來亞時, 可以把他們看成當時是處於「無國籍」狀 態的一群人嗎? 無論是一九○九年清政府頒布的大清國籍條例, 抑或一九二九年由國民黨 政府制定的中華民國國籍法, 都沒有任何條例撤回逃離者的國籍, 除非逃離者申請辦理放 棄國籍。在中共執政以後, 舊的國籍法仍然沿用, 直到一九五五年萬隆會議之後, 才有改 改變。157故此, 這群南來文人, 如姚拓、力匡等人, 理當處在仍可被歸為具有 $「$ 中國國

${ }^{154}$ Martin Baumann, “Exile.” Diaspora: Concept, Intersections, Identities, 2010, p. 19.

${ }^{155}$ Paul Allatson and Jo McCarmack, "Introduction." in Paul Allatson and Jo McCarmack (eds.) Exile Cultures, Misplaced Identities, New York: Rodopi, 2008, p.13.

156這譬喻式的說法, 來自 Schlesinger 的論文 “W.G. Sebald and the Condition of Exile.” 轉引自 Devleena Ghosh, "Coda: Eleven Stars Over the Last Moments of Andalusia." in Paul Allatson and Jo McCarmack (eds.) Exile Cultures, Misplaced Identities, New York: Rodopi, 2008, p.279.

157 雖然一九四九年人民共和國已經成立, 但還未頒布新的國籍法。原來的國籍法仍可沿用, 使到在中國境 外居住的華人, 甚至土生華人和逃離渡港者, 都仍屬中國子民, 且可擁有雙重國籍; 至到一九五六年周恩 來跟印尼簽訂「關於華僑的雙重國籍問題條約」之後, 才明確說明中國不再接受雙重國籍, 已經在國外定 居的華僑, 必須在在地公民權與中國國籍之間作出選擇。許文堂〈越南華人公民地位的變遷〉, 陳鴻瑜主 編, 《海外華人之公民地位與人權》, 臺北：華僑協會總會, 2014 , 頁 148 。李恩涵《東南亞華人史》, 臺北：五南，2003，頁 590。Leo Suryadinata, “China's Nationality Laws and the Chinese Overseas.” in Jayati 
籍」的情況下, 從家鄉逃到香港, 再從香港來到馬來亞。但在此的 stateless, 乃是指他們 在 $\ulcorner$ 自願逃亡」到香港時, 已經做了放棄出生之地的家園、另外擇地定居的打算。以當時 馬來亞聯合邦對公民權討論得紛紛揚揚的狀況, 能否獲得公民權是個困難的問題。但由於 友聯創辦時在香港的反共背景, 以及和馬來亞華人執政黨的友好關係, 大部分來馬的編 輯, 後來都有獲得居留權。158故此, 到底他們是否處於「無國籍狀態」, 或這樣的狀態持 續多久; 或因個人條件不同, 故國家體制給予他們的承認與接納, 也各自有別; 其中有者 如馬摩西的南來情況較為特殊, 也將在第五章裡特別討論。

這份論文以「離散」來概括這群文人南來的流動經歷。但言及離散, 並不排斥在地 與本土。從跨界到安居, 這過程中離散與本土既是共存, 亦相互印證。《蕉風》的家園建 構，其實懷有冷戰中與左翼競爭、獲取發言位置的作用；一邊催化兼教育讀者，產生在地 認同的情感, 另一方面, 對本土的觀察以及敘述在地生活而湧現的感情, 亦不無感動自身 以投入在地，建立彼此的共同理念，以此地為家，來結束過渡中的無國籍狀態。

最初在方天擔任編輯的時期, 馬來亞化大行其道, 《蕉風》並沒多少版位予南來文 人去抒發異鄉或懷鄉書寫, 但在《學生周報》, 以故鄉為題材的文章, 自創刊以來卻篇幅 不少。 ${ }^{159}$ 以友聯南來的編輯而言, 在地認同與離散情境, 應該是同時並存的。一些文人數 年後回返香港或再遷移到歐美國家, 不少因為中共執政而流亡南來的文人, 包括姚拓、馬 摩西、力匡、蕭遙天、黃潤岳等, 都在這裡定居終老、或至退休, 且投入於在地的文化或 華教事業，白圭自身亦在此定居長達二十多年。

在討論這群非左翼離散文人的貢獻之時, 也有些問題與侷限, 需要提出。如薩伊德 認為流亡的孤獨情境所予人的獨立性, 必然源自於與集體的民族主義保持疏離, 才能小心 維持其主體性：

民族主義關乎群體，但放逐給人带來的極爱尖鋴的感知，卻是人在群體外邊的孤 獨感：那種自己不屬於任何公共、社群居處的剝集感。那麼，一個人要如何克服 這種流亡的孤獨感時，同時又不掉入那周遭的民族主義傲慢的言語、那種集體的

Bhattacharya and Coonoor Kripalani (eds.) Indian and Chinese Immigrant Communities: Comparative Perspectives, Singapore: ISEAS, 2015, p.43-54.

158 奚會暲口述, 王建武口述, 《香港文化眾聲道 第 1 冊》, 頁 70 , 頁 152 。

${ }^{159}$ 以一九五六年的《學生周報》, 就有秋貞理, 〈王麻子的剪刀〉, 第 4 期, 論著版。黃思騁, 〈艱苦的 生活〉, 第 67 期, 生活與思想版。郭良㯖, 〈一隻棉鞋〉, 第 $78-79$ 期, 穗華版。姚拓, 〈雨滴織成的 回憶 $\rangle$, 第 79 期, 穗華版。 
抒情與激情裹頭呢? 如果一邊強調著流亡的極端經歷，同時又給捲入民族主義狂 熱的宣言裹，這到底有什麼好處呢？民族主義與流亡之間的關聯是否本質性的? 抑或僅是雨種互相衝突的偏執而已? ${ }^{160}$

但在這份論文研究的個案中, 《蕉風》似乎在挑戰中共論述之餘, 同時也支持了馬來亞的 國族論述。馬來亞雖然也和香港一樣是英國人的殖民統轄區, 但馬來亞的多元種族, 畢竟 存有政治地位上的差異。不比香港雖是英國的租借地, 但英國人卻是外來的殖民者, 香港 邊界仍然對南來者開放。在馬來亞, 由於英國人與馬來統治者的協商關係, 使得他們願意 承認馬來人的土著地位, 因而其他種族則相對為外來者。161 在這情況下, 華人與其他種 族的效忠常備受質疑。故此, 來到馬來亞的友聯刊物, 《蕉風》與《學生周報》的編輯, 之所以在短時間內, 就承認自己是 $\ulcorner$ 馬來亞華人」，這樣的表態或許是不得不然，論文第 二章將對此再做討論。此外, 對於《蕉風》的編輯隊伍而言, 更大的意義是, 通過表明對 在地的認同, 也意味著自己已經割捨了對中國的認同。彼時仍有大量華人以中國為祖國想 像，而方天與其他南來文人的在地聲明，就表明他們不與彼等（中國＝祖國）同路。

與此同時，他們又被收編為國家體制的合作者。流亡始於國共分裂易權的一九四九 年。以反共為前提, 其他有助於反共的機制, 就有可能成為友聯的「同路人」。譬如, 以 馬來亞的情況而言, 他們就與當時的國族論述配合, 也幫助馬華公會競選。從這點來看,

《蕉風》刊物內部分的「馬來亞化」報導, 實是與英屬馬來亞聯邦政府的國族話語配合、 兼為反共策略的一環。在當時, 南來文人要在東南亞䚇職並不容易, 根據趙綺娜論文提 及, 一九五 $\bigcirc$ 年代, 美國一個接受華府資助的民間團體「援知會」, 在幫忙配置、遷徙因 逃避中共政權, 而流亡香港的知識分子難民時, 難民們多數首選美國, 其次東南亞, 然 而, 要幫他們在東南亞䚇職比想像困難, 其中一個原因是出於東南亞政府對華人有所猜 忌, 尤其對華人在當地辦校和堅持的文化感到不滿。 ${ }^{162}$ 雖然根據現有的研究, 《蕉風》的 成員並非是由「援知會」安排南來, 「亞洲自由協會」在資助非共菁英的出版社與媒體以 及安頓相關人員的時候, 他們也面臨相似的問題。在新加坡友聯社的個案裡, 則因有馬來 亞獣共需求的穿接連線, 使得美援文化資助的出版社業務得以延伸到東南亞, 同時也由此

${ }^{160}$ Edward Said, "Reflections on Exile", in Marc Robinson (ed.), Altogether Elsewhere: Writers on Exile, Boston: Faber \& Faber, 1994, p. 140.

${ }^{161}$ R.K. Vasil, Ethnic Politics in Malaysia, New Delhi: Radiant, 1980, p. 13-14.

162 趙綺娜, 〈冷戰與難民援助：美國「援助中國知識. 人士協會」，一九五二年至一九五九年〉, 頁 98 。 
增添安頓南來文人的去處。與此同時, 《蕉風》邀稿的本地作家, 亦有不少是四九年之後 南來的非左翼作家, 包括力匡、馬摩西、蕭遙天等, 都在學校執教, 在適應當地的過程 中, 對於其多元族群政治結構的敏感之處, 理當有所體會。《蕉風》的編輯既受到馬華公 會的政治要員梁宇臮邀請南來, 同時又仍與亞洲自由協會保持聯繫, 同時又必須與本土的 官方權力機制合作, 面對多方權力的政治要求與禁忌, 以獲得合法性的批准與位置, 因而 同時與本土的權力體制與諸多華人文化團體, 呈現出極微妙複雜的關係。

根據 Stuart Hall 對於離散者的理想（他自言是隱喻式而非字面義的）中，乃是因著 離散身分, 而得以與國家與環境保持異質與差異 :

我這裡要談的離散, 並非是本質性的或霸權的, 而是屬於異質與混雜的; 透過混 雜, 一個能真正體現與活出差異的身分認同。離散的身分認同, 當是屬於那些能 夠不斷通過差異來蜕變轉化, 重新生產、再產自己的人們。163

恰如 Stuart Hall 對離散的引用, 那延伸向多元、混雜與持續變動不居的離散, 它實則並不 與本土或在地的意識抵觸。換言之, 即便認同在地, 或對所居之地日漸懷熟悉的感情, 或 積極投入於認識、參與、奉獻在地進行的各種活動, 離散也並非全然結束。主體意識到那 投入之中, 仍然與結構之間存在的隙縫, 不去妄想它能在與國族或集體和解後, 便密合無 痕一與其說離散有個明確的「終結期」, 不如它總是與本土、地方意識, 同時並存, 浮 動。因此, 離散與本土, 兩者可以並不是全然對立的狀態。為了終結離散, 便得轉向認同 本土, 以本土為家; 然而自覺為身居外來者, 又不能不與當地政治小心翼翼, 探觸距離; 其中有者如蕭遙天、李定華的書寫, 筆下有不少觀察本土與㽎酌自身的文化觀點與在地環 境實情的差異, 馬摩西的書寫也不無探問自身對於在地的情感與認同意識, 正是離散情景 與心理的顯現。

職是之故，這裡的離散不以一個起源的境外家園為中心。在去除中心化的論述裡， 離散也可能與「在地」的意識並存。主體會以為, 為了結束這離散的無家狀態, 主體必須 投入在地。如果主體投入在地, 但又未能被那在地的權力結構接受。對其所落腳生活在地 的結構來說, 這外來個體 (包括幾代之後仍然被認為是外來族群) 仍然呈現為異質的特 殊, 包括其文化、宗教、語言、日常習性等, 且必然會為了維護自己的生存生態, 如在此 權力結構中所佔據的位置, 與各種資源、權力之平等以及和其他族群的關係而與國家的官

${ }^{163}$ Stuart Hall, “Cultural Identity and Diaspora”, p. 235. 
方論述展開拉鋸與競爭。雖然在權力結構中位居邊緣, 然而, 這並非全然沒有角力、交 流、影響或行動的周旋策略, 包括在國族的話語中騷動, 維持差異、發言和為自己的歷史 敘述發聲的策略。自身的視角就不得不持續變化, 認同的詮釋也就不斷經歷重塑。但這樣 的過程之中, 主體穿越各種視角框架出人, 沒有固定的位置, 甚而賴以為憑的「主體性」 認知, 其實不無問題, 如拉康所言, 主體的構成本身就是病徵。在主體的界限遭到瓦解的 瞬刻, 觀看, 就不得不從諸多斷裂的外邊狀態, 往所謂族群的意識內裡審視, 而後, 又不 斷從內往外看。由於所有據點都不穩定，單純而純粹的本土，便也不能成立。

然而, 在此, 另一問題是, 僅只是地理上的遷移, 不一定就會產生反思與抽離的思 考。基於這樣的離散乃是一種隱喻式的情境, 換言之, 遷移不一定能帶來抽離或批判的思 考, 世代居留者也不是不能察覺到自身與所在社會的邊緣性、自身與國家體制之間的異殊 因素。同時, 在日常生活中, 由於不得不承受各種不穩定的、因資源有限而來的打擊, 即 便不再是移民, 而是公民, 而且仍然住在這裡, 但因著這種種的艱難, 他也可能在所有可 茲介人的交流網絡上（當然可決定疏離、緘默或參與發聲）一一同時與民族主義的狂熱、 與集體激情、與所有的人際網絡, 保持疏離的前提下, 就能夠在孤獨的處境中, 提出獨立 的觀點——對國家體制以及國族論述與本土相關的種種問題，提出質問。

在去中心的意義上, 使用離散這詞彙, 並不意味著否定在地經驗, 也不代表仍然堅 持對祖宗國的認同。世界各個地區的同語系文學中, 文學創作主體經過世代的安居、融 人, 因而有了國籍的身分認同, 不復以最初祖輩的遷居起點為中心（譬如祖宗國為中 國), 可能同時有兩地（或兩地以上）都認同為家鄉的牽連（或者沒有）, 但以離散作為 跨域流動以及落腳之後, 數代後裔的生存情境, 它可以提供同時與多方面權力論述中心, 保持抽離、旁觀而加以審視的可能, 無論是針對文化強勢的祖宗國, 抑或針對國族論述與 本土主義, 都保持謹惕、批判與反思的距離。那麼, 《蕉風》南來文人的書寫, 在展開與 中共迴異、抵抗的詮釋之餘, 他們也能夠同時與本土的國族論述, 保持「批判與反思的距 離」嗎?

出於冷戰與文人離散越境的這段歷史, 才使得諸般在地的地緣因素, 與南來的「反 共」宗旨, 交錯衍生出相當獨特的文學體質。作為反共刊物, 以《蕉風》的銷量、稍後轉 向現代主義、趨向菁英階層的文學品味這點而言, 它能施加於大眾的影響力, 可謂為「局 限的收效」。然而在起步階段, 它確確實實以中共延安文藝為參照, 批評、反對其觀點, 同時也樹立自身的文學定位與論述。爾後, 它也在那原來奉行現實主義為主流的馬華文壇 
上, 另僻蹊徑, 掀起現代主義運動, 帶來典範遞變。如前所述, 友聯文人對文學的追求, 並不十分受到美援資助者所重視, 現代主義的發展, 可能確實如白圭所言的, 超出了當初 反共宗旨的策畫, 比較起現代詩改革的論述, 當時同期推出的 $\ulcorner$ 人文主義」才是反共的正 題。現代詩的改革, 恰如白圭所言, 較傾向於文學上小眾的開拓。但它所提出的去政治話 語的、偏向寫作美學的探索, 可能填補了當時文學上普遍所實乏的、個體話語的需求。

無可否認, 從現代詩起步的現代主義, 不難發現其對政治的迴避。箇中緣故, 除了其 牽絲萬縷的創辦淵源、資金來源、為馬來亞官方權力網絡所收編的關係, 當時緊急狀態時 期的監控嚴峻, 也使人深為忌憚。更加深刻的原因, 或許出於分裂流亡的創傷, 使得情感 纖細敏感者如白圭, 不欲多談政治。尤其對於千篇一律謾罵式的政治話語, 感到厭倦。他 曾引何振亞之言：

政治使人分隔，文學使人瞭解，在文學的天地裡，馬新同一方圆，此際踓值分隔的 風頭火勢，卻是文學超越政治的最佳時刻。164

$「$ 政治使人分隔，文學使人瞭解」點明了流亡文人長期以來受到的歷史積成的創 傷。遷移離散他鄉, 在嚴峻的政治氛圍中求存。對於在地的政治, 雖然表面上表達認同, 但其落葉歸根的態度, 也使他們對在地的政治問題, 相當保守壓抑。就此而言, 現代詩的 文學追尋，不無治療離散與流亡創傷，抒發與昇華的意義。

\section{六、文獻回顧綜述}

以方修為主的左翼史觀與馬華文學史系列, 曾經漠視《蕉風》與《學生周報》的成 果, 未將之列入馬華文學史。165 學界近年來頗著重闡述《蕉風》與《學生周報》的文學 特質與貢獻, 以補充過往文學史的關漏。惟在這樣的前提下, 多數肯定非左翼文學的論 者, 肯定現代主義的文學成果, 然而, 對其侷限, 往往也較為網開一面。雖然馬來亞左翼 的現實主義, 在獨立後漸趨嚴厲的政治監控中, 長期以來的反映現實論, 幾近於虛有其 表, 敘述公式也僵化老套。然而, 總的來說, 現代主義對於政治的逃逸, 或因其美學與闡 釋符碼的菁英化, 而趨向隱晦曲折的表達, 可能都需要根據文本再做䦐釋, 既非否定其語

164 白圭, 《縷雲起於綠草》, 頁 97 。

165 白圭, 《縷雲起於綠草》, 頁 113 。 
言蛻變與可能䔋含的政治意義, 但亦非一概視之為語言反叛的姿態。此外, 現代主義白堊 紀的起步, 始於詩歌, 如白圭沿襲梁宗岱詩觀, 傾向於想像一個「獨立純粹的宇宙」, 後 者可能有以法國詩人保羅 - 梵樂希(Paul Valéry)的象徵主義為基礎。白圭也從中國民國時 期的現代詩歌那裡, 汲取其內在抒情的現代詩風, 這種內在抒情傾向個體化的特性, 並不 能直接等同於冷戰時期美國輸入的自由主義價值觀。

目前對《蕉風》的研究, 多集中於現代主義成果, 尤其是以一九六 $\bigcirc$ 年陳瑞獻掀起 的第二波現代主義運動。可見於張錦忠《南洋論述一一馬華文學與文化屬性》書中收錄的 單篇論文, 〈文學史方法論：一個複系統的考慮; 兼論陳瑞獻與馬華現代主義文學系統的 興起〉。張錦忠本書是以新興文學的複系統來考察《蕉風》的現代主義運動, 提出雙重 性、多重性同時並存, 從諸多面向, 闡明馬華文學現代主義的屬性, 也肯定《蕉風》對於 現代主義典範轉移的貢獻。張錦忠在二○一一年出版的《馬來西亞華語語系文學》，也整 理編彙了相當多與《學生周報》、《蕉風》及其相關群體作家的資料。166 方桂香的博士 論文《新加坡華文現代主義文學運動研究——以新加坡南洋商報副刊《文藝》、《文 叢》、《咖啡座》、《窗》和馬來西亞文學雜誌《蕉風月刊》為個案》, 把研究的時間範 圍定在新馬分家、新加坡獨立以後, 一直到一九八三年。方氏對《蕉風》月刊的分析, 集 中於第九章, 其中關於《蕉風》的研究, 鎖定在陳瑞獻加入《蕉風》推行現代主義的一九 六九至一九七四年間。167

張錦忠、方桂香對於《蕉風》奠定與開創現代主義的貢獻, 持肯定的態度。莊華興 則對於現代主義的文學成果與風格, 抱持疑問。其文〈語言、文體、精神基調：思考馬華 文學〉認為馬華文學現代主義以降，尤其在八十年代批判頓挫、缺乏政治抵抗與思考，流 於中國追思悠想的抒情書寫。168莊華興認為馬華文學現代主義, 從一開始吸收的美國式自 由主義, 在與此同時, 也失去了過去左翼文學曾有過的批判性與精神基調。莊華興 < (民 國) 文學遺址: 文學史再勘察〉也認為, 友聯南來文人實際上是在馬華文學中, 建構一個

\footnotetext{
166 張錦忠，《馬來西亞華語語系文學》，吉隆坡：有人，2011。

${ }^{167}$ 方桂香, 《新加坡華文現代主義文學運動研究——以新加坡南洋商報副刊《文藝》、《文叢》、《咖啡 座》、《窗》和馬來西亞文學雜誌《蕉風月刊》為個案》, 新加坡：創意圈，2010。

168 莊華興, 〈語言、文體、精神基調 : 思考馬華文學〉, 《思想 : 大馬華人與族群政治》2015 年第 28 期, 頁 199-220。
} 
能延續民國文學的場境。169「文學遺址」，也說明所欲延續與重建者，源於那已成逝去廢 噓的歷史斷裂時刻。論文將在稍後延伸討論。

對於現代主義所帶來的偏重語言美學的趨向, 論者如張光達在〈文學體制與六 $O$ 年 代馬華現代主義〉文內, 曾經賦予頗富政治意義的解釋。他認為到了六 $\bigcirc$ 年代, 馬華文學 在長期的政治言論監控以及文學身分被國家邊緣化的處境之下, 其書寫根本無法直面現實 的敏感議題, 即便是自詡以現實批判為原則的現實主義陣營, 在書寫上也相當受困, 因而 無法達到反映現實的理念。但與現實主義的處境比較之下, 馬華現代主義作家, 則選擇走 另一條路, 即透過文學語言「借用／翻譯另一種異化的語言（觀念）來遁逃／拒絕融匯入 馬來文化為核心的他者異文化」。170從六 $\bigcirc$ 年代開始，現代主義在馬華文學影響力漸長， 且引入了豐富的西方藝術語言, 張光達認為它之所以能席捲年輕一代的作者, 是由於受到 整體政治環境、民族意識的本土處境逼迫所致。現代主義是遺忘文化母體的求變者, 轉向 從西方文化資源尋求一個足以抵抗國家政體、同時亦是填補與母體切斷之後, 餘留下來的 空白位置的替代物。171

溫任平〈馬華現代文學的意義和未來發展：一個歷史的回顧與前瞻〉是早期馬華文 壇論述現代主義的文章, 試圖梳理現代主義的緣起與概括其未來的走向。他提出白圭的 〈麻河靜立〉應該為馬華文學現代主義詩歌的起點, 由此把現代主義起步的時間推至一九 五九年。172他也認為白圭的現代詩創作意念, 是受到臺灣現代主義思潮所影響。但張光達 認為, 馬華現代主義的萌芽, 也必須從其與在地場域應對的語境脈絡來看, 不能簡單視之 為承其餘緒; 臺灣現代詩當時要反抗的是, 國家反共政策下的權威控制, 而馬華現代詩的 反抗對象, 主要則是當時已在文壇上盤據多年、且其文學創造力已經僵固了的現實主義主 流。173

無論是相對於六 $\bigcirc$ 年代的現代主義, 抑或相較於左翼的現實主義研究，論者對五 $\bigcirc$ 年代以《蕉風》為刊登據點的現實主義, 似乎興趣較少。極少數的研究, 夾存於專書論著

\footnotetext{
169 莊華興, 〈戰後馬華 (民國) 文學遺址：文學史再勘察〉，《台灣東南亞學刊》第 11 卷第 1 期, 2016 年, 頁 7-30。

170張光達, 《馬華現代詩論——時代性質與文化屬性》，臺北：秀威，2009，頁 56。

171 張光達, 〈文學體制與六 $\bigcirc$ 年代馬華現代主義〉, 《馬華現代詩論——時代性質與文化屬性》, 臺北 : 秀威, 2009, 頁 39-72。

172溫任平, 《文學·教育·文化》, 霹靂 : 天狼星詩社, 1986。

173 張光達, 《馬華現代詩論——時代性質與文化屬性》, 頁 44。
} 
的少數章節之中, 或者單篇發表的論文裡。謝詩堅的《中國革命文學影響下的馬華左翼文 學 (1926-1979)》，在撰述《蕉風》早期與左翼對峙的狀況方面, 倒提供不少資料。書 中有幾個章節概述《蕉風》與《學生周報》的創辦經過, 與左翼陣營之間的衝突, 包括遭 到左翼杯葛的大致情況, 也介紹數位參與編輯《蕉風》的南來文人及其背景, 當中只有方 天與姚拓才以較長篇幅詳細介紹生平經歷。關於左翼陣營對《蕉風》與《學生周報》的批 評, 也參考一些學潮運動的彙整史料, 尤其鄭文波、楊景水《二十世紀五十年代學生運動 史料匯編》。174

張錦忠對《蕉風》的研究與撰著甚是豐富，無人能出其右，不過，張錦忠過往的論 述比較集中處理現代主義。對於一九五 $O$ 年代的在地化現實主義, 處理較少, 但計畫摘要 〈文學離散與馬華文學的寫實主義〉提出幾個重要的觀點, 包括根據馬森的觀點, 以「現 實」和「寫實」分指兩個不同的意識形態與文學立場, 前者作爲社會主義的現實主義, 而 後者作爲文學傳統上反映現實、描摹現實逼真的文學理念。175以《蕉風》裡方天的寫實主 義小説為主要個案, 探索寫實主義對於離散南來文人的意義。惟過後卻沒有再延續撰寫成 論文, 但近幾年來在《南洋商報》撰寫的專欄篇章, 對方天的生平資料也作了補充。176

林春美的一系列關於《蕉風》早期創刊的論文, 從馬來亞政治歷史、友聯的反共立 場, 集中論述冷戰獨立時期開始的非左翼文學, 提共了精闢見解。論文闡明了國家建制時 期, 政治語境對於《蕉風》的深刻影響, 也追溯各造「馬來亞化」的概念。重要的文章, 包括〈獨立前的《蕉風》與馬來亞之國族想象〉 ${ }^{177}$ 以及〈非左翼的本邦：《蕉風》及其 $\ulcorner$ 馬来亞化」主張〉 178 , 闡述一九五七年前《蕉風》内的國族想象論述，她提出《蕉風》 的在地化主張, 並非是感性書寫, 實際上亦是出於冷戰反共的策略; 林春美的第二篇論

174 鄭文波、楊景水, 《二十世紀五十年代學生運動史料匯編》, 全馬華文中學生捍衛華教運動五十周年工 委會, 2009, 頁 166-167。

175 張錦忠, 〈文學離散與馬華文學的寫實主義〉 (Literary Diaspora and (the Rise and Fall of) Realism in Mahua Literature），中山大學人文中心離散論述研究群組計畫， 2007 http://zephyr.nsysu.edu.tw/researchcenter2/document/060908\%20\%E5\%BC\%B5\%E9\%8C\%A6\%E5\%BF\%A0\%E 8\%80\%81\%E5\%B8\%AB\%EF\%BC\%BFLiterary\%20Diapora\%20and\%20Realism\%20in\%20Mahua\%20Literatur e.doc

176 張錦忠，〈小寫方天〉，《南洋商報》，2015 年 8 月 31 日，南洋文藝版。

177 林春美, 〈獨立前的《蕉風》與馬來亞之國族想像〉, 《南方華裔研究雜誌》 2012 年第 5 期, 頁 201208 。

178 林春美, 〈非左翼的本邦：《蕉風》及其 $\ulcorner$ 馬来亞化」主張〉, 《世界華文文學論壇》2016 年第 1 期, 頁 71-79。 
文, 也點出了《蕉風》與左翼早期馬來亞化論述的差別, 指出後者的論述受限於階級的鬥 爭。

伍燕翎、潘碧絲、陳湘琳發表的論文〈從《蕉風》（1955-1959）詩人群體看馬華 文學的現代性進程〉, 針對《蕉風》在前五年草創階段所刊登的詩作進行整理, 發現這些 詩歌在意像、空間感以及情歌上都表現本土認同, 認為《蕉風》早期對現代性的認同, 包 含了本土認同以及現代情感、生活方式和心理。179 並認為現代性的意義可擴大至對於當 下時空感的體會。從這樣的詮釋出發, 提出《蕉風》對現代性的追求, 比起一九五九年改 版後的現代主義思潮還更早。只是這篇文章關注的是現代性, 而非現代主義。這篇論文未 能處理到後期《蕉風》追求現代化的思潮變遷因素。

關於蕉風創刊早期的歷史, 有幾個相當關鍵的問題, 包括《蕉風》的反共立場、與 美援文化的關係, 長期以來懸而未決。雖然長期馬華文壇上就有傳言《蕉風》與《學生周 報》為接受美援的刊物, 惟基於資料上的不足, 上述多篇論文皆對此有所保留, 懸而難 論。但近年來多份文獻, 相繼出爐, 包括前述香港中文大學盧瑋鑾、熊志琴編輯整理的口

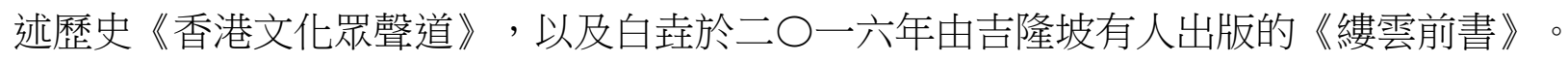
兩本均屬來自當事人追憶的重要資料。《香港文化眾聲道》受訪諸人的口述資料, 頗說明 了友聯社與美援反共的關係, 惟對於《蕉風》與《學生周報》作為友聯旗下接受美援的項 目與否, 始終難獲確認。

在此需要討論《緀雲前書》做為參考資料的可能性與局限。此書分成上下冊, 極富 自傳性質, 兼具追憶友聯人南來的歷史風雲記事。惟此書開頭屝頁就印著馬克吐溫的名句 $\ulcorner$ 真實比虛構更離奇」以及白圭自擬 $「$ 我寫的是 fiction, 你認真, 是你的想像」, 頗有虛 構與真實之間浮游難定的提示。白圭曾經提到趙滋藩的兩部小說：「《半上流社會》與 《半下流社會》, 即以真實人物作線, 寫那個時代的風雨人生。」趙滋藩的小說「涉及多 位日後頗有作為、影響深遠的文人, 用同音字、同義字或反義字, 代表真實人名」, 本尊 身份總是「有迹可循」。180 白圭寫《緀雲前書》亦仿趙滋藩作風, 大抵以這樣的方式, 使他較能從容襄貶。此外, 其他地方也與趙滋藩《半上流社會》有些相似, 譬如《縷雲前 書》也納人了一個不具姓名的老人 (在趙滋藩書中, 這位老人應該是自由文化運動先驅何

179伍燕翎、潘碧絲、陳湘琳, 〈從《蕉風》（1955-1959）詩人群體看馬華文學的現代性進程〉, 載《西 方圖像: 馬來西亞英殖民時期文史論述》, 加影: 新紀元學院馬來西亞與區域研究所（馬來西亞歷史研究 中心）, 2011, 頁 83-96。

180 白圭, 《縷雲起於綠草》, 頁 33-34。 
魯之; 在白圭書中則可能是錢穆，何魯之則現身為「老人」的朋友；故與趙書實有相映呼 應之意) ${ }^{181}$, 為第一人稱的「我」徬彺於南來之際, 點撥疑慮。 ${ }^{182}$ 白圭寫作此書, 一開 始就自嘲虛構, 實際上也蘊含了重敘與回顧當年南下初心, 也有再度自我肯定之意。作為 參考材料, 參考者不得不面對從那書寫符碼指涉向參照現實的壏攰地帶。人的記憶與追 憶, 本來就充滿了選擇、重釋、注釋的成分。從局部片段加以串連, 猶如編織一張充滿隙 縫的濾網。從過往已逝繁雜, 重組、篩選、濾出、使之浮顯, 連緅成形, 這樣的詮釋過 程, 也使得自傳與歷史敘述含有虛構成分。白圭書中, 時而依照章節處理不同議題或個 案, 包含陳述人物、事件、時間、歷程與對話, 從個人親身經歷、或根據檔案資料加以補 充。所敘人事，包括結識馬華公會政要與在地名人（如林碧顏律師、梁宇臮等人），皆能 一窺友聯文人抵達馬來亞之後, 展開的人際網絡、活動場景、編輯的反共立場、現代詩展 開起步的階段（這部份多與《縷雲起於綠草》重疊）、《學生周報》和《蕉風》與學生互 動交流的學習營活動、推行講座的主題。因此, 在徵用援引此書資料的時候, 雖對於閒聊 對話的細節部分（如現場眾人之間的言談）有所保留, 但其中指涉的實際事件仍可資參 考, 人物之間交換的觀點, 也能提供一個大概的輪廓, 但仍需要與其他文本印證。此外, 其中章節有關梁宗岱詩歌的閱讀闡述，顯然意在表述作者早年的詩觀啟蒙路徑。

此外，有關當時馬華文學的愛國主義以及在緊急狀態與獨立時期的文壇背景，也參 考潘碧華的多篇論文。她有多篇文章研究一九五 $\mathrm{O} \sim$ 六 $\mathrm{O}$ 年代的馬華文學, 包括〈取經的 故事一馬華文壇與外來影響（1950－1969）〉183、〈五、六十年代香港文學對馬華文學 傳播的影響〉（1949-1975） ${ }^{184}$ 等文, 從文學傳播的角度描述了馬華文學如何接受外來影 響而茁長。她的研究較為側重左翼文學與現實主義的發展, 如〈中國現代文學與馬華文學 的關係〉雖觸及現代主義產生的殖民背景因素, 但現代主義並非重點。185〈五、六十年代 香港文學對馬華文學傳播的影響（1949-1975）〉撰述香港書刊在新馬流通達到普遍可見 的情況, 作者認為從五十年代中期開始, 就有香港期刊流通到馬新一帶譯介現代文學作

\footnotetext{
181 白圭, 《縷雲起於綠草》, 頁 34 。

182 白圭, 《縷雲起於綠草》, 頁 114-124。

183 潘碧華, 〈取經的故事- - 馬華文壇與外來影響 $(1950-1969)$ 〉, 載何國忠編, 《社會變遷與文化詮 釋》, 吉隆坡：華社研究中心, 2002, 頁 277-292。

184 潘碧華，〈五、六十年代香港文學對馬華文學傳播的影響 $(1949-1975)\rangle$ ，頁 747-762。

185 潘碧華, 〈中國現代文學與馬華文學的關係〉, 《馬華文學的現代詮釋》, 吉隆坡: 馬來西亞華文作家 協會, 2009, 頁 72-79。
} 
品。然而, 到底哪一些期刊雜誌負擔此現代主義的任務, 並未廓清。一些啟迪香港現代主 義的刊物如《詩朵》（1955 創刊）、《文藝新潮》（1956 創刊）、《新思潮》（1959 年 創刊）以及稍後六 $O$ 年代的《好望角》（1963 創刊），當時在馬來亞的銷售與流通管道 和網絡, 仍有處理的空間。186 此外, 也參考蘇燕婷的論文, 〈跨出的步伐一從姚紫的小 說看 1950 年代馬華「現代小說」〉, 她從跨區域的現代性交流觀點出發, 因著當時馬華 文學特殊的邊緣位置, 其現代性的語境反而具有抗衡中國（中心）與中共主流政治話語的 作用。187蘇燕婷也提出不同於溫任平的現代主義觀點, 即從一九五○年代期間《蕉風》刊 登的現代文學裡, 就可見到現代性的追求。故此, 在獨立前後, 馬華文學的現代性, 並不 只表現在現代詩裡。

基於一九五 $\mathrm{O}$ 六 $\mathrm{O}$ 年代期間馬來亞華人社會內部的激烈衝突, 馬華文學史的現代 ／現實主義之間的二元對立總是較受矚目。為此, 鍾怡雯〈遮蔽的抒情一一論馬華詩歌的 浪漫主義傳統〉指出, 現代主義與現實主義之間的割裂源於特定歷史時空的需要, 然而在 藝術創作的實踐上, 現代與現實難以分割。她提出除了現代／現實對立的模式之外, 尚有 浪漫主義的空間，同時存在於那些被認為是現代或現實主義的詩作之內。188

此外也參考黃錦樹《馬華文學與中國性》、《文與魂與體論現代中國性》，對左翼 馬華文學現實主義的寫作及文學史觀之批判。1 89 亦參考王潤華《華文後殖民文學一一本 土多元文化地思考》中，關於五四新文學在左翼馬華文學陣營中塑立的傳統。

關於冷戰時期美援文化的背景, 參考鄭樹森〈「遺忘的歷史, 歷史的遺忘」一五、 六 $O$ 年代的香港文學 $\rangle$, 文中回溯冷戰期間美援反共的策略, 當時香港接受美援的出版社 狀況。通過扶持反共出版社, 美國相當成功地介入與改變了香港的文學與文化面貌。190當

186潘碧華, 〈馬華文學中的國家認同與文化反思〉, 《河南科技大學學報 (社會科學版) 》2 008 年第 26 卷 第 5 期，頁 $62-67$ 。

187 蘇燕婷, 〈跨出的步伐一從姚紫的小說看 1950 年代馬華「現代小說」〉, 《中文人》2006 年第 4 期, 加影: 新纪元学院中文系, 頁 23-29。通過細讀姚紫的小說, 蘇燕婷闆釋了其小說中的情慾敘述, 與上海 一九三○年代新感覺派之間的關聯。

188 鍾怡雯, 〈遮蔽的抒情一論馬華詩歌的浪漫主義傳統〉, 載潘碧華編, 《馬華文學的現代詮釋》, 吉隆 坡：馬來西亞華文作家協會，2009，頁 151-178。

189黃錦樹, 《馬華文學與中國性》, 臺北: 元尊, 1998 。黃錦樹, 《馬華文學與中國性》, 臺北: 麥田, 2012 。黃錦樹, 《文與魂與體論現代中國性》, 臺北：麥田，2006。

190 鄭樹森, 〈「遺忘的歷史, 歷史的遺忘」一五、六○年代的香港文學〉, 載《香港文學大事年表 $1948-$ 1969》，香港：香港中文大學人文學科研究所香港文化研究計劃，1996，頁 1-8。 
時大量文人南來暫避戰亂, 大部分的流亡知識分子, 既不支持中共, 亦不支持蔣介石的國 民黨政府。美國㨢絡這批文人, 希望他們能夠成為打入華文圈子的反共力量。尤其在一九 五 $\bigcirc$ 年六月韓戰爆發後, 美國駐港新聞處, 提供豐厚的資金, 資助反共的出版社, 把左右 冷戰的形勢從香港延伸到東南亞的華文文學場域裡, 冀望能夠削弱共產主義的影響力。接 受美援的出版社, 包括人人出版社、友聯文化出版社、亞洲出版社, 都持有反共宗旨, 其 中友聯出版社在文學上的影響深遠, 在香港的《中國學生周報》，以及在新馬的《蕉風》 與《學生周報》, 從六 $\bigcirc$ 年代開始, 逐漸成為有影響力的現代主義旗手。鄭樹森認為, 正 是這段冷戰與美援歷史, 詭地改變了香港文學乃至到東南亞整體中文文學場域的面貌。

根據趙綺娜的研究, 冷戰乃是美蘇兩大陣營, 向世界各地爭取民意支持的意識形態 鬥爭。透過反共, 美國把自身關於「自由」的價值觀, 連同其影視與流行文化, 成功輸送 到中國以外的華人讀者群中, 使美國猶如與自由畫上等號。191 趙綺娜一系列關於美援政 策的研究, 從諸多不同視角, 梳理出美國主導下的反共策略、其權力觸角伸展的方式, 參 閱檔案紀錄, 呈顯出美方對外界解釋的諸多修辭方式。趙綺娜除了關注臺灣在冷戰位置的 諸多問題之外, 其研究也涵蓋了東南亞這一區域, 作為冷戰時期接受東亞文化產品輸出影 響的地理範圍與對象。

王梅香的博士論文《隱蔽權力：美援文藝體制下的台港文學》與碩士論文《蕭殺歲 月的美麗／美力：戰後美援文化與五、六十年代反共文學、現代主義思潮發展之關係》， 亦為極重要的參考文獻。192尤其關於美援體制如何影響港臺現代文學與文化重塑的過程, 包括美新處如何干涉、參與、改編與重寫若干寫作計畫的作品, 提供極具批判性的觀察角 度。其中一位參與美新處寫作計畫的簽約作者之一, 燕歸來, 既是友聯出版社的聯繫人, 也是向亞洲自由委員會交代與報帳的「在地聯繫人」。她曾將一九五二年由香港友聯出版 的著作《紅旗下的生活》改寫, 以英文版 Umbrella Garden 出版。193

191 趙綺娜, 〈一九五。年代的香港美國新聞處：美國在亞洲之反共宣傳政策研究〉, 同前注。

192 王梅香, 《隱蔽權力: 美援文藝體制下的台港文學》, 國立清華大學 : 社會學研究所博士論文, 2015。 王梅香, 《蕭殺歲月的美麗／美力：戰後美援文化與五、六十年代反共文學、現代主義思潮發展之關 係》, 臺南：國立成功大學台灣文學研究所碩士論文, 2005。

${ }^{193}$ 王梅香, 《隱蔽權力：美援文藝體制下的台港文學 (1950-1962)》，頁 85 。 
關於美國新聞處的解密檔案, 則以美國中央情報局的圖書館網頁, 以及美國國家檔 案局的網路檔案資源為主要搜尋管道。194另外也參考威斯康辛大學麥迪遜分校(University of Wisconsin-Madison)的網路電子書《美國的外交關係》(Foreign Relations of the United States), 尤其是《東南亞 : 一九五五至一九五七 (卷八) 》 (Southeast Asia, 1955-1957, Volume VIII)，《外交資助與經濟防衛政策：一九五五至一九五七 (卷十)》(Foreign aid and economic defense policy,1955-1957, Volume X)《緬甸、馬來亞一新加坡、東亞區域、 柬埔寨：一九五八至一九六 $\bigcirc$ 年 (卷十五/十六之第一部份) 》(Foreign Relations of the United States, 1958-1960, Burma; Malaya-Singapore; East Asia Region; Cambodia, Volumes XV/XVI, Part 1), 《南亞與東南亞 : 一九五八至一九六 $\bigcirc$ ( 卷二十二) 》 (South and Southeast Asia, 1958-1960, Volume XXII)。195亦參考姚百慧的〈淺談美國國務案檔案〉所 列分類 ${ }^{196}$, 尤其搜查〈香港一九六 $\bigcirc$ 年至一九六三年一月的國內與外交事務〉（第七 卷）, 惟大部分檔案都是美新處關注香港與臺灣媒體討論擬定的策略, 本論文僅著重於香 港刊物對與東南亞的影響部分。197根據美新處收集的資料，到一九六○年，香港外銷的刊 物與報紙其價值總數，達致五百一十三萬八千六百一十三元港幣，在一九六一年則達到五 百六十六萬五千三百八十六元港幣。最大的入口國家即為馬來亞（在一九六一年時，人口 的印刷物價值占四百七十三萬四千八百二十七港幣）。198可見馬來亞華文閱讀人口所佔據 的比例。

194 美國中央情報局的圖書館館藏網頁(CIA Electronic Reading Room, FOIA Search tool) https://www.cia.gov/library/readingroom/search/site。美國國家檔案局的館藏網頁(The National Archives Catalog), https://www.archives.gov/research/catalog。

195 The Digital Collection of University of Wisconsin-Madison Libraries: FOREIGN RELATIONS OF THE UNITED STATES. http://digicoll.library.wisc.edu/cgi-bin/FRUS/FRUS-idx?type=browse\&scope=FRUS.FRUS1 196 取自廈門大學東南亞研究中心網頁, 2013 年 4 月 22 日 http://ny.xmu.edu.cn/Article/UploadFiles/201304/2013042610495647.doc。姚百慧, 〈淺談美國國務案檔 案〉, 載徐藍主編, 《近現代國際關係史研究》2013 年第 3 輯, 北京：人民出版社, 第 288-314 頁。 197 這檔案分類為 “Hong Kong 1960-January 1963 Internal and Foreign Affair”。由於檔案眾多, 僅列出論文有 徵引的文件, 包括 Amconsul Hong Kong to Department of State, “Hong Kong- Influnce of Hong Kong Publication in Southeast Asia.”Jul 24, 1962. Ching Pao,"United And Division In the Arab and Communist Bloc”, December 28, 1961. Sydney Liu, Jack Friedman,"Memo of Conversation”, July 11,1962.

198 Amconsul Hong Kong to Department of State, "Hong Kong- Influnce of Hong Kong Publication in Southeast Asia."Jul 24, 1962. 
為了補充英殖民政府的觀點, 也參考新加坡國家檔案圖書館內的資料, 包括〈新加 坡, 第三勢力的活動, 移民檔案〉, 前面已討論過。 ${ }^{199}$ 〈駐新加坡與東南亞國家駐中國領 事館代表, 在英國承認中共政權之後〉的檔案之一, 〈東南亞國家對共產主義策略的反 應〉報告。這份報告顯示出美新處對於一九五五年萬隆會議之後, 東南亞各國的外交政治 走向甚是關注、尤其對於東南亞與中共的關係變化, 所做的判迦分析。200其餘所徵引資 料, 將在稍後各章討論時再引註說明。此外亦有〈友聯圖書公司〉 (Union Book Co) 的登記 檔案, 惟其資料與現知的友聯書局多所不符, 暫擱不論。201

\section{七、問題意識與章節架構}

這份論文志在處理從《蕉風》創刊以來, 至到第一波現代主義掀起, 這個時期的文 學觀遞變。根據這段時期南來文人的書寫, 以及《蕉風》在這期間的文學主張, 可列出的 文學路線與定位, 包括純馬來亞化（一九五五）、現實／寫實主義（一九五五一）、人文 主義和自由主義（一九五九－）, 以及現代詩革命／第一波現代主義（一九五九一）。論 文選擇四個南來文人, 析論作品與編輯方針, 分別是方天 (純馬來亞化與在地現實主 義）、馬摩西（純馬來亞化與地方書寫）、姚拓（寫實主義、人文主義和自由主義）以及 白圭（現代詩革命／第一波現代主義）。觀察他們的書寫路線、風格與主題, 闡述他們可 能擁護的宗旨與群體目標, 或是因為偶然因素, 而與宗旨剝離、轉移分歧的書寫。

在此, 對友聯諸人的研究, 在肯定貢獻之餘, 也必須指出他們的局限。出於實踐反 共的目的, 他們選擇與國家和政黨合作, 似乎也導致他們的在地論述失去了異議的能力。 誠然這使得現實主義反映真實的寫作理念, 因此難以落實。至於寫作, 似乎也難以在配合 反共與本土認同的呼籲下, 體現出獨立於政治任務之外的藝術自覺性。冷戰局勢的編碼, 似乎把個體牢縛在權力網絡裡發聲和發言; 然而, 閱讀個別南來文人的書寫, 則又可以察

\footnotetext{
${ }^{199}$ FCO 141/14536: Singapore. Activities of the Third Force. Secret - Migrated Archives.

${ }^{200}$ FCO 141/14394: Singapore. Chinese Consular Representation in Singapore and South East Asia after the Recognition of the Chinese Communist Government by the UK Government.

201 檔案名稱為 “Union Book Co”, 相當簡略, 從起於一九五五年的登記證明、包括以後屢次更換公司地址 的紀錄、業務合夥與擁有人表格及更換合夥人的紀錄，一直到最後終結於一九七一年的結業紀錄。但地址 與起始年份, 與現今所知的新加坡友聯書局的創辦日期及辦公室地址不符。其註冊擁有人共有三位, 皆為 華人。其中兩位為英籍華人, 一位為中國籍華人。
} 
覺到那些殊多分岔、無關宏旨的岔徑與裂隙。通過以下這些章節鋪陳, 論文想要探討這個 問題 : 從一九五 $\bigcirc$ 年代, 到一九六 $\bigcirc$ 年間, 以《蕉風》南來文人當時堪稱簡樸的文學書寫 方式, 是否也有可能從權力網路中撥開一道逃逸的路徑?

第一章為緒論, 介紹論文的研究動機、歷史背景、「非左翼」的定義、離散理論、 文獻回顧與章節架構。概述冷戰局勢、亞洲自由協會和友聯出版社的關係, 《蕉風》南來 創刊的背景, 包括《蕉風》與馬華公會之間的密切關係, 《蕉風》在馬來亞當時反共的政 治局勢中可能扮演的角色。這一章也梳理南來文人跨境流動的詮釋問題（離散或流亡）。

第二章論述《蕉風》在創刊初期的馬來亞想像, 時值獨立將屆, 愛國主義熱潮壟罩 文壇。幾位南來文人剛抵達不久, 短期內就表達在地認同。《蕉風》建構的家園想像, 並 非是早期中國民族主義者「境外原鄉」的家園, 而是一個以本土為中心的「境內家園」, 這一章節也討論創刊初期, 與在地認同相關的幾個面向, 包括馬來亞化的主張、本土意 識、國族想像以及南來文人對建國體制的回應。

從第三章至第六章, 每章專論個別南來文人。

第三章討論第一任主編方天。方天 (張海威) 於一九五五至一九五七年間短暫居留 馬來亞，擔任《蕉風》的首任編輯，同時大量創作寫實主義的小説。這兩年方天 「停駐」 馬來亞的時期, 不僅給他個人, 同時亦給馬華文學史留下精工細筆與在地化的現實主義作 品。這一章觀察方天的書寫如何處理本土認同、階層關懷及個體意識, 以及他偶而表現出 來的, 與現實主義剝離的面向。

第四章討論馬摩西。馬摩西是創刊早期書寫馬來亞化最落力的作者，也是《蕉風》 編委之一。在當時眾多南來的文人當中, 像馬摩西那樣兼具外交官與宗教觀、同時又通曉 埃及語文和以中文寫作的伊斯蘭教徒, 可說是別無僅有。這一章從馬摩西南來之後的旅 行、家居書寫切人, 梳理他跨越中國、埃及、馬來亞的流動經驗裡, 所經歷的現代性視野 與身分認同的變化。

第五章以姚拓為主, 同時兼論其他受邀助陣的南來文人作家黃思騁和古梅在《蕉 風》與《學生周報》刊出的作品。姚拓在任期間, 也是《蕉風》創刊以來推行反共意識較 為明顯的時期。一九五九年《蕉風》改版, 同時提出自由主義與人文主義兩個主張, 也增 
添了「文壇雜話」版與「文訊」版, 這兩個版位尤其鮮明地傳遞出反共的意味。這一章也 概述《蕉風》的人文主義與香港新亞書院人文精神之間的關係。

第六章以白圭和一九五九年開始的第一波現代主義新詩改革為主。雖然人文主義與 現代詩改革, 兩者看似各自提議, 互不相涉, 惟分析白圭的現代詩革命主張, 又會發現兩 個議題之間, 實有相連的脈絡。這一章也對白圭的現代詩和幾個同期的現代詩人作品, 進 行符旨、典故、意象、象徵在詩歌傳統以及與同代人文本中符碼置換的析讀。從白圭詩中 的觀照, 延伸到那因著歷史偶然性, 而在此地開枝散葉的馬華文學; 彷彿是給未來留下的 饋贈那般, 從這語言與文學場域可能「空無」的知覺, 獲得「意義」的啟迪。

第七章為總結。這一章討論文學的轉移、逃逸以及對系統欠缺的嵌補。這章從小文 學理當與政治相連的預設視域, 開始提問。基於早期《蕉風》的反共意識, 使得出現在 《蕉風》中的現代詩和現代主義書寫, 似乎缺乏了昔日左翼的「批判力度」。這一章提出 不同的觀察角度，來討論寫作本身賦予文學自權力網絡中逸離的可能性。 


\section{第二章}

\section{《蕉風》的本土認同與家園想像}

\section{一、快速的認同}

所登文字, 一律以提倡南洋文化為標準; 如有文㙯創作, 也一律以描寫南洋生活和 景物者為限。

—《叻報》副刊「楖林」，一九二九年七月二十四日 凡以馬來亞為背景之文藝創作，如小說、散文、戲劇、新詩、歌曲、寓言、童話、 遊記、雜感、隨筆、民間傳說、歷史故事、人物特寫、文藝評論、名著介紹及漫 畫、木刻、素描、攝影佳作等皆所歡迎, 翻譯作品須附原名及原作者姓名。

$$
\text { 一《蕉風》創刊號，一九五五年十一月 }
$$

以上兩段引文, 分別出現在戰前與戰後的報刊雜誌上。一九二 $○$ 年代, 南洋的報章副 刊開始提倡南洋色彩。1僑民意識與本土關注的文藝觀點持續消長, 其時馬來半島與新加 坡仍未獨立。一九四六年英殖民政府成立「馬來亞聯邦」(Malayan Union), 在「馬來亞聯 邦」提出的制度底下, 作為馬來人族群象徵的蘇丹皇室權力將被削弱, 大量華人可獲公民 權, 馬來精英份子群起激烈反對, 迫使英殖民地政府在兩年後取消原來的計劃, 更換為 $\ulcorner$ 馬來亞聯合邦」(The Federal of Malaya), 不但確保蘇丹地位以及馬來人土著特權, 同時 也收窄公民權的門戶。2 在提出「馬來亞聯合邦」將主權回返馬來民族的一九四八年, 英

\footnotetext{
1 楊松年指出, 南洋色彩最早出現在 1919 年《益群報》副刊徵稿要求。楊松年, 《戰前新馬文學本地意識 的形成與發展》，新加坡：新加坡國立大學中文系、八方文化企業，2001，頁 29、34。

${ }^{2}$ Halim Salleh, "Globalization and the Challenges to Malay Nationalism as the Malaysian Nationalism", Leo Suryadinata (ed.), Nationalism and globalization: East and West, Singapore: Institute of Southern Asian Studies, 2000, p. 135.
} 
殖民政府也實施對待馬來亞華人的政策 $「$ 馬來亞化」, 以促進華人對本土的認同, 使之效 忠馬來亞，並與馬來人一起成為融合的馬來亞國族，同時也削弱左翼意識對華社的影響。

3 隨著聯邦成立, 公民權問題浮上檯面, 華人對馬來半島的認知始由「南洋」轉成 $\ulcorner$ 邦」, 再由「邦」至 $「$ 國」。報章副刊與雜誌刊物的徵稿, 也要求其文章背景由「南 洋」轉向「馬來亞」。

若檢視一九四○年代馬來亞聯邦成立初期的各族反應，馬來民族主義的團體在公民權 問題上反應激烈。4 華人卻不參與這場辯論, 論者多認為華人之所以回應冷淡, 是由於大 部份華人傾向於認同中國民族主義。5 哈勃(Timothy Norman Harper)以為, 在最初的建國 監圖計劃裡, 馬來亞聯邦對華人提供了相當寬鬆的條件, 使將近百分之八十的華人有資格 獲得公民權, 這對華人在馬來亞獲得有保障的政治地位是相當有利的, 不過, 由於當時華 人社會多傾向於僑民認同, 在 $「$ 國家」的認同與「民族」的認同之間形成一道分裂的界 限。6 二戰甫結束, 抗日時期激起的「祖國」激情未熄, 左翼仍在華裔中下層階級與文壇 上有其影響力。華裔社群當時實際上並非均質地皆為左翼的支持者或同情者，國民黨人以 及其他無關左右兩翼的大眾也不在少數。然而, 華人仍然無法在馬來文與英文的討論空間 中提出意見或參與辯論，因此錯過了一個參與建國政治與公民權決策的重要歷史時機。

在文學場域裏，馬華文藝屬性卻長時間經歷本土與僑民文學之爭。7 一九四八年，中 國南來作家與當地作家之間掀起了「僑民文藝」與「馬華文藝」論戰，爭辯「馬華文藝」

\footnotetext{
${ }^{3}$ Ong Hak Ching, Chinese Politics in Malaya 1942-55: The Dynamics of British Policy, Bangi: Universiti Kebangsaan Malaysia, 2000, p.137-170.

4 當時馬來精英堅持馬來民族為土著, 故需享有超越其他種族的優勢地位, 1945 年 12 月 15 日抗議的遊行中 高喊 $「$ 馬來亞是屬於馬來人, 我們不要其他種族獲得馬來人應有的權利和特權。」轉引自 Halim Salleh, ibid, p. 135. 關於獨立之前的馬來亞聯邦計畫、公民權問題、馬來民族主義觀點與相關資料, 本文撰寫 時, 為關志華建議、指點與討論所得。

${ }^{5}$ Tan Chee Beng, "Ethnic identities and national identities: some examples from Malaysia", Identities: Global Studies in Culture and Power, 2000, vol.6(4), p.441-480; Leong, Stephen, 'The Malayan overseas Chinese and the Sino-Japanese war, 1937-1941', Journal of Southeast Asian Studies, 1979, vol.10(2), p.293-320. Heng Pek Koon, “Chinese Responses to Malay Hagemony in Peninsular Malaysia 1957-96”, Southeast Asian Studies, 1996, 34(3), p.32-54.

6 Timothy Norman Harper, The End of Empire and the Making of Malaya, UK: Cambridge University Press, 1999, p. 87.

7 楊松年, 《戰前新馬文學本地意識的形成與發展》, 頁 170 。
} 
的文化屬性, 結果馬華文藝本土派勝出, 可說是在獨立之前最明顯的本土轉㨝點。8 這場 論戰的結果標誌了「反映本地」的文學真正獲得認同。這本土認同的文化氛圍對於當時經 由香港、臺灣抵達新馬的南來文人而言, 也相當具有感染作用, 甚至也影響了刊物的方 針。尤其在一九四九年國共内戰結束, 中國大陸由中共掌權, 國民黨敗守臺灣, 前來東南 亞的南來文人需要嘗試在另一環境開創家園。馬來亞當時乃為英國殖民地壓制左翼勢力的 其中一個據點, 對於非左翼文人來說有一定的優勢。其時正逢馬來亞聯合邦（一九四八 年）成立不久, 英殖民政府宣佈馬來亞共產黨為非法的組織, 採取緊急法令壓制馬共的活 動, 並切斷馬來亞與中國之間的書籍與各個方面的聯繫。緊急狀態從一九四八年延續到一 九六 $\bigcirc$ 年, 這期間馬來亞建國與文化場域的互動, 亦為英美組成的右翼勢力一一為了防堵 紅色勢力蔓延至東南亞的冷戰形勢—一所牽制造就。一九四九年, 馬來亞國民黨關閉以 後, 前國民黨成員另覓替代性的抉擇, 他們的影響力仍然滲透馬來亞的華團。9 這期間進 人星馬一帶的華人, 多來自港臺兩地。南來文人在香港託庇、䚇職、交往而來的文化互 動, 也隨著他們的遷移蹤跡延伸到新馬一帶。

《蕉風》創刊之際，就有意識地建構本土認同。《蕉風》的一群編輯抵境之後，認同 速度之快, 今天看來相當讓人驚詫。一九五 $\bigcirc$ 年代, 在新加坡《蕉風》的編委與編輯當 中, 有方天、李汝琳、陳振亞、范經、馬摩西、申青與姚拓。 ${ }^{10}$ 其中方天、陳振亞、馬摩 西、申青與姚拓, 南來不到一年內就認同了本土性的文學觀點。最早提倡現代文學的南來 文人白圭, 南來不到兩年, 就以「我是馬來亞的華人」自居。11一部分原因, 固然是由於 國籍身分的「歸屬」，對當時的華人來說，是個必須抉擇的現實問題。另一個原因，在於 一九四九年中共執政後, 對於這群南來文人而言, 政治大局已定, 故鄉不復可返; 從流亡 至香港, 而後再䚇職遷移到馬來亞, 他們需要新的家園, 結束放逐的狀態。

8 這場論戰也首次批判了僑民文藝的中國認同。當時本土一派提出馬華文藝必須擺脫中國文學的附屬地位, 反映「此時此地的客觀現實環境」才能發展自己的獨特屬性, 以及建立自己的主體性。趙戎編 1971 , 《新馬華文文學大系 (史料)》, 新加坡：教育, 頁 192 。

${ }^{9}$ Mohd Shukri Shuib, Mohamad Faisol Kelling, Mohd Na'eim Ajis, "The implication of cold war on Malaysia state building process," Asian Culture and History, 2009, vol.1(2): 89-98. C.F.Yong \& R.B. McKenna, The Kuomintang Movement in British Malaya (1912-1949), Singapore: NUS Press, 1990.

10 姚拓, 〈四十二年來的蕉風〉, 載江洺輝主編, 《馬華文學的新解讀》, 八打靈 : 馬來西亞留台校友會 聯合總會，1999，頁 79 。

11 張錦忠，〈亞洲現代主義的離散路徑：白圭與馬華文學的第一波現代主義風潮〉，載林春美、郭蓮花 編，《江湖、家國與中文文學》，沙登：博特拉大學現代語文暨傳播學院，2010，頁 226。 
當時在馬華文壇上, 本土意識的影響力, 漸趨凌駕僑民的意識; 而在國家政治論述 上, 也有英國人針對馬來亞華人社群擬定展開的「馬來亞化」(Malayanization)方針。在 《蕉風》創刊詞中強調的「純馬來亞化」，應當理解為依據哪一方詮釋的脈絡呢？那之間 錯綜複雜的關係為何? 從當時各造的論述與實踐情況來看, 似乎並非全然一致, 但亦有彼 此呼應之處。這裡面，或許具有除了「反共」以外，其他尚可探討的不同空間。

\section{二、二戰前後的馬來亞化主張}

\section{（一）戰後英屬馬來亞聯合邦政府的 $「$ 馬來亞化」方針}

英殖民政府對待馬來亞華人的政策「馬來亞化」，始於一九四八年。目的是為了應 對華人在政治上, 對於聯合邦施政的激烈反應, 包括當時在檳城發生的「分離運動」, 以 及中國政局變化對東南亞華人帶來的政治效應。英政府為此擬定對待馬來亞華人的方針， 並決定實行 $「$ 馬來亞化」策略來削減華人對共產黨的支持, 使華人從原來的祖籍國轉向對 馬來亞效忠。12 同一年內 $「$ 馬來亞聯合邦」成立。「馬來亞化」也是與剿共計畫(Briggs Plan)同時進行的施政計畫, 這方針深入到社會上的許多層面，從華校教育、教科書內 容、公民權、馬來人的經濟地位問題乃至到將華巫融合成具有馬來亞意識的國族論述等 等。

在致力於使華人融入馬來亞國族的前提下, 英國人也催生了馬華公會, 大部分成員 為海峽華人，此外也有不少人是當時居留馬來亞的國民黨代表。這些國民黨人曾經在地方 上，動員基層支持創立馬華公會，並寄望能以馬華公會取代因落敗而關閉的國民黨。他們 在華社裡也相當積極地散播支持馬華公會的認同感。譬如當時住在怡保的國民黨外交官回 裔馬天英，就曾經在馬華公會創辦前數周，開始著手部署霹靂州內的基層，組成小團隊， 準備加入馬華公會。13在非左翼的南來文人之中, 原來也是國民黨的外交官馬摩西, 從一 九五三年開始加入馬來亞公務體制, 轉職為宗教官, 並曾在新村巡迴宣講傳教, 英國人曾 冀望能藉此在新村減少華人受到左翼影響，這點將於稍後在第四章裡討論。

\footnotetext{
${ }^{12}$ Oong Hak Ching, Chinese Politics in Malaya 1942-55: The Dynamics of British Policy, Bangi: Universiti Kebangsaan Malaysia, 2000, p.137-170.

${ }^{13}$ Oong Hak Ching, Chinese Politics in Malaya 1942-55: The Dynamics of British Policy, p.146.
} 


\section{（二）馬共與馬華公會的「馬來亞化」方針}

$\ulcorner$ 馬來亞化」的口號，也可能追溯至戰前一九三○年代，當時馬共提出要實踐馬來 亞化。根據白安娜(Anna Belogurova)的論文, 馬共當時在提出建立一個馬來亞化的 $\ulcorner 民$ 族」表述時, 可能面臨傳遞與接受過程中的語意問題, 這與民族這個中文詞彙, 相對於翻 譯的語意, 所具有的多重意義有關。14

白安娜從馬共的「民族」論述開始梳理。她認為馬共提出的馬來亞化民族觀，可溯 自一九三○年四月廿二至廿三日馬共成立的會議, 當時馬共黨內的馬來黨員人數極少, 在 當時因此遭到同時出席會議的國際共產(Comintern)批評。15這使得馬共在三十年代, 開始 有意建立一個能概括多元民族的、有馬來亞國族特色的黨, 即便當時作為邦國的馬來亞尚 未存在。國際共產十分關注馬共的這個問體, 因為當時不僅只有馬共才面對種族的問題, 即便東南亞其他國家的共產團體亦然。16而馬共所提的諸多概念, 除了「解放受壓迫的馬 來民族」這甚具有共產鬥爭意識的口號之外, 馬共也試圖提出一個不同於過去的馬來亞概 念, 意在促使華人認同中國為祖國之餘, 也能認同馬來亞為祖國的「雙重國族」認同的馬 來亞意識。這樣的雙重意識其實又可溯自一九二○年代末期, 在中共與國民黨的合作分裂 而失敗之後, 國際共產的論述曾經轉向孫中山那具有國際觀的, 泛亞洲的華人共同體與愛 國意識, 並將之與具有馬共的馬來亞國族論述結合。17不過, 這樣的多元族群與共同體想 像的觀點, 雖是由國際共產促成的, 但其實也吸收了陳禎祿的觀點。

陳禎祿在一九二○年代擔任海峽殖民地立委時，曾針對華人權益對英殖民地發言， 當時也強調華人在此土生土長、或數代移居而因此理當被接受為在地子民, 亦啟迪馬共的 馬來亞國族論述。因而在左翼的馬來亞化論述裡, 除了有國際共產促成、孫中山泛亞洲華 人論述共體的想像, 亦有取自陳禎祿在一九二 $\bigcirc$ 年代的觀點, 當時他提出華人認同在地乃 為爭取權益之必然趨勢。這樣的觀點流動並非單向, 而是在吸收之後, 又經過複雜的改造 與衍生，稍後，在二戰後，在馬華公會主張多元族群與認同在地的馬來亞化論述裡，也能

\footnotetext{
${ }^{14}$ Anna Belogurova, "The Malayan Communist Party and The Malayan Chinese Association: Internationalism and Nationalism in Chinese Overseas Political Participation, c.1920-1960", Leslie James \& Elisabeth Leake (eds.)

Decolonization and the Cold War: Negotiating Independence, London: Bloomsbury, 2015, p.125-144.

${ }^{15}$ Anna Belogurova, "The Malayan Communist Party and The Malayan Chinese Association: Internationalism and Nationalism in Chinese Overseas Political Participation, c.1920-1960”, p.129.

${ }^{16}$ Anna Belogurova, ibid, p.130.

${ }^{17}$ Anna Belogurova, ibid, p.131-133.
} 
見到與馬共在一九三○年代所提的 $\ulcorner$ 馬來亞」化論述, 彼此相似。從在一九四 $\bigcirc$ 年代到五 $\bigcirc$ 年代, 戰後馬華公會陳禎祿與馬共, 都在競相提出 $\ulcorner$ 馬來亞化」, 並互相爭辯自己的

$\ulcorner$ 馬來亞化」是較為成功的範例, 所論爭的關鍵就在於它能否促進一個團結的馬來亞、培 養馬來亞人民的意識以及友族的合作。 ${ }^{18}$ 雖然一般論述中傾向於強調兩者的觀點是對立 的, 但白安娜的論述卻從其觀點的相似與重疊, 重新梳理了兩造的論述脈絡與系譜來源, 多重對比, 使陳禎祿在戰後率領馬華公會時期, 與馬共彼此競逐的馬來亞話語, 兩者亦宛 如彼此的回聲與振鳴。19

謝文慶對馬共「馬來亞化」的研究, 則集中在戰後。二戰之後, 馬共在馬來半島曾 經面臨相當嚴峻而混亂的華巫種族衝突局面。日殖時期的日本殖民政府為了打壓馬共, 採 取的策略, 使華巫關係惡劣分化。20為了爾合過去對馬來民族社群認識不足的問題, 以及 促進黨內馬來友族的關係, 從一九四六年九月開始, 馬共開始在黨內推行 $「$ 馬來亞化」, 其步驟包括研究了解馬來人的宗教、習性、興趣與特性, 吸引馬來人加人共產黨, 培訓華 裔黨員, 甚至在必要時改信他們的宗教和認同他們的種族, 以便可在與馬來人相關的事務 上協調、解決問題、帶領或組織起馬來友族的人力。當時，他們通過鼓勵黨員讀書、討論 與學習, 以解放馬來亞（從資本主義解放出來）為黨的宗旨與義務。一方面教育黨員, 無 論僑民抑或土生者, 皆要認同在地, 通過交流不同的經驗, 來達到對馬來亞化的認同。雖 仍舊關注中國政治, 但也勸諭黨員要更關注在地與黨的事務。21

但即便是馬華公會對馬來亞化的詮釋, 也和馬共一樣, 都得經歷捋扎的過程。22根據 古鴻廷的〈英屬馬來亞聯合邦之華文教育〉, 馬華公會當時得一邊爭取新村華人的信任， 同時一邊得與英殖民地政府對華人的偏見, 極力周旋。在華文教育這個課題上, 雖然馬華

\footnotetext{
${ }^{18}$ Anna Belogurova, ibid, p.136.

${ }^{19}$ Anna Belogurova, ibid, p.130-139.

20 根據謝文慶(Cheah Boon Kheng)的研究, 由於日本人在殖民期間, 常以馬來人當帶路人, 去尋找馬共的藏 身處, 亦以馬來警察逮捕、嚴刑逼供馬共黨員, 並把華人烙上共產黨的標籤, 由此加劇了華巫分裂, 也使 馬來人認為「華人＝共產黨」, 對華人與共產黨有極深的防備與偏見。一九四五年, 各地發生華巫之間的 激烈衝突, 大量鄉區的華人被馬來人屠殺。Cheah Boon Kheng, Red Star Over Malaya: Resistance and Social Conflict During and After the Japanese Occupation of Malaya, 1941 -46, Singapore: NUS press, 2014, p.194-239. ${ }^{21}$ Cheah Boon Kheng, Red Star Over Malaya, p.70.

${ }^{22}$ Anna Belogurova, "The Malayan Communist Party and The Malayan Chinese Association: Internationalism and Nationalism in Chinese Overseas Political Participation, c.1920-1960”, p.136.
} 
公會先前曾與巫統協商獲得共識成果, 即以華文為教學媒介, 並給予華校補貼, 但在大選 過後，這個課題卻遭到英國殖民政府所棄置。23

從戰後到獨立這個階段, 馬來亞化對華人社會來說, 也是個充滿問題與激烈的政治反 抗過程, 包括族群權益的問題, 也涉及華教與教材改編的問題, 在獨立前後, 曾經折起全 國大規模的學潮。24 當時在馬來亞化的方針下, 從語文教學（包含馬來文與英文）乃至到 教材內容（減少以中國為典範的中心, 使之更加本土化與馬來亞化）, 這問題牽涉到大量 的教材 ${ }^{25}$, 再加上當時華校被罩上馬共汙名化的偏見, 從 $「 巴$ 恩報告」到後來的「威菲報 告書」, 尤其後者出自於殖民地高官, 他們持有華文教育就是左翼溫床的觀念。26如威菲 (L.D. Whitfield)曾言, 「多教英文, 少教中文, 共產思想難在華文中學滋長, 亦可避免共 產黨分子滲人」。27 種種的查審、改制等要求, 曾使華校經歷憤怒與污名化的創傷震盪, 並擔憂會因此在這塊土地上失去自身的語言與文化。28對華校而言, 這段轉型認同的過程

23英殖民者強硬實行的新村搬遷計畫, 使華人不滿而責怪馬華公會, 但陳禎祿當時確實盡力在反共方面, 給 予新村各種幫助, 包括成立自衛團、補貼建屋經費、生活費補貼, 售賣十八期彩券提供醫療設備。陳禎祿 曾經提呈備忘錄予英殖民地政府，駁斥 $\ulcorner$ 馬來亞華人是馬來亞共產黨武裝力量根源」，並提出社會不滿現 象實為共產主義之精神糧食, 䁹英國人善待華人。馬華公會在選舉前提出的華校補貼與以華文為教學媒介 的問題, 在馬六甲曾獲巫統領袖的同情, 但因同意大選不以此為訴求, 以免激起馬來民族不滿, 在大選勝 出後, 即遭英殖民者擱置。陳禎祿曾經提呈備忘錄予英殖民地政府, 駁斥「馬來亞華人是馬來亞共產黨武 裝力量根源」這一偏見, 並提出社會不滿現象實為共產主義之精神糧食, 箇英國人善待華人。古鴻廷,

〈英屬馬來亞聯合邦之華文教育〉, 《教育與認同：馬來西亞華文中學教育之研究 (1945-2000)》, 廈 門大學出版社, 2003, 頁 29-56。

24 崔貴強, 〈從“中國化”走向“馬來亞化” 新加坡華文教科書的嬗變. 1946-1965〉, 《第四屆世界海外華 人國際學術研討會論文集 I》, 臺北：中央研究院, 2001 , 頁 271-286。鄭文波、楊景水, 《二十世紀五 十年代學生運動史料匯編》, 全馬華文中學生捍衛華教運動五十周年工委會，2009。

${ }^{25}$ Lee Ting Hui, Chinese Schools in Peninsular Malaysia: The Struggle for Survival, Singapore: Institute of Southeast Asian Studies, 2011, p.51.

26 根據古鴻廷的研究, 英殖民地在戰後十年內, 對華文教育的觀點, 有急遽的轉變。在一九四八年以後, 因馬共叛變、中國政局改變、韓戰爆發與冷戰局勢, 使他們更擔憂華社裡的左翼意識, 因而開始對華文教 育採取敵視的態度, 乃至於到一九五一年出爐的《威菲報告書》(The Whitfield Report)裡, 仍有行文修辭 掩飾對於華教的敵視觀念。古鴻廷、曹淑瑤, 〈馬來亞華族母語教育的維護, 以《方吳報告書》的理念為 例〉, 《2013 年臺灣的東南亞區域研究一東南亞區域經濟整合下的臺灣與東南亞》, 宜蘭: 佛光大學公 共事務學系暨國際與公共事研究中心。網址：fgumail.fgu.edu.tw/ cseas2013/3-4-1.doc。

27 古鴻廷, 〈英屬馬來亞聯合邦之華文教育〉, 頁 54 。

${ }^{28}$ Amry Vandenbosch and Richard Butwell 1957, "MALAYA: A Problem in Nation Building”, Southeast Asia Among the World Powers, University Press of Kentucky, p.209. 
實在難以想像地崎嶇艱難, 除了因巴恩報告引起的華教關閉隱憂之外, 在許多方面得與英 殖民政府對歭、反抗以及在一些談判上退讓, 包括接受負苛甚重的三種語文教育, 不過, 與此同時, 他們也願意認同本土化, 接受課程內容的去中國化, 以及增加新馬本地內容偏 重的比例。2

\section{（三）友聯在馬來亞的文化工作}

友聯就在 $\ulcorner$ 馬來亞化」實施了大約六年之後抵達。如之前第一章所述，他們來到馬來 亞, 最初乃是出於馬華公會梁宇者邀請：

我們剛去的時候，馬來西亞還在剿共，「他們」那時候希望在香港找一、雨個人先 去搞一些青年的文化活動、傳媒上的活動。30

談到在馬來亞進行的文化任務時, 都不約而同的提到宣揚中華文化的理念與華文教育, 多 於本土認同的「馬來亞化」：

我們當時辦《學生周報》是想讓年輕一代認識這個社會、華文教育，同時我們增加 活動。31

除了辦與香港相似的活動，例如合唱團、戲劇、文藝創作之外，那邊的工作主要還 是對華僑青年宣揚民主思想與保存中華文化。 ${ }^{32}$

此外，當時才剛大學畢業的古梅追憶:

那邊學生工作更繁重一些，因為希望能夠推廣華文教育。華文在馬來西亞不是官方 語言，華文學校也不多，我們聯絡華文學校同學，不但設通訊員，而且鼓勵他們寫 作。 ${ }^{33}$

\footnotetext{
29 黃庭康, 〈國家權力形構與華文學校課程改革一戰後新加坡及香港的個案比較〉, 《教育與社會研究》 2007 年第 4 期，頁 111-133。

30 何振亞口述, 《香港文化眾聲道》, 頁 20 。一九五 $\bigcirc$ 年代應做 $「$ 馬來亞」, 何振亞與其餘友聯諸人在憶 述馬來亞的經歷時，大多提及今名「馬來西亞」。

31 何振亞口述, 《香港文化眾聲道》, 頁 22。

32 奚會暲口述, 《香港文化眾聲道》, 頁 60 。
} 
在馬來亞創立出版社以後, 友聯出版社往多方面發展, 業務很廣, 除了出版《周報》新馬 版 (即《學生周報》) 外, 還辦華文教科書、《蕉風》雜誌與書店等等。34縱觀友聯出版 社在一九五 $\bigcirc$ 年代引入編撰得極之嚴謹的華文讀參書、教材與學術著作, 其中甚多古典典 籍, 包括頗獲好評的《友聯活葉文選》集, 原來在香港由「友聯編譯所」出版, 中學教材 的選文收錄得相當全面, 注釋詳盡, 銷路很好。35「友聯編譯所」也出版其他教科書、 古典小說, 據林悅恆受訪時表示, 「友聯編譯所」從未曾為亞洲基金會所資助。36但正如 前述, 根據美國的檔案, 友聯出版社在新馬一帶出版華文中學的教科書, 是為亞洲基金會 所支持的項目之一。這套《友聯活葉文選》引入之後, 也在新加坡再版。大概在一九五四 年左右, 友聯針對東南亞一帶的僑校, 邀約多名教授選取國文與新文學文本教材作語譯及 作者簡介, 編印而成。最初目的是給海外的中文教育用作教學、補足教材及進修用的參考 讀物, 以及保存中國傳統文化與文學, 提供優質而統一的課文譯介和賞析。37引入新加坡 之後，又於一九五五至一九五六年間，出版乙、巳、戊、寅、丑、子等多集。

從一九五五年, 直到一九六 $\bigcirc$ 年代初, 友聯出版社在新馬兩地出版的參考書還包括 《星馬華文中學國文參考本》（新加坡 1958）、《星馬高中會考指導》（新加坡 1952）、 《大學中文選》（吉隆坡 1961）、《周秦散文》（新加坡 1960）、《語體散文》（吉隆 坡 年份不詳）、《南洋大學基本國文》（新加坡 1956）、《辭・賦・駢・祭・銘・筬》

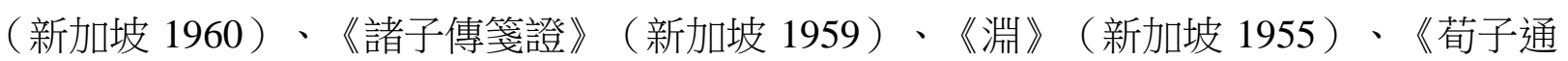
論》（新加坡 $1959 ）$ 等等。

總體而言，友聯出版的教科書，在馬來亞辦得比在香港更好。38 據王建武回憶， 「在新加坡做發行公司時, 我也推銷教科書, 當時馬來西亞用我們教科書的學校相當 多。」39 除了本身自行出版教科書之外, 友聯也與胡家建於一九五九年, 合作成立馬來亞 文化公司, 專門出版教科書, 包括英文科目等, 因為多家學校採用, 接了很大的生意, 據

\footnotetext{
33 古梅口述, 《香港文化眾聲道》, 頁 94 。

34 奚會暲口述, 《香港文化眾聲道》, 頁 60 。

35 王建武口述, 《香港文化眾聲道》, 頁 149 。

36 林悅恆口述, 《香港文化眾聲道》，頁 188 。

37 吳兆剛, 《五十年代《中國學生周報》》, 香港: 嶺南大學, 文藝版研究哲學碩士論文, 2007, 頁 17 。

38 林悅恆口述, 《香港文化眾聲道》，頁 188 。

${ }^{39}$ 王建武, 《香港文化眾聲道》, 頁 154 。
} 
說所獲盈利, 足夠他們在吉隆坡郊區買地建印刷廠和辦公室, 亦為市區內的辦公室建了書 庫。40

不過, 無論任何一個人的口述追憶, 雖略提當時馬來亞剿共的情況, 卻從未曾提到 在馬來亞的華教處境, 包括全國華校教師工會、華校學潮與英殖民地政府之間的激烈對 抗。後者也對友聯諸人以及期下的刊物《蕉風》與《學生周報》抱持敵視的態度。 41 。綜 觀《蕉風》所刊的內容, 雖有寫實主義的小說（如方天、白蒂之作）, 不乏諸多階層的細 筆描敘與逼真考察, 亦有多篇反映教師的貧困處境, 惟對於華教在諸多語言教學與面臨生 存威㤯的處境及其政治尖銳問題, 卻無一字著筆, 除開為了避免觸犯英殖民地政府和馬來 亞聯合邦政府的政治忌諱, 另一方面也是為了與當時較為激進的學潮華教人士之間, 劃分 立場。

友聯諸人來馬之後, 與在地政府的要員關係不錯, 在口述訪問中也數度強調自身的 文化工作，是以「正當」的方式進行，「對馬來西亞文化教育有益的工作」。 ${ }^{42}$ 在此的 $\ulcorner$ 正當」, 應該是指各種活動, 皆獲在地的執政當局所批准。同時, 也應該意味著所辦活 動與方式, 皆符合他們自身的目標宗旨, 包括傳承與保存教育中華文化的信念。古梅曾經 提到「從新亞研究院熏陶養成的信念」，包含了自由主義、民主和對中華文化的維護。43 無可否認, 論及自由主義與民主觀念, 當與亞洲自由協會所欲推行的教育宗旨, 脫不了關 係。綜觀亞洲自由協會曾積極資助多家在港的大學院校, 與學人交流密切, 美國的自由觀 念滲透校園, 並不意外; 但對於民主與自由的觀念, 亦可溯自中國大陸民國時期, 知識分 子對現代化的想像。

不過, 收錄於《香港文化眾聲道第 1 冊》内、曾經短暫來過馬來亞推行《學生週 報》活動的受訪者, 沒有任何一個人提起過《蕉風》的定位「馬來亞化」。也許因為他們

\footnotetext{
40 王建武, 同上注。
}

${ }^{41}$ 王琛發, 〈馬來亞冷戰陰影下的風雨聲、讀書聲與罷課聲一一 1950 年代華校學生運動在歷史上的定位及 影響〉, 載鄭文波、楊景水, 《二十世紀五十年代學生運動史料匯編》, 〔出版地不詳〕全馬華文中學生 捍衛華教運動五十周年工委會出版, 2009, 頁 379-398。他在文中重提五十年代時, 反殖意志高昂的華校 生, 多數對《蕉風》與《學生周報》抱持鄙視排斥的態度, 王氏一方面認可《蕉風》與《學生周報》對個 人主義與自由主義的追求與堅持, 一方面又強調後者缺乏自覺, 不知自身受到美國的反共大計所操縱。

42 奚會暲口述, 《香港文化眾聲道》，頁 70 。

43 譬如古梅在提到友聯的理念時, 認為主要是 $\ulcorner 民$ 民主政治、公平經濟及文化自由」。她也認為自身所持的 文化觀念, 主要源自新亞研究院的薰陶, 多於友聯出版社的指導。 
在馬居留短暫, 加以時空遙隔, 且當時舉辦的活動都以《學生周報》的讀者爲主, 相對於 《蕉風》提倡的 $「$ 馬來亞化」, 「維護中華文化」與「推廣華文教育」的議題似乎更為熟

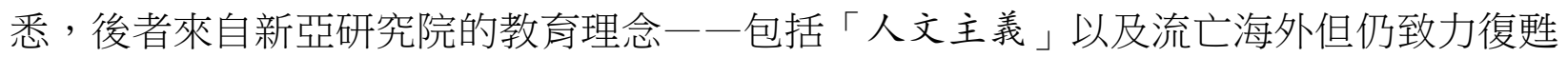

$\ulcorner$ 中國固有的歷史文化的基本意識與基本觀念」。4

與受訪諸人相對，其他定居較久的編輯人員（方天、姚拓，劉國堅（白圭））當初 卻能在短時間内認同馬來亞化, 對於在地的情感, 顯然與古梅等人不同。由於《香港文化 眾聲道第 1 冊》無法訪問到方天與姚拓, 但姚拓與白圭都有出書結集追述友聯往事, 故稍 後將從他們寫下的文本, 再作闡述。

\section{（四）剿共形勢與各方張力}

在過去關於友聯出版社的《蕉風》與《學生周報》的立場，經常在「反共」與否的 角色糾結不清。但打從《蕉風》創刊號提出的「純文藝」與「純馬來亞化」標語開始, 就 已經在擺明，他們抱持的是「非共」的立場，「反共」目的較為隱蔽。若參考香港的友聯 出版社印在手冊上的創立宗旨, 其反共立場卻是明顯清楚 :

就短期來說，我們希望與其他團體及個人合作，影響華僑社會、教導自由世界 （尤其束南亞）的中國青年, 使他們認清共產主義和共黨統治的真相, 與束南亞 其他人民全心合作, 以對抗共黨的顛覆活動。我們所有的中文刊物, 殊途同歸地 都是以束南亞華僑為主要對象——知識分子、青年學生、以及兒童。

就長期來說，我們希望促進雨千萬自由中國人的文化運動、政治運動和社會運 動，使他們成為一個強大的、團結的民主力量，以影響大陸局勢，促使中共政權 結束。 ${ }^{45}$

根據受訪的年輕編輯，他們認同的乃是自由主義的立場，同時維護「中華文化」。「純」 意味著全然不沾階級鬥爭、不含政宣意圖、去除認同中國為祖國的意識, 以及表明無論是

\footnotetext{
${ }^{44}$ 錢穆, 〈告新亞同學們〉, 《錢賓四先生全集——新亞遺鐸》, 臺北：聯經, 1995 , 頁 21-23。亦參見 〈研究所計畫綱要〉, 頁 72-74。

${ }^{45}$ 也斯, 〈解讀一個神話?一試談《中國學生周報》〉, 《香港文化空間與文學》, 香港: 青文書屋, 1996 , 頁 162 。
} 
在文藝創作或在建構馬來亞方面, 都不為達致其他目的, 或許也在表達這份刊物意欲「如 實」( 即不帶左翼意識形態) 呈現出馬來亞的意思。

一九五五年, 由於綑共, 以及當時對華文的污名化偏見之下, 華教面臨存亡的緊張 狀態, 左翼與學潮運動掀起激烈的抵抗, 連帶也把矛頭指向與美援文化有關的《蕉風》和 《學生周報》，如同古梅所言，當時在馬來亞遭到的敵意要比在香港「稍微嚴重」。 ${ }^{46}$ 由 於香港的英殖民地政府不欲得罪中國, 故左右兩翼在香港都相當活躍, 彼此尚有對話周旋 的空間。雖然在港英政府的控制與警告之下, 美新處得在表面上, 把美援的反共動機加以 修飾, 予以看似中立的解釋。然而, 在大批流亡知識分子滯港且活躍參與的情況下, 香港 依舊是非左翼和反共陣營出版的重要陣地。

不過，在馬來亞，緊急法令委員會並不像港英政府那樣，對中共懷有一定的顧慮。 馬來亞的英殖政府在剿共行動上投入軍事資源之不遣餘力, 與在港英政府對於美新處高調 反共的忌諱, 截然不同。在馬來亞, 美國新聞處的一些文化資助項目, 也甚受英殖民政府與 馬來亞聯盟陣線所歡迎。譬如從一九五 $\bigcirc$ 年代至一九六一年間, 在馬來亞與新加坡大量設立 的公共圖書館, 便是為了反共目的, 當時均獲得美新處與英國文化協會大量捐書。 ${ }^{47}$ 為了改變 在地居民的意識形態, 使反共意識全面滲透華社圈子, 馬來亞政府多方面與英美雙方合作。 雖然在一九四九年, 中國政治易權之後, 英國首先表示承認中共的政權, 宣布其殖民地區 的國民黨為非法組織等等。霹靂州的華人大會堂, 曾經憂慮霹靂州會出現一個中共派遣的 赤色外交官, 因而組團呈上備忘錄, 以表反對。 ${ }^{48}$ 國民黨人與馬華公會之間往來密切, 前 者甚至是組成馬華公會之重要勢力之一。英殖民政府對於華社的左右翼分裂, 馬來亞國民 黨人與左翼之間的意識差別、矛盾和衝突, 其實亦了然清楚。他們觀察到當時一些在馬來 亞的報刊和華校, 本來也同時在中國登記, 報刊的目的是為了能夠持續獲得來自中國（國 民黨）政府的資金支持, 而華校的目的則是要保障自身文憑獲得中國承認, 使學生畢業回 國後, 可以在中國持續學業或深造。這些團體在中國政權變更之後, 都各懷不同的疑慮與 利益考量 ; 而對於英國人來說, 他們尤其不欲見到中國政府, 對當地華社持續發揮影響

46 古梅口述, 《香港文化眾聲道》, 頁 97 。

${ }^{47}$ Lim Edward Huck Tee. Libraries in West Malaysia and Singapore; A Short History. Kuala Lumpur: Malaya University, 1970, p.32. 這篇論文從冷戰歷史闡述圖書館的創立, 曾接受各方反共團體挹資協助。至到一九 六一年, 馬來亞共有一百五十家中文圖書館與九十家馬來文圖書館, 且大部分中文圖書館都座落在新村。 48 見檔案 FCO 141/14394: Singapore. Chinese Consular Representation in Singapore and South East Asia after the Recognition of the Chinese Communist Government by the UK Government 之 00128/49: “Chinese Assembly Hall of Perak Submits Petition to High Commissioner objecting to Red Consul in Perak." 
力。根據英殖民政府的理解, 過去中國國民黨為了對付共產黨, 曾經有過控制海外華文報 刊的威妿舉措，譬如「損及中國政府的報導者，將在中國遭禁」、「涉及的出版者將被禁 止回國」之類的法律, 因此, 如果當地報刊、學校與文化機制, 在這之後轉向與中共建立 聯繫, 決非英殖民者所樂見。 ${ }^{49}$ 尤其正值緊急法令時期, 在英殖民官員看來, 容許當地華 社與中國方面保持聯繫, 或者接受中共派遣的大使, 簡直就是在給彩共行動留下可擊的弱 點。故此，政府一方面積極取締傾共的報刊，同時也援引一九三九年的出版法令，更加嚴 密監控在地政府出版的刊物。 ${ }^{50}$ 另一方面, 迎入友聯諸人在本地出版刊物, 藉以重建一個 能鼓吹認同在地與融入馬來亞國族觀念的文化空間, 在他們來看, 不旁為取締左翼之後, 更好的抉擇。

在緊急法令期間, 由於英殖民地政府視華校為共產黨的溫床，同時也多方面壓制華 教, 使得華校掀起激烈的華教運動, 後者且扮演著非常關鍵的文化守護與抵抗不公安排的 鬥士角色。故此, 當友聯諸人也在這種局勢中, 推行中華文化與華文教育的時候, 該要如 何理解其意義?

從當時刊登的小說來看, 《蕉風》並非不無意識到華教面對的各種問題。多篇小說 側重於華校教師薪水微薄的苦況, 亦有以學校裡的濫權為題材, 如創刊不久即採用的小 說, 重陽所著〈教師節〉相當尖銳, 國家允諾的可待前景, 總及不上近在眉睫的生活壓 力, 華校經營的資金匱乏, 以致教師負擔沉重終至崩潰。其他以華校為題材的小說, 亦常 見華校被國家體制忽略的邊緣處境, 壓力轉向學校內部的鬥爭、教界的虛偽人際與校長濫 權等訴諸於道德的批評, 惟政治因素, 卻常給模糊化或避重就輕。 ${ }^{51}$ 惟有數篇小說, 卻相 當敏銳地捕捉到華校的問題, 如重陽、吕朗與方然的作品。重陽與呂朗的小說尤多細節鋪

49 見前述檔案 CSO 00128/49: “Forteenth Commissioner-General’s Conference(Malaya-Borneo Territories):

Establishment of Communist Chinese Consulates in British Territories in South East Asia”, 頁 4 。這份會議報 告的議題, 包括鳌清中國大使的權限與任務, 分析馬來亞華社對中國大使的實際需求, 以及如果中國大使 駐馬來亞，對於英殖民政府剿共計畫可能導致的不利因素。

50 其商討見檔案 CSO 00128/49: “From Officer Administering The Government to Secretary Of State(date 4.1.50)”。

51 重陽, 〈教師節〉 (上), 《蕉風》1955 年第 3 期, 頁 10-13; 重陽, 〈教師節〉(下), 《蕉風》, 1955 年 第 4期, 頁 11-13。零丁, 〈宋伯- - 甘傍依干的大人物〉, 《蕉風》1956 年第 8期, 頁 30-31。呂朗, 〈暗流〉, 《蕉風》1957 年第 30 期, 頁 6-9。紅蕉, 〈教師日記〉, 《蕉風》1957年第 32 期, 頁 1516 。黃山, 〈萬世師表〉, 《蕉風》1957年第 45 期, 頁 $14-15 \circ$ 方然, 〈未了情〉, 《蕉風》1957 年第 50 期, 頁 4-8。 
陳。小說雖也召喚多元族群共存的美好想像, 然而意識到族群偏見之僵固難移, 華校的體 系在資源與理念多重圚乏下, 常顯得左右支絀。從這些作品與選刊來看, 《蕉風》編輯 （尤其是到一九五七年還在職的方天）, 對於本土的華校體制與政治痽結理當有相當理 解, 而且在「傳承中華文化」的前提下, 華校的狀態, 也應該是南來友聯文人相當關注的 面向。但基於與馬來亞聯盟政府合作的關係, 其發聲方式以及所能探㽎、批評的尺度, 仍 有相當約束。 ${ }^{52}$ 那政治的痽因被含糊化處理。友聯與馬華公會之間的關係極為良好, 當時 的領袖是陳禎祿。陳禎祿對華教的態度與梁宇臬於一九六 $\bigcirc$ 年參與《拉曼達立報告書》表 現的態度, 立場截然不同。陳曾在華教議題上極力向巫統爭取, 甚至屢上備忘書予英殖民 政府, 要求在各種課題上善待華人。53

姑且不論當時的華教鬥士與學潮運動者是否意識到以下這點：友聯出版社在新馬自 一九五 $\bigcirc$ 年代開始推行的文學刊物、華文教育、華文寫作等工作，確實提供了與左翼全然 不同的文化詮釋。在中共執權之後, 流亡各處的非共知識分子, 仍然試圖延續、建立一個 非左翼華文教育與華文文學場域的可能性。他們引入了一個存在中共政體之外的一一主要 從香港開始、稍後又散佈到東南亞一一離散各地的中華現代文學想像。換言之, 美國在一 九四九年後, 在香港扶助的第三勢力以及由而來的文化資源, 在歷史偶然中打開了一個與 左翼文學觀點競爭的, 後來影響擴展至全球的離散華文文學。對於馬華文學來說, 因友聯 文人南來所開啟的現代主義書寫, 稍後既已是本土馬華文學的一環, 也就不能不與整體馬 華社會的諸多文化資源結構（包括華文教育）, 在其續存上有無法否定的（讀者來源、評 論關注）必須緊繫相依的關係。54 華文文學與文學刊物的生存, 必須與華文教育唇齒相

52 從文學創作的層面而言, 相對於開拓表達方式與文字美學, 政治表述似乎非屬「文學本位」。然則, 著重 形式或美學手法，並不必然擯棄「觀點」，這包括對於「政治」提出「文學的觀點」。固然在寫實主義 中, 那貫穿敘事的批判力量, 往往僘關政治。但即使拋開寫實主義的觀點不談, 「文學本位」理當能夠賦 予文學以窎盡各種可能的關注「對象」, 無論是美學、技巧、語言、觀點、人性與普世價值（慾望、倫理 等等），乃至到政治，都應當可以成為文學所觀察與感興趣的對象之一。

53 古鴻廷，〈英屬馬來亞聯合邦之華文教育〉，頁 51-53。

54 盡管, 在馬來亞獨立之後, 華文教育漸行崎嶇, 水平一再降低。在馬來民族為中心本質論的國家體制 裡, 華文教育與文學空間的堅持, 有賴於民族主義情感來撐起, 處於必須自救自助的狀態; 而對華教學潮 反殖歷史, 懷有強烈認同的王琛發, 始終認為友聯文人開拓的非左翼文學園地, 是美國冷戰策略主導下, 使東南亞華人政治意識轉型的成功複寫。王琛發, 〈馬來亞冷戰陰影下的風雨聲、讀書聲與罷課聲 1950 年代華校學生運動在歷史上的定位及影響〉, 頁 379-398。然而, 將左翼等同於抵抗, 而非左翼文學 與現代主義等同於馴服, 由此證實資本主義勝利的二元論, 未能開展更多的討論空間, 何況近代的現代文 學研究, 關於文學書寫的不及物性與反思資本主義壓抑現代性的成果上, 已走得更爲曲折幽遠。 
依, 這點與後來馬華部長陳修信、梁宇者講求實際效用而主張捨棄華文教育的求存態度, 顯然存在分歧。

由於友聯出版社的創辦者來馬時, 是受馬華公會梁宇臬邀請南來。其反共立場, 似 乎也相當於英殖民者和執政黨的「同路人」。然而, 在地馬華作家的紛繁意見, 可能也使 《蕉風》的政治觀變得豐富, 不獨只有反共的立場。在獨立以前, 尤其陳禎祿尚在的時 期, 在地華人的共同體想像, 實際上是非共, 但同時又非資本主義的。 ${ }^{55}$ 在共產 /反共產 主義的軸向之外, 華社還有其他關心的課題, 包括對於在地公民權、華教, 緊急法令時期 的諸多失序問題與福利要求等等; 而友聯諸人念茲在茲的, 還有中華文化的傳承任務。馬 華公會當時也受到亞洲第三世界國家, 尤其是繼萬隆會議之後的中立觀點所影響。 ${ }^{56}$ 在一 份由美新處遠東研究部門撰寫的報告裡, 他們注意到自從一九五五年四月亞非會議以來, 中國轉向與周邊國家建交的方式, 而非輸入其共產思想來支配東南亞區域的政治。中國並 沒有像美國預測的那樣, 繼續往東南亞蔓延其赤色勢力。除了緬甸、越南之外, 東南亞多 國傾向採取中立, 不跟冷戰的美、蘇任何一方結盟。 ${ }^{57}$ 在萬隆會議之後, 許多亞非國家聯 合發出的反殖民主義、反帝國主義以及關心人權和各國主權等主張，形成戰後東南亞區域 極有影響力的國際觀點。這些強調區域自主性的觀點, 似乎也是冷戰左右政治對壘之外的 另一選擇。當時也影響部分《蕉風》的作家，如陳振亞，認為這也該是馬華文學應有的特 色。這點將在第三章再論述。

\section{三、《蕉風》的「純馬來亞化」主張}

\section{（一）本土認同}

根據前述何振亞、奚會暲和王建武的追憶, 一九五五年友聯出版社之所以能夠來馬 創立，緣起於當時的勦共委員會，立意從外地尋找可在本土從事非共或反共的文化工作， 以便改變當時傾左的文化場域。不過，即便同在友聯陣營中，個別的編輯、作者，也會因 其所投入的面向、經歷各異, 而為彼時彼地的生活經驗, 留下深淺力道不同的刻痕。奚會

\footnotetext{
${ }^{55}$ Anna Belogurova, "The Malayan Communist Party and The Malayan Chinese Association: Internationalism and Nationalism in Chinese Overseas Political Participation, c.1920-1960”, p.138.

${ }^{56}$ Anna Belogurova, ibid., p.138.

${ }^{57}$ Division of Research for Far East, "Reactions to Current Communist Tactics In Southeast Asia." April 27, 1956. Document No. 7243. p.1-5.
} 
暲、古梅等人, 各有自身的流動經歷與對中華文化更深的認同, 這與後來劉國堅、姚拓對 馬華文學的認同, 以及馬摩西對自身在馬來亞的安居抉擇, 都不一樣。《蕉風》創刊時的 編務籌委, 包括馬摩西、李汝琳、范經, 皆非剛剛南來的友聯社員, 他們都是在地居留了 好幾年的南來文人。58 當時在馬來亞執行編輯工作的方天、社長申青, 他們的文章亦比何 振亞、奚會暲、古梅, 都流露更多對馬來亞的認同感。《香港文化眾聲道》一書裡的受訪 者, 大都已在他鄉定居多年, 在馬來亞居留時期則相對短暫, 故難以切中《蕉風》的策畫 方針對於馬華文學的影響。

雖然友聯來馬, 出於當局為反共而引入的文化工作者, 但這並不排除, 他們與在地 的文人接觸、交流、互動之後, 吸收更多的在地觀點。當英殖民地政府與馬來亞聯合邦政 府於一九四八年提出馬來亞化時, 並非所有政府的觀點都為華社所反對。當時華人也在多 個領域裏, 包括教育, 表明對本土化的支持。從一九五一年的方吳報告, 可以顯見當時華 教人士其實願意接受馬來亞聯合邦政府提出 $「$ 馬來亞化」要求, 雖然當局對 $「$ 馬來亞化」 的意義沒有解釋得很清楚, 但華教人士在編訂華文學校教科書時, 基本上都有表現出支持 本土化的態度, 這樣的接受也出於對自身與本土關係的理解, 他們認為中華文化與自身在 此地數代的歷史, 必然也是本土歷史與文化的一部分。59

從這一點而言，《蕉風》在走向本土論述的「馬來亞化」，它採納此處頌揚多元、 雜無繁茂的文化論述, 漸漸淡化了由新亞學院所主張的「維護中華文化」論述。不過, 這 在地化的過程，在漫長的時間裡經歷起伏，並非一開始就如同創刊詞的聲明那麼固定。

以下將根據文本, 闡述《蕉風》所提的 $「$ 純馬來亞化」, 及其家園與本土論述, 這其 中固然有與英殖民者或執政者同路、相似與差異之處, 但是與左翼的語彙也並非全無重 疊。這一切都要回返到當時的歷史情境中, 才能對《蕉風》的「純馬來亞化」觀點、貢獻 與局限，做出評價。

《蕉風》於一九五五年十一月的創刊詞這麼寫 :

\footnotetext{
58 馬摩西在一九四 $\bigcirc$ 年代末時, 以外交官身分派駐來馬。李汝琳在一九四七年南來新加坡, 執教南洋華僑 中學、新加坡師訓學院和南洋大學。范經, 筆名常夫, 出生於中國福建邵武。一九四七年移居新加坡。曾 任新加坡南洋女中、中正中学、公教中学教員。資料參考：黃孟文、徐迺翔編，《新加坡華文文學史初 稿》（東南亞華人研究叢書之六）, 新加坡：八方文化, 2002 。常夫, 《牆外集》, 新加坡: 蕉風出版 社, 1957。

59 古鴻廷、曹淑瑤, 〈馬來亞華族母語教育的維護, 以《方吳報告書》的理念為例〉, 頁 $11 。$
} 
「如何去瞭解一個民族，決不是翻閔幾本史地書籍，或誦讀幾篇宣傳的文字所能濟 事的……沃野上的一山一水, 生活上的點點滴滴都可以透過文藝的筆法, 清楚的體 現在我們的面前, 觀微知著, 這也許就是我們了解環境達到與其他民族和平共處的 最好辦法。

「幾位文化界的朋友每當談到上述問題時，都有共同的感覺，一致認為在今日的星 馬，創辦一份純馬來亞化的文藝刊物，實在太需要了。」 60

有關《蕉風》這一時期的主張與本土書寫, 在這之前已有伍燕悀、潘碧絲、陳湘琳發表的 論文〈從《蕉風》（1955－1959）詩人群體看馬華文學的現代性進程〉做過初步討論。她 們認為《蕉風》在前五年草創時期主張「馬來亞」階段時期的詩歌除了顯示本土認同之 外, 也折射了現代情感、現代生活方式和現代心理。6 ${ }^{6}$ 細讀當時的文本, 可發現其本土認 同其實相當曲折。

《蕉風》的「純馬來亞化」是表達認同與歸屬本土的聲明, 雜誌透過全面在地化的 內容、策劃以便能獲得與其他族群融合共存的視野。在這本創刊號封底的〈讀者・編者・ 作者〉篇裡, 編輯也強調這是一份「純以馬來亞為背景的文藝刊物」, 《蕉風》編輯並未 特意解釋何謂為 $「$ 純」馬來亞化, 但縱觀創刊前五年的內容, 「純馬來亞化」的宗旨當是 指所刊內容一律為本土性題材、至少故事背景發生在馬來亞一實際上, 從翻譯作品、作 者來稿、專題版位, 幾乎全都以馬來亞為背景或取材, 小說內容即便並不 $\ulcorner 反$ 反映」馬來亞 的本土現實, 往往也特意提及地點以表明故事是發生在本地。

《蕉風》開闢多個版位, 專門刊登與本土相關的稿件, 除了接受讀者創作投稿的文 藝理論、新詩、小品、小說之外, 每期還特設版位刊登馬來亞與新加坡地方掌故、馬來人 傳說、神話與寓言、馬來文學作品翻譯以及馬來民族的生活習俗、歷史或野史故事。62

從一九五五年創刊以來，直到一九五九年第七十八期改版之前，寫實主義與「馬來 亞化」可說是《蕉風》最鮮明的旗幟。63在撰寫馬來亞地方與文化相關的文章方面，初期

\footnotetext{
60 蕉風, 〈創刊詞：春風吹遍綠洲〉, 《蕉風》1955 年第 1 期, 頁 2 。

${ }^{61}$ 伍燕翎、潘碧絲、陳湘琳, 〈從《蕉風》（1955-1959）詩人群體看馬華文學的現代性進程〉, 頁 8396 。

62 亦可參見林春美〈獨立前的《蕉風》與馬來亞之國族想像〉文內, 《蕉風》在創辦首兩年內, 相關本土 性編輯的版位列表。
} 
較重要的作者有馬摩西與蕭遙天; 負責翻譯馬來人神話、寓言和馬來文學作品, 則有余壽 浩和鍾劍雄; 新加坡的地方掌故主要是由許雲樵提供。此外, 不少小品、詩歌與小說也以 馬來亞的華人社會為題材, 小品文也頗多書寫地方史、追溯中國古人先輩南來的歷史事 蹟、南來移民對當地生活起居住行適應等問題。

《蕉風》刊登的本土書寫, 最初大多為資料整理、提供本土知識的欄位。這樣的策劃 方針，可能起於與英殖民地當權的「馬來亞化」配合，但也不無認同當時馬華文壇上高浱 的本土意識。在一九五七年獨立之前, 對 $\ulcorner$ 本地化」的要求幾乎所向披靡, 廣見於左翼與 非左翼的文藝界, 作品多「高歌獨立」、為「即將到來的新時代而深深動情」, 文壇盡是 一片歌頌國家的浪漫激情。64在一九五 $\mathrm{O}$ 、六 $\mathrm{O}$ 年代, 左翼的馬華文學作品大量敘述抗日 反殖鬥爭以及馬共革命, 並持續提倡以服務工農兵為文藝最主要的任務。到一九五九年, 有一篇由忠揚發表的〈論愛國主義大眾文化底建設〉, 文內就以左派觀點來建構「馬來亞 化」, 語氣非常樂觀。65謝詩堅在《中國革命文學影響下的馬華左翼文學（19251976）》一書中, 就以愛國主義與馬來亞化文學命名左翼文學的本土意識。他指出當時左 翼陣營為了持續擴展階級鬥爭意識的文藝觀, 也曾積極推介由巫至華的翻譯, 然而左翼的 馬來亞化未能真正達到對馬來人在文化、信仰、習性各個方面的了解, 僅透過單向的翻譯 工作想達到種族交流，卻不免還是「左翼華人『一廂情願』的文化觀」。66

國家獨立帶來的局勢變化，催生了對本土的認同，但即便在支持本土認同的群體中， 所持觀點亦各自受到不同的意識形態與政治立場而各有差異。左翼拒絕承認未納入新加坡 的馬來亞。與此相比, 非左翼的文學刊物《蕉風》更多配合執政者的族群和諧論述, 經常 報導當時巫統舉辦的友族節目。雖然這些報導行文腔調不免流於官方, 但另一方面, 雜誌 每期都向在地學人如許雲樵等邀稿, 從本土文化、文學、知識全方位建構。當時短暫居留

${ }^{63}$ 《蕉風》刊登的寫實主義作品, 無論是敘述對象或書寫形式, 仍互有差異。方天撰寫不少寫實主義的作 品, 筆法相當細淢, 但並非如同延安文藝要求的反映寫實論者。姚拓的創作則混合了寫實主義之作, 以及 有部份是表達倫理、概念近於抽象的作品。此外, 其他人如黃思騁和黃崖皆有寫實特色, 題材多樣, 包括 學校、教育、商場、職場、都市生活、家庭倫理等等。姚拓也根據當時所看到的作品, 把這些作品分成了 四大流派, (一) 左翼寫實, (二) 傳統寫實 (非左翼) , (三) 不含動機的純粹只為文藝而寫作以及

（四）現代派寫作四類。姚拓, 〈二十年來的新馬華文文學〉, 載香港中國筆會文選委員會編, 《二十年 來的中國文學》, 香港: 香港中國筆會, 1979 , 頁 78-82。

64 潘碧華, 〈馬華文學中的國家認同與文化反思〉, 頁 62-67。

65 謝詩堅, 《中國革命文學影響下的馬華左翼文學 $(1925-1976) 》$, 頁 185 。

${ }^{66}$ 謝詩堅, 《中國革命文學影響下的馬華左翼文學 $(1925-1976)$ 》, 頁 186。 
的文人亦不乏書寫南洋風情者, 如於一九五二年至一九五七年期間來馬任報章副刊編輯的 香港作家劉以䍘, 就曾寫過以新加坡及馬來亞為背景的小說。67不過, 正如張錦忠所言, 南來作家「開始對「本土」產生興趣與關懷（不一定是歸屬感）」，此外，「提倡翻譯馬 來文學更是關注本土的他者／異質文化之表示。」故距離建構本土認同的馬華文藝屬性言 之尚早。68

以下將集中處理《蕉風》當時南來文人對馬來亞獨立建制的反應，以及創刊早期的 現實主義論述情況，前者尤以蕭遙天和馬摩西為主要討論對象。

\section{（二）南來文人對國家建制的反應}

在一九五八年由《蕉風》所舉辦的一場「漫談馬華文藝」的座談會中，可見到國家建 制帶來的衝擊。如參與者葉綠素的意見：

目前馬來亞正走向獨立，文藝寫作者應該暴露舊的，闡揚新的，應該寫出未來馬來 亞的遠景。配合獨立運動，馬華文藝可以找出一條路向。69

另一位與會者常夫（范經）也以星洲華人的情況來呼應華人遭到否定的「痛苦」：

拿星洲來說, 它所處的地域環境, 是束西的交通孔道……社會環境而言，華人來 此踓是蕃客，但卻又佔全人口百份之八十。這種種都是可以形成馬華文藝特質的束 西。例如，在這裡華人佔人口百分之八十，應該是主人之一，但人家卻又不承認我 們是主人，在爭取獨立中，華人也是很積極的，但是為誰爭取獨立，為甚麼爭取獨 立呢? 這都是華人的痛苦, 都是寫作的題材。70

\footnotetext{
67 劉以䍘當時擔任報社編輯, 包括新加坡《益世報》、《新力報》、《鐵報》, 以及馬來亞吉隆坡《聯邦 日報》, 曾任各地徵文比賽的評審委員, 期間他以葛里哥筆名寫過以新加坡及馬來亞為背景的小說, 收錄 在短篇合集《熱帶風雨》以及《甘榜》, 香港獲益出版社於 2010 年推出。潘碧華, 〈五、六十年代香港 文學對馬華文學傳播的影響〉, 頁 747-762。梁秉均、譚國根、黃勁輝、黃淑嫻編, 《劉以档與香港現代 主義》, 香港：香港公開大學, 2009, 頁 225。

68 張錦忠, 〈馬華文學與文化屬性：以獨立前若干文學活動為例〉, 載《南洋論述：馬華文學與文化屬 性》，臺北：麥田，2003，頁 95-110。

69 諸家，〈漫談馬華文藝〉，《蕉風》1958 年第 20 期，頁 3 。

70 諸家, 〈漫談馬華文藝〉, 頁 3 。
} 
雖然常夫發言中所敘的是星洲, 但當時新馬華文作家, 都認同兩地創作皆同為馬華文學的 整體。柯思仁在〈想像馬來亞, 操演多元文化一一五 $\bigcirc$ 年代新加坡華文知識界的馬來亞意 識 $>$ 一文中指出, 在一九五 $\bigcirc$ 年代, 新加坡華文文學在追尋本土認同的過程中, 常想像一 個多元文化精神的馬來亞圖景。雖然當時新加坡在政治概念上, 並非是馬來亞的一部分, 但在殖民歷史上, 兩地人民生活與往來互動, 使新馬猶如整體。 ${ }^{71}$ 在一九五 $\bigcirc$ 年代, 新加 坡華文社群民間, 包括政黨與文學界裡, 都有表達期盼新馬合併獨立的聲音。根據一九四 七年英殖民政府執行的人口調查, 新馬兩地加起來的華人人口比率, 為所有族群中最高。 2然而馬華文學對於馬來亞的想像，仍然是著重於一個多元族群與語言共存的理想。

《蕉風》在一九五六年的第十六期與第十八期都刊登了有關建國「馬來亞化」掀起的 問題。慧劍在第十六期刊出的〈馬來亞化是甚麼? 〉一文中討論馬來亞化與馬來化, 並依 據人口比率、華巫兩族移民來到的先後, 質疑巫人優先他族的合理性。馬摩西與海燕稍後 在七月號的第十八期《蕉風》裡發表了〈馬來亞化問題〉以及〈馬來亞化與馬來化〉，對 於種族政策的文化與權益地位不公平，都紛紛提出回應。馬摩西在〈馬來亞化問題〉裡認 同慧劍的觀點, 他從比較各國的排華與語言政策、華人移民對本土的態度（如視本地為經 商謀生之地而對政治封閉）、語文問題、參政權力、國民教育乃至政府公務人員的比例， 都大略談及。他體認到建制的偏差源於華人移民對政治的封閉與冷淡, 故此需要轉換成更 積極的態度去爭取：

近年來踓說多少有了政治的覺醒，然而在爭取參政權的過程中，久居的華人既受年 資的限制，甚至連當地出生的人，也被視作化外之民，這使我們懷疑馬來亞的前 途，是否走向一條偏塽的路子上去，把所有馬來亞人口半數以上的華人，被視為其 他民族的附庸。這一連串擺在眼前的問題一一如公民權，「國民教育」，以及行政

\footnotetext{
71 柯思仁, 〈想像馬來亞, 操演多元文化一一五 $\bigcirc$ 年代新加坡華文知識界的馬來亞意識〉, 《人間思想》 2012 年第 1 期, 頁 170-190。

72 當時馬來亞聯合邦的華人人口占百分之三十八點四十，新加坡華人人口則將近百分之七十八，兩地華人 人口加起來將近百分之四十四點七十。M. V. Del Tufo, Malaya Comprising the Federation of Malaya and the Colony of Singapore: A Report on the 1947 Census of Population, London: Crown Agents for the Governments of Malaya and Singapore, 1949, p.40.
} 
人員在比例上的調整等。都需要我們作積極性的表示, 把是非真理求得正確的答 案。73

這些對獨立將臨的變化提出意見的作者都是南來文人, 他們對國家與國民主體的想像, 和 馬來民族主義者的想像分歧極大。當時馬來民族的國族運動較能獲得英殖民地支持, 甚至 遠在獨立前, 英殖民政府就已經透過讓馬來精英以及在本地師範學院受教育畢業的馬來知 識份子在公共機關受聘就職, 使他們在建制的過程中可以超越其他族裔（比如華人和印度 人）而優先佔據支配地位。74意識到獨立後, 局勢將不同以往, 華裔文人（包括南來文 人) 僅能在馬來精英已經 $\ulcorner$ 優先」掌握建國位置的形勢之下, 盡量展開討論的空間, 提出 異於馬來民族主義者的看法。

馬摩西的問題較集中於討論國家建制以馬來文化與語言為中心的範圍。他在〈馬來亞 化問題 $>$ 裡提出多種語言勝於單一語言：「我想若用馬來文去對印度人傳達意見, 或散佈 文化, 其效用也遠不如用他們的文字為易」。75他對規定學習的語言政策也不以為然, 指 出「在聯邦生活的人, 多能操馬來語, 可惜我們沒有花一點時間學習他們的拼音文字。由 此可見, 華人學習馬來文一事並不一定要政府強迫的命令方有致成, 相反的, 硬性規定是 否能達到預期的效果, 實堪懷疑。」 76 「總之若推行馬來文, 最善莫如出於自動的要求, 其所得的效果當會較任何命令為佳」, 甚至提出了語言學習應當雙向進行才有助交流：

$\ulcorner$ 同時我們也希望馬來人, 能有少數人學習華語, 以便於了解華人的生活情況, 這對於馬 來亞的安定和繁榮是有益的。」 77

這些建議對於今天已經長期為馬來中心主義為國家教育／文化主流所形塑的公民來 說, 幾乎是讓人驚奇和難以想像的。不過在獨立之前, 人們還未受到國家以單一的語言觀 念模塑, 提出這樣的意見卻是理所當然的。正如馬摩西在文中所言, 「究竟是把馬來亞當 做永久的家鄉, 或者仍像過去似地一天算一天」, 故必須起而行動改變對待本土的觀點。 若要以此為家, 便不能重複前人與本土疏離的做法：「如果我們要把馬來亞當做永久居住

73 馬摩西, 〈馬來亞化問題〉, 《蕉風》1956 年第 18 期, 頁 2 。

${ }^{74}$ Raymond L.M. Lee, 'The state, religious nationalism, and ethnic rationalization in Malaysia', Ethnic and Racial Studies, 1990, vol.13(4), p.486-501.

75 馬摩西, 〈馬來亞化問題〉, 頁 3 。

76 馬摩西, 〈馬來亞化問題〉, 頁 2 。

77 馬摩西, 〈馬來亞化問題〉, 頁 3 。 
的家鄉, 就該加重自己的責任, 介紹自己民族優良文化, 和尊重各族的文化, 以建立名符 其實的獨立的馬來亞。」 78

從這些文章來看，《蕉風》可說是提供了一個讓南來文人表達與馬來民族主義者觀 點相異的空間。這些建議並不會被即將獨立的國家政體所接受, 甚至也不見得會被馬來民 族主義者看見、或可能與馬來民族主義者對話。雖然這些話題不屬於文學的範圍, 然而當 時建國的政策確實令到文人對未來中文在本土的發展感到焦慮。盡管如此, 他們仍然熱衷 地、幾乎是激情澎湃地在各篇文章裡滔滔不絕地表達愛國之意。

例如, 《蕉風》第六期有一篇記事, 黎青〈母土的呼喊 : 記巫統婦女部遊藝會〉, 便 對馬來文藝或文學表現出極友善的接納。這篇文章記敘作者在現場觀看舞蹈與笑劇的經 驗，在聽不懂馬來語的情況之下，觀者僅靠聲音與視覺來感受現場的氣氛：

……位穿著天蓝色布紗籠的女學生獨唱馬來古典歌, 這個歌富有極濃厚的回教色 彩，不參雜近代西洋歌曲的成分，是道地的馬來人的歌，歌聲悠揚且哀怨，正好像 在馬來亞的森林裡、草原上，當夕陽斜落，黄昏近暮時，從回教堂的塔頂傳至遙遠 的頌禱。筆者不懂馬來語，但是從歌聲裡卻能聽到一個民族的哀怨和堅誠的信心。 79

我踓然聽不懂，但是看著那滑稽的模樣，又受了霂場笑聲的感染，也止不著大笑。 看了和聽了他們的歌舞戲劇，筆者深覺得馬來人富有藝術的天才，他們唱的歌聲充

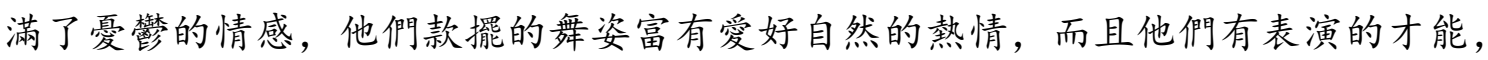
這大概是瑰麗而熱情的馬來亞所孕育出來的吧。 ${ }^{80}$

這篇文章所敘的本土氛圍相當和諧, 對馬來人與土地不吝讚美。巫統乃是主張馬來人特權 立場的政黨, 是在反對馬來亞聯邦的運動過程中, 於一九四六年成立。81 它在一九五五年 大選之前, 與另外兩個以族群為建基的政黨一一馬華公會及印度國大黨一一組成聯盟, 相 當成功地贏取了華裔與印裔的支持。聯盟政府採取了內部的「靜默的協商」(quiet negotiations), 避免在種族議題上過於確定表態, 甚至在馬來人與非馬來人的權益問題上

\footnotetext{
78 馬摩西, 〈馬來亞化問題〉, 頁 2 。

79 黎青, 〈母土的呼喊一記巫統婦女部遊藝會〉, 《蕉風》1956 年第 6 期, 頁 16 。

80 黎青, 〈母土的呼喊一記巫統婦女部遊藝會〉, 頁 17 。
}

${ }^{81}$ Mohammad Yunus Hamidi, Sejarah Pergerakan Politik Melayu Semenanjung, Kuala Lumpur: Pustaka Antara, 1961, p.126. 
保持含糊, 以便避重就輕地獲得支持。在這段期間, 愛國意識蓬勃滋長, 透過聯盟的族群 成員黨召喚各族成員，國家意欲塑造的國族意識也得以傳播到各族群體之中。82

對於這群在獨立時期抵達馬來亞的《蕉風》南來文人而言，他們所描敘的家園想像， 與早期的「中國原鄉」恰好相反, 幾乎改寫了自十九世紀晚清以來就佔據馬華文學的民族 主義想像。83在進行馬來亞化的本土書寫時, 不少仍沿用先輩描述南洋既有的觀點或敘述 修辭, 繼續建構馬來亞天性本質自然、淳樸、熱情、樂土沃野的想像。藉由這類理想與美 化的本土意像, 催化接納（即便是想像投射的）異族他者, 也驅動作者群著手實行「去中 國化」的本土書寫，將「居住之地」構塑成可被認同的「歸屬之地」。 ${ }^{84}$ 翻閱早期的《蕉 風》, 介紹馬來民族與原住民文化習俗的文章幾乎是從各個方面蒐集組合。 ${ }^{85}$ 正如安德森 (Benedict Anderson)所言, 一個群體建構主體性的方式, 不在於本身的「虛假／真實」， 而在於「想像」的方式。86 他們透過想像表達對國家的認同, 將自身與過去認同中國民族 主義的先輩區別開來。

\section{（三）現實主義觀點}

${ }^{82}$ Helen Ting, 'The Politics of National Identity in West Malaysia: Continued Mutation or Critical Transtition?' Tonan Ajia Kenkyu (Southeast Asian Studies), 2009, vol.47(1), p. 35-36.

83 黃錦樹, 〈中國性與表演性 : 論馬華文化與文學的限度〉, 《馬來西亞華人研究學刊》1997年第 1 期, 頁 59-96。文中提到獨立建國之後, 馬華文學從寫實主義進展至現代主義, 寫實主義強調「反映現實」

$\ulcorner$ 此時此地」的寫作, 把中國性排除在外。

${ }^{84}$ 比如説在首五年草創時期的《蕉風》, 有不少認同馬來亞獨立, 表達國家認同的新詩, 如薛樂〈馬來亞 的黎明〉（第 10 期）、葉綠素〈日子〉（第 12 期）、黎青〈開芭人的行列〉（第 23 期）。亦有回溯新 加坡拓荒傳說的新詩, 山芭仔〈獅子城〉（第 14 期）。

85 從一九五五年至一九五七年獨立以前, 這些文章包括出現在一九五五年第三期的胡德本〈談馬來詩歌 $\ulcorner$ 班頓」〉以及鍾劍雄〈馬來人的魔術〉、第六期纕英〈馬來人的婚俗〉、第十二期丁乙〈馬來人與弄 迎〉、第十四期劉強〈馬來人的風俗〉、第十五期魯秀〈馬來人為甚麼忌食猪肉呢〉、第十八期劉強〈馬 來人的生活〉、第二十期馬摩西〈光榮的馬來家庭〉、第二十二期諸家〈再談馬來文藝〉、第二十七期燈 籠椒〈華巫婚俗的異同〉直到一九五七年八月二十五日出版的第四十四期莫斯存〈馬來民族的習俗〉。獨 立以後, 對馬來人生活習俗與文化的介紹依然持續, 但也開始出現介紹原住民的篇章, 包括第五十六期阿 里譯〈馬來班頓十首〉、第五十八期寒草（馬來亞的沙蓋族）、第六十期高峰〈我所見到的沙蓋人〉以及 方生〈馬來亞的矮黑族〉、第六十三期魄力〈馬來情詩選譯〉以及白石〈朝拜聖地的回教徒〉、第六十八 期亞文〈沙蓋的愛情故事〉等等。

${ }^{86}$ Benedict Anderson, Imagined Communities: Reflections on the Origin and Rise of Nationalism, London: Verso, 1982, p.15. 
寫實主義隨著南渡文人越境, 當時的環境使得華文文學的寫實主義與西方的寫實主義話語 大為不同, 挾帶頗多社會主義的語境。創刊以後緊接著第二期至第五期之間, 一系列文藝 理論由李亭執筆, 包括〈此時此地的文學〉（第二期）、〈文學的現實性〉（第四期）、 〈封建主義的文學〉（第五期），甚具社會主義的寫實主義色彩，觀點不離反殖、反封 建、反投機的口號：「我常見許多所謂作家天天咒罵殖民地主義, 但對於殖民地主義的現 實題材, 竟毫無表現, 這是甚麼原因? 以我所見, 他們大概是把自己的現實忘卻, 而追求 著另外一個現實的緣故。」 ${ }^{87}$ 又如〈封建主義的文學〉，李亭對封建主義文學的批評是 $「$ 憚於改革，怯於接受新事物」、「保守主義、神怪迷信」、「不會反對現實」。他舉例 說明何為「錯誤的現實」、痛斥當時文壇劣風，88指責這種形式的文學 $「$ 保守」、「神 怪」以及對現實默認許可, 剥削改革現實的可能性。89當時文壇流行模仿古典章回故事的 創作, 而引起評論者如李亭與洛萍的批判。如洛萍在〈小說題材的處理與運用〉文中直斥 這些才子佳人悲歡離合的故事「總脫不了是同一類型」、「故事情節的發展只在其一成不 變的思想模型中打轉」, 但與李亭不同, 洛萍較對社會主義的陳腔濫調有所警惕, 他甚至 批評 $「$ 當代蘇聯一些文藝作家作品的公式化, 也是犯了同樣的毛病」, 即 $\ulcorner$ 所描寫的人 物, 成為傳播他的思想和道德觀念的工具」。90故《蕉風》雜誌雖被視為與左翼對立的刊 物, 然而其作者群中卻和而有異, 既有持社會主義的文藝觀者, 亦有以純文藝創作為自我 定位者。

不過隨著第五期李亭的評論結束之後，《蕉風》的文藝理論幾乎一連消失了十數期， 除了第十一期有一篇黃昱〈談新詩〉, 以及第二十期有〈漫談馬華文藝〉座談會的報告之 外。第二十期以後, 每期恢復刊出文藝評論。此時的評論者有黃昱和洛萍, 他們較少為寫 實主義或社會主義搖旗呐喊, 除了第二十期刊登〈漫談馬華文藝〉的講座紀錄當中白蒂的 觀點之外; 白蒂試圖以社會主義的服務觀點來解決本土認同的難題。91他把反殖、反封 建、反地主、反資本主義, 再加上反種族主義, 將之並列為馬華文藝該有的「特殊精

\footnotetext{
87 李亭, 〈此時此地的文學〉, 《蕉風》1955 年第 2 期, 頁 2 。

88 一是指當時頗多討好僑領（頭家）的歌功頌德文章，另一是指從「其他地方」被模仿照搬過來的「傳統 封建文學」。

89 李亭, 〈封建主義的文學〉, 《蕉風》1956 年第 5 期, 頁 $2-3$ 。

90 洛萍, 〈小說題材的處理與運用〉, 《蕉風》1955 年第 3 期, 頁 1 。洛萍為《蕉風》編委之一陳振亞的

筆名。

91 諸家, 〈漫談馬華文藝〉, 頁 4。
} 
神」。92雖然《蕉風》幾乎被公認為是非左翼文學陣營的據點, 這類語彙在早期《蕉風》 的文藝空間偶有出現。華文文學中的寫實主義在離散跨境的過程中, 從二 $\bigcirc$ 年代至五 $\bigcirc$ 年 代, 幾乎在中共的社會主義語境中停滯不前, 即便是非左翼刊物《蕉風》蕉風發表的寫實 主義評論, 亦夾帶相似的修辭與語彙。比如在一九五六年十月第二十三期, 有一篇沙風所 寫的〈文藝創作的價值〉, 一方面批評左翼階級鬥爭、階級對立指導下的文藝觀點, 一方 面又同時複述社會主義文學的服務觀點, 比如在談及如何撰寫爭取獨立這題材所需要的典 型代表性人物時, 他認為應以「廣大的殖民地人民群眾」為主要的典範。9 3 從《蕉風》草 創時期所刊的現實主義的評論稿, 可發現它與左翼文學觀點的邊界並不蔚然分明, 雖各有 派別界限, 但寫評論時採用的語彙習性, 其實難以非此即彼。《蕉風》本身也並不完全排 除社會主義的話語。

在接下來一連幾屆的馬華文藝座談會中, 所爭議的文藝觀點, 多圍繞著認同、語言與 政治對文藝屬性的影響展開。當時愛國意識影響頗鉅，提倡馬來亞化的並不只有《蕉 風》。 ${ }^{94}$ 馬來亞化這口號，其實並不始於友聯。無論是後期一九五八年代的南大生學運， 還是早期的馬華新興文學運動, 都曾提出馬來亞化這個議題。95「純本地性發展」的口號 也不始於友聯的南來文人。冰梅在一九五四年於〈小說馬來亞化〉中就已強調馬來亞化便 是再現此地華人的成果：「因為華人是馬來亞社會一大民族，雕塑此間華人本質的作品， 認真說起來，它就是馬來亞化。」96如黃錦樹所言，現代國族建立帶來各種認同與自我限 定的問題, 即便當文學轉向「去中國性」的「愛國」認同, 並沒有比之前更能開展文學自 身的本位，「文學乃成為表徵他物的場域」。97誠然本土的語質、生活經驗等賦予的在地

92 白蒂認為「馬華文藝在本質上還是以中國文化為本位的, 只看怎樣馬來亞化吧了」。盡管如此, 他認為 需去除歧視此邊陲區域的 $「$ 正確態度」表達得相當截釘截鐵：「來到馬來亞的華人, 有三種心情 : 一、流 落蕃邦，二、落籍蕃邦，三、流亡蕃邦。這三種心情現在都該取消。」

93 沙風原文: 「如以爭取獨立為題材寫小說, 則具有典型代表性的人物決不是任何一位政黨領袖形象的寫 照, 而是從廣大的殖民地人民群眾中, 由他們共通的現實生活處境, 思想觀念, 意志力量所凝結而成 的，他的存在價值也就是作品的永恆價值。」

${ }^{94}$ 比如, 當時呼應愛國意識的, 除了 《蕉風》之外, 也包括一九五六年創刊的《匯流》雜誌。一九五八年 創刊的《蜜蜂》, 內容也頗多本地化的嘗試, 一九五 $\bigcirc$ 年創刊的《南洋月報》的策劃亦多關注馬來亞政治 局勢的發展，不過這些雜誌都傾向以發展社會主義為已任。

95 謝詩堅, 《中國革命文學影響下的馬華左翼文學 $(1926-1976)$ 》, 頁 44、47、200。

96 苗秀編， 《新馬華文文學大系（理論）》，新加坡：教育, 1971，頁 123 。

97 黃錦樹, 〈境外中文, 另類租借, 現代性論馬華文學史之前的馬華文學〉, 《文與魂與體論現代中國 性》, 臺北：麥田, 2006, 頁 94 。 
文學屬性, 早在二戰以前就可見諸於郁達夫的規勸, 他認為「南洋這地方的固有性, 就是 地方性」, 乃是這區域的文學主體 (南洋的華文文學) 該有的走向。9 ${ }^{98}$ 惟這不同於戰後高 揚的愛國主義, 後者的政治正確意識, 覆蓋了文學對於現實話語所需要的懷疑、反思與距 離。

當時出生於當地的文人已進行各種地方書寫, 行文前後往往充斥大量的愛國話語, 比 如土生土長的魯白野於一九五三年出版的《獅城散記》與一九五四年出版的《馬來散記》 99, 文中滔滔不絕地傾訴對這片土地的愛：「但我更愛馬來亞, 我絕對不會忘記這孕育我 的純潔而耿直的靈魂」, 須回報先輩開墾之恩：「我要把故鄉成長的過程忠實地紀錄下 來, 要親切地寫我們的先人曾經怎樣流了無盡的血汗在努力開拓它, 耕耘它, 創造了一個 幸福, 繁榮的新天地。」100 鲁白野的浪漫語調賦予這塊領土一種本真自然的本質化想 像。正如鍾怡雯在〈遮蔽的抒情一一論馬華詩歌的浪漫主義傳統〉文中所言, 早期馬華文 學的浪漫主義在現代／寫實長期對壘之下被遮蔽乃至隱而不見。101雖然鍾怡雯所指的是稍 後現代主義與寫實主義二元對立的情況, 但卻並非不能追溯至獨立前的國家認同書寫。獨 立時期的認同書寫經常大量描述、讚美這個國家具有如自然之母般的淳厚特性, 寓居之地 被想像為母土, 將南來文人擁抱在懷而得以脫離原來的母體。此時的地方書寫亦有作出聲 明, 不斷重申自己對新興國家的熱愛, 表現出來的是浪漫主義的風格與想像。馬摩西在 《蕉風》介紹魯白野的獅城書寫時, 認為它可為過去被認為是文化沙漠的南洋豎立起 $\ulcorner$ 一 塊足以識別好壞的標號」, 也可抵抗「來自遠方的高等動物」對「無喜的馬來亞華人」所 作的「不著邊際的批評」，意識到自身不僅在地理位置、同時亦在文化結構上處於邊陲， 透過介紹魯白野, 馬摩西姿態鮮明地傳達出對本土的認同。102文人所面對的不復是階級鬥 爭, 而是場域中話語權的鬥爭。在地居住的文人需要在當時仍然由左翼陣營掌控詮釋權的 文化場域中爭取發言位置, 馬摩西與本土文人展開交往、建立關係，努力地接近本土視 域，以此聲明表現出自身無疑具有參與本土文學的資格、其熱愛不輸給先到者的證明。

\footnotetext{
98 郁達夫, 〈幾個問題〉, 《郁達夫南游記》, 香港：世界, 1956, 頁 55-61。

99 魯白野 $(1923-1961)$ 為出生於本土馬來亞怡保的詩人, 戰後移居新加坡, 原名李學敏, 其他筆名有威 北華, 越子耕, 樓文牧等。

100 轉引自馬摩西, 〈獅城與馬來散記一評魯白野的創作〉, 《蕉風》1956 年第 5 期, 頁 30 。

101 鍾怡雯，〈遮蔽的抒情一論馬華詩歌的浪漫主義傳統〉，頁 $151-178$ 。

102 馬摩西, 〈獅城與馬來散記——評魯白野的創作〉, 頁 31 。
} 


\section{四、離散論述中的家園想像}

現有的研究多指出, 離散的論述因其獨特的邊緣位置, 具有批判性的角度。離散帶來 異質性使國族結構不穩定與更多斷裂。103在薩依德的〈放逐思考〉一文中，他提出流放者 的孤獨個體與國族主義之間有極密切的關係, 國族主義首先必須是一種主張, 這主張聲明 個體隸屬於土地、人群與傳統, 經由對語言、文化和習俗的認同, 產生一體感, 從而得以 終止放逐的狀態。104反過來說，離散者也可能特意採取邊緣位置、與國族主義或集體認同 保持疏離，這樣的位置使得離散者可以對看似穩定的權力架構維持批判性的視角。

然而, 若因種種原因遠離出生地（或故鄉）、無可回歸的流放者, 也有可能會渴望在 新地尋求認同, 把無法實現的家園夢想, 轉移到新的居住地。有關離散者的家園想像, 論 者如柯里福(James Clifford)即以為, 離散者總是在兩地逢遭無可歸屬的失落感, 總是處在 疏離、無法歸屬的狀態。105 比如大部份以回歸作為訴求中心的離散論者, 總以為在離散 者的記憶與文化符號之中, 有個境外原鄉成為離散者眷戀回歸的終點。106 根據薩孚朗 (William Safran)的看法, 認為離散的成員除了經歷地理上越過國界的遷移之外, 必然也牽 涉到以下狀況：

……離散必須是由一種特殊的移民所構成, 他們保留了在文化上與故鄉相連的記 憶; 他們擁有可以反映故鄉文化或宗教的機構; 他們在符號或實践的層面上與故鄉 相連; 他們對於自己能否為寓居地所接受仍存有懷疑; 為了生存他們把自己塑造成 與他人不同的群體; 此外他們當中有不少人還懷抱著回歸的想法。107

然而這不足以解釋獨立時期來到馬來亞的南來文人創辦《蕉風》的複雜情況。其離散情境 與家園想像的複雜, 非上述諸家的離散定義所能概況。

\footnotetext{
${ }^{103}$ Stuart Hall, 'Who Needs 'Identity'?', Stuart Hall and Paul du Gay(eds.), Questions of Cultural Identity, Los Angeles, London, New Delhi, Singapore: Sage Publication, 1996, p. 4.

${ }^{104}$ Edward Said, "Reflections on exile", p.139.

105 James Clifford, 'Diasproras',Cultural Anthropology, 1994, vol.9(3), p.431.

${ }^{106}$ Robin Cohen, Global Diaspora: An Introduction, Seattle: University of Washington Press. William Saftran,

'Diasporas in modern societies: myths of homeland and return', Diaspora, 1997, vol.1(1): 83-99. Khalid Khayati, From victim diaspora to transborder citizenship? Diaspora formation and transnational relations among Kurds in France and Sweden, Linköping: Linköping University, 2008, p.21.

${ }^{107}$ William Safran, 'Deconstructing and comparing diasporas', Waltraud Kokot, Khachig Tölölyan and Carolin Alfonso(eds.), Identity and religion: New directions in theory and research, London,New York: Routledge, 2004, p. 10.
} 
這群文人甫抵澾馬來亞不久, 即使不被國家政體所認同（以公民權的條件而言）, 卻在短期內對居住之地表達熱烈的認同。他們在居住之地所創造的家園意像, 並不總是以 境外原鄉為藍本。從《蕉風》的本土書寫裡, 可發現到當時南來文人反而是在切斷回歸原 鄉的關係上, 另塑以本土為中心的「境內家園」想像。這固然是出於, 在中共執政之後, 原來民國中國的原鄉已經蕩然無存; 而蔣介石統治下的臺灣民國, 又無法為這群流亡離散 南來的文人所認同。對於友聯南來文人在馬來亞進行的文化耕耘工作, 莊華興嘗以「民國 遺址」稱之。108他認為, 流亡文人在經歷失鄉亡國之後, 他們南來馬來亞, 除了反共之 餘, 亦試圖重建那能延續與實現其文化理念的傳承工作, 那座在精神上遙銜往昔民國文化 的家園, 隱陻浮現於本土。

「遺址」固然說明了那在心靈上故國已逝, 其文化空間逝如廢墟、滅如灰燼的消亡 譬喻。但從這群南來文人的書寫來看, 方天、馬摩西、姚拓、白圭的風格與路線各異, 方 天與馬摩西似難列入其中。那在地的混雜元素與不得不應對的在地政治因素, 同時沖蝕了 那與 $「 民$ 國」銜接的家園想像, 其後強調本土政治正確的意識, 又深鑄於反共的語境之 中, 與個人的憶鄉情感相互牴牾。這重建心理中的弗詭因素在於, 那在一九四九年從中國 大陸消失的「民國」, 本身在實現現代的系統上, 實多潰敗, 使得那文人所意圖重建的民 國遺址, 其本體打從一開始就不存在。由此溯源, 遺址宛如源自歷史空無之處。打從晚晴 民初以來, 那能實現民主自由與現代化振興理念的體制, 文人雖念茲在茲, 卻始終未得; 而文化播苗之傳承理念, 原先並非是中國知識分子所強調的責任, 它母寧是冒現於中共執 政之後, 文化政策變異, 歷史斷裂的隙間; 始自流亡開始, 故鄉頓「無」的時間。友聯南 來馬來亞之後, 所一直強調的播苗文化與古典知識傳承的教育工作, 其理念雖可說是產生 於中國大陸民國體制消亡的那一刻。然而, 另外一方面, 如同新亞書院錢穆對於傳承傳統 的期許, 實際上帶著朝向未來的時間意識; 這時間意識必須穿籢當下各種在地的文化交會 因素。友聯文人在馬來亞所欲重建的文學圖景, 亦因其在地, 而遂有必須吸收在地當下的 多種文化因素。

\section{五、「馬來亞化」的樂土想像}

108 莊華興，〈戰後馬華（民國）文學遺址：文學史再勘察〉，頁 7-30。 
馬摩西在創刊號執筆寫下散文〈沙漠的邊緣〉, 呼應《蕉風》的創刊詞〈蕉風吹遍綠 洲〉, 寫到在馬來亞這片文化沙漠之地生產文化的可能性：

有些富有信心的人，認為文化落後的地區、正是文人發揮所長的良機。譬如馬來亞 有三百萬華人，一直在畸形的狀態中生活，不能產生純地方性的文化，實因我們缺 少發展文化的組織信心。（創刊號，頁4）

如果說《蕉風》的主題一一純馬來亞化一一的文藝創作是正確的, 那倒需要更多興 趣相投的朋友來合作，使柬南亞各地的讀者，能增加一點認識馬來亞深浅的資料， 不致於在腦中老是䌂著文化落後地區的惡感。109

上述引文說明了南來文人對馬來亞文化空間的普遍感觀。無論如何, 若要把 $「$ 此地」視為

$\ulcorner$ 家」，認同此「地」為「家」，則必須克服這問題，並嘗試在此地實現或延續自我認同 的空間。南來文人對此地的感觀, 仍然未脫處在邊陲之地的「落後」之感, 同時又不免與 中國內陸的「優勢」文化位階做比較。一方面既意識到兩地文化階級差異鴻溝之大, 另一 方面亦不無受到前人的南洋想像所影響, 使得對馬來亞的本土性觀點, 揉和了極端相對的 異質化他者的想象（落後／樂土）。將熱帶視為落後與樂土會合之地, 在英殖民地期間的 文學並非罕見。110《蕉風》裡有不少詩歌與篇章都反覆複述馬來人的天性淳樸、熱情, 讚 美之詞滿紙洋溢。雖然有認同「新家園」的需要, 但與此同時仍懷有對自身中國文化傳統 的「優勢」意識, 使得他們筆下對異族他者的想像與書寫, 鄙讚兼具。

舉例而言, 蕭遙天〈馬來亞的天氣〉如此詮釋熱帶居民的「特質」：

南風吹拂之下的馬來亞，土地膏腢，使人民易於安居樂業，這也是一種美善之風的 象徵。但它不僅解「愠」, 輕輕地吹來, 更使人昏惑慵供, 懵懵懂懂地失去思考的

\footnotetext{
109 蕉風，〈讀者作者編者〉，《蕉風》1955 年第 4 期，頁 32 。

110 當時馬華華文文學中對馬來亞他者化的描述, 也可以與殖民者文學中的互相對照、比較。對南洋或馬來 亞當地人的美化或天真化的看法, 實際上並不僅見於華文文學, 同時也見於殖民者對這個區域的馬來婦女 與原住民生活的描繪, 後者經常被殖民者呈現為「非現代」(non-modern)的天真淳樸的形象, 殖民時期在 這樣的呈現之中, 被呈現者總是被消音的, 但對於遙隔的讀者而言, 這樣的呈現效果, 卻常被認為是寫實 或真實的。參考 Tan Chee Gay Danny, In the image of... : Looking at visual representations of the Iban people of Sarawak, Malaysia. Singapore: NUS Southeast Asian Studies Programme. James R. Ryan 1997, Picturing empire: photography and the visualization of the British Empire, Chicago: University of Chicago Press, 2009.
} 
能力。敬姜論勞逸, 所謂「沃土之民不材」, 好像給她言中。這裡的氣候, 造成馬 來人都有一種不計功利的人生態度，只要有差不多的生活就滿足了，不再想努力， 也不想更好……‥11

蕭遙天經常以中國文化的觀念來詮釋他理解中馬來亞環境與當地居民之間固有的「本質」 關係。不過, 他對中國文化觀點所造成的局限也頗有自覺, 將自己比喻為來自寒帶的植 物：「它有北國的舊憶與南國的新感。…..然而它總得像向日葵般很勇敢地去面對那赤炎 炎的現實。心裡是既矛盾也醒定的。」「食風樓隨筆」多書寫氣候帶來的感觀體驗, 主要 寫南來者如何適應熱帶、本土的日常經驗與起居生活, 以及他個人如何看待前人的南洋想 像與自己的熱帶經驗之間的差距。正如布拉訶(Avtar Brah)所言, 「家園」乃是離散群體 想像的欲望, 所謂「家」當屬於能夠 $「$ 經驗本土生活的所在之地」。112閱讀蕭遙天的「食 風樓隨筆」系列文章, 可發現其認同與疏離同時並存於本土日常書寫, 讀來十分有趣, 他 的隨筆並非是創傷性的書寫, 而幾乎是隨遇而安的經驗之談, 個中也包含了閲讀經驗一 比如在上述這篇〈馬來亞的天氣〉裡, 作者苦惱於熱帶氣候單調缺乏四季變化, 所提出的 解決之道, 竟是構想一個 $「$ 唯心」的具有四季意像的馬來亞, 以及如何為這想像的四季在 馬來亞的地理環境中找到對應, 以解鄉愁的辦法。

另一個幫助自己對當地產生認同的方式, 是尋回先人的經歷, 蕭氏以前人紀錄來比 對自己的越境經驗, 但過去先輩的南洋觀點與自己卻又頗多差距。他列舉前人的南洋想 像, 如數家珍, 目的其實是要打開「現實的新觀感」, 其方法便是透過重讀前人謳歌南洋 的文章, 再與當時的現實對照之後將荒謬處逐一駁斥, 以瓦解過去一廂情願的、美化南 洋、脫離現實的想像。113 例如, 他在〈熱帶女兒〉中寫道：

當我進入馬來亞，天天飲水，更看見每個中等人家的家庭多有一隻水廂，我又從這 一方面的錯覺聯想，否定他那一方面的錯覺聯想了。一切揣懸之詞都靠不住的，我 必須冷静地取得實實貼貼的經驗。114

\footnotetext{
111 蕭遙天, 〈馬來亞的天氣〉, 《蕉風》1995 年第 4 期, 頁 8 。

112 轉引自 Khalid Khayati, From victim diaspora to transborder citizenship? Diaspora formation and transnational relations among Kurds in France and Sweden, Linköping: Linköping University, 2008, p.22.

113 蕭遙天, 〈熱帶女兒〉, 《蕉風》1956 年第 6期, 頁 18-20。

114 蕭遙天，〈熱帶女兒〉，頁 18 。
} 
體認「現實」的觀感總是被層層錯覺所覆罩，蕭氏過濾前人「南洋」的說法，以建構有別 以往的「熱帶」、「南洋」或「馬來亞」的觀察視角。115

在這篇〈熱帶女兒〉裡, 蕭遙天對李詞傭的〈檳榔樂府〉把南洋女性美化的寫法, 頗 不以為然, 形容李氏寫的是 $「$ 綺麗的舊夢」, 認為其鏤金錯彩的美文充滿了假象。不過, 蕭遙天無意於改變物化女性、評頭品足的「文藝寫作」，而是志在於揭露李詞傭行文的謬 誤, 他對李詞傭筆下關於娘惹或馬來女性的描述有所抱怨, 這與他對於把馬來亞描述成樂 土的公式化讚美感到難以忍受, 其實是一致的。如他所言, 為了要找到 $「$ 實實貼貼的經 驗」, 「連同在熱帶圈內的感受也要打些折扣」, 故首先得揭穿前人謳歌南洋的矯揉作 態。透過這樣的方式蕭遙天給自己標明了發言的位置: 他乃是與先輩有別的南來者, 不抱 持樂土天真幻想的本土日常經驗重寫者。他駁斥過去前人遊記文學所投射的片面想像, 以 獲得描寫當時身心感受的日常經驗視角。他自身具備的中國與西方文化素養與口味偏好, 使得他在融入本土方面有些困難, 但也提供了他知識性的詮釋空間和樂趣。與此同時, 他 又自我要求必須切實地看待本土的生活經驗, 並致力於使自己與中國先輩的視角保持距 離。事實上，這兩者（中國經驗與馬來亞本土經驗）在蕭遙天的日常書寫裡彼此詰問，加 上對氣候環境等不適的諸多抱怨, 時或以自嘲解憂, 這使得蕭遙天的「食風樓隨筆」系列 文章在《蕉風》創刊前兩年眾多熱情地認同本土的書寫中，顯得格外特殊。

與蕭遙天不同, 馬摩西幾乎完全去除故地舊憶, 緊盯著居住之地, 在文化沙漠中探索 開拓文化事業的可能一一創造綠洲。正如英殖民者對馬來人的看法（比方說對於惰性的偏 見），將之歸納為天氣的緣故；婣遙天在〈食風與沖涼〉中亦對熱帶生活的觀察亦頗多他 者化的想像和評價。116在馬摩西筆下亦然，他留意到文化事業萎靡不振，便借用熱帶氣候

115 到底如何使用 $「$ 南洋」與「馬來亞」這兩個詞彙, 蕭氏在文中似乎隨意使用, 並不依照馬來亞聯邦成立 的時間作為區分。如刊於一九五五年十一月至十二月第二、第三期以及一九五六年一月第五期《蕉風》 的〈食風與沖涼〉, 由於其視角大多沿續過去身在内陸或在香港時對東南亞的看法, 故稱「南洋」, 但 在這幾篇文章裡, 即便是南來以後的觀察, 亦有將此地稱爲南洋者。刊於一九五五年十二月第四期《蕉 風》的〈馬來亞的天氣〉, 以及刊於一九五六年一月至二月第六至八期的〈熱帶女兒〉, 這兩篇文章都 使用 $\ulcorner$ 馬來亞」。

116 此文於一九五五年底至一九五六年初分成三期刊登, 《蕉風》1955 年第 2 期, 頁 $12-13$; 《蕉風》1955 年第 3 期, 頁 27-28; 《蕉風》1956 年第 5 期, 頁 19-20。尤其第五期, 蕭遙天對印度人與馬來人沖涼以 抵禦炎熱環境的看法尤為奇特。「我覺得, 南洋的氣候悶熱, 物產豐富, 氣候使人困惰渴睡, 物產又給與 人謀事容易的暗示, 故居民大多好逸惡勞, 犯了『沃土之民不材的大諱』。…..談到較早移民來到的華 
使人昏惑之說來諷刺：「是否受氣候的影響, 已染上懶惰的毛病, 不然, 為何許多知識份 子, 都拋棄宣揚或建立文化的責任感？」然而, 熱帶氣候也可能有另一面效果：「一般 生活在熱帶地區的文人, 多少受熱氣的燻陶, 對事情的看法, 不致於完全絕望。」 ${ }^{118}$ 諸如 此類。馬摩西想要以開拓文化空間的方式與居住之地建立聯系。透過建立文化空間, 從而 認同居住之地為有歸屬感的本土, 惟有把這塊新來乍到落腳的土地與文化事業相結合之 後, 才能談得上以此為家。《蕉風》創刊時提出的馬來亞化主張, 從其策劃而言, 乍看似 乎沒有留下多少空間留戀故土。和蕭遙天比較起來, 馬摩西對馬來亞的認同顯得毫不猶 疑。馬摩西文中不乏讚頌南洋情景的筆墨。從沙灘、漁舟、棕櫊、楖樹、亞答屋的景象, 描繪如樂土。不過，他對這種樂土產自想像，並非全無自覺：

許多沒有到過南洋的人，他們聽到這些未曾親身經歷的事蹟時，他們會幻想此地是 一片樂土，住居樂土裡的人又是何等樣地縹紗。一切都有待於我們的創造。119

意識到此地樂土是過去前人對遙遠他方的想像。「馬來亞化」主張雖非始自《蕉風》, 卻 是南來文人抵達以後尋找認同、同時自己也能認同此地的途徑。除了文字之外, 《蕉風》 的封面、封底、封內頁, 也常以熱帶植物如芭蕉、鄉村（甘榜）椰林、漁村之景等馬來亞 本地風光的繪畫或木刻為設計。《蕉風》可說是全方位地表達對「馬來亞」的憧憬。然而 在文學上實踐馬來亞化, 卻仍有其無法彌補的缺陷, 一如曾將 $「$ 馬來亞化」概念, 視為傳 播共產意識形態工具的左翼陣營, 在馬摩西這裡, 作為表達認同的文學實踐, 本身也因認 同他者（國族建構）, 而需要藉由驅除樂土的幻象, 來展開建立理想家園的論述。如他寫 的〈馬來亞頌〉，開段就寫：

啊，你這善良而樸實的馬來亞， 你麗質天生, 原可安静過日子, 多情善感的夜鶯, 為你常啼血, 你卻逆來順受期待如意的明天，因為獅虎多落網，風暴必收停，

僑「他們能夠振奮勞動, 關鍵在這冷水淋頭的功夫, ......所以, 南洋文化, 也可稱為沖涼文化。」蕭遙 天, 〈食風與沖涼〉, 《蕉風》1956 年第 5 期, 頁 19-20。 117 馬摩西, 〈沙漠的邊緣〉, 《蕉風》1955 年第 1 期, 頁 4 。 118 馬摩西，〈沙漠的邊緣〉，頁 4 。 119 馬摩西, 〈沙漠的邊緣〉, 頁 4 。 
似乎你曾熟讀忍尤含垢的篇章, 妄想狼和羊同居, 猫和鼠嬉戲, 啊，你這䇺富而美麗的馬來亞 …... ${ }^{120}$

詩中第二人稱的寫法, 為馬來亞這「對象」塑出相當鮮明的人格化想像。詩歌不只讚美自 然風光, 而且還穿梭時空, 誦詠文化與歷史, 對未來滿懷期待, 在此作者不僅從自然風光 來認同這塊土地, 同時也認同了緊急發令時期壓制共產黨的官方主流話語, 以及由此建構 的國家主體。

就《蕉風》發表的作品而言, 除了現實主義之外, 浪漫主義的風格似乎亦頗盛。如林 風的詩歌〈明天〉就以熱切的語言書寫, 以初生的嬰兒比喻新興國家的前景：「是不是, 初生的嬰兒, /從此睜開了朦朧的眼, /看到的世界是完全的乾淨歡愉, 」詩歌將馬來亞 置諸於世界性的時空與地理意識。林風寫道:

在極北極南的地域, 有春夏秋冬的時序， 這時, 那裡踓正封著皓皓寒雪,

有火爐的，或沒屋頂的， 都懷著雪化春生的預期。

緊接著轉入赤道線上「但在馬來亞, 這條赤道線上啊！／明天和今天是一個意義，」 意識到因其地理位置, 一整年上並無四季的變異, 卻仍能注意到熱帶的氣候變異 $「$ 只有季 候風, 有時乾燥, /有時帶來豐盛的雨滴。」 121

林風是早期在《蕉風》發表相當多作品的詩人, 他的詩幾乎句句對馬來亞盡訴衣情, 另一首〈漫步〉發表於一九五五年, 當時離國家獨立還有兩年, 詩人想像這裡是一片可以 開墾拓荒的沃土, 與之對應, 自己便是參與建國的開墾拓荒者：

落葉年年溧霂青草,

120 馬摩西, 〈馬來亞頌〉, 《蕉風》1955 年第 2 期, 頁 10-11。

121 林風, 〈明天 〉, 《蕉風》1956 年第 5 期, 頁 4-5。 
青草代代覆被黄土，

黄土下煙埋著枯骨,

枯骨又滋生了新樹。

現在太陽依然照著,

我，一個新的荷斧者,

在這裡漫步。 ${ }^{122}$

不僅內容, 甚至連創作形式上亦表現出文人試圖接近、認同馬來民族的文化。比如一 九五六年一月第五期的《蕉風》, 刊出林子基仿馬來班頓(pantun)的詩作三首。123分別如 下:

〈願〉

渺渺的沙粒兒，

願它砌成泥塊。

一顆顆的心兒，

願它融合一塊。

〈流浪〉

荅穹甄逸的浮雲，

無有它自己的方向。

街頭巷尾徬徨的流浪人，

回不了他們底家鄉。

122 林風，〈漫步〉，《蕉風》1955 年第 3 期，頁 9 。

123 林子基, 〈願〉、〈流浪〉、〈傷〉, 《蕉風》1956 年第 5 期, 頁 20 。『斯敏土』指水泥地。 
〈傷〉

門前的『斯敏土』,

縱横著破裂的隙縫，

我撕碎了手中的詩,

心裡無限悲痛。

詩歌內容未直接觸及國家認同，但其形式卻依據馬來文學的詩歌傳統，即前兩句為後 兩句的押韻, 內容重心主要透過後兩句傳達, 這在當時倒是相當特殊的、跨族裔語言 /文 學傳統的創作形式。124

\section{六、小結：未能平撫的焦慮}

一個值得再作探析的有趣面向, 是這層浪漫的想像與現實之間的距離。重讀林風的詩 〈漫步〉：

我不懂你們的語言,

但千年來，你們便有話傾吐， 你們一定有一種深意,

不輕易，不輕易向人告訴。

在此所謂不能懂得的語言, 並非來自一個政體, 而是來自這片土地的自然空間（泥河與風 中的綠）, 它神祕地遊蕩悠遠的時空, 竟驅動個體投入其中開荒拓土, 彷彿它是先驗地存 在於族群或家國之前, 存在於土地, 以超驗的、本質的聲音在對主體呼喚。這樣的感召亦 浮現在前述黎青〈母土的呼喊：記巫統婦女部遊藝會〉文裡（參看前一節的引文），她在

124 這裡參考莊華興的說法。莊華興提到一九五 $\bigcirc$ 年代的華馬馬小說對國家表達認同, 成為當時獨特的形 態, 包括當時有作者吳天才創作馬來班頓和新詩。如此來看, 林子基的華語班頓詩歌創作亦當如是。莊華 興, 〈序論：七十年家國（第三節--落葉生根：華馬馬小說的認同之旅）〉, 載張錦忠、黃錦樹、莊華興 編, 《回到馬來亞：華馬小說七十年》, 吉隆坡：大將出版, 2008, 頁 17 。 
現場雖然聽不懂歌曲或戲劇演出的馬來語, 仍深深為之慟情, 乃至帶來 $\ulcorner$ 土地孕育」的感 嘆。在美化他者的想像之中, 認同猶如一個深層的、潛在的、幾近原初的欲望。主體的認 同雖告失落, 不知始於何方, 或將歸於何處, 故而轉向大自然或更純樸的表徵物上尋找爾 補, 由此消解不被國家認同的挫敗以及遭到體制排除的焦慮。浪漫化的歌詠, 以及各種地 方性知識／資料的挖掘, 是否足以指涉向未來家園（馬來亞）的地理、政治、族群與文化 的位置? 無可否認, 《蕉風》成功建構了具有本土認同意義的文化場域, 他們策劃與啟迪 讀者共同認識此地的異族文化, 以及從各個方面書寫在地的經驗與知識。但在急於取消 $\left\ulcorner\right.$ 流落、落籍、流亡『蕃邦』」（白蒂之語） ${ }^{125}$ 的意識之下, 馬來亞在此認同需要中, 被 塑造為完美家園之所在, 對它的愛意猶如可超越種族政治表面活動而匍匐蔓延、被想像為 更本質化, 且與自然地理和環境屬性相結合的樸質地帶, 於是那如原初欲望般的樂土, 繼 續盤踞其中, 持續引發對這座構想中未來將臨的理想家園, 滔滔傾瀉愛意, 足以抹平未能 被國家認同的焦慮, 也消解了離散邊緣所可能具有的批判性。

但是這道焦慮騷動的㱀褶也偶會冒現。如在山芭仔〈新村底夜〉裡, 在防堵共產黨影 響力而以鐵絲網圍起來堵新村裡, 居民的夢境被槍聲所打破, 使寧靜的夜晚變得不安。126 在白蒂〈山野底孩子〉裡, 住在膠園裡的主人公, 望向一片尚未開墾的荒地時一

「時時刻刻都在做一個美麗的夢, 他要在這一大片的耕地上, 像在祖國一樣種雨季 稻子一季改種蕃薯, 另外, 留一嘼種植菠雚, 一畧種植各種各類的青菜、香蕉、木 瓜、菠雚到小市鎮販䝴，將來有辦法就把張德記的小園丘買下來，也像左邊的『紅 毛園丘』一樣翻種新樹苗, 到那時候一切就不同啦! 」

「這一場美麗的夢化為他的生命力，使他從早到晚永無休止也毫無怨言地辛勤工作 著, 哌地、除草、翻土、播種、燒水……」。 ${ }^{127}$

在祖國不能實現的家園夢想, 主人公渴望能在新的居住地實現。獨立時期南來文人文學中 表達的國家認同, 其實是在去除中國民族主義之後, 更緊繫求存與文化資源的根本需求一 一這並非就是不正當的。他們雖然察覺國家建制傾向馬來中心主義優先的體制, 但仍然努

\footnotetext{
125 諸家, 〈漫談馬華文藝〉, 頁 3 。

126 山芭仔, 〈新村底夜〉, 《蕉風》1956 年第 17 期, 頁 21 。

127 白蒂, 〈山野底孩子〉, 《蕉風》1956 年第 5 期, 頁 6 。
} 
力去塑造一個樂觀的本土語境。但正如白蒂的故事迅速轉向拮据的現實, 是傾向於經濟壓 迫的而非種族或政治性的, 點出南來移民前往馬來亞開拓樂土之夢其實困難重重。南來文 人這一離散群體, 在揣度這塊土地是否適宜居住這一方面, 乍看似乎為愛國與認同本土的 樂觀所填滿, 卻並非全無懷疑困惑的間隙。 


\section{第三章}

\section{方天在《蕉風》的寫實主義書鴧}

一、一個國籍

一九五五年, 方天隨同申青自港抵新, 成為《蕉風》的首任編輯。這年十一月創刊 出版的《蕉風》, 打著「純馬來亞化」標語, 對本地的認同快得驚人。在這一年, 中國改 變了對待第三世界國家的外交政策, 包括承認其周邊國家的中立與不結盟決定。周恩來為 與周邊國家示好, 與東南亞國家簽約取消海外華人的雙國籍, 並鼓勵東南亞各地的華人融 入當地社會。1

東南亞的華人開始面臨只能選擇「一個國籍」的局面。在馬來亞, 聯合邦的英殖民 政府與聯盟達成內部協商, 華人可有機會獲得公民權、可以投票選舉。新馬聯盟政府掀起 馬來亞化運動, 口號如「愛馬來亞」、歌頌「種族和諧」等, 也頻密地出現在當時的詩歌 與小說中。2英殖民政府採取圍堵共產黨的計畫, 尤其是把膠林區的華人遷居新村的畢禮 斯計劃, 相當成功地削弱了共產黨的力量。新村華人長期疲於緊急狀態, 共產黨在此形勢 下難以繼續保障華人在本土的利益。對於華社團體而言, 左翼的言論與中國色彩變得極其

敏感, 且需去除、甚或劃清界限以避嫌。《蕉風》認同馬華文學有發展「純馬來亞化」的

\footnotetext{
${ }^{1}$ Leo Suryadinata, Understanding the Ethnic Chinese in Southeast Asia, Singapore: Southeast Asia Studies, 2007, p. 96.

2 這當時也是全民整體性的運動, 以建構國族的認同, 尤其戰後, 聯盟政府鼓吹馬來亞認同、和諧友好的論 述, 具有修補種族裂縫的作用, 馬來人與華人的關係在日據時期加劇分裂。如在聯盟政府結盟之初, 翁惹 阿化就提到需要重修華人和馬來人的關係, 這類話語也貫穿整個爭取獨立時期的愛國運動中。見 Joseph M. Fernando, "Elite intercommunal bargaining and conflict resolution: The role of the Communities Liaison Committee in Malaya, 1949-51”. Journal of Southeast Asian Studies, 2012, vol. 43(2): 280-301.
} 
需要, 主要則是配合冷戰時期英軍圍剿左翼, 官方鼓吹本土意識的策略。但同一時期, 馬 華文學亦廣泛認同本土為主流趨勢。3

如張錦忠所言，馬華文學的「現實主義」，其實乃是中國文學的社會主義離散南來之 後,「減輕其社會主義或淡化中國連結的『本土化』做法」、「這些離散文化人將身體放 置到另一個文化與空間, 從而試圖（以作為文化政治意識形態的寫實主義）操縱這異文化 空間的書寫生產活動。」。 4 不過, 在方天的小說裡, 卻可以發現, 他的 $「$ 在地化」小說 雖然淡化了中國連結, 但社會主義的色彩卻非常鮮明。在二戰以後, 「本土化」因民族運 動興起、冷戰時期左右對峙的形勢與國籍問題等等多重複雜的因素所造就。獨立時建構的

$\ulcorner$ 國家意識」，既帶來本土意識（以此建構／想像反殖民的主體地位），但同時也帶來壓 抑。5當時的「客觀現實主義」的論述乃是由階級鬥爭、國家意識、文學反映論與實用論 等綜合而來。

在以多（趙戎的筆名之一）〈現階段的馬華文學運動〉一文, 這篇文章回顧一九五一 至一九五九的文壇「沈寂期」，提到「由于政治的原故」（即英軍壓制共產黨的行動）， 使得左翼的文藝空間亦遭約束。該文提及這段時間南來的港派文人，只說他們「乘機南下 掘金」、「大寫黃色和準灰色的東西」。6 然隱去姓名, 不知所指為何人。

當時從香港南來的文人除了有隨著申青到來的《蕉風》諸人如方天、姚拓與黃思聘之 外, 也有非屬《蕉風》的劉以㰒（編輯報章副刊）。黃思聘任《蕉風》編輯時, 亦邀在港 文人助陣, 劉以睏所編的副刊版位, 呈現出香港與南洋兩地的都市生活、消費、娛樂、文 化特色，或談男女兩性觀點等軟性文章，其版位的風格較爲輕鬆，而難以被具有「愛國意 識的現實主義」者納入所認可的「現實」視域當中。

${ }^{3}$ 自一九四八年的馬華文藝論爭以後, 脫離中國的附屬地位、建立在地的文學主體, 變成馬華文學普遍具有 的意識。趙戎編, 《新馬華文文學大系（第八集史料卷）》, 頁 192 。本土化的馬華文藝觀點大致「勝 出」,「僑民文學」漸失吸引力。因國籍而生的國家意識, 廣泛影響文壇, 故提倡這觀點的, 不只有《蕉 風》。潘碧華, 〈馬華文學中的國家認同與文化反思〉, 頁 62-67。

4 參考張錦忠, 〈文學離散與馬華文學的寫實主義〉摘要。

5 這裡也參考黃錦樹批評方北方現實主義局限的意見, 認為方氏的現實主義流於認同國陣宣導的國家主義, 而壓抑了歷史意識。其他限制也包括美學縮減。黃錦樹, 《馬華文學與中國性》, 臺北：麥田, 2012 , 頁 95-114。

${ }^{6}$ 以多, 〈現階段的馬華文學運動〉, 《現階段的馬華文學運動》, 新加坡：南洋大學創作社出版兼發行, 1959 , 頁 12 。 
無論如何, 閲讀《蕉風》刊物中方天的現實主義小說, 怎樣都離黄色文學與灰色文學 很遠。檢視英殖民地末期至建國獨立這一時期, 出現在非左翼刊物《蕉風》的現實主義小 說, 不旁為補充長期被馬華文學所忽略的面向。以下本文將以方天的在地現實主義書寫為 主要討論範圍。

\section{二、方天的生平資料}

方天 (原名張海威), 又名張維翰, 約於一九二七年生 ${ }^{7}$, 畢業於上海交通大學, 是 前中共領導人張國壽的兒子, 母親楊子烈, 祖籍江西萍鄉。張國壽在一九三八年投奔國民 黨, 一九四八年移居臺北。根據路海江《張國壽傳記和年譜》, 張國壽於一九四九年冬 天, 攜帶全家離開臺灣遷至香港, 約於一九四九年底到香港。方天在香港時曾任《中國學 生周報》編輯。

在新加坡期間, 方天也曾在華僑中學任職。如根據《蕉風》一九五七年五月號第三十 七期的文訊版, 方天應該是這年離開崗位後, 才轉任華僑中學。8他勤於考察新馬兩地華 人勞工的生活與工作環境, 撰寫多篇現實主義小說, 收錄在短篇小說集《爛泥河的嗎咽》

（一九五七年由新加坡蕉風出版）。在更早的時候, 也出版寓言劇集《黃融與杜鵑》（一 九五五年由香港友聯出版），以及小說集《一染小紅花》（一九五五年由香港中國學生 周報社出版）。一九五七年二月開始, 編輯工作轉由姚拓接任。根據現有的資料, 不能確 定方天是在甚麼時候離開, 以及離開後遷往何處; 到底是先到香港才移居加拿大, 抑或從 新加坡直接到加拿大, 馬崙與姚拓的說法各異。9 根據姚拓, 一九五八年《蕉風》搬到吉 隆坡時, 方天隨父親移民到加拿大教書。10但這說法與《蕉風》搬遷的日期有出入。《蕉 風》要到一九五九年一月才把印務公司遷往馬來亞八打靈區, 從一九五九年第七十八期

（這一期也是提出自由主義與個體主義的改版號）開始, 其出版社與印務部門才在八打靈 運作。11

\footnotetext{
${ }^{7}$ 馬崙, 〈方天的寫實作風〉, 《南洋商報》1982 年 4 月 16 日, 寫作人版。

8 馬崙, 〈方天的寫實作風〉, 同上注。蕉風, 《蕉風》1 1957 年第 37 期, 文訊版。

9 馬崙, 〈方天的寫實作風〉提到方天在離開新加坡以後返回香港, 才移居加拿大。謝詩堅採馬崙的說法,

《中國革命文學影響下的馬華左翼文學 (1926-1976)》，頁 195 。

10 姚拓, 《雪泥鴻爪》, 頁 570 。

11 參見第一章第二節底下的列表。
} 
根據馬崙, 方天先回返香港, 然後才移民加拿大。12 而在一些誇述敘述張國壽晚景淒 涼的傳聞裡, 則以為方天先到加拿大, 而後張國壽與楊子烈才於一九六八或一九六六年時 投奔兒子。13僅能確定一九六 $\bigcirc$ 年代時, 方天就已在加拿大的多倫多大學從事研究或教學 數理的工作, 約於一九八○年代期間（根據姚拓）或一九八三年（根據馬崙、謝詩堅）, 方天在加拿大去世。14

關於方天, 現有的紀錄極少, 包括方天的生卒年、來去新加坡前後的動向。由於方天 本身沒留下多少撰寫個人經歷的文章, 僅能從他人（姚拓、白圭、《香港文化眾聲道》） 憶述, 以及張國壽的傳記裡, 搜集零星片段。但由於張國壽脫離中共之故, 關於他的傳 記, 行文多主觀且未見資料徵引, 包括一九三○年代末時, 可能隨父母遷移的時間與經歷 （應當是從延安遷移到武漢, 再至上海）, 幾本關於張國壽的傳記, 無論就時間年份、事 件記敘, 多有出入。15張國壽與楊子烈的自傳, 又僅止於他們在中國共產黨時期的敘述, 未見孩子出生或養育的家常記敘。 ${ }^{16}$ 較可信的, 是在一九四八年時, 父親張國壽在上海創 辦反共周刊《創進》，其時方天也已經人在上海，是上海交通大學的學生。

據《南洋公學一交通大學年譜》, 在一九四八年底下, 記有「工業管理系」三七级畢 業生姓名（及籍貫, 附个人標准照片）, 其中包括「張海威（萍郷）」。萍鄉正是張國壽 與張海威的籍貫故鄉。但同在一九四八年, 也有兩筆資料, 一是張海威於一九四八年九月 初, 在上海因演劇被人指控其动作有污辱領袖之嫌, 而遭逮捕。17另一項《西安交通大學 大事記（1896 2000）》「抗戰勝利後的交通大學・1948 年」，記同年「八月廿七日黎 明, 國民黨特刑庭派人来校拘傳有『共產黨嫌疑』學生三十五人, ......上午又拘去張海威

12 馬崙, 〈方天的寫實作風〉, 同前注。

13 姚金果、蘇杭，〈張國壽叛逃後的生活〉，《中國地名》2004 年第 116 期，頁 23-24。

14 姚拓, 《雪泥鴻爪》, 吉隆坡：紅蜻蜓, 2005, 頁 570 。謝詩堅採馬崙的說法, 《中國革命文學影響下的 馬華左翼文學 $(1926-1976) 》 ，$ 頁 195 。

15 這包括路海江、姚金果與蘇杭為張國壽寫的傳記。如根據姚金果、蘇杭，〈張國壽叛變投敵後的狼狽境 遇〉, 《北京農業》2013 年 3 月中旬, 頁 39-43, 方天 (張海威) 在一九三七年五、六月間, 隨母親楊子 烈與姨媽楊子玉從延安到武漢與父親會合; 但根據路海江, 《張國壽傳記和年譜》, 北京：中共, 2003 , 頁 69 , 張國壽要到一九三八年四月間才離開延安到漢 $\square$ 。姚金果、蘇杭, 〈張國壽叛逃後的生活〉,

《中國地名》2004 年第 116 期, 頁 23-24, 也提及五十年代初, 張海威在港教書。

16 張國壽, 《我的回憶》, 北京: 東方出版社, 2004 。楊子烈, 《張國壽夫人回憶錄》, 九龍: 自聯出版 社, 1970。

17「西安交通大學檔案館」網頁【《南洋公學一交通大學年譜》一1948 年一戊子年（民國三十七年）】 http://58.206.125.28/?p=4756 亦見路海江 2003， 《張國濤傳記和年譜》，北京：中共，頁 $184 。$ 
一人」之句。18張錦忠在一篇文章裡綜合上述兩筆資料, 指出其中出入, 並已以「資深中 共黨員邵有民回憶 8.26 的大逮捕」, 補充張海威被逮捕入獄的事件, 「其中『張海威是 這次唯一一位被捕的交大學生, 他的父親就是叛徒張國壽』」「十月, 他們在獄中絕食抗 議。某日他看見張國壽夫婦帶蛋炒飯来看張海威, 勸他進食被拒。」19召有民的回憶相當 精彩 20 , 但未曾讀過方天或其他人撰寫與此事有關的敘述, 詳細實情宜有保留。惟邵有民 的回憶，至少補充了張海威曾經就讀上海交通大學的可能性。

邵有民的回憶口述記敘了張海威和同學們一起被捕入獄之事。21惟至今沒看到其他資 料可茲佐證。根據路海江《張國壽傳記和年譜》, 一九四八年十一月, 張國壽創刊的反共 周刊《創進》停刊後, 舉家移居臺北, 一九四九年冬天, 張國壽攜帶全家離開臺灣遷至香 港。22在大部分關於張國壽的傳記, 多沿襲中共的歷史詮釋, 突出張國壽背叛後的失敗與 狼狽。從中共創黨元老, 到中共黨史中的叛徒, 張國壽被賦予的負面形象, 幾乎深入民 心。《香港文化眾聲道》孫述宇的口述回憶, 亦以玩笑口吻形容初見張國壽的印象, 如見 「魔鬼現形」。23

擁有一個如此受到矚目且被中共否定的父親, 從方天現存的書寫裡, 很難看出這對他 有甚麼影響。他來到新加坡後, 致力於投入書寫「馬來亞化」的現實主義小說，挑筆耕 文, 觀察周圍、為他人發聲, 對自身的經歷、異鄉心境, 無一字提及。他完全沒有提到家 人與故鄉。在友聯諸人收於《香港文化眾聲道》的歷史口述中，對方天的敘述亦不多。唯 一談到較多的, 僅有孫述宇, 孫述宇接替方天原先在香港《中國學生周報》負責的版位， 在孫述宇的印象中, 由於方天也是 $\ulcorner$ 念數學或甚麼的, 彼此有話題」，提到他在新亞念書

18 「西安交通大學檔案館」網頁【《西安交通大學大事記（1896～2000）》抗戰勝利後的交通大學・1948 年】 http://58.206.125.28/?p=4360

19 張錦忠，〈文學史料匱乏之窘境——方天为例〉，《南洋商報》，2015 年 9 月 28 日，商餘版。

20 邵有民口述, 周奕韵採訪整理, 〈黎明前的獄中鬥争歲月〉, 《上海黨史與黨建》2009 年 3 月号, 頁 $14-$ 16 , 邵有民的回憶〈黎明前的獄中鬥争歲月〉曾提到監獄中, 十月九日當天, 張海威與同學一起絕食, 邵 的敘述相當突出張國壽在年輕人心目中為叛徒的負面印象, 以及方天跟隨同學, 與父母之間的衝突。

21 邵有民被捕時尚是中學生, 他回憶八月二十六日到二十七日凌晨, 國民黨以「危害國民罪」或「奸黨 罪」開出了三百五十八張傳票和拘票, 对學生實行大逮捕。當時多數學生在牢獄內被關押五個月, 但張海 威很可能在那期限之前就已被釋放。

22 路海江, 《張國壽傳記和年譜》，頁 185 。

23 孫述宇口述，《香港文化眾聲道》，頁 121 。 
時, 即在一九五四至一九五八年期間, 方天的父親也住九龍塘。24但關於方天何時加入友 聯出版社、如何加入, 以及身為張國壽之子, 為何竟會被派來新加坡擔任第一任《蕉風》 主編, 亦無人提及。南來新加坡是否為他本人的選擇? 抑或受友聯派遣? 當時馬來亞聯合 邦與馬華公會正如火如茶展開反共, 對於前中共領導幹部之子在馬來亞, 有何反應? 此 外, 在離開新加坡, 到了加拿大以後, 雖然友聯諸人彼此多年來相互保持聯繫, 卻無人知 道他後來的狀況, 甚至連後人也聯絡不上, 由此看來, 方天與友聯諸人別離後相當生疏。 反而是後來到馬來亞擔任編輯的白圭, 以及在地的作家苗秀, 對方天的描敘稍生動。白圭 〈浮槎繼往船黃石〉寫他與方天見面的印象：「我右邊的詩人蔡炎培, 說方天喜歡演戲、 寫小說, 也寫詩。我左邊的詩人沙基, 說方天是將門之後。」後到大嶼山附近的梅窩郊 遊, 他們在船上交談, 涉及文學上的問題, 白圭認為方天的 $「$ 七首文學觀, 頗類魯迅」、

「他並不雄談, 但理路清晰。」 25 在新加坡出生的本土作家苗秀, 則形容方天為「熱愛生 活」的寫作者。 ${ }^{26}$

方天在新馬的時間只有一兩年左右。方天離開新加坡後, 他的編輯任務改由南來文人 黃思聘、黃崖以及姚拓等先後擔任。27雖然他居留新加坡的時間短暫, 然而他在《蕉風》 發表寫實主義的作品在質與量都相當可觀, 以下首先討論《蕉風》的在地視域與現實主義 論述, 過後再論方天刊於《蕉風》的作品, 以短篇小說為主。

\section{三、在地書寫的方言與混雜的語彙}

\section{（一）南來文人與異鄉 /本土的語言異質性}

一九五 $\bigcirc$ 年代寫實主義小說中的多種方言, 並非是一個理所當然的現象, 尤其如果考 慮到南來作家來自中國南北各處, 籍貫與語言各異, 要在抵達後的短促時間內, 在寫作中 攝入在地混雜的方言, 其實相當不容易。就這點而言, 他們對周遭語言的混雜與異質特 性, 顯然具有驚人的敏銳能力。當中也不無可能, 對異鄉音質感到確實的興趣。28當然這

\footnotetext{
24 孫述宇口述，《香港文化眾聲道》，頁 121 。

25 白圭, 《縷雲起於綠草》, 頁 70 。

26 苗秀, 〈導論〉, 《新馬華文文學大系（小說）》（第五集），頁 8 。

27 謝詩堅, 《中國革命文學影響下的馬華左翼文學 $(1926-1976) 》 ，$ 頁 195 。

28 黃錦樹認為, 那混雜的在地語言對南來文人而言, 與其說是本土, 母寧是異鄉的語言。黃錦樹, 〈香港

一馬來亞：熱帶華文小說的兩種生成，及一種香港文學身分〉，《香港文學》2015 年 5 月號, 頁 8-15。
} 
在《蕉風》以前就已見於馬華小說。在左翼文人群中, 早有作者如趙戎以方言音譯, 在小 說裡大量創造在地感的語彙。29

一九五六年第十六期《蕉風》「讀者來函」裡, 有個署名微塵的中學生, 曾在題為 〈關於用方言寫作的商榷〉文中, 提出這種寫作方式會否使中文失去「純正」的問題。30 自創刊伊始, 《蕉風》每期刊登的小說中, 就常見「在地化」與他族混雜的語言、形形色 色的鄉音方言, 尤其是方天與陳振亞的小說。

值得留意的是, 雖然《蕉風》編輯當中有者如姚拓, 不諳廣東話, 在香港的時候, 難 以用廣東話與中學生溝通。 ${ }^{31}$ 但是編輯與作者當中也有者如方天與陳振亞, 能夠在小說裡 匯聚多種方言（包括廣東話、客家話等等）。陳振亞祖籍福建南安, 在一九四六年就已南 來新加坡, 他要適應在地的方言, 應該要比祖籍萍鄉的方天來得容易。32然而, 方天小說 中卻呈現出更為豐富的方言腔調。白圭曾經形容他寫的小說, 「陃巷窮街, 俚言俗語, 與 升斗小民憂戚與共」33。他的首兩篇小說〈一八四一年的一夜〉和〈膠淚〉雖未明顯, 但 從《蕉風》第三期的小說〈豆腐檔前〉開始, 就混雜各色聲響。他南來未及一年, 在如此 短促的時間內, 就能在小說裡攝入這許多方言的詞彙, 不能不歸功於他本身對於語言的敏 感；再者由於寫實的信念，著力模擬(mimic)語言聲腔的音質與口語，克服自身籍貫方言 經驗的局限。

在〈豆腐檔邊〉, 小說以一名在攤檔抹桌子的工人為第一人稱視角, 呈現出都市中 的小販攤檔, 各色鄉音混雜往來。無論是第一人稱的敘述聲音、或是各個角色（攤檔老 板、顧客、工人）在現場的對白，小說努力揣摩，選擇恰當的語詞以趨近多種方言的音 調，如接近客家話的「轉來」（回來）、「愛」（要）、「企」（站）、「裏位」（這 裡）。34在另一篇以碼頭苦力為背景的〈十八溪墘〉, 則有大量福建腔的發音, 羔杯烏

\footnotetext{
29賀淑芳，〈關於在地書寫的翻譯〉，《備忘錄 新加坡華文小說讀本》，新加坡：八方，2016，頁 40。 30微塵, 〈關於用方言寫作的商榷〉, 《蕉風》1956 年第 16 期, 頁 32 。

31姚拓在港居留時亦任 《中國學生周報》的編輯, 據他回顧, 當初編輯《中國學生周報》, 由於不諳廣東 話, 而香港的中學都以廣東話為教學媒介, 「只能紙上談兵, 卻無法和香港的中學生們直接溝通」, 所以 才遷移到新馬編輯《學生周報》。姚拓, 《雪泥鴻爪》，頁 561-562。

${ }^{32}$ 陳振亞, 筆名有洛萍、白蒂、江陵、史進、黃板、賀斧等。祖籍福建南安, 一九四六年來新加坡定居。曾 任新加坡〈中興日報〉、檳城〈光華日報〉、吉隆坡〈虎報〉主筆及總編輯。李成利, 〈中新南安文学历 史沿革〉, 《中新南安籍作家作品选》，1994。 http://sgcls.hi2net.com/blog_read.asp?id=48\&blogid=9767 ${ }^{33}$ 白圭, 《縷雲起於綠草》, 頁 71 。

${ }^{34}$ 方天, 〈豆腐檔邊〉, 《蕉風》1955 年第 3 期, 頁 7-8。
} 
（咖啡烏）、汝（你）、勿多（不壞）、甚麼郎（甚麼人）、令伯（我）、拍誰（打誰） 等等。35在以新村華人在錫礦工作為背景的〈暴風雨〉中, 也有很多廣東話, 如禀個 （誰）、唔該（請）、添日（次日）。36

這些地方語彙，大都出現在小說對話的句子中，對話以外的敘述部份則是標準正統 的中文。純正中文（書寫）與在地的方言（口語）, 分置於小說敘述與人物對白的兩道音 軌。這樣的書寫方式, 同時也標示出小說敘述者的本身的身分來源所在, 那敘述的純正中 文來自北方, 那是異鄉人在經歷地理遷移之後, 仍然保留自身觀察的視角與敘述的語調。

方天的小說相當用心地依據小說内的時空、角色與其工作性質，選擇符合場景的方 言, 描摹一個對作家而言, 或許是頗為新穎、陌生且多元的語言經驗。但是, 方天並非每 一部小說都出現在地化的混雜語言特色, 他在這兩年間撰寫的小說, 幾乎遍涉新馬一帶的 華裔工人所從事的各行各業, 想像他們在謀生求存中所遭逢的各式挫折, 成爲小説裡小人 物跌宕起伏的命運遭遇。他在書寫勞工的身體經驗方面, 常展現出獨到的觀察; 人們在不 同的工作環境中, 應該會有怎樣的身體經驗。小說中的語言亦隨著工作場合與人物的文化 水平, 而加以變化, 或特意抉擇。在〈排字女工的日記〉裡, 由於排字女工是屬於受中文 教育且對文字敏感的階層, 故其第一人稱的內心敘述, 便多為純正的中文, 尤其小說裡的 排字部女工, 具有拘謹寡言的性格, 其敘述多為內心獨白, 極少口語。 ${ }^{37}$ 在另一部敘述鞋 店店員的小說〈我的博士論文〉, 和另一篇寫兩個文人相互調㑆對話的〈預感〉 中, 其內 心敘述與對話，均以流暢純正的中文書寫。38

\section{（二）「在地」和「僑民」之間競逐的觀點}

從《蕉風》早期刊登的文章中，隱約浮現「在地」和「僑民」之間爭議的觀點，「僑 民意識」與「在地意識」經常是同時並存。《蕉風》意欲實現的「純馬來亞化」文學觀， 必須與盤踞讀者群中（甚至是編輯與作者群中）的「祖國」觀念競爭或共存。在文學上認 同的本土轉向, 並不必然與國家情感的認同一致。

\footnotetext{
35 方天，〈十八溪墘〉，《蕉風》1956 年第 7 期, 頁 2-6；《蕉風》1956 年第 8 期, 頁 13-17。 36 方天，〈暴風雨〉，《蕉風》1956 第 16 期，頁 1-5； 《蕉風》1956第 17 期，頁 13-17。 37阿瓊, 〈排字女工的日記〉, 《蕉風》1956 年第 21 期, 頁 6-8; 《蕉風》第 23 期, 頁 9-11。 ${ }^{38}$ 金然, 〈我的博士論文〉, 《蕉風》1956 第 28 期, 頁 21-23; 方天, 〈預威〉, 《蕉風》1957年第 30 期, 頁 13-14+封底內頁。
} 
在一篇典型批判資方的小說中, 華卿〈理髮椅上〉, 一個來自湖南的中國人與剪髮女 工 (當地娘惹) 之間展開一段對話。小說透過這番對話, 揭露當地女工被資本社會剥削的 堪憐處境, 但箇中也流露出「新客」觀看在地出生的華人為他者的優勢意識（這優勢同時 又與顧客與工人、問者與答者的身分對應）。39「回歸祖國」與「講好中國國語」為當時 普遍深植南洋的觀念, 即便是土生土長者, 亦不乏把中國當成祖國。 40 藉由認同「祖 國」, 文化傳統與跨地的族群情感被歸屬聯繫為一體, 然而以中國性情結來聯繫的「共同 體」，也受到祖國（文化起源地）為中心、而南洋為邊緣的理解框架所限。

《蕉風》試圖接近本地人的視域, 經常以回應的方式, 來修正上述中心／邊緣的視 野。比如在一九五六年二十一期的「蕉窗閒話」版裡, 申青的〈唐山何處? 〉討論靜子君 〈我剛從唐山來〉一文。靜子君的文章刊於《南方晚報》所編印的徵文文集《馬來亞之 戀》，否定當地「娘惹」將「唐山」指稱「祖國」（即中國）的用語。 ${ }^{41}$ 申青的反駁雖然 僅是略論「當地人腦海中『唐山』的地理概念」, 卻也顯見他為《蕉風》策劃馬來亞化， 非僅為尋找蕉風椰雨入文聊表其事而已，他必須更徹底的認識、認同當地的語言與語彙。 惟有透過語言或語彙，才有可能去光照或加冕「純馬來亞化」的認同觀念。42

\section{（三）方天的馬來亞文學視域}

方天的文學觀點，多見於一系列文藝座談會的紀錄（以方天或辛生之名發表），尤 其有關詩歌與戲劇的討論特別多。他對「有國籍」的馬華文學以及一個未來能夠融入各族

\footnotetext{
39華卿, 〈理髮椅上〉，《蕉風》1956 年第 13 期, 頁 23-24。

40 讀者普遍認同馬華文學在地化, 書寫在地的事物、地方、生活等等, 不過亦有者依然保持對祖國（中國） 的認同。比如從一九五六年第十二期《蕉風》開始, 連續三期刊登遊記, 新加坡作者紫燕撰寫〈馬來亞去 來〉, 文中提到祖國意識：「我們絕大多數是僑生於南洋, 也沒有回過祖國, 住在 「長年都是夏」的星 洲, 不知祖國涼爽的天氣是給人怎樣的一個享受。」紫燕, 〈馬來亞去來〉, 《蕉風》1956 年第 13 期, 頁 21。

41 有關這本文集的介紹, 參見曾鐵忱在該書的〈後記〉, 是《南方晚報》為創刊五週年紀念的徵文作品 集。亦可見馬漢, 〈正經 800 : 報社舉辦的徵文比賽〉, 《南洋商報》2012 年 6 月 16 日, 「副刊商餘 版」。

42 申青，〈唐山何處？〉，《蕉風》1956 年第 21 期，頁 5。
} 
的 $\ulcorner$ 馬來亞文學」充滿樂觀之感。五正如方天本身所意識到的, 當時馬來亞正面臨 $「$ 偉 大」的歷史關鍵時刻。

他談的不僅是馬華文學，而是馬來亞文學：「至少應該做到，把馬亞與馬印的文學 翻譯到馬華文學中來, 也把馬華文學介紹到馬亞與馬印文學中去。」44他認為透過翻譯, 可以突破原有的疆界, 可從他族的文學成果中找到讓彼此交流、刺激、互動而來的創作可 能，幫助作者超越圊限自身族群的視域，以產生更具在地特性的馬來亞文學。

這也是當時頗能鼓舞南來文人的文學圖景一一他們從殖民地的混雜與多元文化互動 中, 指出了這有別於故地中國文學的創造生機, 並以此相勉; 相信若能跨越不同種族、語 言作品中的視野, 便可刺激創作, 使之更具獨創生機。對於要在此地另外建立新的文學主 體, 他們表現得相當樂觀。他們對這區域的文學主體及未來, 所抱持的信心, 比起今日甚 至可說是有過之而無不及, 如申青之語：「多產生些飲譽國際文壇的馬來亞文藝作品, 正 是今日馬華文藝工作者所應該努力的。」45

\section{（四）文學語言與殖民地現實經驗}

殖民地具有混雜特色的語言, 到底如何 $「 反$ 映」? 誠如前一章所提, 友聯諸人南來 時, 雖然帶著維護中華傳統、推行華文教育的理念, 不過, 以方天、申青、陳振亞等人為 編委推行的馬來亞化文藝觀來看, 他們均認為有必要推行混雜多元的文學語言, 一邊推行 中華文化, 一邊同時也在文學書寫上織入在地的混雜語音, 使文學更具在地的語質。方天 在一場〈當前華校戲劇問題〉的座談會裡, 認為「讀詞法比發音重要」, 當時戲劇演員的 中文發音多為「南洋國語」或 $「$ 南洋腔」, 但方天以為這樣的腔調乃是生活此地 $「$ 長年累

$43\ulcorner$ 國籍」概念, 其實滲透了官方的國族語境。馬華文學獨立後逐漸滑落至國家體制邊緣的處境, 卻非當 年南來文人所能預見。國籍一方面是當時華人期待獲得公民權, 保障安居、有家園歸屬的身分標誌。但國 籍對於馬華文學而言, 卻未帶來相等的接納意義。國籍雖然不是文學創作本位的要素, 但相關資源卻可能 有助於擴展、培養讀者群、作家、出版、發表空間、交流空間與扶助相關的文化機構體系等等。從今天追 溯過去, 「有國籍」之說冉寧是歷史留下的諷刺。「有國籍」的馬華文學長期與國家體系呈游離狀態, 雖 然獨立以後, 馬華作家多有國籍, 但從實質資源而言, 馬華文學猶如一直處在「國籍的等候室」, 總是強 調自力更生、或通過各種文化機構從民間籌款，或爭取政黨層級分配下來的些許恩賜資源。

${ }^{44}$ 方天的發言, 〈一九五七年馬華文壇的展望一文藝座談之五〉, 《蕉風》1957年第 29 期, 頁 20 。 45 申青的發言, 〈一九五七年馬華文壇的展望一文藝座談之五〉, 《蕉風》1957 年第 29 期, 頁 3 。 
月的習慣形成」, 雖然也提出可能可以改正的方法, 但依舊認為, 「南洋腔」根本不是決 定話劇成功與否的因素。46

由是，方天從寫作（書寫文字）到戲劇（發言腔調）都相當重視在地的音腔特色， 甚至致力於收入混雜、普羅或草根的語言, 甚且說, 《蕉風》所推行的在地化, 已不復限 圊於反共的政治語境, 而進一步延伸向實踐在地文學所需要的語言, 就現實主義的美學而 言, 當取自現實經驗。在方天擔任編輯期間, 曾刊登沙里明的文章〈論文學創作的語言運 用〉, 文中提出, 既然文學語言來自現實經驗, 文學的語言與語彙應當有區域的獨特性。 47

在《蕉風》一九五六年第二十二期，一場「再談馬華文藝座談會」曾圍繞馬華文學 在地語言的混雜特性展開辯論。一些作者如重陽提出當地語言「融治一爐」當為殖民地不 可忽略的區域色彩, 子凡主張馬華文學需要突顯在地的 $「$ 區域特性」或 $「$ 個別性」, 以超 越中文文藝的「一般性」, 皆是當時馬華文學尋求主體性地位、脫離中國文學的主張。48 強調在地的混雜語言, 是因為那能區辨中國文學與馬華文學之間最顯著的差異, 就在於本 土混雜語言所構成的獨特語質。一旦在文學創作中採用殖民地混雜的語言創作, 就宛如表 明，認同本土文學與其文化場域的主體性。

如 Iain Chambers 所言, 在後殖民的語境下, 遷移者總是在這過程遭逢他人的文化、 語言與地理空間等衝擊, 主體的認同感與視角也就因此經歷不斷被形塑以及再形塑的過 程。49 《蕉風》草創時期對在地充滿正面期盼浪漫的語言色彩, 試圖通過培植在地的隸屬 感而催促 $「$ 純馬來亞文化」文藝主體的產生, 固然這口號或宣言看似過於確定, 然而何謂 $\ulcorner$ 純馬來亞化」, 乃為多重權力詮釋、形塑而成的結果, 尤其遷移者來到新的環境之後, 他本身也成為這在地的「混雜」元素之一。 ${ }^{50}$ 在一九五六年「再談馬華文藝座談會」中, 關於在地混雜語言的討論, 也使得各種既存的觀念（比如文學語言）被翻新。如張錦忠所 言, 「地方感性」為馬華文學帶來創新的書寫生機, 也塑造了馬華文學的語言特質。 ${ }^{51}$ 在

46 辛生, 〈當前華校戲劇問題〉, 《蕉風》1956 年第 27 期, 頁 7 。

47 沙里明，〈論文學創作的語言運用〉，《蕉風》1957 年第 32 期，頁 3-4。

48 諸家, 〈再談馬華文藝〉, 《蕉風》1956 年第 22 期, 頁 3-5。

${ }^{49}$ Iain Chambers, Migrancy, Culture, Identity, London: Routledge, 1994, p.24.

${ }^{50}$ Lippard, The Lure of the Local: Senses of Place in a Multicultural Society, New York: The New Press, 1997, p.56.

51 張錦忠, 〈重寫馬華文學史, 或, 離散與流動 : 從馬華文學到新興華文文學〉, 張錦忠編, 《重寫馬華 文學史論文集》，南投：國立暨南大學東南亞研究中心，2004，頁 55-67。 
當時寫實主義的創作中, 在地的方言土語滲透到書寫, 不旁為從 $「$ 身體」在地經驗過渡到 寫作語言的經驗。

\section{四、方天的寫實主義書寫：本土化與社會主義傾向}

\section{（一）社會主義與現實主義}

倘若和文學語言的「在地化」比較, 要在現實主義的書寫上, 反映本土化的真實, 以達到馬來亞化的書寫, 後者面對的挑戰, 更加棘手。那真正能深入「刻劃」馬來亞現實 的題材, 總不免要涉及政治的禁忌。在寫實主義(realism)的理想中, 寫作不同於古典亞里 斯多德藝術觀中的模擬(mimesis), 模擬是純粹按照著一個客觀的現實, 趨近逼真的描摹, 寫作卻具有改變、挑戰社會結構的意義。寫作總是屬於受過教育、具有書寫能力者的活 動, 尋找那些時代「典型」的形象（比如被逼為娼的女性、無法上學的超龄孩童或被剝削 的工人等等), 也意味著寫實總是對於他人的觀察、注視著某一階層的生活與經驗, 而加 以挟擇的再現。即便語言的風格、小說敘事的觀點與結構部署, 成功締造幻若來自窮苦階 級發聲的效果, 它仍然是經過文字、符號佈置、敘事元素與語言風格所修飾虛構, 且為特 定的意識形態所主導。 52 馬華左翼現實主義長期以來的觀點, 卻是以客觀的現實爲反映對 象, 並要求在客觀反映現實之餘再加以批判。53

固然, 要求文學反映客觀現實與批判的觀點, 並不獨為左翼所有。自清末民初以來, 中國文學便背負著改進民族與文化的重大使命, 加上長期尊崇的儒家觀點, 亦使中國文學 常被「習慣性」地賦予社會義務的要求。54倘若沿襲馬森將「現實」與「寫實」區分的定

52 西方理論頗多闡述現實主義的特質。寫實主義的反映論視符徵直接等同符旨，「寫實」其實是特定運用 語言的方式所產生的效果, 往往是其風格、語言與結構的方式, 使讀者產生如實的幻覺, 對文本信以為 真, 而忽略它被産生的過程。Rosalind Coward and John Ellis, “From Language and Materialism:

Developments in Semiology and the Theory of the Subject", Theory of the novel: a historical approach, (ed.) Michael McKeon, Baltimore : The Johns Hopkins University Press, 2000, p. 593-599.

53 如方修的觀點, 他認爲低級的現實主義是止於客觀的現實主義作品, 具有批判性的現實作品要高一級。 方修，《馬華文學的現實主義傳統》，新加坡：洪爐文化，1976，頁 20-31。

54 張誦聖, 《現代主義·當代臺灣 : 文學典範的軌跡》, 臺北市 : 聯經, 2015, 頁 $36 \circ$ 沙里明, 〈論小說 創作問題〉, 《蕉風》1957 年第 31 期, 頁 3 , 開頭就摘引中外諸家, 將創作目的在載道、美學之間比 較。 
義, 即以背負革命文學政治社會意義者為「現實主義」, 那麼方天的小說, 可否說是不帶 （左翼）意識形態的寫實主義嗎? ${ }^{55}$

白圭在〈浮槎繼往船黄石〉寫方天的筆觸，提到：

當時華人的話題, 是落地生根與落葉歸根的爭論, 《蕉風》創刊號上的「純馬來亞 化」, 不言自明。方天意裁中的馬來亞化鴧實主義, 是文学反政治汗染的立地生 根。與落葉歸根為政治服務的寫賽主義，完全逆向。56

這裡點明, 關於「純馬來亞化」, 在「左翼團體」與《蕉風》《學生周報》之間何 者, 還有何者孰「純」的爭議一一哪一方才真正實踐「馬來亞化」。白圭認為, 基於左翼 的現實主義, 乃是以中國（中共）為認同, 並非以「此時此地」為重心。白圭這段話裡並 沒有提到, 當時在現實主義坐大的文壇上, 社會主義文學觀帶來的影響可能也已超越了左 右分野的界限。方天的現實主義書寫, 其實帶有相當濃烈的社會主義特色, 小說裡吸收不 少社會主義的語裹, 且相當貫徹社會主義的關懷。

對於當時的馬來亞華社而言, 左右翼的分野, 很可能其實不限於階層結構。 ${ }^{57}$ 比如一 向被認為是右翼團體的馬華公會, 它的會員很多來自勞工階層, 而馬共的會員也不乏富有 的商人, 尤其馬華公會興起時, 它最初是幫助華人解決各種社會與經濟問題的福利團體， 直到一九五一年, 才轉型為政黨。58

對於貧窮階層的關懷，其實亦不限於左翼陣營。方天跟「左翼團體」的最大分別，在 於他貫徹了《蕉風》的本土意識, 那是去中共化之後的、更全面認同本土，同時又仍然保 持著社會主義階層關懷的寫實主義書寫。

方天小說中確實有相當鮮明的社會主義觀點，不能因為他身在《蕉風》就否定這點。 從一九二○年代開始, 社會主義在中國知識分子菁英群中掀起相當重要的影響力。社會主

$55 「$ 現實」與「寫實」在定義上的區分, 始於馬森, 他認為現代中文文學的現實主義歷史, 當溯自左聯作 家為尋求振興民族, 而奉俄國社會主義現實主義為典範。馬森以作品依循社會主義與否, 將「寫實」歸為 衍自創作内在的美學表現, 而「現實」則為屈從政治體制要求的寫作結果, 後者亦被稱爲「擬寫實主義」 或「僞寫實主義」。馬森，〈從寫實主義到現實主義：擬寫實主義與革命文學〉，《西潮東漸：第一度西 潮與現實主義》，臺北：印刻，2015，頁 498-510。

${ }^{56}$ 白圭, 《縷雲起於綠草》, 頁 71 。

${ }^{57}$ Anna Belogurova, "The Malayan Communist Party and The Malayan Chinese Association: Internationalism and Nationalism in Chinese Overseas Political Participation, c.1920-1960”, p.134.

${ }^{58}$ Anna Belogurova, ibid, p.134-139. 
義關懷大眾的精神, 堪受當時知識分子推崇, 不限於左聯或後來跟隨毛澤東《延安談話》 的左翼群體。具有社會主義意識的現實主義文學, 寫作者不一定支持中共, 作者可能獨立 於中共政權或左翼政權之外。方天的小說並非沒有發自「創作内在的美學表現」, 但也沒 少了「反映」貧窮階級和對待苦力的同情。

方天曾經廣邀左右不同政治傾向的文人來為《蕉風》助陣。在一九五七年《蕉風》的 座談會裡，從方天的發言可以佐證他期望的文學精神：

生活像一片浩瀚的海洋, 海洋上震壍著無恨的綠波, 在綠波的下面有森林, 有暗 礁，有火燒的摮熱在地殼上震顫著。如果我們滿足，或止於模仿，那麼我們只能掬 起一團飄流著的水草木片，或者撿拾一些沙灘上的貝殼，此外甚麼也不能得到了。 59

方天在任期間, 《蕉風》刊登的藝評, 包括知微〈文藝與現實〉、沙風〈文藝創作的價 值〉都批評左翼的文學觀, 同時又主張文學有用於社會的功能論。知微認為文學具有反 映、批判與改造現實的三個步驟, 文學反映現實並非能客觀得「如同照相」, 而是透過 $\ulcorner$ 把握社會發展史的未來動向」, 以便「對歷史與社會現實有批判」，而後「撼動」讀 者, 「改造現實」。60沙風主張寫作必須有「正確的」觀點與角度, 才能更好的創造人物 真實與典型，又強調文學有三大任務，即 $\ulcorner 反$ 映」、「揭露」以及為貧窮階層的痛苦與社 會問題, 「提出解決」的路向。61故而, 在當時有關現實主義文學的爭辯裡, 其中一個需 要騰清的問題, 在於現實主義的純粹客觀性已不復可能。方天上述的發言「如果我們滿 足, 或止於模仿, ......甚麼也不能得到了」就說明他所期許的, 乃是要有更多介入和在地 獨特視野的現實主義書寫, 而非抱持純粹中立客觀的描摹, 或延續過往中國大陸觀點的寫 實主義。換言之, 方天認為, 在地特性的文學, 必須體現此時此地的語言腔調、社會結構 與生活情狀。誠然亦是呼應自一九四八年馬華文藝論爭以來, 大體奠定的本土觀點。

鑒於方天小說對貧窮與苦力階層的頗多關注，得承認方天的現實主義亦有吸收社會主 義影響的部分, 同時也並非不無政治功能。然而, 基於方天小說中細瀻的美學表現, 以及 遠離延安文藝的政治規範，故仍以寫實主義來指稱方天早期的幾部小說。誠然，馬森為區 分現實主義與寫實主義而下的定義，提出了能夠區辨兩種寫作的方法。但是方天筆下的小

\footnotetext{
${ }^{59}$ 方天的發言, 〈一九五七年馬華文壇的展望一文藝座談之五〉, 《蕉風》1957 年第 29 期, 頁 $20 。$ 60知微, 〈文藝與現實〉, 《蕉風》1956 年第 21 期, 頁 3-4。

61 沙風, 〈文藝創作的價值〉, 《蕉風》1956 年第 23 期, 頁 3-4。
} 
說, 同時懷有社會主義意識、以及「發自内在的美學表現」, 亦非純粹為貫徹呼㗳本土認 同, 較像是體現社會主義文學理念。當時華文文學的現實主義與寫實主義, 兩者的思路其 實互有滲透（兩者都無法脫離「振興民族」的責任以及俄國社會主義現實主義的影響, 以 至於那想像的、清晰可辨的界限其實並不存在）。不過, 馬森其實也是受到一九五 $\bigcirc$ 年代 左右兩翼政治對立的語境所影響, 以其作品遵從延安文藝的革命意識與否, 作為辨別現實 ／寫實主義文學的判斷。然而, 寫實主義也不是方天寫作的全部特質。他的小說不乏著墨 描敘個體孤獨存世的惘焵感受, 這感受總是裹藏著對於體制的反省, 方天的小說因此體現 了一個具有社會主義理念, 同時寫實主義與現代主義兼具的特質。

\section{（二）小說析讀：從階層的身體到政體}

在他擔任《蕉風》編輯期間的創作, 除了小說之外, 也有不少童話創作和馬來亞民間 故事。在此僅討論他的寫實主義小說及地方書寫。他筆名除了方天之外, 還有「阿瓊」、

$\ulcorner$ 辛生」和「金然」，後來都一律以「方天」正名，收錄於一九五七年出版的《爛泥河的 鳴咽》短篇小說集內。

小説多描敘華裔低下階層的生活苦況, 如〈膠淚〉〈豆腐檔邊〉〈暴風雨〉等等, 所 敘述的對象包括割膠工人、小販、錫礦工人等各行各業的苦力。若按照寫實主義慣常的説 法, 方天的作品可說是實踐了寫實主義寫作的任務, 包括「批判」階級之間不對等的權 力, 「刻畫」華裔勞工掙扎求存的面貌。在他筆下, 低下層階級之間的權力關係更顯複 雜。他有幾篇小說也描述在都市消費空間（如百貨公司）裡工作的店員, 但他對這些工人 的再現，都不若對「苦力」寄寓較多同情。

方天敘述苦力或勞工的小說, 都寫得極度細緻, 表現超乎《蕉風》其他小說作者的寫 實水平。白圭因此稱他的寫實主義小説, 是「寫實主義的真品」。62小説内有大量經由觀 察 (或考察) 而來的細節, 無論是對碼頭、街巷小販、錫礦抑或船廠的場景描繪, 相當有 實在感。寫作技法精緻, 如他以筆名「辛生」發表的短篇小説〈爛泥河的鳴咽〉, 從開首 第四段開始, 小説沿著河邊的場景, 描敘鋪陳各種紛繁動靜, 透過聲音、光線、視覺、物 質流動的速度與節奏, 構塑出以主人公為中心, 所感知到的、河岸兩旁船廠的場景。63

${ }^{62}$ 白圭, 《縷雲起於綠草》, 頁 71 。

${ }^{63}$ 辛生, 〈爛泥河的鳴咽〉, 《蕉風》1956 年第 24 期, 頁 20-22。 
方天「刻畫」華裔處境的小說語調，經常沈重悲痛，如他剛來到的第一篇小說〈膠 淚 ${ }^{64}$, 小說裡孤獨的主人公, 身在一大片黑漆漆的膠林裡, 樹隙間充滿不可解的雜音, 宛如少年膠工對未來就學的前途感到彷得、迷惘的心靈空間, 這惘然的恐懼, 也來自於英 殖民地政府為獣共而實施的緊急法令控制, 「使他最擔心的卻是, 為著早一點割膠, 而違 犯黎明前不准割膠的命令, 實在有很大危險。」65 對於甚麼原因導致危險, 方天在此採取 隱藏的寫法, 幾乎是以緘默的方式為小說保留了更多空間。雖然這篇是他初來乍到刊登的 第一篇小說, 寫來卻是意象豐盈、織入了他所觀察到的華人在地生存的問題, 其中對心靈 徬得的敘寫卻甚私人, 從膠林的諸多動靜, 透過白描, 凝成瀰漫膠林內的隱蔽感和危機 感。遣詞措字, 極富個人化的語質。這篇小說, 比起他後來諸多描敘華裔勞工痛苦現實的 作品, 具有更多個體孤獨的存在意識。

〈十八溪墘〉一開始就從高處俯視碼頭苦力所在的空間, 呈現出狹窄凌亂的屋宇、碼 頭苦力負載重物疲勞的身體、濕漉漉的街上以及工人賭錢消遣的棧房。6 6 沿著骬骿布滿油 污的新加坡河, 這道新加坡河除了是穿過都市重要的地理標誌之外, 同時也是把這區域的 階級加以劃分的界限。67 小說以同情的語調, 呈現出在物質上一無所有的窮困生活。他們 不能不冀望於身體, 身體成爲穹人唯一的資產。透過男性勞工的敘述視角, 注目於年輕女 性的身體, 雖然其目光盡顯戀慕, 然而對女性來説, 出於自身階層的貧困挫敗, 幾乎也阻 礙了婚姻與戀情的可能性; 女性的身體引起欲望, 男性的身體雖然陽剛, 但卻也同時為種 種不安的意外陰影所籠罩, 未來充滿各種危機。二戰剛結束不久, 社會急需勞工來「重 建」, 卻未賦予勞工任何保護或保障, 一次意外就可能摧毁他們唯一的謀生資本, 那看似 陽剛、實質脆弱的血肉之軀。

從方天的小說中也可以看到現代工業的生產系統，如何劃分兩性的身體及空間經驗。 他以「阿瓊」之名發表的小說〈一個排字女工的日記〉, 以女性勞工為第一人稱的自述視

${ }^{64}$ 方天,$\langle$ 膠淚〉, 《蕉風》1955 年第 1 期, 頁 25-28; 《蕉風》1955 年第 2 期, 頁 26-28。

65 方天，〈膠淚〉，《蕉風》第 1 期，頁 26 。

${ }^{66}$ 方天，〈十八溪墘〉，《蕉風》1956 年第 7 期, 頁 2-6 ; 《蕉風》1956 年第 8 期, 頁 13-17。

67 新加坡河的周遭地區, 在歷史上曾被賦予文化空間與階級的屬性意義。新加坡河本身也是碼頭運貨載送 的主要交通路線, 也是苦力生活的居處。河流由南至北, 把城市劃為東西兩邊。在英殖民地二戰以前, 南 來苦力多聚居新加坡河周圍, 四周圍多是輕工業。James Francis Warren, Ah Ku and Karayuki-san: prostitute in Singapore, 1870-1940, Singapore: Singapore University Press, 2003, p.39, p.261. 
角, 描寫她們如何觀看自己與他人為鉛灰所覆的身體, 經由視覺而來的感受, 體認到自己 隸屬於勞工階層的身分：

排字的男工雖然他們也是技術工人就愛不起來，因為看慣了他們在字房裡的樣子， 就是脫下工房的衣服洗刷得再乾淨, 穿著得再整齊, 腦子裡還忘不了他們那一身的 灰與油墨, 而自己給他們的印象恐怕也是工房裡蓬頭灰髮的醜樣。……其實灰與油 墨有甚麼可嫌處，一身灰與油墨正是他可敬可愛的標誌。68

上述這段, 可說是複述社會主義改革的自勵話語, 以便抵銷、匡正美醜觀念。作者同情勞 工的立場相當鮮明, 可說是不空讚頌, 也突出工人之間的情誼。從這點來看, 方天相當認 同社會主義的立場。甚至更進一步說, 方天還極同情那些體力受到剝削、處境較為可憐的 勞工階層。他意識到工人階級並不是均質的, 工業生產精工劃分的需要, 把女工加以分門 別類地安置在生產單位中, 由此帶來差異不等的身體經驗。工業的劃分因此銘刻在女工身 上，在不同的工作場合與崗位上，養成相應的氣質：

裝釘部的姐妹衣著比較鮮亮, 儀容也比較修整; 排字房的姐妹則賽似煤渣堆上打過 滚來似的。洋貨店那邊，她們一個個裝束得花枝招展，頭髮是外國明星式的，衣裳 是色澤鮮醘濃烈，剪裁得緊身合體，曲線畢呈; ……我們這邊的姐妹大半不喜歡多 講話, 講話也是細細的聲。仿彿長年封在地獄裡的幽魂一旦到陽光裡也不敢充分顯 露自己; 她們那邊則是有說有笑, 各逞塈攬顧客的口才談得高興時嘴裡夾著整串的 英文。 ${ }^{69}$

除了方天 (阿瓊、辛生) 之外, 尚有另一位作者羅紫〈寶寶真累人〉亦對工人的身體與空 間經驗, 投以細䑄的描述。70羅紫的寫實主義風格與方天頗相似, 對勞工的工作情況都仔 細考察。他們的小説大都專注敘寫城市裡的低下階層, 往往窮得僅能顧及生活中最基本的

$\ulcorner$ 食」與「住」。一如方天, 羅紫也對女工的身體經驗, 敘寫深入。在小說裡, 從事製造 男裝軍鞋的女工, 各自從身體的不同部位感到酸痛, 這些不同的酸痛部位, 也與工人負責 的產品部份相對應, 由此折射出分工生產的製造業, 猶如把工人的身體分割、工具化地支

${ }^{68}$ 阿瓊, 〈一個排字女工的日記〉, 《蕉風》1956 年第 23 期, 頁 9 。

${ }^{6} 9$ 阿瓊, 〈一個排字女工的日記〉, 《蕉風》1956 年第 21 期, 頁 9 。

70 羅紫, 〈寶寶真累人〉, 《蕉風》1957 年第 52 期, 頁 16-18。 
配。與其他職業的工人相比, 在工廠勞作的身體經驗, 幾乎無甚愉悅可言。即便賦之以鼓 舞勞動的社會主義話語, 仍然無法改變身體為鉛灰壟罩而腊淡的事實。然而, 又正是那匡 正美醜觀念的言語, 同時安慰了女性勞工可能會有的自卑感。與此同時, 「可敬可佩」之 語云云, 又悄然施予道德勸諭的訓導。於是, 在這些社會主義的觀點與聲明裡, 振作鼓舞 與壓抑規範, 也就同時並存。

譬如小説裏透過第一人稱敘述的女工，道出的反黃觀點：

今天撿了一篇稿子的字, 越撿越生氣, 稿裹寫的是霂紙荒淫無恥之言, 讓人看了 臉紅，恨不得一把撕碎它。後來問敏姐，才知道是小報的稿，不明白廠方爲什麼 要承印這種黄色柬西。從前我還以爲自己雖是工人，在人眼睛裹踓然低賤，但是 所謂推展社會的文化，我們也有一份勞績的。我們是文化綫上的無名英雄。今天 才知道，散佈黄色毒素，也有我們一份，我們也是毒販子的幫手。我們是這個社 會複雜的大機器上的一個小齒輪。71

小説藉女工之口道出對淫黃書寫的道德斥責, 在方天這篇小説裏, 他賦予排字女工異常獨 立的自省能力, 意識到在生產的體制裏, 任何人都不能置身事外, 即便是想要循規蹈矩地 服從體制的安排。當排字女工遇上黃色文學, 她的抵抗便從「揀字」着手。小說把原來抽 象的符徵, 具現爲中文鉛字, 正是這可觸、可摸、可握與可選擇的 $「$ 字」, 彷彿也是集體 道德意識的延伸。無可否認, 小說結尾, 仍帶著流於道德教化的感喟。相對於英殖民地政 府對中文的防範, 將中文視爲培孕共產意識、擾亂馬來亞社會安寧的搖籃, 在方天的小説 裡, 中文的文本產生過程, 經過了多重出版機制、包括印刷排字的過程, 其中就有各方意 識在周旋角力。當各種道德與價值觀念穿越個體, 使個體彷彿成爲群體價值觀的戰鬥場所 時, 個體如何可能從既有的觀念解放出來? 在當時, 對華人社會而言, 社會主義式的思維 與觀念, 無疑最具號召力; 然而, 從另一方面來説, 方天的小説雖然攜帶了社會主義的語 彙, 並不意味他在政治上就認同左翼。小說似乎較傾向於經由女性勞工之手, 體現出一個 極為理想的圖景, 即把知識與勞工階層相連起來, 形成共同申述抵禦腐敗的敘述模式。72

\footnotetext{
${ }^{71}$ 阿瓊, 〈一個排字女工的日記〉, 《蕉風》1956 年第 23 期, 頁 11 。

${ }^{72}$ 方天對於女性的情感相當陌生, 這使得他的小說裡的女性敘述, 僅能有限地止於公共領域。他善於觀察, 筆下細節也蠻能細心呈現女性在公共場所中的言談舉止; 至於那些在規範底下、更為私密的欲望, 雖然在 文本偶而也隱隱浮現, 但卻始終被阻攔於各種既有的、正當的觀念界線之前。方天的小説讓人看到了欲
} 
在方天的這篇小説裏, 雖然鉛字如此具有中文方塊字的意像, 但華人社群在政治上 的異議幾乎是靜默的。在諸多意義的軸向上, 方天回避了英殖民地政府對華教的壓抑, 而 轉向了訴諸於階級與道德意識的主題。

誠然這使這篇小說的視野有所局限, 但是, 從小說選擇的題材來看, 通過當時印刷 業務的鉛字形象, 隱隱碰觸到族群與文化的問題, 其中牽涉的權力衝突, 可能甚至超出了 方天本身的意識。到底現實主義如何能介入現實、更深人到諸多衝突中去呢? 在面對英殖 民地的政治控制，以及友聯本身持有的反共宗旨下，現實主義的理念又如何能實現？

方天的小説偶爾也會有超出社會主義之外的觀點。在一九五六年第十七期, 他刊登了 自己一篇關於錫礦工人的小說〈暴風雨〉, 雖然結尾的悲劇似為典型常見的窮人悲歌, 不 過小說內對於個體與階級之間的內在約束，卻寫得相當隱晦微妙。

小說中來自同一階層的聲音, 不斷複述窮人的憤怒與不滿（比如訴說工人們為工作犧 牲卻毫無報償），但這同一階級的集體聲音卻與金發看待自我價值的觀點錯開了。在馬華 文學寫實主義的小說中, 集體共有的遭遇與同情, 往往覆蓋了個體內在的衝突與焦慮, 同 一階級共享的語言, 預設了屬於群體共有的情感, 應該要超出個體自我的意識。主人公金 發對守護錫礦的任務表現得異常投入, 表面上似乎由於家庭負擔所驅, 但他對錫礦場出奇 強烈的牽挂, 卻並非養家活口的需要而產生。由於年紀輕輕就被賦予管班的任務, 使他感 到自己的幸運, 異於同輩, 因而在受到賞識的 $「$ 召喚」中, 認同了「盡責」本身即為實現 主體（這主體性須為他者所承認）的基礎所在。然而, 由於家庭責任的負擔，才使得這位 年輕管班無法全心投入, 而大自然的暴風雨又非人力與簡陃的技術所能應付, 以致於為此 飽受心靈折騰。小說中透過金發這角色寄寓自我認同的價值所在, 對個體、階級與認同價 位的關係, 曲折地傳達出頗為複雜的質問。

方天在《蕉風》當編輯的時期, 新馬正處於實行緊急法令的狀態。〈暴風雨〉小說也 描述了男主人公金發出入新村的情況。自衛團在傍晚七點關閉鐵門、金發在夜裏離開新村 回去礦場, 需要獲得好幾個層級批准, 包括村長、馬打 (警察) 和自衛團。73新村內外, 這層層監控、限制穿越的防備界限, 源於殖民者視華族即為共產黨的偏見與懷疑。華裔工

望, 如何爲這些正當的、階級關懷與其話語所堵塞, 卻無法跨出這道界限以外再作探索。故此可以說, 正 是現實主義那主張為群體利益服務的書寫理念, 反而阻攔了文學去實現深刻書寫他人、爲他人發聲的故 事。

73 方天，〈暴風雨〉，《蕉風》1956 年第 17 期, 頁 13 。 
人在殖民地生活朝不保夕的處境, 以及在面對建國歷史時刻的種種焦慮, 在方天的小說中 佔據了相當重要的分量。

在方天這些後來收錄於《爛泥河鳴咽》的小説中, 並無空間留予緬懷家鄉, 也沒有鮮 明的痕跡顯露出以中國為祖國的情意結。主人公通常無多餘分文, 三餐勉強溫飽, 無論是 國族認同或政治激情, 對此貧困交迫的階層而言, 都太過遙遠。但為了能夠繼續居留本地 與繼續謀生, 國籍或公民權遂為不得不去面對、反思的問題。以辛生筆名, 刊於一九五六 年第十二期的《蕉風》短篇〈一個大問題〉 74 , 時空置於黃昏的甘榜, 透過一場在華裔主 人公以及兩個馬來友族之間的對話, 小說表達了當時華人申請公民權的諸多障礙。他們之 間的對話, 語音混雜, 氣氛幾乎和諧, 如同共治一爐。小說由此回應當時各種質疑華裔能 否融入在地的成見, 包括他族對華裔落腳地之不以為然（隨時可回唐山）, 以及通過主人 公之口表達華裔不欲回歸, 而想落地生根的意願。

$\ulcorner$ 地方感的認同」不一定由「國族認同」而來, 兩者也不必然重疊一致。不同於國族 認同是由政治話語所建構, 地方感則是由日復一日的日常經驗與習慣累積, 以及和當地社 會成員之間的互動, 逐漸對地方產生依戀與認同的感情。然而, 即使因為長期居留而對落 腳之地產生了依歸的感情, 華裔所面對的仍然是 $\left\ulcorner\right.$ 不被認同」的問題。 ${ }^{75}$ 正如小說主人公 阿興伯所言, 他認為自己來馬來亞居留且生兒育女已經多年, 視自己為本邦人, 故此以為 被認同為本邦人, 本該是天經地義。76

《蕉風》標明本土路綫的寫實主義, 除了顯示這份雜誌去除「中國色彩」的鮮明立 場, 箇中的本土語境, 譬如在方天這篇小說〈一個大問題〉裡, 並不迴避當時與官方的馬 來亞運動之間, 以及華人對於公民權觀點的衝突。若與當時《蕉風》内常見到的歌頌國 家、熱烈認同獨立的正面語言相比，方天這篇小說包含更多諷刺與對馬來民族本土主義的 質疑。在公民權問題上, 各種「交流」其實充滿了一連串需要費盡唇舌、說也說不完的

$\ulcorner$ 解釋」。「解釋」雖然可以換來友族友善的「建議」, 但最終所有的「建議」還是勸服 華人服從國家的建制。小說在回教堂黃昏的祈禱聲中, 以一個居高臨下的觀點來俯視國家 體制與個體信仰之間的差距出入, 伊斯蘭的經文傳達公平博愛之意（「真主教我們公平與 善, 愛你的鄰人如愛自己」），但實際上政體已經把「國族」劃出等級之分；三方對話在

\footnotetext{
74辛生，〈一個大問題〉，《蕉風》1956 年第 12 期，頁 3-7。

75 參考張錦忠, 「馬來 (西) 亞民間華社在文化屬性與政治認同的問題所在, 不在於認同, 而在於不被認

同。」張錦忠, 《南洋論述一一馬華文學與文化屬性》, 臺北：麥田, 2003, 頁 110 。

76辛生，〈一個大問題〉，頁 6 。
} 
暮色結束後, 仍未能獲得滿意的解釋與解決之道, 卻仍然以維持和諧關係的方式, 互道 $「$ 猛得卡」（獨立）口號, 來結束這場無法解決問題的對話。

小說內外洋溢的愛國意識, 其實都對國家愛得不清不楚：愛國與獨立的口號喊得再怎 麼聲嘶力竭, 底下卻仍然滿腔難言的五味雜陳。哪怕對公民權有諸多意難平, 此焦慮也依 然得與「愛國意識」的熱情共同起伏在一九五 $\bigcirc$ 年代馬華現實主義的文本中。

對於甫到新加坡落腳的南來文人來説, 如此快速地表達自身為馬來亞華人, 雖說是出 於反共、進而鼓吹本土, 但這樣的聲明, 亦鮮明地傳遞出告別過往的意味。方天無疑是

《蕉風》的作者當中, 其身世最為特殊、寫實作風最鮮明的作家。與姚拓、陳振亞等其他 作者相比, 方天的寫實主義夾帶更多的社會主義特色, 到底是甚麼原因使他加入到《蕉 風》陣容中呢? 白圭在《縷雲前書》中, 回憶友聯的前輩提及方天時直為「小共產」, 語 氣卻無不敬之意。 ${ }^{77}$ 書中追憶接觸方天的零星片段, 包括某次方天與文友們在香港出遊, 在香港梅窩的沙灘上，方天讚揚王實味的小說《野百合花》，同時也批評了延安文藝。78

中國易權後, 離散者由北到南, 在不同的地理緯度經驗了現代性與殖民地的時間差 異, 香港和新加坡表面上看似接近, 然而前者的殖民地時間還很漫長, 而後者卻已至英殖 民地的尾聲。正如他在《蕉風》創刊號中發表的短篇小説, 一篇絕非現實主義之作〈一八 四一年的一夜〉, 這場回溯鎖住時間定點, 試圖捕捉鴉片戰爭爆發時, 南洋的新加坡在同 一時刻的畫面。一八四一年也是香港英殖民地開始的那年。這篇小説對南洋移民的想像其 實有些刻板, 是方天在《蕉風》刊出的第一篇作品。透過對往昔的遙想, 小說把新加坡與 中國晚清帝國衰弱的關鍵時刻銜接起來, 無疑是對一九五五年《蕉風》創刊、友聯出版社 南來, 致以歷史追憶的手勢。方天離開香港, 隨同友聯南來創辦分社, 都標誌著在中國現 代化進程中、中國政權轉向共產主義的另一階段, 在這政權中遭到排擠的文人再度越境流 亡離散。香港與新加坡這兩個英屬殖民地, 因此在冷戰形勢有所跨域交會, 進而延伸到華 文文學的場域之中。

\section{五、非共的社會主義寫實主義}

\footnotetext{
77 白圭, 《縷雲前書》（上冊），頁 253-258。

78 白圭, 《縷雲前書》（上冊），頁 255-256。
} 
以下這一問題, 將會瓦解以友聯為「非左翼」團體的一致性想像 : 倘若與稍後的南來文 人, 如姚拓、黃思駎等人的小說相比, 方天的小說難道不也具有社會主義關懷的意味嗎? 要如何看待方天這些蘊含著階級關懷、批判資本主義意味深濃的寫實主義作品出現在《蕉 風》呢? 此外, 那與《蕉風》對立的左翼文學陣營, 到底是怎麼被想像的?

\section{（一）左翼精神}

在一九五 $\bigcirc$ 年代及之後的馬華文學論述中, 所提到的左翼現實主義文學陣營, 無法不 將之與一九四九年中國的政治變革, 區分開來。中共執政後, 將毛澤東一九四二年「延安 文藝講話」付諸實踐, 再加上多次鎮壓行動, 壓制了原先尚能尊崇左翼精神的知識份子。 在這之後被中共認同的「左翼」與早前一九二○年代時期, 尚能針對強權（當時主要是國 民黨）發言的知識份子, 所持的左翼精神, 大為不同。79這些群體勢態各異, 除開魯迅、 蕭紅、蕭軍、丁玲等等具有現實主義作風, 部份海派作家如施蜇存、劉呐鷗等有新感覺派 的美學，都不旁為認同革命理念的知識分子。 ${ }^{80}$ 馬華文學自六十年代開始，才有現代 /現 實對立的論述。在馬來亞獨立之際, 受抗日文學影響下的馬華統戰文學, 幾乎全面地跟隨 毛澤東《延安講話》的左翼文藝觀。故多數的研究者, 針對一九五 $\bigcirc$ 年代時期及過後的 $\ulcorner$ 左翼陣營」的指稱, 多以跟隨毛澤東延安文藝指導者為標籤。後者對毛澤東文藝觀的遵 循, 亦見諸於一九五 $\bigcirc$ 年代期間, 與《蕉風》對歭的左翼群體, 他們杯葛友聯旗下刊物,

79一九四九年之後, 中共掀起多場整䎘與鎮壓, 除了清洗對強權質疑的異議聲音, 也檢舉了各種被認為是尚 存小資品味的殘餘習性, 包括那些被指為頽廢、消極與流於情慾的書寫。在此略為分析中國「左翼文學群 體」詞彙定義的變化。過去參與中國左翼聯盟者, 當為左翼文學的狹義定義。但是除了左聯之外, 那些曾 經接受歐洲社會主義與階級理論影響, 為革命理念所召喚而表達正義與道義信念的群體, 包括被稱為京派 與海派的部分作家, 雖然沒有參加左聯, 也當為在廣義上體現左翼精神的現代文學群體。然而在一九四 二年以後, 就政權統治劃分的地理區域範圍而言, 在上海租界等地, 與在延安統治區, 兩地聚集的文學群 體與其文化生態, 差別幾如雲泥。在延安之外, 尤其以上海租界為主, 各種意識形態與藝術觀點並存競 逐, 故說在一九二 $\bigcirc$ 年代、未受延安文藝指導所匡正、詮釋的文學群體, 那時候的革命信念與自由主義同 時並行, 絕非言有過之。在這些勢態各異的群體中, 當中如魯迅, 面對國民黨強權, 亦無畏於提出批判 與異議。然而, 這樣的特質, 在毛澤東延安左翼政權意識形態劃一的政策下, 遭到壓制, 知識分子那善 於用典、精微辨別與闡述細緻的能力, 甚至被認為是 $\ulcorner$ 小資產階級劣根性」。方維保, 《紅色意義的生 成—20世紀中國左翼文學研究》, 合肥 : 安徽, 2004, 頁 52-91。

${ }^{80}$ 方維保, 《紅色意義的生成》, 頁 138 。 
當時發表的文宣裡, 不乏大段引用毛澤東的觀點。81 從資料來看, 當時與《蕉風》立場敵 對的左翼團體, 似乎服膺於延安文藝那套將意識形態與藝術劃一之後的左翼文學觀; 與此 相對, 《蕉風》則致力於想要改變或規勸馬華文學裡的新進寫作人, 切勿跟隨延安文藝的 觀點, 而應該轉往文學美學的思考。82不過, 「左翼陣營」反對《蕉風》的原因與背景其 實很複雜, 從針對英殖民的剿共行動, 乃至到由於對華教不利的調查報告出爐, 為了維護 華教而激起眾憤。當時掀起的學生運動, 固然主要是針對英殖民者, 但也連帶抨擊具有美 援背景與反共宗旨的友聯; 基於對英殖民者的憤怒, 遂把友聯出版社和相關的文人, 都視 為與英殖民者同路的敵對者。在此, 有鑑於當時主要的杯葛起於校園的學潮運動, 故此接 下來僅以學潮團體, 而非左翼群體, 來指稱當時的杯葛者。尤其馬華文學的左翼文學群 體, 譜系亦非一致。馬華文學寫實主義陣營中, 不乏認真探索文學美學與實踐傳統寫實主 義的作家，包括苗秀、韋量、姚紫、趙戎乃至到《蕉風》的方天。

在毛澤東執政之前, 中國的現代文學, 曾經出現具有高度自由的現實主義群體。在當 時多元的文化生態裡, 現實主義甚至能夠與自由主義並存。83隨著延安文藝與革命路線擴 展至馬來亞, 服務大眾式的現實主義也在馬共與左翼掀起下, 蔚為主流, 同時一併把過去 戰前多元風格的左翼文學, 依照《延安講話》來歸納詮釋。為了和左翼展開不同的詮釋,

${ }^{81}$ 見杜康於一九六 $\bigcirc$ 年發表的〈「論藝術的社會價值」的價值〉, 轉引自謝詩堅, 《中國革命文學影響下的 馬華左翼文學》，頁 199 。

82 至到一九六三年現代主義開始之後, 《蕉風》的系列講座裡, 這樣的觀點就更加明顯。如在黃崖擔任主 席的座談會裡, 鮮明地傳遞出反對延安文藝的文學觀, 包括「不要不自覺跌入現實主義的陷阱裡, 而變成 某種集團的『革命現實主義』的工具」、「不應把一種『文藝路線』或一種『教條』緊砸在文藝創作 上」,「現實主義已經失去表現的效能, 應該是譬喻、聯想、意象、象徵、抽象、超現實主義等表現技巧 共同使用, 才能創作出好的作品來」。蕉風, 〈我們對馬華文壇的看法〉, 《蕉風》1963 年第 133 期,

頁 3-4。謝詩堅, 《中國革命文學影響下的馬華左翼文學》, 頁 398 。

83雖然近代論者多指出, 經過漫長的時間, 從清末民初梁啟超、嚴復等引入的自由主義, 在中國的實踐已宣 告失敗, 但自由主義也確實曾經有過短暫的蓬勃時期。在梁啟超的革命失敗以後, 資本主義的自由主義在 中國影響轉弱, 並不受落。尤其社會主義在一九二 $\bigcirc$ 年代崛起, 知識分子多對資本主義難以接受。黃克武 的論文裡, 提到在民初梁啟超的影響轉弱之後, 仍然有知識分子與精英追求一種非與資本主義結合的自由 主義, 如傅斯年就有 $「$ 放棄資本主義」, 讓自由主義保其 $\ulcorner$ 人道主義」的「靈魂」的說法。根據許紀霖的 論文, 從一九二 $\bigcirc$ 年代到一九三○年代, 英國拉斯基 (Harold Laski) 的費邊自由主義在中國走紅。費邊 自由主義, 據蕭乾解釋, 並不必然與資本主義結合, 也可以與社會主義結合, 甚具個人主義色彩。許紀 霖, 〈現代中國的自由主義傳統〉, 《二十世紀雙月刊》1997 年 8 月號第 42 期, 頁 27-35。黃克武〈西 方自由主義在現代中國〉, 黃俊傑編, 《中華文化與域外文化的互動與融合》, 臺北市: 喜瑪拉雅研發基 金, 2006, 頁 341-378。 
《蕉風》在姚拓擔任編輯之後, 從一九五七年第三十七期開始, 推出一系列名為「文壇雜 話」的專闌, 每期介紹當代跨越左右翼的中國作家, 提出與延安文藝主導的詮釋, 全然迥 異的當代文學詮釋。84

方天擔任編輯的創刊初期, 是《蕉風》推行在地化現實主義最重要的時期。這時期刊 登關於現實主義的評論如下：

一、李亭〈此時此地的文學〉（一九五五年第二期）提出在地化論述, 認爲馬華文學 需要一個適合此時此地、能夠表現殖民地現實主義的文學。

二、李亭〈文學的現實性〉（一九五五年第四期）的在地化論述, 認爲馬華文學需要 的文學，必須是反殖民地主義、反封建主義、反投機主義。

三、知微〈文藝與現實〉（一九五六年第二十一期）談到文學與現實的互動, 認為文 學應當有反映、批判與改造現實的三個步驟，文學反映現實，並非是全然中立客觀 不帶立場。

四、沙風〈文藝創作的價值〉（一九五六年第二十三期）批評左翼的文學觀, 包括左 翼常見的教條主義、階級對立。然而他也認為文學不能擺脫社會責任。他不認同那 純粹為藝術的寫實, 認爲思想意識、道德觀念、立場角度必然左右寫實主義的寫 作；同時又主張寫作必須有「正確的」觀點與角度。

五、洛萍（陳振亞）〈創作的動機與目的〉（1956 年第 28 期）他認爲文學並不能如鏡 子般盡其反映, 創作源於作家意欲表達的思想、意識, 而意識又來自作家的現實生 活。

六、沙里明（陳振亞）〈論文學創作的語言運用〉（1957 年 32 期）則論及語言, 認爲 文學語言必須得從現實社會的一般語言去提煉, 脫離現實經驗則語彙枯歇。文學的 語言語彙應當有屬於區域的獨特性。

上述最後兩篇「洛萍」和「沙里明」皆為陳振亞的筆名。陳振亞的文學觀點較少訴諸 於社會改造功能論。在〈創作的動機與目的〉, 他以爲文學内容來自作者的意識, 作者的 意識即為現實的整體經驗, 雖然寫實主義不是寫作唯一的美學目的, 但文學作品所「想象

84 謝詩堅, 《中國革命文學影響下的馬華左翼文學》, 頁 198 。 
的人物、題材、故事」, 必須「在現實生活中有存在的基礎」。 85 這觀點在他另一篇以

$\ulcorner$ 白蒂」發表的〈論文藝創作的内容與形式〉加以延伸, 但補充了讀者的角色: 文學若要 有價值，作家的意識必須能投入到讀者有所感應的心靈裡。86

從方天本身撰寫的小說, 以及他擔任《蕉風》編輯時, 刊用的藝評稿件、登場的作家 陣容和同時期刊登的小說來看, 《蕉風》確實有如徵稿聲明的, 實踐不分派系、多元包容 的文藝觀。

仔細瀏覽《蕉風》當時的稿件, 方天在任期間, 既為《蕉風》推行在地化現實主義最 重要的時期, 同時亦是社會主義意識的寫作同時並存的時期。一些篇幅短小的稿件, 如黃 昌虎撰寫的小說〈美麗的小鬥士〉, 體現出解救窮人、拋棄小我愛情的鬥爭敘事模式。87 在翻譯小說之中, 除了馬摩西翻譯的埃及小說之外, 還有呂卓翻譯的數篇印尼小說, 皆出 於印尼抗日與獨立世代的作家之筆, 包括孫達尼(Utuy T. Sontani)的短篇小說〈沙末的商 品〉、獨幕劇〈女招待〉, 以及蘇的亞蘇加馬(Rusman Sutiasumarga)的短篇小說〈布加西 姑娘〉(Gadis Bekasi)。88 〈布加西姑娘〉敘寫被殖民獨立史所拋棄的邊緣畸零人。〈沙末 的商品〉與獨幕劇〈女招待〉亦關注低下階層, 但不僅止關注物質上的窮困, 也探索宗教 與精神心靈的關係、虛假與真實、從約束到尋求自由的諸多意義。這些具有左翼傾向的小 說，出現在方天編輯的《蕉風》，難道方天其實依舊認同共產主義嗎？

這乍看奇怪, 不過在一九四九年以後, 香港第三勢力吸收部署的軍政要人, 本來就不 乏前共產黨員, 包括方天的父親。若根據桑德斯(Frances Stonor Saunders)的研究, 美國在 冷戰時期, 吸收頗多前共產黨的左翼份子（桑德斯稱之為「非共左翼份子」, NonCommunist Leftish）, 這稱謂是從美國外交部的反共視角出發而來。他們發現, 能夠瓦解 共產主義的敵人, 莫過於前共產黨人或信仰民主自由的社會主義人士。 ${ }^{89}$ 對於所網羅的大 量左翼作者群體, 美方不會直接干涉或主導, 而是相當慎重地對待, 資助他們出版刊物,

\footnotetext{
85 洛萍, 〈創作的動機與目的〉, 《蕉風》1956 年第 28 期, 頁 4 。

${ }^{86}$ 白蒂，〈論文藝創作的内容與形式〉，《蕉風》1956 年第 34 期，頁 3-4。

87 黃昌虎, 〈美麗的小鬥士〉, 《蕉風》1956 年第 26 期, 頁 18 。

88 吕卓譯, 孫達尼(Utuy T. Sontani)著, 〈沙末的商品〉, 《蕉風》1956 年第 21 期, 頁 17-18 ; 〈女招 待〉, 《蕉風》1957 年第 32 期, 頁 17-20；1957 年第 33 期, 頁 20-23+8、9。呂卓譯 , 蘇的亞蘇加馬 (Rusman Sutiasumarga)著, 〈布加西姑娘〉, 《蕉風》1957 年第 29 期, 頁 6-7。

${ }^{89}$ Frances Stonor Saunders, The cultural cold war: the CIA and the world of arts and letters, New York: New Press, 2000, p.53.
} 
然後觀察、監控其刊物, 以防他們變得激進。 ${ }^{90}$ 此外, 在另一些寫作的個案, 如果交上的 作品內容超出美方所能接受的限度, 就會要求對方重寫, 以便能交出 $\ulcorner$ 代表美國觀點 $」 之$ 作。桑德斯的紀錄與整理, 幾乎完全重建美國外交部的觀點。甚至部分接近美國資助香 港第三勢力時期的部分狀況。當時所延攬的不少都是前中共要人, 包括方天的父親張海 壽。

惟對於作者如方天在文學中顯現的複雜特質，似乎並非能以桑德斯的「非共左翼份 子」來概括。但無可否認, 方天確實體現了那外在於中共政權的左翼精神, 其文學書寫體 現出非共左翼作家的社會主義寫實主義理念, 甚且也不無包含具有批判意味的現代主義。

桑德斯的「非共左翼份子」這個詞彙源於美國外交部在冷戰中的反共目的, 用以概括 在某一類所要延攬的目標群體。然而, 從文學群體本身的實踐方式與視角來看, 其身分卻 可能比美方的定義更為複雜。方天來到馬來亞之後, 可說是被多重的話語所圍繞。桑德斯 所揭露的美國外交部的視角與分類方式, 其實難以闢釋方天在馬來亞, 那聚合了反共（友 聯）、剿共（馬來亞聯邦）、本土認同（《蕉風》與馬華文壇）、社會階層關懷的寫實主 義作風（個人的出身背景與文學習性）等等, 那經由諸多觀點與話語交錯造成的位置。方 天小說中對低下階層與苦力持有的濃厚關懷和混雜特性, 其馬來亞化書寫也直挑公民權的 政治忌諱。後來的寫作文風漸見變化, 幾近現代主義, 但也仍可見對體制與歷史的思考。 他似乎也在竭力實踐, 作家王實味對權勢說真話的理念。然而, 美新處或馬來亞官方對方 天的表現可滿意? 方天為何離去? 截至目前為止, 從白圭的《縷雲前書》或馬崙的零星文 章中追憶的方天事跡, 都未有說明方天加入友聯的經過, 以及他離職的原因。

無論是對方天抑或對當時的馬華文學而言，寫實主義確實被推崇為嚴䎘文學的典範。 方天在任時期, 《蕉風》所刊出翻譯的小說裡, 如孫達尼的小說, 不僅具有左傾意識, 孫 達尼本身就是具有左翼意識的印尼作家。但與《延安講話》的教條式寫法不同, 這些印尼 小說寫來嚴謹沉重, 不至流於訴諸鬥爭呐喊的口號, 雖然獨幕劇〈女招待〉的「出走」甚 具象徵意義，但〈沙末的商品〉與〈布加西姑娘〉依然顯現出嚴格的「寫實主義」美學， 但敘述筆法極度風格化。資本主義不僅以物役人, 亦從權力結構上支配個體, 左翼文學提 倡反資與反殖等口號, 所求者, 當包括維護求知、探索與認識事物的自由。方天本身習得 的寫作文學觀，誠然受到社會主義觀點的思路影響。但若為實踐如魯迅般的七首文學觀，

\footnotetext{
${ }^{90}$ Frances Stonor Saunders, The cultural cold war: the CIA and the world of arts and letters, p.83.

${ }^{91}$ Frances Stonor Saunders, The cultural cold war: the CIA and the world of arts and letters, p.273.
} 
這樣的自由不在中共, 亦不在臺灣的國民黨。在一九五六年第七十八期, 《蕉風》也翻譯 了朝鮮的一篇抗日小說, 端木鈴譯 、金北鳴著〈帶來死亡的人〉。92 抗日文學當為左、 右兩翼均有的敘事, 不僅僅只是通過翻譯外國文學來遮蔽反共動機, 從雜誌的刊用稿件, 可看出編輯的文學觀點。方天的文學理路, 也確實如同輩人習得寫實主義的脈絡那樣, 經 由抗日文學、階層關注以及各個流派的寫實主義文學而培養起來。對於在地的馬華文學而 言, 《蕉風》通過翻譯引入的各地視角（除開上述的印尼小說、朝鮮小說, 同一時期亦有 馬摩西翻譯的埃及小說, 將在第四章論述）, 結果也開拓了文學視野, 使讀者看見這些不 同區域的文學作品, 與中國現代文學的寫實主義作品迥異的寫作筆法, 在這些各地區的後 殖民文學，其本土敘述已有怎樣的成果。

\section{（二）殖民地政治禁忌與現實主義的局限}

根據創刊以來的徵稿宣言, 這份刊物應當可以容納、使多種意識型態與藝術形式都同 時兼收並蓄, 以免抹除其他藝術形式存在的空間。在此, 雖言不分派系, 仍有其模糊之 處, 比如它未能解決權力介入的問題, 也無法接受同情馬共的觀點。無可否認, 一九五○ 年代中旬, 《蕉風》創刊初期所舉辦的一系列馬華文藝的座談會, 確實迴避了政治的問 題。除了討論語言風格、在地知識、把生活所見的社會現象加以在地化處理之外, 真正阻 礙當時的寫作人, 在書寫中達致寫實理念的核心意義, 正是反共政治導致的排除性。所有 敏感的政治問題, 也都是闡釋現實至為關鍵的課題，包括關於華教、族群關係（華巫分 裂、公民權問題）、語言政策、身分認同以及包括馬共在內的政治禁忌所在，而其中又以 被緊急法令列為禁忌之處, 即馬共的存在問題。按照寫實主義文學的理念, 所謂禁忌之 處, 正是文學該要貫穿之路。裴海燕(Jana Benešová)在《從「現實」到「寫實」：一九八 $\bigcirc$ 年代兩岸女性寫實小說之比較》書裡指出, 文學評論長期以來對現實主義存在著「不証 自明的反對立場 $\lrcorner^{93}$ 。這值得反思, 並對於這立場加以檢視、重讀和理解其歷史的必要。

西方的寫實主義文學史演變的過程, 很大部分跟「真實」（總是被想像為處於文學外 邊）、「反映」（文學怎樣可能把真實反映得更好）的概念變化有關。十九世紀的現實主 義, 從浪漫主義的文化與文學蛻變而生, 當時是極為嚴鷫的藝術, 想像文學可以真摰地反

92 端木鈴譯, 金北鳴著, 〈帶來死亡的人〉, 《蕉風》1956 年第 28 期, 頁 8-9。

93 裴海燕（Jana Benešová），《從「現實」到「寫實」：一九八○年代兩岸女性寫實小說之比較》，臺北： 秀威, 2015, 頁 14 。 
映真實。喬治雷萬 (George Levine)在《現實的想像》的前言中, 為闈明維多利亞時期的寫 實主義所寫的一段話，或許可作為寫實主義理念的註腳：

寫實主義，作為一種文學的方法，就其名稱而言，可被定義為一種格外具有自覺性 的努力，通常是在對於倫理道德精神的尊崇下，力圖道出真實，以及將對人類的同 情心擴展、超越限制，使文學的呈現一如現實，而不是其他的語言。故此，一個作 者必須畫其所能执棄那些已成常規的表現手法，並努力創造新的。沒有任何維多利 亞的一流作家會真的相信他們是在提供一個不經中介的現實。但即使以他們自己主 觀所僅有的知識，仍盡力掙扎以便能接觸、接通那外邊的世界，以及打破那在傳統 和語言上形成的唯我主義的局限。94

上述這段解釋, 目的是為了反駁, 那種以為「寫實主義就是天真地認同文學是透明的中 介」這種偏見指控。小說必然是以意符與一連串結構（敘述觀點、場景、時間等）構塑成 彷彿為真的效果, 對此作家不可能沒有知覺。寫實主義宣稱的「真實」觀點, 是為了打破 浪漫主義長久形成集中於上流社會浪漫才子佳人敘事格局的陳規, 因此, 寫實主義便具有 $\ulcorner 反$ 對虛假」與「對現實負責」的意義, 但也因此在逼近其理念的過程中, 會經歷與自身 有限經驗的「掙扎」和內在辯證的矛盾。95現實是各種 $「$ 充滿矛盾與衝突」的一系列差 異, 但對現實的觀念卻非固定, 而且會「隨著世代和文化觀念的改變而改變」, 這是因為 文學總是會有「新的方式去深人到現實裡」。維多利亞後期現實主義鮮明的宣言, 如喬治 吉辛(George Gissing)所言，乃與為了與那種 $「$ 文學是寫來取悅人」的「心理習性」抵抗， 也為了打破小說須有情節、應該要有歡快結局的固有觀念。然而, 喬治雷萬也指出, 諷刺 的是, 維多利亞時期冒起來的寫實主義, 後來也陷入當初所反對的「心理習性」臼巢, 而 遠離了衰於現實的理念。96

中國文學現實主義承自十九世紀歐洲的寫實主義，最初它對於知識份子而言，是可 茲傳遞革命真理的新聲。97 然而自魯迅以降的寫實主義書寫，卻也顯示了那寫實主義內在

\footnotetext{
${ }^{94}$ George Levine, The Realistic Imagination: English Fiction from Frankenstein to Lady Chatterley, Chicago: Univ. of Chicago Press, 1981, p.8

${ }^{95}$ George Levine, ibid., p.10.

${ }^{96}$ George Levine, ibid., p.10.

${ }^{97}$ 王德威, 《茅盾, 老舍, 沈從文: 寫實主義與現代中國小說》, 臺北：麥田, 2009, 頁 20 。
} 
定律與真理之間的斷層, 意欲以文學再現革命的真理更是不斷被意符抹消。98 而在馬來亞 於一九五 $\bigcirc$ 年代施行緊急法令的時期, 寫實主義或現實主義意欲詮釋的真實, 被迫安頓在 受到監控的「安全」或「正當範圍」、在政治禁忌之外; 然而所迴避不提的, 便會以買乏 或缺失的形式, 從而否決了書寫所宣稱的真實反映。由此寫實主義或現實主義無法達成使 命, 書寫得不斷逼近那禁忌之處, 然而毫不顧禁忌逾越限制地書寫, 又會意味著作者連同 其空間的整體存在, 都會冒著被強權拭滅的危險。

在緊急法令時期，如此嚴厲的管制下，寫實主義如何可能實踐呢？當時在馬華文學現 實主義的討論裡, 那些講究典型、反殖、反資、反種族主義這些近乎教條的口號構成的議 題，如何可能探入馬華社會現實的內在核心? 關於寫實主義文學該寫甚麼，這問題總會走 向何者具有書寫的價值。譬如說, 刻劃勞工、窮苦大眾與在地多元族群總有文學價值, 但 是反映多元族群卻又優先於殖民者分而治之的權力結構, 而道德批判又優先於政治上的探 觸。盡管在寫評論與討論發言時, 他們總提醒應該要批判殖民者, 可是在小說作品裡總是 難以辦到。大部分陳振亞的小說就體現出這點批判殖民與同情窮苦階級的兩難。99

無可否認, 方天小說裡確實迴避了馬共與華教的問題, 盡管他的小說對於緊急法令時 期的勞工遭遇, 總是懷抱濃有的同情心。這固然是因為在緊急法令時期, 馬來亞移民南來 的華裔, 甚至包括在本地出生的第二代, 仍多為苦力勞工, 教育水平低, 孩子失學的問題 也很普遍。另一方面, 諷刺地說, 以窮苦對比壓迫者的二元對立寫法, 具有掩護功能一一 免於把矛頭指向殖民歷史中更尖銳的政治問題。誠然, 這對居留在地僅有一兩年的方天, 可能也太困難。但從這方面來看, 難道不正是華文文學的現實主義文學觀, 那以階級關懷 優先於其他差異、差別的敘述模式，遠離了在地的現實?

把中國社會主義現實主義的反封建、反殖、反封建、反階級的元素，搬到馬華文學挪 借為觀察的框架, 對剛抵達在地的南來文人而言, 是相當自然的, 因為要在抵達數年內, 立刻產生在地視野與獨特視角並不容易。除了方天之外, 在《蕉風》創刊初期, 和他一起 勤於供稿的南來文人陳振亞, 幾乎亦有相似的寫作路徑。

${ }^{98}$ 王德威, 同上注。

99 陳振亞以白蒂或江陵為筆名發表的小說, 雖然有部分觸及到在地華人, 從英海峽殖民華人到商界的光怪 陸離現象, 然而小說的二元對立, 訴諸於道德化的教訓。稍後將做討論。 
陳振亞也是創刊早期的編委之一, 在最初兩年, 他以洛萍為筆名發表評論〈小說題材 的處理與運用〉和〈創作的動機與目的〉 100 , 稍後又以白蒂、沙里明為筆名發表了一系列 文藝評論。這些評論大致偏向創作理論的討論, 包括經驗、語言、内容與形式。雖然如 此, 當他在座談會中談到馬華文藝觀點以及本土文學創作的問題時, 仍不免挪借五四文學 的語彙來概述他對於馬華文藝的心得, 其發言題為〈馬華文藝的精神是反封建的 反殖民 地主義的 反頭家主義的 反種族主義的 $>$ :

中國的文藝精神自五四以來是反封建的反帝國主義的，後來封建體制是被推倒了， 但還留下了封建的殘餘精神。在馬來亞，反封建依然是文藝中一個重大的題目。但 馬來亞的封建殘餘是和洋化精神一一也就是殖民地主義, 結合成一體的，因此馬華 文藝的特殊精神是反封建的，反殖民地主義的，反頭家主義的。拿目前獨立聲中出 現的種族問題，它又應是反偏陝的種族主義的。1 ${ }^{101}$

雖是借用五四文學運動拯救民族、匡正弊俗的語彙，卻還是能夠挑出在地的問題。關於反 種族主義之必要, 自是不在話下。不過關於反殖民地主義, 卻不免含糊其辭, 並無更進一 步閭述，僅從小說裡才可窺見他的想法。在陳振亞以白蒂署名發表的多篇小說裡，也融入 了各種在地華人社會的議題, 包括種族猜疑、族群偏見、崇洋問題以及傳統遺留的糟粕習 俗等等。華裔社會中的傳統随俗, 竟荒謬地為殖民地法律所維護。

陳振亞以白蒂為筆名撰寫的〈還我的孩子來〉 102 、〈渣滓〉 ${ }^{103}$ 這些小說傳遞鮮明的反 殖意識，對積弱成病的民族感到焦心，主題圍繞在憂心過度現代化會使移民華人社會內部 的文化變遷、道德價值崩解等等, 小說〈還我的孩子來〉如此批評英殖民地政府的法律制 度 :

\footnotetext{
100 洛萍, 〈小說題材的處理與運用〉, 《蕉風》1 955 年第 3 期, 頁 2 。洛萍, 〈創作的動機與目的〉, 《蕉風》1956 年第 28 期, 頁 3-4。

${ }^{101}$ 白蒂發言, 〈漫談馬華文藝—文藝座談之一〉, 《蕉風》1956 年第 20 期, 頁 4 。

102 白蒂，〈還我的孩子來〉，《蕉風》1956 年第 9 期，頁 2-5。

${ }^{103}$ 白蒂, 〈渣滓〉, 《蕉風》1956 年第 14 期, 頁 $12-16$; 《蕉風》1956 年第 15 期, 頁 $19-22$; 《蕉風》 1956 年第 16 期, 頁 18-23。
} 
在一個奇異的地區既然有許多不可思議的法律，可以使許多好人的生活獲得保障， 也可以保護壞人為匪作多, 自然就有許多依靠這種不可思議的法律為生的傑出人 物。104

法律的問題在於，「這地區奇異法律最精彩的一部分就是『尊重各民族的傳統習 慣』」即准許鴉片公賣與三妻四妾。105他批評殖民者的法律漏洞假現代與尊重之名, 實際 上卻庇護了傳統的糟粕, 予民族弊病繼續杽長的空間。在小説〈渣滓〉中, 他敘述了一場 荒謬的鬧劇, 在新加坡開始納入民主體制之際, 煙館也意欲推出「黃皮書」, 借用民主包 裝不倫不類的名堂, 試圖為吸食鴉片的文化在現代國家的體制中保留合法的位置。其中對 國家與建國的諷刺, 不言而喻。在另一篇以白蒂筆名發表的〈第二代〉, 小說也梳理在地 華人階層或社群的不平等現象。106 小說從一個受英文教育的海峽殖民地家庭開始敘述, 試 圖呈現一個世代居留在地的家庭成員, 一對姊弟接受不同的教育系統, 具有不同的個性氣 質, 由此分述兩人不同的發展與經歷, 作者顯然意在維護中華文化, 抨擊英文教育, 認為 後者喪失傳統薰陶, 導致年輕一代風氣敗壞, 敘事方式相當戲劇化, 在中英文教育、富有 人家與窮苦人家、主人與傭人、壓迫與弱勢者, 形成了一系列二元對立且極富道德化的教 訓。當時在海峽殖民地與新加坡的華社裡, 使用華文與英文的群體, 彼此文化背景隔閬, 幾乎互為他者。在觸及華教、華文文化與華文文學的問題時, 華文寫作群體亦可能把受英 文教育 (且輕視華文教育) 者, 視為背祖忘宗, 是和英殖民政府一樣的壓迫者。

然而要在短時期內, 展開全新的在地文學視野, 是非常困難的。過往五四新文學的 影響, 長期壟罩馬華文學, 使得寫作者以五四的新文學經典的敘述、觀點、技巧為典範, 而難以從自身的生活經驗開發新的觀點與新的寫作技巧，如王潤華所論，那是寫作人為了 獲得認同, 遂而依循已成典範主流的敘述模式。 ${ }^{107}$ 於是, 本土化的寫作, 便具有摸索、突 破這些「境外」的典範文學影響的意義。然而, 無論是方天、陳振亞, 都無法不挪用五四 運動中的語彙和觀點一一那亦是當時為華文文化界所熟悉的, 一個世代共享的語言地表一 一以此延續、銜接、植入, 以探尋在地文學的出路。由於《蕉風》的自由主義作風, 能夠 容納與開放多元觀點, 其實有助於南來文人㽎拓在地書寫的各種可能性。然而, 當小說不

\footnotetext{
${ }^{104}$ 白蒂, 〈還我的孩子來〉, 頁 2 。

${ }^{105}$ 白蒂, 〈還我的孩子來〉, 頁 2 。

${ }^{106}$ 白蒂, 〈第二代〉, 《蕉風》1955 年第 2 期, 頁 18-23; 《蕉風》1955 年第 3 期, 頁 21-26。

107 王潤華，〈從反殖民到殖民者一一魯迅與新馬後殖民文學〉，頁 66 。
} 
得不繞過在地歷史與政治上禁忌的尖銳問題, 以另一個在政治話鋒上稍少尖銳與危險的情 境置換，文學是否還能夠有效地對應現實經驗，便成為疑問。

\section{六、小結：一點輕微的剝離}

方天在一篇評論戲劇的文章〈評「劇作選輯」中的諸劇〉裡, 提出對寫實主義藝術與 技巧的要求, 比如故事需在鋪排情節與細節上入情入理等等。108他在剛抵達時發表的寫實 主義小說, 尚且得借助戲劇性的元素, 比如在結局時透過撕心裂肺的呐喊表達窮人的悲慘 處境（如〈暴風雨〉） 109 , 但在後來的小說相當節制表達悲痛, 將悲憤轉以更深沈的方 式，譬如〈爛泥河的鳴咽〉小說結尾的方式。110

在他最後一篇發表的小說〈預感〉篇裡, 向來應該位居旁觀的敘述者在小說中現身, 使得小說與過去往常貼近工人的視角不同。在辦公室工作的主人公與友人, 針對「不幸預 感」這話題, 展開一場辯駁。透過主人公與友人對 $「$ 不幸預感」充滿調㑆的話題, 使得往 常在方天的寫實小說中那不可或缺的敘事元素 $\ulcorner 厄$ 厄運」, 被抽離出來, 成為一個可被加以 審視、反省的對象。這篇小說, 可能是方天最少社會主義現實主義元素, 幾乎近於現代主 義，探索在個體命運、生存威脅㟠惘的陰影。

一九五 $\bigcirc$ 年代馬華文學現實主義所要「再現」的現實, 乃是一套釀製高潮與同情心的 敘事模式, 「厄運」往往是主人公不可避免的悲劇, 故事往往要把主角推往無助的境地以 引起悲憤。在〈預感〉這篇小說裡, 主人公對厄運的注意, 也是在殖民地都會中對險境的 感知, 「一切世界上可能發生的事都有發生的可能」111。受意外陰影籠罩的, 不僅是勞 工, 可以是任何人, 在任何時刻與任何地方。標誌現代性的機械技術已經來到, 但對殖民 地的子民來說, 那還是無法自主、凡事都還沒有保障的時代。厄運雖未發生, 卻已被認定 了遲早要發生, 成了等待應驗的預言, 在現實的意識中根深蒂固, 就像它已經寫在寫實主 義的故事中那樣, 這種對悲慘下場的期待, 竟然成為方天的現實主義書寫中、一種可預期 的、體會現實的模式。

\footnotetext{
${ }^{108}$ 方天, 〈評「劇作選輯」中的諸劇〉, 《蕉風》1956 年第 25 期, 頁 20-22。

${ }^{109}$ 方天，〈暴風雨〉，《蕉風》1956 年第 17 期, 頁 13-17。

110辛生, 〈爛泥河的鳴咽〉, 頁 20-22。

111 方天, 〈預感〉, 《蕉風》1957 年第 30 期, 封底內頁。
} 
方天的寫實主義, 不免受到整個文壇離散南來的社會主義式的現實主義觀點所限：沒 有厄運, 則沒有故事。沒有階級, 就沒有現實。在國籍與邊界長成之際, 語言與文化疆域 也立起圍籬, 離散者的飄泊或游離狀態必須盡快結束。如果沒有一個國家作為可以認同的 對象, 這樣的存在幾乎是不可思議也不正當的。這一切是如此地理所當然, 幾乎難以想象 還有其他可能：沒有國家認同, 則沒有文學主體; 文學主體, 竟不得不依附在對國家主體 的認同上。當現實主義書寫為迎接獨立正面、樂觀的意識所包裏, 對這地區的敘述同時植 人了國家政體與階級關懷的話語。一方面, 對階級問題的討論, 都得寄寓於譴責殖民者的 不公（殖民者有如統治/資本階級）, 才能表達出文學的關懷, 另一方面, 對國家建制的 問題卻又得借助愛國意識才能展開敍述。

方天所能達到的突破, 是在一些非常微小的細節上著手, 比如把厄運與悲劇經營得更 為內劒潛藏, 在少數的短篇小說裡, 敘述者發現主人公是極為孤獨的個體, 個體的意識浮 現, 與階級的共同體意識便拉開了距離。但這距離太過微小, 旋即在集體話語的浪潮中消 失。這樣的跨越, 在他的小説中時而浮現, 非常珍貴, 卻也在受到階級意識與愛國意識主 導的現實框架中, 有所局限。

方天兩年來在現實主義的小說中, 從小說的戲劇張力、階級關懷, 對厄運與悲劇的反 覆書寫, 直到一九五七年第三十期〈預感〉, 終於累積成對「厄運」這觀點的反思與凝 視。112 這可能是方天最少社會主義現實主義意味的小說, 其幽密未語、深沉之處, 幾近 現代主義之作。

112 方天, 〈預感〉, 《蕉風》1957 年第 30 期, 頁 13-14 及封底內頁。 


\section{第四章}

\section{馬摩西的旅行、搬遷與本土書鴧}

旅途給我以辛勞／休息給我以安慰／因而我為行旅歌唱／從昨天到今天

一趙宗言〈旅行的生機〉, 1956

我屡次被登記手續糾䌅，照例須填下出身的籍貫時，我常有多餘的感覺，最好填下 東西南北或四海為家，比較符合實際，就正如我們的住址，無法寫下永久二字一 樣, 因我們的行蹤, 總是沒有停止的。

一馬摩西〈旅行的生機〉, 1955

\section{一、搬遷南來}

馬摩西〈旅行的生機〉這篇文章刊於一九五五年《蕉風》第四期。1在刊出之前, 他 居無定址的生活就已經結束了。當時他已落腳新山兩年, 一九五三年開始在柔佛州宗教局 上班, 一年後遷居新山。此後定居柔佛, 至一九七一年逝世。

馬摩西 (不詳 - 一九七一) ${ }^{2}$ 是筆名, 原名馬俊武, 其他筆名尚有 $「$ 興周」和 $「$ 馬興 周」。3他曾在國民黨統治中國期間擔任外交官。一九四九年, 國民黨在大陸的內戰中敗

${ }^{1}$ 馬摩西, 〈旅行的生機〉, 《蕉風》1955 年第 4 期, 頁 4-6。

2 馬摩西的出生年份有待查證, 沙立班(Rahmat Saripan) 的論文將之記為一九一三年二月二日, 但未見資料 徵引出處, 查國家檔案局的資料, 亦未見出生紙證明。一九六一年《海峽時報》的一篇關於馬摩西的報 導, 介紹他那年是四十五歲, 即其出生年為一九一六。《新華歷史人物列傳》則記馬摩西的生卒年為一九 一八至一九七一年。The Straits Times, “MCA Youth Chairman.” October 10, 1961, p.11. Rahmat Saripan,"Haji Musa Ma Jinwu: Kegiatan Pensyarah Agama Kerajaan Johor dalam Zaman Darurat (1953-1959).”(哈芝馬穆沙俊 
守臺灣, 共產黨執政中國。自前一年開始, 英殖民政府在星馬一帶禁止共產黨活動, 左翼 人士北返、右翼人士南來。馬摩西就在一九四九年春天攜妻離開南京, 經杭州南下。4國 民黨在該年秋天戰敗, 馬來亞的國民黨領事館隨之關閉。那之後, 馬摩西以接受政治庇護 者的身分，在馬來亞留下來。他辭掉外交官職位，轉職到新加坡的中正中學執教。

當時, 在中共執政後, 英女王即承認中共政權。當時馬來亞的英屬聯合邦政府, 開始 商討各種中國外交官的問題。根據英國外交部的指示, 這些外交官沒被強制遣送回中國或 台灣, 而是遵重他們的選擇另作安排。那些不想返回中國或台灣的外交官, 可以獲得相等 於政治難民(political refugee)的庇護居留權(sanctuary residential), 並允許居住此地, 至到 他們符合移民條件成為在地公民，或遷移到另一個國家為止。5

最初馬摩西在新加坡島上東搬西遷, 住過東陵區(Tanglin district)、丹絨加東路 (Tanjong Katong)、干榜馬來由區（此為普遍名詞, 非專屬地名, 地點不詳）。他並非一 開始就決定居留馬來亞。最初他想到菲律賓去, 曾有回教祈禱團的友人為他做了安排。然 而諸多原因陰差陽錯, 始終無法成行。6 直到一九五三年才前往新山, 就任宗教局公務員 一職, 從此定居下來。7

\section{二、馬摩西：從外交官至宗教官}

本文對馬摩西的討論，以他刊於《蕉風》和彙集成書的文章為主。馬摩西在《蕉風》 的姐妹報《學生周報》裡亦有稿件, 惟目前新馬所藏《學生周報》資料仍有從缺, 從《學 生周報》所見到的馬摩西稿件僅有五篇, 各別屬於知識、閱讀、地理新聞、埃及小說翻譯

武：柔佛宗教局傳教官於戒嚴時期的活動), Malaysia Dari Segi Sejarah, 1990, vol.18, p.22-29. http://myrepositori.pnm.gov.my/xmlui/bitstream/handle/123456789/3531/MDSS_1990_Bil.18_2.pdf?sequence=1 $3\ulcorner$ 興周」這筆名, 乃是把馬摩西以「興周」筆名發表《蕉風》的文章, 與收錄於一九五七年出版《集愚 集》收錄的文章, 比對所得。「馬興周」僅有一篇, 寫〈蘇彝士運河種種〉刊於《學生周報》（1956 年 8 月 17 日）。

4 馬摩西, 〈淡寫新山〉, 《蕉風》1956 年第 6 期, 頁 32 。

5 新加坡國家檔案局 FCO 141/14394, 文件編號 1177/41/49, 1949 年 10 月 7 日, 來自外交部副委員總監, 致 予新加坡委員總監辦公室的信件。

6馬摩西, 《集愚集》, 新加坡: 蕉風出版社, 1957, 頁 1-12。

7馬摩西, 《集愚集》, 頁 11-12。 
和報導一篇。 ${ }^{8}$ 馬摩西並非是友聯社員, 他是《蕉風》創刊早期投稿最頻密的其中一位作 者, 同時也是在《蕉風》創刊前給予意見、合作創立《蕉風》出版社的編委會成員之一。 9 有鑑於馬摩西與創刊時期的《蕉風》有密切的交流往來, 故本文將他列為《蕉風》這個 時期重要的非左翼南來文人之一。《蕉風》的編輯編委與所網羅的文人作家群中, 有國民 黨背景的其實不多。除了馬摩西是國民黨外交官之外，僅有編輯姚拓是國民黨軍人。

馬摩西從未在散文裡透露自己在馬來亞所任的公職，僅含糊地說他曾經獲得獻議，

$\ulcorner$ 目下政府急需一個人做華巫兩族的聯絡工作。」10柔佛州宗教局稍後出版了一本馬摩西 翻譯的《默罕默德傳》11, 據本書前言, 馬摩西當時也負責撰寫宣傳伊斯蘭教的中文文 獻, 這些傳教的文獻皆刊於華文報章。這篇簡短的前言也介紹了譯者的背景 : 馬俊武是出 生於雲南昆明的伊斯蘭教徒, 在雲南東陸大學畢業後, 他到埃及的愛資哈爾大學修讀碩 士。在馬來亞的回教社群中，馬摩西也廣被稱爲馬穆沙哈芝(Haji Musa Ma Jinwu)。

在一九三○年代期間, 中國曾出現留埃學生團, 馬摩西是在一九三四年第三屆由雲南 明德中學遣送至埃及的學生。12不過這些論文都遺漏了他在東陸大學語言系畢業的學歷, 只提他從埃及愛資哈爾大學取得的學士資格, 而且只有馬博忠補充了馬俊武後來赴新定居 之事。比較詳細的資料, 還是來自馬來亞出版的刊物。譬如, 根據光華日報出版的《這半 個世紀（一九一零一一九六零）：光華日報金禧紀念增刊》（以下稱這半個世紀），便如 此介紹作者的家世與宗教背景 :

8 從一九五六年七月起至一九六 $\bigcirc$ 年的期數, 來自馬來西亞新山的南方學院大學馬華文學館藏, 亦輔以一九 五九年至一九六 $\bigcirc$ 年, 新加坡國立大學總圖、東南亞中文書庫的館藏。這五篇文章的題目分別是〈讀書的 樂趣〉（1956 年 7 月 27 日）、〈蘇彝士運河種種〉（1956 年 8 月 17 日）、〈奇怪是知識的來源〉

（1957 年 5 月 10 日）、翻譯埃及穆安奈斯的小說〈在馬路上〉（1956 年 8 月 17 日）以及報導性質的 〈回教清真寺概況〉（1957 年 7 月 12 日）。後文的討論會提及〈蘇彝士運河種種〉。

9 在新加坡友聯出版社《蕉風》創立的前一年, 創辦人申青 (原名余德寬) 來到新加坡開辦書店, 會見當時 已經在地居留數年的馬摩西、李汝琳、陳振亞諸人, 他們一致贊同出版《中國學生周報》, 也建議應該再 有另一份純文藝的刊物在本地出版。次年友聯即出版《蕉風》及《學生周報》。姚拓, 《雪泥鴻爪一一姚 拓說自己》，頁 570 。

10 馬摩西, 《集愚集》，頁 11 。

${ }^{11}$ 馬摩西譯, 《穆罕默德傳》, 新山：柔佛宗教部, 1954。

12 傅統先, 《中國回教史》, 臺北 : 臺灣商務印書館, 1996 , 頁 225 。馬博忠, 〈近現代中國留埃回族學生 歷史簡述〉, 《回族研究》 2012 年第 1 卷第 85 期, 頁 67 。馬積廉, 《到麥加去: 民國時期到中東去的 旅行記述研究》（1911-1949）, 新加坡：新加坡國立大學碩士論文, 2012, 頁 2。 
世代信奉回教, 祖先多擔任回教教長。畢業於東陸大學文學院文史學系, 以埃及 國王福阿德一世獎學金入埃及國立愛資哈爾大學，獲文學碩士及法學士学位。返 國後歷在外交部工作。戰後來星, 轉入中正中學執教, 一九五三年受柔佛蘇丹任 命為宗教部宗教官，現任全國馬青團文化組任，新山馬青團團長。13

底下也列出馬摩西出版過的散文集、阿拉伯譯本或其他與伊斯蘭教有關的譯本與著作。這 裡提到馬摩西到新山的日期, 亦跟他在《集愚集》散文集内〈搬家記〉裡提到的遷移日期 一致。14根據《新華歷史人物列傳》, 馬摩西就職過的單位包括中國外交部、中國駐開羅 領事館、新馬領事館、中正中學、新山寬柔中學以及《馬青月刊》。

此外, 根據一份一九九 $\bigcirc$ 年由沙立班(Rahmat Saripan)發表的馬來文論文〈馬穆沙哈芝 俊武: 柔佛宗教局傳教官於一九五三至一九五九年間戒嚴時期的活動〉 (Haji Musa Ma Jinwu : Kegiatan Pensyarah Agama Kerajaan Johor Dalam Zaman Darurat (1953-1959) ), 根據 馬來西亞柔佛州的檔案, 把馬摩西就職前後的生平整理得相當詳細：一九一三年二月二日 生於雲南, 他大學畢業後, 到埃及開羅的愛資哈爾大學深造, 在開羅居留長達十年, 故他 應是在一九四四年才回返中國, 過後就在蔣介石的國民黨政府裡服務, 處理與回教相關的 宣傳活動，至到一九四○年代末才被派駐霹靂州的怡保。15

在當時眾多南來文人當中, 無論是獨立之前或之後, 像馬摩西那樣通曉埃及文和中文 的伊斯蘭教徒, 以其宗教、碩士學歷及前國民黨外交官身分, 無疑相當特殊。馬摩西在 《蕉風》刊登不少埃及文學作品的翻譯。然而, 馬摩西 (或馬俊武) 不是唯一留下來擔任 公務員的特例, 當時幾乎所有具有較高學歷的華裔回教徒, 都來自中國, 包括馬俊武、馬 天英在内, 皆是民國時期領公費留埃的學生。也因為他們具有精通中文的語言能力、高學 歷與宗教背景, 使得他們在當時的公務行政體系裏有了可嵌入的恰當位置。早在一九四八 年英國人設立馬來亞聯邦以前, 長期分而治之的政策, 已形成一個認可馬來精英管理其他 民族的公務員體系。16各州的行政結構大部分是由馬來人擔任公務員, 其次是海峽華人或 峇峇人, 後者多不諳華語, 主要的溝通語言是英語及馬來語, 無法有效地和華人社群溝

\footnotetext{
13 劉問渠, 《這半個世紀 : 光華日報金禧紀念增刊》，檳城：光華日報, 1960, 頁 216 。

14 馬摩西, 《集愚集》，頁 12 。

${ }^{15}$ Rahmat Saripan, "Haji Musa Ma Jinwu: Kegiatan Pensyarah Agama Kerajaan Johor dalam Zaman Darurat (19531959)", p. 22-29.

${ }^{16}$ Raymond L.M. Lee, "The State, Religious Nationalism, and Ethnic Rationalization in Malaysia." Ethnic and Racial Studies, 1990, vol.13(4), p.485.
} 
通。當時公務行政系統極需一個不受左翼影響、又能跨族溝通的華人。為了剪除左派的影 響力, 打從一九四八年緊急狀態以來, 英殖民者就嚴庽實行圍剿馬共的軍事行動以及言論 控制的行動。馬來亞華人公會與其成員, 因能符合英殖民者的要求, 成為英殖民政府與華 人之間的橋梁, 為新村華人提供各項社施福利。

根據一份關於一九三○至一九五 $\bigcirc$ 年代期間, 柔佛州華裔皈依伊斯蘭的研究論文指 出, 在一九五 $\bigcirc$ 年代時, 聯邦秘書 R.H. Oakley 建議柔佛州的回教局應該設立一個讓華人 來擔任的宗教官職位, 他們期望這個宗教官能吸引更多新村華人接受伊斯蘭教, 同時還能 抑制左翼意識形態在新村的影響。17

諾丁胡申(Nordin Hussin)的論文提及一九五二年哈芝馬穆沙（Haji Ma Musa，即馬摩 西）受聘就任, 但這年份與馬摩西散文內的自敘及前述《這半個世紀》紀念刊內所陳不 符。據馬摩西所述, 他受聘的時間當為一九五三年, 而前述沙立班的論文亦據檔案紀錄其 就聘時間當為一九五三年六月二○日, 但僅是作為一個「暫時受聘的宗教官」, 因他當時 還不是馬來亞公民。18此後，他就在柔佛一帶工作，除了走訪新村、傳教之外，也同時幫 助那些想皈依回教的華人處理、協調入教的安排與問題, 這也包括那些準備與回教徒結婚 而必須入教的申請者。19在一九五八年時, 他曾以宗教官的身份, 在南馬的黑區麻坡, 進 行一場爲期八天的探訪, 走訪華人新村。在這場訪問裏, 他要求新村居民和政府剿共的行 動合作，以使緊急狀態時期早點結束。20這些宣講的地點，包括麻坡的啟智會堂(Chai Chee Assembly Hall)以及冬甲的馬華公會會所。21馬摩西過後就在馬來亞安頓下來，且持

\footnotetext{
${ }^{17}$ Nordin Hussin, “Conversion to Islamic Religion among Chinese Minors in Johore 1930-1950's.” Jebat, 1993, vol.21, p.125-135.

18 根據國家檔案局 (柔佛州分行) 的資料 SSJ 2048/52, 一封從新山州秘書寄予新山總警察官的信件, 署於 一九五三年三月十二日, 馬摩西受聘的年份當為一九五三年。這一年, 柔佛州宗教局前後幾乎花上半年的 時間, 來核准聘請馬摩西。

${ }^{19}$ Nordin Hussin , “Conversion to Islamic Religion among Chinese Minors in Johore 1930-1950's”, p.132-133.

${ }^{20}$ The Straits Times, "Off on tour of 'black' area”, May 15, 1958, p. 9.

${ }^{21}$ Rahmat Saripan, “The State, Religious Nationalism, and Ethnic Rationalization in Malaysia”, p. 26. 麻坡的啟智 會堂, 是啟智書報社在一九五二年建立的會所。啟智書報社是麻坡國民黨（麻坡同盟會）的外圍組織, 一 九一○年創立。啟智會堂目前的譯名有 Dewan Chei Chih, 其夜校也有譯成 Ch'ei Chin Night School。參 見：杜月嬌〈麻坡啟智會堂重建成綜合商業大厦〉 http://www.sc.edu.my/jiaofeng/mix-detail.php?id=642。鄭 昭賢〈啟智夜學的貢獻〉http://southeastasiachinese.blogspot.my/2011/07/blog-post_02.html。「馬來西亞華 團總名冊」http://huazong.my/HuaTuanDIR/Johor.pdf。
} 
續參與在地的文化與政治活動。一九六一年, 當他四十五嵗時被選為柔佛州的馬華青年團 主席。22

馬摩西並非是唯一留下來發展的國民黨外交官。他和另一位更廣爲人知的華裔穆斯 林, 馬天英, 皆於一九四○年代末派駐馬來亞。日殖時期之後, 馬來亞曾發生數宗當地巫 人與南來中國人之間爆發的激烈衝突, 尤其在有許多華人苦力工作的採礦區, 傷亡慘重, 而牽涉在内的華人常被逮捕, 甚至被判死刑。在一九四八年, 為了減少這類族裔間的衝 突, 中國的國民黨政府, 派遣伊斯蘭教的外交官馬天英, 到怡保的領事處服務, 協助處理 相關事務。23才就任一年, 中國大陸的國民黨戰敗, 國民黨政權崩解。馬來亞的領事館關 閉後, 馬天英接受東姑阿都拉曼的邀請, 仍然留在馬來亞聯邦從事傳教的工作, 成為馬來 亞首任華裔穆斯林協會的主席。

馬摩西亦與馬天英在相近的時期被派駐到馬來亞。由於他們穆斯林的身份，以及不認 同左翼的政治立場，他們很快獲邀加入馬來亞的公務系統。相較於其他南來文人，他們的 條件顯然更佔優勢。

\section{三、一九五 $\bigcirc$ 年代回教宣講與鲴共計畫}

在一九五 $\bigcirc$ 年代, 英殖民當局也曾嘗試通過回教教義的宣講, 來削減共產主義的影 響。在一九五二年十一月間, 曾有回教徒建議應該在廣播節目裡添加回教宣講, 以抵抗共 產主義。24當時馬來亞電台總部位於新加坡, 在一封由馬來亞電台致予柔佛宗教局的信 裡, 電台要求宗教局批准一名宗教司參與這個計畫, 信中寫道：「伊斯蘭教的宣講, 應當 能夠防範、消除那些走入歧途的敗壞思想, 即共產思想。」這封信也強調他們相信回教的 宣講應當能夠「清楚解釋我們的教義，如何能夠抵抗共產主義的傳播」。25

\footnotetext{
${ }^{22}$ The Straits Times, "MCA Youth Chairman”, October 10, 1961, p.11.

${ }^{23}$ Fujio Hara, Malayan Chinese and China: Conversion in Identity Consciousness 1945-1957, Singapore: Singapore University Press, 2003, p.59.

24參見柔佛宗教局一九五二年的檔案, PAJ 208/52, 「馬來亞吉隆坡電台戒嚴部要求柔佛宗教司通過電台宣 講以對抗馬共意識」。

${ }^{25}$ PAJ 208/52 檔案, 同上註, 見來自新加坡的馬來亞電台 Abu Bakar bin Ahmad 致柔佛州宗教局之間的馬來 文信件，1952 年 11 月 19 日。
} 
姑且不論其效用如何, 抑或這是否為回教社群說服英國人的策略, 藉此爭取更多傳播 資源, 來擴大伊斯蘭教在本土的影響。這建議當時立即獲得緊急狀態時期的電台總裁同 意, 他在回信裡表示, 他也認同以回教宣講來「迎接戰鬥」, 而且當即付諸實行。2 6

看來英殖民者確實寄望, 通過宗教宣講, 能夠有效圍堵共產主義, 故而在稍後, 繼續 尋找能對華人宣講的宗教司, 甚至向柔佛宗教局獻議, 應該增添華裔宗教司的職位。來自 中國的漢語回族外交官如馬摩西, 當時便在這剿共的特殊歷史境遇中, 獲得了轉職馬來亞 公務員的機會, 而定居下來。

這以現代化的宗教話語來抑制共產主義的效果, 大不同於過去二戰甫告結束時, 一個 由極端的伊斯蘭概念引發暴動的結果。中東的伊斯蘭教現代化改革進程, 早在戰前, 就已 經引入馬來半島, 當時也是通過馬來民族, 想滲透多元族群。當時馬來半島也有回教學 生, 到埃及麥加或愛資哈爾大學留學, 把這些峘新的概念帶回來。27在戰後, 這些宗教概 念卻被強化為民族主義運動的核心部分。二戰之後, 英軍尚未回來, 馬來半島處於失序狀 態, 馬共持槍械護衛華人村落, 掌管局面。由於在日殖時期, 馬來人曾被日軍聘為警察, 曾經逮捕、拷打馬共的抗日份子。故日軍退走後, 馬來人恐懼馬共會大舉報復與控制馬來 半島, 部分馬來人在古老的、半神秘化的蘇菲派教團 Qadiriyyah 影響下, 展開極端的 Sabilillah 運動, 在一九四五年五月期間, 從柔佛州的峇株吧轄區開始, 展開血腥大屠 殺，屠殺事件遍及半島多處，許多住在郊區的華人慘重傷亡。28

在一九五 $\bigcirc$ 年代的緊急狀態時期, 上述以回教宣講來減少共產主義影響的計畫，實行 起來卻是相對和平有秩, 經過現代化的詮釋定義, 幾乎能與國族的話語一起重建馬來亞聯 合邦的秩序。在這新的框架裡, 馬共被宣布為非法, 徹底遭到排除, 英殖民政府對此賦予 的解釋, 肇因於馬共謀殺霹靂州英籍園坼經理的行動, 馬來亞聯邦英軍認為事態嚴重, 必 須全面部署以徹底消滅馬共軍力。2 9 各種嚴峻的措施執行數年後, 到了一九五三年, 局勢

${ }^{26}$ 見當時緊急指揮兼廣播電台的總裁 David L. Lyttle 和柔佛宗教局之間的信件。在一封署期 1952 年 5 月 8 日 以馬來文寫成的信裡, David L. Lyttle 提及馬來亞聯合邦政府宣傳部(Pejabat Penerangan Persekutuan Tanah Melayu)的官員向他推薦一位宗教司, 希望能安排在廣播節目中宣講回教教義, 將安排在新加坡錄音, 每 次播放十分鐘, 並和回教徒 $「$ 一同迎接戰鬥, 希望獲得宗教局允許」。

${ }^{27}$ Cheah Boon Kheng, Red Star Over Malaya, Singapore: National University of Singapore, 2012, p.10.

${ }^{28}$ Cheah Boon Kheng, Red Star Over Malaya, p.194-239.

${ }^{29}$ 根據英殖民軍方的解釋, 緊急狀態的起因, 始於一九四八年六月十六日, 馬來亞霹靂州和豐(Sungai Siput) 的膠園裡, 有三個歐洲人園坻主遭到殺害。同一天, 在太平和柔佛, 也有兩個華商被謀殺。研究者 Nazar 認為由此開始的緊急狀態, 實際上也是對馬共宣戰的狀態, 惟軍方為減少損失, 以俾日後能獲得倫敦保險 
已大為緩解, 從這年開始, 那些表現良好、與官方合作的地區, 就被獎勵以脫離戒嚴為 「白區」。30

馬摩西過去在埃及深造時, 也曾吸納現代化的伊斯蘭概念。到馬來亞擔任外交官以 後, 主要的宣教對象為華人。姑且不論這職位在圍堵共產黨方面是否確實收效, 不過, 在 吸引華人的依回教方面, 其成果卻甚是鼓舞。

\section{四、散文中的「沒有」：宗教官身分的經驗及故鄉敘述}

馬摩西鮮少在散文中提及自身作為宗教官的公務員身份，亦甚少書寫對故鄉的回憶。 以下分別針對這兩項梳理一些問題。

在一九五 $\bigcirc$ 年代, 由於報刊的左翼空間削弱、右翼空間增長, 左翼聲音被壓抑, 「和 平」的願望在當時的主流報章上反覆回響。這一切話語都有利於建構國族和諧的集體想 像一一尤其在一九五一年, 聯盟陣線(Perikatan)成立以後, 數家未被緊急法令查禁、仍然 出版發行的報章, 更傾向於復述聯盟建國的宣言與聲明。31雖然這股愛國熱潮也影響文 壇, 不過, 這並不意味當時的文學作品會毫無保留地跟隨當時風行的愛國意識, 有些作品 仍能看到認同與徬得同時並存。32然而, 樂觀、歡悅與熱烈的情緒遠勝猶疑, 大量的在詩 歌與散文裡表達愛國、振奮的精神, 馬摩西或許是其中最顯著的一人。

馬摩西發表在《蕉風》的雜文和散文稿件所涵蓋的範圍，大致上可分爲政治的、地方 記敍、旅遊和日常生活以及大量的翻譯埃及文學。他在一場一九五七年的馬華文學論壇 裡，除了主張馬華文學在地化、華文文學的交流應擴展至東南亞區域（包括印尼、北婆羅

公司的賠償, 才在官方文告中宣布為緊急狀態。轉引自 Nazar Bin Talib, Malaysia's Experience In War Against Communist Insurgency And Its Relevance To The Present Situation In Iraq, Marine Corps University, 2004, p.1.

${ }^{30}$ Hack, Karl, “The Malayan Emergency as counter-insurgency paradigm”, p. 15.

31 在一九五 $\bigcirc$ 年代, 當時的三家大報, 《星洲日報》、《南洋商報》和《光華日報》, 分別由胡文虎、陳 嘉庚與孫中山創辦, 皆是受國民黨影響的報章。Yong C. F. and R. B. Mckenna, The Kuomintang Movement in British Malaya 1912-1949, Singapore: Singapore University Press, 1990, p.215.當時其它還在運作出版的報章, 如《建國日報》、《中國報》以及《中興日報》均非傾左報章。至於原先為左翼喉舌的《現代日報》、 《民聲報》與《南僑日報》, 則早在一九四九年先後, 遭到政府查禁而停刊。

32 如山芭仔〈新村底夜〉（《蕉風》1956 年 7 月第 17 期）、方天〈一個大問題〉（《蕉風》1956 年 4 月第 12 期）、白蒂〈山野底孩子〉（《蕉風》1956 年 1 月第 5 期）。參見第二章的總結與第三章第四節。 
洲) 外, 也主張接納更多外來的文藝思潮, 包括亞非國家作品。 ${ }^{33}$ 而這些意見無疑的都是 為了打開有別於以中國為中心的華文文學版圖。通過與其他向來被中國文學所忽略的、各 個區域的文學進行交流, 馬摩西認為這裡有可以「融會貫通, 大同小異的親切感」, 亞非 國家還有「許多歷史悠久的文明古國」, 從他們「民族自決的信念」當可獲啟迪。 ${ }^{34}$ 由此 為一九五 $\bigcirc$ 年代的《蕉風》，打開跨中東、東南亞區域的文學翻譯。過去中國文學所翻譯 的, 如一九二 $\bigcirc$ 年魯迅引入的外國文學, 向來是以西方文學、包括俄國文學為主。馬摩西 這種重視歐洲西方文學之外的各區域文學觀點, 迴異於美援文化那傾向於引入西方文學翻 譯的作風, 或許是呼應一九五五年萬隆會議帶來的影響。當時與會的中東國家曾針對中共 的加入, 提出 $\ulcorner 反$ 殖」與 $\ulcorner 反$ 共」的爭議。馬來亞並不在列席國家內, 但中東曾是過去當 國民黨執政時, 中國回族焏欲爭取合作的對象。馬摩西當時雖已身在馬來亞, 然基於泛伊 斯蘭情懷, 自身擅長的埃及語言以及游學經歷, 仍然使他焏欲將伊斯蘭世界, 連同其他亞 非國家第三世界的文學, 補充到 $「$ 純馬來亞」文學應該與之交流的框架裡。這體現在創刊 早期，尤其方天擔任編輯的時期，馬摩西在《蕉風》有多篇埃及小說的翻譯成果。

獨立之前為中國外交官，獨立之後轉為宗教官的作家，那樣的身份是馬華文學中絕無 僅有的個案。然而, 在他發揮文藝寫作的空間裏, 卻相當少或幾無伊斯蘭教的成分。他很 少寫及自己的公務員工作, 亦不多提自己的宗教, 不但少提伊斯蘭的宗教哲學, 而且行文 中還頻頻摘取舊約的章句, 比可蘭經更為頻密。35 顯然, 馬摩西本身在文藝愛好方面, 對 宗教持開放的態度, 他對小說敘事的觀點, 亦不受宗教所牽制。根據他後來發表在《蕉 風》埃及文學的翻譯, 有許多是宮廷歷史傳奇以及現代都會的愛情故事, 這些小說皆是現 實主義之作，故事多離奇轉折、節奏輕快、情節豐富，常講述男女兩性自由戀愛，雖然凸 顯都市的爾虞我詐, 但仍以獎善懲惡的道德教訓圓滿結束。這些文學情節相當俗世, 甚少 訴諸於宗教教義作為解決手段。

33 蕉風, 〈一九五七年馬華文壇的展望〉, 《蕉風》1957 年第 29 期。

34 蕉風，〈一九五七年馬華文壇的展望〉，同上註，頁 3 。

35 馬摩西的散文〈一根好手杖〉, 幾乎有一半篇幅引自《舊約 ·出埃及記》。馬摩西, 《歐美采風錄》, 新加坡：星洲世界書局, 1957, 頁 116-118。 
從馬摩西後來就任宗教官的表現所見, 他似乎有一道明確的界限, 將文藝與宗教信仰 隔開來。馬摩西在緊急狀態時期, 相當積極的奔走新村宣教。為了要進行宣教活動, 他還 向政府申請撥款買車，僅在一九五三年，就成功幫八十五位華裔的依伊斯蘭教。36

馬摩西在宗教局相當受到器重, 他負責撰寫與發佈中文稿件, 包括宣傳當時準備在吉 隆坡設立的伊斯蘭學院。37在一九五五年或稍早時候, 馬摩西也被宗教局委任負責興建柔 佛州的回教村, 根據柔佛州檔案裡收藏的剪報, 當時曾為中英文報章廣泛報導, 最初是由 華裔與印裔回教徒向柔佛宗教局陳情申請, 獲宗教局答允撥地興建。這些申請者來自勞 工、教師等各階層。他們有感於新柔兩地, 的依伊斯蘭的華裔人數稀少, 故希望能住進一 個為少數族裔穆斯林而設的回教村裡, 以便「能守望相助」、「共同學習來培育彼此的宗 教信心」、「以養晚年」。38馬摩西被委以重任, 負責回教村的種種建設, 包括醫院、回 教堂、路、籬笆、學校、遊樂場、水井、菜市場等等。39

在所有致力於讓華人認識馬來亞, 以馬來亞為家的在地書寫裏, 唯獨關於華人皈依伊 斯蘭教的種種, 馬摩西應該最為熟悉, 卻隻字不提。雖然在當時的文壇裡, 愛國主義頌聲 響亮, 馬摩西也屚次呼㗳認識馬來亞在地書寫的必要, 卻對自己身居參與跨族、宗教經驗 如此特殊的位置, 無甚敘述。顯示對在地的華文刊物讀者來説, 盡管當時有熱烈的愛國聲 音感召、勸勉讀者要儘量「在地化」地認識馬來亞, 但實際上關於何者能夠攤開敘述, 隱 然有一道界線在區別或框限了那可討論和書寫的層面, 因此使得 $\ulcorner$ 可寫的現實 」, 不得不 受到政治的禁忌所切削，不正顯示了「在地化」這個理念，其實難以貫徹?

馬摩西在《蕉風》投稿較勤時, 是從一九五五年創刊的年底至一九五七年五月。一九 五六年七月, 當馬摩西在《蕉風》發表一篇〈馬來亞化問題〉時, 他已經在新山宗教局裏 任職好幾年了。他在這篇文章裏非常熱心地寫出對馬來亞建國的諸多看法, 比如不贊同以

${ }^{36}$ Rahmat Saripan, "Haji Musa Ma Jinwu: Kegiatan Pensyarah Agama Kerajaan Johor dalam Zaman Darurat (19531959)", p.23-25.

${ }^{37}$ Rahmat Saripan 1990, ibid, p.25.

${ }^{38}$ 見柔佛宗教局檔案, P.A.J. 419/52。有一封由六位華裔穆斯林集體呈上的信件, 署於一九五四年十二月十 八曰, 來自 Wong Tsah, Salim Kua Sang Peng, Ibahim Chong Kwa Hon, Ali Lee. Lee You Wai, Eunos Yew Kok Tech, Ibrahim Liew Kuak Hong 說明他們都來自勞工階層。另一封信, 署於一九五七年二月九日, 來自 於一位印裔穆斯林, 曾在森美蘭 Jelebu 英校擔任校長, 他也希望能遷入回教村以養晚年。

39 見柔佛州宗教局檔案 P.A.J. 419/52, 題為「在華語源流社群裡擴展回教影響以及為皈依的華裔穆斯林設立 特殊的地區」。在一封署於一九五五年一月八日的公文裡, 題為 Land for converted Chinese Muslim (2) DOJB(L) 201/54, 是由當時的柔佛州宗教局總裁 Haji Lemin Bin Alias 致予土地收成官員的信件, 裡頭交待 馬俊武是負責興建回教村設施的官員。 
馬來文為官方語言, 而且認爲應該要有多種語言同時並列爲官方語言, 才能符合多元社會 的情況。40他表達這些意見都直接了當。

然而, 在中文刊物裡, 面對中文讀者, 要在散文裡更深入的書寫族裔與宗教之間的面 向，殊為不易。在前述一九五四年柔佛州宗教局出版的那本《默罕默德傳》（馬摩西譯） 裡, 前言已提過, 馬摩西翻譯的伊斯蘭教中文文獻, 早已見諸於其他報刊。然而, 一個宗 教官的生活經歷, 在散文中完全閶如, 實在有些不自然。這究竟是因為他認爲以一個宗教 官的自述或敘述, 與文藝創作的領域格格不入? 抑或因為盡管在呼籲在地化、認同馬來亞 的聲音中, 寫、讀友族知識的文稿雖然能促進彼此的了解, 但在一份中文刊物裡, 要以一 個華裔宗教官的經歷來把如何安排、處理華人的依穆斯林經過的諸多事項娓娓道來, 恐怕 作者馬摩西本身對中文的文學讀者能否接受, 也難以把握。換言之, 在鼓吹 $「$ 在地化」、 認同馬來亞的聲音當中, 這裡頭並非所有的在地事物都可被書寫, 有些宛如給置於遮蔽的 陰影裡。雖然身為宗教官, 馬摩西撰寫不少伊斯蘭的宣教文獻, 然而將之進行文學創作上 更深層的探索, 卻超出他的能力之外, 大概也不在他興趣之內。雖然一些關於異族的知 識, 在啟迪讀者進行教育的動機下, 大量撰稿（譬如認識他族習俗）, 但仍符合建國藍圖 中的國族話語, 至於那些與反共宗旨相關的計畫、或與華人身分屬性相關的問題, 卻殊不 容易, 在當時, 關於公民權與族群權益（包括對語文官方地位等問題）爭議不斷, 因而難 以在散文中直曝道來。故而, 在主張「在地化」、「反映現實」的文藝聲明中進行在地化 的書寫, 實則是在篩選、隱蔽, 可寫與不可寫的面向中勘酌運行。正因為其促進社會和諧 的功能，遠遠超越文學探索的追求，使其書寫反而遠離了凝視「在地」現實的初衰。

無疑英殖民與聯邦政府對左翼有所戒備，懷疑，因而使得大部分的華文作者必須小心 翼翼, 避免沾惹上馬共份子的嫌疑。殖民政府與馬來聯邦對左翼的防備, 始於馬共在勞工 階層中推行反殖反資的力量。一九四八年馬共被宣布為非法組織, 以後轉向武器鬥爭。4 從一九四八年英殖民者在馬來亞實行緊急法令以來, 一連串嚴峻的措施使華社壟罩在把馬 共污名化的恐懼裡。這些措施包括把激進的左翼份子、被認為是馬共的同情者以及馬共的

${ }^{40}$ 馬摩西, 〈馬來亞化問題〉, 《蕉風》1956 年第 18 期, 頁 1-3。

41 關於馬共武裝鬥爭的起因, 今史學論者多質疑由馬共導致武器斗爭的說法, 故而近代對這段歷史的研究趨 勢, 傾向於綜合多方敘述, 從當時馬共組織內部的狀況、英殖民與聯邦政府的反應與立場可能導致馬共抗 爭的整體歷史脈絡, 包括陳平「我方的故事」, 將各方的敘述版本, 各自競爭的政治主體意義, 再重作詮 釋。Chin C.C., "Re-examining the 1948 Revolt of the Malayan Communist Party in Malaya", Kajian Malaysia, 2009, 27(1 \& 2), p.11-38. A.J. Stockwell, "Chin Peng and the Struggle for Malaya”, Journal of the Royal Asiatic Society, 2006, 16(3), p.279-297. 
同謀者, 不加審訊地大量逮捕, 亦關閉多家由左翼掌控的報刊, 以及處罰那些被認為是與 馬共有合作關係的華裔村民, 軍方曾把有幫助馬共嫌疑的村子焚毀, 無辜的村民則被遣送 回中國或逮捕 ${ }^{42}$, 僅在一九四九年就逮捕了五千三百六十二人。43聳當時韓國、台灣、越 南直到馬來亞和印尼, 整個地區壟罩於冷戰氛圍之中, 英國與澳洲均調動了大量資源, 以 制止左翼意識形態在東南亞蔓延。到一九五三年, 馬來亞與英殖民政府的反共開銷, 甚至 達到每日二十三萬四千美元。44各種嚴厲的控制行動, 使馬華文學對馬共與左翼敘述產生 政治上的忌諱。華裔族群對自身的定義與身分認同，亦在此時從中國轉向馬來亞。

從一九五五年創刊至一九六○年間, 馬摩西刊於《蕉風》的稿件幾無家鄉的書寫。相 較於其他的南來文人, 如姚拓, 尚能在散文中回憶故鄉與親人, 但馬摩西對家鄉的書寫卻 非常稀少, 從他出版的著作裡, 僅有一篇〈家居閒談一一我的動靜生活的自剖〉才提到故 鄉的生活。懷鄉的書寫需要面對過去與故鄉的傷感, 但在當時馬華文學崇尚高昂熱騰與積 極精神的時代氛圍裡, 傷感與憂傷卻是被壓抑的情感。在當時, 這場域裡運作的話語以及 對文學語言的看法, 可能限制或支配了寫作人的情感流露, 如同群體的話語會塑造現實, 甚至包括心理的現實。但也不否認, 馬摩西特殊的身分與經歷, 使他能夠與其他離鄉背井 者, 對故鄉與流動懷有不同的感受與看法。

在一九五○年代，除了馬共，國民黨亦同時被英殖民者宣布為非法組織。從一九四 八到一九四九的兩年内, 馬共與國民黨的政治活動相繼被禁止, 國民黨後來改成以俱樂部 的形式轉為地下, 且仍持反共擁蔣的立場。 ${ }^{45}$ 馬摩西鮮明的本土認同寫作, 顯然迴異於國 民黨以中國為中心的反共政治話語。但馬摩西對往昔民國政府的認同, 可能根本不是一個 簡單的, 以國民黨為中心的認同。回族在認同國民黨政府塑造的國族想像裡, 還包含一個

\footnotetext{
${ }^{42}$ Hack, Karl, “The Malayan Emergency as counter-insurgency paradigm”, p. 3.

${ }^{43}$ Cheah Boon Kheng, "The Communist Insurgency in Malaysia, 1948-90: Contesting the Nation State and Social Change", New Zealand Journal of Asian Studies, 2009, 11(1), p.137.

${ }^{44}$ Cheah Boon Kheng, "The Communist Insurgency in Malaysia, 1948-90: Contesting the Nation State and Social Change", p.137.

45 國民黨本來在馬來西亞蓬勃發展, 在馬來亞各地, 包括新加坡, 都有設立衆多支會。直到一九四九年, 因海峽殖民地不准外國政治團體在新加坡活動才解散。該年馬來亞聯邦於七月的立法會議通過《強制社團 註冊法案》, 國民黨的支部因此解散, 但仍以俱樂部的形式轉爲地下活動。為了自存, 以及表明配合英殖 民地剿共的政策, 馬六甲的支部曾經在一九四九年請求撤銷承認中共, 同時提出撲滅馬共的建議。若與馬 共比較, 國民黨與海峽殖民地能夠維持比較友好的關係。參見朱浤源, 〈中國國民黨在新馬: 戰前與戰後 的比較〉, 李元瑾編《新馬華人: 傳統與現代的方法》, 新加坡 : 南洋理工大學中華語言文化中心, 2002 , 頁 201-258。
} 
對現代性伊斯蘭文化的想像。在辛亥革命結束以後, 民國政府與中東國家, 尤其是埃及, 開始建立外交與教育交流的管道, 使得過去與中東接觸有限的中國回族, 獲得全球化現代 性的視野。46馬摩西在埃及留學的經歷, 乃是一個接觸到全球化與現代化體驗的開端, 當 時, 埃及開羅愛資哈爾大學, 成為中國回族留埃學生的主要據點。這體驗帶來的開放、振 奮，也賦予他日後宛如游牧民族般，隨遇而安的力量。

馬來亞之於馬摩西, 可能也是延續反殖希望、具有伊斯蘭現代性與獨立意義的地 方。從異鄉到成為家園, 在這過程當中, 馬摩西熱衾於在地與旅行書寫、敘記此刻此地的 家居生活。透過表達本土認同, 以及主動積極地投入於伊斯蘭與維護本地華裔穆斯林團體 的活動，他確實有意地選擇了一個有別於過去的身分。

除了對在地意識熱烈的擁護之外，馬摩西個人特殊的經歷、遊歷與個人的文學觀點， 他在馬來亞這獨立建國的體制中切合資源的位置, 以及這個時期馬華文學場域中對文學要 求的激昂語言與樂觀話語, 仍然至為關鍵。47故以下將從馬摩西關於他個人的經歷、地方 的敘寫和回憶書寫來著手, 這不僅為了描敘馬摩西個人的南來圖像, 也不僅只是為了概括 他在寫作上的成果與局限, 這一切當為這獨立時期的馬華文學, 標誌著極為獨特的現象。 描繪馬摩西個人的南來文人圖像, 其實並不自外於冷戰的歷史脈絡與國族塑造。正是由於 馬來亞這特殊的社會與族群定義的結構, 才會在這冷戰時期南北文人跨越地理流動的遷移 史上, 出現像馬摩西那樣極為特殊的案例。

\section{五、從病體到痊癒／遷移}

\footnotetext{
${ }^{46}$ Mao Yufeng 從國民黨政府構塑的國族論述, 以及回族本身從國族敘述架構裡, 所欲找到的認同觀點出 發, 過去國民黨政府經常把回族頌揚成抗日志士。Mao Yufeng 以一九三八年底, 留埃學生攔截日本代表 團的麥加朝聖之旅, 做為討論個案, 指出回族在二戰期間的抗日過程裡, 其實懷有更為迂迴豐富的動機與 策略。Zvi Ben-Dor Benite 的論文則以一九二八年留埃的王靜齋為例, 閪述民國時期中國留埃學生為中國 回族打開翻譯埃及阿拉伯文本帶來的伊斯蘭現代化。無論如何, 兩者皆認為在民國時期, 留埃教育交流是 中國回族接觸外界現代性的重要據點。Mao Yufeng, “A Muslim Vision for the Chinese Nation: Chinese Pilgrimage Missions to Mecca during World War II.” The Journal of Asian Studies, 2011, Vol.70(2), p.373-395. Zvi Ben-Dor Benite, "Taking 'Abduh' to China: Chinese-Egyptian Intellectual Contact in the Early Twentieth Century" in James L. Gelvin and Nile Green (eds.) Global Muslims in the Age of Steam and Print, Berkeley and Los Angeles: University of California Press, 2014, p. 249-267.

47 南洋理工大學歷史系陳聰榮老師(Chen Song Chuan)曾在課堂上, 對我的報告提出問題與建議, 是否樂觀以 對, 難以承擔憂傷, 也是出於南來文人在異鄉求存, 不得不然的態度? 本文論及南來文人如馬摩西和姚 拓, 其文學語境樂觀的現象, 也有部分是受到陳聰榮老師的提問所啟迪。
} 
早在《蕉風》創辦以前, 馬摩西已經在新馬一帶住了將近六年, 而李汝琳、陳振亞則 已待了八、九年。馬摩西因在新山任公務員, 兩、三年後就被其他朋友視為「當地人」。 48他們居留的這幾年也是本土意識增長頗快的時期, 尤其在一九四八年「僑民文藝」與 $\ulcorner$ 馬華文藝」的爭論之後, 更奠定馬華文學有需要「此時此地」的寫實特性。

馬摩西散文〈搬家記〉回顧南來以後，在新柔兩地的生活：

我踓在星馬住了六年, 總感到身上披著的旅行外衣仍未脫去; 我由甲城搬到乙城既 是常事, 就是住在一個城裡, 也常由這區搬到另一區。以前我在星洲曾由束陵區搬 到加束區, 後又搬到干榜馬來由區。搬家是一種損失, 搬多了不但感到乏味, 也使 固定的家庭經濟，失其平衡的預算。没有搬家經驗的人，還以為搬家是厥舊喜新， 調換環境的玩意兒呢。的確, 我們居於黄河流域的祖先, 原是逐水草居住的游牧民 族，但生在幾千年後的我們，又怎麼依舊保持那樣流動的遺侸性呢? ${ }^{49}$

如同方天, 馬摩西在散文裏很少寫出離開故鄉的傷痛。唯一比較明顯彷徨的時期, 是在剛 抵達的前數年, 他不確定自己能否獲得居留, 是否真的會在馬來亞居留一輩子, 這樣的疑 問就在他從一棟房子搬到另一棟房子的過程中極具體化的浮現, 似乎是對於遊牧民族的想 像給了他更多的慰藉。但這與過去僑民意識中所認同的, 以「中國」原鄉為依歸的情感, 兩者㗽往的心靈景象是完全相反的。正如穆格勞爾(Mugerauer)所言, 就算是在現代來臨 之前, 並非所有的「有家之感」都須以「扎根」為核心，遊牧民族就是例子。他們居無定 所, 安於「無根」(rootless), 與自然季候同律, 四處移動, 四處以天地為家。50馬摩西響 往的, 是怎樣才能夠在安於變動的情況下繼續生活。

上述的這篇散文〈搬家記〉, 當寫於一九五五年, 收錄於一九五七年出版的《集愚 集》。 51 有一位作者傅清評馬摩西的《集愚集》說他善於寫日常生活家常瑣事, 「凡是這

${ }^{48}$ 馬摩西, 〈淡寫新山〉, 《蕉風》1956 年第 6 期, 頁 29-32。

${ }^{49}$ 馬摩西, 《集愚集》，頁 7 。

50 穆格勞爾此言是紅正海德格的觀點謬誤而發, 海德格以為在現代性來臨之前, 人們依循傳統扎根家鄉, 與自然和諧共存故而能獲得真正有歸屬感的詩意棲居, 不比現代性來臨以後, 人們過度依賴科技, 遺忘與 自然和諧共存, 遂流落為茫然飄泊的「無家感」(homeless)。Mugerauer Robert, “Phenomenology: Romantic Nostalgia or A New Way of Seeing?” EDRA, vol.20, 1989, p.200-206. http://www.edra.org/sites/default/files/publications/EDRA20-Mugerauer-200-206.pdf

51 根據刊於《蕉風》一九五六年第二十八期〈雞的幻想曲〉一文, 提到他在前一年寫了〈搬家記〉, 當時 馬摩西已住新山。 
一類以『我』為中心的文章, 都寫得親切細淢。」甚且借用周作人講究 $「$ 忌火氣」的散文 觀, 認為馬摩西的散文, 正是「沒有火氣, 總是平平穩穩。」52馬摩西書寫個人的瑣事, 確實語調平靜。他在詩歌或地方見聞記事裡, 有頗多迎合建國時期歌頌愛國的話語, 惟寫 個人生活瑣事卻趣味盖然, 竟無他在地方記事中常出現的愛國呼籡。他對搬家雖非全無抱 怨, 但若有, 也不過略微惋惜體力與經濟等物質的損失, 竟無多少對故地的緬懷或感傷。 他不以離鄉背井為苦, 甚且為此鼓舞：「至於我們卻相信歐洲人搬到美洲, 卻開闢了新的 天地；我們的祖先向南移置，才廣布了中原的文化，足見搬家也有內在的特殊效果。」53

比起對家鄉與故鄉, 馬摩西更鄉往流動。由於認可與想像這流動的精神, 遷移異地之 於馬摩西, 其實並不置入於一個悽苦或漂泊的流亡敘述, 游牧可能更為接近其心靈的狀 態, 但又因其促發點源於一九四九年的政權變異, 馬摩西實際上是以接受政治庇護的流亡 者的身分, 留在此地。 ${ }^{54}$ 馬摩西在〈旅行的生機〉裡提到, 流動與遷徙提供重振的生機。 在早期供稿給《蕉風》的文人當中，無疑馬摩西流動的經驗最爲豐富。如他在《歐美采風 錄》中的〈敍言〉：「我生平最愛旅行」55, 或〈戰後的歐美〉：「回憶我個人的生活 史，旅行佔據了不少的篇幅。當我在不同國籍、種族、風俗、膚色、語言的環境中走動 時, 我的心情是多麼活躍愉快。」56

根據數篇出現在《蕉風》的評論，馬摩西被視為一個「正面」或具有「樂觀的奮鬥精 神」的作者。57 如柯坎評馬摩西〈亦莊亦諧的《集愚集》〉，在介紹馬摩西〈沙漠的邊

52 傅清，〈讀「集愚集」〉, 《蕉風》1957 年第 41 期，頁 16-17。

53 馬摩西, 《集愚集》，頁 16 。

54 馬摩西本身曾在國民黨政府服務, 他能到埃及留學, 亦乃是在回族與國民黨達到共識的現代化方針下出 國。雖然共產黨在建國之後初期, 對回族少數民族僅採取防止族群衝突的友善政策。惟回族的情況亦相當 複雜, 不見得全都支持國民政權, 如新疆亦有支持蘇聯的派系, 參見 James Z.Gao, “The Call of The Oases: the 'Peaceful liberation' of Xinjiang, 1949-53 of Victory." in Jeremy Brown and Paul G. Pickowicz (eds.) Dilemmas of Victory, Harvard University Press, 2007, p. 84-204。。雖然國民黨政權在國族論述上, 與漢族穆 斯林致力於維持友善的關係, 不過馬摩西可能更認同自己的社群。對馬摩西而言, 在中共執掌政權之後, 回去中國, 前途實難評估。但他亦沒選擇到台灣蔣介石的政府。根據馬摩西於一九四○年代末期攜妻南下 的敘述, 路經杭州, 所見盡是烽火四起的戰亂景象, 國共戰敗後, 故鄉不復能回歸, 故頗近流亡(Exile)。 但來馬定居後, 行文卻無甚流露懷鄉情緒。如他行文所云, 游牧頗近他的心境與想像。但今天的遊牧理 論, 多數強調無政治、宗教的壓力, 故馬摩西所敘述的, 實是為隨遇而安, 在心境自我調適的轉換。

${ }^{55}$ 馬摩西, 《歐美采風錄》, 頁 1 。

56 馬摩西, 《歐美采風錄》, 頁 197 。

57 柯坎, 〈亦莊亦諧的《集愚集》〉, 《蕉風》1957 年第 37 期, 頁 10-11。 
緣 $>$ 時, 也大量以「擳風沐雨」「開展荒野」以喻華僑教育經歷的蔇辛與精神。58在這種 $\ulcorner$ 畸形的狀態中生活」, 以及必須努力爲華僑教育「開闢新天地」的過程中, 馬摩西及當 時的文人傾向于稱頌「樂觀的奮鬥精神」, 以此作爲渡越此歷史現實的克難精神與集體驅 動力。以文學為行動, 稱頌積極且「健康」地繞過、也避免陷入民族主義的悲情與悲感。 在〈會心的微笑〉裏, 馬摩西對樂觀情緒的期盼就更加清楚了。他想象了一個充滿歡笑與 享樂的世界, 世界變成只有幸福的樂園, 但同時又意識到, 這笑聲膨脹的樂園對一個離世 隱居者而言, 既是讓人驚奇, 也是讓人無語的。59

固然, 除了對集體認同的召喚之外, 這種對憂鬱、缺憾與悲傷的無力承擔, 馬摩西也 試圖賦予自己個人生命經歷的解釋。在〈家居閒談一一我的動靜生活的自剖〉中, 馬摩西 談到自己爲何會對文藝中的哀嘆憂愁不以為然。他在回憶中剖析「病體」肇因。他追憶童 年在家鄉因戶外林裡冒險、遇猛獸表兄受傷, 遂在父親誘導下轉移性情, 從本來活躍戶 外, 變成蝸居室内, 由此開始熟讀《楚詞》與拜倫的《哀希臘》。「受了文學的影響, 一 心想做感時傷世的詩人」, 後竟因憂愁過度使身體衰弱, 終日與藥瓶藥罐為伍, 「為甚麼 讀書人的身體都這樣瘦弱呢? 」 ${ }^{60}$ 及至考上官費留學埃及後, 到國外被五光十色的都市所 吸引, 渾忘古典詩歌, 又變得「逍遙自在」、「胸懷寬闊」。他寫自己在 $「$ 異域」逗留十 三年後身心健康地回國：

我有十幾年沒有害過一次病, 原因就是少讀詩詞, 多讀富有幽默的小品; 少看悲 劇，多看喜劇; 不存隐逸念頭，多讀社會科學的書籍; 少静坐，多運動的緣故。61

比較之下, 家鄉的記憶因父親與文學帶來傷感的影響, 竟是憂缽與壓抑, 而離開故鄉之 後, 在埃及的生活卻猶如重生：生命可以透過地理流動與越界，而獲得自由與釋放。

馬摩西對樂觀與去除憂愁的偏好，似承自五四文學拯救民族自強振興的語境。他在 〈文章與思想〉中講求讀文章要深刻理解, 同時又要「無知無識」的樸素與樂觀主義。他 自言自己年輕時曾「妄想將來能成為社會的改良家」, 喜讀胡適的文學革命理論, 但是

\footnotetext{
58柯坎, 〈亦莊亦諧的《集愚集》〉, 頁 11 。

${ }^{59}$ 馬摩西, 《集愚集》, 頁 101-102。

${ }^{60}$ 馬摩西, 《集愚集》, 頁 34 。

${ }^{61}$ 馬摩西, 《集愚集》, 頁 35 。
} 
$「$ 卻厭惡他捉妖打鬼的整理國故功夫」。62他視憂愁為導致病弱的因素。在〈家居閒談一 一我的動靜生活的自剖〉中更清楚顯見這點, 他否定傷悲的美學, 認為悲傷帶來的負面影 響非身心所能承受。馬摩西致力於去除悲愁感懷, 與他在故鄉的生病經驗, 以及後來在異 域生活的兩次轉折有關。他在故鄉病愈後, 就把悲傷從生活裏徹底驅除：「當我坐在戲院 中看戲劇或影片時, 我自然無法再吟哦絕句了。當我在游泳池和海灘上嬉戲時, 什麼是 詩, 早已抛到九霄雲外去了」。63這場病癒彷彿也把他與憂傷區隔開來, 也許亦宛如當時 的中國現代文學振興運動中，因民族病弱而致力排除文學的傷感情緒，亦如集體「病愈」 後的集體情感, 馬摩西留學之後轉為「積極」的經驗, 可能不是馬摩西所獨有, 而是因留 學埃及, 接觸到現代化的外界而來的視野開拓。他在開羅愛資哈爾大學, 大量接觸埃及文 學、歐洲文學, 其文字的情感質面亦與父親教導的古典詩詞全然迥異。回憶埃及的生活經 歷, 他認同那最能合乎已意的性情是開朗、樂觀以及自由自在的, 「到了外國, 看到五光 十色的都市景物, 和笑口常開的一切容顔, 於是我冷靜的心情被吸引了, 生機被滋潤了, 心花怒放了」。64

以這些散文裡的描敘來看, 馬摩西留學埃及時所感受到的現代化, 並不只有伊斯蘭教 義上的現代化, 而是極其多元的, 多向吸收, 而且也保持開放的現代性。相較之下, 故鄉 的記憶卻貫穿了, 從天真自然到幽閉詩詞、變得憂愁病弱的體驗。馬摩西在散文〈家居閒 談一一我的動靜生活的自剖 $>$ 裡追憶, 童年時期發生的一場驚險而血腥的意外。他敘述當 時一群孩子荷槍實彈到松樹林裡玩槍戰, 結果出現一隻金錢豹把他的表哥抓得遍體麟傷, 他看見表哥的父親為子哀哭。65這之後, 馬摩西在父親的誘導與提防下轉移性情, 而且也 確實在父親強力且費盡心機的誘導下, 遠離了那意外的場景, 同時也離開那些槍彈武器。 在馬摩西留學之後, 又因中國政權變異而遷移駐留他方, 與家鄉的距離持續拉遠, 使得他 與當初驚駭的場面持續地在知識、時空、個性塑造上層層隔離, 直到跨越邊界、遠離家 鄉, 超出他父親的想象之外。

這裡所敘的, 馬摩西從病到癒、從封閉到開放之間轉換的體驗, 既是他極私人的體 驗, 同時亦有從民國漢化到留埃之後汲取全球性伊斯蘭視野的流動與轉變。馬摩西在中國 是屬於具有豐富漢語文化修養的回族, 漢語回族跟漢族文化之間的關係, 在不同的區域與

\footnotetext{
62馬摩西, 《集愚集》, 頁 49 。

${ }^{63}$ 馬摩西, 《集愚集》, 頁 35 。

${ }^{64}$ 馬摩西, 《集愚集》, 頁 35 。

${ }^{65}$ 馬摩西, 《集愚集》, 頁 32 。
} 
社群裡各有差異, 並不全然都是對立的。對馬摩西而言, 五四文學裡如胡適的革命寫作, 在精神上亦不乏啟迪意義。在當時民國抗日的論述裡, 回族經常被頌揚認可其勇於抗日的 奉獻, 而回族亦希望在民國現代化和改革性的架構裡, 比起被古老帝國治理的過往, 他們 能有更好的位置與空間, 五四追求現代性的革命精神與振奮, 亦使回族看到現代性的轉變 可能，這也包括寄望在抗日、反殖成功以後，他們的生存空間也會變得更好。66

在民國崩解之後，馬摩西和一批曾經留埃被派駐馬來亞當外交官的回族（包括馬天 英在內）, 在馬來亞留下來。無可否認, 在此亦有馬摩西本身自覺的意願, 他主動地選擇 了自我看待的方式, 也重新定義自己, 在跟過去的鏈結切斷關係之後, 從流動、旅行各個 方面, 表達他自己新的人生走向。他認爲自己到了中年, 需要以這種「發熱的心」, 才能 $\ulcorner$ 走出靜默沉思的迷宮」。67他不以頻密遷居為苦。他認為思鄉大多是因自然氣候造成生 理不適應的結果, 並不認為有其他因素會造成旅行者對新的地方感到失落。甚至如果能夠 搬到適宜身體構造的地方, 「我願意讓我旅行的生機停止, 搬家的意志消滅, 也心甘情 願」。68

然而，在此，馬摩西似乎有無法盡情流露的界限所在。在上述這些樂觀的語言裏， 那個以前憂傷的「我」因病癒而徹底消失; 一如馬摩西將宗教官的身分與經驗, 從寫給中 文讀者看的散文裡，隱藏起來那樣。

馬摩西對遷移的敍述, 有別於離家背井的傷感敘述, 幾乎全無哀愁陰影, 其「積極樂 觀」與《蕉風》創刊詞的聲明幾乎一致。《蕉風》為辦一份「純馬來亞化的文藝刊物」, 一九五五年的創刊詞強調盡可能不墜入「秋風夜雨的淒凉悲調」, 致力塑造更爲正面、熱 烈、有助於建立地方認同的語言與內容。然而, 閲讀這些南來文人的書寫, 無論是小説、 散文、地方見聞或遊記, 那些衆多無關宏旨的細節、以個人為中心的小敘述, 包括對在地 的日常生活經驗、觀察和地方體驗的敘述, 相較於迎合獨立建國而寫的集體呼籲, 要來得 更有文學的趣味性。

馬摩西為新山寫的地方記聞〈淡寫新山〉, 篇幅頗長, 分成四期刊登（第六期至第九 期）, 撰述新山地方的自然風景、蟲獸、歷史文物、地標、海關、商業氣象、日常娛樂、 城市空間、文化教育等等。許多地方名與人物名稱, 多採用漢字音譯。如柔佛巴魯

\footnotetext{
${ }^{66}$ Mao Yufeng 2011, "A Muslim Vision for the Chinese Nation: Chinese Pilgrimage Missions to Mecca during World War II”, p.373-395.

67馬摩西, 《集愚集》, 頁 37 。

${ }^{68}$ 馬摩西, 《集愚集》, 頁 17 。
} 
（Johor Bahru，今譯為新山），愛布伯克大教堂(Sultan Abu Bakar Mosque), 依斯丹拿依 薩宮(Istana Besar)等等, 這些取名今天看似拗口, 但其時這些在地的音譯用字仍未規範, 許多南來文人不諳馬來語, 擇字音譯組成詞彙, 但在主張馬來亞化文藝的旗幟下，文學創 作轉向書寫在地的事物, 因而攝入了在地各族語言及混雜的方言詞彙。這寫作語言裡的 $\ulcorner$ 地方感性」打從戰前就已經開始, 有許多語彙因此走進馬華文學中, 因而得以與中國文 學有鮮明的區別。69

正如他在〈淡寫新山〉裡所寫的：「今日到處可聽見馬來亞化的口號」70, 馬摩西的 地方記事便證明了上述此言不假。當作者描敘地方居民響應馬來亞獨立運動的活動、各族 相處狀況、街道景象、政治關切以及公共設備時, 這些以馬來亞前景期盼的語言便也出現 在行文之中, 如稱頌當地各族之間和諧共處, 乃至這系列開首寫「新柔一家」的小節, 從 地脈相連到海峽所隔, 乃至到以人工長堤為連繫。71當馬來亞於一九五七年獨立時, 新加 坡仍是英屬殖民地。直到一九六三年, 新加坡才加入馬來亞宣布獨立。〈淡寫新山〉不僅 只是作者本身的地方經驗觀點, 也吸收了過往漢語語境描敘馬來半島的地理和空間意象, 同時也複述了聯盟政府建構國族、打造種族和諧想象時，所採用的修辭。

這篇文章羅列出當地的建築、古跡、植物、生物, 報告式地介紹當地特色、歷史掌故 與古蹟建築的人文價值, 以及個人在地方上漫遊的所見所聞, 再揉雜當時千篇一律的歌 頌, 或穿插一些看似旁枝末節的小事與細節。這些細節很難說是岔題, 因為文章分切的小 標題下, 但凡有關者皆可一概入題, 無論是就敘述、抒發個人感受、個人回憶或議論問 題。其中寫得最生動的, 該是「新山的蟲獸」一節底下：

我剛搬到海濱的屋子去居住時，我由星洲带去的書報，其中一批只適於平放而不 能直豎的雜誌，有不少阿拉伯文資料，是經多年的心血蒐集的，因書多架少，暫 時堆在屋角樓板上, 前後不到二十天, 這些雜誌的中間, 全被白蟻毫不留情地蛙 蝕一空。踓然到了發現時, 立即用殺蟲油, 向成千累萬的白蟻堆上澆灌, 總是得 不償失，只後悔太缺乏防蟻的經驗了。

後來我竟成了防蟻的主腦，每天都得花一些時間去偵察。有一次工部局也派専家 來巡視, 他們經過在屋中仔細地找寻, 發現有許多柱子和木板的中間已受白蟻破

69 張錦忠, 〈緒言〉, 《南洋論述：馬華文學與文化屬性》。

70 馬摩西, 〈淡寫新山〉, 《蕉風》1956 年第 9 期, 頁 29 。

71 馬摩西, 〈淡寫新山〉, 《蕉風》1956 年第 6 期, 頁 30 。 
壞。他們就在屋子四周掘了深坑，把幾大桶殺蟲油灌進去，但仍捉不到白蟻的女 王。經過了這次的襲擊後白蟻是少了, 但仍沒有斷根, 偶而也在低處的木屑中發 現。72

對於像蟲蟻這樣到處可見的微小生物, 馬摩西投以莫大的關注, 並有節制地不做使之象徵 化的詮釋，僅敍述白蟻對藏書的破壞、以及他必須展開的搶救工作等。但這無力撲滅白蟻 的場面, 卻使得積存地方上的殘舊事物與大自然的威勈變得鮮明, 比較起那些通篇陳腔濫 調、對愛國的激情歌頌與力圖描繪新山地方上的事物, 後者實是乏味之極, 而前者蟻災的 難以應付, 卻顯得更有可讀性一一那些數量龐大但藏匿在事物核心中自內往外吞噬, 贅蝕 力與生存力強大、行蹤隱密且難以滅盡殺絕的白蟻, 看起來「非常軟弱, 但卻有一股排山 倒海的力量」。73南洋的潮濕氣候使白蟻大量繁殖, 每每蛙空物產。即便這群公務員盡其 所能尋找、採用當時任何可以找到的各種殺蟻藥物, 最終對白蟻還是一籌莫展。

經過這次蟻災之後, 馬摩西不得不棄屋另遷。簡陃的現代滅蟻技術不足於對付蟻災。 故此, 在另一棟新的房子裏, 防範必須一早準備 :

根據我數度遷居的經驗，我因重視衛生設備，精力消耗不少，但我總能在短期内， 使荅蠅蚊䖵螞蟻絕跡。我為節省開支起見, 總是自己下手修茸廁所和浴室的懎壁和 地面，以及廚房的灶台和菜盆。我在各處鋪上白瓷磚，既美觀又易洗刷，所有細 菌，都被水沖走。74

馬摩西〈搬家記〉把他在地遷移的經驗與記憶加以組織過, 透過遷移日期與地點的標記, 他記錄了個人生命在星柔兩地的遷移史。寫成散文時, 事情總已成過去, 許多屬於個人生 命的重要事件一一比如搬遷、出發、抵達、離去——都有明確的日期。靠著這些像圖釘一 樣標誌各個階段的日期, 個人零碎的生活就此與冷戰時期的事件連接起來。在遷移的過程 中, 個體總是會面臨連串的問題：要到哪裏去? 該要住在哪? 一連串的選擇等著裁定。盡 管那時他已經抵達新加坡, 戰亂已成過去, 但往昔兵荒馬亂的記憶仍然覆罩當下, 仍然有 不知何時才真正結束飄泊的㟠惘之感, 於是各種標誌著駐留安定的勞作, 都不得不加以掂 量 :

\footnotetext{
${ }^{72}$ 馬摩西，〈淡寫新山〉，《蕉風》1956 年第 7 期, 頁 22 。

${ }^{73}$ 馬摩西, 〈淡寫新山〉, 同上註。

74馬摩西, 《集愚集》, 頁 10 。
} 
搬家與修屋成了我必須通過的難關, 好像過不完的樣子。我自己是否能在一所屋子 裡過一輩子，也沒十分把握，一切只有聽其自然發展。但願搬家的期限，能往後拉 長一點，也算幸事了。 ${ }^{75}$

但我住的屋子是公家的，一想到自己沒有永遠住居的主宰權，恐怕一紙文書指令搬 迷, 叫我如何把霂園結實票票的果樹搬走, 豈不後悔。76

他回憶那些臨時的居所時, 總是一併憶起各種各樣勞作的感受。「自然」在家居空間範圍 內乃是有意打造與加工的人工景觀。給廚房和浴室鋪上瓷磚, 打理園地, 設置花架、挖池 養魚、裝置雞寮養雞、種植花木, 自嘲 $「$ 以盡厚生之德」。「好在我的右手的活動已成習 慣了, 雖數小時也不致於酸痛。我全身的汗珠, 盡量由毛孔中湧出, 好像水晶似地透 明。」 77 諸如此類。親自打造家園, 使居所合乎心意, 家既是從外界退出的私人天地, 同 時也是迎接他人進來的地方：「總覺得朋友們到來時, 自己的住家能使他們有良好的印 象, 等於說替朋友佈置一個良好的環境。」 ${ }^{78}$ 馬摩西對家的打造, 還包含「生產」的想 像一一但是迴異於左翼對生産的歌頌, 馬摩西的勞作, 乃是以手工體力布置家居環境 :

$\ulcorner$ 如果我對雞的幻想曲所包涵的深義是生產, 那麼我的人生哲學, 就是發揮厚生的原 則。」「我想著, 我將建設自己的家, 無須去住他人蓋好的, 不合審美和實用條件的房 屋, 我的農產品將是分門別類的, 含有寓藝術於生產的條件。」 79

即便是回憶搬遷頻繁的那些年, 仍然勾勒一幅幅平靜的日常畫面。馬摩西對身在馬來 亞的搬遷與居家勞作的書寫, 誠然是個人投入到本土在地生活認同的展現, 透過以手工體 力經營身邊物件、悉心照料家居草木與家禽生長的過程, 才有了從身體到心靈情感投入的 過程, 才有了此地為家園之感, 這過程極度個人。馬摩西的本土認同, 最易顯著的發聲方 式, 莫過於口號式的呼籲, 以及那些極度突出地方屬性的主題, 然而, 使之成為文學的, 是那些更微小的觀察與體驗。提出這點, 並不是表示對文學書寫的重視, 就會拐離在地或 反對本土, 而是書寫若無這些個人體驗的層面, 恐怕就會近於 (本土意識的) 文宣品, 而 非 (本土) 文學。

\footnotetext{
${ }^{75}$ 馬摩西, 《集愚集》, 頁 16 。

${ }^{76}$ 馬摩西, 〈雞的幻想曲〉, 《蕉風》1956 年第 28 期, 頁 14 。

${ }^{77}$ 馬摩西, 《集愚集》, 頁 11 。

${ }^{78}$ 馬摩西, 《集愚集》, 頁 15 。

79 馬摩西, 〈雞的幻想曲〉, 頁 14 。
} 
比起《蕉風》內多篇以寫實主義小說 $「 反$ 映」文人教師捉襟見肘的艱苦生活，馬摩西 顯然在經濟上相當寬裕。在這些搬遷、裝修與布置居所的瑣碎敍事裏, 從未出現過任何對 窮困、資源不足的抱怨一一他似乎並無經濟上實乏的問題, 他的生活與起居空間安頓得不 差, 甚至在獲得新山的公務員職位之前, 他也能活得相當悠閒。然而在實際上, 根據檔案 紀錄, 他在當教師時, 月新四百八十五元, 轉職成為宗教官之後, 月薪僅有三百三十元。 80 在一九五五年六月, 馬摩西獲得配給新山的公務員宿舍, 終於結束他南來之後的「遊牧 生活」。

似乎我與旅行, 已結了不解的緣份, 只要有動的機會, 總是不肯輕易放過的。雖則 說：在目前我的行止，已被工作重重地㧢綁著，休想那麼自由。但我不管三七二十 一的勇氣，尚未受到阻礙，仍有決定意識形態的主宰權。不自由的原因，就是除了 例行公事外，還食著幾百只麗康鷄。每天看顧地們，維持地們的生命，若疏忽大 意, 就會招來損失, 扡們是多麼地嬌㙰著。 ${ }^{81}$

旅行能使人保持生機, 使思考機敏, 而日常公事的穩定生活則使人變得乏味。諸如此 類的感嘆, 不但對於左翼的文藝書寫, 甚至是對於經過兵荒馬亂遷移的人而言, 都是不可 思議的。像這類談論個人而非僅關注集體公共利益的文字, 如此隨心所欲地書寫個人在家 居的物質生活中如何享受, 而非積極搏鬥, 幾乎有如一些右翼雜誌（如《今日世界》）中 的家居生活分享, 但馬摩西並不追求商品, 他更興致勃勃地敘述自己如何以手工體力來搭 建一個符合他個人品味的家居空間, 包括種花、養魚、養雞。對於後者, 他也將之視爲可 增加收入的活動。雖然他的感嘆似乎很矛盾, 彷彿是一邊享受著穩定的生活, 同時又冀望 著另一種生活。

馬摩西的公務員生涯，其實並不像表面上那樣順利。至到一九五八年，他仍未有能 力參加馬來文考試, 但取得馬來語及格證明, 卻是加新的必要條件。 82 在一九五八年他因

\footnotetext{
${ }^{80}$ Rahmat Saripan, "Haji Musa Ma Jinwu: Kegiatan Pensyarah Agama Kerajaan Johor dalam Zaman Darurat (19531959)", p.23.

81 興周〔馬摩西〕，〈難忘的遊踪〉，《蕉風》1956 年第 24 期，頁 17 。

${ }^{82}$ Rahmat Saripan, “Haji Musa Ma Jinwu: Kegiatan Pensyarah Agama Kerajaan Johor dalam Zaman Darurat (19531959)”(哈芝馬穆沙俊武: 柔佛宗教局傳教官於戒嚴時期的活動), p.28. 此外, 查柔佛州檔案局, 文件 P.A.J/KS 747 , 根據一份馬摩西於一九五六年向部門申請貸款購車的表格, 註明馬摩西最初受聘的起薪,
} 
健康不佳而請病假, 但從年底到年初期間, 卻不知何故, 在所批准的休假結束後, 又擅自 延多五天才返回上班, 導致薪水被扣五天, 他因此投訴「照理我只應被警告, 而不是一犯 錯就扣薪」。 ${ }^{83}$ 馬摩西從未在散文書寫中, 流露出任何個人在職務上的困難。若與同一時 期抵達柔佛州的另一位華裔穆斯林, 來自廣東的 Mr Yaacob Ma Tawoo（馬達五）相比 ${ }^{84}$, 來自雲南的馬摩西可能較有方言不通的問題。然而馬摩西從未在寫作裡曝露這些挫折, 他 的宗教信心或樂觀進取, 使他積極地前往新村去宣教, 努力吸引更多在地華裔的依伊斯蘭 教, 他也通過馬華在新村設立的會場進行宣教。或許正是這些接觸群眾的實際成果, 使他 後來更加投入社群與團體的活動, 多於寫作。

\section{六、緊急狀態時期的旅途上}

總之今日正是喊和平口號, 喊得快到聲嘶力竭的時候, 誰也不敢相信兵荒馬亂的年 頭已成歷史的痕跡，只看我們每個人的旅行生機，不管它是受經濟或政治的影響， 反正是與承平時期，大大地走樣了。 ${ }^{85}$

當時並非承平時代，一九五五年馬來亞聯邦仍處於緊急狀態中，要到一九六○年才 解除。尤其在華玲舉行 $「$ 和平」會議的前後, 「和平」這字眼出現得很頻密。當時的報章 經常反復強調, 「和平」是全民一致的願望, 只有在緊急狀態結束後, 和平才會到來。86 在當時的寫實主義小説裏, 有關緊急狀態的敍述, 經常刻畫下層階級與秩序維護者之間的 衝突, 以及由此而來的生活苦況, 但對馬共的批評或譴責卻很少。 ${ }^{87}$ 在遊記裡, 有關緊急

以及他在一九五六年的新水增至四百五十元。在一九五七年獨立後, 馬來文正式成為官方語言, 故公務員 須證明有馬來語文能力。

${ }^{83}$ Rahmat Saripan, ibid, p.28.

${ }^{84}$ Rahmat Saripan, ibid, p.24

${ }^{85}$ 馬摩西, 〈旅行的生機〉, 頁 5 。

86 譬如一九五五年十一月十五日, 《南洋商報》的馬來亞版位上刊出當時副內政部長巴哈曼重申英殖首相 波靄氏的聲明：「馬來亞的緊急狀態一日不結束, 國家便不能獨立」。當「和平」會議在華玲舉行時, 報 章又再次強調「和平」是全民一致的願望。

87 比如刊登於一九五六年第十一期《蕉風》的〈又是你! 〉, 作者西林, 敍述了在時代動盪與緊急時期受 到逼遷影響者的謀生問題。男主人公被逼遷之後, 原來的膠林被隔離在「恐怖地區」内, 故須另尋謀生之 道。這些小説通常讓人看到緊急狀態是一段異常焦慮的時間, 生存的壓力蔓延在恐怖地區之外。緊急狀態 的民生總是充滿壓力、衝突, 對被刻畫的小人物而言, 這現實總是讓人倍感沮喪, 生活益發難難而秩序了 
狀態的描寫, 則往往是在時空流動中, 體會到脫離日常秩序的特殊經驗, 尤其是在鄉野與 近森林地帶。從霹靂到彭亨、半島中部的高原, 不少近森林地區的旅遊景點都被列爲黑 區。譬如在《蕉風》第二十六期, 萬景添在〈神經病患者之鄉一一紅毛丹〉中提到, 緊急 法令把紅毛丹與附近的一座溫泉, 都一併列爲禁區, 使得往昔頗盛的旅遊區在這之後變得 冷冷清清。88在馬摩西以另一筆名興周寫的〈難忘的遊玩〉裏, 亦提到金馬侖在緊急狀態 的戒嚴令, 「每買一件食品都得登記」, 又因同行友人申青腿痛, 「為攜帶幾小瓶藥和一 束膠帶必須到警局去要通行證。」 ${ }^{89}$

緊急法令並非在全國每個地方、每座新村或城鄉均同等嚴庽, 而是各處逐步放鬆管 制。90當時在馬來亞各處穿梭流動, 多能體會到各區之間的管制差異。正如從第十一期開 始在《蕉風》連載至第十三期, 紫燕撰寫的〈馬來亞去來〉文中所觀察到的, 從新加坡出 發北上馬來亞聯邦旅遊, 一路便連續經過黑區、白區。

在紫燕的描述裏, 一路上的查禁、軍方對壘時出現的封路、物品管制的麻煩不少。比 如金馬崙山下的小鎮打巴, 當時仍屬糧食管制的禁區, 整團五十人到來, 尋遍餐館竟無飯 可吃, 僅能吃碗麵充飢。9 在金馬崙的半山腰, 他們也被當地人提醒此地屬於戒嚴區。物 品管制甚嚴, 舉凡食物、藥品皆在禁止攜帶之例, 曾經有旅客因帶一瓶萬金油而被罰金五 十元, 且還拍照備查。 ${ }^{2}$ 回程經過柔佛古來, 那裏爲了圍剿馬共, 膠林砍光, 但當局仍時 刻防備, 每有風吹草動, 便動員大兵搜尋圍捕：

無人情味。如上述林西的小説〈又是你! 〉, 並沒有任何批評或譴責馬共的語言, 它更著意的是在緊急狀 態中的生活苦況。西林, 〈又是你！〉，《蕉風》1956 年第 11 期，頁 2-4。

88萬景添，〈神經病患者之鄉—紅毛丹〉，《蕉風》1956 年第 26 期，頁 8-9。

89 興周〔馬摩西〕，〈難忘的遊玩〉1956 年第 24 期, 頁 19 。

90從一九五四年以來至一九五七年, 全國各地有不少地方逐漸被宣佈脫離「黑區」。譬如在一九五四年, 馬 六甲、丁加奴、吉打、玻璃市與森美蘭都被宣佈為已清除馬共勢力的白區, Ooi Keat Gin, Historical Dictionary of Malaysia, Lanham: Scarecrow, 2009, p.190. 譬如在《蕉風》第十期, 林我的散文〈記打西乳咯 村〉便留意到各個新村之間, 其管制鬆嚴均有差別。他形容位於威省北部的打西乳咯新村(Tassek Yeugor New Village )為「有新村之名, 而無新村之實」。居民當初遷居, 主要是出於安頓居民謀生的需要, 原先 工作的膠林被收回, 政府須另劃荒地供居民移植, 加上當地並非馬共活躍的地區, 故此, 「這裡看不到高 牆似的鐵絲網」,「一天廿四小時内, 隨時可以自由出入, 食糧也不受管制」。作者是前來這座新村教書 的教師, 對於此地在緊急法令期間竟能如此自由, 感到非常驚訝。林我, 〈記打西乳咯村〉, 《蕉風》 1956 年第 10 期, 頁 31-32。

91 紫燕, 〈馬來亞去來〉, 《蕉風》1956 年第 13 期, 頁 21 。

92紫燕, 〈馬來亞去來〉, 同上註, 頁 20 。 
經過古來，看見路旁停著雨三架戰車，車上安放著大駁和機關梒，正對準那個山 頭; 山脚下有一隊英兵持梒躡步, 小心翼翼地正在做那搜寻的功夫。我們進也不 能, 退也不得, 心想: 若隻方真的打起仗來, 一時要逃到哪裹去避難呢? 幸而搜寻 的結果，大約又是一場空，嚴重的對壘一經解除，我們的車兒也就繼續前行了。93

到得檳城, 旅行團的到來竟也引起政治部的注意而特予警告：

飯後得莊之明告，適才有政治部的人員到這裡來調查旅行團的行動甚詳; 又有華 校總監來探訪, 並留下一張字條。這位華校總監英國藉, 很年青, 國語倒說得很 流利，他希望我細心看管旅行團的團員，不要讓他們跟檳城的學生搞在一起。94

雖然緊急狀態仍未能全面解除, 在地旅行團還是頗有號召力。紫燕寫的〈馬來亞去 來〉, 旅行團連住宿、行程都沒規劃好, 就倉促上路, 但仍能吸引五十個團員組成兩輛巴 士。路上雖不免有管制或檢查行李而導致損失, 卻仍不減興味。

盡管有這些不便, 在認識本土、足踏遍地觀賞風物的前提下, 各種各樣的旅行書寫仍 然大受鼓勵。一九五六年一月, 《南方晚報》透過徵文選, 出版了一本《馬來亞之戀》, 根據後記所言, 遊記作品在馬華文壇中向來是最缺乏的, 這次十五篇作品裏, 也有三篇是 遊記。95然而這三篇並非通篇遊記, 旅遊與搬遷掺雜文内。當時由於謀生之故, 四處流動 搬遷是常事, 從這幾篇文章裡可以讀到作者回憶本身所住過的地方, 有一些是相當罕有的 觀察。譬如在光華〈萍蹤偶遇〉 中, 提到彭亨河的郵政交通, 所動用的人力景象, 那也是 一段艱辛的路程：

我和一位來自馬來亞西海岸的歐籍人站在河邊洮望，眼見一位馬來籍的中年郵差背 扶著郵包，從泥演的淺灘上竭力推著舢板，然後把郵包擱在舢板中，自己划著漿逆 水慢慢前進。

郵件的輸送工具是因環境而臨時決定的，現在我已經登實了這句話。那位歐籍人對 我說: 「用般板運載郵件, 我還是第一次看到, 這實在是一椿艱苦的工作。」在初

\footnotetext{
93紫燕, 〈馬來亞去來〉, 同上註, 頁 22。

94紫燕, 〈馬來亞去來〉, 《蕉風》1956 年第 12 期, 頁 17 。

95藍屏等著, 曾鐵忱編, 《馬來亞之戀》, 新加坡：南方報社, 1956, 頁 163 。
} 
次的見識中，這或許是有趣的，那種慢吞吞的划進，事實上卻是一種艱苦的生涯。 96

這種如此耗費體力、艱苦的例常行事, 僅能是一幅旁觀的風景, 對於一個途經的旅客而 言, 這艱苦的負擔是不可能承接過來的。在此文章描述了兩道觀察：一個源自他本身（本 地人) 的目光, 另一個則是來自外地人的目光。透過一個歐洲旅客, 這景象勾起的異常感 受才給顯得明晰。本土日常事物的獨特性, 有時候得通過一個外地人或異鄉人的眼睛, 才 從背景裡聚焦凸顯。觀察與感受事物的能力, 似乎也經由陌生化才得以甦醒。然而本地人 ／異鄉人的身分, 其實也是相對的。跟歐籍人士比起來, 敘述者宛如本地人; 但相較於本 地出生者, 那因謀生而搬遷到來的敘述者, 也往往被認為如同外地人。

一九五 $\bigcirc$ 年代的報刊或雜誌為推行本土書寫, 常鼓勵投稿者撰寫在馬來亞生活的記 敍、遊記。大部分所陳述的, 總是局部的流動經驗, 「馬來亞風光」也總是個體經歷的片 段, 是局部而非整體的敍寫, 是停駐、暫居與旅遊, 相互摻揉、補緅而呈多孔狀的, 一地 一角落的敍述。

然而, 旅行真的能夠使人更愛或更投入這個國家嗎? 在遊記中抒發的愛國意識, 有 時候是複雜的。紫燕的遊記〈馬來亞去來〉中, 寫及金馬崙的天氣使她想起祖國：「我們 絕大多數是僑生於南洋, 也沒有回過祖國, 住在『長年都是夏』的星洲, 不知祖國凉爽的 天氣是給人怎樣的一個享受。」97對當時不少仍舊持有僑民意識的華人來説, 這比只認同 $\ulcorner$ 一個國籍」是更爲自然的, 愛馬來亞同時也不放棄對「祖國」之愛。如《馬來亞之戀》 的編輯後記所言的, 他既想去 $「$ 偉大的祖國」, 但最終「還是要回到馬來亞」。98愛國並 非只能二擇一。

在大部分的書寫裡, 愛國意識是否壓抑了對當地的真實感受呢? 馬摩西雖然經常熱 心的鼓吹在地認同, 不過, 偶而也會坦白地流露出遺憾之感 :

我們在赤道綫上生活的人，常感覺頭昏腦脹，缺乏可寫的事物，在天地間都充霂了 可寫的對象, 要看我們是否有化平淡為神奇的手法了。9

\footnotetext{
96監屏等著, 《馬來亞之戀》, 頁 149-150。

97紫燕, 〈馬來亞去來〉, 《蕉風》1956 年第 13 期, 頁 21 。

${ }^{98}$ 藍屏, 《馬來亞之戀》, 頁 161 。

${ }^{99}$ 馬摩西, 《歐美采風錄》, 頁 61 。
} 
近來蛰居在赤道旁的馬來亞，雖有時也興起内地旅行的興趣，但印象總不大深刻， 既乏名山大川可以邀遊，更缺人工的建筑雕塑可以欣賞。100

在馬摩西的多篇散文中, 「旅行」一詞本身包含了在地表上流動的各種方式, 無論是南 遷、搬家與觀光, 他都一概以「旅途」論之。在散文〈旅途的生機〉裡, 他從古今中外舉 出一連串遷移的例子, 包括離鄉背井、戰爭沙場, 乃至於咙山涉水、游牧沙漠, 響往能夠 突破日常局限、跨越疆界的流動, 藉由旅行來抵禦被「工作的魚餌」上鈎的誘惑, 以及安 分謹守「在固定的圈子裡㿞轉」的生活。101旅行使個體保持對外開放而非封閉的狀態, 使 得個體對生活的觸感復毝, 旅行也是追求「知識與經驗配合」認識世界的方法, 這些都是 他強調的益處, 至於透過旅行拓展認識馬來亞的國家地理與文化環境, 因爲這赤道旁的馬 來亞, 所見缺乏大川與歷史深厚的人文建築, 幾乎是乏味而不足以道了。

我於是常和友人們訴説這種内心沉盟的實況，他或她們雖有同感，卻為我指出了 熟帶情調極鴬濃厚的峇里和曼谷, 是值得一游的名勝地。也有人說戰後的歐美, 一切生活情況都已改觀，和往日大相遥庭了。102

友人建議他正面看待現況且接受現實, 把眼光轉投於東南亞當地的區域。無論如何, 從外 交官更換職業至宗教官, 也意味著他得揮別那些未能踏足的遠方, 不僅僅只是告別故鄉而 已。在馬摩西的散文裡, 他對旅途有更多幻想。誠然若與故鄉相比, 他表達認同馬來亞的 作品 (包含詩與散文) 來得更多。然而在遊記裏, 才流露他出對歐美等地有更大的鄉往。

馬摩西對地理越界遊動的想象, 與姚拓的科幻小説〈七個世紀以後〉中, 那因國籍困 惑而生的幻想, 彼此有共通之處。〈七個世紀以後〉中的主角醒來, 面對一個主體概念完 全變更了的未來世界, 小説流露出對世界與自由主義的鄉往, 所有與身分相關的標誌：語 言、國籍、護照、國界的概念均崩解消散, 世界成為一個徹底自由流動的空間。103

在一九四○年代至一九五 $\bigcirc$ 年代期間, 亞洲區域國家紛紛獨立, 邊界劃定, 國族建 構的公民概念取代祖國成為新的身份認同。馬摩西想象的「遊牧民族」可依季候律時而遷 移流動, 但所能踏足的地幅, 畢竟得受國界所限。由於馬來亞能提供穆斯林較為優惠的條

\footnotetext{
${ }^{100}$ 馬摩西, 同上註, 頁 61 。

${ }^{101}$ 馬摩西, 〈旅行的生機〉, 頁 5 。

102 馬摩西, 《歐美采風錄》, 頁 197 。

103姚拓, 〈七個世紀以後〉, 《蕉風》1957 年第 47 期, 頁 8-11。
} 
件, 且以馬摩西個人的宗教身分與語言專長, 繼續留在馬來亞顯然比到其他國家來得更舒 適, 至少不必在未知的異域去經歷熯難的搏鬥。

馬摩西在留學遊歷過程中, 只有一篇文章談到過去的愛國感召。他唯一一篇撰寫伊斯 蘭經驗的〈回教聖地麥加巡禮〉, 收錄於《歐美采風錄》, 裡頭敍述了一場中國回教學生 如何防範傾日的回教學生爭奪中東回教徒的支持。

事件從一九三九年九月十三日一封送至開羅的電報開始, 馬摩西與同學接到電報, 有 日本佔領軍派了華北的回教徒, 將到麥加「借世界回教徒大聚會的日子, 宣揚日本對中國 回教的德政」。104馬摩西在這長達七頁題為「回教聖地的麥加巡禮」的小節裏, 就用了一 頁半來敍述此事, 宛如一場發生在異地留學生群中的間諜戰。這件事相當為回教學生團所 津津樂道。另一位當時也參加麥加朝聖團的學生天僕, 亦將此事寫成〈朝唓日記〉, 但馬 摩西所記敘的日期與其他文獻的紀錄頗有出入, 文獻咸以為是一九三九年初二至三月之 間。105 Mao Yufeng 的一篇論文亦討論此事, 時間記為一九三九年初, 支持國民黨的中國 穆斯林學生代表團, 從開羅出發到麥加, 阻止日本遣來的學生團在朝聖時期, 與中東的權 貴會見, 當時中國國民黨政府與日本都想要爭取中東穆斯林國家為盟友, 如回教學者王增 善, 延續過去孫中山的觀點, 提出中東和中國一樣都是受到西方強權壓迫的弱勢民族與國 家，故此，中國需要與埃及和其他中東國家結為盟友來抵抗殖民勢力。106

在這過程裡, 來自開羅支持中華民國的留學生團, 亦步亦趨地監視為日本那一方效 勞的學生：

他們不論走到什麼地方, 我們都有人跟蹤著, 不論他們願不願意, 反正我們是憑 著良心替國家做事，尤其在當地政府的各部門，我們都已先把他們的危害國家民 族的罪狀，存過案了，那些熱心的暗探已把他們的腳印，記錄下來，那些愛國的 中國哈止，更對他們抱『敬鬼神而遠之』的態度了。107

104馬摩西, 《歐美采風錄》, 頁 170 。

105 鐵維英, 〈抗戰時期中國回族穆斯林在麥加的一段愛國鬥爭經歷〉, 《回族研究》 1991 年第 3 期, 頁 76-81。天僕, 〈朝覲日記〉, 《月華》1939 年第 11 卷第 $4 \cdot 5 \cdot 6$ 期, 頁 13 , 載寧夏少數民族古籍整 理, 《月華》第 9 冊, 銀川: 寧夏人民, 2010 , 頁 421 。

${ }^{106}$ Yufeng Mao, "A Muslim Vision for the Chinese Nation: Chinese Pilgrimage Missions to Mecca during World War II”, p.378.

107 馬摩西, 《歐美采風錄》, 頁 173 。 
在上述遭到圍堵的親日回教代表團裡, 有三個中國人和兩個日本學生, 中國人分別是在華 北辦報的主編唐玉塵, 周姓北平珠寶商, 以及一個張姓的回教教育者。奇怪的是, 在這場 回憶裡, 細節很少, 馬摩西本人在這過程中究竟負責或做些什麼, 其實是含糊而不清楚 的。也許是出於馬摩西親身參與的部分很少, 抑或因為時間遠去而記憶模糊。在他的敘述 裡，集體行動多於個人化的體驗。但他這篇文章的敘寫方式，與前述天僕寫的〈朝覲日 記〉, 相當相似。他們都甚少描敘自身的位置。天僕也寫朝聖的所見所聞, 會見埃及中東 權貴要員的經過, 但內容更為詳細, 從一開始 (中華民國二十八年, 即一九三九年一月十 九日）就道出, 那年全體留埃的學生, 都獲得民國政府撥款資助去麥加朝唓, 組織成 $\ulcorner$ 中 華民國回教朝䚓團」, 同時也肩負任務, 圍堵、監視另一批由華北派去的親日回教團的行 動。108其文記敘朝䚆旅途，始於一月十九日至二月二十一日回到開羅結束。

Mao Yufeng 認為, 在上述這宗天樸朝聖團的個案裡, 留埃學生的敘述策略, 頗有超 出世俗國家話語的意義。109盡管如此，在這些行動裡牽涉到的「我方」與「彼方」（來自 日本的回教團）之二分, 其實無法不受到國家體制與政治疆界所限制。馬摩西則在這當中 講述了麥加朝聖的起源, 亦即伊斯蘭教犧牲節的起源, 有關亞伯拉罕欲弑子以獻真主盡 $\ulcorner$ 忠」的故事, 後來蒙真主恩准, 以羊代替兒子作爲愷牲品：「我已深知你們父子之間, 除了慈愛之外, 還有忠孝, 我將使你們的善行和品德, 作為人類的模範」。110這則可蘭經 的天啓故事, 究竟該如何與親日回教徒競爭以獲得中東伊斯蘭教徒支持的事件, 一起閲讀 呢？「真忠真孝，不獨可以使家庭快樂，並可以使社會和諧及國家安寧」。宗教上對神的 忠誠, 可以轉化成使族群社會與國家和諧之愛; 對國家的忠誠, 其實又從伊斯蘭教徒的社 群與生存空間出發。在一九三九年, 雲南桂林發行的《月華》期刊裡, 有一篇〈古蘭中關 於動員的教訓〉, 闆釋戰爭時需要回民投入軍事之外的政治宣傳工作, 試圖從超越俗世的 觀點來回看個體對國家的服務。作者拈引可蘭經, 解釋自身的位置與國家之間的關聯, 從 俗世生命之短暫有限如「夢」的觀點出發, 肯定對社稷付出之貢獻, 因為「當斯時我回教

${ }^{108}$ 天僕，〈朝唓日記〉，頁 18-26。

109這裡參考了 Mao Yufeng 的觀點。這過程跌宕起伏, 代表團在事前事後與出國和回國前後, 對已方全盤勝 利的詮釋與陳述, Mao Yufeng 認為這顯示出漢族穆斯林 (Chinese Muslim, 或稱華語源流穆斯林 Sinomuslim 或漢語源流穆斯林 Han-muslim）在國民黨構塑的國族論述裡, 其實發揮了動機豐富極富策略性的 敘述能力, 最後達到維護與改善回族族群在國家體制裡的地位這個目的。他們的敘述既非合乎國家意識形 態的愛國者, 亦非出於與國家對抗的二元敵對關係, 參見 Mao Yufeng, “A Muslim Vision for the Chinese Nation: Chinese Pilgrimage Missions to Mecca during World War II”, p.373-395 。

110 馬摩西, 同上註, 頁 173 。 
民眾既身在中國, 中國即為我之國家, 國亡家破, 宗教安能完整。」111對國家俗世政體的 奉獻, 實是根據可蘭經的詮釋而來。維護國家, 目的是為了照顧回教社群的利益, 故此回 教社群與所在國家的關係, 並不直接等同於俗世國家定義下的國家與子民的關係。國家較 像是一個僅在與社群群體有所互利互惠的條件下，才付出保衛效忠的政體。112

從宗教出發、到投入社稷的思路, 在馬來亞多元族群的社會裡, 也分外著重其 $「$ 和 諧」的面向。然而, 在馬來亞, 國家與回教社群的關係, 關係愈發密切, 不若中國國民黨 時期與回教社群的關係。在中國大陸國民黨統治底下, 回教社群對國家的效忠尚有距離。 在馬來亞獨立之後, 以馬來民族為核心的政治結構, 也同時把伊斯蘭教定義為馬來民族與 國家文化的核心, 使得國家形成了主催、執行維護回教社群利益, 以及被授予法治權來監 度教徒操守的嚴密體制; 國族塑造與宗教幾乎合一。

如同再度讓使命延續, 馬摩西將之分開在文學與宗教上分別實踐展開, 一是在文學上 敦促作家書寫能促使族群關係和諧的文章; 另一則是通過宣教使更多華人認識、接受與的 依伊斯蘭教。

\section{七、小結：國族的濾斗}

如前述引自〈搬家記〉之語：「我願意讓我旅行的生機停止, 搬家的意志消滅, 也心 甘情願。」馬摩西不欲為逝去了的外交官職位傷感, 既然歷史已無可改變, 他必須在這新 的架構裏, 繼續尋找可能性。此外他也沒有興趣去深掘自己的内在動靜一一使「自剖」真 正像「自剖」那樣挖向更深的記憶。他幾乎是個全盤「外向」的寫作者，在他的書寫裏全 無陰影。從中國雲南到埃及開羅, 馬摩西體會到生命的擴張, 但從國民黨的外交官、到馬 來亞的宗教官, 他也喪失了外邊那廣亭地表的未來。他能征踏的旅途, 從全球縮減到半島 上。然而他並不眷戀舊職, 那如同眷戀已逝的中國國民黨政權, 而後者要繼續掌權的基 礎, 在他當上外交官時老早就已不穩定了。

$111 「$ 至現世之生活, 本有為數之時日, 勞者畢生, 終將空手而回, 況啟示中所主論者, 為動員作戰之事,

若一般貪生怕死者, 其不伏於地面而將奈何也? 但智者皆知此光陰世界之不久, 或喻之以夢, 或譬之以逆 旅, 皆示不久長也, 若人生一世不為社會造福, 不留功績於後世, 與草木同朽流水同盡, 其人生有何價 值? 故當看破此點, 一方面盡力為宗教為社會為國家造福, 一方面希圖將來之真樂世界永久幸福之到來, 識此則為正義任何犧牲在所不顧矣！」志程, 〈古蘭中關於動員的教訓〉, 《月華》1939 年第 11 卷第 $1 、 2 、 3$ 期, 頁 2 , 載寧夏少數民族古籍整理, 《月華》第 9 冊, 頁 394 。 112 志程, 〈古蘭中關於動員的教訓〉, 《月華》第 9 冊, 頁 394-395。 
抵達馬來亞, 家乃是一個在流動中, 持續塑造的過程。馬摩西在許多討論馬華文學的 場合裏, 多次強調在地認同。當時馬來亞正處於初步建立伊斯蘭宗教局的時期, 確實能賦 予他適合的職位與資源。馬摩西的樂觀、積極也使他更快融入與投入此地爲家園。第九期 的〈淡寫新山〉流露出亟欲培育現代文化與知識的熱切之心, 意欲引入更多現代化的意識 予在地的華裔社群。113 在一九五六年撰文介紹漫畫家黃堯來到馬來亞拜訪時, 也希望黃堯 能多畫馬來亞的漫畫。114在一篇關於燕歸來的詩歌評論裡, 題目裡的「海外」兩字, 已清 楚表明「境外」與「在地」之別；對燕歸來除讚其「勇毅」、「純正情操」之外，亦再度 提到 $\ulcorner$ 純馬來亞化」, 認為燕歸來若多居時日, 必能對當地的 $「$ 純馬來亞風味的詩的園 地」, 產生影響。"15燕歸來在馬來亞期間, 他也跟燕歸來會見多次, 行文中詳細介紹燕歸 來出身於北大, 曾是新文化運動的搖籃。"16從馬摩西在《蕉風》所寫的評論看來, 他也擁 有極豐富的中文文學學養。他對自己身為馬來亞華人的認同是毫不猶豫的。他的書寫精神 崇尚樂觀, 筆下的情感偶爾流於扁平, 再加上馬摩西習慣以大量資料堆砌的方式寫作, 隨 著後來, 那更追求形式與語言技藝的現代主義降臨之後, 馬摩西的詩歌與散文顯然是被淘 汰的。爾後, 文學在他生命中的位置便讓位予政治。他從《蕉風》中出現的時間很短暫, 在一九五七年五月最後一篇〈象徵派詩人李金髮〉後, 直到一九五 $\bigcirc$ 年代結束, 都不再有 其他稿件。

如同另一位南來文人, 《蕉風》的首任編輯方天, 他們兩人當時都熱烈地表達了在 地認同, 兩人在《蕉風》的登場都很短暫。然而, 馬摩西的身份、語言及宗教之特殊, 使 他能契合此地的資源結構; 但方天卻不能。若比較兩人的寫作, 方天那經過嚴謹考察精筆 描述的現實主義小説, 其成就要遠遠超過馬摩西。馬摩西的埃及翻譯文學, 對馬來亞的現 實主義小説發展未見影響, 而在他當時所呼籡的文學使命——需以文學來調和種族之間的 衝突——既不能收效, 也無益於文學本身。他在將近獨立的一九五七年四月裏, 在《蕉

113 馬摩西在文中寫：「至於一般華人的生活, 我沒有什麼較深的印象, 說起來也摸不着頭腦。總括一句可 說是舊文化的連續, 譬如社團中多有地方性的古樂, 而不提倡現代音樂; 有潮洲戲上演, 就缺乏國語話 劇; 有迎神賽會的熱鬧, 就看不見一種爭取大衆福利與公民權的活動; 有祭祖迎親的喜䇥, 就沒有一種促 進學術文化發展的集會。許多人願意在婚噩的儀式上, 揮金如土, 大事鋪張; 就不肯節省一點錢來辦 學。」

${ }^{114}$ 馬摩西，〈牛鼻子寫真記〉，《蕉風》1956 年第 16 期, 頁 16 。

115 馬摩西, 〈海外詩人燕歸來〉, 《蕉風》1956 年第 19 期, 頁 22-23。

${ }^{116}$ 馬摩西, 〈海外詩人燕歸來〉, 頁 22 。 
風》發表的〈文藝的新使命〉, 以發生在檳城差點爆發種族排擠的事件為例, 認為族群間 因語言分化而致的隔閡與猜忌, 需要透過文學來彌補, 文學寫作、翻譯、跨族流通與閲讀 的效果, 總是好過政客的行動。117然而, 他的建議並非是透過文學來認識歷史上的創傷一 一即便視文學有療傷的可能, 仍不免有其疑問 : 文學因何能療傷? 因其呈現出 $「$ 真實情 況」?「把誤會解釋清楚」? 「把雙方的界限盡量消除」? ${ }^{118}$ 然而, 文學之所以能為文 學, 仍然有其本身在形式、語言與觀點上的翻新需要完成, 在逝去的灰燼上重生, 死逝的 語言, 經過反覆的複述論為扁平的聲明, 伸不出觸角去至那真正藏著傷灶的邊緣之處, 琵 觸傷 $\square$ 。

馬摩西這筆名除了來自他的伊斯蘭教名(Musa)之外, 同時也可能擇取另一個意義。在 《可蘭經》與《聖經》裡, 摩西在四十歲時, 離開法老王宮廷, 曾在荒野中放牧四十年。 在前述散文〈旅行的生機〉裡, 馬摩西曾經提到對游牧民族的響往。他的筆名摩西, 這個 先知的名字, 恰好承載了《舊約 - 出埃及記》裡, 那接受神諭, 帶領族人出紅海逃亡、從 信仰中尋覓新生的使命。摩西曾經從埃及習取多方面的知識, 爾後離開埃及帶著族人回歸 到先祖之地迦南生活。在近代離散的研究裡, 這迦南之地, 後為耶路撒冷城, 一直被視為 猶太人精神意向的家園。在近代關於離散的研究中, 「離散」(diaspora) 源自猶太人在公 元前八世紀被亞述人驅逐至美索不達米亞北部, 公元前五九七年巴比倫王佔領猶太國, 大 批猶太人遭驅離各地, 公元前五八七、五八六年耶路撒冷的聖殿被毀, 那之後猶太人散居 在巴比倫境內, 但仍堅持自己的宗教習俗而拒絕融入周遭的社群, 一直到二戰以前, 散居 於歐洲的猶太人依然與歐洲其他社群有一道無法融入的隔閡, 以遵行猶太教維持與那無法 回歸的上帝「應許之地」, 即與耶路撒冷之間的精神相銜之路。 ${ }^{119}$ 由此而來的離散論述, 因此有一回歸的中心, 但與此同時, 亦有者抱持不同的觀點主張：比起 $「$ 回歸」住在那精 神聖城的家園, 一個在家園之外的離散者, 能接觸到更多資源、與他人有更多互動的機 會。120在馬摩西的遷移路徑裡, 家園就在他最後認同的停駐之處, 他並未再回返那政權已 經變異的中國。馬摩西書寫回憶留學埃及生活的種種, 行文之中回憶埃及留學的愉悅, 多 於對家鄉的懷念, 埃及的留學生活, 標誌其性情與言語特質轉向開放的轉捩點。馬摩西留

\footnotetext{
${ }^{117}$ 馬摩西, 〈文藝的新使命〉, 《蕉風》1957 年第 36 期, 頁 5-6。

${ }^{118}$ 見其文〈文藝的新使命〉中的用語。

119 Martin Baumann, "Exile" in Kim Knott and Seán McLoughlin (eds.) Diasporas: Concepts, intersections, identities. London, New York: Zed Books, 2010, p. 20.

${ }^{120}$ Martin Baumann 2010, ibid, p. 23.
} 
在馬來亞成為宗教官, 是否出於宗教上獻身的追尋, 從他的散文來看, 實際上線索很少。 他從來不在文學裡書寫深入探索宗教與個人的心靈體驗。他翻譯的埃及小說, 亦多是現代 都會的愛情故事。那麼, 他當宗教官確實是出於宗教的召喚嗎? 可能確實如此, 從他捨棄 教職轉向月薪更低的宗教官職位來看; 然而, 這也有可能是因為馬來亞的宗教與公務員體 制架構, 比起英屬新加坡的華校教職更適合他。馬摩西的祖輩亦多擔任回教教長。121無論 如何, 馬摩西是在馬來亞剿共的計畫底下, 被邀請到宗教局任職, 以新村華人為宣教目 標, 使更多華人皈依伊斯蘭, 若以本土的國族語境而言, 這似乎也有助於塑造馬來亞民 族, 因為這使得華裔的族群與宗教身分更為複雜與多元; 若從馬摩西本身的經歷而言, 這 職位也能延續他之前所具有的, 開放的、把漢族也包括在內的伊斯蘭族群情壞。然而, 在 馬來亞的政治結構下, 要對中文讀者暴露自己的宗教使命, 卻又難以盡情道之。若從馬摩 西本身書寫涵蓋的諸多知識、興趣面向來看, 他的認同不僅限於宗教, 而是同時具有諸多 開放可能性的多元身分。漢語或漢族文化系統與伊斯蘭, 於他並非是全然分隔或不能擇取 所需而融合的。

馬摩西雖然對故鄉寫得較少, 但在書寫、報導埃及或翻譯埃及文學方面的稿件時, 卻 相當熱心, 幾乎異常關注。他曾經以興周這筆名, 在一九五六年八月的《學生周報》裡, 寫過一篇地理新聞〈蘇彝士運河種種〉, 描述當時埃及總統將蘇彝士運河歸為國有, 導致 英、法、以三國介人, 引發戰爭, 這實際上是殖民剝奪埃及資源的事件。122蘇彝士運河銜 接地中海與紅海, 為歐洲經中東區域最重要的交通樞紐。馬摩西以反殖民的立場報導這事 件, 其實也延續了過往民國留埃時與埃及同盟的情誼。他們當時從埃及學習阿拉伯語、翻 譯, 那使命既是幫助民國與埃及建交, 同時亦是幫助中國回族, 與當時現代化了的伊斯蘭 世界開拓溝通、交流管道。如同中國與埃及, 馬來亞當時即將從殖民者那裏脫離, 走向獨 立, 馬摩西投入於馬來亞, 繼續在此地呼㗳讀者關心蘇彝士運河事件, 仍然可以延續他從 留埃時期與其他留埃穆斯林夥伴一起進行的反殖運動與理念。

馬摩西來到馬來亞後, 從外交官變成宗教官, 專門處理與解決當地華覴皈依伊斯蘭教 之後, 率涉到諸般需要與相關家庭交流交涉的事項。在面對自身身分何去何從之時, 必須 得從現有的結構中尋覓生存之路。職是之故, 關於遷移的敘事, 其實乃是關於人從位置的 變動中尋找資源持續生存的故事, 個體在異地的結構中, 固然會面臨失落、各種與預期的

\footnotetext{
121 參見這一章前註 13 。

122 馬摩西, 〈蘇彝士運河種種〉, 《學生周報》1956 年第 4 期, 綜合版。
} 
落差, 但同時亦可能有新的資源與機會。在這樣的變動中, 個人的生命圖像也隨之變異更 移, 所肩負的「使命」由於對文化的認同多元而更加複雜, 甚至更加模糊。因此, 對一個 流動者而言, 「使命」（無論是宗教的, 抑或是文化上的, 如馬摩西念茲在茲的, 要在文 化沙漠中開拓綠洲）使得個體在異地落腳時, 可能有所依憑延續與開拓自身存在的意義, 但所肩負的「使命」也可能造成對敘述與探索書寫形式上的局限, 譬如在文學敘述中, 使 命賦予的宏旨與任務, 限制了書寫去探索那語言、細節與書寫形式的風格與特色。馬摩西 對宣教非常熱衰與積極投入, 但由於這些文學以外的活動, 包括其公務員身份, 馬摩西鮮 少在散文中提起, 故此《蕉風》與《學生周報》等中文刊物的讀者都沒有看到他這一面。 他將自身的穆斯林身分與中文寫作人的身分, 分由不同場域展現, 似乎以此才能維持他多 元多面向的身分。過去他經由國民黨政權的國族論述與現代化改革, 培育成具有漢語文化 修養的穆斯林, 馬摩西對於這一身分的回顧, 並非把穆斯林與漢語文化視之為對立的, 諸 如胡適的革命文章仍然頗合馬摩西的閱讀喜好, 他汲取、判斷哪些性質的書寫符合他自身 認可的性情, 或哪些對他的個性有益, 同時賦予自己流動在外, 比留在家鄉更能恢復自我 本性的解釋。馬摩西作為一個會講漢語的回族, 在民國的時候, 其社會地位其實優於土耳 其裔／語回族的地位。

這身分的塑造, 在他遷移到馬來亞之後, 持續進行。如同無意識的回應了馬來亞從獨 立後逐漸演化的族群分裂, 他也把自己的多元身分分開展現。從最初身兼宗教官與中文寫 作者的階段開始, 他就把自己這同時具有漢語文化修養的穆斯林身分, 區分開來, 如鏡像 般, 在不同語言的刊物與場合裡, 各別地顯露與隱蔽。 


\section{第五章 \\ 「人文主義」與「自由主義」 \\ 一一姚拓時代的《蕉風》}

\section{一、南來經歷}

我現在已忘記這些物件的清單, 但加在一起的總數絕沒有記錯, 一共 34 件。舉凡 是我們家中所有的物品, 一律都带到了新加坡。衣服和廚房用具自不必說, 連大床 彈簧大床熱、桌子、椅子、衣匮, 甚至連縫衣車、淂衣板都上了輪船。我們女兒的 睡床當然是必带之物, 我岳母想的更爲周到, 特地還訂做了一張上下鋪的隻人鐵架 床，以備我的第二個和第三個孩子出世後有個睡眠的地方。1

一九五七年二月，帶著這三十四件行李，三十五歲的姚拓偕同妻女搭乘輪船抵達新加坡。

${ }^{2}$ 由於當時輪船並無貨艙, 乘客得想辦法找空間來安置自己的行李。這些行李分散在船上 的三十四處, 牆角、梯後、小門旁、通道角落等等。姚拓得把這些行李與散置的地點, 都 記錄在一本小記事簿裏。3他如此回憶過境的手續 :

那時候星馬兩地和香港一樣, 都是英國的殖民地, 在香港申請一張出入准証, 就 可以隨便在新加坡或馬來亞登陸和居留。4

\footnotetext{
1 姚拓, 《雪泥鴻爪》, 頁 563-564。

2 姚拓, 《雪泥鴻爪》, 頁 562 。以這些笨重家具的行李, 為研究姚拓的論文起點, 也是歷史系陳聰榮老師 (Chen Song Chuan)在課堂上的建議。

3 姚拓, 《雪泥鴻爪》, 頁 564 。

4 姚拓, 《雪泥鴻爪》, 頁 562 。
} 
當時港、新、馬之間英屬殖民地過境需要申請出入准證, 或稱入境證(certificate of admission)。「從前因爲交通不方便, 香港人大多認爲星馬兩地仍是個落後地區。」「誰 知到了新加坡一看, 這個城市和香港一樣的熱鬧和繁榮, 什麼東西都不缺。」一九五七年 的南來旅途, 幾乎具象地描繪了姚拓此後的生命轉向, 且與他當初離家流亡的景況不同。 一九四九年, 姚拓拋下家鄉的妻子, 從河南魯莊偷渡至香港。八年以後, 姚拓前往馬來亞 的路上, 卻浩浩蕩蕩地帶了整副家當。航海數日, 家具行李暫成零散的狀態, 抵達後安頓 下來, 又重新組裝成家。這些實用的家具, 有些甚至是嶄新的, 從未用過, 竟都完好具 在。

姚拓於二 $○ ○$ 五年出版的《雪泥鴻爪》, 可說是他的自傳。原名姚天平, 又名姚匡, 另署姚拓、張兆、鲁莊、鲁文, 後兩個筆名顯然紀念故鄉。一九二二年, 姚拓出生于中國 河南省珘義市魯莊。一九三六年志願參加抗日, 而到洛陽入伍, 日本投降後, 又參加内 戰, 在國民黨敗退前, 他已晉升任總司令部警衛團少校團附。5 戰後, 中共實行重農土改 政策, 由於待在家鄉, 無法當教師, 便離開家鄉到南京去, 想連絡昔日從軍的友人, 暫時 在哥哥的香煙廠內做事。6 後因煙廠倒閉, 姚拓的哥嫂離開南京。此時昔日同伍的友人王 正明找上門來, 兩人一同流浪至香港。一九五 $\bigcirc$ 年姚拓抵港。住調景嶺的難民營, 靠打散 工為生, 曾經做過挖鵭礦、賣礦米等多份雜工。7這段期間他也開始投稿到報章上, 一九 五三年二月, 他到《中國學生周報》應徵校對的工作, 獲得聘用。四個月後, 余德寬把姚 拓升任為《中國學生周報》總編輯。8 一九五六年, 他被調任《大學生活》的社長兼主 編。在香港這段期間, 他也參與《友聯活葉文選》的編輯工作。一九五七年二月, 姚拓遷 移到新加坡，擔任《學生周報》的編輯。

在《蕉風》創刊初期數年的編輯與編委會當中, 只有姚拓與馬摩西曾在國民黨的體制 裡服務過。但馬摩西在中國易權之前, 就已身在馬來亞, 而一九五 $\bigcirc$ 年南下逃至香港的姚 拓, 卻是流浪的難民。數年後, 在姚拓離港前與其妻甘美華的合照裡, 衣冠楚楚。其轉折 難料, 恰如當初出發離家時：

\footnotetext{
5 姚拓, 《雪泥鴻爪》, 頁 702 。

${ }^{6}$ 姚拓, 《雪泥鴻爪》, 頁 438 、 475 。

7 姚拓, 《雪泥鴻爪》, 頁 276 。

8 姚拓, 《雪泥鴻爪》, 頁 529 。
} 
我當時根本就沒有想到, 我這次離開家郷, 就像斷了綫的紙感, 隨著時代的狂風暴 雨, 輱到了連上帝都無法預料的地方。9

流亡時的未知與徬徨, 是在事後回顧才意識到的。薩伊德所以爲的, 放逐者必然眷戀原 鄉, 在姚拓這本書裡, 卻因為當時出走之必然, 而不得不擱置多年, 然而行文中的家鄉人 事卻鮮明如昨。其懷念之情, 雖似保留, 不顯依戀, 但其實記憶深切。流亡者在異鄉生 活, 割捨對家鄉的眷戀, 實是不得不然。姚拓多年來安居馬來亞, 甚少流露思鄉悲愁。從 經濟、資源與物質來看, 無論是在河南老家抑或後來從軍南北十年, 都比不上他南來新馬 之後的發展來得穩定。出生的故鄉雖是青春成長所在, 卻也是流亡戰亂、民國破滅的故 土。日後的馬來亞（以及馬來西亞）才是他能夠順利建立家園與事業的第二故鄉。

根據姚拓的敍述，他在香港《中國學生周報》工作的數年（一九五三至一九五六）， 十分愉快。之所以離開香港到馬來亞, 是因爲他感到自己編《中國學生周報》, 卻不諳廣 東話, 難以和當地的中學生溝通, 尤其香港的中學以廣東話為教學媒介語, 新加坡與馬來 亞的華校則是以華文授課, 才想到新加坡另謀發展。10

\section{二、姚拓的編輯方針}

\section{（一）憶鄉書寫與去除純馬來亞化標語}

在姚拓來到馬來亞，加人 《學生周報》兼任《蕉風》編輯之後，《蕉風》裡本土性 稿件顯著減少, 少了地方知識掌故等稿件, 改成了以每期「現代佳作選」的方式, 刊用在 地作者的作品。一九五七年五月《蕉風》第三十七期改版，封面不再有「純馬來亞化」的 標語。 ${ }^{11}$ 增加的是其他南來文人的稿件, 包括黃思騁、秋貞理與古梅等, 不少撰寫故鄉的 回憶, 包括姚拓本人的小說。姚拓多從過去自己從軍的經驗取材, 寫了一系列行軍小說, 或記敘鄉親故里。12在姚拓擔任編輯時期, 《蕉風》不復如方天時期那樣, 全盤以純馬來

\footnotetext{
${ }^{9}$ 姚拓, 《雪泥鴻爪》, 頁 265 。

10 姚拓, 《雪泥鴻爪》, 頁 562 。

${ }^{11}$ 這並不表示《蕉風》放棄馬來亞化的文學, 它仍然經營諸如 $\ulcorner$ 馬來亞一日」的專號, 設計不同主題, 以及 刊登在地出生、成長的文人作品，讓「在地化」以作家自身的感情抉擇自然流露。

12 舉例有: 黃思騁, 〈大樹的故事〉, 《蕉風》1958 年第 66 期, 頁 16-17。秋貞理, 〈北國的春天〉, 《蕉風》1958 年第 66 期, 頁 8-9。王是, 〈長工包阿松〉, 《蕉風》1960年第 89期, 頁 16-17。姚拓, 〈丘陵上〉, 《蕉風》 1960 年第 87 期, 頁 10-13。羊羚野, 〈遙遠的懷念〉, 《蕉風》1 1960 年第 88
} 
亞化為編輯方針。不過, 早在《學生周報》、且自創刊以來, 就屡有南來文人回憶故土的 稿件了。

一九五七年獨立前後, 當憶鄉書寫出現在《蕉風》時, 卻已不復如三、四十年代的僑 民文學那樣, 以祖國為政治認同。對於這群逃亡離鄉的非左翼文人而言, 中國不再是可返 之鄉。這樣的書寫並不始於改版的第三十七期, 早在第三十四期, 就有古梅的散文〈風 砂、黃河、麥浪、騾群〉。 ${ }^{13}$ 古梅的稿件, 在《蕉風》與《學生周報》相當常見。她曾隨 父親在抗戰時期, 遷移到北方居住, 散文多寫故鄉的美好記憶, 譬如該地的織布手作、與 父母和鄉人相處, 但文章不僅抒寫親情溫馨的懷舊記憶, 也寫嚴峻的生存情況, 包括當地 婦女承受的求子壓力與迷信風氣, 以及嚴苛氣候與自然環境覆罩的死亡威勈。同期也刊出 力匡的新詩〈日曆〉, 詩歌排列出兩地共享的農曆時間, 但故鄉記憶與熱帶物候, 卻已然 今昔相異。 ${ }^{14}$

像這樣的兩地書寫, 更早以前有蕭遙天的「食風樓系列」, 但蕭遙天的文章裡, 有較 多篇幅寫馬來亞的見聞。在未改版之前的第二十九期, 蕭遙天也有詩作〈蕃茉莉與蕃拓 榴〉和〈第二個夢〉。15蕭遙天在檳城鍾靈任教。詩歌抒發對兩地故鄉的物象變化、那些 看似相同實則相異的感慨, 彷彿是在安穩日常中, 跟偶而浮現心靈的中閾狀態(liminal space)打照面。如同阿諾德 - 范 ·傑內普(Arnold van Gennep) 的觀點, 他認為個體經歷轉 換或階段變化的過程中, 必然會來到類似中閾的狀態。中閾狀態未必是離散主體才有的經 歷, 亦是個體在經歷社會地位、經濟、遷移、戰爭、疾病、身分變化等等, 人生階段遭逢 改變時的心靈狀態。 ${ }^{16}$ 主體體認到自我確認的憑藉與所處座標, 遭逢變化, 願意順應這些 變化, 或者等待轉移到新的狀態裡。誠如莊華興所言, 這群在國共分裂末期或之後來到馬 來亞的文人, 經歷家國動盪的創傷, 可能就隱藏在他們的書寫之中。 ${ }^{17}$ 但在方天當編輯的 時期, 《蕉風》既已標明純馬來亞化, 以本土化為方針, 當時未能有多少空間留予文人去 梳理這番經歷和變化。

期, 頁 21 。張兆〔姚拓〕, 〈美麗的童年回憶——不曾掏露的秘密〉, 《蕉風》 1960 年第 88 期, 頁 2324 。

13 古梅, 〈風砂、黃河、麥浪、騾群〉, 《蕉風》1957第 34 期, 頁 9-10。

14 力匡，〈日曆〉，《蕉風》1957 年第 34 期，頁 10 。

15 蕭遙天, 〈蕃茉莉與蕃拓榴〉, 〈第二個夢〉, 《蕉風》1 1957 年第 29 期, 頁 13 。

${ }^{16}$ Timothy Carson, Liminal Reality and Transformational Power, Cambridge: Lutterworth Press, 2016, p.2-3.

17 莊華興，〈黄潤岳在（後）大分裂时代的家國想象〉，《當今大馬》，2013 年 11 月 14 日, https://www.malaysiakini.com/columns/246566 
在此將以姚拓上任之後, 《蕉風》第三十七期的改版, 作為討論姚拓編輯方針最主要 的成果。《蕉風》不再以純馬來亞化的文藝為口號, 無論是小說、訊息或雜文, 都出現更 多馬來亞 $「$ 境外」的內容。除了上述所言的文人憶鄉書寫之外, 還有華人文化菁英在全球 走動的稿件或報導, 譬如從第四十七期開始, 有黃潤岳的〈飛越太平洋〉, 他在該年獲美 國新聞處安排到美國哈佛研修半年。 ${ }^{18}$ 其後在第四十八期, 有指畫藝術家吳在炎的報導。 通過這些專欄與報導, 《蕉風》介紹華人跨越區域、在全球流動, 追求現代藝術與文化知 識的範例。

\section{（二）「文壇雜話」}

從《蕉風》第三十七期開始, 推出「文壇雜話」版, 介紹多位中華民國時期的現代作 家。這系列從沈從文開始, 同期也刊出沈從文的小說〈黑夜〉。謝詩堅認為, 姚拓上任後 即實踐反共的立場，這一系列 $\ulcorner$ 文壇雜話』刻意捨棄傳記」，目的就是為了與左翼的詮 釋打對台。 ${ }^{19}$ 當時新馬一帶的左派文學陣營, 對於典範作家的塑造, 尤其可見於魯迅的神 話塑造，幾乎配合毛澤東的文藝政策，將之詮釋為共產主義的思想旗手。 ${ }^{20}$ 根據該期的編 者序言，「文壇雜話」的目的是「要把新文學運動以來」，「許多活著的和死去的」、 $\ulcorner$ 已經成名的和未成名的」作者諸事, 「都編成眾生相」。但或許那真正的用意, 卻要參 考那置於第三項「文訊」底下的解釋：

本刊的一貫立場是反對偶像崇拜, 我們實在不忍看見, 一些有血有肉、能說能笑的 作家們，被有意無意的捧成聖人導師，推進祠堂裡供奉起來。 ${ }^{21}$

這段才顯示了《蕉風》增添的版位（「文壇雜話」、「文訊」等等），打算挑戰、奪回新 文學的詮釋權。這系列「文壇雜話」持續近兩年。內容除介紹生平、文風特色與作家個 性，亦包括文人的交往圈子和他們之間的軼事。撰寫者有柳風、馬摩西、范提摩、趙聰，

\footnotetext{
18 在國共分裂末期, 黃潤岳被派駐至吉隆坡中華民國總領事館, 後獲准居留。他出發到美國時, 正擔任新 文龍中華中學校長。黃潤岳, 〈飛越太平洋〉, 《蕉風》1957 年第 47 期, 頁 6-7。蕉風, 〈讀者・作 者・編者 $\rangle, 《$ 蕉風》1957 年第 47 期, 頁 22 。

19 謝詩堅，《中國革命文學影響下的馬華左翼文學 $(1926-1976) 》 ，$ 頁 198 。

${ }^{20}$ 王潤華，〈從反殖民到殖民者一一魯迅與新馬後殖民文學〉，《華文後殖民文學一一本土多元》，頁 5176 。

21 編者, 〈一張新的菜單〉, 《蕉風》1957 年第 37 期, 頁 4 。
} 
最主要的撰寫者為劉藹如。所介紹的作家包括沈從文、李金髮、徐志摩、魯迅、郁達夫、 周作人、許地山、傅斯年、盧隱等等。

\section{（三）「萬里望」與「文訊」}

從同期開始，也增添「萬里望」及「文訊」版位。「萬里望」每期刊於首頁，跟讀者 徵稿, 內容涵蓋本地與國際、各種五花八門的新聞短訊, 是以去嚴鷫化、行文之間略帶戲 謔與玩笑方式處理的版位。

$\ulcorner$ 文訊」每期刊於最末頁, 或封內頁, 專門報導各地區的文學、文化與學術研究近 況, 也涵蓋藝術活動、作家與藝術家的動向和文化政策異動的消息。每期欄目劃分成三、 四個部分, 分別是星馬、香港、台灣、世界（或稱「國際」）與中國大陸等等，同時呈現 出多個區域華人的文化動態。以下將集中閭述文訊版的編輯方式, 以及這當中蘊含的意 義。

文訊版一開始並無中國大陸的部分, 要從六月號第四十期開始, 才加人中國大陸這區 域, 始於報導老舍、巴金、張恨水與劇作家曹寓的處境。 ${ }^{22}$ 猶如大多數的反共刊物, 中國 大陸的欄目可說是抱著曝露中共面目的目的, 除了報導作家創作出書消息, 也常常報道作 家的發言, 述其抱怨之辭, 似有意為當時受打壓的作家傳達意見。時值中共百花齊放, 文 壇尚有讓作者抒發意見的空間。稍後便陸續刊登中共實施的嚴厲控制, 包括與工農兵劃一 的文藝政策、稿酬分配、檢討批判等。所關注的個案, 多以文化界名人為主, 包括作家、 翻譯家、藝術家、畫家、記者、學者。從中國當局的文藝政策、刊物的編輯原則變動、開 會事項、作家的寫作與出版狀況、被派下鄉勞動的作家群乃至到學術刊物的出版與考釋狀 況。

大部分的訊息都像是裁剪的新聞摘要。資料來源應是由友聯研究所提供。每期刊登三 至八、九項, 篇幅最長時 (中國大陸地區) 也僅佔半頁。雖是簡短數行, 已足以呈現出極 權控制下的社會。這些簡短的新聞, 時間交代多數模糊, 大部分常含糊地表示為 $「$ 最 近」。所報導的區域, 地幅遼廣, 即便發生在邊遠地區, 友聯都能夠蒐集到消息。譬如由 名翻譯家張友松和山東師範學院的幾位教職員, 共同出版的小型刊物《我們的戰歌》, 因

22 文訊版, 《蕉風》1957 年第 40 期, 封底內頁。 
表達對中共不滿, 又在學院內廣為流傳, 而被中共圍剿挖刨。23 時而也有相當戲劇性的描 敘, 如第四十八期描述姚雪垠被打入右派經過 ${ }^{24}$, 第四十九期刊登被打入右派的作家蕭 乾, 針對文壇上的批鬥風氣提出批評 ${ }^{25}$ 。在第五十二期, 報導山東省文人王希堅因詩得禍 一事, 列出詩句之後, 編輯還特別附加註釋, 說明這是一首反詩, 以讓讀者曉得此詩惹禍 的原因。這些報導裡頭, 少數有略加評語, 但大部分都表現出宛如新聞報道般的客觀語 氣, 也有不含反共議題的, 譬如, 第五十三期報導中共最近公佈的漢語拼音方案、以及 $「$ 評劇創始人之一的成兆才先生, 編成了一部《成兆才評劇選集》」。 ${ }^{26}$ 與其他地區的欄 目, 刊於同一頁內, 在與其他地區相較之下, 中共的統治與文化政策, 更顯得分外荒謬。 但與其認為這是為了凸顯中共的極權壓迫, 母寧說, 這樣的排版也同時是因應全球華人社 會的變化而生。在國共分裂之後, 各區域的華人社會也在不同政體下各自求存發展, 中國 則成為與其他區域交流極少的文化區塊。在閱讀這些摘要短訊時, 除了上述發生於中國境 內的政治批鬥與文藝政策壓制的現象之外，同時也會看見各地文化動態的變化。

關於台灣地區的部分, 亦不乏揭露真相之意, 譬如在第三十八期, 就刊有香港的《祖 國周刊》申暢銷台灣一事, 「因為周刊載有左舜生先生所作『對台北壓迫自由的一個抗議』 一文, 運到台北時即被搶購一空」。 ${ }^{27}$ 由此顯露出在國民黨統治下, 臺灣的文化與言論自 由亦遭政府監控的真相。此外, 也觸及當時臺灣的文藝批判現況, 譬如在一九五七年六月 號《蕉風》裡, 文訊版報導臺灣於一九五 $\bigcirc$ 年成立的中國文藝協會, 召開會員大會, 其會 議決議包括減少作品中的形式主義與口號、強調作家應該廣泛吸收知識; 同一期也報導臺 灣文壇有作家對文藝獎金的評審過程感到不滿, 而掀起筆戰。與臺灣文人爭取言論與寫作 自由的情況相比, 同一頁卻有中國大陸的詩人歐外鷗, 圍繞著「反宗派主義」和「教條主 義」的會議議題發言, 表達出在極權面前, 文人無能為力反擊的沮喪事實。28

在眾多受到文化政策影響的事項當中, 與友聯關聯密切的, 當屬古典典籍與文學叢書 出版事項。文訊版對各地的編書過程與成果相當重視, 有多期報導臺灣與中國編彙、出版 典籍叢書的消息。譬如, 在一九五八年初, 文訊版刊登臺灣編纂中華文彙, 並列出書目,

\footnotetext{
23 文訊版, 《蕉風》1957 年第 45 期, 封底內頁。

24 文訊版, 《蕉風》1957 年第 48 期, 封底內頁。

25 文訊版, 《蕉風》1957 年第49 期, 封底內頁。

26 文訊版, 《蕉風》1958 年第 53 期, 封底內頁。

27 文訊版, 《蕉風》1957 年第 38 期, 封底內頁。

28 文訊版, 《蕉風》1957 年第 40 期, 封底內頁。
} 
顯其陣容, 頗讚其校勘精細。 ${ }^{29}$ 同期也刊登中國正有計劃地出版五四現代文學系列, 也展 開校對的工作。兩地各自出版叢書, 方針大為迴異。中國大陸著重現代文學, 強調薄古厚 今, 而臺灣則相反, 由於國民黨實行發揚傳統中國文化的政策, 極度重視漢學古籍編著。 同期也報導中國大陸正主張把學習文藝, 拼人人民文學, 使之更符合社會主義文學的陣 地，因而不惜大幅度調整多份期刊方針。

文訊以短小段落的方式報導各地區的單獨個案, 在短時期内, 尚看不出其社會狀態的 變化，然而經過一段稍長的時間，兩年內跨越百花齊放、大鳴放、檢討時期，這些碎片 的、斷片式的記敍, 也就累積成相當有影響力的份量, 讓讀者看出中共政策的專制以及把 文化與工農兵劃一的政策，對文化各方面造成的龐大破壞。

與中國大陸相對而言, 其他地區如馬來亞與香港, 尚可說是在和平狀態中部署、漸次 進展。至於臺灣方面的報導, 除了開首數期對國民黨政府有較明顯的諷刺之意, 稍後就漸 漸節制, 對於國民黨實行的方言族群與話語空間的壓制, 幾乎全然略過不提。中國大陸寫 來則充滿光怪陸離。實際上, 若與〈文壇雜話〉比較, 文訊版可能更具有反共意識, 表現 出友聯社當初成立時的反國、反共的立場。

在新馬部分, 則關注馬華社會的教育界、文藝界消息, 包括戲劇演出、新書出版、翻 譯叢書與教材出版或運銷本地的消息, 此外也有著名作家（如韓素音）的記者招待會、外 地作家來訪、華文中學與大學中文系的人事更動、南洋研究協會的進展等等。即便是對於 自認為立場左派的文人, 如姚紫的新著出版, 亦不吝於給予關注和報導。同時, 這個版位 也常報導作者的職位異動, 包括方天、蒍遙天、李定華、馬摩西和多位作者的職業崗位, 都是透過這版位才對讀者披露。 ${ }^{30}$ 透過萬里望與文訊這兩個版位, 《蕉風》也表現出它䅅 欲開拓、尤其是在中共統治區以外, 銜通各地華人文化板塊的交流通道, 以及建立與在地 華人文化界之間的聯繫。

\section{三、人文主義的定調}

${ }^{29}$ 文訊版，《蕉風》1957 年第 54 期，封底內頁。

30 方天、蕭遙天、馬摩西的資料, 均參見《蕉風》1957 年第 37 期, 文訊版。李定華的教職與更動狀況, 參 見《蕉風》1957 年第 41 期, 文訊版。 
誠如謝詩堅所言, 姚拓來到馬來亞開始編輯《蕉風》之後, 更為落力地貫徹友聯的 反共宗旨。上述的編輯方針改變，可說是在具體化實踐反共的目標。

\section{（一）歐美冷戰時期的人文主義觀}

一九五九年第七十八期的《蕉風》刊出陳思明寫的改版宣言〈改版的話一一兼論馬華 文藝的發展路向〉, 賦予了這份刊物以人本主義或人文主義為其人文精神期許的觀點。31 文中不乏光明、積極意識的用語。雖然如此, 若僅讀其文本表面, 卻難以從這些抽象的語 彙去指向一個具體的對象, 譬如 「『人性的尊嚴, 生命的和詣』是我們文蒦創作的最高目 標」。 ${ }^{32}$ 故此需要追溯與其文本相連的脈絡, 才可能明白這篇文章如何產生、呼應哪些思 潮。

文章追溯十四、十五世紀的文藝復興時代, 強調 $「 人 」$ 是歷史的中心。 ${ }^{33}$ 文章並沒詳 述與此相關的時代背景, 但人本主義在冷戰時期播散的論述, 從歐美知識分子的英語圈 子, 到中國流亡的知識分子, 各呈分歧。在歐美英語圈子裡, 人本主義被引用為鑄成民主 國家與鐵幕國家之間二元對立的論述。一九四三年, 雅各布克哈特(Jacob Burckhardt)《義 大利文藝復興時期的文明》(The Civilization of the Renaissance in Italy)的英文版在倫敦面 世, 出版後受到矚目。書中對個體自由的高度推崇, 被大量引述以抵禦戰後崛起的極權主 義, 從德國、東歐奉行的共產主義, 乃至到抨擊美國國內發生的麥卡錫主義。34布克哈特 對平均主義與民主極度推崇, 他的論述也突出了過去曾遭壓抑的個體自由。 ${ }^{35}$ 由於五十年 代剛好處於戰後以及下一波學潮之間的階段, 布哈特《義大利文藝復興文明史》在這個時 期也備受重視。稍後, 在一九五五年, 由出生德國、美籍猶太裔的歷史學家漢斯巴倫 (Baron Hans) 所撰寫的《義大利文藝復興初期的危機》出版, 這本書從文藝復興的戰爭 史, 研究這場戰爭如何影響後世對文藝復興的詮釋, 尤其關於戰爭中的其中一方, 自由共

\footnotetext{
31 這份改版宣言署名「本社」，其實出自社長陳思明，參見白圭，《縷雲起於綠草》，頁 74 。

32 本社, 〈改版的話一兼論馬華文藝的發展路向〉, 《蕉風》1959 年第 78 期, 頁 3 。

33 本社, 〈改版的話——兼論馬華文藝的發展路向〉, 《蕉風》1959年第 78 期, 頁 3 。

${ }^{34}$ Lionel Gossman, Jacob Burckhardt: Cold War Liberal, The Journal of Modern History, 2016, vol.74:3, p.538-572.

${ }^{35}$ Lionel Gossman, ibid, p.550.
} 
和國的觀點, 引起冷戰時期歷史學家的共鳴, 在當時蠻有影響力, 也延伸到極權主義與自 由主義的相關論述裡。36

\section{（二）二十世紀初中國民國時期的「新人文主義」}

人文主義的文化脈絡與淵源, 在中國知識分子的圈子裡, 可溯自二十世紀初的新人 文主義, 之後相隔三四十年, 又有香港新亞書院鼓吹的人文教育理念。人文主義引進中 國, 可追溯自二十世紀初, 由學衡派的知識分子、梁啓超與嚴復等人通過翻譯引進而發揚 的新人文主義。37當時, 中國知識分子焏欲吸收西方思潮, 留美哈佛歸來的「學衡派」與 稍後的梁實秋相繼翻譯引入, 所發揚的是美國哈佛大學白璧德的「新人文主義」理論, 屬 於較為收束、節制、理性的觀念, 以克制慾望作為超越神性的展現, 被認為更接近古典主 義, 與當時五四新文化派的啟蒙主義有極大分歧。 ${ }^{38}$ 同時亦跟十四世紀下半葉在義大利興 起的人文主義不同。義大利文藝復興的人文主義, 肯定現世的人生意義, 主張個性解放、 享樂, 肯定人欲, 以此對抗神學理性。 ${ }^{39}$ 二十世紀初, 由學衡派與梁實秋等知識份子, 所 宣揚的新人文主義, 其實更近推崇中西融合的文化理念與傳統。它與後來共產主義的「唯 物」觀, 乃是完全對立的系統。 ${ }^{40}$

一九五九年《蕉風》第七十八期提及的人文主義, 當初並未有充分闡釋, 「改版宣 言」亦未曾言及這段二十世紀初「學衡派」與稍後梁實秋帶來的影響。白圭多年後追憶， 卻點明了當時的人文主義, 即為「新人文主義(New Humanism), 源自十九世紀的美國文

\footnotetext{
${ }^{36}$ Martin A. Ruehl 2015, The Italian Renaissance in the German Historical Imagination, 1860-1930, Cambridge: Cambridge University Press, p.254.

37 黃克武, 〈「個人主義」的翻譯問題一從嚴復談起〉, 《二十一世紀雙月刊》 2004 年第 84 期, 頁 4051 。

38 李怡, 《中國文學的現代性 : 批判的批判》, 臺北 : 秀威, 2010, 頁 103-104。白春超, 〈古典主義與現 代中國文學 $\rangle, 《$ 二十一世紀》網絡版 2003 年 3 月總第 12 期。

http://www.cuhk.edu.hk/ics/21c/media/online/0301047.pdf

39 鍾鳳美, 《梁實秋先生的事蹟及散文之研究》, 臺北 : 國立政治大學中國文學研究所碩士論文, 2003, 頁 109 。李怡, 《中國文學的現代性：批判的批判》，臺北：秀威，2010，頁 105 。

40 鍾鳳美, 《梁實秋先生的事蹟及散文之研究》, 頁 109 。
} 
學大師諾頓(Charles Eliot Norton )」，二十世紀初梁實秋等人引入的「新人文主義」是經 過白壁德闡釋傳授，而白壁德「即為諾頓傳人」。41

\section{（三）冷戰時期新亞書院的人文主義}

冷戰時期，近在香港，則有錢穆、唐君毅、徐復觀與牟宗三等人，在南渡香港之後， 一起鼓吹的人文主義。在一九四九年中共執政之後, 這群知識分子在香港會合。最初他們 在香港創立人文學會, 過後開始以夜間授課的方式, 租用九龍偉晴街華南中學的三間課 室, 開設亞洲文商夜校, 在一九四九年十月十日開課收生。最初全校師生只有二、三十 人。到得次年三月, 因為原來的校監不再合作, 才在教育司署另外註冊新的學校, 即為後 來的新亞書院。 ${ }^{42}$ 錢穆、唐君毅在創辦新亞書院時, 均標舉人文主義精神為新亞的教育理 念, 一般以為是以此來反對中國共產黨的辯證唯物論。43但錢穆的人文主義, 並不僅為了 反共。如最初於一九四九年三月的〈招生簡章節錄〉裡所言：「旨在上溯宋明書院講學精 神, 旁採西歐大學導師制度, 以人文主義之教育宗旨, 溝通世界中西文化」, 強調書院內 的行政事務必須「採絕對民主方式……以求教育精神之始終一致」。 ${ }^{4}$ 雖然其中也有因流 亡、戰亂經歷, 意識到當時蔓延東亞區域的冷戰狀況, 因而也分外強調「在今日民主主義 與極權主義鬥爭之下」, 需要堅持「發揚中國傳統的人文主義精神」。 ${ }^{45}$ 但也意識到香港 的歷史與地理, 具有中西文化匯聚的特殊性, 因而新亞書院的人文主義精神, 亦體現於促 進古典中學傳統與現代的統合, 這一切都形鑄為新亞書院的人文主義精神。香港的新亞書 院, 在唐君毅為教務長, 而錢穆為院長的時期, 便積極重建過去在中國一直無法實現的人 文教育理念。46這包括重新彌補過往在中國長期奉行黨國體制之下, 現代教育走向偏差的

\footnotetext{
${ }^{41}$ 白圭, 《縷雲起於綠草》, 頁 74 。

42 錢穆, 〈新亞書院沿革旨趣與概況〉, 《錢賓四先生全集——新亞遺鐸》, 頁 5-20。亦參見〈研究所計 畫綱要〉, 頁 72-74。廖伯源, 〈第三章 錢穆先生與新亞研究所〉, 收於鮑紹霖、黃兆強、區志堅主編, 《北學南移：港台文史哲溯源（文化卷）》，臺北：秀威，2015，頁 89-104。

43 沈清松, 李杜, 蔡仁厚, 王壽南, 中華文化復興運動總會主編, 《中國歷代思想家 (二十五) : 馮友 蘭·方東美・唐君毅・牟宗三》, 臺灣：商務印書館，1999。

44 錢穆, 《錢賓四先生全集——新亞遺鐸》, 頁 3-4。

45 錢穆, 《錢賓四先生全集——新亞遺鐸》, 頁 7 。

46 陳以愛, 〈錢穆論人文主義教育的失落與重建〉, 《國史館館刊》2015 年第 45 期, 頁 153-198。
} 
問題; 亦試圖平衡那打從抗戰以來, 就廣泛流行的實用主義、理科高踞的教育思維, 再度 重建人文學科的教育空間。

在香港友聯出版社裡, 許多社員包括古梅、奚會暲、王建武和孫述宇，均在一九四九 年底抵港後, 入讀新亞書院。如古梅曾在口述歷史中, 自承深受新亞書院的人文精神所感 召。跨越一九五 $\bigcirc$ 年代, 友聯出版的眾多書目裡, 有包括《人文主義論叢》、《自由民主 論叢》和柯亨(Cohen)所著《自由主義者的信念》等書, 在當時香港《中國學生周報》刊 登書訊的宣傳標語, 就有「探討自由民主之真義 謀求中國文化與再生」之語, 廣告裡所 列的書目, 均為與西方或現代思想與制度研究叢書。47惟這些書裡, 有一部份可能是美新 處翻譯了, 再轉讓友聯發行的。 ${ }^{48}$ 在友聯創社的宗旨當中, 其中一項為「發揚與傳承中華 文化」，一九五九年《蕉風》引入的人文主義與自由主義論，似乎也頗有為「發揚與傳承 中華文化」護航的意思。人文主義除了聲明人的生命乃奠基於自由之外, 也重視傳統。承 襲人文傳統與人文遺產, 使人文精神再生而不致流失, 這樣的意識與過往二十世紀初梁啓 超與嚴復等人宣揚的「新人文主義」（後者對經典與傳統文化極度推崇）, 其實都有共通 點。在新亞書院, 錢穆所鼓吹的人文主義精神, 也具有從香港這塊邊緣之地, 繼承、發揚 文化傳統以及促進中西文化溝通的意義。 ${ }^{49}$ 在一九五 $\bigcirc$ 年代末, 友聯出版社宣傳的發稿 裡, 當初並沒點明相關的脈絡與淵源。但友聯顯然是吸收了新亞書院的人文主義精神, 隨 著離散來到新馬, 在此地加以推廣、傳播。

新亞的人文主義精神, 更多關係到流亡至香港的非左翼知識分子, 從邊陲之地與失鄉 亡國的失落中, 重建文化主體的自我認同。在這層面上, 幾乎如同王愛華(Aihwa Ong)與 當納德 - 那尼尼(Donald Nonini)的跨國主義理論所言的, 脫離母國帝國的極權式監控與統 治機制，這些離散華人以「跨國的流動性」，「身分認同與國家之間的空隙」來閃避國家 的權力, 使其行動不限於一地。 ${ }^{50}$ 但是, 他們對待中共文化語境採取的抵抗與挑戰的意 識, 卻不盡然是 $\ulcorner$ 無國」的, 也不盡然能游離於國家之外。因著戰後現代國族論述的興

47 《中國學生周報》1958 年第 289 期。「香港文學資料庫」網頁， http://hklit.lib.cuhk.edu.hk/pdf/journal/78/1958/177237.pdf

48 林悅恆口述, 《香港文化眾聲道》, 頁 181 。

49 區志堅, 〈以人文主義之教育為宗旨, 溝通世界中西文化 : 錢穆先生籌辦新亞教育事業的宏願及實 踐〉, 王宏志、梁元生、羅炳良主編, 《中國文化的傳承與開拓：香港中文大學四十周年校慶國際研討會 論文集》，香港：香港中文大學，2009，頁 85-180。

50 黃秀玲, 〈去國家化之再探：理論十字路口的亞美文化批評〉, 載《離散與家國想像》, 頁 47-94。 
起, 無論是對於在地的國族論述, 抑或是基於接受美援的資助, 皆有因時因地加以調整、 配合與彈性變動的策略作法, 當中也挟帶著為求生存、建立安穩的物質生活、必須爭取更 多資源等等多重因素。反共, 之於這群南來文人, 並不只是被美援、英殖民地政府或獨立 後的國家體制所召喚。這群流亡知識分子從香港開始, 聚團組社, 形成反共、反國的團 體, 把他們連結成共同體的源頭, 甚可追溯到一九四九以前, 那打從中國尚處於國民黨統 治時期以來, 就老早埋下導致人文體制潰敗的集體創傷。香港新亞書院的人文主義精神, 便是為了重建那遭到過往黨國施政所壓制的人文空間。

\section{（四）在地屬性的人文主義}

陳思明在一九五九年的《蕉風》改版宣言裡, 重提人文主義, 一方面既與新亞書院的 人文主義精神遙相呼應, 一方面也表明希望人文主義能夠在馬來亞延續, 從此地獨有的文 化特性之中, 誕生自己的屬性。通過南來文人的離散, 到在地文化空間中各個層次的參 與, 人文主義的理想並非沒對華文教育與馬華社群的文化結構產生影響。隨著民國末期的 南來文人離散到馬來亞, 建立起具有協商特性的現代華人文化產業; 從古典中學典籍到西 學引入, 乃至於與本土多元面向的對應, 徹底取代左翼, 構築了可融入現代國族語境的文 化資源及產業網絡。

友聯諸人在馬來亞的活動, 其實是甚有策略性地操作 (包括與諸多在地政要建立關 係）。一方面他們的反共立場, 有利於達到自身的宗旨（包括傳承中華文化與人文主 義）, 與此同時, 他們與亞洲自由協會合作的契約, 也促使他們產生了另一不同於左翼、 但也不同於國民黨的文化傳播方式。 ${ }^{51}$

友聯的人文主義也體現出對於在地多元文化的吸收, 這在初期《蕉風》的純馬來亞化 定位裡其實已經彰顯。 ${ }^{52}$ 在由陳思明撰寫的改版宣言裡, 從他對馬華文藝的期許裡可以獲 得證實 :

\footnotetext{
51 蔣介石於一九六 $\bigcirc$ 年代推行中華文化復興運動, 當時也大量促使出版社與學術機構出版典籍譯注, 兼及 通過傳播管道, 塑造台灣國族話語的運動, 惟在這建構中也有排他性, 如排除台灣島上多源流的方言文 化。參考解昆樺, 《轉譯現代性：1960-70 年代台灣現代詩場域中的現代性想像與重估》, 台北：台灣 學生書局, 2010。

52 這點尤其體現於方天的現實主義寫作, 以及《蕉風》早期的各種地方記敘與本土傳說、神話、地方掌 故、友族習俗的書寫。
} 
無疑的，文學與藝術亦必將波瀾壯闊的奔赴這個重新以「人」為中心的歷史路向。 至此，馬華文藝的發展路向已很清楚。

不過，就中華文化的變遷來說，馬華文化的發展應更有另一層意義。……中華文化 南下伸展，在海外已形成了三大「重鎮」：一是台灣，一是香港，一是星馬。雖然 在星馬我們華人除了發揚本身的文化之外，還與其他兄弟民族共同建國、共同創建 新的文化，但作為中華文化「再生與新生的重鎮一點」，其意義卻完全一樣。

從上述這篇改版宣言裡, 陳思明再三強調的, 馬華文學如此被看重, 是因為它在中 華文化傳播的過程中, 分外具有「另一個意義」, 這意義關乎於離散文學, 也是關於吸收 在地特質而生成的文化屬性：「人類文化活動的特性, 是愈能多接觸其他文化、愈能獲得 新血、新的生命力, 便愈能充實、䇺盈」, 在此, 陳思明對於馬華文學的勉勵, 似乎也延 續、再度印證了郁達夫當年對馬華文學的建議, 雖然兩者意識形態不同。當中國經已

$\ulcorner$ 淪」為赤化的統治區域後, 馬來亞作為「海外重鎮」、所能寄寓的非左翼華文文學可能 性, 必然也無法避免融攝在地的文化與語言, 以生成自身的文學屬性。

\section{（五）隱烸的反共意識與修辭}

與本土化多元文化交融的意識, 其實亦與反共的宗旨相當配合。一九五 $\bigcirc$ 年代, 美國 擔心東南亞進一步被赤化, 因而挹注大量資金幫助法國軍隊, 以及支持稍後在南越成立的 西貢政府。反共的文化運動, 顯然有必要擴展成跨境的區域之戰, 以遏制東南亞各國隨著 骨牌效應被赤化。早在一九五一年初期, 亞洲自由協會就已經擬定促進本土化認同的策 略, 以減少共產主義意識對華人的影響。

$\ulcorner$ 以人』為中心的歷史路向」, 這個句子其實過於寬泛且抽象。或許必須將之與中

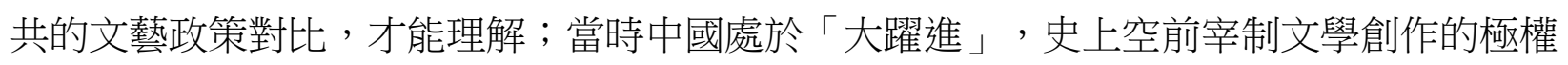
狀態。而在馬來亞, 同樣的控制也經由英屬聯邦的剿共計畫施於左翼陣營, 「以人為中 心」倘若漠視這點, 無疑相當諷刺。在官方嚴厲獣共的行動之後, 過往較為激進的左翼文 化空間, 大為壓縮, 但仍有雜誌刊物、劇團活動, 頌揚崇拜毛澤東的口號標語, 且從者甚 眾; 對《蕉風》與《學生周報》的杯葛方式, 往往徵引毛澤東《延安文藝》, 且動輙謾 
罵。友聯的批判對象, 或許仍是朝向那從中國開始、蔓延到東南亞的毛澤東鬥爭意識。

$\ulcorner$ 以人為中心」，仍然是以中共極權壓制為反面的參照對象。

但在陳思明的宣言裡，反共的用意似乎同時也被隱蔽化，雖然強調「以人為中心」 $\ulcorner$ 人性的尊嚴」, 然而改版宣言中「對人類前途和中華文化抱有極為堅定的信念」, 到底 是甚麼樣的「堅定信念」, 讀來也不免模糊。雖然修辭樂觀鼓舞, 但到底內涵是甚麼, 文 內並無闡述。文章沒有道出, 其「堅定的信念」為何（馬華文學應該要朝向「非共」的方 向發展) ? 是否應該將《蕉風》普遍裡文學意見裡反共的淡化、保留, 理解為遮蔽、掩飾 ${ }^{53}$, 抑或，還存有別的原因?

一部分原因, 誠然如研究港台美援文化文藝體制的王梅香所言, 出於美援反共的體 制有其權力運作的隱蔽性。然而, 友聯出版社對於自身的反共宗旨, 在港時並不諱言。 無可否認, 來到馬來亞之後, 由於英殖民地以巢共目的而壓抑華教, 導致校園裡學潮騰 湧, 使得學潮與維護華校運動者, 也連帶排斥具有反共意識的《蕉風》與《學生周報》, 甚至把參與《學生周報》的通訊員或代理刊物的學生視為走狗。這樣的抗拒與敵意, 一方 面固然影響銷路, 導致《蕉風》與《學生周報》在校園裡遭遇困難重重, 對於招收學生通 訊員, 以及通訊員本身在校內的運作與人際網絡, 也殊為不利, 故而, 在刊物上, 無論是 編後語、徵稿說明、文學意見、評論乃至到改版宣言, 那「反共」色彩, 理當就該低調處 理, 按照這樣的理解, 遮蔽似乎就顯得理所當然。

然而, 從《蕉風》和《學生周報》每期的文訊版來看, 其反共立場, 幾乎是公開的 秘密。

《蕉風》與《學生周報》真正表現得比較隱晦的, 主要還是在於文學論述方面。如 前所述, 高峰為二周年紀念刊宣言而寫的〈酒逢知已千杯少〉, 梳理了「為文藝而文藝」 和「為政治而文藝」的問題之後, 並不因此提供解答, 僅言 $\ulcorner$ 一種文藝風氣的形成, 不可 能有突然的革命行動」。 ${ }^{55}$ 這樣的隱晦目的, 或者出於文學的變革路向, 總是在場域中動 態進行。而「文學意義」難以言盡; 文學本體的解答仍然有待探尋。

53 這裡參考了王梅香的說法。美國的反共行動滲透與編入文學文本, 也構成了意識形態在文學符碼中的隱 蔽特性。王梅香, 《隱蔽權力: 美援文藝體制下的台港文學》, 國立清華大學 : 社會學研究所博士論文, 2015 , 頁 7 。

${ }^{54}$ 王梅香, 《隱蔽權力：美援文藝體制下的台港文學》，頁 7 。

55 高峰, 〈酒逢知已千杯少〉, 見前註, 頁 4 。 
$\ulcorner$ 反共」雖可作為政治立場的參照, 但卻難以指出 $\ulcorner$ 人文主義」理念作為啟開創作 自由的實質意義。周作人曾經嘗試 $「$ 以人為本位」, 提出改革性寫作方向, 追尋自由、解 除靈肉二分的文學觀。陳思明本身並不具有文學思路。僅從其改革宣言來看, 倒像是精神 理念上的召喚。從 $\ulcorner$ 人文」到 $\ulcorner$ 在地」, 兩個軸向其實並無邏輯上的因果關聯, 較像是將 兩個觀念並列, 指出馬華文學有必要在本土建立與實踐多元文化的人文理念。由此也再度 與延安文藝觀影響下的左翼文學, 劃出區別。

公開表明文學上的反共, 與其主張自由主義的文學原則其實有牴觸。恰如編輯在徵 稿啟事裡所言的, 刊物接受各種多元流派、路線的創作。按照自由主義的理念, 就理當接 納各派作風, 無論那是否具有社會主義傾向的現實主義。「自由主義」允許㽎酌其所能接 受的, 乃至與最大衝突的極限共存, 即便是具有左翼特色的社會主義創作。在理念上, 自 由主義應當不能被任何一種流派的意識所壟斷（除了自由主義本身）。然而, 沿著這自由 的無限理念, 仍會抵達那不得不面對的, 横瓦於自身定義的弗詭問題：那理念多樣各異的 文學流派, 如何共存? 把這些殊多差異推至極限的最大邊界在哪? 《蕉風》在一九五九年 推出的人本主義, 「以人為中心」無疑是試圖為此一問題尋找答案。「以人為中心」, 擁 護人作為創作主體的絕對權力, 由此延伸為反對壓抑創作自由的極權性。故此, 自由主義 本身便恐怕不志在反對那寬泛意義的「左翼文學」一一尤其「左翼文學」其實是內容、水 平與風格都仍然多元繁茂的概念, 譜系也多重, 譬如, 以馬華文學而言, 就有左翼的作家 姚紫 ${ }^{56}$, 他的現實/寫實主義小說技藝頗受上海新感覺派的美學觀所影響, 即便如此, 在 反黃時期他的小說也不免被學潮學運團體, 評擊為色情與䅡廢之作。

這份改版宣言所給的意見, 其實也並不純粹屬於文學觀點, 實際上可能更接近文化 觀念。通過文化觀念的梳理, 《蕉風》才能表明它本身的文學立場, 即以 $\ulcorner$ 人文主義」和 $\ulcorner$ 自由主義」為原則, 以培育在地土壤與文化多元作為地方屬性。它並非是立意為支持任 何特定流派、文學風格而生的雜誌。它既欲與中共的意識對抗、同時又不欲陷入任何左右 勢力的定義。一九五五年萬隆會議在地區上掀起的迴響, 也滲透在地的華人社會。《蕉 風》作為一個從離散到在地開拓文化空間的刊物, 並不能忽略周圍的語境轉變。惟從其反 共立場而言, 固然得堅持、極力使這在地的文化土壤「非共」。但是, 萬隆會議所提出 的, 不傾向冷戰中任何一方陣營的主張, 已影響了東南亞國家的政治定位與外交路線。比

56 葉觀仕對姚紫在報社的經歷, 有過如下概括 : 姚紫是左派份子, 一九五六年, 姚紫曾在一家報社《鐘聲 報》任職, 由於他把「左派思想」帶進報館, 因此導致《鐘聲報》被查封。葉觀仕, 《馬來亞華文報業 史》, 頁 122 。 
起美國那以中共為參照的反共觀點, 萬隆會議的主張, 其實更能與那勸諭華人安居本地、 落葉生根的思維所吸收與融合。《蕉風》的文訊版與萬里望這兩個版位, 就相當策略性 的, 試圖在友聯社的反共宗旨之外, 吸收東南亞的國家主體和反殖意識增長的政治語境, 從中尋找一條可以平衡兼顧的路線。

\section{（六）人文主義和文學的關係：置換與過渡}

到底人本主義如何影響「在地化」馬華現實主義小說，如何落實在創作，其實也沒有 清楚的指向。人文主義對力匡的新詩, 或對姚拓與黃思駎的現實主義小說, 可能較見影 響。張錦忠曾經「將『馬來亞化的寫實主義』和『人本／個體主義』合而為一，以着重人 本／個體主義的寫實主義當馬来亞化的寫實主義, 故稱之為『馬來亞化』」, 以此跟左翼 馬華文學向來認同的中共社會現實主義相區別; 但後來在二○○四年討論白圭第一波現代 主義的論文裡，張錦忠做了修正，把 $「$ 馬來亞化的現實主義」與人本主義分開。 ${ }^{57}$ 說到馬 來亞化的寫實主義書寫, 當以方天莫屬。但方天的寫實主義, 其實亦有相當份量的社會主 義意識。方天小說中的個體意識, 總是在與階層的共同體集體意識, 處於矛盾的張力之 中。姚拓與黃思騁的筆耕, 雖可稱之為人本意識、反戰意識的現實主義, 因其小說分外彰 顯出個體的生存慾望, 以及在命運中的浮沉, 與方天那富有社會主義關懷的寫實主義作風 全然迥異。姚黃兩人早期抵馬的小說, 雖從其內容而言, 未必是馬來亞華文小說, 但從華 文文學的區域史上，他們的小說卻顯出，惟獨在新馬與香港，才可能允許「非國、非共」 旋律的抗日敘述。黃與姚兩人的抗日小說中, 頗多反思個體而非訴諸集體（如國族或民族 主義）價值的生命觀, 更主張生命、美醜、平等諸多普遍課題。黃思騁對於現實主義的論 述, 亦質疑了過往的實用論。 ${ }^{58}$ 但這樣的影響, 可能並不全然始於一九五八、五九年《蕉 風》的改革。人本主義對於中國現代小說的影響, 可追溯至一九二○至一九三○年代的新 月派詩作與部分的京派小說。

基於後來的局勢變化，中國民國時期，部分作家群體嘗試從傳統尋找心靈依歸，因而 使這新人文主義的影響也能滲透至現代文學, 尤其新月派和部分京派群體作家。新月派作

\footnotetext{
57 張錦忠，〈白圭與馬華文學的第一波現代主義風潮〉，頁 219-232。

58 黃思騁, 〈小說是怎樣完成的〉, 《蕉風》1959 年第 78 期, 頁 8-9 ; 〈莫泊桑談小說〉, 《蕉風》1960 年第 90 期, 頁 3-5。
} 
家相當浮顯於 $「$ 健康」與 $「$ 尊嚴」的口號, 京派作家與新人文主義的聯繫較少, 卻仍能從 其作品中見到痕跡。 ${ }^{59}$ 其中包括了從一九三○至四 $\bigcirc$ 年代的新月派現代文學, 曾經以人文 主義為其心靈寓所。新月派現代文學, 曾經是戰前現代文學的主力之一, 與白圭所尊崇的 現代詩人梁宗岱也有脈絡可循。由此, 原來看似與人本主義關連不大的現代詩, 在文學史 系譜淵源上實則亦有曲折相連的關係。

但對於人文主義的興趣，可能在更早一些，一九五八年的第七十二期，就已見端 倪，該期有一篇力匡翻譯 D.L.湯瑪斯的〈神曲的作者但丁〉，前言介紹如下：

一個真正的詩人是一個創造者，更進一步而言，他還是一個先知。真的，古代羅馬 人就是如此的，他們用同一的字「vates」來并指詩人和先知。「先知，」卡來雨 就如此地提醒過我們了: 「就是一個顯示我們該做些甚麼的人; 而詩人呢, 就是一 個顯示我們應該愛些甚麼的人。」他是一個探索者和預言家——個被祝福的上天 所賜的带來光明的人。

……我們很少見有保守派的詩人, 多數的詩人都是現實的叛徒。偉大的詩人常在努 力於消除這世上的不公正，和設法使世上的美永存不朽。……是我們一個崇高的兄 弟, 他有預見的眼睛, 他有歌唱的嗓子, 他有一個充霂希望的心霝……再引用一 向卡來爾的話：「詩的氣質是存在於每一個人的心霝的。」(頁 4)

雖然如同過去愛國主義的樂觀與熱烈語言, 在此同樣出現「光明」「希望」「崇高」這類 字眼, 所銜接的卻是人本主義美學中, 追求理性與感性融合共同發展的想像。但丁的神曲 向被視為文藝復興時期人本主義的經典之作, 透過這篇以藝術人工來達到生命盛放的讚嘆 與詩意。雖然人本主義對人的慾望、身心、感性與理性綜合的肯定, 乃是抵抗神意凌駕於 人的展現, 但是從力匡致力於表達頌讚致意的書寫方式來看, 其中修辭, 亦如同西方基督 教沿襲以心為主的譬喻, 大量攝入以心靈感受為主的詞彙。雖然這些詞彙實質指涉的相關 意義與脈絡不同, 詞彙竟然驚人地相似。

回顧馬華文學，從愛國主義到人本主義的引入，也同樣沿用了這種大量的、熱烈的 歌頌用語。這些用語, 在過去五四時期新月派詩人的書寫與文學交流、評論的文章中, 亦 頗為常見。這些表現出浩大、雄渾、壯美的語彙, 彷彿如同角色與演員, 在不同的文化脈

${ }^{59}$ 白春超，〈古典主義與現代中國文學〉，同上註。 
絡裡出入置換。在此似乎也顯示了, 在文學典範變更的過程中, 寫作與閱讀的語言習性, 當中常用的詞彙, 宛如符碼般會起著延續、模仿與抽換意義的作用。那相似的語言、熟悉 的語彙, 似乎可以緩化、遮罩實際上存在於不同文化脈絡與詮釋系統之間的差異, 使得新 的事物可以被接受, 但也可能使那存在於不同的文化脈絡之間, 原來的分歧與差異被模糊 掉。

在改版宣言中, 對人文主義的介紹, 提到了人文主義在稍後十九世紀過後的沒落, 同 時也將共產主義與資本主義的唯物主義並列, 認為無論是共產抑或資本主義, 都一樣對人 文精神帶來威脅。不過, 文中所提 $「 人$ 的再發現」以及「在安定中求進步」, 若擺放在新 馬讀者彼時的現實環境中, 以當時華人仍多居新村、勞工階層廣大、文化水平普遍較低的 生活條件而言, 可能更近於指向獨立建國、萬事待興的未來。若按照一九五 $\bigcirc$ 年代新馬時 值緊急法令中獨立建國的這段歷史情境來看, 此時提 $「 人$ 的再發現」以及「在安定中求進 步」, 似乎有依循官方修辭, 而與左翼的政治陣線競爭之意。盡管如此, 改版宣言似乎也 有意在字面陳述上, 減少、遮蔽起那與左翼團體對歭的意味。《蕉風》提出自身對資本主 義吞噬人文價值的批評觀點, 並不少於它對自身抱持非左翼立場的聲明, 換言之, 《蕉 風》其實想要表明, 它自身的立場, 雖然反共, 但同時也是非右翼的（或非資本主義 的）。供稿予《蕉風》的學者與作者, 並非沒有意識到隨著美援而來、席捲華人社會的美 國文化, 那龐大的影響力。《蕉風》裡刊登的譯介文學理論和文學作品, 多為歐洲與亞非 各國, 包括法國與俄國的文學文本, 以及亞非的翻譯小說, 這使得刊物裡的外國文學, 來 源頗為多元。 ${ }^{60}$ 友聯文人何振亞曾言及, 在香港推銷書籍與從事文化工作, 非常艱難。 ${ }^{61}$ 關 於在商業社會中, 文人得屈就為三餐折腰的容境, 香港文人如劉以凷也頗多感慨。6 2 故 此，惟有同時維持刊物本身「非左」與「非資」的立場，才能保留藝術或純文學的空間。 63

60 見前述方天時期的編輯方針, 頗多埃及、印尼文學的翻譯, 第三章, 頁 114 , 以及姚拓時期的編輯方針, 本章之第五節。姚拓刊用的寫實主義評論, 多為鍾期榮寫的一系列闡述歐洲法國現實主義的稿件。 61 何振亞口述, 《香港文化眾聲道》, 頁 25 。

62 劉以䀞是在國共大分裂時期, 於一九四八年從上海南下, 在香港由於生活熯難, 才放棄繼續經營出版 社, 轉而進報館當編輯, 並大量撰寫通俗小說與稿件以應付生活。易明善, 《劉以齿傳》, 香港 : 明報, 1997 , 頁 50 。

63 在此並非以友聯南來文人來做判斷, 而是僅就雜誌的性質而論。友聯諸人在馬來亞, 開拓商業與企業相 當成功, 不能說他們不認同商業價值, 甚至不乏有漸以政黨為重心, 如馬摩西、黃崖。 
一九五九年第七十八期改版以後，《蕉風》放棄高掛馬來亞化的期幟。「在地化」與 文學「實用論」這兩個主張, 無論是從政治意識抑或從道德意識上, 其實都能幫它贏得較 多大眾的認同。《蕉風》提出的 $「$ 個體化」路線, 置於當時的文學場域是較為冒險的, 由 於它沿著一道跟馬華文學現實主義與愛國主義傳統迥異的路徑, 挑戰頗大。但從另一方面 來說, 這點也部分銜接回五四運動開端之際, 周作人那以「個人主義為本位」的文學話 語。 ${ }^{64}$ 在中文現代文學裡, 個人本位的個體主義論, 並非是陌生的觀念。惟魯文的闡釋, 更具有現代主義的自覺意識。

\section{四、越境之後的「自由主義」}

《蕉風》的藝術追求，是否真的獨立呢？從姚拓到白圭以及魯文的文學觀點裡，其自 由之義, 彷彿僅是以毛澤東的階級鬥爭與工農兵劃一的文藝路線為參照而言。惟當時馬來 亞政府的喇共計畫, 不僅維護英殖民政府, 隨著國家獨立, 亦維護馬來亞聯合邦聯盟陣線 的政權。《蕉風》其實無法自外於官方國族意識形態的立場, 仍然是在一道相當嚴格的, 由國家設下的政治禁忌界限內，展開純文學的追求。

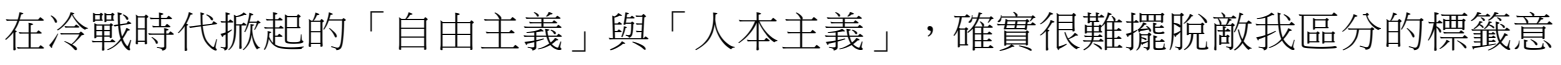
味。立場異議者或作風另類者, 經常將自身展現為支持民主的自由主義者, 而將反對的彼 方歸為獨裁的集體主義。 ${ }^{65}$ 但左翼其實也有不同的譜系, 如社會主義民主系統, 便奉行多 黨選舉制兼接受市場制約的經濟模式, 此外, 被認為是冷戰中提倡自由主義模範的美國, 亦不盡然實踐自由主義的理念, 而是在律法與道德約束下、接受有限度的自由主義的國家 主體。 ${ }^{66}$ 反共運動, 在各個區域, 因應那各處的政治語境、權力結構, 可能會具有「反 叛」、「抵抗」乃至到「迴避」的意義。如果在中共的權力範圍內, 抵抗共產黨所面臨的

\footnotetext{
${ }^{64}$ 在五四運動初期，周作人曾著述〈人的文學〉，提出「個人主義的人間本位主義」，提出改革性寫作方 向, 追尋自由、解除靈肉二分的文學觀。周作人實際上是想要提出有 $「$ 上達人間」與書寫 $「 人$ 的生活」可 能性的文學, 故也強調一切須在 $\ulcorner$ 人情以內, 人力以內」，始為「人的文學」。他是在五四運動啟蒙主義 的影響下, 為挑戰封建制度的桎梏才提出個人本位論。其脈絡固然與梁實秋等人引入的新人文主義不同, 與那肯定人欲的義大利文藝復興的人文主義，也仍有一段距離。周作人，〈人的文學〉，《周作人批評文 集一一世紀的回響・批評卷》，珠海：珠海, 1998，頁 29-37
}

${ }^{65}$ Alan Ryan, The Making of Modern Liberalism, Oxford: Princeton University Press, 2012, p.22.

${ }^{66}$ Alan Ryan, The Making of Modern Liberalism, p.22. 
反抗意義與壓力, 無疑是龐大的; 但在英殖民地統治的馬來亞境內, 這壓力卻較小, 且可 能會被詮釋為是與強權者合流。若在香港這鄰近中國的邊陲之地，因其所反對的對象中 共, 顯然已是統一大國, 而友聯的流亡文人對其政治壓力的憤䩤感受與流亡體驗, 出於這 份地緣上與威脅之鄰近的關係, 香港友聯的運動話語, 依舊能有抵禦威脅、反對極權政治 為其運動話語的核心。但在馬來亞, 英殖民與聯盟政府才是那有權力凌駕各方的掌控者, 而多元族群的結構中, 左翼又被官方視為支持華語與方言源流的華人的政治力量。當《蕉 風》《學生周報》的南來文人越過地理邊界的時候, 也同時越過權力陣營不同的版圖。換 言之, 在越境之後, 若要持續從原來的強／弱系統兩端來判斷「反叛」與「抵抗」的意義 與否, 那因應地方上政治資源、文化傳播的不同對象（譬如通俗、大眾、菁英、少數）乃 至到區域上的政治意識形態的變動, 也就意義各異, 並不能超越地理環境而仍然維持一 致。 ${ }^{67}$ 在馬來亞, 英殖民地劃下的政治禁忌, 可能也同時護持、或鞏固了友聯本身的反共 立場。然則, 友聯要如何建立它自身的正當性呢? 他們選擇的解釋是, 南來新馬赴此任 務, 猶如走進 $\left\ulcorner\right.$ 文化衝突的風暴」, 需要 $「$ 毅力與理想 ${ }^{68}$ 。換言之, 場域中的大眾（讀 者市場、群體）帶來熯難刻苦的鬥爭挑戰, 雖有英美協調與當地政府支持, 但過程並非坦 途, 尤其「受到毛澤東延安文藝思想滲透的學潮年輕學子, 並不曉得中共的真相 $\lrcorner^{69}$, 故 為保存與耕耘中華文化之故, 必須改變馬華文化與文學的土壤質地, 而這文化教育「原則 是正確的 ${ }^{70}$ 。

67 參見白圭, 《縷雲前書》, 頁 138 。李耀桐的發言：「在香港, 右強左弱, 反共是形勢比人強, 新加坡則 完全相反」, 這段話強調了左翼在馬來亞的勢力, 不過, 卻沒提到剿共計畫開始以後, 左翼勢力被削弱的 事實。英殖民地在緊急狀態初期的強硬手段, 使華社與政府更加疏離, 招致激烈的反彈與學潮。即使有由 上至下部署的剿共團隊計畫, 左翼思維在大部分的華語群體裏, 仍然根深蒂固。能否突破左翼的強固堡 壘, 為友聯反共任務成功與否的關鍵因素。

${ }^{68}$ 白圭, 《縷雲前書》, 頁 117 。書內有相當多篇幅, 敘及在港時友聯諸人對馬來亞左翼勢力的想像, 前後 相當一致, 包括「共產黨控制工會, 也掌握了學生會、同鄉會、甚至商會的組織和活動。」（頁 $138 ） 、$ $\ulcorner$ 那邊的輿論, 那邊的文化界, 都同情共產黨。」（頁 143 ) 均視赴新馬任務為艱任, 強調來馬反共, 比 在香港反共更困難。

${ }^{69}$ 白圭, 〈誰出賣了中華文化〉, 《縷雲前書》, 頁 144-147。

70 古梅的口述, 《香港文化眾聲道》，頁 97 。 
基於當時的緊急狀態政治氛圍, 《蕉風》所奉行的自由主義, 因而不免必須是有限的 自由主義。 ${ }^{71}$ 自由主義固然是亞洲自由協會, 所欲灌輸或再教育東南亞華人的價值觀之 一。友聯諸人在馬來亞的教育任務，不外得貫徹美援反共計畫底下的主張。「自由主義」 本身的意義為何呢? 自由主義的特質包括, 較少要求宣誓忠誠的綱領, 成員之間尋求共同 點、討論、辯論與協商為共存之道, 其討論與辯論的目的可能包括為了接納差異, 也毫涉 到如何把各方互不相容的理念與差異, 歁酌出那可共存的邊界。年這樣的協商方式, 也見 於馬來亞官方的成員黨之間, 實乃為消除激進與衝突的合作方式。《蕉風》與友聯文人團 體內的文學觀點與流派, 相當多元, 從現實主義、文學改造社會功能論、乃至到後來冒起 的個體主義, 從這點來看, 他們彼此的文學觀念, 實際頗多差異。惟有秉持自由主義為其 宗旨, 才能共存，也有利於多方吸收不同流派，建立隊伍與擴大鏈結。

\section{五、論述轉向：寫實主義的創作論與小說美學}

在姚拓擔任編輯期間, 就其篇幅而言, 增添更多篇幅介紹中西方文學、文化理論與當 代思潮。這個時期的寫實主義論述，比起早期方天時其由沙理明、李亭等人撰寫的、帶有 社會改造論的現實主義論述, 大為不同。此時的評論更加著重討論小說的藝術形式與寫作 技巧。大量譯介西方文學理論, 從中可見冷戰時期的文學理論翻譯, 如何塑造、調練現代 文學的小說觀念與美學。但並非全部都屬於美國的文學資源，歐洲的文學理論也成為此時 的文學知識來源。

謝冰瑩曾在《蕉風》撰寫〈漫談文學批評〉 ${ }^{73}$ ，她在《學生周報》有更多談論文學創 作的稿件，如〈寫作必經道路〉系列，包含「怎樣寫小說大綱」、「談修改」等等。74

在一九五八至一九五九年間，《蕉風》刊登一系列由當時人在香港的學者鍾期榮的稿 件。每篇大約二至三頁不等, 多篇介紹歐洲現實主義與其相關的思潮運動，傾向於從法國 的現實主義藝術啟蒙切人，如第六十二期〈自然主義的法國文學〉（自然主義與浪漫主義

\footnotetext{
71 譬如, 根據徵稿聲明, 他們不排斥任何流派的來稿, 表明奉行自由主義原則。盡管如此, 《蕉風》界竟 不可能刊登與接受馬共的書寫。亦參見黃錦樹, 〈香港一馬來亞 : 熱帶華文小說的兩種生成, 及一種香 港文學身分〉, 頁 8-15。
}

${ }^{72}$ Alan Ryan, The Making of Modern Liberalism, p.23.

73 謝冰瑩, 〈漫談文學批評〉, 《蕉風》, 1957 年第 75 期, 頁 4-5。

74 謝冰瑩, 〈寫作必經道路〉（一至七系列），《學生周報》1958 年第 105-111 期。 
及寫實主義之間的關係概述）、第六十八期〈法國現代文學的動態和特色〉（思潮變化、 文學、電影、新興文學運動）、第七十三期〈存在主義與沙特〉（介紹一九四五至一九五 ○的存在主義思潮）、第七十七期〈時代尖端的孟典蘭〉（戲劇）、第八十期〈超現實主 義的詩〉。

黃思駎亦有多期撰文介紹西方文學思潮與個別作者的文學觀, 如〈小說是怎樣完成 的〉, 標舉寫作風格當為文章與作家的特色。 ${ }^{75}\langle$ 莫泊桑談小說〉則談寫實主義小說中的 真實觀念與其侷限。 ${ }^{76}$ 莫泊桑是法國文學寫實主義藝術取代浪漫主義之後的崛起的文學 家, 雖然如此, 當時歐洲被標籤為寫實主義的作家, 並不全然都認同這標籤。7 這篇評論 以莫泊桑對文學裡的「真實」觀點為據：「莫泊桑認為一切現實主義的藝術家都應該瞭 解, 光是真實, 並不是全部的真實。」「所謂真實, 在乎把握事實的通常邏輯, 給人以真 實和完全的幻覺, 而不在照著事情層出不窮的紊亂情形將它記載下來。」因此, 寫實主義 文學「要把比現實更完整、更動人、更有依據的幻影給予我們」。

由此, 通過介紹莫泊桑, 黃思騁提出了有別於「反映現實」的看法。黃思騁並沒有以 為, 寫實文學中的真實, 等同於全部的真實, 相反地還察覺到, 寫實主義實際上也是由符 號敘述構成的如真幻覺。但是, 經過藝術自覺的處理, 卻能從擇取的敘述切面, 提出那回 應真實的深層問題。在這篇文章裡, 黃思騁想要提倡的是小說的技術, 包括對於小說的語 言風格, 到底小說需要的是怎樣的語言 :

為了區別思想上一切細微的差異, 我們決用不著托㙯術文字的名義, 強迫人去接受 那些奇怪的、複雜的、無味的語異。我們得憑著極端的霝敏, 鑑別一個字的價值和 它所起的一切變化。要儘量減少意義難以捉摸的名詞、動詞、和形容詞：儘量增多 以種種形式構成、安排巧妙的、有著爽朗韻律的、種種形式的文句。與其成為奇異 言詞的收集者, 還是讓我們成為優秀的文體家吧。 ${ }^{78}$

這裡對小說的關注已經轉移到對於寫作文字語言的意識, 如同他對風格的重視, 認為小說 必然是經由符號、語言縷織如實, 因之由符號語言編成的風格質感與文體肌理就無可忽

\footnotetext{
75 黃思騁, 〈小說是怎樣完成的〉, 《蕉風》1959 年第 78 期, 頁 8-9。

76 黃思騁，〈莫泊桑談小說〉，《蕉風》1960 年第 90 期，頁 3-5。

77 雷内 - 韋勒克(René Wellek)著, 張今言譯, 〈文學研究中的現實主義概念〉, 《批評的概念》, 杭州 : 中 國美術學院, 1999, 頁 218 。

78 黃思騁, 〈莫泊桑談小說〉, 頁 5 。
} 
略。《蕉風》創刊兩年後, 有更多專注於藝術美學的論述, 對於馬華文學現實主義向來秉 持的「反映」論、「任務」論與「光明健康」論, 頗有撥亂反正的用意。

一九五八年第七十四期, 文思奇 〈論小說與故事 ${ }^{79}$, 以小說 (Novel) 具有「題材、 佈局、結構、修辭、練字」等體現出複雜與精密的特質, 而故事 (Romance) 則以曲突詭 異、曲折離奇為標誌, 由此區分出小說與故事的不同; 他又分別舉愛倫坡和福爾摩斯, 各 喻小說與故事的範例, 但不否定小說有故事或傳奇的特質, 且認為, 冊論究其敘述脈絡為 寫實／現實主義或象徵主義, 小說總是與現實有關。雖則他也不能免除肯定「教育與啟 迪」、「推進社會」等「教化」功能, 但是這篇評論文章的觀點, 已經竭力從藝術形式來 討論小說這一文體的形式與美學。

從黃思騁〈小說是怎樣完成的〉和〈莫泊桑談小說〉乃至到文思奇〈論小說與故 事〉, 這時候的寫實主義論述, 完全不同於創刊初期的功能論述, 而更講究嚴謹的小說美 學層面與結構形式。像上述堅持對創作保持自由權利的論述, 與中共自掌權以來推行的反 右鎮壓、乃至到一九五八年的大躍進, 固然是意有所指的對照與批評。尤其〈莫泊桑談小 說〉 中莫泊桑的觀點, 認為小說不應受到任何規則所約束, 文中又引雨果、左拉對小說創 作絕對權的強調, 正與一九五八年中國 $\ulcorner$ 大躍進」中的革命文學與意識型態劃一, 形成尖 銳的對比。

\section{六、姚拓的小說：一九四九之後}

\section{（一）失落的交流}

一九五七年獨立以後, 馬來亞半島有了國籍的邊境。姚拓在短篇小說〈七個世紀以後〉想 像了一個未來世界的烏托邦。 ${ }^{80}$ 這篇小説或許是馬華文學最早的一篇科幻小説。主角

「我」姚拓是個挖礦工人, 由於礦洞塌陷, 歷經七個世紀漫長的冬眠才在未來世界復活, 發現自己身處另一時代, 他所曉得的各種語言, 世上幾乎已經無人能懂。原來一九五 $\bigcirc$ 年 代的種種現代化觀念, 在七個世紀以後都變成落後蠻荒的古代習性。小説也對自由有一種 $\ulcorner$ 進步」的想象: 未來的世界, 人們的行動不再受國家邊界所限制, 要到哪裡就可以到哪

79 文思奇, 〈論小說與故事〉, 《蕉風》1958 年第 74 期, 頁 4-5。

80 姚拓, 〈七個世紀以後〉, 頁 8-11。 
裡。此時的新世紀, 幾乎是比民主更好的世界, 再也無需政府管轄, 借助科學與技術, 人 類的生活世界幾乎達致善美, 不再受任何一方權力所支配, 自然地運行在極為理想的系統 中。

他告訴我，目前世界上能講古中國話的只有雨個人：一個是他，一個就是我。我 聽了不禁大吃一驚, 難道中國這個民族真的滅絕了嗎? 再不然就是亡了國, 再不 然就是被別人同化了 ? ${ }^{81}$

如前所述, 莊華興認為, 民國末期、國共分裂南來的文人, 都經歷了亡國失鄉之痛。 ${ }^{82}$ 這 群南來文人在那數年內, 對於懷鄉書寫、或亡國之痛的抒發, 表現各異。如方天與馬摩西 從不表露離鄉之痛, 而在姚拓的懷鄉書寫裡, 幾乎亦無懷鄉的悲愁之語, 但多挑趣事來回 憶。姚拓在散文中鮮少抒發内心憂傷, 譬如在他晚年出版的《雪泥鴻爪》裡, 即便生死難 卜的情況, 也寫來生動有趣; 戰亂中的恐懼與徬徨, 亦已成為歲月洗淨的平靜憶述。83

跟馬摩西不同，姚拓的流動經歷，並無癒與病／幽閉與開放的私人個體經驗，但亦有 從家鄉到外地, 人生轉向更加開放的抉擇；這幾乎是流亡者共有的經驗。跟馬摩西一樣， 在書寫往昔生活的散文裡, 姚拓也竭力保持樂觀。他最早的文學經驗, 來自家裡木樓的藏 書, 當時所讀皆為古典章回通俗小說。姚拓現代文學的經驗始於當兵時期, 因從軍離鄉在 外, 才接觸到新文學作品。一九四九年他回鄉葬母, 帶了幾本茅盾的小說回鄉, 發現就連 昔日教過他的秀才老師都不曉得這些書，「由此亦可看出當時中國鄉間的閉塞情形」。84 姚拓也閱讀諸如羅曼羅蘭、喬治桑與契可夫等法、俄作家, 如同他在介紹外國文學的稿件 裡所言的, 他偏愛契訶夫多於奧亨利。姚拓如此形容契訶夫的文字:

……是一池連微風都不起的静水, 你可以心平氣和的讀下去, 但又在無形中覺得這 静水的寬宏無邊。他從來不用美麗的鿷藻, 但他的字向卻在精煉中銡出了另一種平 静, 甚至近於淒涼的氣氛。 ${ }^{85}$

\footnotetext{
81 姚拓, 〈七個世紀以後〉, 頁 9 。

82 莊華興, 〈黄潤岳在 (後) 大分裂時代的家國想象〉, 見前注。

83 這裡僅就姚拓的散文而言。在姚拓的小説裏, 他經常以節制的筆法, 把故事中的殘酷一面隱藏起來, 保 留為無以言表的沉默留白。

84 姚拓, 《雪泥鴻爪》, 頁 520 。

85 魯文, 〈短篇小說之王的短篇〉, 《蕉風》1959 年第 75 期, 頁 $11 。$
} 
在另一篇文章裡, 他徵引喬治桑的話：

我們並不反對㙯術家有探討社會創傷，並把那些創傷赤裸裸地呈現在我們眼前的權 利。可是除掉恐怖與威脅的圖畫之外, 現在就難道沒有別的事情可以做了嗎 ?…… 我們喜愛那些優雅與溫柔的臉孔，遠過於那些具有戲劇效果的罪魁。 ${ }^{86}$

姚拓從書寫裡召喚的, 就是這些溫柔與恬靜的記憶面容, 這些作家示範了有別於鬥爭的文 學, 以轉移社會創傷帶來的恐怖與威脅。譬如他從一九五九年到一九六 $\bigcirc$ 年間寫的一系列 $\ulcorner$ 美麗的童年回憶」散文, 追憶過往鄉間的親屬人際與各種物事, 文筆幾近抒情。在一篇 刊於一九六 $\bigcirc$ 年一月號的小說〈丘陵上〉裡頭, 「我」因為家貧, 而被迫輟學去當學徒。 ${ }^{87}$ 秋天裡父親伴「我」出發, 行過一座丘陵時, 父親講了個冬天的故事, 因偶然救助一個 凍量的半死之人, 竟然使得兩人奇蹟般在大雪天裡活下來。在姚拓的多篇小說裡, 生命與 死亡經常會來到一個不可思議的轉折點, 慣常的邏輯得讓位予偶然。小說主題似有寄寓道 德教訓的意味, 但小說形式所傳遞的訊息, 並非僅如父親的勸勉那樣, 行事要符合良心、 幫助別人即為自助這等簡樸的道德道理。因其勸勉包裹在故事中、宛如套盒般的結構, 恰 如班雅明所言的, 說故事的傳統有傳遞智慧的功能, 在口傳與口述的文化裡, 曾經帶來拯 救的力量。在上述這篇〈丘陵上〉的小說裡, 離家的少年宛如即將給拋鄭到世間之前, 聆 聽了父親的故事。倖存的奇蹟, 除了來自救助, 也源於敘事。故事傳達經驗、也予以安身 立命的勸諭。

在姚拓回憶過去的散文裡, 無論是與鄉人、軍中夥伴, 似乎交流無礙。來到馬來亞 後, 他曾寫及參與《學生周報》在金馬倫的生活營體驗, 描敘自己如何感染那青春氣息,

$\ulcorner$ 至於我這個做『壁上觀』的顧問, 也不禁隨著他們一同歡笑, 一同鼓掌一一雬那間我好 像也年輕了二十歲一般。 ${ }^{88}$ 文章裡, 看不出姚拓是否會有表達的問題。但姚拓本身來自

86 張兆〔姚拓〕，〈田園作家喬治桑〉，《蕉風》1958 年第 74 期，頁 6 。

87 姚拓，〈丘陵上〉，《蕉風》1960 年第 87 期，頁 10-13。

88 姚拓, 〈永刻在心裡面的一一張張純潔而微笑的臉孔〉, 《學生周報》1961 年第 234 期, 我們的馬來亞 版。 
河南, 其方言口音使他在新馬社會裏的溝通恐怕也相當困難, 他能聽得懂當地其他人的華 語, 但一般在地念書或出生的華人, 要聽懂他的華語卻很不容易。89

〈七個世紀以後〉這篇小說開首第一段這麼寫：

我說的中國話，他們聽不懂，我鴧的方塊字，他們連連搖頭，伸長了舌頭。9 這情節的取材恐怕源於姚拓自身的語言經驗。對落腳他鄉的放逐者而言, 語言的障礙無異 於第二度放逐：

它導致了再次的放逐，除了個體肉身體驗實質的流放之外，也包括那在知性層面上 的距離。這種轉移到另一種新的語言經驗的過程，是個充滿挑戰與陌異化的過 程，……語言就是放逐者可隨身攜带的、來自家鄉的剩稌物，是使根源與記憶保存 鮮活的憑籍。另一方面，掌握通曉駐居國的語言，又可使得那在語言裡產生的意義 以及轉移到新的文化和社會環境的過程，變得比較容易。91

對於普遍上均為來自華南的馬來亞華社來說, 河南的濃厚鄉音, 不可不謂為陌生。以方天 的寫作方式而言, 攝入在地的語彙, 幾乎是他積極融入在地的證明; 容許那在地的語彙, 被吸收、渗透乃至改變自己的用語。92

在姚拓的書寫裡, 這樣的語言在地化跡象, 卻是極度緩慢的, 不像方天或馬摩西, 能 夠在寫作中, 吸收當地方言土語或馬來語語彙。這原因或許也是因其口語的交流經驗, 限 制了那在地語彙的滲入。姚拓通過書寫的表達, 可能比起口語上的表達來得更為順利。在 小說〈七個世紀以後〉, 倖存者的語言, 在未來時空中, 成為獨一無二的存世古蹟。古語 言學家圍繞著他, 饒有興味地聆聽他的話, 在一個現今語言幾乎絕跡了的未來, 他說的 話, 成了碩果僅存的活化古語, 雖然難以交流的處境依舊未改, 卻因為度過了漫長的時 間, 而獲得全然不同的價值與意義。這部小說似乎也可以撫慰姚拓自身。盡管是難以溝通

\footnotetext{
89 筆者曾於二 $\bigcirc \bigcirc$ 四年當姚拓尚在時, 在吉隆坡訪問過姚拓, 對此印象深刻。冰谷的追憶裡, 亦曾言 $「$ 姚 拓先生那股浓厚的湖南腔, 只能听懂一半」。冰谷, 〈作者野餐會激起的文藝熱潮一一海天社在居林的日 子〉，《星洲日報》，2007 年 12 月 9 日，春秋文藝版。

90 姚拓, 〈七個世紀以後〉, 頁 8 。

${ }^{91}$ Devleena Ghosh, "Coda: Eleven Stars Over the Last Moments of Andalusia", p.285.

${ }^{92}$ Devleena Ghosh, ibid, p.285.
} 
的語言, 卻仍然是倖存者所賴以生存的 $「$ 膠囊 ${ }^{93}$, 因為唯有透過語言, 一個人才能對自 身訴說、解釋與詮釋所有的遭遇; 語言如膠囊, 不僅出於符旨意義組成的系統, 也連帶其 出身、成長養成的腔調與口音。有時故鄉的口音無可改變, 超出主體的意志控制之外; 如 同膚色五官面目，銘刻著主體身體的特性。

\section{（二）懷鄉記憶：轉移之必要}

這語言包裹的故鄉記憶, 如何能滲透到住居之地的語境中呢? 一個離散者, 在新的 居住之地, 總有傾訴的慾望, 那是把離散主體的過去, 通過語言, 轉移到新的體系裡的需 要, 行彿重新組構家具崁置安頓成家園, 同時也是使自身與那撕裂的過去, 盡可能完整連 接的過程。雖然這也許不是唯一的方式, 但卻是讓離散主體在新的環境中, 透過把彼方與 此地、今與昔都縫合, 以便充分表達, 使得那出於亡國與流亡所致的歷史創傷, 在敘事裡 獲得彌合。

相對於姚拓編輯《蕉風》極其鮮明的反共方針, 他那些懷鄉、從軍的小說, 對於中共 的嘲諷卻比較淡薄。小說裡有更多個體生存慾望的觀照。由於姚拓持有的反共、反國立 場, 使他的這些小說, 和同一時期臺灣蔣介石文藝政策底下的戰爭文藝比較起來, 更少強 調反共宗旨（譬如強調反共任務成功等目標），因而仍能保存小說藝術的獨立性。94黃 崖、黃思駎等人的小說亦然。在不認同共產黨、也不認同國民黨的情況下，姚拓、黃崖、 黃思駎等人的小說，留下更多空間予個體的記憶、經驗和關乎於生存的敘述。

在〈名正言順三等兵〉裏, 他說自己是出於愛國情操以及迫近家鄉的危機才去從軍。

$\ulcorner$ 事實上, 凡是有一點點愛國意識的青年, 這時候也非要離開家鄉不可。因爲日本的軍隊 已經打到黃河北岸。我的家鄉距離黄河南岸只有六十華里, 由黃河北岸射過來的砲彈爆炸 聲已隱約可聞。」95 但即便如此接近戰綫, 敍述中卻幾乎對於砲彈威脅無甚恐懼。在他回 憶中, 自小戰爭就是家常便飯, 兄長與鄉人多從軍, 自己也以穿軍服為榮。96在另一篇文 章〈時也命也其奈何〉裏, 他對於自己爲何從軍卻又有另一番解釋 : 在當時軍閥混亂的情

\footnotetext{
$93\ulcorner$ 膠喗」一語, 參見 Devleena Ghosh, ibid, p.285.

94 參考王德威, 〈五十年代反共小說新論———種逝去的文學? 〉, 載張寶琴、邵玉銘、瘂弦主編, 《四 十年來中國文學》，臺北：聯合文學，1994，頁 67-84。

95 姚拓, 《雪泥鴻爪》, 頁 250 。

96 姚拓, 《雪泥鴻爪》, 頁 254 。
} 
況下, 一個人可能一輩子呆在窮鄉僻壤或作餓殍、或一生耕種, 從軍出外至少有發展的可 能。任何離開家鄉的機會, 都充滿未知與機緣的可能性。

他在另一篇文章〈蜀道難 難於上青天〉回憶起最早時候有個隊長認爲他該去念書的 建議：

假如換作是現在的我, 我一定很高興地接受他的建議。可是那時候我的愛國之心 非常熱誠，覺得全中國已經到了生死存亡的緊急關頭，作第一個現代軍人，就應 該親自到戰場衝鋒陷陣。97

民族意識雖然經由自小灌輸的抗日運動而生, 但在姚拓的追憶裏, 這意識並不總是強烈, 儘管喊著口號, 但十年來從槍林彈雨到流亡南下, 書寫中更鮮明的是隨遇而安, 倖存與死 亡皆屬偶然。不過, 與當初從軍時棄文從武的打算相反, 他的文筆反而是在軍隊中當記錄 員時鍛煉出來的。行文流暢, 寫起軍中生活、流浪與搬家過程, 現場氣氛宛如歷歷在目。

從一九五七年至一九五九年間, 姚拓共有四篇小説與一篇散文刊於《蕉風》。散文

〈小貓〉描述了其妻美華欲養貓, 敍述空間穿巡於香港的狹窄街道與公寓之間。98四篇小 説包括上文討論過的〈七個世紀〉、兩篇從軍小説〈最不能忘記的一張臉〉和〈四個結婚 的故事〉以及一篇甚具抽象探索意味的〈石縫中的一朵小花〉。

上述兩篇從軍的故事, 並未如左翼般鼓吹愛國與抗日意味, 反之更多呈現出戰爭中人 所遭遇的存在直限, 有時甚至會同情敵軍, 比如〈最不能忘記的一張臉〉。99敍述一個長 相清秀的日本軍人怎樣死去, 小説反復強調這受傷軍人的年齢之輕、樣貌之秀, 瞬間就死 於中國軍人憤怒砸下的石頭, 那是將人置於敵我對立而生的暴力, 也是出於目睹從軍同伴 受創死亡的憤怒所導致——如是暴力並非能簡單理解為麻木或毫無人性, 相反的它是拔尖 急劇的情感。小説的驚懼與傷慟, 與散文的樂觀語調不可日語。正如在〈七個世紀〉之後 的小説所流露的, 那種對於世界與自由主義的理想願望, 在大部分姚拓的小説也有相應的 的主題。姚拓嘗試在小說中超越二元敵對的局限, 以獲得更合乎個體主義與人道主義的觀 點。

\footnotetext{
97 姚拓, 《雪泥鴻爪》, 頁 274 。

98 姚拓, 〈小貓〉, 《蕉風》1957 年第 39 期, 頁 $12-15$ 。

99 姚拓, 〈最不能忘記的一張臉〉, 《蕉風》1958 年第 55 期, 頁 4-7。
} 
〈石縫中的一朵小花〉不僅是嘲諷左翼流於教條的現實主義, 小説以一種十分簡單的 敘述結構方式, 讓所述對象置於偶然投落的視線當中。它是諸多爭辯的穿梭交織之處, 被 各方的諸多觀點、偏見與欲望所穿過, 而「美」卻是從中冒長出來的, 不可言説之象。小 說中圍繞著花朵構築的意象與敘述, 鋪陳劇幕般來去的對話, 漸次展開了美一一價值一一 愛一一等等, 一系列可以多重遞入的抽象意義, 在小說裡進行各種辯駁, 從政治、華人現 實處境、生命意義乃至理想崇高人性的期望，層疊推進。100

由於長期亂世而養成對生死淡然的認命觀念，姚拓的小説熱著生命與死亡的意識。 雖然散文讀來平鋪直敘, 幾乎無甚曲折可言。如同馬摩西與大部分的《蕉風》諸人, 姚拓 也在來到不久之後, 就聲明認同馬來亞為所愛的國家, 「這片國土, 才是我最熟習的國 土, 我雖然還不懂馬來話, 但我已把這片土地當作了我的國土。」他當時還寫了一首歌 《我愛馬來亞》, 後來不知被誰印在了當時的教科書上。101

愛的對象轉移, 但所謂對於國家之愛, 或許乃是 $「$ 地方」與「可居」之愛。家園必 須是能夠予以謀生機會、庇護與安頓的所在。比起 $「$ 國家」對子民「忠誠」的要求而言， 這為利已目的出發的愛, 誠然, 可能是不夠理想的愛國狀態, 但如何能夠去愛一個想象 的、由邊界劃出的領土呢? 在「效忠」之前, 首先得有屬於地方的, 涵蓋物質經驗以及使 主體心靈獲得滿足的詮釋意義。一九五 $\bigcirc$ 年, 在經過萬隆會議之後, 周恩來對華僑國籍的 問題給了意見, 那之後華人僅能擁有 $「$ 一個國籍」, 因而必須面對此後身分的何去何從。 二戰之後, 跨越五十至六十年代, 國族運動紛紛在後殖民獨立國家興起。對於國族與個體 自由的論述, 這裡有兩種互相對立的觀點。十九世紀末義大利的馬志尼(Mazzini)以為, 國 族乃是人文主義的基礎所在, 他認為兩者沒有衝突和矛盾, 「沒有國家，則沒有人文…… 國家是人文領域的公民, 如同個體是組成國家的公民。」但近代的約翰・司徒亞特 - 彌爾 (John Stuart Mill)則對此提出質疑, 國家對統一的想像, 幾乎總是奠基於一個政府一個民 族, 但在一個由多元民族組成的國家裡, 真正的自由機制幾乎是不可能的。102 這兩種對 於國家的觀點, 一者抱持認同, 一者抱持批判與懷疑, 基於二戰後多國獨立與冷戰局勢的 變動, 大量放逐與離散移民全球流動, 使得身分、族群的觀念持續變化流動。友聯出版社 推行的人文主義與自由主義, 恰好是南來文人選擇自願放逐的狀態中, 從香港這邊陲之地

\footnotetext{
100 姚拓, 〈石縫中的一朵小花〉, 《蕉風》1959年第 84 期, 頁 8-11。

101 姚拓, 《雪泥鴻爪》, 頁 566 。
}

${ }^{102}$ Philip Spenser and Howard Wollman (eds.). Nations and Nationalism A Reader. Edinburg : Edinburg University Press, 2005, p.7. 
出發, 往東南亞延伸。這文化中國的資產結構也散播來到馬來亞, 最初他們採取與國家體 制和諧、友好的策略, 乃至於同意獨立時期的國族話語, 與此同時, 又多方面強調必須接 受、吸納在地的多元性質, 以這樣的策略, 來說服那權力核心的結構來接納離散者攜帶過 來的文化, 讓這文化也能夠在本地持續有活力。換言之, 在執行友聯的反共目標之餘, 同 時也能連帶文化, 在「海外」紮下生存之地。以當時剛剛獨立, 建國伊始, 萬事仍新的狀 態，他們對此確曾寄存希望。

\section{（三）滲透雙鄉的敘述語言}

五○年代的《蕉風》南來文人，文學作風各異。對於那些能夠快速收入在地語彙特 質與書寫在地寫實主義的作家（如方天、白蒂）, 這在地的語言, 因其異域特質, 對他們 而言是相當新穎的。從其題材到方言土語而來的地方感語彙, 都相當具有突破現代文學敘 事的模式 (即中國境內的五四文學或新文學運動以降) 的潛力。對南來作家而言, 在地書 寫確實不無吸引力。但從另一方面來說, 在地的語言特質與作家本身的雙鄉記憶關係, 似 乎很難並存。方天、馬摩西、白蒂雖然擅於吸取在地的語彙與觀察本土的文化與生活, 但 是他們對於故鄉與過去的經歷, 幾乎全盤不提; 至於姚拓、黃思騁和黃崖的小說, 則與之 相反。

姚拓、黃思駎和黃崖的寫實主義，卻始終維持了自身與故鄉中國和香港經驗的緊密 關係, 小說的故事路數也依然緊隨著中國與香港的記憶發展。在地化的寫作, 因此總是在 延後的時間裡。他們的小說處裡或取材自那已逝的過去, 不盡然得取自於當下的此時此 地。換言之, 在沒有必要得立刻進行 $「$ 在地化」書寫的狀態下, 小說就維持所熟悉的過 往, 總是過去的、已逝的藝術。這群在獨立之後才抵達的文人, 雖然在剛到時, 就立刻宣 告自身對此地的認同, 然而, 比起宣告或聲明認同, 小說或散文的書寫需要更多時間, 去 摸索此地的生活經驗與威受。

在一九五七年抵達馬來亞之後, 姚拓的第一篇小說〈七個世紀以後〉即思考了現有 國家與現代體制的反面, 以無政府、無國籍的時空特質, 構成未來烏托邦的圖像。之後他 發表的一連四篇小說與一篇回憶童年觀戲的散文, 都以過去故鄉的生活為小說材料。直到 一九六 $\bigcirc$ 年七月與十二月, 他又發表了兩篇文章, 首次出現馬來亞的在地文化環境與背 景。其中一篇小說〈走死運的人〉, 敘述一個抱持著鬥爭理想的窮苦作家, 某日發生車 
禍, 被誤以為已經死亡。 ${ }^{103}$ 他在「死後」被報導推拱為偉大的作家, 又因為身後蕭條而勾 起社會的同情心, 由此所收到的社會捐款, 竟然可以填補作家生前, 那負擔不起的家人生 活費。小說寫來藏著輕微的諷刺, 然而姚拓確實觀察敏銳, 馬華華社的憐憫與同情心, 經 常超過對文學實質的欣賞與判斷能力; 雖然有那麼多的同情, 文學熱情卻是異常稀薄。左 翼文學由此只剩下非關文學的運動, 其文學或藝術的實質性, 卻經常淹沒在這個社會的淺 薄與同情心裡。

這篇小說包裹著一個被錯誤理解為真的敘事，恰好和前述那篇聆聽父親的〈丘陵 上〉相反, 如果說〈丘陵上〉有來自聆聽而獲得的經驗與智慧, 即一個人應該通過對面對 自我與良心，對於任何有風險的決定負起責任（包括去「承擔」救助他人而可能使自身遭 難的危險）; 那麼〈走死運的人〉則剛好相反, 基於馬華社會宣揚的集體性特質, 個體必 須與社會的集體敘述合作, 當主角在不得已的情況下, 選擇逃避, 自身的位置因此不得不 不從社會結構中除去。姚拓做為小說家, 其實很擅於挖掘事物荒謬一面, 那在各種既定觀 念的交界中, 導致互為否定的悖論所在。正因為這集體蒙蔽的謊言, 才又使得這位小說中 的主人公, 竟然得以從不可能解決的負擔中解脫 ; 以其社會身分的死亡來免除肉身的死 亡。小說提出的悖論, 彰顯出存在的荒謬及倫常責任的殘酷性, 竟因此超出左右翼對立的 二元結構。

另一篇是發表於一九六 $\bigcirc$ 年十二月的散文，〈美麗的童年回憶一一殺豬似的剃頭滋 味〉, 散文從馬來亞大寶森節黑風洞的節慶現場, 目睹印度小孩的光頭, 由此銜接自身過 往給母親剃頭的童年記憶。10散文從在地的語彙、從物件名詞得來的比喻, 滲入他書寫故 鄉的敘述與修辭裡, 如「剃刀是這樣的鈍, 而我的頭髮卻長得像馬來亞的原始森林一 樣」, 同時告訴在地的華文讀者自己過去的經驗：「住在馬來亞的華人, 可能永沒有嘗過 剃頭刀的滋味」。這樣的訴說, 卻不是為了傳遞有用的勸諭或智慧, 而是道出自身那不得 不拋棄身後的過去, 使之可以被聆聽或被閱讀, 也因此成為聽者／讀者記憶的一部分。由 此亦把自己的記憶與過去, 帶到此地, 成為此地閱讀版圖的一部分。如此, 那永不能回返 的過去, 與離散的裂隙, 就在這被閱讀與聆聽的過程中, 獲得癒合, 此地才由此成為第二 故鄉。

\section{（四）趣味性、奇情、抒情}

103 姚拓, 〈走死運的人〉, 《蕉風》1960 年第 93 期, 頁 $15-17$ 。

104 姚拓, 〈美麗的童年回憶一殺豬似的剔頭滋味〉, 《蕉風》1960 年第 98 期, 頁 15 。 
到底要如何看待姚拓的抗戰小說呢? 除了姚拓, 另一位作家黄崖也寫了多篇以抗日 為題材的小說。但他們的抗日敘述, 遠不同於中共以抗日作為鼓吹愛國主義的敘事。

由於這些作品, 並沒有能夠與在地文學主體呼應的要素。它能吸引在地讀者之處, 還是在於華人共同體的想像; 無論是對於在地出生的華人讀者、或南來抵達的新移民, 都 應該會對這段剛剛過去的抗戰敘述有興趣。

比姚拓更早寫這類小說的, 在《蕉風》該算是黃崖。從一九五五年創刊初期, 黃崖 就已有小說刊於《學生周報》。在此僅談他的短篇小說〈秋情曲〉, 這是一篇關於抗日戰 爭時期的愛情故事。105這部小說敘述一個戰區裡的記者, 偶然結識了一個住在軍營戰區附 近的年輕女性。為了幫助這位女主角家裡的經濟, 他介紹其弟到軍隊裡當傳遞員, 但某日 與敵軍交鋒, 弟弟喪生。爾後, 男女主角在戰亂中也失去聯絡。在這篇技巧、文筆都上乘 流暢的小說裡, 敘述者沒有賦予解釋男女主角情感變化的原因。在他的小說中, 較少讀 到一般抗日小說中會出現的說教話語。無論是對日軍鬼子的斥責, 或者呼籥同胞抗敵的陳 胫濫調, 都被降至最低, 甚至亦無太多針對國民黨的成見。換言之, 這些小說確實轉換了 過去文學在政治擺布下的集體聲音, 納入不同的主題, 尤其是關於愛情與戰亂中遭逢的命 運疑問。小說為個體的倖存、想像、愛情與欲望的模糊轉變, 留下更多的敘述空間。黃崖 的小說相當受到新感覺派的影響, 譬如在小說中男女主角對愛情的迷惑與萌芽, 起於戰亂 廢墟的某個黃昏時空, 其轉折的心裡相當複雜, 但他不去解釋那箇中如謎的秘密。戰亂結 束, 和平以後的人事變遷, 黃崖的小說對於主人翁如何修補當初離亂留下的創傷, 保留了 一個開放的可能性。

從一九五 $\bigcirc$ 至一九六 $\bigcirc$ 年間, 可能是諸多友聯文人南來馬來亞, 且交出最多熱帶小 說的時期。他們的小說多注重敘述的趣味性。這個時期其他南來的作家, 譬如稍早南來的 劉以龱 (一九五二至到一九五七) , 則以奇情曲折、出其不意的小說手法, 撰寫大量的新 馬熱帶小說, 後來結集成書出版, 有《蕉風相雨》（中篇小説）、《熱帶風雨》（短篇小 説集）、《甘榜》（短篇小説集）, 但這些小說都是在返港以後才寫的。尤其《熱帶風 雨》裏收錄的小説, 多是一九五八至一九五九年間應李微塵之邀而寫, 曾刊《南洋商 報》。 ${ }^{106}$ 像劉以恖寫的奇情與都市傳奇的小說, 有些集中對女性與厄運的神祕想像, 顯然

105 黃崖, 〈秋情曲〉, 《蕉風》1957 年第 50 期, 頁 $18-22$; 《蕉風》1957 年第 51 期, 頁 20-22; 《蕉風》 1957 年第 52 期, 頁 20-22。

106在劉以䀝的二書《熱帶風雨》與《甘榜》裏, 除了〈巴刹的風波〉以及數篇未署明日期、刊登時間不詳 的作品之外, 所餘下的皆是劉返港以後才發表。從篇後註明的日期來看, 劉以齿返港後, 有長達兩年左右 
是跟隨三十年代上海作家如穆時英、劉呐鷗等人的新感覺派作風。沒有馬共、或者沒有任 何關於馬來亞緊張局勢的記敍, 幾乎是樂土般的馬來亞風情, 劉以龱的小説相當「輕」。 劉以䍘寫的其實是通俗小説, 他避開當前尖銳的政治, 轉向跌宕起伏的情節。小説的快 感，在於一些重復性的、幾可讓讀者預想得到的熟悉情節，而後再從熟悉中發展「意外」 與「驚奇」, 續而構成「奇情」, 產生閲讀的愉悅。像劉以卤這樣, 把星馬小説寫得像是 僅有當地地點名稱、街名、背景、南洋符號點緅的奇情小説, 其實《蕉風》所刊的亦在所 不少。107

這類奇情書寫，大概相當影響在地的寫作者。或許因為奇情路線的稿件太多，姚拓 才寫了這篇論創作的散文, 〈意外的結局〉。文中提到, 由於追求奇情, 使小說淪為『為 意外而意外』的失敗成品。108姚拓質疑當時諸多小說熱衷安排「意外的結局」，認為這對 小說藝術根本沒有幫助。他認為多數尋求驚奇轉折的小說, 既不合情理, 又不符合小說主 題。姚拓文中追溯這類奇情故事的起源, 以愛倫坡與短篇小說家奧亨利為典範。他批評奧 亨利的小說由於熱衷追求意外結局, 失卻了主題的深刻意義。他所批評的對象, 也涵蓋時 下跨越區域的華文文學裡、一些沒有指明道姓的作者, 乃至到當時五十年代的電影, 包括 一部關於現代美國猶太人愛情劇的好萊塢電影, Marjorie Morningstar, 中文譯為《癡鳳啼 痕》。姚拓對這部電影的理解其實有所限, 顯然出於這部電影的介紹與討論, 在英語圈子 與中文圈子裡傳播的訊息差別太大的緣故。到得一九五 $\bigcirc$ 年代末, 《蕉風》雖然已經引入 一些外文小說的翻譯、外國文學理論的介紹, 尚未能使南來文人的編輯去認識西方各別民 族之間差異的文化觀念。

姚拓對於奇情小說抱持的批判, 也出於他本身堅持固守的寫實主義傳統。不過他對 寫實主義的要求, 卻不限於如何反映現實。如同他在前述〈田園作家喬治桑〉這篇文章裡 所提, 文學既非為反映現實, 亦非為反對現實, 兩者均不能成為「文藝的使命」。姚拓寫

的時間撰寫星馬的小説, 一月内刊出多達四、五篇。〈巴刹裏的風波〉僅署日期一九五六年六月廿三日, 〈甘榜〉刊于一九五七年八月出版的《星期六周刊》, 即馬來亞獨立的當月。《星期六周刊》是《南洋商 報》於一九四九年九月時推出。《熱帶風雨》與《甘榜》二書收錄的小説, 大多數發表于《南洋商報》, 除了〈土橋頭〉（一九五八年四月《中外畫報》）與〈熱帶風雨〉（一九五九年十月號《南國電影》）二 篇。

107 譬如韶岩〈愛與恨〉（《蕉風》一九五七年第五十一期）, 小説敍及一個記者出入歌廳、舞臺, 和一個 歌星相戀成婚的故事。陸星〈一個圈套〉（《蕉風》一九五八年第六十四期），小説敍及一個資產階級的 家庭裏, 一個禍水型的女性對戀人的報復, 故事離奇如偵探推理小説, 最後查出真相大白。

108 姚拓，〈意外的結局〉，《蕉風》1958 年第 74 期，頁 7 。 
小說的技巧, 其抒情方式, 經常表現為從主角（通常是第一人稱「我」）私人的內在心緒 或感情狀態, 轉移到外界去描繪當時物景。藉由描敘「景」, 從而避免直敘事件, 故而留 白, 就這點而言, 姚拓對於描摹真實, 講究節制的技巧, 使其小說更少受限於 $「 反$ 映」客 觀現實的功能。黃思駎對寫實主義的討論亦不拘守於社會功能論, 極重視技藝、意象、象 徵等各種手法。這批寫實主義的小說, 一方面遵循著寫實主義營造真實感的敘事邏輯, 包 括維持觀點前後的統一、大致上忠於歷史背景（以從軍抗日小說而言）。另一方面, 這些 小說在敘事美學上的經營亦見用心, 從敘述結構, 敘事上簡化枝葉以顯其脈絡, 此外也顯 見隱喻、象徵和整體觀點上維持一致的敘述準則。

有些小說, 甚至可以說是相當具有銳利的批判性。譬如, 黃思騁刊於《蕉風》的小 說〈荒唐的事〉。 ${ }^{109}$ 他寫關於現代司法的虛偽面, 小說以第一人稱展開, 講述一群法官知 法犯法、官官相護。這部小說的語言節制, 無甚喧染, 通過若無其事般的敘述語調, 推 進, 傳遞出事件深沉的荒謬感。

他們的寫實主義小說, 與五四以降現實主義小說, 已經脫鉤。五四文學的現實主 義, 無論表現為科幻、童話、寓言乃至到烏托邦等各種具有幻想特質的敍述形式, 都不脫 憂民憂國的振興意圖。 ${ }^{110}$ 這點大不同於歐洲維多利亞晚期, 那在浪漫主義之後崛起的寫實 主義, 當時寫實主義曾被認爲是可以呈現 $「$ 真實」的文學, 小說朝向不同階層的題材與人 物開放。 ${ }^{111}$ 姚拓、黃崖和黃思騁的寫作, 似乎僅是在美學、題材觀察上, 才顯示出個體與 社會結構之間飽含衝突的複雜關係, 頗有以此來傳達、並釋放「以人為中心」的意圖。在 《蕉風》第四十二期, 有一篇譯自印尼小說的作品〈失蹤的兒子〉, 也觸及宗教習俗對 個人與個體慾望的擺布與壓抑。 ${ }^{112}$ 姚拓的小說, 似乎尚無顛覆或挑戰傳統道德價值的用 意, 他更傾向於傳達人際之間的和諧, 以及如何在經歷戰亂、流亡離亂之後, 以個體對幸 福的慾望為求存的動力。

\footnotetext{
109 黃思騁, 〈荒唐的事〉, 《蕉風》1957 年第44 期, 頁 10-11。

110 彭小研, 《超越寫實》, 臺北: 聯經, 1991, 頁 180 。彭小妍認為, 五四的中國知識分子雖然在文學上 呼籲實踐寫實, 但其寫實的本質, 僅是體現在主題上, 即從内容與意識上關注寫實, 可是在文學上形式卻 並非一定要寫實。

111 雷内 - 韋勒克, 〈文學研究中的現實主義概念〉, 《批評的概念》, 杭州 : 中國美術學院, 1999, 頁 218 。

${ }^{112}$ 阿姆魯拉著, 吕卓翻譯, 〈失蹤的兒子〉, 《蕉風》1957 年第 42 期, 頁 7-9。
} 
姚拓的散文與小說並未見美化農村社會的懷舊傾向, 即便是在純樸的農村裡, 依然 有各種封建觀念對人造成約束, 亦有鴉片腐蝕身心的陰影。他在〈走親戚〉這篇散文中, 提到了家鄉農村親屬之間往來贈禮的習俗, 在中共執政以後, 被共產的配給制度破壞殆 盡。 ${ }^{111}$ 像這樣揭露中共破壞民俗的回憶敘述, 可說是典型的、美援反共的寫作模式之一。 美新處資助的文學作品當中, 不乏撰寫知識份子對中共感到失望、幻滅的經歷。114這樣的 反共宗旨, 無可否認, 也能從姚拓憶童年的書寫裡, 獲得印證。然而, 除開反共的使命以 外, 一部文本並不只有單一的主題, 只是其意藴很可能為當時的文化論述與政治思潮所忽 略。從另一方面來說, 這些具有「反共效果」、技巧純熟的回憶, 其實寫來也相當紀實。

散文裡描敘的諸多細節, 對故鄉各種物質觸搓的記憶。彷彿透過書寫, 他仍能與故 鄉的諸多人事說話, 雖然其書寫語言不見得攜帶故鄉的聲調。抑或因其敘述的美學觀, 抑 或出於對讀者而言, 那語音意義難以掌握, 他並未將故鄉的語調發聲轉化成文字。姚拓本 身的河南發音, 似乎是脱離文字而存在。閱讀 (默讀) 文本而來的內在聲響, 固然會受到 讀者自身的語音經驗所限；而作者自身的腔調口音（以聲音而言）, 也無法藉由這些通曉 明白的中文來傳送。但在一個這種方言語音為罕有少數的社會裡, 將其語音音譯為華文詞 彙來書寫、創作為文學語言, 倘若不被理解, 因此是不可思議的; 從姚拓的立場看來, 自 身的語音經驗, 因其孤伶而難以為讀者所吸收與聆聽, 無法想像如何可能融入為地方感性 的語言。由此, 地方感性的文學論述, 在這樣的離散狀況下, 也就顯示其侷限。人際交談 中的口語與聆聽, 實際上是聲音與身體在場的交流經驗; 這種身體在場的經驗（包含了視 覺與聲響氣息), 實為人際之間最直觀的體驗, 先於語言所能詮釋。這種交流隔閶的缺 揻, 可能無法透過書寫與閱讀, 在作者與讀者之間建立起同等的橋樑來彌補。然而, 書寫 與閱讀卻是另一種富含想像力的交流方式, 以其記叙與事件重組, 釋放時空遙隔所封存的 物事觸感, 可能再度回裹與撫平人在異鄉的失落。

\section{（五）非左翼抗戰小說：倖存的意義}

姚拓的抗日從軍小說, 〈最不能忘記的一張臉〉, 故事起於幾個人相聚閒談。其敘 事開頭, 仿照了傳統、典型的寫實主義敘事結構, 從一開始就交代故事的來源, 使小說讀 來彷似為真。姚拓熱衷於書寫他年少時期隨軍的故事。戰事值得敘述, 固然因為這是切身

\footnotetext{
113張兆〔姚拓〕，〈美麗的童年回憶一走親戚〉，《蕉風》1960 年第 94 期, 頁 $11 。$

${ }^{114}$ Frances Stonor Saunders, The Cultural Cold War, p. 53-54.
} 
經歷, 其可寫性亦受到二戰以來抗戰文學的風潮所影響; 從軍中的生死難料、災厄威脅, 諸多價值觀與秩序在戰亂中崩壞, 諸多衝突交會, 恐怕對姚拓而言, 那體驗之難忘, 之可 寫可敘，遠非馬來亞的日常與和平生活所能謧比。

在姚拓這些從軍的小說裡，隊友之間的情誼、青春與陽剛，都是小說敘述不可或缺 的背景氣息, 也是支撐軍隊與團隊凝聚的要素。小說常以男性之間詼諧的話語, 消減戰亂 的沉重感, 同時, 也使得這記憶變得更加的個人化。由於追憶總是要透過語言來敘述, 在 語言裡調度情感、記憶的色澤溫度, 對過去的敍述因此也就能牽動主體對於此刻倖存的意 識。在馬華文學那些主張語調樂觀、健康的愛國主義文學裡, 正是這健康、積極的語言帶 來振奮與鼓舞生存的作用, 但這特性對文學而言, 往往也意味著得犧牲掉關於憂傷、心靈 陰影、歷史禁忌、秩序結構的反面或負面特質等等各方面的探索, 因而失去深刻的向度。 以這樣看似樂觀、健康的語調寫作, 如何能夠逼真地呈現出現實經驗, 尤其戰爭中那些為 人所不樂見的諸多經驗與景象, 似乎就變得不可能。然而, 從另一方面來說, 這種樂觀的 語調, 也可能是體會過死亡戰亂, 才轉向從語言索求, 那些能鼓舞生存意志力的語彙與修 辭。

閲讀姚拓的散文與小説, 確實滿紙洋溢愉悅和熱情, 但他也沒有掩藏面對死亡的複 雜感受。在〈最不能忘記的一張臉〉裡, 小說這麼描敘在戰場上進攻之際, 一個士兵丟棄 他背負的背袋，裡頭裝著母親為他準備的衣物與家書：

這些都是身外之物啊！當一個人知道他將要面對死亡而又絕對無法避免時, 那麼, 還要這些身外之物做甚麼? 還要這一些可回憶一一而又令人沉痛的回憶之物做甚 麼? ${ }^{115}$

現場處處散落死者的遺物, 讓人無法注目。這段描敘, 著著實實地發乎於個體與死亡打面 照而來的頓悟, 生者的世界在死亡面前闔上。在姚拓大部分的從軍書寫裏, 他迴避了沉重 的語言, 但即便看似慣於輕快書寫的作者, 筆下仍不免流露出那記憶裡曾有的 $「$ 令人沉痛 的回憶之物」。

〈四個結婚的故事〉，也是關於戰亂中倖存的故事。小說講述了四個軍人面對職務 軍令召喚時, 分別做出不同的四道選擇。小說在結尾時, 透過那第一人稱的「我」現身説

115 姚拓, 〈最不能忘記的一張臉〉, 《蕉風》1958 年第 55 期, 頁 5 。 
法, 幾乎有如夫子自道般表明小説的觀點。個體追求幸福與倖存的照望, 那意義並不少於 愛國主義或民族主義強調的群體利益。

姚拓的寫實主義作風, 和方天不同, 他比較關心個體如何從險境中生存下來的問 題, 而非階層或社會體制的不公。姚拓的小說如〈一張無法忘記的臉〉或〈丘陵上〉, 均 總結以人生亂世的倖存之道。姚拓的小說, 也隱隐呼應和平安居, 終結流亡放逐的願望。 這樣的生存意識, 也許源自於〈丘陵上〉, 兩父子走在霧中, 父親護送孩子離家工作, 孩 子也最後一次聆聽父親的故事, 所獲得的啟迪。父親追憶當年拯救一個幾乎快凍死的路 人, 但是拯救人是個沉重的負擔, 兩人幾乎一起在冬雪中凍僵䍜難。在這個父親道來的故 事裡, 生存究竟繫於意志或偶然的冥冥天意, 其實沒有答案。但那來自父親的勸勉, 道出 生而為人應有的人本價值觀, 也貫穿了姚拓的多篇小說。

黃思騁也有一篇關於劫後餘生的小說〈空葬〉, 刊於一九六 $\bigcirc$ 年的《蕉風》, 主人 公坐上友人的二手車, 在金馬崙山路上遇險。路途從吉隆坡出發, 車子開到金馬崙山上, 為了閃避一輛車子, 而失控懸掛在䯚崖邊。這故事看似平常、只不過是日常生活裡的某次 出遊。雖然以本土空間為背景, 小說並沒有特意去撰寫或呈現本土性這一題材, 而只是集 中於那更普遍化的, 譬如死裡逃生這一主題。一個人如何能在危境中拯救自己同時也拯救 他人, 以便能共同在新的世界制度裡生存, 這樣的主題貫穿了姚拓、黃思駎的寫實主義書 寫, 幾乎是他們共同擁有的現代意識。

在獨立之後, 戰亂結束, 馬來亞仍在剿共。這份倖存者的視角, 與獨立之際官方複 述安穩建國的聲音, 兩者其實頗有共譜和音的效果。對於倖存經驗的確認, 也呼應了當時 的政治意識轉向：接受反共、中庸、和平與脫離鬥爭的意識形態。在黃思駎的小說裡, 一 開始就描寫了求生本能引起的一連串聯想：

試想一想吧, 一個人坐在一架被現代文明所创造出來的滾動囚車裡, 然後又在不備 之中阔進路邊的山野, 在五丈左右的斜坡上, 像表演驚險鏡頭那樣翻著筋斗落下 去。正當要葬身萬丈深淵的之際, 又遇上雨棵大樹, 連事带人搁住, 好像野蠻民族 塞行空葬一般。事後想來, 彷佛造物主預先就知道我們的車子要在那地方翻身, 然 後才讓那地方長出雨棵大樹來似的。 
我用盡全副精力，從破碎的窗口爬出來的時候，還弄不明白眼前的世界是原來的那 一個，還是已經到了另一個世界。116

對於倖存或者生存的本能, 驅使敘事圍繞著主體為中心, 賦予一連串因果關係神秘的解 釋。從過去大自然的驚怖, 轉移到現代性的生活裡, 這裡頭仍然有那無可確定的、被拋橂 於世的未知惘惘。這裡同時存在著雙重的意識：一方面追求安穩的生活, 一方面又對這聲 稱和平安穩的現代體系, 存有懷疑。因為這樣的雙重意識, 現代文學的敘述勢必得經歷分 裂, 去面對那為體制馴服而來的安穩幻影, 那由於國共分裂、中國易權、冷戰氣候與國籍 身分, 使得個體的自我認同與所在之地, 都經過了權力的重新編碼, 雖然能夠「安穩」倖 存，但此身所在的此時此地，也已然是被撤換了的世界。

回望馬華文學的寫實主義，打從左翼提出「現實化」這任務以來，這現實化的任務 從來就沒有完成過。 ${ }^{117}$ 關於現實, 以及何謂現實的解釋, 參照的框架何在? 符號與符旨如 何可能捕捉「現實」這一客體在筆下的意義？根據羅蘭巴特對現實主義規範的拆解, 便一 再以那棤瓦於符旨/意義之間不可抹消的距離, 作為反駁寫實主義反映論的譬證基礎。 ${ }^{118}$ 但 是在符號與符旨斷裂、滑動的關係上, 語言又如何能賦予意義, 包括賦予歷史主體與國族 身分的意義呢?

\section{七、小結：在地屬性與文化異子}

由於這是一份自創刊伊始就聲明本土認同的雜誌, 故而讓人期望, 刊出的作品應當 能夠體現出在地文化, 或與在地文學、文化觀點交流的聲音。如同先前所述, 陳思明於第 七十八期的改版宣言裡，提出了須以多元文化來使文化保持生命力的勸勉。多元，固然可 理解為在地的混雜文化特質, 然而, 未嘗不能包括, 南來文人與此地, 兩種文化的交會與 相遇。早期姚拓、黃崖、黃思駎等人的憶鄉、抗戰書寫, 以本土雜誌《蕉風》為「反共基 地」而發表的小說, 正好為境外文學與本土文學之間, 提供觀照何謂馬華文學的個案。

\footnotetext{
116 黃思騁，〈空葬〉，《蕉風》1960 年第 91 期，頁 $18-20$ 。

117 免升, 〈馬華文化為甚麼要現實化? 〉, 方修編, 《馬華新文學大系：理論批評 (卷二)》, 星洲世界 書局, 1972, 頁 331。

118 譬如, 當羅蘭巴特提到現實主義的意蘊總是被推測為穩定的成分, 然而根據他對羅伯格里耶小説的閲 讀, 說明文學的意義總是落空的; 故而文學總是非現實的。羅蘭巴特著, 懷宇譯, 〈關於羅伯-格里 耶〉，《文藝批評文集》，北京：中國人民大學出版社，2010，頁 236-245。
} 
南來文人不全然都能實踐此時此地的在地書寫, 尤其獨立後南來的文人, 在最初數 年內, 並不立刻投入在地化的寫作, 究其原因, 也可能與獨立建國之後的期朌落差有關。 諸多種族文化、教育與語言的問題, 在獨立後浮上橲面。對於南來文人而言, 離散與本土 可能具有同時被意識到的雙重性, 兩者都在場。 ${ }^{119}$ 姚拓的科幻小說〈七個世紀以後〉, 也 是在這歷史氛圍中, 因對國家體制、語言與國籍身分的問題刺激而生。除了這部作品之 外, 其他作品皆以香港和中國抗日戰爭為背景。黃思騁、黃崖的小說亦多描述地點不詳的 北方空間, 包括中國和香港。

如同薩伊德所言, 流亡他鄉, 意味著一個人必須把那失去的, 永遠割捨、留在背 後。與此同時, 薩伊德也認為, 經歷這樣撕裂, 流亡仍可能賦予現代性文化機制以強大的 再生與重生能力。1 20 這正如同陳思明在前述第七十八期改版宣言中提到的, 「愈能多接觸 其他文化、愈能獲得新血、新的生命力」。中華文化與母體剝離之後, 必然得從異鄉的土 壤生出有地域屬性的文化異質體質, 使得那通過知識分子遊走全球、散布或傳播海外的 $\ulcorner$ 中華文化」, 在異鄉生成與母體迴異的異子; 就在這層意義上, 重塑馬來亞「本土性」 的華人文化。

如同姚拓南來的三十四件行李, 抵達後成家, 這過程當中, 家具需要加以重組嵌 置。姚拓個人以及其他南來文人, 他們之於友聯社的關係, 以及友聯之於美援文化、英屬 馬來亞聯邦的反共、剿共體制, 均有如層層裝置、權力釀嵌的編碼網絡。但對於馬來亞官 方而言, 冷戰時由友聯發揚的「中華文化」, 最初彷彿是作為防禦內部族群成員分裂的黏 合物而收納。在極力掃除中共左翼引入的華文教育資源以後, 這留下的空白需要填補, 但 在此所置換的, 不能再是認同中國為祖國的想像。因之, 友聯的「中華文化」, 一方面帶 有過去斷裂的意義, 另一方面, 友聯的 $「$ 中華文化」卻又是把這小文學連接上離散全球的 華人文化想像的萌脈通道一一只是不復航向中國。

這樣的中華文化傳播, 無疑是一場與「祖國」（中國）母體斷裂、又因與區域互 動, 廣泛從周邊吸收, 而長成跨地域的交流網絡。無可否認, 這些區域之間多中心的系 統, 彼此條件並不對等, 因為文化、資源與歷史條件差距之故, 中心與邊緣位階的差異, 幾乎歷時而更加顯著。

\footnotetext{
119 譬如說, 雖然本土認同、愛國在日常裡為主流, 但是一旦選擇移民、或居留國外發展事業, 其身分或空 間意識, 便即翻轉改變。離散或者本土，其實並不如這些語彙的定義，所指定的那麼堅固。
}

${ }^{120}$ Edward Said, Reflections on Exile, p.137. 


\section{第六章 \\ 現代主義白垩紀 ${ }^{1}$ : \\ 白圭的反叛、局限與待續}

馬華文壇叛逆者的名字，不是個人的名字，而是反叛文學作品共有的名字：現 代詩。2

詩是一個絕對獨立、純粹的宇宙。 ${ }^{3}$

\section{一、開端}

一九五九年《蕉風》同時推出人文主義、自由主義與現代詩改革。如前所敘，人文主 義對馬華文學的落實其實廣泛而不明顯。改版宣言裡強調, 人文主義乃是 $\ulcorner$ 以為中 心」, 然而現代主義的書寫似乎不志在體現 $「$ 以人為中心」這個意義。據白圭所言, 當時

$\ulcorner$ 現代詩微末初起，未見枝葉，應非主幹。人本文學的新人文主義內涵，才是正題。」 可見《蕉風》雖然把這兩個議題（「人文主義」與「新詩改革」）一起推出，但其實各自 分述, 所關注的範圍不同。據白圭所言, 由於新人文主義理論複雜嚴密, 當時反對與杯葛 友聯出版社的團體, 無法對此展開攻擊, 遂把焦點轉移到當時同期刊出的凌冷 (白圭筆

1「白垶紀」, 白圭喻為一九五九年現代主義開端初期。白圭, 〈現代詩的前侏儸紀〉, 《縷雲起於綠 草》, 頁 173 。

2 白圭, 〈林裡分岐的路一反叛文學的抉擇〉, 《縷雲起於綠草》, 頁 82 。

3 語出梁宗岱一九三十年代的《詩與真》。轉引自白圭, 〈敢為流俗別蹊行一一再革命的火苗〉, 《縷雲 起於綠草》, 2007, 頁 94。

${ }^{4}$ 白圭, 同上註, 頁 90 。 
名）〈新詩的再革命〉, 文中提到「橫的移植」，引致各方抨擊，結果反而促成現代詩獲 得的關注, 竟遠勝 $\ulcorner$ 人文主義」。

$\ulcorner$ 人文主義」與「新詩改革」, 前者和二十世紀初「新人文主義」有關，後者則重提 五四時期格律詩與自由詩的詩歌觀點。從 $「 人$ 文主義」到「新詩改革」, 這兩個議題所獲 得的注意不同, 一方面說明馬華文學的創作普遍上較能獲得感性迴響, 論述則因教育或學 術條件實乏之故, 而難以展開; 但另一方面, 詩歌的變革與形式蛻變, 其實也無法以人文 主義中那「以人為中心」的理論來概括。詩歌改革並不釋放人, 而是釋放書寫, 使得書寫 可以從反映現實的義務剝離出來。

\section{二、盜火者白圭與現代詩起點}

在白圭的譬喻中, 現代詩起步如黑暗中持火的「反叛」者, 可能是這場文學史遞變過 程中, 色質最鮮明的圖像。這 $「 火 」$ 既從台灣現代主義運動盜來, 但也有從一九三○至四 $\bigcirc$ 年代中國現代文學（尤其是象徵主義、自由體現代派新詩）以及中國現代文學「五四」 那裡盜過來。6張光達已道出白圭的現代主義, 所要打破的, 就是當時馬華文學現實主義 蔚為主流的局面。7

目前學界的結論多以為, 第七十八期的《蕉風》改版, 是這份刊物最初開啟現代主義 的標誌。一九五八年, 白圭在《學生周報》發表突破格律體詩的現代詩《麻河靜立》, 同 年年初, 他曾和冷燕秋與其他學友, 在怡保街頭散步時, 談及格律體詩需要突破的問題,

《麻河靜立》發表後, 引起了冷燕秋和周喚的注意, 三人開始創作起現代詩。 ${ }^{8}$ 但最初極 小眾。如白圭所言, 大部分在《蕉風》寫現代詩的作者, 原先已在《學生周報》試煉寫 詩, 《蕉風》的新詩培育其實源於《學生周報》〈詩之頁〉。9

在一九五 $\bigcirc$ 年代非左翼南來文人群中, 或許是白圭與姚拓的資料, 最為完整。白圭 （一九三四一二○一五）, 本名劉國堅, 出生於中國廣東, 一九五三年從香港考入臺大,

\footnotetext{
5 白圭, 同上註, 頁 90 。凌冷（白圭），〈新詩的革命〉, 《蕉風》1959 年第 78 期, 頁 19 。

6 黃錦樹, 〈别一个盗火者〉, 《星洲日報》, 2015 年 7 月 5 日, 文藝春秋版。亦見白圭, 《縷雲起於綠 草》, 頁 90 。

7 張光達, 《馬華現代詩論一時代性質與文化屬性》, 頁 6 。

8 張錦忠, 《馬來西亞華語語系文學》, 吉隆坡 : 有人, 2011 , 頁 56 。白圭, 《縷雲起於綠草》, 頁 86 。 ${ }^{9}$ 白圭, 〈路漫漫其修遠兮——現代詩的起步〉, 《縷雲起於綠草》, 頁 85-88。
} 
在臺灣的時候, 他曾參與編輯《台大思潮》, 主編還有逯耀東, 刊物的顧問老師是傅啟 學。10一九五七年從歷史系畢業後到香港, 他在港時, 曾短期擔任友聯旗下的《大學生 活》編輯, 後轉赴馬來亞的《學生周報》工作。一九六九年後, 才加人 《蕉風》編輯陣 營。一九八一年移民美國。

在臺灣留學時, 白圭曾經主編《台大思潮》。他在一九五七年十一月抵達吉隆坡時, 馬來亞獨立已過兩個月。他最初在《學生周報》負責通訊部（即作者讀者的活動中心，這 份工作包括與全馬各地的通訊員交流, 以及辦生活營）, 同時兼編每期一頁的〈詩之 頁〉。 ${ }^{11}$ 在一九六九年後, 白圭才正式接編《蕉風》。

在一九六四年的《蕉風》裡, 白圭曾經提及, 「菲律賓有一份文學刊物, 將本邦馬 華現代詩的出現追溯到一九五八年八月間學生周報詩之頁所刊登的一首詩起 ${ }^{12}$ 。關於馬 華現代詩的源起與回顧, 已有溫任平、陳應德、張錦忠和張光達撰文討論。張錦忠認為一 九五九年《蕉風》第七十八期是第一波現代主義的起點, 這一期也為人本／個體主義定 調。 ${ }^{13}$ 張光達認可溫任平的看法, 即同意陳應德所發現的、一九五二年間的現代詩, 當為 現代詩「史前史」的孤立個案, 故此, 仍以一九五八年至一九五九年間的現代詩初現, 為 第一波現代主義的開端, 認為當時白圭接編《學生周報》過後, 開始出現的現代主義詩 風, 較具文學史上典範轉移的意義。 ${ }^{14}$

\section{三、文藝的個體主義}

一九五 $\bigcirc$ 年代末, 馬來亞的 $\ulcorner 反$ 共」計畫, 在獨立後獲得大量華人支持, 而《蕉 風》創刊首兩年的「在地化」標語, 也已然取下, 這一切似乎都標誌《蕉風》在地化任務 已完成。白圭追述當年揭竿而起的過程务促, 十分簡陃, 但從當時極小眾的部分作者所寫 的現代詩, 已可見到其詩歌語言和風格表現, 都和之前的新詩不同, 不復為傳遞、使用、 承載功能的表達方式。

\footnotetext{
${ }^{10}$ 白圭, 〈我的 1953 1957〉, 《中國時報》, 2014 年 2 月 4 日, 藝文副刊版 http://www.chinatimes.com/newspapers/20140204000418-260115

11 白圭, 〈路漫漫其修遠兮—現代詩的起步〉, 《縷雲起於綠草》, 頁 85 。

12 白圭, 〈藏拙不如出醜——現代詩閒話〉, 《蕉風》1964 年第 140 期, 頁 12-13。

13 張錦忠，〈亞洲現代主義的離散路徑：白圭與馬華文學的第一波現代主義風潮〉，頁 219-232。

14 張光達, 《馬華現代詩論一時代性質與文化屬性》, 頁 6 。
} 
從第七十八期的革新號來看, 當時並未立即有現代主義的理論引領風潮。那變化首 先展現於詩歌的語言、結構、分句與空間。在一九五九年的學生周報〈詩之頁〉與些許現 代詩裡, 那最鮮明的反叛與革新, 除了不再高歌愛國主義與現實主義之外, 也卸下了過往 所強調的樂觀、光明的語調。反之, 對於個體在時空中的感受與觀照, 在現代詩裡開始成 為文學主題。現代詩語言的隱密與多義的特性, 使得詩歌的語言本身成為具有獨立特性 (automony)的藝術領域，宛如一個「純粹、獨然的宇宙」。

在一九五八年至一九五九年間, 於《蕉風》刊登的五篇文章, 除了第七十八期出自 陳思明但僅署名「本社」撰寫的〈改版的話〉, 是在傳遞友聯社的宗旨之外, 其他同期刊 出的稿件, 包括魯文 (白圭認為是徐東濱化名) 〈文藝的個體主義〉 ${ }^{15}$ 、凌冷〈新詩的再 革命〉和同期刊登的兩首詩, 周垂〈海岸上的灰衣人〉 、白圭〈八達嶺的早晨〉, 再加上 第七十九期隨刊附送的詩集〈美的 V 形〉, 都可說是第一波現代主義啟航的聲明。雖然

《蕉風》在稍後也有刊出數篇討論新詩或爭議現代派文學價值的文章, 但至到一九六○ 年, 都未見再有可以銜接這幾篇宣言的闢論。

這幾篇文章之中, 只有〈新詩的再革命〉討論詩歌, 其餘數篇, 可說是延伸「個體」 作為文學主體, 以及闡明 $「$ 以人為本位」的觀點。人本主義的主張, 除了旨在表明與中共 毛澤東《延安文藝》的作風截然迥異之外, 亦有揮別文學功能論的意義, 故此具有雙重的 革新意味。雖然過去《蕉風》早已以「純馬來亞化」及「純文藝」來表達與中共迥異的非 左翼立場, 然而何謂「純馬來亞化」及「純文藝」, 畢竟内涵模糊, 況且由於愛國主義盛 行, 馬來亞化與在地色彩在當時廣受認同, 刊物徵稿多奉為圭臬。現實主義的實踐觀點, 無論左右翼, 多廣見認同。即便《蕉風》刊登過的現實主義藝評, 亦多見文學實用嚾點。 惟魯文〈文藝的個體主義〉與改版的人本主義宣言, 卻是獨樹一幟, 一反過去強調文學需 要背負道德責任、訴諸改造社會的義務與習性。

〈文藝的個體主義〉這篇文章銜接改版宣言, 開宗明義討論「今後文藝的方向」。作 者把當時馬華文學的寫作風格劃為四類, 寫實主義（反映現實）、理想主義（為人生而藝 術, 主張文藝大眾化與普遍化) 、個人主義（主張寫作個性的發展, 為這四類之中的最小 眾）以及最後顯然是左翼社會主義文學觀點的鏡子旗子派。文中提出「文藝必須是文藝」 的時候, 就強調了文藝的獨立特性, 即「文藝應該獨立於所有文藝的「效果」之外」。

15 關於〈改版的話〉出自陳思明, 而〈文藝的個體主義〉作者魯文非姚拓, 白圭認為是徐東濱化名, 見 《縷雲起於綠草》，頁 $74 、 80$ 。 
例如古典主義或理想主義者, 認為理性是重要的, 認為文藝應為人生而服務。他們 認為文藝的某一方面的效果，可以改革人生，使人生向善。可是，請注意這只是 「效果」，這只是「果」一卻並不是文藝㓣作的「因」。假如把「效果」當作鴧 作的動機, 這就無異於把文藝當作了工具。無論甚麼事情，只要你一把它當作了 「工具」使用，你就會慢慢地走到完全「實用」的地步（文藝踓有實用的用處，但 並非為了實用），作為工具的東西，往往是陝小的，拘束的，結果就會完全失去了 文藝應有的「美」的條件，恢復到古典主義時代所犯的毛病。16

在五 $\bigcirc$ 年代, 當現實主義坐大為主流時, 僅有極少數的群體, 敢稱自身為個人主義者。 ${ }^{17}$ 魯文文中談到個體主義, 頗近「個人主義」, 但較注重地位「平等」、且有互為主體、地 位均衡的概念。談到個體主義注重「表達」, 而社會主義現實主義注重「傳遞」, 已大不 同過去在現實主義或浪漫主義書寫中，一律遵循以文字來傳遞「意義」的傳統文學觀。

與改版宣言比較，魯文〈文藝的個體主義〉也更多強調文學語言的自覺特性；除開發 自文學美學目的的 $「$ 表達」之外, 任何通過「傳遞」達到的教育與教化效果, 都外在於文 學, 不能構成文學何以為文學。這應當是《蕉風》從一九五八、五九年間乃至其後數年, 最具文學意識的聲明了。以五 $\bigcirc$ 年代馬華文學的學術情況, 並未有評論者能就此充分回 應。 ${ }^{18}$ 當時馬華文學諸多流派, 但大部分都仰賴於文學的效果, 來指認文學, 猶如透過影 子來指認本體一樣。

此外，個體主義的出現，還可追溯得更早。盡管評論者多以一九五九年第七十八期 改版, 以魯文 (據白圭, 此魯文非姚拓, 而是徐東濱) 撰寫的〈文藝的個體主義〉為起 點。不過個體主義在《蕉風》的出現, 早有一段酤釀、探索的過程, 譬如在一九五七年第 四十二期王恢撰寫〈陶淵明的思想、人格和作品 ${ }^{19}$, 就點出 $\ulcorner$ 個體」乃為藝術創作不容 否定的本質 :

16 魯文, 〈文藝的個體主義〉, 《蕉風》1959 年第 78 期, 頁 4-5。

17 魯文, 〈文藝的個體主義〉, 頁 4 。

18 雖然下一期有一篇齊梁〈重新發現文藝本身的真正價值〉回應魯文, 但除卻重複反對政綱教條的觀點之 外, 卻無能就文學本體上的意義, 再加以推演、闆發。甚至以魯文之名發表的其他評論, 譬如魯文〈文藝 欣賞的 $「$ 尺子」〉（發表於一九五九年第八十六期）亦無超前之見。

${ }^{19}$ 王恢, 〈陶淵明的思想、人格和作品〉, 《蕉風》1 957 年第 42 期, 頁 4 。作者王恢, 據編者介紹, 原是 香港人生雜誌社的編者, 當時應聘南來聯邦新文龍中華中學執教。 
一切的藝術, 都是「個人」的產品, 尤其是文學的製作, 必須有他個人的自由, 因 為創造的瑰寶是深藏在一個人孤獨的心霝裡的。

在同年十月廿五日第四十八期的《蕉風》, 亦有一篇高峯撰寫的, 紀念創刊兩年的文章 〈酒逢知已千杯少〉。 ${ }^{20}$ 這一篇文章則解釋藝術跟個人、以及從個人至他人與群體之間的 交流關係。文章追溯藝術的發生, 從「藝術是感情與意象相交的單純心靈活動」到 $\ulcorner$ 人類 有交感共鳴的需要」, 以魯濱遜飄流孤島為例, 「真的與世界隔絕了, 但他還要想盡辦法 找一隻狗和一個土人來作他的伴侶, 可見人與人之間感情與思想的交流, 是最原始而普遍 的本能。」最後得出結論, 文藝有先天的社會性, 無法遺世獨立; 既不能苟同於集體意識 或社會改造功能論, 亦不願圊限於個人論或自我論。但是, 高峯留意到藝術表達有超出字 面或符號象徵的意義, 交流不限於意義的傳遞, 而是以未能言盡幾近默契的心靈振鳴, 才 能使之「浸潤」讀者的心靈深處, 故需要如詩人孟郊那樣逐字推敲。雖然作者並未明白點 出, 這篇文章其實納人了古典文學與詩學的藝術起源論。個人化的藝術觀點並非全然屬於 現代情境, 它是極古老的思維, 而藝術的心靈發生論也可溯自中國上古詩學傳統, 諸如 《詩大序》中的「情動於中而形於言」與劉妿《文心雕龍》的「應物斯感, 感物吟志, 莫 非自然」。21藝術的心靈發生, 源於個人感應, 文章追溯本源力證創作根本不可能排除個 人因素。

高峯這篇寫於創刊兩周年的文章, 比起兩年後第七十八期改革號的〈改版宣言〉、凌 冷〈新詩的再革命〉與魯文的〈文藝的個體主義〉, 討論得更細淢, 可說是在為馬華文學 介紹幾乎是純粹性的藝術觀點。但這篇〈酒逢知已千杯少〉（刊於兩周年創刊紀念特輯） 之後, 並未同時跟著任何具有變革性與影響力的文學運動。無疑當時, 這篇文章的觀點, 也意在反對中國自一九五 $\bigcirc$ 年以來掀起的鎮壓右派和壓制作家創作自由的政策。同時又以 文學有呼應主體間際交流與共感的需要, 以此突破當時馬華文學文壇上, 以為談論「個人 主義」和個體主義, 就必然會陷入個體框限的僵固看法。

這篇文章的觀點, 其實相當菁英。《蕉風》並不暢銷, 每期銷量大約只有一千五百 本, 一九五五年創刊時, 每期虧損約為一千五百元。如謝詩堅所言, 從其銷量而言, 《蕉

20 高峯, 〈酒逢知已千杯少 - 謹以此文作為本刊二周年的賀禮〉, 《蕉風》1957 年第 48 期, 頁 4-5。

21 劉若愚著, 杜國清譯, 《中國詩學》, 臺北 : 幼獅, 1977, 頁 112 。 
風》對馬華文學的影響力, 可能相當有限。22但以「量」做為影響力的衡量, 恐怕會錯失 文學觀遞變的過程以及觀念醞釀、交縷、萌芽的路跡。

\section{四、與集體的政治話語疏離}

在一九五九年, 《蕉風》提出這兩個人文主義與個體主義的理念時, 現代詩也才開始 出現, 此時的文藝反叛姿態其實是雙重的 : 一者朝向左翼、另一個是針對整體上馬華文學 長期遵循的反映論, 後者不分左右翼。現實主義在這之後, 仍然持續、繼續運行到六、七 十年代為小說主流。那麼, 關於那受到英殖民政府壓抑, 使得（政治的）批判精神在文學 書寫中弱化的問題, 值得再做討論：關於批判性的文學想像, 倘若以反抗強權作為衡量, 其中仍有弗詭之處? 一方面如王德威所闢述, 由於寫實主義小説中内蓝的否定辯證 (negative dialectic), 導致革命行動與革命書寫, 彼此相互作廢。 ${ }^{23}$ 馬華文學中的寫實主 義, 其力有未逮之處, 無疑要歸各於當時的政治威脅。現實主義的批判特性, 總是驅使書 寫的箭矢朝向那可貫穿權勢與權力的不公義核心; 然而, 觸犯權力、與之拉鋸的結果, 又 會導致寫實主義文學難以生存, 被逼抹除。故以各種書寫技巧, 迁迴逼近那不可直寫的對 象; 但在書寫過程中, 書寫符碼, 本身也面臨真實之難以精確指涉, 文字總有模糊與晦暗 之處。不僅因為權力與政治的威覌, 即或從文字意符與符旨的關係而言, 書寫本身與真實 之間總有一道無法磨滅的距離。無論是書寫穿越的軌跡, 抑或那所欲再現的對象, 皆會因 為詮釋的分忿而變得模糊多義。從這方面來說, 寫實主義的 $「 反$ 映」之局限, 或許也經由 這層自覺而不得不另外發展, 有所轉移。即或如方天的寫作, 也有現代主義的層面。從一 個具體外在的實體對象, 而延伸到那塑造主體的結構與秩序, 進而反身思考經此結構而來 的生存處境。現代主義的批判力量並非能以弱化來斷然論之, 母寧是為了與所欲反思或探 索的對象, 而轉向挖掘內在或探視複雜的脈絡, 因而削減了其中的二元對立意味。比起現 實主義, 現代主義也更加小眾、異類、菁英化, 其審美和詮釋符碼與大眾更加疏遠。然 而, 即或文字符碼對真實的指涉為遙不可及, 但從符碼輻射開來的語義岔叢中, 仍能投射 出多重閱讀（包括誤讀）的可能性。

\footnotetext{
22 謝詩堅, 《馬華左翼文學》, 頁 197 。

${ }^{23}$ 王德威, 《歷史與怪獸一歷史, 暴力, 敍事》, 臺北 : 麥田, 2011, 頁 88 。
} 
馬華文學中的第一波現代主義, 所欲揮別的, 不僅是左翼的觀點, 亦包括《蕉風》早 前於方天編輯時期, 由李婷等作者所論述過的、曾經蔚為一時的文學實用論。根據白圭 《縷雲前書》〈蚊雷並不兆雨〉篇中所記, 在一場於一九五八、五九年間於怡保舉行的座 談會裡, 他強調必須擺脫政治的包䘞, 有必要與新文學以來的政治任務, 徹底了斷：

我們有必要將文學與政治徹底分開。尤其是詩歌……這把劍，應該捍衛文學自由， 不應作為爭權的武器。詩人有他另一套法寶, 與詩創作是雨件不同的事, 在實際政 治上, 詩人將運用他神聖的一票, 正如一個小販, 一個工人一樣, 選擇一個他喜愛 的政府。 ${ }^{24}$

如此斷然將政治與文學隔開, 應該是出於對中共當時「批判」與「交心」話語之氾濫, 感 到極度厭惡與排斥之故。《縷雲前書》也記敘一九五六年間, 某一場由方天談論王實味的 《野百合花》講座, 方天講述王實味創作的緣由、其寫實主義信念、以及延安當時的不公 平階級制度, 以及《野百合花》發表之後, 不能見容於延安主流, 使得王實味遭判死刑。 ${ }^{25}$ 其時白圭尚未抵達新馬。他如此慎重整理這一章節, 不只因為方天對王實味「說真話」 的推崇, 亦因為王實味《野百合花》之作, 凸顯了寫實主義的理念, 在中共執政後變得不 可能。 ${ }^{26}$ 根據白圭自身的解釋, 他對當時蔓延到新馬的批鬥風氣和政治狂熱, 極度反感, $\ulcorner$ 任何文化活動, 都與政治劃上等號, 非左即右, 沒有中道」。在白圭的回顧中, 「他對 政治本來興趣缺缺」, 而後, 「懷疑能否繞過政治的襖熱, 讓文化的縷雲再起」。 ${ }^{27}$ 兼且 獨立之際, 馬來亞有諸多政治禁忌與敏感, 超出他的掌握。由此可以理解, 在前述的怡保 座談會上, 白圭強調必須走向純文學的詩歌寫作, 由此奠定這場現代詩文學變革的意義; ${ }^{28}$ 全盤轉向開拓詩歌語言美學的翻新、創造與突變, 讓《學生周報》的詩歌作者, 這群 $\ulcorner$ 年輕的侏羅紀小恐龍」, 能夠充分在創作中展放「奇思怪句」、「狂慧幽光」。29盡管 如此, 轉向 $「$ 去政治化」的詩歌藝術、從周遭壟罩日常的政治話語（無論是來自官方、政 黨抑或本土的左翼陣營）中突破, 這種寫作語言的鍛鑄與蛻變, 本身不是沒有政治反叛意

\footnotetext{
${ }^{24}$ 白圭, 《縷雲前書》（下），頁 379。

25 白圭, 《縷雲前書》(下), 頁 114-121。

26 白圭, 《縷雲前書》(下) , 頁 120 。

27 白圭, 《縷雲前書》（上）, 頁 282-283。

28 白圭, 《縷雲前書》（下）, 頁 378-381。

29 白圭, 《縷雲前書》(下) , 頁 366 。
} 
義的。盡管白圭認為, 這番改革所要克服的, 是左翼的文學觀, 但實際上, 從切斷文學創 作與政治的關係而言, 或許亦遍及左右翼都有的文以載道觀念。

對於《蕉風》現代主義第一波改革而言, 「人本主義」的影響似乎誇大了, 很難從白 奎及之後追隨者的詩作裡, 看出它有甚麼切實的影響。除開在力匡的詩裡, 他對於人文與 藝術這些議題, 偶而會表現出帶有反駁意味的興趣, 透過在詩中創造的多種分身或角色來 代言、表達, 寫出對人文主義致以省思的作品。如刊於一九五八年的《學生周報》封面頁 的《拾穗者》, 詩歌寫這幅名畫：「拉菲雨的题材永遠離不了宗教, /他除了畫聖母外就 畫教皇, /信徒來購埾母像時肯付重價, /教皇的恩睗使他鈛包腫浱。//學院的畫家只 畫英雄的事蹟, /永不肯用畫筆解及一次平常, /他們不知道䒱術該基於現實, /他們的 畫布上只有虚幻渉茫。」然後詩歌轉向自身所在的「此地」與「現實」意識：「拾穗者的 完成又過了一個世紀，/米勒的筆解替多少畫家指出方向，／如今我也拿起了我的彩筆， /去繪畫這裡的拾穗者與這社的陽光。 ${ }^{30}$ 盡管已經如此熱切地表明, 詩人想要感受當下 此地的心意, 然而, 多首詩作也熱衰於描繪一個旅者, 始終朝向渺遠他方, 其內在的矛盾 既拒還迎：「但他要到深沉而無邊函的大海，／單獨地駕駛自己的船，／他一天跟著一天 航行在平静的海面，／到了有一天海上湧起巨浪如山。」「没有誰知道他最後的捊扎，／ 如今海上浮著失掉生命的水手和桅干, /呀! 他本來可以安安稳稳地在岸上度日, /一直 活到使別人和自己全不耐煩。」 ${ }^{31}$ 力匡的詩歌經常表達那處於邊境之間的俳徊, 並凝望那 於邊界處晃動起伏的模糊狀態，詩歌由此拒絕凝定於穩固的線條。

在力匡詩作中, 這股拒絕恆定、抗拒溶人集體的疏離意識, 跟現代主義對現代秩序的 質疑沈思觀點, 骨子裡幾乎相通。不過, 他的詩歌語質卻是抒情的, 那語言風格甚至幾可 說是平鋪直敘, 從未表現過絲毫語義上的岔䕕突變。

但從另一方面說, 〈水手之死〉詩裡那寧捨陸地, 也要出航的旅人, 也許就摺藏著, 那稍後發生於次年, 《蕉風》與《學生周報》開始啟航的現代詩探索之旅。如同放棄一道 穩定的意義實線, 放棄改造社會的主張、減少以馬來亞化為寫作的準則, 從「光明、樂 觀、健康」的語調，轉向意義未定、語言裂生、眾聲喧嘩潮湧紛碎的層層虛線。

30 力匡, 〈拾穗者〉, 《學生周報》1958 年第 105 期, 封面頁。

31 力匡, 〈水手之死〉, 《學生周報》1957 年第 46 期, 「椰林」版。 


\section{五、現代主義的序幕}

\section{（一）留臺時期的臺灣現代主義詩壇}

在這時期，並未有任何足以標明現代主義的理論引入，除了《蕉風》《學生周報》 作者群體本身的評論稿件和詩作之外, 比較多的討論, 可能是通過白圭主講的座談會或講 座, 但也僅寬泛籠統稱為現代詩。在改革號第七十九期, 凌冷〈新詩的再革命〉和這一期 隨刊附送的詩集〈美的 V 形〉, 部份用語引自臺灣現代主義（「横的移植」「美的 V 形」）。從一九五八至一九六 $\bigcirc$ 年間, 《蕉風》有邀請香港與臺灣的詩人登場助陣, 但最 初發表的, 多為抒情詩, 以及夢幻、神秘與象徵主義的詩歌。譬如, 一九五 $\bigcirc$ 年代的香港 詩人慕娜桑（馮兆榮）〈楓〉, 譬喻自身在香港的心境：「我是野地上拾荒的人 / 埋下幾 瓣楓葉 / 在這不毛的土地上」32。此外亦有臺灣詩人梅占魁的〈生命之歌〉：「那載著一 對知音人的馬車去遠了 / 在維也納的森林中 / 不再有敲響大地之鼓的蹄聲 / 向戰神抗議的 微弱羊鳴 / 歌頌幸福黎明的林鳥 / 吹響自然之歌的牧笛...... / 悲戚的森林遠仰視荅穹 / 叨 問宇宙底意志為何」33, 全詩意境朦朧夢幻。臺灣藍星社詩人覃子豪亦曾有稿件發表於 《蕉風》, 包括〈台灣十年來的新詩〉, 涵蓋中國新詩對臺灣新詩的影響, 介紹臺灣在一 九五三至一九五八年期間的詩歌、詩社與詩刊, 包括由覃子豪負責主編《藍星詩週刊》和 《藍星詩選》的藍星詩社、紀弦主編《現代詩》季刊的現代詩社以及張默主編《創世紀詩 刊》的創世紀詩社。34〈象徵與比喻〉, 主要討論修改詩作, 評賞意見。35〈由抽象到具 象〉, 覃子豪談他如何批改一首題為〈音樂〉的詩作, 教導讀者如何保留詩中神秘的夢幻 情調, 免得流於寫實。36這首詩歌〈音樂〉, 與上述梅占魁的詩歌極為相似, 稍後再論。 從一九六○年起, 《蕉風》開始轉載、刊登㾐弦的詩歌, 包括〈舵邊〉、〈懷古〉、〈遠

\footnotetext{
32 慕娜桑, 〈楓〉, 《蕉風》1960 年第 93 期, 頁 11 。

33 梅占魁, 〈生命之歌〉, 《蕉風》1960 年第 92 期, 頁 7 。

34 覃子豪, 〈台灣十年來的新詩〉, 《蕉風》1959 年第 76 期, 頁 10-11。

35 覃子豪, 〈象徵與比喻〉, 《蕉風》1959年第 83 期, 頁 5-7。

36 覃子豪, 〈由抽象到具象〉, 《蕉風》1960 年第 88 期, 頁 3-4。
} 
洋感覺〉與〈邊疆小夜〉。 ${ }^{37}$ 這些詩有些之前已經發表過, 如〈遠洋感覺〉就刊於《藍星 詩選》一九五七年第二期的「天鵝星座號」。

當現代主義在臺灣湧現的時候, 臺灣還稱不上具有高度現代化與都市化的條件, 故有 論者黃崇憲稱為「沒有現代性的現代主義」。 38 在多方的研究中, 咸以為臺灣的現代主義 不像西方的現代主義, 始於對資本主義與現代性帶來的人文危機意識。39解昆槿認為, 臺 灣的現代詩, 雖然未有面臨現代性的危機感, 但在戒嚴體制下, 卻有個體被政治化的焦慮 感, 詩歌創作排解這份焦慮, 誕生出更加千變萬化的私體詩語, 反叛社會話語的單一化。 40 蔡明謗的論文反駁了過往學界包括陳芳明過去對現代詩賦予的反抗政治觀點, 且認為現 代詩論述，限於模仿西方文學的藝術觀點，並不具有反抗的意義。41

由於白圭曾經有過在臺灣求學的經驗, 可能有受到啟發。在此略述臺灣現代主義詩歌 於一九五 $\bigcirc$ 年的概況。當白圭在一九五九年從臺大歷史系畢業時, 臺灣已經掀起了現代詩 創作的風潮。在一九五三至一九五四年間, 《現代詩》季刊與《藍星》相繼創刊, 覃子 豪、余光中等人也在一九五四年三月期間創立《藍星》詩社。一九五六年二月, 紀弦在 《現代詩》發表〈現代派信條與釋義〉主張「横的移植」, 引發《現代詩》和《藍星詩 選》的爭論。覃子豪在次年八月於《藍星詩選》獅子星座號刊登〈新詩向何處去〉一文， 對紀弦「横的移植」和「主知」詩風，展開猛烈評擊：「若全部為横的移植，自己將植根 何處」,「最理想的詩, 是知性和抒情的混合物」。㙡這篇開始, 之後圍繞著現代主義 詩歌觀念，包括主知與抒情，横的移植與縱的繼承等等問題，「藍星」的覃子豪、余光

37 瘂弦, 〈舵邊〉, 《蕉風》1960 年第 92 期, 頁 20 ; 〈懷古〉, 《蕉風》1960年第 93 期, 頁 19 ; 〈遠洋 感覺〉, 《蕉風》1960年第 96 期, 頁 18 ; 〈邊疆小夜〉, 《蕉風》1960年第 97 期, 頁 4 。

38 黃崇憲, 〈「現代性」的多義性／多重向度〉, 黃金麟、汪宏倫、黃崇憲編, 《帝國邊緣：台灣現代性 的考察》, 臺北: 群學, 2010 , 頁 50。

39 張誦聖, 《文學場域的變遷》, 臺北：聯合, 2001, 頁 8 。

40 解昆樺, 《轉譯現代性：1960-70 年代台灣現代詩場域中的現代性想像與重估》, 臺北：臺灣學生, 2010 。

41 蔡明諺, 〈一九五 $\bigcirc$ 年代台灣現代詩的幾個面向〉, 《臺灣文學研究學報》2010 年第 11 期, 頁 89-112。 ${ }^{42}$ 白哲維, 〈覃子豪詩作與象徵主義〉, 《東海大學圖書館館訊》2013 年第 44 期, 頁 38-69。 http://140.128.103.27/thulibm/upfiles/144\%E6\%9C\%9F/144\%E6\%9C\%9F38-69.pdf 
中、黃用、羅門, 以及《現代詩》刊的紀弦和林亨泰, 相繼應戰。至到一九五八年十二

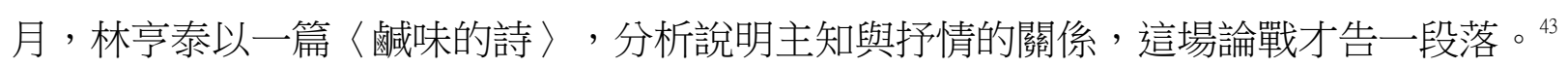

當白圭在一九五八年離開台灣的時候，這場論戰仍在進行。但在白圭於五九年的四月 號《蕉風》發表〈新詩的再革命〉時, 這場論戰就已經結束, 而第二波現代主義詩歌的論 戰（蘇雪林與藍星詩社之間, 關於李金髮的象徵主義詩體的論爭），仍未開始。從其字眼 來看, 白圭在〈新詩的再革命〉文中提到的 $「$ 横的移植」以及 $\ulcorner$ 主知與主情」，似乎不無 臺灣現代詩壇的影響。不過, 白圭挪借這些詞彙時, 他已經以一個 $「$ 馬來亞華人」的觀點 加以詮釋過了。雖然詞彙相同，實質的意義卻不必然相同。

紀弦所提的「横的移植」，指的是引入、借鑑西方文藝流派的思潮，根據丁威仁的整 理, 總共包括象徵派、立體派、達達派、超現實主義、新感覺派、意象派以及純粹詩運 動。通過這些藝術流派的借鑒, 才帶來語言與詩歌美學的創新, 以便能與自由詩形式的 新詩區分開來, 突顯出現代主義詩歌更具激進與實驗的意味。上述借鑒的流派之中, 其中 一項為純粹詩運動, 也是紀弦現代派的信條之第五條。強調純粹的詩歌運動, 目的即為排 除政治的干涉。與紀弦的觀點相對, 覃子豪反對整個西方藝術思潮的移植, 他認為新詩 $\ulcorner$ 極需外來的影響, 但不是原封不動的移植, 而是蛻變, 一種嶄新的蛻變」, 以便能真正 創造出「中國新時代的聲音, 真實的聲音。」 ${ }^{45}$ 當時在刊物的發刊詞中, 對於政治干涉的 不滿都銷聲隱去, 浮現的則是對當時文壇仍奉行的五四詩觀大加抨擊。 ${ }^{46}$ 在他們的爭辯 裡, 其實都認同現代詩需要吸收外來影響, 以獲得創新的啟迪與打開藝術和文化視野。在 這樣的辯論之中, 紀弦的主知與非情之論, 顯得激進且與傳統詩學離得太遠。但是紀弦的 現代詩也並非沒有來自中國五四新詩, 尤其是象徵主義詩派的詩歌特質, 他的現代主義涵 義是極度廣泛模糊的, 包含「自波特萊爾以降的一切新興詩派之精神與要素」。 ${ }^{47}$ 而覃子 豪的蛻變之言, 其實亦甚為抽象含糊, 對此余光中回憶說：「我們雖不以直承中國詩的傳

43 侯作珍, 〈藍星詩社對現代詩發展的貢獻—以五 $\bigcirc$ 年代三次論戰為探討中心〉, 《文學新錀》 2003 年創 刊號, 頁 58 。

44 丁威仁，《戰後臺灣現代詩的演變與特質》，臺北：新銳文創，2012，頁 24-26。

45 覃子豪，〈新詩向何處去? 〉, 《藍星詩選》第 1 期, 1957 。

46 如《監星詩頁》的發刊詞: 「有些人腦中的新詩, 還停留在五四時代的作品。他們沒有耐心讀一讀現在 的新詩, 即大發議論說新詩沒有成就, 沒有進步。」編者, 〈發刊詞〉, 《藍星詩頁》創刊號, 1958。 47 柯慶明，〈六十年代現代主義文學？〉，《四十年來中國文學》，頁 85-146。 
統為已任, 可是也不願意貿然作所謂『横的移植』」 ${ }^{48}$ 。在整個論戰的過程中, 不少關於 現代主義的問題討論得相當透徹, 尤其關於「横的移植」與「縱的繼承」關係, 尤其可見 諸林亨泰〈中國詩的傳統〉, 雖然林亨泰「廣義的繼承」之說, 不無為紀弦讋護之意, 然 而這也道出了一個民族的文學傳統特質, 經過漫長的流動與反覆往來的傳播, 那連同異質 特性再度吸收的曲折過程。 ${ }^{49}$ 通過補充艾略特對傳統的看法, 林亨泰也道出了「現代」意 識, 其實與傳統的知覺與其歷史脈絡的結構有相連的關係：「史的意識不但包括著過去性 的知覺, 而且也要包括著過去的現在性的知覺; 即史的意識不但驅使一個人不得不寫他親 身經歷的自己時代的感覺, 而且也要使他去寫自荷馬以來的歐洲文學的全部感覺而在此感 覺中自國全部文學成為同等第的秩序體的。」 50

這些討論的結果，對白圭應該不無啟迪。但白圭卻也不是原原本本地挪用這些語彙， 而是依循馬來亞華人文化的地緣因素, 把中華文化與馬華文學的關係, 何者為横與何者為 縱, 重作詮釋, 提出了相當獨特的看法。

\section{（二）在地化調整與突破五四文學慣性}

〈新詩的再革命〉中所列出的觀點包括：一、新詩是舊詩橫的移植，不是縱的繼承。 二、格律體與韻腳的廢除。三、內容決定形式。四、主知與主情。五、新與舊、好與壞的 選擇, 也是詩質的再革命。 ${ }^{51}$

在此，白圭「横的移植」，並非以借鑑西方的現代思潮為「移植之花」，而是表述 中國文學之於馬華文學, 其實亦經過地理流動的文化跨境, 有所移植。他從馬華族群與祖 先南來的離散史開始闡述, 提出在地華人「與祖國的關係, 只是血統的繼承, 而功業則是 棤的移植」, 故此馬來亞的華文新詩「也應該是横的移植」。52「功業則是横的移植」, 意味著即便沿襲傳統, 書寫舊詩體, 舊詩體不免亦是經歷跨境的「橫的移植」, 而無法是

\footnotetext{
48 余光中, 〈第十七個誕辰〉, 《現代文學》1972 年第 46 期, 頁 11-27。

49 林亭泰, 〈中國詩的傳統〉, 《找尋現代詩的原點》, 彰化：彰縣, 1994, 頁 12-21。（原刊《現代詩》

季刊 1957 年第 20 期。)

50 林亭泰, 〈中國詩的傳統〉, 頁 13 。

51 凌冷 (白圭) , 〈新詩的再革命〉, 《蕉風》1959年第 78 期, 頁 19 。

52 凌冷 (白圭) , 〈新詩的再革命〉, 頁 19 。
} 
$「$ 縱的繼承」。白圭分外著重馬華文學、文化的在地屬性，但並非是政治意識的勸諭或灌 輸, 而是想要點出, 無須為了堅持繼承中華民族的傳統文化觀念, 而固守於舊體詩為唯一 的詩歌文體。白圭雖然喜愛寫舊體詩, 但是他同時也認為, 現代詩當為突破傳統慣性、表 達這個時代的生活與開展語言美學的必要文體。傳統文化與現代意識, 可以與華人的身分 並存; 或者說, 正是由於傳統與現代、再加上 $「$ 在地」的意識, 能夠賦予華人以心靈支持 和文化意蘊：「我不會忘記自己是華人, 我也知道我是馬來亞的華人。甚麼樣的土地, 甚 麼樣的陽光和水分, 就結甚麼樣的果子。 $\lrcorner^{53}$ 在說服讀者從舊格律體詩轉向現代詩的時 候, 他也認為本地的馬華文學與文化, 已經積蓄、蓢含了本身因地緣因素而來的有機文化 體質。

即便《蕉風》已不再將本土化表達為顯明的口號, 在白圭本身的詩歌文本中, 不難看 到, 其本土特性並非全然取消, 而是轉向以極少的符碼留下空間。詩中的本土經驗, 織入 更多的私人體驗、個體觀看事物的獨特方式，由此而來的本土意象，因此不同以往。

對於馬華文學而言, 到底詩歌需要怎樣的「再革命」呢? 若根據這篇文章〈新詩的再 革命 >所列的五個要點來看, 其思路似為處理新詩突破格律詩慣性的侷限, 恰如白圭所 言, 「是借五四的火把, 照當下的天空, 把『文學改良雛議』的部分主張, 籠統地再說一 遍 ${ }^{54}$ 。在〈新詩的再革命〉這篇文章裡, 從各個不同角度表述, 說明自由詩比起格律詩 有更多空間, 格律詩由於韻腳與行數的限制, 往往使得寫詩宛如只是在依循押韻與行句填 充內容, 故提出 $「 內$ 容決定形式」：「今人的生活形態和接觸到的空間會比古人為廣, 而 感受也比古人為多，其內容絕非某一些形式所可決定。」55

根據《縷雲前書》的補充, 有一篇接受採訪的發言稿與四篇演講稿, 談論現代詩, 這 些材料或為記錄、或為作者補充、追溯，但仍可作為參考，以了解白圭的看法和經歷。 ${ }^{56}$ 從這些材料來看, 第一波現代主義, 實際上是從閱讀、認識中國大陸民國時期的現代詩與 理論開始, 包括梁宗岱、聞一多、李金髮。白圭尤其推崇梁宗岱, 而非人人熟悉的徐志 摩。 ${ }^{57}$ 他有感於馬華詩壇沿襲五四詩風, 寫法已近陳腐僵化, 詩歌作者長期安適其中, 詩

\footnotetext{
53 凌冷 (白圭), 同上註。

54 白圭, 《縷雲起於綠草》, 頁 90 。

55 凌冷（白圭）, 〈新詩的再革命〉, 同上註。

56 白圭, 《縷雲前書》（下）, 頁 370-389。

57 亦參見白圭, 《縷雲起於綠草》, 頁 92 。
} 
觀與創意滯急退化。 ${ }^{58}$ 相對於遵守五四的文學觀, 他強調現代詩的精神是 $「$ 另僻蹊徑, 是 一種創造精神, 千山不許一溪奔」。 ${ }^{59}$ 亦有感於馬華詩壇對於現代詩學的視野與知識出奇 貧乏：

五四以後，他們談的只是徐志摩、劉大白、艾青。其他與詩有關著作，朱光潛的美 學概要, 他們聞所未聞, 舊詩理論, 他們連王國維的名字也是陌生的, 要說發揚傳 統，怎可以遺漏這些名字。……如果你關心現代文學、現代新詩，對這樣文學的䬭 乏現象，除了心底悠然而生的悲涼之感外，應該用各種方法消除讀者和作者對現代 新詩的誤解，另一方面，也要秘富這塊貧乏的現代新詩土地。6

在另一篇（「一場在檳城學友會的講座」），他也批評了左翼馬克思主義文學觀導致的詩 觀狹隘, 只曉得郭沫若和艾青。他的批評可說是左右開弓, 並非只是為了與左翼唱對台, 既涵蓋左翼, 也包括非左翼的詩人群體, 批評他們僅滿足安適於五四以來的詩歌資產。在 一九五 $\bigcirc$ 年代, 星馬詩壇上的主流, 主要有格律詩、現實主義與左翼的鏡子旗子派。白圭 〈新詩的再革命〉讀來, 並沒特別針對後兩者（現實主義與左翼的鏡子旗子派）。一反過 去長久壟罩文壇的政治口號習性, 他提出去政治化的純文學意識。在當時學潮運動與政治 規勸話語起伏的時代, 他如此明顯地厭倦於政治話語。他的觀點因此也表現出與其他人鮮 明的區隔，也更突出個體意識的、「純粹」的文學空間。

在改革號過後, 《蕉風》邀來香港、新馬多位名家評論新舊體詩。在第九十四及九十 五期, 《蕉風》編輯以民主精神的立場, 「容許不同意見存在」 ${ }^{61}$, 推出一連兩期的「新 詩研究專輯」, 同時刊出新舊詩體雙方的稿件。在這兩期的專輯裡, 各個作者指稱新詩體 的詞彙, 紛繁不一。除了「新詩」之外, 尚有「現代詩」、「現代派」詩。《蕉風》每期 給詩歌欄目安放的標題, 亦是隨意, 時而安放「現代詩」, 時而作「新詩」。 ${ }^{6}$ 如魯文在 〈文藝的個體主義中〉提及西方詩歌各個流派時：

\footnotetext{
58 白圭, 《縷雲前書》(下), 頁 374 。

${ }^{59}$ 白圭, 《縷雲前書》(下) , 頁 372 。

${ }^{60}$ 白圭, 《縷雲前書》(下) , 頁 373 。

61 蕉風, 〈編者的話〉, 《蕉風》1960 年第 95 期。

62 這些欄目的標題, 安放得相當任意。在標題「新詩」下的詩歌, 不乏現代詩。譬如, 一九五九年七月號 第八十一期, 以「現代詩」為題, 刊出平盾〈陰陽界〉、白圭〈四月已逝〉、李迎〈眸之呢喃〉、羅曼 $\langle$ 你走了〉 四首, 詩歌寫法在當時相當新穎。一九五九年四月號第七十八期的改版號, 仍以「新詩」為欄
} 
「現代派」的新詩則頗為發達，他們不著重韻腳，不著重排列，有如散文的分句， 而這些分向又是零亂排列著。現代派著重的是象徵的、撲朔迷離的意境，他們日後 的成績如何，目前似尚難判定。63

魯文此處談到「『現代派』的新詩」, 未舉例子，僅說這些新詩多吸收象徵手法，意 境朦朧。此外, 徐速在〈新派詩平議〉裡, 以「舊派新詩」指稱五四運動初期的新詩, 以 $\ulcorner$ 新派詩」指那些近期六七年內崛起的新詩, 指出「新派詩」在台灣陣容較盛, 香港的新 派詩人也沒有台灣那麼多：

新派詩是近年來的產物，有人稱它們是「新印象派」、「新感覺派」、「新現實 派」，到現在也沒有一個統一的名稱。64

徐速的分析, 指出了現代詩變革的斷裂。五四以來的舊派新詩, 一直維持著自抗戰以 來的現實主義作風, 至於五 $\bigcirc$ 年代期間從臺灣傳到香港的「新派詩」（即爲現代主義風格 的新詩）, 徐速觀察到這新派詩人, 奉惠特曼與法國存在主義為師, 「用字古怪」、「立 意新奇」且 $\left\ulcorner\right.$ 形式自由」 ${ }^{65}$ 。

這兩期專輯的討論, 多各自表述維護格律詩或自由體詩, 何者孰優 ; 惟對於現代詩的 變革, 卻難有開展的見解。舊體詩擁護者對新詩的批評尖刻有加, 即便那是五四文學的經 典詩作。舉例第九十五期有作者童蒙〈站住吧, 詩人們〉, 把數首具有社會現實主義詩風 的作品, 包括藏克家〈老馬〉、艾青〈樹〉、田間〈兒童節〉、馮至〈晚報〉, 批評為 $\ulcorner$ 牛頭不對馬嘴」、「沒有音樂性」、「沒有深刻意境」，從而斷言詩歌不可能西化。66 一九六 $\bigcirc$ 年第九十四期, 《蕉風》編輯在編後話〈蕉風對新詩創作所採的立場〉中指出, 當時風行馬華文壇而引致舊詩維護者群起攻擊的新詩體, 可溯自抗戰前期一九三○年代, 大量湧現的詩刊, 如胡風於上海所編的《七月》以及抗戰爆發之後創刊的《文藝陣線》,

題, 刊出周垂〈海岸上的灰衣人〉、白圭〈八達嶺的早晨〉、平盾〈古戰場〉、覃子豪譯〈中午的鄉村〉

四首。改版以後, 也常見把詩歌欄目安置為「新詩」。

63 魯文, 〈文藝的個體主義〉, 頁 4 。

64 徐速, 〈新詩派平議〉, 《蕉風》1960 年第 96 期, 頁 23 。

65 徐速, 〈新詩派平議〉, 頁 23 。

66 童蒙, 〈站住吧, 詩人們〉, 《蕉風》1960 年第 95 期, 頁 24-26。 
皆為左翼現實主義的刊物。67現實主義詩人如胡風、艾青、田間等人, 對新馬的讀者有頗 大影響。在第七十九期〈新詩的道路〉裡, 凌冷 (即白圭) 就提到了有三位作者受到艾青 現實主義詩風所影響, 即鍾祺、周橴、杜紅三人。 ${ }^{68}$ 上述這篇童蒙的評論, 卻老實不客氣 地評價、貶低了這些權威性的作品。這兩期專輯的新詩評論, 也顯示出雖然五四的新詩革 命已經過去了數十年, 卻難以撼動舊體詩的地位。顯然, 艾青等人的現實主義詩歌, 寫得 過於直白無味, 無法打動古典格律詩的愛好者, 在美學上既無法與格律詩謧比, 亦無法引 領新詩風潮。

《蕉風》之所以會大張旗鼓, 展開新舊體詩的專題, 不僅是因為要提出有別於左翼現 實主義詩歌的觀點, 也因為這些寫來千篇一律的詩歌, 大量佔據文藝空間與稿件。變革遂 有必要。即便是當時白圭負責編輯的, 《學生周報 - 詩之頁》的來稿, 亦不免有同樣的問 題。如冷燕秋初識白圭時, 對〈詩之頁〉提出的疑問, 據白圭回顧：

冷燕秋關心的是文學世代的慣性，文學如果不斷重複同樣的風格，既非創作，他擔 心詩之頁會陷入慣常的漩渦。69

但是，相對於格律詩長期為讀者所熟識的藝術符碼，自由體詩不必再拘守於押韻行句 的限制、時或辭意生澀, 也設下了與大部分讀者的陌生距離。有感於此, 林以亮（宋淇） 如此寫道:

在剥集了這些限制之後, 詩人的困難反而只有增加。形式彷彿是詩人與讀者之間的 一架共同橋梁, 拆去之後, 一切傅達的責任, 都落到作者身上了……ำ

$\ulcorner$ 一切傳達的責任, 都落到作者身上了」，意味這現代詩的推動者，得持續展開䦐 釋、論述、傳授與教育的工作, 以培植和召喚它的讀者, 擴展影響。如前所述, 《蕉風》 的兩期新詩專輯, 既已提示五四以降的現實主義詩風缺乏活力; 而馬華文壇對詩歌美學與 知識觀點, 仍然狹隘貧乏。白圭的現代詩運動揭竿而起, 便有展開全盤改革、取而代之的 意義。他完全摒棄五四文學運動以來的社會主義論調, 亦不談文學風格的民族性之宏見

\footnotetext{
67 蕉風, 〈蕉風對新詩創作所採的立場〉, 《蕉風》1960 年第 94 期, 頁 25 。亦參見朱汝睹, 《中國現代 文學流派漫談》, 台北：秀威資訊科技，2010，頁 133 。

68 凌冷 (白圭) , 〈新詩的道路〉, 《蕉風》1959 年第 79 期, 頁 7 。

${ }^{69}$ 白圭, 《縷雲起於綠草》, 頁 86 。

70 蕉風, 〈新詩的前途——摘自名詩論家林以亮的詩論〉, 《蕉風》1960 年第 94 期, 頁 25 。
} 
${ }^{71}$, 但連接上中國古典詩的抒情傳統。實際上白圭對舊詩之愛, 幾乎不下於現代詩, 兩者 於他，均深摰傾注，並不厚此薄彼。 ${ }^{72}$

如張錦忠所言：

白圭自身在五十年代末，也多寫格律體新詩，一如當時不少香港或星馬的新詩作 者，繼承的是中國新詩的新傳統或系統（code）。而此系統中自有開創新形式主義 的商賴體（孫大雨、馮至、吴興華）、向自由體傾斜的象徵派與現代派（李金髮、 戴望舒、下之琳）。73

商賴體(sonnet)在中國文學, 是一九二 $\bigcirc$ 年代新月派詩人, 包括聞一多、徐志摩、梁宗 岱、六之琳等, 從歐洲的十四行詩, 轉借而創造的格律詩形式。聞一多在〈詩的音節的研 究〉將十四行詩譯為商籟體, 他在尋找契合中西詩體的結構時, 發現中國傳統律詩的內部 結構與十四行詩體相似, 「一首理想的商籟體, 應該是個三百六十度的圓形」。 ${ }^{74}$ 根據白 圭收錄在《縷雲起於綠草》書中第一輯的詩作, 約有九首爲格律詩。到卷二（一九六一至 一九六六年的詩作），也仍有不少講求音聲押韻、行數均衡的格律詩。白圭雖然熱衾於開 拓、引介現代詩，卻並非是要完全否定格律新詩。

按照白圭的説法, 當時在星馬一帶, 無論是詩人還是學生小詩人, 普遍上對詩歌的欣 賞, 仍然直限於格律的形式, 另一方面, 自由詩又被濫用爲散文化的分行, 形成如同「電 影説明書式的平鋪直敘的流水賬」。그五七年後南來的詩人力匡詩作, 主要亦是格律 詩, 而且跟隨者頗眾, 數年間「力匡體」蔚爲潮流。對此, 白圭直言批評：「用字用語和

71 參見白圭, 《縷雲前書》, 頁 385-389。〈多角的鑽石〉篇, 為某次作者野餐會上的專題講稿。文中指 出, 民族風格難以界定。由於文化與傳統歷時變化流動, 故民族風格的涵義, 也因此流動不居; 尤其在馬 來亞, 華人的民族風格因為與多元族群交流, 更是混雜多變：「以馬來亞的華人來說, 今天的華文文學作 者, 有不少人講究文學中的民族風格。我們表現的民族風格, 是純華族的呢? 或是土生華人的傳統呢? 這 又是一個混亂的題目。」白圭從構塑群體性的認同, 轉向探索文學自身的蛻變:「我們在文學中所要表現 的一些東西, 所要依據的一些傳統既然是不斷在變, 一件在變的事物, 很難作為我們的永久依據, 為甚麼 我們不自行蛻變一種新的風格, 而斤斤計較一種舊風格的強調呢。」根據上述的論述, 白圭表明, 馬來 亞化」是流動變化中的概念。

72 見〈舊詩紀事〉一文。白圭, 《縷雲起於綠草》, 頁 176 。

73 張錦忠, 《馬來西亞華語語系文學》, 頁 56 。

74 錢理群、吳福輝、溫儒敏、王超冰, 《中國現代文學三十年》, 北京：北京大學, 1998, 頁 391 。

75 凌冷 (白圭), 〈新詩的道路〉, 頁 7 。 
格律方面很有天才, 音韻鏗鏻, 較之徐訏的新詩更容易背誦, 也很有意境, 可惜內容太過 淺白, 讀兩三次還可以, 再讀就覺得索然無味了。」76從這裡讀來, 當時整體星馬詩壇與 讀者的狀況, 對於新詩的認識衹有形式上（分行、押韻）的表徵、且流於意境淺薄, 從白 圭文中對各方詩作的介紹來看, 他真正想進行的, 乃是打開或引導詩歌場域, 走向能夠體 現出詩歌在美學方面的成長。這樣致力於提升馬華詩歌美學的意念, 甚至超出左右翼對立 的意識形態之外。

\section{（三）現代主義與白圭的現代詩觀點}

從一九五八至一九六 $\bigcirc$ 年間, 《蕉風》與《學生周報》裡現代詩, 最初衹是由白圭、 周垂和冷燕秋等小眾作者開始創作, 尚未造成群體響應的氣勢。這時期也未見有引入諸如 西方現代主義艾略特的詩歌論述, 反而是從中國民國時期的現代詩那裡, 繼承、吸收、延 續。白圭曾撰文引述梁宗岱的詩觀，他把詩歌喻之為純粹的宇宙世界：

「所謂純詩，便是像音樂一樣，它自己成為一個絕對獨立、絕對自由，比現世更 純粹、更不朽的宇宙。這純詩運動, 其實就是象徵主義底後身, 濫觞於法國底波 特萊爾，奠基於馬拉美，到梵樂希而造極。」現代詩祭酒艾略特（T.S. Elliot）, 當年尚屬後生, 承其餘緒, 拔乎其萃, 終領風騷。7

白圭引述梁宗岱時, 強調他早在一九三○年代就已在詩壇上「另僻蹊徑」, 而不把他 做任何流派的歸類。梁宗岱的詩觀, 正如他對詩歌的譬喻, 卓爾不群, 獨立自由, 白圭深 引為典範, 亦將之引為馬華現代詩的文學理念, 「一個絕對獨立、純粹的宇宙, 是六十年 代馬華文壇叛逆者的文學理想 ${ }^{78}$, 而他對梁宗岱的讚語「敢違流俗」、「另僻蹊徑」,

亦常在行文中致予馬華文學的現代主義詩人群體。比起臺灣與香港多吸收西方現代主義詩 歌論述（如艾略特、惠特曼等）, 白圭卻是以梁宗岱的詩觀為精神支柱, 吸收中國大陸在 民國時期的現代詩藝術, 與中國古典詩學融會貫通。他在《縷雲前書》裡, 特意回顧中學

\footnotetext{
76 凌冷 (白圭), 〈新詩的道路〉, 頁 7 。

77 白圭, 《縷雲起於綠草》, 頁 92 。

78 白圭, 《縷雲起於綠草》, 頁 108 。
} 
時期, 通過詩人夏侯無忌, 初學梁宗岱的經過, 顯見梁宗岱為其現代詩經歷的核心, 也 「承其餘緒」，終領馬華文學的現代詩詩潮。79

如前所述, 在一九五 $\bigcirc$ 年代, 對於這批還在摸索著的新詩體, 文壇只攏統隨意地稱之 為「新詩」、「現代詩」、「新派現代詩」等等。在這個萌芽的階段, 對於這批開始自覺 到要在詩歌語言與形式上創新的自由體詩, 當時難有定義、解釋與命名。根據《縷雲前 書》卷十二的〈藏拙不如出醜〉篇, 所載的演講稿, 白圭也這麼認為, 現代詩其實難以定 義, 「最簡單的說明, 現代詩是當代的詩, 是我們生命所存在的世界的詩……不同於過 去, 不同於將來。我們有自己的感受, 有只屬於這一代的時代精神。」但現代的意義因應 歷史, 總是轉瞬逝變：「現代詩中的現代一詞, 應該不斷的隨時光充實, 每一個將來都會 在一瞬間成為現代。」 ${ }^{80}$ 到一九六 $\bigcirc$ 年為止, 《蕉風》裡從未見過這些關於現代性時間瞬 變意識的闡釋, 未能確定是否白圭當年 (一九五八、五九年間) 在吉隆坡講座裡就有談 到, 抑或成書時才加以補充修改。追溯與回顧的敘述, 總伴隨修補、重組與闈釋過去。但 觀諸《蕉風》至到一九六 $\bigcirc$ 年的文章, 白圭確實從未對現代詩下過定義。「現代詩」這名 詞似乎也只能權宜一時, 時代一過, 原先現代的也就不復現代。

到底現代主義這詞彙的內涵是甚麼呢？現代主義, 似乎該是由現代性(modernity)的特 質而生。現代有與古代相對之意，現代一詞中的 “modo”的意義就是「現在」。 ${ }^{81}$ 然而， 根據各處的文化運動實情與不同的歷史階段, 現代性指涉的時空範圍, 實可多元, 且根據 不同的文學史詮釋, 所指涉的時間範圍, 甚至可以溯自「中古世紀以降」, 如《劍橋現代 史》的用法。 ${ }^{82}$ 根據馬泰卡林內斯庫(Matei Calinescu)的考察, 現代性這個詞彙從十七世紀 才開始在英語中流行。馬泰卡林內斯庫認為, 「現代性廣義地意味著成為現代(being modern), 也就是適應現時及新穎性(newness)」。 ${ }^{83}$ 歷史發展的過程中, 不斷有股持續更

79 他對梁宗岱詩學美學的吸收, 可參見白圭, 《縷雲前書》（上）, 頁 220-265。白圭在此藉由孫述憲（筆 名有齊桓、夏侯無忌、宣子) 這一角色, 來回顧往昔在廣東培正中學階段, 最初接觸梁宗岱詩歌的經過, 同時也大量記下梁宗岱詩歌的譬喻、精華句子, 以及與友人展開討論、闡釋與鑑賞梁宗岱的詩作。

80 白圭, 《縷雲前書》（下），頁 384 。

81 韋勒克(René Wellek)著, 劉象愚編, 〈文學史上象徵主義的概念〉, 《文學思潮和文學運動的概念》, 北 京：中國社會科學, 頁 253 。

82 韋勒克著, 〈文學史上象徵主義的概念〉, 《文學思潮和文學運動的概念》, 頁 253 。

83 馬泰卡林內斯庫(Matei Calinescu)著, 李瑞華譯, 〈現代性, 現代主義, 現代化一一現代主題的變奏 曲〉, 載周憲編, 《文化現代性讀本》, 南京：南京大學，2010，頁 98-117。 
新(continuos renewal)的動力, 使文化產生與傳統分裂的一連串衍變, 這股動力常被視為現 代的。 ${ }^{84}$ 因著這樣持續蛻變的特質, 波特萊爾指出了現代性總是在朝向未來開顯, 總是 $「$ 過渡、短暫、偶然」, 然而這份「轉瞬即逝」的時間特質, 卻又正好是「藝術的一半, 另一半是永恒和不變」。85 從實質上的歷史狀況而言, 依據不同的關注脈絡, 現代性被賦 予不同的意涵。如根據韋伯(Weber)的解釋, 現代性當來自於歐洲宗教信仰轉向理性化的 一系列辯證, 爾後經由個體獲得的自由, 由此啟開理性與人文主義。 ${ }^{86}$ 在馬歇爾伯曼那 裡，他從當前的日常生活體驗中，指出現代性就體現於這個時代特定的時間與空間裡，從 自我與他人的關係中, 開拓「生活中的種種可能性與危險的體驗」; 由於世界共同存在著 嶄新、讓人欣喜的自我變化以及威勈和摧毀的雙重特性, 現代性「把我們推向了一個持續 分裂與更新、抗爭與矛盾、困惑與苦惱的大漩渦。成為現代的, 也就是成為如馬克思所說 的『一切堅定的東西都煙消雲散了』的宇宙的一部份。」 ${ }^{87}$ 馬歇爾的論述, 固然是嘲諷與 批評了資本主義運作下, 右翼知識份子對現代性懷有的膚淺想像, 但也慎重地回應了馬克 思的現代觀點：作為先鋒的藝術流派, 現代主義(Modernism)創作的動力要回返到日常生 活打開的生活體驗、人與人之間的各種關係之中，尤其那帶來各種沖破地理與種族、階級 與民族、宗教與意識形態的界限之變化，故仍對現代主義滿懷信任與信心。88

上述西方哲學中的現代性闡釋，誠然與中國、臺灣、馬來亞等各處的現代化狀況其實 不同。以中國文學而言, 現代化的追求可以上溯至十九世紀初的西學引入, 包括二十世紀 現代文學中的現實主義、浪漫主義以及多種先鋒藝術的實踐。有關中國文學裡現代性起步 的時間範圍, 近年的研究不斷推出新的界定。如王德威在《被壓抑的現代性》一書中, 他 將中國文學中的現代化追求, 上溯至晚清；指出晚清小說中的現代化想像，展現了與五四

84 在此也參考了蔡鋝雲的觀點。蔡鋝雲, 《從現象學到後現代》, 臺北：三民，1995，頁 120、頁 128131 。

85 轉引自楊向榮, 〈距離〉, 周憲編, 《文化現代性與美學問題》, 北京：中國人民社會大學, 2005, 頁 315 。蔡鋝雲, 《從現象學到後現代》, 頁 120 。

86 蔡鋝雲, 《從現象學到後現代》, 頁 117-138。

87 馬歇爾伯曼(Marshall Berman)著, 周韻譯, 〈現代性一一昨天, 今天和明天〉, 載周憲編, 《文化現代性 讀本》, 南京：南京大學, 2010, 頁 27。

88 馬歇爾伯曼(Marshall Berman)著, 周韻譯, 〈現代性——昨天, 今天和明天〉, 頁 27-52。 
文學全然不同的, 多變、求新的特質。 ${ }^{89}$ 晚清小說中顯現的創新、求變活力, 帶來不同的 奇情趣味與喧嘩特質, 與五四文學諸家的壓抑大為不同, 由此中國文學對現代化的回應, 自晚清以降, 在不同的文化階層的文本裡, 產生出多樣並陳、眾聲喧嘩的特性。從王德威 的觀點延伸到本論文的研究, 由於地域和文化應對的歷史條件, 西方現代性之於華文文學 與其文化傳統兼在地化的特質, 使得現代主義在不同區域, 也可能衍生出多樣的實踐方 式、路徑與獨特的藝術規範樣態。

法國安托瓦納·貢巴尼翁根據波特萊爾對現代藝術闈釋的觀點，歸納出現代主義的藝 術具有「非完善」、「零碎」、「無意義或意義的喪失」、「自反的循環性」四個特點。 ${ }^{90}$ 在香港與臺灣兩地, 經過林以亮、李英豪乃至到臺灣的夏濟安與紀弦穿接引入, 艾略特 的詩歌觀點幾乎成為中文文學裡, 被尊為現代主義的典範, 「詩歌并非是情感的釋放, 而 是從感情上逃逸。與其說是對個人性(personality)的表達, 册寧說是從個人性那裏逃 離」, 如此堅持文學藝術乃為達到自身的完善, 詩歌語言有屬於文學藝術境域的、近乎哲 學化的面向。91雷蒙威廉(Raymond William)如此形容現代主義文學的語言特質，認為這是

$\ulcorner$ 去自然化的語言」，不再是那種對自然的模擬，尤其在佛洛依德精神分析學之後，語言 不復是透明的或如鏡映照。92在一九八七年發表的演講詞中, 雷蒙威廉提出越境流動當爲 現代主義不可忽視的特性之一。二戰前後, 現代主義作家如海明威, 就有越境流動、在大 都會之間遷移的生活經驗，都市裏大量移民與陌異的語言氛圍，在文學裡凝成單一人稱的 敘述，流露孤獨、貧困拮据、無家之感與無法掌控的瞬變。93但在羅蘭巴特的論述裏，這 種現代生活又根本算不了什麼，因為他認為現代主義的書寫僅存於符號語言的媒介之中，

89 王德威, 《晚清小說新論——被壓抑的現代性》, 臺北: 麥田, 2003 。王德威指出, 過去對中國文學現 代性的論述, 總是不脫中、西方之間的落差, 對於現代化的觀念也偏向以西學為尚。

90安托瓦納·貢巴尼翁(Antoine Compagnon)著, 周憲許鈞主編, 《現代性的五個悖論》, 北京：商務, 2005 , 頁 24-27。

91 鄭蕾, 〈葉維廉與香港現代主義文學思潮〉, 《東華漢學》2014 年第 19 期, 頁 449-476。侯作珍, 〈藍 星詩社對現代詩發展的貢獻—以五 $\bigcirc$ 年代三次論戰為探討中心 $\rangle$, 頁 51-72。Nels C. Pearson, “The

Moment of Modernism: Schopenhouer's 'Unstable Phantom' in Conrad's Heart of Darkness and Stevenson's The Master of Ballantrae." Studies in Scottish literature, 1999, vol.31(1), p.185.

92 Raymond William. “When Was Modernism?” New Left Review 175, 1989. 48-52.

${ }^{93}$ Raymond William. "When Was Modernism?" 50. 
除了文本自身, 不再指向別的, 現代主義者「背離社會, 面對衆多客體的世界, 不參與任 何形式的歷史或社會生活」。94

根據雷內韋勒克的研究, 在歐洲文學史上, 曾經有人建議以「現代主義」或類似相關 的術語, 如德語中的「現代派」, 來概括現實主義結束之後的文學。不過韋勒克認為, 用 現代主義(Modernism) 一詞泛指所有先鋒派文藝, 就模糊了象徵主義時期和後象徵主義時 期（即未來主義時期、超現實主義、存在主義等）的分界。95 然則, 不同地域與歷史階段 的現代主義, 因當時狀況實情不同, 難以一貫而言。在臺灣與馬來亞, 現代主義詩人頗多 吸收前人的詩學美學（如象徵主義的李金髮、梁宗岱、戴望舒）, 以及大量翻譯引入的法 國文化與文學思潮（如存在主義），才提煉成無論在藝術手法、抑或語言創新上都有自覺 的意識, 甚至在寫作上不乏激進的嘗試。在馬華文學的現代主義, 雖說也在冷戰局勢中接 受大量西方文藝思潮翻譯輸人而生, 但並不淹覆對古典文學的吸收與化用, 再加上從中國 大陸民國時期繼承的詩歌美學，才生成白垶紀時期的現代詩特質。

在一九五九年白圭掀起的「新詩的再革命」運動裡, 其中透顯的現代主義特質當包 括：那「非能服鹰於服務功能的文學意識」（魯文〈文藝的個體主義〉），從「個體」出 發的「自由」意識, 擺脫五四文學的陳腐僵固觀念, 背離當時熾熱的在地政治話語要求, 轉向創新的反叛動力、在語言與技術上要求蛻變, 由此「詩心突變」。如同白圭所言, 當 時有 $\left\ulcorner\right.$ 一種對全新的追求與渴望」。 ${ }^{96}$ 這種突破場域中原有的文化僵固習性的求新, 以及 宛如異類的自覺, 並不只發生於近代, 在過去的古典文學史上, 都有這種創新的慾望與異 類的意識在推動藝術的典範遞變。「現代」在時間軸上縱現如逝，而「新」的意義亦然。 藝術美學運動中的「現在」、「現代」，也與「新」的瞬生即逝意識，相伴隨行；白圭將 當時的階段喻為「侏儸紀」與 $「$ 白珐紀」, 這命名又賦予當時的「現代」已逝、不復現代 的意味。

誠如之前所論, 現代主義白堊紀的歷史背景與緣起, 與那離散南來的反共出版業務關 係密切。如同左翼的運動, 以讀書會、社團活動來爭取學潮中的學生為其改革力量, 而友

\footnotetext{
94 轉引自馬歇爾伯曼(Marshall Berman), 〈現代性一一昨天, 今天和明天〉, 載周憲編, 《文化現代性讀 本》, 南京：南京大學, 2010, 頁 43 。

95 韋勒克, 〈文學史上象徵主義的概念〉, 頁 252-253。

96 白圭, 《縷雲前書》（下），頁 366 。
} 
聯在馬來亞的教育工作, 也通過聯誼、生活營、學友會來培育年輕的學生, 建立年輕讀者 的網絡, 交流互動。這些年輕學生, 都是在本土出生, 接受華校教育的第二代華人, 不若 第一代移民大多為苦力、文盲或教育水平低淺, 這批學生以其教育水平、修養與知識能 力, 在未來能影響馬華文學土壤的質地, 無疑是雙方所要爭取、模塑、影響的對象。

當時友聯設置「友聯文化協會」, 專門主理青年活動, 陳思明兼任會長, 而白圭負責 實際會務, 「會務包括負責與兩刊作者聯絡, 通訊部、學友會的活動, 舉辦生活營、野餐 會、文藝講座, 也贊助社會文化團體的活動。 $\lrcorner^{97}$ 其中通訊部, 是建立與學生交流的重要 管道, 是作者讀者的活動中心, 後來改稱學友會。內有學術組、合唱團、舞蹈組、戲劇 組、美術組 ${ }^{98}$ 它跟《學生周報》關係密切, 在吉隆坡的辦公室裡, 牆上還有手寫的小小 壁報, 也是《學生周報 - 詩之頁》延伸的交流空間。99在不少關於中文文學與華文文學常 見的觀念裡, 從與社會主義現實主義相對的視角來看, 現代主義常被賦予「頽廢、形式主 義、異已」的負面意義。不過, 基於友聯所維繫組織的多為學生活動, 詩歌寫作從校園與 年輕作者開始，使得最初萌芽的現代詩，不乏青春感的明淨氣息。

最早對白圭「新詩再革命」的回應, 蚌蚌欲動, 多來自在籍學生, 包括冷燕秋（麥留 芳）、周喚、李迎（李保章）、羅曼（李德美）。100冷燕秋最初與白圭會面時，是怡保育 才中學初中二年級學生。101

白圭當時在吉隆坡負責通訊部, 那時候「《學生周報》報社在老古路律(Old Pudu Road), 廣東會館後面一條小道上, 一家兩層民房的樓上, 有一間小小的圖書室, 有一塊 黑板, 有一張綠色的乒乓桌, 有一部老舊的黑色鋼琴, 有一間小小的圖書室。」幾乎每日 與辦公室附近的學生交流, 學生多數是只有十五、六歲的中學生。 ${ }^{102}$ 此外經常行走半島各 處的城鎮, 與各地的通訊員開會。當時他生活裡的人際往來, 除了一同派駐馬來亞的編輯 文人之外, 還有大量的年輕人, 學生、通訊員與《學生周報》的讀者。從離散到跨越半島

\footnotetext{
97 白圭, 《縷雲起於綠草》, 頁 77 。

98 白圭, 《縷雲起於綠草》, 頁 84 。

99 白圭, 《縷雲起於綠草》, 頁 87 。

100 白圭, 《縷雲起於綠草》, 頁 172 。

101 白圭, 《縷雲起於綠草》, 頁 171 。

102 白圭, 《縷雲起於綠草》, 頁 29 。
} 
南北走動的流動經驗, 廣闊時空與「青春」氣息, 以及與此相對、益發鮮明的時逝甚或飄 泊傷感, 都給引渡到詩歌裡。103

在五 $\bigcirc$ 年代, 現代性尚未廣泛地顯現於日常生活的物質水平, 而是首先寄附於獨立後 的現代國家體制上, 以制憲立法的民主系統和馬來亞化的國族話語, 來縫合殖民時期過後 的族群裂隙。白辇紀時期的現代詩, 從未在反共之餘, 顯示出任何挑戰在地當權政府的聲 音, 惟在堅持創作自由的理念方面, 多次強調必須「突破專横」。104無可否認, 對於在地 諸多建國以後的政治問題（如國籍／國族身分、華人社會對於語言、教育與文化位置的焦 慮）, 現代詩幾乎是沉默的。南來文人對於這剛獨立的國家政治, 尤其當時處於緊急狀態 時期, 那些諸多尖銳的政治問題, 大多不欲捲入。再加上友聯諸人與馬華公會關係友好, 使他選擇一個有限的政治面向，即只反對中共的文藝政策，來迴避其他的政治問題。

白圭本身性情與感受, 也極度細淢。如他在〈現代詩的前侏儸紀〉文中, 提到在寫 〈麻河靜立〉前後, 從記憶中的前人詩作 (梁宗岱、李金髮) 乃至到禪意濃厚的文學典 範, 一直到再度置身現場, 體會到時空恆駐若逝, 才釀成這一首現代主義經典之作。這份 對於時空瞬逝的體會, 絕非早前政治語境（愛國主義、馬來亞化等等）主導的詩歌觀點所 能及。梁宗岱、李金髮和古典文學宇宙詩觀的淺移默化, 固然是白圭個人的詩學系譜。如 此融會貫通而來的時空觀點, 使得詩歌為他提供一道從政治焦慮逸脫的出口, 以進入一個 極純粹的詩歌藝術世界, 正如他所推崇的, 梁宗岱筆下那「純詩的」、「像音樂一樣 的」、「絕對自由、絕對獨立」的宇宙。白圭的詩歌信念完全圍繞著這個音樂般的宇宙運 轉, 投人大量的熱情, 凌駕於其他外界（譬如政治激情的）要求。

今天回望這段白堊紀時期的現代主義起點, 必須承認, 馬華文學現代主義那偏向高度 審美的詩歌境界, 確實是在當時緊急狀態的剿共、建國體制以及跨區域的冷戰編碼, 多股 勢力的交涉作用下, 受到多方政治資源護持, 才得以展開。這多少模塑了馬華文學當時那 個世代（甚至也可見諸六○年代）裡的現代主義文學體質，形成政治關懷、社會關懷與藝 術二分的美學觀點與價值判斷。在當時情境下, 對於政治迴避似乎不得不然, 因而使其書 寫總有局限。但若從現代詩突破當時政治普遍貧乏的日常用語來看, 卻又必得要有這份横

103 白圭, 《縷雲起於綠草》, 頁 82-88。

104 在五 $\bigcirc$ 年代初期, 「文學的專横」意指中共文藝政策, 但到六 $\bigcirc$ 年代, 「文學的專横」, 所指已不再區 分寫實或現代。白圭, 《縷雲起於綠草》, 頁 $78 \cdot 82 、 112$ 。 
笔擊壤的現代詩運動。它確確實實肩負了那個時代的文學美學使命, 賦予了詩人與讀者群 體感受語言的體驗, 使語言從 $「$ 傳達意義」跨至「表達」的美學蛻變。

\section{六、詩心突變，抒情重寫}

白圭最初也多寫格律新詩。如一九五八年他以「林間」這筆名, 發表於《蕉風》的詩 歌〈老屋〉:「新月和蔓草攀上牆頭, /枯枝猶可窥昔日繁華的園直, /潮濕的青苔爬上 石階, /呵! 這欄杆拂過多少素手。//西風拂過剝落的窗檽, /池塘的星映閃爍依舊, /猶可想見當年的兩行燭光引路, /女主人送客後仍頻頻回首。／／而容顏與聲音都隨時 光凋落, /銅鏡與琴弦也皆蝕銹, /空餘屋邊的蟲叫鎖住院門, /呵! 幾代的榮華, 一朝 枯朽。」105詩裡描寫了自然朽壤所餘留的現場痕跡, 以前後兩段的景象, 裹著那「猶可想 見」的往昔虛景, 繁華與生命宛如幻覺, 詩歌的語言近於芻向表達對自然變化的感受, 但 所擇取的物與景, 總是局部的, 藉由「銅鏡」昏暗的反射鏡影, 「琴弦」聲調不復清脆而 黯啞, 以及那代替了人聲「鎖住」空屋的卿卿蟲聲, 這詩歌融攝了過去常見於中國古典抒 情詩, 象徵流逝與敗枯朽亡的意象。刊於第七十四期的〈晨舞〉則從自然界的物象聲色, 以一系列擬人的比喻, 經過連串排比, 詞與物互相叮應精巧, 宛如一場望之悅目舒適的舞

蹈：「一片、兩片的落葉飄旋林薄, /枝絲垂上如淒亮的黃繩, /山崗消瘦而枝頭蒼白 呵, /你卻踏住了天邊的一點晴。／／呵！你的鼻息和著早風在樹梢, /你的小足在我的 夢裡穿行, /你的笑容掛在太陽的臉上, /你的眼睛如九月夜裡的流螢。／／隔絕了眼前 的笙歌管樂, /你記憶裡有遠方寧靜的城, /奔躍在十月寂寞的山頂, /你將等待的沉默 揚化作生命的激情。//接受松濤與鳴泉的邀請, /你的銀梳是新月頭飾是群星, /我的 思念駕上西風的雙翼, /我要帶你去虹尾搖鈴。／／奔躍在十月寂寞的山頭啊, / 你將等 待的沉默化作生命的激情。」 ${ }^{106}$ 自然意象賦以感官比喻, 在瞬間湧向四面八方, 上至蒼空 下至山谷泉淕, 自然的象徵在詩中彷彿佔據得無邊無際, 至直收攏成心靈裡雙重共存的情 感, 沉寂與激情, 竟而完整和諧。

105 林間, 〈老屋〉, 《蕉風》1958 年第 73 期, 頁 13 。

106 林間, 〈晨舞〉, 《蕉風》1958 年第 74 期, 頁 23 。 
一般學界談及現代性那「過渡、短暫、偶然」的特質, 追溯至波特萊爾對現代藝術的 詮釋。然而這份瞬逝的時間特質, 在白圭的詩歌寫作裡, 既是現代的, 亦是古典的, 如

「寒山拾得」那甚有禪思意味的餽贈。打從一九五八年白圭寫下現代詩〈麻河靜立〉以 來, 那之後的兩三年間, 他也寫了不少格律體的抒情詩, 這些詩歌在他早年的創作裡佔據 相當的分量。白圭並沒有在寫出現代詩〈麻河靜立〉之後, 就完全捨棄那些自然意象的抒 情詩。即使在寫出〈麻河靜立〉之後, 他也仍然繼續發表那些較為傳統但技藝上乘的抒情 詩作。

在一九五九年四月改版的《蕉風》, 周垂 (寀耀東的筆名) ${ }^{107}$, 發表一系列組詩〈海 岸上的灰衣人 $>^{108}$, 當中這首同名的詩歌：

最初和最後是一個街接

海岸上孤獨的灰衣人踝踝而行

八月䬉風將至的预告

海上天空呈現一抹淡紅

呼吸窒息，心臟閉塞

呵呵，海洋的大心臟開始激動地跳躍

最初和最後的灰衣人祇是一個

海岸上沒有留下他的腳印

當狂風乍起的時候

一道眺望遠方的視線。海天際線無邊無際地蔓延, 必在某處「始終」縫合, 銜接成可把 $\ulcorner$ 一個灰衣人」裹起的圓環。這環狀的天地世界，超出了詩人眺望所及的視域。

全詩沒有標明地點, 在那巨大的圓弧與灰衣人之間, 既可無限擴張成浩瀚空曂, 又似 可收窄成灰衣人佇立之處。從 $「$ 最初和最後是一個銜接」到 $\ulcorner$ 最初和最後的灰衣人祇是一 個」, 詩句以扣環的方式, 成其起承轉合的結構, 但仍然留下缺口, 過客會離開, 且曾在 也未必留痕, 但曾經在場的體驗, 如同恆遠海洋, 在詩社跳動如心臟。無論是與《蕉風》 那數年間刊登的馬華新詩比較, 抑或與白圭自己的作品比較, 這組題為〈海岸上的灰衣

107 白圭, 〈我的 1953 1957〉, 見前注。逯耀東曾和白圭一起合編《台大思潮》。

108 周垂, 〈海岸上的灰衣人〉, 《蕉風》1959 年第 78 期, 頁 11 。 
人》系列組詩, 都該是極富現代語言感性的詩作。流逝的瞬刻意識, 彷彿為字詞所逮住, 貫穿每一首詩。如其中的〈舵〉：「在零點的時候／你和我分手的／北北東風，偏左／航 向未定／岸上有人流淚／在冷風中／這個世紀太短促」 ${ }^{109}$ 同樣屬於這組詩的一首〈桅〉：

$\left\ulcorner\right.$ 迷失的舵沒有歸來, 永遠地/沒有歸來, 沉湎在牛奶的霧中」 ${ }^{110}$ 後者直如美國詩人桑德 堡 (Carl Sandberg) 那首著名的〈霧〉中意象 :「霧踏著／小貓腳步而來。／／靜靜蹲坐 ／細細俯視／海港和城市／然後再起行。」在紀弦《祭黑貓》詩裡, 他也挪用了桑德堡 〈霧〉中意象。

在同期也有一首白圭發表的〈八達嶺的早晨 $\rangle{ }^{111}$ ，寫來氛圍相當柔美。詩歌以重複疊 句的方式, 在閱讀上產生押韻的趣味, 行句之間, 景與心緒穿插, 行句的布置方式為以景 在前, 而感受的心緒在後：

牛車在陽光中行遠了

蹄聲碎落滿地

而聖堂的鐘聲幽幽

他們告我

最好早晨散步

聽聖堂的鐘聲幽幽

看修女們淺淺的白

日子這般美好

太陽在風向針和十字架上發光

姑娘 你不來啦

有人戚戚地走進那拱門

歌聲四起思潮遂缺堤而奔了。

但到了「有人戚戚地走進那拱門」之後, 原先層次分明的景與心、內與外, 彷彿被他人的 悲傷給感染, 因而秩序也給擾亂了。相對於宗教的肅穆與神聖, 人內心的諸多感受卻不受 控制, 聖歌如屏帳般掩攏, 而「思潮遂缺堤而奔了」。這不是露骨勇猛的反叛, 而是心緒 與他人有感應而來的起伏變幺𠃌。整首詩歌的語言輕盈簡淨。詩歌擇取的物件, 如風向針、

\footnotetext{
109 周垂, 〈舵〉, 《蕉風》1959 年第 78 期, 頁 11 。

110 周垂, 〈桅〉, 《蕉風》1959 年第 78 期, 頁 11 。

${ }^{111}$ 白圭, 〈八達領的早晨〉, 《蕉風》1959年第 78 期, 頁 13 。
} 
鐘聲、修女, 呈現了一個在過往馬華文學作品裡, 鮮少出現的本地景象, 這甚有西方的、 現代感的空間線條, 與過去讀到的全然不同, 但一所教堂也仍是屬於本地城郊的某處風 景。

白圭另一首稍後幾期刊出的〈四月已逝〉, 卻是略帶古典意味的抒情詩, 不過, 詩歌 打從一開頭就置換了〈八達嶺的早晨〉裡的句子 「他們告我／最好早晨散步」，延續改 寫, 「傍晚, 你來靜靜告我 /四月盡了, 並輕輕和我道別」。以一種與他人對話的方式來 鋪寫情詩。詩歌情感深幽。如同余光中, 他也把古典意象與詞藻化用到詩裡。聽來宛如回 聲的足音、不再響起的琴聲, 沉至無詩處, 思念卻愈深：「明日一／明日, 可能又有雨 ／南方遂有虹影輕悄」。112

白圭的現代詩裡, 不乏融入那屬於「華人」與「他族」的典故、傳說與神話, 譬如一 九五九年七月在 《學生周報》發表〈海邊的—〉 ${ }^{113}$

說書中有人失去第一次邀約

在此投海, 浮起, 再化成礁

哭在海上, 輕輕的拍落一些苔

彷佛又有人在岩上嘆息了

姑娘, 小浪花要打濕你的裙啦

「這本是我的前身

我來是找遺落的鞋

擁我, 以潮吧!」你說

遂披秀髮吹口哨赤足而行

如此身無屬, 姑娘

海比你的衣衫還要蓝呢

記憶是蓝蓝的

拾些貝殼回家吧！悄悄的

要燃松火送你過長堤嗎

112 白圭, 〈四月已逝〉, 《蕉風》1959 年第 81 期, 頁 22 。

113 白圭, 〈海邊的一〉, 《學生周報》1959 年第 158 期, 詩之頁版。 
如不怕談往事，小茅屋裡有燈

而且燈舊, 多麼好的 Chatting time

白圭多首寫海的詩, 情感極淡, 詩中的邀請者, 是個旁觀者般的對談者; 正如艾略特 對詩的看法, 詩歌首先從個體性的情感剝離, 而後方可能拉出距離, 像個旁觀者那樣書 寫, 才可能 $「$ 在詩裡喚醒」那熟悉之物, 如此字句便不復「沉沒於忘川」, 相反地, 那靈 感湧過時, 就像「醒著聽人魚唱歌」, 而且是聽著「不曉得的語言所唱的歌」。 ${ }^{114}$ 盡管如 此, 人魚的歌聲並不能僅靠聆聽就內化成已物, 那歌聲永不能被據為已有, 這種不可能滿 足的追尋, 引誘後來者追溯這讓人傾倒的意象起源, 與此同時也催使克服、孕育與翻新的 慾望, 寫作便是這樣無盡頭的慾望與激情, 宛如沿著圓環, 圍繞著一個永遠無可佔據的 $\ulcorner$ 空無」, 前赴後繼地尋求蛻變。如同這首〈海邊的一〉詩歌開頭, 「說書中有人失去 第一次邀約 / 在此投海, 浮起, 再化成礁」, 應是收人了馬六甲海峽的孕婦島(Pulau Besar)有關孕育與死亡的神話。 ${ }^{115}$ 礁比之島嶼, 因潮汐變化而更為隱密, 只在退潮時才顯 現出岩面的蝕孔。對水手而言, 礁比島嶼更加危險, 也更加沒有用途, 但對大自然而言, 岩沙積沉, 能使海洋水質多元豐富。羅蘭巴特曾言, 那為民族文化所認同的母語, 在現代 文學裡總是經歷磨損。 ${ }^{116}$ 但在馬華文學, 那使母語磨損的異質與混雜特性, 也替代性地賦 予文學活力。海洋把島嶼與陸地隔開, 但亦可以說, 是海洋把分離的陸地連接。在孕婦島 神話裡, 懷孕的公主死後化為沉默之島。這座山陵起伏, 讓航海人辨認的島嶼, 也同時是 那神話裡從死亡轉化的孕育之母。詩歌把這典故摺藏, 其結構如螺旋般交錯, 把原先露在 海水線上的島嶼, 隱藏淹沒, 轉化成危險的礁石; 而原先那因死亡而硬化成山岩的孕育形 象，卻化成詩裡極柔軟的開場白，而且是一場相遇、重生與邀約的開端。

這首詩語調輕柔, 宛如初遇時, 極其友善的招呼。所有沉重的往昔 (如因慾望難捨而 硬化為島／礁）, 在現代詩裡亦宛如歷經輪迴蛻變, 變成旅人暫歇之處。過往傳說裡, 那 些誓言般的約定, 在詩裡化成了輕盈的意象（失落的鞋子）。倘若不能尋回, 亦不妨礙自 由的姑娘赤足而行。

\footnotetext{
${ }^{114}$ Nels C. Pearson. "The Moment of Modernism: Schopenhouer's “Unstable Phantom” in Conrad's Heart of Darkness and Stevenson's The Master of Ballantrae.” 1999, p.184, 187.

115 方天曾經撰寫過這則神話。辛生, 〈孕婦島〉, 《蕉風》1955 年第 2 期, 頁 14-16。

116 羅蘭巴特著, 李幼蒸譯, 《小說的準備》, 北京：中國人民, 2007, 頁 422 。
} 
詩歌收入的表象與物件, 彷佛讓人期待有所提示, 然而, 與其說這裡別有深意, 不如 說, 白圭在寫海的時候, 他其實退到了象徵意義的邊緣。擇取細節, 研磨人詩, 同時抵禦 這些細節被全盤象徵化, 但又要使之揮發, 使它一方面如謎神祕, 一方面又能喚醒潛在心 靈共有的隱喻。神話本身, 並非是有自覺意識的創作或表述, 它乃是「投落在心靈缺口上 的陰影」, 但文學的詩歌語言, 卻是從神話思維產生質變, 使神話的意象宛如 $「$ 以太一樣 的光照」, 它「經歷著往返不已的靈魂輪迴, 經歷著既是感覺亦是精神的再生」。”對於 這些細節與典故, 詩歌輕輕叮訪, 恰如這首〈海邊的—〉 對姑娘伸出的邀請手勢, 請她 在一寍舊燈下敘述。邀者與被邀者, 固然同時扮演說者與㯖者、主人與客人的角色, 但在 文學這棟房子裡, 兩者皆為途中相遇的旅人。

在另一首同年發表的〈酋長之夜〉 ${ }^{118}$, 則引用了射日神話：

知是夜, 知是太陽䠰崖自畫了的

黑魂所化，酋長

你的吆喝韾呢?

你的刀斧手呢?

你的弓你的箭呢?

射不下天狼和犀牛星座

你的影频便焦慮而灰白了嗎?

夜依舊, 狩獵期依舊

㷫㷫的皮鼓依舊, 營帳依舊

你的權威依舊不?

我見到你出而欲語低泣

一一想念那段英雄的日子

火場的舞與祭

今夜你的子民

正在跳 Calipso 與 cha cha cha

117 恩斯特 - 卡西勒(Ernst Cassirer), 于曉等譯, 《語言與神話》, 臺北：桂冠, 1990, 頁 7、頁 84 。

118 白圭, 〈酋長之夜》, 《蕉風》1959 年第 79 期, 頁 19 。 
如陳鵬翔的研究點出, 台灣文學現代詩史裡, 有從神話探索生命意義乃至到抒發本真失落 的主題。 ${ }^{11}$ 顧蕙倩的研究延續陳鵬翔的觀點, 認為現代詩對神話的召喚, 除了賦予詩歌以 神話般的洞見，同時也在文學裡「溯源追本」，發現「詩的端倪」，從自然的威嚴與驚 嚇, 感受到震攝與戰慄, 因而能在現代空間裡留下 $\left\ulcorner\right.$ 側身的觀察視角」。 ${ }^{120}$ 由此, 透過神 話, 現代詩召喚那遠古的心靈意象。雖然后羿射日的神話耳熟能詳, 但詩裡「你的髯䰅便 焦慮而灰白了嗎」, 更接近台灣泰雅族的射日神話, 英雄們完成任務後, 因路途遙遠, 回 到家鄉時, 發現自身蒼蒼老矣的情節。臺灣早在一九五 $\bigcirc$ 年代初期, 就已有關於原住民神 話的資料, 為民族研究所收集出版, 而上述泰雅族的神話, 日本在二十世紀初曾收集出版 ${ }^{121}$, 故白圭住臺灣期間, 有可能讀過或聽過。但詩歌引入的神話, 局部如剥落的鱗片, 其 所指與來源模糊, 其擇取方式因此呈現混合的、斷裂的碎線, 雖為象徵的意義所滲透, 但 主題與意義也無從鎖定。122白圭寫這首詩時, 比余光中在一九六一年發表的〈鼎湖的神 話〉還更早：「表弟們, 據說我們是射日的部落/有重瞳的酋長, 有彩眉的酋長/有馬喙 的酋長, 卵生的酋長」。白圭這兩首詩, 〈酋長之夜》與〈海邊的一〉, 分別以不同的 語調, 探問兩則不同的神話故事。相較於前一首詩〈海邊的一〉語調如此輕柔, 這首詩 卻以相當緊湊、近乎揭幻驅魅般的語調, 拋出連串問題, 責問射日神話裡的英雄。這些橂 出的連串問題, 帶出了不同版本的神話裡那些變異的細節 : 酋長用來打落太陽的武器（有 些是箭, 有些是刀和斧頭）, 英雄爆發的呐喊與姿態也各自不同。123神話裡對抗災難的超 凡勇氣, 在歸來多年以後, 彷彿穿過了一道界限, 困滯於現實, 不復有可用武之地。在現 代文學的書寫裡, 冒險這個主題, 也經常意味著可以和日常現實的平庸, 拉開距離。齊美 爾曾把現代文學裡的冒險, 闡釋爲現代人越境生存的哲學。 ${ }^{124}$ 白圭這首詩歌, 則反過來詢 問, 冒險終結之後, 英雄要如何面對黑暗的挑戰。「知是夜, 知是太陽躍崖自盡了的/黑 魂所化」那是宛如書夜之間, 截不相容的對立。「知」並不是普照的強光, 反而是深濃的

\footnotetext{
119 陳鵬翔, 《主題學理論與實踐》, 臺北：萬卷樓, 2001, 頁 73-79。

120 顧苇倩, 《臺灣現代詩的浪漫特質》, 臺北：秀威, 2012, 頁 $170 。$

121 李福清(B.Riftin), 〈射日神話比較研究一以臺灣布農族神話為主〉, 《東亞文化》1993 年第 31 輯, 頁 53-78 • http://s-space.snu.ac.kr/bitstream/10371/87686/1/ 7.\%20 사일신화비교연구.pdf 122 多個太陽造成旱災的神話, 跨越世界各地, 各版本細節不同, 各有差異。馬來亞半島也有「多餘太陽」 的神話, 為 Semang 人的傳說。一九二六年, 有德語漢學家 Eduard Erkes 為此作研究, 參見 Derk Bodde, Essays on Chinese Civilization, New Jersey: Princeton University, 2014, p.71.

123李福清(B.Riftin), 〈射日神話比較研究一以臺灣布農族神話為主〉, 同上註。

124 楊向榮, 〈距離〉, 頁 315-357。
} 
陰影, 這股黑暗裹住知覺, 使酋長清醒地面對現實; 人們對拯救者的付出, 竟然是如此冷 淡, 夜晚終於恢復漆黑, 但英雄並沒被眾人包圍。詩歌把這歸來之途, 幾乎無限期延後、 直到「現代」。很遺憾的是, 英雄射日解旱的拯救意義, 未能為後人所銘感。英雄知曉拯 救的意義, 惟不能以此來獲得榮耀或景仰。「現在」的時間刻度如此含糊：過去從來未能 真正過去。英雄的失落, 不復能以神話來彌合。然而, 並不是沒有解決的, 就沒有意義。

$\ulcorner$ 知」到底是知道些甚麼呢? 那便是知曉即或遭到遺棄, 人在黑暗中仍須獨存的意義。英 雄們咙涉長途而拯救的群體生命, 原來如此膚淺, 生命委實無意義。但是, 正因為這意義 的缺乏, 才又能同時獲得這一切。如何能面對這生命意義之空無? 詩歌的建議似乎是, 跳 舞吧, 繼續舞動。詩歌裡的 Calipso 與 cha cha cha, 替代了過去的祭神火舞、從美洲渡入 的流行舞蹈, 彷彿重複了神話傳播的路跡。然而, 卻已不能再使同一意義顯現。意義不斷 轉移, 一個意義取代先前原以為固有的意義。但所有顯現的意義, 都是暫時的, 不可能固 定不變, 意義如此難以掌握, 以至於必須接受與承認, 所追尋的意義背後乃是空無的事 實。盡情投入舞蹈, 堅持舞下去, 方為持續生存的方式。

撿蚌的老婦人在石灘上走去

不理會岸上的人

如我 她笑

卻不屬於這世界

風在樹梢 風在水流

我的手幖落了

再乘浪花歸去

一個回旋

沒有誰在岸上 我也不再

那個世界不屬於我

那老媂人 那笑那浪花

第八次在外過年了

而時間不屬於我

日落了呢 就算是元宵又如何 ${ }^{125}$

125 白圭, 〈麻河靜立〉, 《學生周報》1958 年第 137 期, 詩之頁版。 
上述這首〈麻河靜立〉, 在一九五八年三月發表。據白圭追憶, 是他出差途經麻坡時寫 的。 ${ }^{126}$ 在〈現代詩的前侏儸紀〉裡, 他寫到這首後來被認為是現代主義之作的〈麻河靜 立〉, 當時兩天之內, 往返再訪的麻河場景：

夕陽下，那光景、那對話，十分動人，當晚回到宿舍，很想鴧詩，寫我熟悉的十四 行，可怎樣也表現不出那簡單的境界。我想起了怡保街頭的對話，想起了李金髮， 想起了梁宗岱，想起了寒山拾得。第二天黄昏時再訪麻河，多少年了，仍然記得樹 林下的一灣藍水, 在風裡緩緩地流。那是麻河, 四十年前的麻河, 一九五八年的麻 河, 沒有橋, 只有渡船。從碼頭走向那林, 走過去, 走入那林, 走過去, 走出那 林，蓦見河海交接，水聲嘩然，月亮升起，感覮卻是一片静，那年、那月、那日的 黄昏，就那樣寫了那首〈麻河靜立〉。127

相較於〈酋長之夜〉的失落, 老婦人的生命觀更為從容、镕朗, 尤其時間與世界「都不屬 於我」。〈麻河靜立〉的老婦人應是後來, 與於次年九月發表的〈海邊的一一詩裡的少 女, 宛如對鏡般的前身——但這是一面被時間隔離的鏡子, 如同〈酋長之夜〉、〈海邊的 $\longrightarrow>$ 這幾首詩歌, 透過時間拉開的距離, 原本熟悉的事物變得陌生, 宛如雙重(double) 並置。白圭的詩歌, 往往能夠在隱喻、手法與典故化用上, 顯示出變奏與延續的結構。老 婦人任由一切逝消, 而少女雖然 $「$ 此身無屬」, 尚想尋回她失落的鞋子。這首詩不如上述 兩首那樣, 以神話典故為軸, 其簡潔之處, 僅以對此生有限的頓悟。透過「看」與「被 看」對調位置, 才驚覺這裡有個「不在」的空無之處, 那原以為在場的觀者, 其所在之處 也瞬間化為空白, 體現了「在場」與「缺席」均都同在給頓悟的意義, 頗有禪意。與周垂 〈海岸上的灰衣人〉的時空觀點, 可說是呼應。

這一首詩〈麻河靜立〉, 被學界公認為是白圭最早發表的、具有現代主義特質的詩 歌, 各家論述均肯定它領先、影響後來者的歷史地位。白圭另外幾首也寫及海洋的詩歌, 反而被忽略。在一九五八至一九六 $\bigcirc$ 年間, 白圭寫及河口、海岸的詩歌, 都體現出時間瞬 逝、疏離旁觀的特徵。他本身在書寫這些海濱系列的詩歌時, 也總流露出「空無所屬」的 感受。在一九五九年九月, 一篇刊於《蕉風》題為〈漁村〉的散文裡, 他描敘漁村之景, 已經盡顯安靜冷峻的筆法。「這是一個寂寞的存在, 沉默又孤獨, 我匃务來又匃匃地離

126 白圭, 〈現代詩的起步〉, 《南洋商報》2004 年 6 月 12 日, 南洋文藝版。

127 白圭, 《縷雲起於綠草》, 頁 172 。 
去」「幾十戶珊瑚礁石圍牆的人家, 彷彿被人遺忘了似的, 默默地隱藏在島上一個偏僻的 角落裡, 靜靜地躺在沙灘環繞地懷抱中; 在沙灘的外面時時有浪濤的起伏, 尤其是在起風 的日子裡, 風沙夾帶著海水呼嘖著向岸上撲來, 沙灘上幾隻廢棄的漁船, 在洶湧的浪濤 中, 扯緊那繫在岸上的纜, 不停的旋轉和浮沉著, 彷佛在每一艘船上都載著一個沉重而悲 愴的故事。」 ${ }^{128}$

他在這篇散文裡，也想像了從「我」到他人之間的觀點調換。文章開首，即寫：「這 是一個寂寞的存在, 沉默又孤獨, 我匄冬來又訒各地離去」, 在文章末尾, 他試圖從這空 曠天地的人類活動, 探索生命有限的意義：「我又轉過頭去凝望著浩瀚的大海, 我彷佛在 那裏尋找些甚麼, 最後才發現我已從他們身上, 找到生活的另一種解釋, 雖然那是寂寞和 孤獨的, 但他們卻勇敢地生活著。」 ${ }^{129}$ 以白圭對政治冷淡的性情, 以及對文學的偏好, 無 論在《蕉風》或《學生周報》, 應該都是個異類。在〈非關立異與標奇〉這篇文章裡, 他 寫到自己曾經有段時期, 「差不多是《蕉風》《學生周報》〈詩之頁〉的候補編輯, 別人 不幹了才由我補上, 有人編了, 便用不到我。……在周喚、李蒼之前, 我編得相當寂寞, 寂寞到要寫〈現代詩閒話〉, 就像孤獨的夜行人吹口哨。 ${ }^{130}$ 雖然這篇文章裡所敘的記 憶, 僅始自一九六九年《蕉風》改版, 而周喚於一九六七年才加入接編《學生周報・詩之 頁》。 ${ }^{131}$ 但是在五 $\bigcirc$ 年代, 跟他一起在 《學生周報》辦公室的同事, 如黃崖、姚拓, 都不 若他專注於詩歌或純粹的文學。從《縷雲前書》的追憶裡, 他還提到初來乍到時的拮据困 窘，當時極度失落，特別閱讀普希金的詩歌，記詩排遣。 ${ }^{132}$

而在一九六○年發表的〈曲終〉, 仍然是一首格律詩, 有更多自然化的意象、表達抒 情風格的詩作, 語句連綿、曉白, 情意深濃。詩裡有個所欲呼喚的角色：「姊姊啊, 你要 再回憶, /回憶那溫柔的時光, ／小樓浴著黃昏的色彩, ／那大橡樹屹立的山崗」, 而 後, 悲傷濤湧：「木葉盡落海上的浪濤鳴咽不息, ／無限環繞原是思懷的淚, ／當活著的 痛苦比痛苦還深, /想像的本身已不是傷悲。」及至哀悼與告別：「淚光閃爍向大地作末

\footnotetext{
128 周垂，〈漁村〉，《蕉風》1959 年第 83 期，頁 20 。

129 周垂, 〈漁村〉, 同上註。

130 白圭, 《縷雲起於綠草》, 頁 174 。

131 白圭, 《縷雲起於綠草》, 頁 97 。

132 白圭, 《縷雲前書》（上）, 頁 244 。俄國普希金的詩歌〈假如生活欺騙了你〉：「一切都是暫時的, 轉瞬即逝 /而那失去的將變為可愛。」
} 
次的憑虫, /我的視野穿過時間與空間 /縱一切都已死亡, 愛仍是一個意象。」 ${ }^{133}$ 在此, $\ulcorner$ 我的視野穿過時間與空間／縱一切都已死亡」使詩歌轉向與慾望剥離、無所屬的狀態。 $\ulcorner$ 愛乃是一個意象」, 彷彿把「愛」置於一個可為文學性的話語所庇護的、淨化的境地。 但從另一方面來說, 正是透過文學的意象, 偶然的隱沒與重現, 才能使得那意義無法恆駐 的往昔, 一再被追憶。於是, 詩歌開首殷殷叮囑：「你要再回憶」。回憶是只有生者才能 做的事。懷念不再歸來之人、或懷念不能再回返的故鄉。白圭這些格律詩, 如同與其格律 詩相連的過去時空, 而轉喻地植人了他對往昔故鄉的懷念。這些詩大量地抒發那無法具名 對象的鄉愁。思念塵附於物件與地表, 由於這些物件都不能佔據, 而這些棲附的情感, 竟 然在詞與物的意義網絡裡, 喚出物件死後的棚栩鬼未影。如同大部分的文學意象, 總會經歷 飽滿、衰亡、消歇、起伏, 或因偶然被發現、重寫翻新而奇蹟重燃。與這首詩相似的, 小 樓孤清的意象, 白圭也延續、重寫, 織入另一首詩裡〈當你走後〉。 ${ }^{134}$ 在前一首〈曲 終〉, 他把思念之淚重寫成後, 降落為自身所在的南方的連綿細雨, 規律性敲打屋簷的淅 瀝雨聲, 緩撫、包裹家屋, 有如巢穴外邊的液態纖維。它持續下在曠大的地表上, 以及濡 濕土壤深處的腐枯與待生孵物。因親人過世, 感知時空永遠為陰陽相隔, 試圖追索那為死 亡阻斷的冥境：「沒有人真正死過／正如微塵從未消失／莫當夜深, 以那哭聲翏我魂／死 不是終結, 生也不是起始」(〈陰陽界〉) ${ }^{135}$ 由此, 生死遂從相隔的彼岸, 轉化為往返相 銜的時間，如往昔小樓裡循環的來回踱步：「他年來路／最後的線是一個迴輪」。136

\section{七、小結：詩語和場域的啟示一一空無與意義}

白圭的現代詩善於待調度古典詩歌的詞藻與意境。譬如刊於第七十八期, 白圭以 $\left\ulcorner\right.$ 平盾」筆名發表的詩作〈古戰場〉 ${ }^{137}$, 詩意稍微晦澀。戰馬飛馳、箭戈廝殺的風沙畫 面, 似在想象那塞外的大漠戰場。但它同時也是把萬物吞噬的時空, 「人生在熔爐中揚爲 灰燼」，幾乎接近元朝詩人劉因〈黃鐘人月圓〉詩句「茫茫大塊洪爐裡，何物不寒灰？」 裡, 那總是近乎無情的永恆宇宙, 以及生命翻騰無常的本質 :

\footnotetext{
133 白圭, 〈終曲〉, 《蕉風》1960 年第 90 期, 頁 9 。

134 白圭, 〈當你走後〉, 《蕉風》1960 年第 94 期, 頁 6 。

135 平盾, 〈陰陽界〉, 《蕉風》1981 年第 81 期, 頁 22 。

136 平盾, 〈陰陽界〉, 同前註。

137 此詩亦收入白圭, 《縷雲起於綠草》, 頁 202-203。
} 
彷彿有模糊的聲音來自

曠野——

白畫過後是夜

夜後又是黎明

來自塺土的復歸塺土

宇宙奔向一個不變的前程 138

$\ulcorner$ 彷彿有模糊的聲音」, 但這聲音來源不明, 不知終結何處, 雖像是來自內在的領悟, 但 同時也像是來自外邊的聲音。這不知源於何處之聲, 也見於受邀上陣的台灣現代詩, 包括 前述覃子豪於一九六○年刊登的詩作 :

那熟悉而又陌生的音樂來自何處

是在呼喚我的露魂去到無何有之鄉?

那裹是虚無, 神秘

空虚處卻有無畫的璸藏 139

這遠古的神祕之歌, 也彷彿是對當時的現代詩人發出的呼應。在梅占魁的詩裡, 亦有「生 命的音符, 凝固了變遷的一切」之句。 ${ }^{10}$ 這源頭模糊的聲音, 有時衹是跨越空間, 使一切 變成空無幽響, 有時則波動起伏成神秘的樂音, 詩歌網捕它, 宛如招回遠古幽靈、呼喚心 靈的原初聲音。這樣的聲音, 彷彿也游離於理性所建構的語言與秩序之外, 詩歌衹是察 覺, 遂而聆聽, 與這份震顫的心靈有所感應。 ${ }^{141}$ 在白圭的詩歌〈酋長之夜〉裡, 詩歌延長 了英雄彌留現代的時間, 拉長了前現代的陰影, 卻並非為了呼喚心靈再度沉入神話思維 中, 而是邀請讀者, 一起注目於那心靈創口無法為神話所彌合的事實, 而必須直面現代文 學裡, 那自太陽被擊落、神逝以降的現代時間。世界固然無法再爲神話所拯救, 但若能面 對這樣的知覺, 創作本身即為救贖。相對於現實主義語言的反映功能, 現代詩的語言有較

\footnotetext{
138 平盾 (白圭) , 〈古戰場〉, 《蕉風》1959 年第 78 期, 頁 7 。

139 覃子豪, 〈由抽象到具象〉, 頁 5 。

140 梅占魁, 〈生命之歌〉, 同前註, 頁 7 。

141 關於詩中聲音的內外相互迴盪, 宛如「深處的震顫」之幻聽, 亦參考加斯東 · 巴歇拉 (Gaston

Bachelard), 龔卓軍、王靜慧譯, 《空間詩學》, 臺北 : 張老師, 2003, 頁 274 。
} 
多摺疊與空隙。跨入一九五八、五九年間, 友聯兩份刊物的新詩, 開始出現較多美學上呼 應新詩再革命、意義較為隱匿的現代詩。

譬如冷燕秋早年的詩作〈有一個晚上〉，詩歌有三段，整首如下：

有一個晚上，

憂䄳使勁地，打從

緊闣的眼臉摔出。

那浩重的群風,

带著如冬天的水氣,

像一個熱帶的女兒，

由腳尖, 吻我至臉龐。

這時我開始愛聽,

這南國風鈴的獨奏。

小樓外的荷葉，背駅著

很多的雨露睡去了,

而螺子們欲將扡們喚醒!

料及烈風中的後園,

將有一齣別離的悲劇,

是果實葉片哀傷地別了母體—

於是，昆蟲們遂奏一首哀悼的歌!

現在，時針立在第四驛站：

失眠的鐘鉈被催著說:

睡吧，貓頭鷹已把頭藏向翅下! ${ }^{142}$

對於當時本土定位開始消退的《蕉風》來說, 接納詩中的四季變化與北方時空其實並無不 可, 白圭雖常自言自己是馬來亞華人, 但詩作如前述的〈八達嶺的早晨〉也寫及花中有 $\ulcorner$ 春意」。以季節為意向, 挪借, 並不需要符合 $「$ 真實」或 $「$ 現實」的要求。現代詩容

142 冷燕秋, 〈有一個晚上〉, 《蕉風》1960 年第 97 期, 頁 9 。 
納、打開過去獨立之前馬華文學所不能承擔的內在書寫; 有時看似不合諧的內在書寫, 但

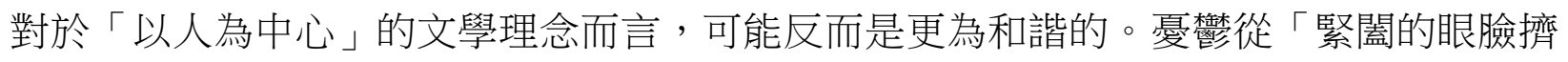
出」, 而後茂長成奇異、宛如仲夏夜之夢般的奇詭花園。其意念看似微小、無甚深刻, 但

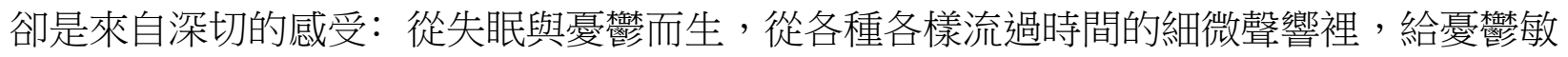
銳的心靈一個暫時的棲所。

這些夢幻意味濃厚、或象徵主義濃厚的詩作, 是在《蕉風》轉向現代詩之際, 同時 出現的風格。張光達曾以象徵主義與存在主義扼要地蓋括六十年代重要的現代詩人周喚、 艾文的詩歌特質, 在當時非左翼的文學場域裡, 象徵主義、存在主義也曾為現代主義所吸 收。 ${ }^{143}$ 其思潮系譜也跨越港臺。一九六 $\bigcirc$ 年《蕉風》刊登李國彬的詩歌〈音樂台的側 面〉：「音樂台以半圓形鋼筋混凝的巨石。在喃喃的／吞食著㯖眾們的靈魂的穀粒」。 ${ }^{144}$ 這首詩也刊於當時發行香港的《中國學生周報》。 ${ }^{145}$ 文字與意象詭麗, 詩義更趨晦澀冷

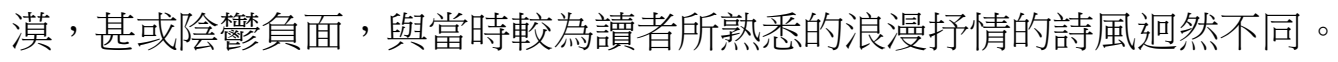

白堊紀時代起步的現代主義, 宛如奠基於與左翼對歭的理念上。但這樣的看法, 或 許不無偏頗; 閱讀《蕉風》中的多首詩作, 雖偶有隱晦, 大多抒情曉白, 少有艾略特詩觀 那般知性疏離之作。然而, 與早前現實主義或浪漫主義的詩歌比較, 白堊紀時期的詩行、 意象之間, 畢竟有更多詩義迂迴的空間。誠然如布朗修所言, 詞語與意義的關係虛無飄 渺, 意義無法恆駐, 由於符旨不斷滑轉, 故而意義也就在這滑離中, 形同空缺? 抑或, 那 隱晦未明的「意義」，應該被聆聽為有如一個「秘密」，如同諾艾勒畢宇侯(Noël Bureau) 那本 《伸出的手》書中的詩句：「他的秘密是 $/ \cdots . . . . /$ 聆聽花朵 /披染上她的色彩」? ${ }^{146}$

在大部分白圭的詩作裡, 對於生命有限的時空意識, 有份靜觀無我般的氣息。從一 九五八至一九六 $\bigcirc$ 年間撰寫的多首詩裡, 大多呈現出靜䍀空明之感。收錄於《美的 $V$ 形》裡的〈長隄路〉, 詩歌裡行路人在橋上踏出的腳步聲響, 以及偶然劃破周遭靜夜的火

\footnotetext{
143 張光達, 《馬華現代詩論》, 頁 3。

144 李國涁, 〈音樂台的側面〉, 《蕉風》1960 年第 88 期, 頁 20 。

145 李國涁, 〈音樂台的側面〉, 《中國學生周報》1959 年第 378 期。

http://hklit.lib.cuhk.edu.hk/pdf/journal/78/1959/184475.pdf

146 轉引自加斯東 ·巴歇拉（Gaston Bachelard）, 龔卓軍、王靜慧譯, 《空間詩學》, 頁 269 。不過英譯版 是 “Her secret was $/$ Listening to flowers $/ \ldots \ldots .$. . wear out their color." Gaston Bachelard, Maria Jolas (trans.),
} The poetics of space, Boston: Beacon press, 1994. p.177. 
車鈴聲,「我見新山碉樓的燈亮了, 而你我仍在橋上」 ${ }^{147}$, 頗有與泫之琳的詩歌呼應之 意。白圭善於讓詩歌停頓, 使詩意靜棲於那「未完」的「不言」之中。在一九六○年發表 的兩首抒情詩〈當你走後〉與〈曲終〉, 卻都在告別的主題裡, 流露比較纒綿廝磨的情感 與記憶。

在白堊紀之後, 現代詩歌在六○年代掀起第二波的現代主義運動。以後在群體彼此 呼應、抗拮詮釋的過程中，那實是馬華文學與對於現代主義的想像，以及對文學 $「$ 意義」 的多重探索。如莊華興所點出, 從初民國後期南來的大批文人, 塑造了整整兩代人的馬華 文學與文化的精神面貌與品味。 ${ }^{148}$ 始于五十年代末、跨越六十年代直到八十年代的現代主 義群體, 從神州詩社對中華文化的母體回歸, 乃至到八十年代知識分子對民族的憂患意識 書寫, 精神面貌各異。 ${ }^{149}$ 但是, 前述上世紀八十年代時期的民族憂患意識的寫作, 在獨立 初期的新詩裡, 也已經顯現, 譬如一九六 $\bigcirc$ 年發表於《蕉風》一月號, 羊城撰寫的新詩 〈送殯〉，詩歌前兩段如下：「一列長棺／沒有哭泣，也沒有音樂／我夾在送殯的行列／ 很長很長的行列中 / / 走著, 我低下頭走著／和你一同走著／和億萬的炎黃子孫／一同默 默地走著」。150「炎黃子孫」之句, 固有表達集體性哀悼之意, 同時也意識到, 在這群體 意識裡頭, 又總有無法消泯的個體疏離與獨異感受。這些政治意識與文化立場, 對於不同 的群體而言, 所顯現的意義與路徑各異 ; 對於馬華文學的系統而言, 因其與政治的深刻關 係，使得文學「意義」其實也無法全然剥離政治歷史的複雜脈絡與背景。

現代詩轉向技藝與文學自覺意識的意義為何? 如前所述, 根據魯文〈個體主義〉中 所提的, 文學不為「實用性」所奠定, 亦不能為文學之外的效果而成之為文學。雖然這反 實用之語, 比較普遍的理解, 是爲指向用於改造社會的功能。但進一步地說, 若以表達感 受或抒發慾望而言, 這仍然不無心靈與心理滿足的實用功能。若沿著這如此廣義的書寫功 能論, 層層剥離, 就會來到布朗修的疑問 : 文學書寫的意義為何? 在追索文學何以成為文 學的這一問題上, 或許布朗修的觀點值得參考。布朗修認為, 由於文學上的藝術語言要 求, 經常體現為一種對真實的接近, 使人以為, 透過語言進行的寫作, 可以接近真實, 或

147 白圭, 〈長隄路〉, 收於羅門等著, 《美的 $\mathrm{V}$ 形》, 八打靈 : 蕉風, 1959, 頁 1 。

148 莊華興，〈語言、文體、精神基調〉，頁 209 。

149 莊華興, 〈語言、文體、精神基調〉, 頁 214 。鍾怡雯, 《靈魂的經緯度》, 吉隆坡 : 大將, 2006, 頁 15-59, 頁 72-79。

150 羊城, 〈送殯》, 《蕉風》1960 年第 87 期, 頁 13 。 
表達意義。但基於那作為符旨的語言, 其實也無法完全貼近所欲表達的真意, 故在言與意 之間, 常有無法彌合的裂隙。 ${ }^{151}$ 故此, 他認為, 文學並無法接近那所欲表達的真實意義, 文學的意義, 恰好不在於給予意義。作家幻想可能在藝術裡, 獲得意義的永恆頓駐, 這乃 為追逐「真實」意義的「不可能」之「放逐」, 換言之, 使文學成為文學的, 並不是意 義, 而是「空無」, 空無源於那整體語言與符旨的系統的源頭。125這是一種它者似的空 無, 會把所有的意義都吞噬。153按照蔡淑玲的說法, 由於文學既然不能提供意義, 或者, 文學給予的 $「$ 空無」, 就是一種 $\left\ulcorner\right.$ 無意義」的意義, ${ }^{15}$ 故而, 布朗修的研究乃是在召喚讀 者, 從以為已經洞見藝術真理的「第一夜」, 邁向這真理幻象消散的另一夜。155這樣的過 程, 並不是一次渡越就完成, 而是得經歷許多次, 一層又一層的剥除。這就是文學所予的 探索與渡越的歷程。

確實作家無論為個體或群體, 無法不執著於追索與闡釋自身的寫作意義為何, 而關 於意義的解釋, 總會把各種競逐之欲捲入。即或以最純粹的、無求利益的書寫企圖, 哪怕 僅僅只是為了精神上的追索, 也仍然不能不去承受這一連串包含了經典、美學、意識形態 乃至到經由符旨置換轉移的慾望, 與嵑盡所能而來的反省, 和透過書寫與日常生活而構築 的「真實」共處。確實, 一個作家沒有辦法不陷入這經由符號與忿望築成的迷宮, 只有體 認到符旨本質上就無法為真, 而文學有如剩餘的屍骸, 所指向的真實總同時又包含「空 無」的可能, 或許才會稍微拉遠距離來觀看與反省文學的意義。盡管如此, 這位置到底有 多真摰或有多清醒, 可能也還是裏在幻覺裏。

在人的活動中, 人無法承受這傾盡全力之後的成果, 竟會了無意義。即便是在毫無 讀者、無實用性、無經濟價值轉換、稿件焚毀成空、或者, 以此地中文環境的隱憂, 同一 文學系統中那同一語言的讀者群體, 在數代後或因政治緣故竟至消失, 導致這小文學或許 有日成為無人閱讀的局面, 人仍然會為寫作找出意義。由於這意義的詮釋, 也是人們對自 身與文學的依存關係而講述的故事, 這個故事本身, 就在這些一再重敘、重寫的過程中, 探問那與生存相繫的意義—舉例而言, 即便是在被認為與文學毫無關係的口述歷史裡,

151 在此參考了蔡淑玲, 〈德希達與白朗修對「空無」看法之義同：符號與現實之間的關係〉, 《中外文 學》1994 年第 22 卷, 第 20 期, 頁 99-115。

152 蔡淑玲，〈德希達與白朗修對「空無」看法之義同：符號與現實之間的關係〉，頁 100-105。

153 蔡淑玲, 同上註, 頁 108 。

154 蔡淑玲, 同上註, 頁 110 。

155 蔡淑玲, 同上註, 頁 108 。 
一些邊緣的弱勢者, 正是透過語言的敘述, 憑籍語言符號, 達到重新組織對於自我身份的 詮釋 156 一一即或因這種種外部的原因, 或如以上所敘的, 基於對族群或語言體系, 於在地 國家體制中那不確定的因素, 或因爲如同南來文人那般經歷過流亡與亡國, 而不斷地與歷 史時空中那「空無」的意識打照面, 那麼, 關於這書寫、寫作的意義, 或許便可以這樣看 待, 那經由文字照亮的表達慾望, 縱或其間曾有失敗的陰影, 仍然會驅使一個寫作者, 在 不得不透過語言符號來續存的文學經驗中, 持續構築各種意識的詮釋, 以及促成「無意 義」的震顫盛放。這流動的詮釋連同迸湧的「無意義」的意義, 便持續運轉成這樣的形 狀：彷彿圍繞著那沒有可能實化的「意義」, 追逐成一道文學自身的圓環。不能替換成它 物, 不能換成權力或別的, 這即為文學, 就在這層本然的意義上, 趨近於愛。

白圭的〈酋長夜晚〉, 也許亦可這麼閱讀, 在詩歌裡那自從擊落太陽, 使大地恢復 書夜循環以來, 文學再度意識到那在心靈缺 $\square$ 上的秘密, 那彷彿絲毫不曾被想起過的恐懼 與戰慄。如果說神話乃是一道投落的陰影, 宛如在混沌夢境中圍繞生存驚懼而來的心靈密 碼，那麼現代文學就是在清醒中，凝視著這些來自古遠神話思維的隱喻，再度與其陰影會

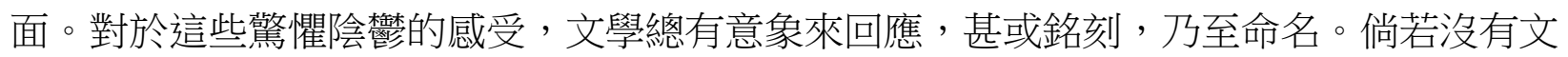
字追蹤, 它必然會自然地生起與消歇, 宛如從來未曾存在過。因此, 這在語言之外的生歇 消長，無法在文學書寫中重現與再度被經驗。在一個不獲任何回報的漫長時空中，在知曉 生命根本不若文學所欲賦予意義那般的肯定上，詩歌以質問的方式，一連串為何的問題， 卻幫助英雄卸落「拯救」任務之負擔（意義），遂能轉向輕盈之舞。那來自牙賣加的「卡 利索」之舞，與那在希臘神話中，意圖留下航海的尤里西斯於島上的「卡利索」同名。一 九五八年，香港有一首葛蘭唱的「我愛加力索」，舞動的姿態妖媚歡悅，這舞不再如遠古

156 譬如在 Alessandro Portelli 關於口述歷史的看法, 他提到敘說過去, 與一個人重建自我的認識, 有如此密 切的關係：「敘述一個故事, 就是在抵禦那時間的威脅, 為了抵禦時間, 或防禦時間的腐蝕。講故事使得 敘述者免於遺忘過去。這個故事重構一個人的身分標誌, 以及面對他或她在未來的時間裡無法實現的遺 憾。」Alessandro Portelli, The Death of Luigi Trastulli, and Other Stories: Form and Meaning in Oral History. New York: State University of New York Press, 1991, p. 59. 無疑, Alessandro 在此賦予敘述以抵禦時間的意 義, 正是布朗修所欲批評的。然而, 既然敘述動用的符碼無法自我壟斷為單一語義, 也無法主導它對於他 者符顯的意義。在完成講述或書寫過後, 意符便即死逝如屍骸, 變成空的屍骸, 宛如器囊或容器之物。但 是, 即便意義是如此地虛無變幺, 對於敘述者而言, 在敘說的當下時刻, 這容器已經被投落以那宛如雲天 流影般的意義, 即使僅維持瞬間, 「敘述」本身仍然不無救贖的意義。 
的舞蹈那般具有獻祭意義, 而是 $「$ 只有今朝」, 享樂與遺忘多於歷史記憶。白圭的詩歌從 射日酋長到卡利索, 從希臘神話轉至的流行意符, 意義已轉移數重。

如此, 在沒有肯定, 亦無所謂否定的書寫中, 文字所能喚起的, 正好如同龐德〈地 鐵站〉詩中, 那人潮湧動中臉孔的隱與顯, 「䵢黑沾湿枝头的点点花瓣」。誠然, 文學無 法如實再現, 任何流淌於文學之外的經驗, 書寫喚起的已然是別的事物, 有別於心靈的原 初體驗, 那便是寫作主體, 以不斷重複的書寫, 以及重複地剥離與再度涉人, 如此延長了 那流逝的時間物象, 呼喚緘默中的平衡瞬間。如同蔡淑玲的詮釋所言, 文學所賴以存在的 符號系統背後, 有著把這一切吞噬消沒的「空無」它者。 ${ }^{157}$ 然而, 如果是在以「空無」為 文學源頭的脈絡, 那麼, 這空無也就說不上所謂「吞噬」或「吐孕」。如同死亡就在生 裡, 從誕生之初, 死亡一早就在。這離散的中文文學系統, 其續存、壯大或萎縮的未來時 間, 總是不可預期, 重複的書寫, 彷彿預先演練對於「無所屬」的彼岸之凝望。對於那因 為歷史的偶然因素, 而在此開枝散葉的馬華文學來說, 這裡仍然有明或未明的原因, 驅使 個體延續著寫作的慾望。雖然從開端以來, 隱隱仍有此身寄存的系統, 或會消亡的威脅, 但 $\ulcorner$ 此時此地」, 這小文學仍然蓬勃待續。或許所謂的空無, 其實乃是因為有 $「$ 意義」無 法言盡, 以致於喧騰如遠洋, 又寂靜無語。

157蔡淑玲, 同上註, 頁 108 。 


\section{第七章}

\section{總結}

在《卡夫卡》一書中, 德勒茲與瓜達希關心的是更大範瞦的文化環境一即 西方的資本主義文化一主導的社會秩序強調個人主義，並將個人與政治拆 分開來。…...在少數文學中，「個人關懷立即與政治相連」。1

史都華 - 霍爾(Stuart Hall)的文化研究觀點以為, 任何文化文本不可能產自真空, 故此 會與文化產業、政治社會的意識形態勾連。以這樣的觀點來看《蕉風》與南來文人, 便會 來到這個問題：難道不正是出於主體本身的定義（由反共而來，選擇與國家政體合作）, 終致異議能力的喪失嗎? 但是, 根據這樣的疑問, 同時亦可反向地提問 : 難道除了反共 （以及本土、自由主義……等等宏旨）之外, 沒有其他的異議 $/$ 異義 ${ }^{2}$, 藏伏在他們的寫 作裡嗎?

文學場域中的個體，宛如被權力編碼的網鏈穿過，縛在座標上發聲。借用艾布拉姆斯 (M.H. Abrams)的說法, 有時候針對某個特定對象的觀念展開的抵抗和反對, 也可能使抵 抗者重複那所欲反對對象的語質，包括詞彙、語彙、概念和觀念。3固守於二元對立的位 置，針對極權還以敵意的反擊，亦可能使抵抗者同樣染上極權的病徵。語言符碼，確實不

\footnotetext{
1 雷諾・博格, 李育霖譯, 《德勒茲論文學》, 臺北：麥田, 2006, 頁 198 。

2 在此, 異議／異義, 本文的區別是 : 前者緊縛於一個特定議題, 後者則不限於議題, 而是指那隱藏在文本 或字面底下, 有待發現的隱蔽事物或岔徑。文本表面上的主題, 或者符碼的字面義, 有時也會遮蔽了, 潛 在的, 未被文本表面點明的隱義。

3 艾布拉姆斯(Meyer Howard Abrams), 麗雅牛、張照進、童慶生譯 , 《鏡與燈：浪漫主義文論及批評傳 統》，北京：北京大學，2015，頁 211。他如此分析柯爾律治的詞彙來源。柯爾律治運用機械哲學的詞 彙, 來描敘、解說文學的想像與幻想。
} 
可能逸離於權力詮釋的系統之外。然而, 與此同時, 又正好是 $「$ 寫作練習」, 才賦予主體 從權力網絡逸離的路徑。4

友聯南來開設分行、創辦《蕉風》, 這過程當中牽涉的諸多權力關係, 確實顯示出反 共產業與國家政體的語境之間, 存在著同謀或合作的關係。或許, 這表面上的合作關係, 其實也是策略性的運作, 如罩屏般保護刊物內偶有不馴的聲音。在《蕉風》創刊之初, 方 天擔任編輯時期, 曾經重視一些巫統的活動節慶、予以數頁篇幅, 似乎藉此表明, 《蕉 風》確實有「正派」「合法」地配合國家的論述。之所以說這是策略, 因為正是在這個時 期, 《蕉風》較敢刊登與公民權、語言、反殖等等與馬來亞政治相關的小說、稿件, 從馬 摩西、慧劍、方天的作品來看，他們此時，都比往後更願意討論政治的問題，諸如語言、 公民權課題。方天的小說, 甚且側寫緊急狀態時期, 壟罩華人心頭的不安陰影。但是, 在 一九五七年獨立以後, 這樣的空間一再收窄。姚拓接手後, 反共意味的版位與憶鄉書寫相 對增加, 對馬來亞現實禁忌的刺探減少。這並不是說, 在姚拓擔任編輯的時期, 就完全沒 有關注本土政治的書寫。

打從創刊以來, 《蕉風》確實在整體策畫上, 與國族論述相當配合。但在個別作者的 書寫裡, 對於國族論述和當時的處境, 並非全然毫無懷疑與困惑的餘地。5 在獨立前後, 《蕉風》不乏跨族戀的小說, 彷彿只有寄冀於跨族戀情, 才能讓族群之間的創傷癒合。然 而, 在大部分跨族戀的小說裡, 這樣的願望, 如非遭到挫折、釀成悲劇, 就是年輕情侶一 起從故鄉逃離, 出走他方。6 對於那底下的隱因, 這些小說似難深掘, 但或許這些小說分 岔為如此兩極的敘述模式, 亦可挪借來討論以下的問題。馬華文學那有待跨界的 $\ulcorner$ 出 走」, 或許就在於跨出「本土」預期的敘述模式。一九四九年的馬華文藝論爭, 把華文文 學要反映的現實, 從中國調轉到在地, 大量的本土地方知識與詞彙出爐。一方面, 「此時 此地」的經驗, 理應能在書寫中自然而然地展開。但另一方面, 基於長期以來受到五四文 學的觀念所影響, 本土文學可敘、可寫的面向, 卻難以自然而然地展開於筆下, 或者難以 找到打開, 那有別於五四文學的角度。

4 雷諾・博格, 《德勒茲論文學》, 頁 204 。

5 見第二章的小結, 以及第三章第四節。第三章第四節討論方天的在地現實主義小說, 這問題尤其顯見於 方天的小說〈一個大問題〉。

6 譬如卿華, 〈甘榜之戀〉, 《蕉風》1956 年第 8 期、第 9 期。曹兮, 〈愛莎〉, 《蕉風》1956 年第 12 期。羅紀良, 〈阿末與阿蘭〉, 《蕉風》1957 年第 36 期。高雅領, 〈白蒂那〉, 《蕉風》1957 年第 46 期。李牛才, 〈太平湖之戀〉, 《蕉風》1958 年第 64 期。 
馬華文學中的本土性, 往往被簡化成易於辨認的標誌, 風景、地標、植物、食物等各 種詞彙, 卻忽略了本土書寫, 其實亦有賴於情感所繫。南來文人剛剛底達的時候, 最初不 免以異鄉人之眼來看待周遭, 所寫的 $「$ 在地現實」, 可說是此時 $「$ 此地」的異鄉風景。然 而, 如果對此地風物習以為常, 那本土書寫, 便應當能超出這些標誌鮮明的地景風物, 而 轉向日常生活中, 那分外飽含情感意義之物。有關本土的書寫, 因此實是發自個人的生活 體驗; 從日常重複穿行的路線、聽到的聲響、街巷裡的叫喚、人們的穿著、食物的滋味等 等, 卻不一定是跟區域標誌有關的熱帶物件。對作者而言, 這些事物之所以能成為有意義 的載體, 除了源於個人的體驗之外, 同時亦跟文學美學觀的調度有關。當代壟罩群體的文 學習性, 從中突顯的詞彙、物件名詞, 也會累積成一個世代共同擁有的語彙地表。由此構 成的本土書寫, 實際上也是由群體書寫的文本符碼, 匯聚而成。從這點而言, 本土寫實主 義書寫, 因此也難以辦到全然反映一個客觀的現實, 囿寧是從當代文本中, 再度攝取、生 產本土的表徵。

然而, 書寫同時具有克服符碼與所指客體之間、越過那道深淵距離的慾望。亦即, 書 寫會努力道出、說出、描敘那些還藏在晦暗中、還未曾被說過、表述過的事物, 此即為文 學主體本身的表述慾望; 搜索枯腸, 遣詞措字, 就像以手指來指出事物那樣。在這樣的過 程中, 其實就已經開啟一道, 通向表達慾望的書寫。從日常生活中的所見所感、那些觸動 心靈之物, 揣磨那藏於其中、最初不曉如何表達的一一直如挖掘對自己而言尚像是「秘 密」的未知物, 經過研磨才能讓書寫從這「秘密」煥發展開。

學界現有的論述廣泛認為, 現代主義與現實主義之間的根本區別, 就在於其美學觀與 文字符碼之間的關係。寫實主義奠基於符碼反映透明如實的信念, 而現代主義的詩學語 言, 傾向於隱晦曲折的隱喻, 更加突顯出語言符碼的意義多岔, 意義不斷在書寫中滑離, 輻射出無止盡蔓延的岔叢。一則文本, 一首詩, 在寫下之後, 那書寫時所欲讓人了解的意 義, 結果卻像遁走的神祕動物, 沿著這些岔叢小徑, 一路幻變不同的模樣。

雖然按照上述所言, 現代主義與現實主義, 被建構為宛如二分對立的文學概念。然而 在寫作的過程中, 對表述符碼的意識總是游走。在貫徹現實主義理念的文本之中, 也可能 會有現代主義那語義幽微的浮動特質。

按照寫實主義的所欲貫徹的關懷現實的理念, 文學的表述力量, 在於對權力結構的質 疑、批判和挑戰。這包括對於殖民者、資本家、雇主與既得利益者, 等等。然而, 現代主 
義也並非沒有批判現代社會的反思能力, 甚至其批判性與對現代處境的反思, 可能更為滲 透、不止朝向上層階級, 而是超出階層, 滲透到「個體」那裡去。

由於對服從於主流話語所形成的邊界, 有所疏離與懷疑, 驅使現代文學去質疑、瓦解 那使大眾馴服的話語, 並探索更個體化的語言改革, 以便突破那些在日常生活中, 模塑主 流價值觀的平板語言。

白圭的現代詩運動, 所展現的叛逆精神, 主要是針對當時馬華文壇上, 已成僵化的五 四與現實主義文學觀念, 並非對國家（馬來亞）官方政治的叛逆。白圭在政治上所反叛的 參照對象, 始終是中共。他對於這個極權政體底下的文藝政策, 深惡痛絕, 似乎更甚於馬 來亞獨立後族群偏差的文化施政。

誠然, 如德勒茲與瓜達希所言, 小文學裡的「個人關懷立即與政治相連」。若從在地 的國家政體或文化政策的政治語境來看, 白圭的現代詩論述, 似乎並不能夠㘓明上述「與 政治相連」的小文學例子。德勒茲與瓜達希所談的小文學書寫, 總能從文學書寫中, 挑戰 各種塑成主體的原則定義與詮釋, 作家從文本敘述的各種生存情境中, 闡述那無法為主體 所信仰的原則、價值觀, 所能解決的悖論。小文學當具有分裂主流政治論述的能力。但透 過書寫, 干擾政治的反叛方式, 同時亦體現在文學語言的藝術層面上。

白堊紀時期的現代主義運動, 一方面分裂了當時長期蔚為主流的寫實主義觀點, 另一 方面, 它同時也分裂了《蕉風》與《學生周報》的「反共」話語。從這點而言, 它表面上 的去政治化, 卻也不經意地拐離了美援/反共的宗旨, 竟而體現出反政治語言的文學意 義。

如前所述, 那最初共同濔漫在左翼與《蕉風》評論者群中的文學實用論觀念（諸如 「改造」、「改善社會」），並不獨由任何一個作者所創。作者有如鹗武鳥般，傳遞那來自 社會, 包裹他的話語聲響, 彷彿把一切借來的, 又原原本本地散播出去。但是寫作就是攪 拌、醃製、雜交、沸騰, 因而又能把借來的, 量散出變異的氣息。從文學語言的寫作練 習, 鍛造磨練, 至到蛻變發生, 同時迎向政治議題, 便能如七首般截向那集體共享的語彙 絨面。拒絕跟隨那些既定的政治觀點與模態 , 否則就根本不必寫作。寫作由此同時是表 達方式、語言風格，同時也是對於現實觀點的蛻變。

德勒茲以為, 少數文學中的政治相連特性, 必須表現為超出大眾或群體陳腔濫調的想 法。7獨特的寫作, 因此沿路曲折, 充滿窒礙, 麻煩重重。那麼, 隱藏在文學中的政治關

7 雷諾 ・博格, 《德勒茲論文學》, 頁 99 。 
懷, 就不僅止於把問題與意見加以重述。這樣的觀點, 或許也可以稍微補充一九五 $\bigcirc$ 年代 末, 《蕉風》的文學改革意識。文學文體形式的改革, 就意味著期待書寫形式上的變異。

「改革」這詞彙看起來, 總是充滿號召意味。改革的呼喚, 總期待傳來回應的聲海。從單 一孤獨的寫作, 複數化為群體共赴的盛宴。但是如同雷諾・博格所言, 群體同路, 雖然可 以相伴共威共鳴, 但對於文學經驗的深切蛻變, 必然是在各自的心靈深處體會, 而後才在 交流中展開。

方天的現實主義小說寫作, 馬摩西的馬來亞化、旅行搬遷、地方與家居書寫, 姚拓的 非左翼抗日敘述以及白圭的新詩, 都不是那種挑戰形式的實驗性寫作。他們沒有寫出太過 挑戰讀者閲讀習性的文章。一九五五年南來文人跨越邊界, 從亞熱帶來到熱帶, 經歷空間 與語音的遽然切換, 文學聲明皆被反共宗旨與馬來亞化意識所蒸騰。這份論文的各章, 除 了指出他們的書寫如何實踐這些目標之外, 也試圖從他們的書寫中, 翻找若干偏離宗旨的 跡象。在公共領域中, 他們宣揚反共、中華文化重建、在地認同等等主張。但文學書寫裡 不經意納入的, 卻不止於這些友聯出版社的宗旨。那些未曾為當時思潮所重視的部分, 譬 如因離散異鄉而來的處境與懷疑, 個人私人的經歷, 文學幽微的書寫方式, 同時也在干擾 這些宗旨, 如陰影般投落在宗旨光照不及的隙縫深處。

對逃離在外的流亡者而言, 中國大陸的民國消亡, 標誌著斷裂的歷史時間。那已經發 生、過去了的時刻, 不能再回返。這種與過去斷裂了的時間意識, 貫穿了方天、馬摩西、 姚拓和白圭的書寫。方天出現在《蕉風》, 幾乎是歷史的錯置。他簡直如同插隊那般, 從 中國的左翼陣營轉來到這支有許多國民黨人的友聯隊伍。他的現實主義小說, 若和《蕉 風》裡其他文人的寫實/現實主義寫作比較, 顯然最具階層關懷的意識。他的寫作似乎師 法一九三 $\bigcirc$ 年代早期的傳統寫實主義。方天過去多以苦力勞工的遭遇為題材, 但他在《蕉 風》最後刊出的兩篇小說, 卻有顯著的改變。方天最後一篇發表在《蕉風》的小說〈厄 運〉, 小說裡的〈我〉朝向高空凝望, 投以忧目驚心的雯那一瞬, 彷彿可以逮著那即將發 生/或沒有發生的關鍵時刻。但因為畢竟甚麼都還沒有發生, 一切懸而未決。小說彷彿把 那過去分岔的歷史時間, 再次通過敘事、故事、文體語調的組裝, 迎接到小說裡, 屏息遙 望。這篇小說, 已經超出寫實主義的框架, 近於現代主義與存在主義, 與其說它反共, 不 如說它更關注個體面對命運未知臨在的抽象處境：通過厄運的預感, 隱隱提出了一個相當 富含哲學意味的、焦昫的問題。事物現狀與機緣處境, 總是一連串歷史選擇的結果, 然則 個體自身意志抉擇的極限何在? 在這共同生活的空間裡, 個體日常的穿梭路線, 仍然可能 
遭逢來自他人、某個環節的鬆脫而降臨的厄運。小說中惘惘存世之威妿, 仍然藴含著方天 對於個體與集體共存的思考。

在來馬一年多後寫的小說, 〈我的博士論文〉, 刊於一九五六年十二月《蕉風》, 寫 男店員觀察女顧客的攻心術, 竟有新感覺派小說中訛虞我詐的心理特質, 只是他將之搬演 到商業關係中來。8〈我的博士論文〉以告白式的自嘲的語氣貫穿全文。小說第一人稱的 主人公「我」, 在商店裡賣鞋子, 得不斷討好客戶、察顏觀色、估算進退。雖然看似能全 盤掌握顧客心理, 但小說的敘述聲音卻反諷的透顯出, 「我」實際上也被那龐大的商業體 系擺佈了。對於這份自我欺騙的幻覺, 「我」彷彿「甘之如飴」, 但最後還是不禁承認：

$\ulcorner$ 我雖能以虛假贏得勝利, 但一旦動起真來, 便要失敗了」。小說裡藏著兩種痛苦。那給 商業制度主宰得失去自我的痛苦; 以及另一種發自真情的痛苦（真情雖苦, 難道不也能使 人甘之如飴？）如同把顧客分類, 「我」也把生活劃分成好幾塊, 一些時候必須算盡心 機, 另一些時候卻真情難阻, 但正是後者才彌補了心靈上的枯燥, 也只有後者才能恢復那 因功利而失去的心靈本真。真情無法估算得失, 即使從外邊 $\ulcorner$ 一無所得」, 但從本質而言 卻是「已得」。文學之於語言, 猶如醃漬之池, 對於文學的慾望, 使人沉醉於「寫作練 習」裡，甚至召喚個體挑戰那些已成典範的規則，以創造空間。

流亡離散南來的友聯文人, 在肩負反共任務之餘, 亦實踐傳授、繼承、耕耘散播中華 文化的任務。文化傳承, 總是仰賴那可瓦存於時間, 承載、銘刻意義的物質。然而, 在獨 立之初, 華文教育系統, 實無保障。由此投入的文化耕䎣與銘刻意義的慾望, 就在「空 無」與「意義」的深淵之間往返。

如此純粹的「寫作練習」有甚麼「意義」呢？為了再度回返到那「已然」失去的時 間封穴? 還是藉由重寫而得以真正告別過去? 宇文所安(Stephen Owen)對藝術中的時間， 有如下解釋：「藝術不能拒絕時間性一一如果它拒絕, 那就將沒有任何他性的可能, 因而 也就沒有任何欲望。」佈局、陳述的欲望, 了解那斷裂的時刻, 重新組織那已失落位置的 欲望, 乃至到完成書寫, 再次有被閱讀與聆聽的可能, 「把過去作為一種得到確認的失 落, 因而也是作為一種可能性, 包容在現在之中。」9

\footnotetext{
8 金然, 〈我的博士論文〉, 《蕉風》1956 年第 28 期, 頁 21-23。

9 宇文所安(Stephen Owen), 程章橴譯, 《迷樓一詩與慾望的迷宮》, 北京：三聯, 2003, 頁 292 。
} 
在姚拓那些回憶童年的散文裡, 批共的訓示, 簡直是簡白易曉地曝露文內。10散文 有這麼一段回憶過去：「我喜歡到五里外三嫂的娘家去走親戚, 因為三嫂的父親早年去 世, 家中只有母親和小弟弟, 那麼我玩起來可以毫無忌憚, 吃起束西也可以盡量, 不必留 甚麼面子。他們家後院有一棵最好吃的雵子樹, 我每次不但爬上樹吃個肚脹, 回家時還要 带個霂篮。」 ${ }^{11}$ 雖沒盡敘, 卻把那樹影窸窣的氣息送到讀者前面來。無可否認, 讓流亡者 敘說自身經歷、寫出中國人中共執政前後的生活、對照前後的轉變, 是美援文化反共策略 中, 最常見的敘述方式之一。文章結尾的批共之意, 表述得清楚明白。謝詩堅曾把姚拓形 容為實踐反共最為落力的編輯之一。從姚拓反共的立場來看, 也很容易讓人認定, 行文中 的童年懷舊與抒情, 僅僅只是為了柔化反共訓示的抒情鋪陳。在另一篇科幻小說〈七個世 紀以後〉, 雖然表面上小說的時間調到未來, 但實際上也䯳掛在過去與未來都夠不著的時 空裡。主人公從死亡到廷醒, 那短暫的復活時間竟隔離如孤島。就在這座時間孤島上, 小 說端出各種高度智慧與前進的開放觀念, 轉向了與中共極權控制, 完全相反的另一個烏托 邦：人類倘若持續進步, 那未來的世界到底會怎樣呢? 沒有任何語言宗教之分、人人平 等。但击詭的是, 這樣完美的體制, 結果竟然也和中共所欲鳘述的烏托邦, 有不少相似之 處。不過, 〈七個世紀以後〉的烏托邦, 小心地裹藏著姚拓自身那未能獲得滿足的、交流 的傷痕; 即便在那短暫的復活過程中, 他仍然未能擺脫語音帶來的隔膜與交流障礙的問 題。

旅途如果沒有挑戰與啟迪, 似乎也就無甚意義。在馬摩西的旅行書寫裡, 他渴望獲 得啟迪、視野上的改變, 也希望能潄補從未能滿足的游牧幻想。獨立將屆, 雖然他已有公 務員職位, 生活彷彿都穩定了, 卻似仍有未實之感, 體現為對未竟之旅途、他方之遙想。 馬摩西的身分並不在擇定國籍與安居之後, 就能順利落定。他在中國是「漢語源流的回 族」, 來到馬來亞後, 卻在不同語言的媒介上, 分裂展現為「華語源流的文人」和 $「$ 回教 徒」。由於國族話語傾向締造族群和諧的畫面, 馬摩西的身份二分幾乎是隱蔽的。在當時 的歷史情境中, 對非左翼南來文人而言, 能夠參與獨立時刻, 似乎也是意義重大的。故 而, 無論在馬摩西的馬來亞地方書寫、抑或在白圭的追憶裡, 獨立初期的馬來亞回憶總是

\footnotetext{
10 譬如〈走親戚〉這篇文章裡, 參見前論, 第五章。

11 張兆（姚拓）, 〈美麗的童年回憶——走親戚〉, 頁 11 。
} 
美好的, 而獨立建國的歷史時刻也讓人很興奮, 如白圭寫：「此土此民成此國, 人人都想 為新邦新國出點力, 充滿落地生根而衍生的鳳凰自信」。12

「現代主義常被認為是不涉政治的運動, 語言實驗僅被認為是形式上的創新。」13 德勒茲的研究, 致力於把卡夫卡的語言實驗, 與政治的批評聯繫起來。現代主義的書寫㟲 脱符號系統的穞定指涉, 使得種族、身分、政治意義的指涉性, 都可能在誤讀與意義的斷 裂中, 轉移, 鬆動。現代詩似乎因此提供了「去身分」的可能性, 從大寫歷史、政治與意 識形態的網絡逃逸。但這樣的解釋, 未免遺忘那宛如臍帶般接通虛構世界、或藝術創作的 世界, 與由無數權力嵌置、疊疊架起來的系統。如同旅行並不能從這地平線逃逸, 文學那 讓人醉心忘我（忘記身分的）寫作練習, 因此具有這樣的雙重性：它既打開它也閉上。恰 如白圭詩中那道射日的箭矢, 這股寫作的力量總想朝向某處, 也許懷帶著拯救與癒合的使 命。但為著不可言說的「美」, 它又與權力疏離, 投入「練習寫作」。又由於如此醉心寫 作，意義就在其中。但由於符碼的難以恆固，故此文學並無真理。

直到一九六 $\bigcirc$ 年, 現代主義白堊紀剛剛啟程。現代主義開始探索左翼長期以來, 從 未能啟動的「純粹寫作」。過去左翼未能提供的, 白堊紀時期的現代主義開始彌補。這持 續的嵌和補, 行彿仍然在延續一九五七年姚拓南來, 那組行李與家具的重置與安頓的過 程。馬華文學史中的典範遞換, 宛如一直持續著這股嵌補的運動變化。由於長期為左翼的 抗爭路線所壟罩, 故此迎來現代主義極度著重美學與藝術自覺的詩心突變。爾後, 在寫作 美學與觀點變得二元化的情況下、對文學的美學予以關注, 竟意味著排除掉那包圍主體, 如同羅網般的權力與政治體制, 這樣的嵌補, 似乎少了點甚麼; 職是之故, 下一趟的變 革, 就如支點傾斜, 傾倒、涌向所匱乏的那一邊。就在嵌與補的過程中, 文學運動持續展 開, 不斷補充那原先所匱乏的。

緊隨而來的六 $\bigcirc$ 年代《蕉風》研究, 除卻現代主義的第二波革命, 尚有年輕的一代 寫作人, 包括魯葬、山芭仔 (溫祥英) 、憂草。他們的本土感性, 又與過往一九三 $\bigcirc$ 年代 的愛國主義不同, 亦與南來文人為結束離散狀態而表達本土認同的面貌不同。對於本土性 顯為熟悉日常的群體而言, 本土的生活經驗寫來似乎更為隱匿。如同駱駝之於沙漠, 蕉風 楖雨之於馬來亞, 因不覺陌生, 反而不會特意人文。於是, 本土的表現, 就更形隱淡, 棄 除顯明標誌, 那滲入的氣息, 就理當更為細瀻、隱密, 因為, 當「此地」的草木事物成為

\footnotetext{
12 白圭, 《縷雲起於綠草》, 頁 26 。

13 雷諾 - 博格, 《德勒茲論文學》, 頁 208 。
} 
感情傾注所在, 而不是政治認同的意識之時, 文學書寫, 或從小處著筆, 或描摹而不點 名, 來喚起會心的共感。這可能是從情感出發的寫作方式。然而在一段時間內, 由於削減 了左翼的抵抗特性之故, 馬華文學少的, 可是政治的尖銳性? 哪怕是隱晦的批評, 抑或形 諸於表達結構的隱喻。政治性質, 並非僅指納入議題。文學除了應和那意識形態與政治性 的環境之外，同時還針對個體存在的秩序、結構來發問。

在上述所討論過的小說裡, 姚拓的〈走死運的人〉 ${ }^{14}$ 、方天〈預感 ${ }^{15}$ 便遊走在冷戰 編碼的意義之外。〈走死運的人〉小說主人公由於假死, 徹底被放逐於個體的「真實身 分」的系統之外; 然而也正是這樣的（假）死亡, 才使他同時在剥除身分之餘, 也得以從 家庭那幾乎拖垮生命的倫理責任解除, 他的家人竟然在一個以虛殼替代本尊的豐沛社會支 援中, 得以舒適地「倖存」下來, 在這部小說裡, 「倖存」就有了與謊言對照的荒謬處 境。

在莊華興的論文裡, 他很尖銳地指出了目前馬華文學有關現代主義觀點的局限。他 認為現代主義的美學觀點, 使大家都忽略了馬華文學那因為現代主義而削弱的精神基調。 然而, 在關懷政治的時候, 一方面, 任何結構與詮釋系統中的問題, 總會不斷驅使個體的 良心去詢問那些各種不公或不義的偏差問題; 但另一方面, 圍繞著這樣的問題來穿透或審 視, 卻又不能迴避, 一系列既定觀念運作的局限, 由此, 文學就有必要去挖掘出屬於文學 應該發現的問題, 這種問題總是試圖搖晃, 所有率涉到的系統、被觀察的「客體」物件, 也包括正在進行觀察和練習寫作中的自我。文學對公共事件的批評, 猶如戴上代言面具, 隱蔽在那些群體為公共利益而共舉的盾牌背後。 ${ }^{16}$ 如果文學僅能按照群體的話語演出, 不 免又繞過了那處於資源權力網絡中, 那平凡的個體倘若處在相似的（譬如與「加害者」相 似的）位置上, 所會面臨的怯懦與恐懼。

然而, 正是這隱蔽在個體深處的怯懦, 才是文學通向反省那社會語境所欲掩蓋的裂 隙與深淵。現代主義文學賦予凝視這隱藏於體系之內（現代的、資本主義運作的）闇黑深 處的能力。

那麼, 似乎經由這樣的慎思, 便能提出, 對於文學而言, 那可堪稱為有意義的問題 了。然而, 基於「意義」正好奠基在言語符碼編造的系統上, 那一系列由符碼詮釋交織、 互相銜咬勾連, 所構成的區塊, 它實則浮盪如島。一九五 $\bigcirc$ 年代在《蕉風》裡起步的現代

\footnotetext{
14 相關討論見第五章第四節, $「$ （三）滲透雙鄉的敘述語言」底下。

15 相關討論見第三章的小結。

16 借用宇文所安在《迷樓》一書中, 論及柏拉圖討論城邦理念中, 那公正群體的觀點時, 所構想的譬喻。
} 
詩、以及小說中偶而浮現的現代主義意識, 一方面是在展開語言美學的鍛鑄磨練; 另一方 面, 對於當時政治話語中, 種種施加於個體與主體的觀念, 小說可以對此展開更加深沉的 探問。盡管這些小說關於主體存在的意義, 可能超出了作者的意識。文學如何能夠敏銳地 察覺, 那構成主體觀念背後的悖論? 以及又如何能夠持續展開那文學形式與美學上的探 索? 如何能夠兩者同時並重, 而不是在追求純粹的美學中, 排除掉對政治與主體面向的探 問? 長期以來, 這兩者彷彿一直難以平衡。馬華文學在經過五 $\bigcirc$ 年代至六 $\bigcirc$ 年代漫長的政 治監控中, 可能遭到了相當的壓抑而不自知。

然而, 深入的探索, 往往意味著, 面對種種難以盡全的解釋。如同對一個由符碼相 銜串連編成的意義區塊不斷敲打, 又勢必會同時察覺到, 就在言詮路途上, 意義持續滑 動, 難以捕牢, 由此恍見的空無, 恰如星叢萬年遙光。一旦以為書寫逮到正義與不公的核 心, 這書寫就假了, 因為那導致不公正的導因, 置諸於人的處境裡, 尤其是在所寄存的政 治體系裡, 因著生存的資源與爭奪, 而造成詮釋上的拉鋸, 使得人們對於真相的解釋, 僅 能從自身所知與所欲的立場出發。敘述如何可能超越這局限的觀點？由此，文學之錦繡， 就在於其豐富的語言, 不斷從無可預期之處流動匯人。其織錦把主體裹送、抖落至另一位 置; 從邊緣的處境, 去面對主體那賴以詮釋自身的定義、原則與價值觀一一就寓存於那意 義飄渺如蜃樓的語詞一一而在諸多價值觀之間, 又相互否定成悖論。現代主義的小說（現 代主義時間仍在繼續）, 因之也對真理與真相總有保留, 讓疑問浮現, 但答案擱懸。知性 的探索, 會使疑問不斷衍生, 小說也就不斷持續重寫：不斷看見那在這此身寄存的體制 中, 蔓延增生的裂隙; 縱入那隙縫深處, 文學有如永無終點的旅程。在此處有吞沒、有浮 動、有攪亂、有孤寂深淵與相聞呼喚, 對於手藝的玩磨與未明疑惑, 以及對於那所言之物 的距離與無窮遙追, 無邊無涯。 


\section{附錄}

表 1.1 ：方天刊於《蕉風》的作品列表（從創刊至 1960 年）

\begin{tabular}{|c|c|c|c|c|c|}
\hline 序號 & 題目 & 文類 & 筆名 & 刊號 & 日期 \\
\hline 1 & 一八四一年的一夜 & 小説 & 辛生 & 1 & 1955 年 11 月 10 日 \\
\hline 2 & 膠淚 & 小説 & 方天 & $\begin{array}{l}1 \\
2\end{array}$ & $\begin{array}{l}1955 \text { 年 } 11 \text { 月 } 10 \text { 日 } \\
1955 \text { 年 } 11 \text { 月 } 25 \text { 日 }\end{array}$ \\
\hline 3 & 孕婦島 & 民間傳說 & 辛生 & 2 & 1955 年 11 月 25 日 \\
\hline 4 & 豆腐檔前 & 小説 & 方天 & 3 & 1955 年 12 月 10 日 \\
\hline 5 & 給孩子 & 詩 & 方天 & 6 & 1956年 1 月 25 日 \\
\hline 6 & 十八溪墘 & 小説 & 方天 & $\begin{array}{l}7 \\
8\end{array}$ & $\begin{array}{l}1956 \text { 年 } 2 \text { 月 } 10 \text { 日 } \\
1956 \text { 年 } 2 \text { 月 } 25 \text { 日 }\end{array}$ \\
\hline 7 & \begin{tabular}{|l|} 
大肚國王與千里香 \\
一又名生命的水, \\
是椰子的故事
\end{tabular} & 寓言童話 & 辛生 & 9 & 1956年 3 月 10 日 \\
\hline 8 & 一個大問題 & 小説 & 辛生 & 12 & 1956年 4 月 25 日 \\
\hline 9 & 暴風雨 & 小説 & 方天 & $\begin{array}{l}16 \\
17\end{array}$ & $\begin{array}{l}1956 \text { 年 } 6 \text { 月 } 25 \text { 日 } \\
1956 \text { 年 } 7 \text { 月 } 10 \text { 日 }\end{array}$ \\
\hline 10 & 一個排字女工的日記 & 小説 & 阿瓊 & $\begin{array}{l}21 \\
23\end{array}$ & $\begin{array}{l}1956 \text { 年 } 9 \text { 月 } 10 \text { 日 } \\
1956 \text { 年 } 10 \text { 月 } 10 \text { 日 }\end{array}$ \\
\hline 11 & 爛泥河的鳴咽 & 小説 & 辛生 & 24 & 1956 年 10 月 25 日 \\
\hline 12 & $\begin{array}{l}\text { 評「劇作選輯」中的 } \\
\text { 諸劇 }\end{array}$ & 㙯評 & 辛生 & 25 & 1956 年 11 月 10 日 \\
\hline
\end{tabular}




\begin{tabular}{|l|l|l|l|l|l|}
\hline 13 & 勇敢的孩子 & 童話 & 方天 & 28 & 1956 年 12 月 25 日 \\
\hline 14 & 我的博士論文 & 小說 & 金然 & 28 & 1956 年 12 月 25 日 \\
\hline $\mathbf{1 5}$ & 預感 & 小説 & 方天 & 30 & 1957 年 1 月 25 日 \\
\hline
\end{tabular}

表 1.2 ：方天刊於《蕉風》的座談會發言

\begin{tabular}{|c|c|c|c|c|c|}
\hline 序號 & 題目 & 發言題目 & 筆名 & 刊號 & 日期 \\
\hline 1 & 漫談馬華文藝弆 & $\begin{array}{l}\text { 指出生活方向與倉 } \\
\text { 作的深度 }\end{array}$ & 方天 & 20 & 1956 年 8 月 25 日 \\
\hline 2 & 當前華校戲劇問題 & 讀詞比發音重要 & 辛生 & 27 & $\begin{array}{l}1956 \text { 年 } 12 \text { 月 } 10 \\
\text { 日 }\end{array}$ \\
\hline 3 & $\begin{array}{l}\text { 一九五七年馬華文壇 } \\
\text { 的展望（文藝座談之 } \\
\text { 五） }\end{array}$ & $\begin{array}{l}\text { 克服現有缺陷 擴大 } \\
\text { 已有建樹 }\end{array}$ & 方天 & 29 & 1957 年 1 月 10 日 \\
\hline 4 & $\begin{array}{l}\text { 詩的創作問題（文藝 } \\
\text { 座談之七） }\end{array}$ & 謅詩人的品質 & 辛生 & 33 & 1957 年 3 月 10 日 \\
\hline 5 & $\begin{array}{l}\text { 談報告文學（文藝座 } \\
\text { 談之八） }\end{array}$ & $\begin{array}{l}\text { 舉辦『馬來亞的一 } \\
\text { 日』 }\end{array}$ & 辛生 & 35 & 1957 年 4 月 10 日 \\
\hline
\end{tabular}


表 2 馬摩西刊於《蕉風》的作品列表（從創刊至 1960 年）

\begin{tabular}{|c|c|c|c|c|c|}
\hline & 題目 & 類型 & 筆名 & 刊號 & 日期 \\
\hline 1 & 沙漠的邊緣 & 散文 & 馬摩西 & 1 & 1955 年 11 月 10 日 \\
\hline 2 & 馬來亞頌 & 詩歌 & 馬摩西 & 2 & 1955 年 11 月 25 日 \\
\hline 3 & 旅行的生機 & 散文 & 馬摩西 & 4 & 1955 年 12 月 25 日 \\
\hline 4 & 獅城與馬來散記 & 散文 & 馬摩西 & 5 & 1956 年 1 月 10 日 \\
\hline 5 & 淡寫新山 & 散文 & 馬摩西 & $\begin{array}{l}6,7 \\
8,9\end{array}$ & 1956 年 1 月 25 日 \\
\hline 6 & 燈蛾 & 詩 & 興周 & 12 & 1956 年 4 月 25 日 \\
\hline 7 & 牛鼻子寫真記 & 人物與藝評 & 興周 & 16 & 1956 年 6 月 25 日 \\
\hline 8 & 馬來亞化問題 & 散文 & 馬摩西 & 18 & 1956 年 7 月 25 日 \\
\hline 9 & 海外詩人燕歸來 & 人物與藝評 & 馬摩西 & $\begin{array}{l}19(22- \\
23)\end{array}$ & 1956 年 8 月 10 日 \\
\hline 10 & 光榮的馬來家庭 & $\begin{array}{l}\text { 散文（地方紀 } \\
\text { 事） }\end{array}$ & 馬摩西 & 20 & 1956 年 8 月 25 日 \\
\hline 11 & $\begin{array}{l}\text { 莭險的行程- } \\
\text { 李汝琳新書推介 }\end{array}$ & 藝評 & 馬摩西 & 21 & 1956 年 9 月 10 日 \\
\hline 12 & 向風抗議 & 詩 & 興周 & 22 & 1956 年 9 月 25 日 \\
\hline 13 & 微笑的魔鬼 & 埃及小説翻譯 & 馬摩西 & 24 & 1956 年 10 月 25 日 \\
\hline 14 & 難忘的遊玩 & 散文 & 興周 & 24 & 1956 年 10 月 25 日 \\
\hline 15 & 蘇丹娜 & 埃及小説翻譯 & 馬摩西 & 25,26 & $\begin{array}{l}1956 \text { 年 } 11 \text { 月 } 10 \text { 日- } \\
11 \text { 月 } 25 \text { 日 }\end{array}$ \\
\hline 16 & 綠的原野 & 埃及小説翻譯 & 馬摩西 & 27 & 1956 年 12 月 10 日 \\
\hline 17 & 雞的幻想曲 & 散文 & 馬摩西 & 28 & 1956 年 12 月 25 日 \\
\hline 18 & 幸福的日子 & 埃及小説翻譯 & 馬摩西 & 30 & 1957 年 1 月 25 日 \\
\hline 19 & 新婚之夜 & 埃及小説翻譯 & 馬摩西 & 31 & 1957 年 2 月 10 日 \\
\hline 20 & 奸滑 & 埃及小説翻譯 & 馬摩西 & 32 & 1957 年 2 月 25 日 \\
\hline 21 & 評江陵的新書： & 藝評 & 興周 & 32 & 1957 年 2 月 25 日 \\
\hline
\end{tabular}




\begin{tabular}{|c|c|c|c|c|c|}
\hline & 從黑夜到天明 & & & & \\
\hline 22 & 迫害與受罪 & 埃及小説翻譯 & 馬摩西 & 33 & 1957 年 3 月 10 日 \\
\hline 23 & 心的覺醒 & 埃及小説翻譯 & 馬摩西 & 34 & 1957 年 3 月 25 日 \\
\hline 24 & 再會吧, 夏天! & 埃及小説翻譯 & 馬摩西 & 35 & 1957 年 4 月 10 日 \\
\hline 25 & 文藝的新使命 & 藝評 & 馬摩西 & 36 & 1957 年 4 月 25 日 \\
\hline 26 & $\begin{array}{l}\text { 象徵派詩人李金 } \\
\text { 髮 }\end{array}$ & 藝評 & 馬摩西 & 38 & 1957 年 4 月 25 日 \\
\hline
\end{tabular}


表 3 姚拓刊於《蕉風》的作品列表（從創刊至 1960 年）

\begin{tabular}{|c|c|c|c|c|c|}
\hline & $\begin{array}{l}\text { 題目 } \\
\end{array}$ & 類型 & 筆名 & 刊號 & 日期 \\
\hline 1 & 一張新的菜單 & 卷首語 & 編者 & 37 & 1957年 5 月 10 日 \\
\hline 2 & 小貓 & 小說 & 姚拓 & 39 & 1957 年 6 月 10 日 \\
\hline 3 & 七個世紀以後 & 小說 & 姚拓 & 47 & $\begin{array}{l}1957 \text { 年 } 10 \text { 月 } 10 \\
\text { 日 }\end{array}$ \\
\hline 4 & 最不能忘記的一張臉 & 小說 & 姚拓 & 55 & 1958 年 2 月 10 日 \\
\hline 5 & 四個結婚的故事 & 小說 & 姚拓 & $65-66$ & $\begin{array}{l}1958 \text { 年 } 7 \text { 月 } 10 \text { 日 } \\
1958 \text { 年 } 7 \text { 月 } 25 \text { 日 }\end{array}$ \\
\hline 6 & 田園作家喬治桑 & 外國文學介紹 & 張兆 & 74 & 1958 年 12 月 \\
\hline & 意外的結局 & 創作散論 & 姚拓 & 74 & 1958 年 12 月 \\
\hline 7 & 短篇小說之王的短篇 & 外國文學介紹 & 魯文 & 75 & 1959 年 1 月 \\
\hline 8 & $\begin{array}{l}\text { 一串耀目奪魄的寶石 } \\
\text { 評介羅曼羅蘭的「約翰 } \\
\text { 克里斯朵夫」 }\end{array}$ & 外國文學介紹 & 張兆 & 78 & 1959年 4 月 \\
\hline 9 & $\begin{array}{r}\text { 美麗的童年回憶 } \\
\text { 一看戲的日子 }\end{array}$ & 散文 & 姚拓 & 83 & 1959 年 9 月 \\
\hline 10 & $\begin{array}{l}\ulcorner\text { 天之驕子」的年紀 } \\
\text { 一四十自況 }\end{array}$ & 散文 & 張兆 & 84 & 1959 年 10 月 \\
\hline 11 & 石縫中的一朵小花 & 小說 & 姚拓 & 84 & 1959 年 10 月 \\
\hline 12 & $\begin{array}{l}\text { 美麗的童年回憶 } \\
\text { 一二月裡的風筝 }\end{array}$ & 散文 & 張兆 & 86 & 1959 年 12 月 \\
\hline 13 & 丘陵上 & 小說 & 姚拓 & 87 & 1960 年 1 月 \\
\hline 14 & 走死運的人 & 小說 & 姚拓 & 93 & 1960 年 7 月 \\
\hline 15 & $\begin{array}{l}\text { 美麗的童年回憶 } \\
\text { 一走親戚 }\end{array}$ & 散文 & 張兆 & 94 & 1960 年 8 月 \\
\hline 16 & $\begin{array}{l}\text { 美麗的童年回憶 } \\
\text { 一殺豬似的剔頭滋味 }\end{array}$ & 散文 & 姚拓 & 98 & 1960 年 12 月 \\
\hline
\end{tabular}


表 4：白圭刊於《蕉風》的作品列表（從創刊至 1960 年）

\begin{tabular}{|c|c|c|c|c|c|}
\hline & 題目 & 類型 & 筆名 & 刊號 & 日期 \\
\hline 1 & 老屋 & 詩 & 林間 & 73 & 1959年 11月 \\
\hline 2 & $\begin{array}{l}\text { 晨舞 } \\
\end{array}$ & 詩 & 林間 & 74 & 1959年 4 月 \\
\hline 3 & 海岸上的灰衣人 & 組詩 & 周垂 & 78 & 1959年 4 月 \\
\hline 4 & 八達嶺的早晨 & 詩 & 白圭 & 78 & 1959 年 4 月 \\
\hline 5 & 古戰場（白圭） & 詩 & 平盾 & 78 & 1959 年 4 月 \\
\hline 6 & 新詩的再革命 & 詩歌意見 & 凌冷 & 78 & 1959年 4 月 \\
\hline 7 & 新詩的道路 & 詩評 & 凌冷 & 79 & 1959 年 5 月 \\
\hline 8 & 酋長之夜 & 詩 & 白圭 & 79 & 1959 年 5 月 \\
\hline 9 & 陰陽界 & 詩 & 平盾 & 81 & 1959 年 7 月 \\
\hline 10 & 四月已逝 & 詩 & 白圭 & 81 & 1959 年 7 月 \\
\hline 11 & 漁村 & 散文 & 周垂 & 83 & 1959 年 9 月 \\
\hline 12 & 新詩? 新詩！新詩。 & 詩評 & 白圭 & 85 & 1959 年 11 月 \\
\hline 13 & 終曲 & 詩 & 白圭 & 90 & 1960 年 4 月 \\
\hline 14 & 當你走後 & 詩 & 白圭 & 94 & 1960 年 8 月 \\
\hline
\end{tabular}




\section{參考書目}

一、專書／論文合集

Alan Ryan 2012. The Making of Modern Liberalism. Oxford: Princeton University Press.

Alessandro Portelli 1991. The Death of Luigi Trastulli, and Other Stories: Form and Meaning in Oral History. New York: State University of New York Press.

Benedict Anderson 1982. Imagined Communities: Reflections on the Origin and Rise of Nationalism. London: Verso.

Chamber Iain 1994. Migrancy, Culture, Identity. London: Routledge.

Chan Kwok-Bun 2005. Chinese Identities, Ethnicity and Cosmopolitanism. London \& New York: Routledge.

Cheah Boon Kheng 2012. Red Star over Malaya. Singapore: National University of Singapore.

David McKnight 2005. Beyond right and left: new politics and the culture wars. Crows Nest, N.S.W.: Allen \& Unwin.

Derk Bodde 2014. Essays on Chinese Civilization. New Jersey: Princeton University.

Elazar Barkan and Marie-Denise Shelton (eds.) 1998. Border, Exiles, Diasporas. Stanford: Stanford University Press.

Frances Stonor Saunders 2000. The cultural cold war: the CIA and the world of arts and letters. New York: New Press.

Fujio Hara 2003. Malayan Chinese and China: Conversion in Identity Consciousness 1945-1957. Singapore: Singapore University Press.

Gaston Bachelard 1994. Maria Jolas (trans.) The poetics of space. Boston: Beacon press.

George Levine 1981. The Realistic Imagination: English Fiction from Frankenstein to Lady Chatterley. Chicago: Univ. of Chicago Press.

James Francis Warren 2003. Ah Ku and Karayuki-san: prostitute in Singapore, 1870-1940. Singapore: Singapore University Press.

James R. Ryan 1997. Picturing Empire: Photography and the Visualization of the British Empire. Chicago: University of Chicago Press.

Khalid Khayati 2008. From Victim Diaspora to Transborder Citizenship? Diaspora Formation and Transnational Relations among Kurds in France and Sweden. Linköping: Linköping University.

Lee Ting Hui 2011. Chinese Schools in Peninsular Malaysia: The Struggle for Survival. Singapore: Institute of Southeast Asian Studies.

Leo Suryadinata 2007. Understanding the Ethnic Chinese in Southeast Asia. Singapore: Southeast Asia Studies. 
Leon Comber 2015. Templer and the Road to Malayan Independence: The Man and His Time. Singapore: Institute of Southeast Asian Studies.

Lim Edward Huck Tee 1970. Libraries in West Malaysia and Singapore; A Short History. Kuala Lumpur: Malaya University.

Lippard 1997. The Lure of the Local: Senses of Place in a Multicultural Society. New York: The New Press.

Martin A. Ruehl 2015. The Italian Renaissance in the German Historical Imagination, 1860-1930. Cambridge: Cambridge University Press.

Mohammad Yunus Hamidi 1961. Sejarah Pergerakan Politik Melayu Semenanjung. Kuala Lumpur: Pustaka Antara.

M. V. Del Tufo 1949. Malaya Comprising the Federation of Malaya and the Colony of Singapore: A Report on the 1947 Census of Population. London: Crown Agents for the Governments of Malaya and Singapore.

Nazar Bin Talib 2004. Malaysia's Experience in War against Communist Insurgency and Its Relevance to The Present Situation in Iraq. Quantico: Marine Corps University.

Oong Hak Ching 2000. Chinese Politics in Malaya 1942-55: The Dynamics of British Policy. Bangi: Universiti Kebangsaan Malaysia.

Ooi Keat Gin 2009. Historical Dictionary of Malaysia. Lanham: Scarecrow.

Paul Allatson and Jo McCarmack (eds.) 2008. Exile Cultures, Misplaced Identities. New York: Rodopi.

Philip Spenser and Howard Wollman (eds.) 2005. Nations and Nationalism A Reader. Edinburg: Edinburg University Press.

R.K. Vasil 1980. Ethnic Politics in Malaysia. New Delhi: Radiant.

Rey Chow (eds.) 2000. Modern Chinese Literary and Cultural Studies in the Age of Theory: Reimaging a Field. Durham and London: Duke University Press.

Riley Sunderland 1964. Organizing Counterinsurgency in Malaya, 1947-1960. Memorandum RM-4171-ISA, Santa Monica: Rand Corporation.

Robin Cohen 1997. Global Diaspora: An Introduction. Seattle: University of Washington Press.

Singapore 1957. The communist threat in Singapore, Singapore: Legislative Assembly.

Tan Chee Gay Danny 2009. In the Image of... : Looking at Visual Representations of the Iban People of Sarawak, Malaysia. Singapore: NUS Southeast Asian Studies Programme.

Tim Cresswell 著, 徐苔玲、王志弘譯 2004 , 《地方：記憶、想象與認同》，臺北：群學。

Timothy Carson 2016. Liminal Reality and Transformational Power. Cambridge: Lutterworth Press.

Timothy Norman Harper 1999. The End of Empire and the Making of Malaya. UK: Cambridge University Press.

Yong C.F. \& R.B. McKenna 1990. The Kuomintang Movement in British Malaya (1912-1949). Singapore: NUS Press.

Yung Mei Lin (2014) Index to Famous Historical Figures of Singaporean Chinese（《新華歷史人物列傳》）. Singapore: National University of Singapore Libraries. http://libguides.nus.edu.sg/content.php?pid=353075 
艾布拉姆斯(Meyer Howard Abrams)，麗雅牛、張照進、童慶生譯 2015，《鏡與燈：浪漫主義文論及批 評傳統》，北京：北京大學。

也斯 1996 ，《香港文化空間與文學》，香港：青文書屋。

文史哲編輯部編 2015 ，《左翼文學研究》，北京：商務。

方天 1957 ，《闌泥河的鳴咽》，新加坡：蕉風。

方修 $1976 ，$ 《馬華文學的現實主義傳統》，新加坡：洪爐文化。

方桂香 2010 , 《新加坡華文現代主義文學運動研究一以新加坡南洋商報副刊《文藝》、《文叢》、

《咖啡座》、《窗》和馬來西亞文學雜誌《蕉風月刊》為個案》，新加坡：創意圈。

方維保 $2004 ，$ 《紅色意義的生成一20 世紀中國左翼文學研究》，合肥：安徽。

王梅香 2005 , 《蕭殺歲月的美麗／美力：戰後美援文化與五、六十年代反共文學、現代主義思潮發展 之關係》，臺南：國立成功大學台灣文學研究所碩士論文。

王梅香 2015, 《隱蔽權力：美援文藝體制下的台港文學》, 國立清華大學：社會學研究所博士論文。

王德威 $2009 ， 《$ 茅盾，老舍，沈從文：寫實主義與現代中國小說》，臺北：麥田。

王德威 $2011 ，$ 《歷史與怪獸一歷史，暴力，敍事》，臺北：麥田。

王潤華 2001，《華文後殖民文學——本土多元文化地思考》，臺北：文史哲。

以多 1959 ，《現階段的馬華文學運動》，新加坡：南洋大學創作社出版兼發行。

加斯東 ·巴歇拉(Gaston Bachelard) 2003，壟卓軍、王靜慧譯，《空間詩學》，臺北：張老師。

白圭 2007 ，《縷雲起於綠草》，八打靈：大夢書房。

宇文所安(Stephen Owen)著，程章喍譯 $2003 ， 《$ 迷樓一詩與慾望的迷宮》，北京：三聯。

安托瓦納·貢巴尼翁(Antoine Compagnon)著, 周憲、許鈞主編 2005, 《現代性的五個悖論》, 北京：商 務。

朱汝瞳 2010，《中國現代文學流派漫談》，臺北：秀威資訊科技。

李有成、張錦忠主編 2010 , 《離散與家國想象：文學與文化研究集稿》，臺北：允成。

李怡 2010, 《中國文學的現代性：批判的批判》，臺北：秀威。

李恩涵 2003 , 《東南亞華人史》, 臺北：五南。

李歐梵 1996 , 《現代性的追求 : 李歐梵文化評論精選集》, 臺北 : 麥田出版股份有限公司。

沈清松, 李杜, 蔡仁厚, 王壽南, 中華文化復興運動總會主編 1999, 《中國歷代思想家（二十五）：

馮友蘭・方東美・唐君毅・牟宗三》，臺灣：商務印書館。

吳兆剛 2007 , 《五十年代《中國學生周報》文藝版研究》，香港：嶺南大學，哲學碩士論文。 
林亨泰 1994 , 《找尋現代詩的原點》，彰化：彰縣。

周作人 1998 ，《周作人批評文集——世紀的回響 $\cdot$ 批評卷》，珠海：珠海。

周憲編 2005 ，《文化現代性與美學問題》，北京：中國人民社會大學。

易明善 1997 , 《劉以宷傳》, 香港 : 明報。

苗秀編 1971，《新馬華文文學大系（理論）》，新加坡：教育。

苗秀編 1971，《新馬華文文學大系（小說）》（第五集），新加坡：教育。

郁達夫 1956 , 《郁達夫南游記》, 香港：世界。

姚拓 2005 , 《雪泥鴻爪一一姚拓說自己》, 吉隆坡：紅蜻蜓。

恩斯特 - 卡西勒 (Ernst Cassirer) 1990, 于曉等譯, 《語言與神話》, 臺北：桂冠。

烈浦、莫河編輯 2003 , 《力匡散文・詩歌・遺作選》，新加坡：錫山文藝。

馬摩西 1957 ，《歐美采風錄》，新加坡：星洲世界書局。

馬摩西 1957 , 《集愚集》, 新加坡：蕉風出版社。

馬摩西譯 1954 ，《穆罕默德傳》，新山：柔佛宗教部。

馬積廉 2012 , 《到麥加去：民國時期到中東去的旅行記述研究》（1911-1949），新加坡：新加坡國立 大學碩士論文。

高全之 2008, 《張愛玲學》, 臺北：麥田。

常夫 1957 , 《牆外集》, 新加坡 : 蕉風出版社。

張光達 2009 , 《馬華現代詩論一時代性質與文化屬性》, 臺北：秀威。

張國壽 2004 , 《我的回憶》, 北京: 東方出版社。

張詠梅 1996 , 《力匡作品研究》, 香港 : 香港中文大學, 中國語言及文學碩士論文。

張誦聖 2015 , 《現代主義・當代台灣：文學典範的軌跡》，臺北：聯經。

張誦聖 2001 , 《文學場域的變遷》, 臺北：聯合。

張錦忠 2011 , 《馬來西亞華語語系文學》, 吉隆坡：有人。

張錦忠、黃錦樹、莊華興編 2008, 《回到馬來亞：華馬小說七十年》, 吉隆坡：大將出版。

張錦忠 2003 , 《南洋論述：馬華文學與文化屬性》，臺北：麥田。

張寶琴、邵玉銘、癋弦主編 1994, 《四十年來中國文學》，臺北：聯合文學。

梁秉均、譚國根、黃勁輝、黃淑嫻編 2009 , 《劉以出與香港現代主義》, 香港 : 香港公開大學。

莫河編 2009 , 《力匡散文選集》，新加坡：新加坡海南會館。 
陳正茂 $2011 ， 《$ 五○年代香港第三勢力運動史料蒐秘》，臺北：威秀。

陳正茂 2011 , 《逝去的虹影》, 臺北：秀威。

陳鴻瑜主編 2014 , 《海外華人之公民地位與人權》, 臺北：華僑協會總會。

陳鵬翔 2001，《主題學理論與實踐》，臺北：萬卷樓。

傅統先 1996，《中國回教史》，臺北：臺灣商務印書館。

單德興 2009, 《翻譯與脈絡》, 臺北：書林。

彭小研 1991，《超越寫實》，臺北：聯經。

程思遠 1988 , 《政海秘辛》, 香港：南粵出版社。

曾麗萍 2011 , 《西馬來西亞華文報業發展的政經分析》, 臺北：世新大學新聞研究所碩士論文。

黃孟文、徐迺翔編 2002 , 《新加坡華文文學史初稿》（東南亞華人研究叢書之六）, 新加坡：八方文 化。

黃錦樹 $2006 ， 《$ 文與魂與體論現代中國性》，臺北：麥田。

黃錦樹 2012，《馬華文學與中國性》，臺北：麥田。

黃錦樹 1998, 《馬華文學與中國性》, 臺北：元尊。

黃繼持, 盧瑋鑾, 鄭樹森主編 1996 , 《香港文學大事年表, 1948-1969》, 香港: 香港中文大學。

楊子烈 $1970 ， 《$ 張國壽夫人回憶錄》，九龍: 自聯出版社。

楊松年 2001 , 《戰前新馬文學本地意識的形成與發展》, 新加坡 : 新加坡國立大學中文系、八方文化 企業。

溫任平 1986 , 《文學·教育·文化》，美羅：天狼星詩社。

葉觀仕 $1996 ，$ 《馬新新聞史》，吉隆坡：韓江新聞傳播學院新聞傳播系。

解昆樺 2010，《轉譯現代性：1960-70 年代台灣現代詩場域中的現代性想像與重估》，臺北：臺灣學 生。

路海江 2003 , 《張國濤傳記和年譜》, 北京：中共。

雷諾・博格(Ronald Bogue) 2006, 《德勒茲論文學》，臺北：麥田。

裴海燕(Jana Benešová) 2015 , 《從「現實」到「寫實」：一九八○年代兩岸女性寫實小說之比較》, 臺 北：秀威。

趙戎編 1971，《新馬華文文學大系（第八集 史料卷）》，新加坡：教育。

趙勳達 2008 , 《「文藝大眾化」的三線糺葛：一九三○年代台灣左、右翼知識份子與新傳統主義者的 文化思維及其角力》，臺南：國立成功大學台灣文學系博士論文。 
劉以䍘 2010 , 《甘榜》, 香港 : 獲益出版。

劉以眓 2010 , 《熱帶風雨》, 香港 : 獲益出版。

劉若愚著，杜國清譯 $1977 ， 《 中$ 國詩學》，臺北：幼獅。

劉問渠 1960 , 《這半個世紀 : 光華日報金禧紀念增刊》，檳城：光華日報。

蔡鋝雲 $1995 ， 《$ 從現象學到後現代》，臺北：三民。

潘碧華編 2009，《馬華文學的現代詮釋》，吉隆坡：馬來西亞華文作家協會。

鄭文波、楊景水 2009 , 《二十世紀五十年代學生運動史料匯編》, 全馬華文中學生捍衛華教運動五

十周年工委會。

鄭樹森、黃繼持、盧瑋鑾編 2000 , 《香港新文學年表（一九五○一一九六九）》, 香港 : 天地。

鄭樹森 2007 , 《從諾貝爾到張愛玲》, 臺北：印刻。

盧瑋鑾、熊志琴編 2014, 《香港文化眾聲道 第 1 冊》, 香港 : 三聯。

蕭阿勤 2012，《重構台灣：當代民族主義的文化政治》，臺北：聯經。

錢理群、吳福輝、溫儒敏、王超冰 $1998 ， 《 中$ 國現代文學三十年》，北京：北京大學。

錢穆 $1995 ，$ 《錢賓四先生全集一一新亞遺鐸》，臺北：聯經。

謝詩堅 2009，《中國革命文學影響下的馬華左翼文學（1926-1976）》，檳城：韓江。

鍾怡雯 2006, 《靈魂的經緯度》, 吉隆坡 : 大將。

鍾鳳美 2003 , 《梁實秋先生的事蹟及散文之研究》, 臺北：國立政治大學中國文學研究所碩士論文。

藍屏等著, 曾鐵忱編 1956 , 《馬來亞之戀》, 新加坡：南方報社。

羅門等著 1959 , 《美的 V 形》, 八打靈：蕉風。

羅蘭巴特著, 李幼蒸譯, 2007 , 《小說的準備》, 北京: 中國人民。

羅蘭巴特著，懷宇譯 $2010 ， 《$ 文藝批評文集》，北京：中國人民大學。

顧德倩 2012，《臺灣現代詩的浪漫特質》，臺北：秀威。

\section{二、單篇論文／單篇文獻}

A.J. Stockwell 2006. "Chin Peng and the Struggle for Malaya." Journal of the Royal Asiatic Society, vol. 16(3), p.279-297.

Amry Vandenbosch and Richard Butwell 1957. "MALAYA: A Problem in Nation Building." in Southeast Asia among the World Powers. Lexington: University Press of Kentucky, p.186-211. 
Anna Belogurova 2015. "The Malayan Communist Party and The Malayan Chinese Association:

Internationalism and Nationalism in Chinese Overseas Political Participation, c.1920-1960." in Leslie James \& Elisabeth Leake (eds.) Decolonization and the Cold War: Negotiating Independence, London: Bloomsbury, p.125-144.

Cheah Boon Kheng 2009. "The Communist Insurgency in Malaysia, 1948-90: Contesting the Nation State and Social Change.” New Zealand Journal of Asian Studies, vol.11(1), p.132-152.

Chin Chong Cham 2009. "Re-examining the 1948 Revolt of the Malayan Communist Party in Malaya." Kajian Malaysia, vol.27(1 \& 2), p.11-38.

Devleena Ghosh 2008. "Coda: Eleven Stars Over the Last Moments of Andalusia." in Paul Allatson and Jo McCarmack (eds.) Exile Cultures, Misplaced Identities. New York: Rodopi, p.277-287.

Edward Said 1994. "Reflections on Exile." in Marc Robinson (ed.) Altogether Elsewhere: Writers on Exile. Boston: Faber \& Faber, p.137-149.

Emma J. Teng 2005. "What's Chinese in Chinese Diasporic Literature" in Charles A. Laughlin(eds.) Contested Modernities in Chinese Literature. New York: Palgrave, p.61-80.

Halim Salleh 2000. "Globalization and the Challenges to Malay Nationalism as the Malaysian Nationalism." Leo Suryadinata (ed.) Nationalism and globalization: East and West. Singapore: Institute of Southern Asian Studies, p.132-174.

Helen Ting 2009. "The Politics of National Identity in West Malaysia: Continued Mutation or Critical Transition?" Tonan Ajia Kenkyu (Southeast Asian Studies), vol.47(1), p. 31-52.

Heng Pek Koon 1996. “Chinese Responses to Malay Hagemony in Peninsular Malaysia 1957-96.” Southeast Asian Studies, vol.34(3), p.32-54.

Ien Ang 2000. "Can One Say No to Chineseness? Pushing the Limits of the Diasporic Paradigm.” in Rey Chow (ed.) Modern Chinese Literary and Cultural Studies in the Age of Theory: Reimaging a Field. Durham and London: Duke University Press, p. 281-300.

James Clifford 1994. "Diasproras.” Cultural Anthropology, vol.3, p.302-338.

James Z.Gao 2007. “The Call of The Oases: the 'Peaceful liberation' of Xinjiang, 1949-53 of Victory.” in Jeremy Brown and Paul G. Pickowicz (eds.) Dilemmas of Victory. Harvard: Harvard University Press, p. 84204.

John Brandt 1998. "Sharing the Unshareable: Jabés, Deconstruction, and the thoughts of the 'Jews" in Elazar Barkan and Marie-Denise Shelton (eds.) Border, Exiles, Diasporas. Stanford: Stanford University Press, p. 134-147.

John Rex 2005. "Foreword" in Chan Kwok-Bun, Chinese Identities, Ethnicity and Cosmopolitanism. London \& New York: Routledge.

Joseph M. Fernando 2012. "Elite intercommunal bargaining and conflict resolution: The role of the Communities Liaison Committee in Malaya, 1949-51”. Journal of Southeast Asian Studies, vol.43(2), p.280301. 
Karl Hack 2009. "The Malayan Emergency as counter-insurgency paradigm.” Journal of Strategic Studies, vol.32(3), p. 383-414.

Law Wing Sang 2009. "Cultural Cold War and the Diasporic Nation.” Collaborative Colonial Power: The Making of the Hong Kong Chinese. Hong Kong: Hong Kong University Press, p. 131-148.

Lee, Raymond L.M. 1990. "The state, religious nationalism, and ethnic rationalization in Malaysia." Ethnic and Racial Studies, vol.13(4), p.486-501.

Leo Suryadinata 2015. "China's Nationality Laws and the Chinese Overseas." in Jayati Bhattacharya and Coonoor Kripalani (eds.) Indian and Chinese Immigrant Communities: Comparative Perspectives, Singapore: ISEAS, p.43-54.

Leong Stephen 1979. "The Malayan overseas Chinese and the Sino-Japanese war, 1937-1941." Journal of Southeast Asian Studies, vol.10 (2), p.293-320.

Lionel Gossman 2016. "Jacob Burckhardt: Cold War Liberal." The Journal of Modern History, vol.74(3), p.538-572.

Mao Yufeng 2011. "A Muslim Vision for the Chinese Nation: Chinese Pilgrimage Missions to Mecca during Worlemm War II.” The Journal of Asian Studies, vol.70(2), p.373-395.

Martin Baumann 2010. "Exile” in Kim Knott and Seán McLoughlin (eds.) Diasporas: Concepts, intersections, identities. London, New York: Zed Books, p.19-23.

Mohd Shukri Shuib, Mohamad Faisol Kelling, Mohd Na'eim Ajis 2009. "The Implication of Cold War on Malaysia State Building Process.” Asian Culture and History, vol.1(2), p. 89-98.

Mugerauer Robert 1989. "Phenomenology: Romantic Nostalgia or A New Way of Seeing?” EDRA 20/1989. 200-206. http://www.edra.org/sites/default/files/publications/EDRA20-Mugerauer-200-206.pdf

Nels C. Pearson 1999. “The Moment of Modernism: Schopenhouer's “Unstable Phantom” in Conrad's Heart of Darkness and Stevenson's The Master of Ballantrae.” Studies in Scottish literature, vol.31(1), p.182-202.

Nordin Hussin 1993. "Conversion to Islamic Religion among Chinese Minors in Johore 1930-1950's." Jebat, vol.21, p.125-135.

Rahmat Saripan 1990. "Haji Musa Ma Jinwu: Kegiatan Pensyarah Agama Kerajaan Johor dalam Zaman Darurat (1953-1959).”(哈芝馬穆沙俊武: 柔佛宗教局傳教官於戒嚴時期的活動). Malaysia Dari Segi Sejarah, vol.18, p.22-29. http://myrepositori.pnm.gov.my/xmlui/bitstream/handle/123456789/3531/MDSS_1990_Bil.18_2.pdf?seque $\mathrm{n}$ ce $=1$

Raymond William1989. “When Was Modernism?” New Left Review, vol. 175, p.48-52.

Rosalind Coward and John Ellis 2000. "From Language and Materialism: Developments in Semiology and the Theory of the Subject." in Michael McKeon (ed.) Theory of the novel: a historical approach. Baltimore : The Johns Hopkins University Press, p. 593-599.

Stuart Hall 1996. “Who Needs 'Identity'?” Stuart Hall and Paul du Gay (eds.) Questions of Cultural Identity. Los Angeles, London, New Delhi, Singapore: Sage Publication, p.1-17. 
Stuart Hall 1996. "The Problem of ideology: marxism without guarantees.” David Morley and Kuan-Hsing Chen (eds.) Critical Dialogues in Cultural Studies. London \& New York: Routledge, p.24-45.

Stuart Hall 1990. "Cultural Identity and Diaspora.” in Jonathan Rutherford (ed.) Identity:community, culture, difference. London: Lawrence \& Wishart, p.222-237.

Tan Chee Beng 2000. "Ethnic identities and national identities: some examples from Malaysia." Identities: Global Studies in Culture and Power, vol.6(4), p.441-480.

The Straits Times 1958 May 15, “Off on tour of 'black' area”, p. 9.

The Straits Times 1961 October 10, "MCA Youth Chairman”, p.11.

William Safran 1991. "Diasporas in modern societies: myths of homeland and return.” Diaspora, vol.1(1), p.8399.

William Safran 2004. "Deconstructing and comparing diasporas." in Waltraud Kokot, Khachig Tölölyan and Carolin Alfonso (eds.) Identity and Religion: New Directions in Theory and Research. London, New York: Routledge, p.9-30.

Yang Kuisong 2008. "Reconsidering the Campaign to Suppress Counterrevolutionaries." The China Quarterly, vol. 193, p.102-121.

Zvi Ben-Dor Benite 2014. “Taking 'Abduh' to China: Chinese-Egyptian Intellectual Contact in the Early

Twentieth Century" in James L. Gelvin and Nile Green (eds.) Global Muslims in the Age of Steam and Print. Berkeley and Los Angeles: University of California Press, p. 249-267.

力匡 1957 ，〈日曆〉，《蕉風》第 34 期，頁 10 。

力匡 1957 ，〈水手之死〉，《學生周報》第 46 期，椰林版。

力匡 1958 ，〈拾穗者〉，《學生周報》第 105 期，封面頁。

山芭仔 1956 ，〈新村底夜〉，《蕉風》第 17 期，頁 21 。

天僕 1939 , 〈朝唓日記〉, 《月華》, 第 11 卷第 4、5、6 期, 頁 13-15, 載寧夏少數民族古籍整理 $2010 ， 《 月$ 華》第 9 冊，銀川：寧夏人民，頁 421-423。

天僕 1939 , 〈朝唓日記〉, 《月華》, 第 11 卷第 $7 、 8$ 、 期, 頁 10-16, 載寧夏少數民族古籍整理 $2010 ， 《$ 月華》第 9 冊，銀川：寧夏人民，頁 434-440。

天僕 1939, 〈朝覲日記〉, 《月華》, 第 11 卷第 10-15 期, 頁 18-26, 載寧夏少數民族古籍整理 $2010 ， 《$ 月華》第 9 冊，銀川：寧夏人民，頁 458-466。

文思奇 $1958 ， 〈$ 論小說與故事〉，《蕉風》第 74 期，頁 4-5。

方天 $1955 ， 〈$ 膠淚〉，《蕉風》第 1 期，頁 25-28。

方天 $1955 ， 〈$ 膠淚〉，《蕉風》第 2 期，頁 26-28。

方天 1955 , 〈豆腐檔邊〉, 《蕉風》第 3 期, 頁 7-8。 
方天 $1956,\langle 十 八$ 溪墘〉，《蕉風》第 7 期, 頁 2-6。

方天 1956 ，〈十八溪墘〉，《蕉風》第 8 期，頁 13-17。

方天 1956 ，〈暴風雨〉，《蕉風》第 16 期，頁 $1-5$ 。

方天 1956 ，〈暴風雨〉，《蕉風》第 17 期，頁 13-17。

方天 1956 ，〈評「劇作選輯」中的諸劇〉，《蕉風》第 25 期，頁 20-22。

方天 1957 ，〈預感〉，《蕉風》第 30 期，頁 13-14+封底內頁。

方然 1957 ，〈未了情〉，《蕉風》第 50 期，頁 4-8。

王思睿 2007 , 〈主動右派中的修正主義者〉, 《二十一世紀雙月刊》5 月號總第 102 期, 頁 46-56。

王恢 1957 ，〈陶淵明的思想、人格和作品〉，《蕉風》第 42 期，頁 4 。

王是 1960 ，〈長工包阿松〉，《蕉風》第 89 期，頁 16-17。

王晉民 $1998 ， 〈$ 香港「綠背文化」思潮評介〉，《廣東社会科學》第 2 期，頁 87-91。

以多 1959 ，〈現階段的馬華文學運動〉, 《現階段的馬華文學運動》，新加坡：南洋大學創作社。

古梅 1957 ，〈風砂、黃河、麥浪、騾群〉，《蕉風》第 34 期，頁 9-10。

古鴻廷、曹淑瑤 2013 , 〈馬來亞華族母語教育的維護, 以《方吳報告書》的理念為例〉, 《2013 年台 灣的東南亞區域研究一東南亞區域經濟整合下的台灣與東南亞》, 宜蘭：佛光大學公共事務學系 暨國際與公共事研究中心。網址：fgumail.fgu.edu.tw/ cseas2013/3-4-1.doc。取用日期：2016 年 6 月 18 日。

古鴻廷 2003 , 〈英屬馬來亞聯合邦之華文教育〉, 《教育與認同：馬來西亞華文中學教育之研究

(1945-2000 )》，廈門：廈門大學，頁 29-56。

平盾（白圭）1959，〈陰陽界〉，《蕉風》第 81 期，頁 22 。

平盾（白圭）1959，〈古戰場〉，《蕉風》第 78 期，頁 7 。

本社 1959 ，〈改版的話一兼論馬華文藝的發展路向〉，《蕉風》第 78 期，頁 3 。

申青 1957 ，〈雙重使命〉，《蕉風》第 29 期，頁 3 。

申青 1956 , 〈唐山何處? 〉, 《蕉風》第 21 期, 頁 5。

白圭 $1960 ， 〈$ 終曲〉，《蕉風》第 90 期，頁 9。

白圭 2014 , 〈我的 $1953 \sim 1957$ 〉, 《中國時報》， 2 月 4 日，「藝文副刊」

http://www.chinatimes.com/newspapers/20140204000418-260115

白圭 1958 ，〈麻河靜立〉，《學生周報》第 137 期，詩之頁版。

白圭 1959 ，〈八達嶺的早晨〉，《蕉風》第 78 期，頁 13 。 
白圭 1959 , 〈四月已逝〉, 《蕉風》第 81 期, 頁 22 。

白圭 1959 ，〈酋長之夜〉，《蕉風》第 79 期，頁 19 。

白圭 1959 ，〈海邊的—〉，《學生周報》第 158 期，詩之頁版。

白圭 1959 , 〈長堤路〉, 載羅門等著, 《美的 V 形》, 八打靈：蕉風, 頁 1 。

白圭 1960 ，〈當你走後〉，《蕉風》第 94 期，頁 6 。

白圭 2004 ，〈現代詩的起步〉，《南洋商報》，6月 12 日，南洋文㙯版。

白春超 2003 , 〈古典主義與現代中國文學〉 , 《二十世紀》網絡版三月號總第 12 期。 http://www.cuhk.edu.hk/ics/21c/media/online/0301047.pdf

白哲維 2013 , 〈覃子豪詩作與象徵主義〉, 《東海大學圖書館館訊》第 44 期, 頁 38-69。 http://140.128.103.27/thulibm/upfiles/144\%E6\%9C\%9F/144\%E6\%9C\%9F38-69.pdf

白蒂 1955 ，〈第二代〉，《蕉風》第 2 期，頁 18-23。

白蒂 1955 ，〈第二代〉，《蕉風》第 3 期，頁 21-26。

白蒂 1956 ，〈渣㳯〉，《蕉風》第 14 期，頁 12-16。

白蒂 1956 ，〈渣㳯〉，《蕉風》第 15 期，頁 19-22。

白蒂 1956 ，〈渣㳯〉，《蕉風》第 16 期，頁 $18-23$ 。

白蒂 1956 ，〈還我的孩子來〉，《蕉風》第 9 期，頁 2-5。

白蒂 1957 ，〈論文藝創作的内容與形式〉，《蕉風》第 34 期，頁 3-4。

西林 1956 ，〈又是你！〉，《蕉風》第 11 期，頁 2-4。

伍燕翎、潘碧絲、陳湘琳 2011, 〈從《蕉風》（1955-1959）詩人群體看馬華文學的現代性進程〉, 載《西方圖像：馬來西亞英殖民時期文史論述》，加影：新紀元學院馬來西亞與區域研究所（馬來 西亞歷史研究中心），頁 83-96。

朱浤源 2002 , 〈中國國民黨在新馬：戰前與戰後的比較〉, 李元瑾編, 《新馬華人：傳統與現代的方 法》，新加坡：南洋理工大學中華語言文化中心，頁 201-258。

羊城 1960 ，〈送殯〉，《蕉風》第 87 期，頁 13 。

羊羚野 1960 , 〈遙遠的懷念〉, 《蕉風》第 88 期, 頁 21 。

免升 1972 , 〈馬華文化為甚麼要現實化? 〉, 方修編, 《馬華新文學大系：理論批評 (卷二)》, 新 加坡：星洲世界書局，頁 331。

冷燕秋 1960 ，〈有一個晚上〉，《蕉風》第 97 期，頁 9 。 
冰谷 2007 , 〈作者野餐會激起的文藝熱潮——海天社在居林的日子〉, 《星洲日報》, 12 月 9 日, 春 秋文藝版。

余光中 1972 , 〈第十七個誕辰〉, 《現代文學》第 46 期, 頁 11-27。

李成利 1994 , 〈中新南安文學歷史沿革〉, 《中新南安籍作家作品選》 http://sgcls.hi2net.com/blog_read.asp?id=48\&blogid=9767

李亭 1955 , 〈此時此地的文學〉, 《蕉風》第 2 期, 頁 2-3。

李亭 1956 , 〈封建主義的文學〉, 《蕉風》第 5 期, 頁 2-3。

志程 1939 , 〈古蘭中關於動員的教訓〉, 《月華》第 11 卷第 1 、 2 . 3 期, 頁 2 , 載寧夏少數民族古籍 整理, 《月華》第九冊, 頁 394-395。

李國彬 1959 ，〈音樂台的側面〉，《中國學生周報》第 378 期。

http://hklit.lib.cuhk.edu.hk/pdf/journal/78/1959/184475.pdf

李國涁 1960 , 〈音樂台的側面〉, 《蕉風》第 88 期, 頁 20 。

李福清(B.Riftin) 1993 , 〈射日神話比較研究——臺灣布農族神話為主〉, 《東亞文化》第 31 輯, 頁 53-78 • http://s-space.snu.ac.kr/bitstream/10371/87686/1/ 7.\%20 사일신화비교연구.pdf

杜月嬌 2003 , 〈麻坡启智会堂重建成综合商业大厦〉, 《蕉風》，6月16日。

http://www.sc.edu.my/jiaofeng/mix-detail.php?id=642

沙里明 1957 , 〈論文學創作的語言運用〉, 《蕉風》第 32 期, 頁 3-4。

沙里明 1957 , 〈論小說創作問題〉, 《蕉風》第 31 期, 頁 3 。

沙風 1956 ，〈文藝創作的價值〉，《蕉風》第 23 期, 頁 3-4。

辛生（方天） 1955 , 〈孕婦島〉, 《蕉風》第 2 期, 頁 14-16。

辛生（方天）1956，〈一個大問題〉, 《蕉風》第 12 期, 頁 3-7。

辛生（方天） 1956 , 〈當前華校戲劇問題〉，《蕉風》第 27 期，頁 7 。

辛生（方天） 1956 , 〈闌泥河的鳴咽〉, 《蕉風》第 24 期, 頁 20-22。

周垂 1959 ，〈漁村〉，《蕉風》第 83 期，頁 20 。

周垂 1959 ，〈桅〉，《蕉風》第 78 期，頁 11 。

周垂 1959 , 〈海岸上的灰衣人〉, 《蕉風》第 78 期, 頁 11 。

周垂 1959 ，〈舵〉，《蕉風》第 78 期, 頁 11 。

林子基 1956 , 〈流浪〉, 《蕉風》第 5 期, 頁 20 。

林子基 1956 , 〈願〉, 《蕉風》第 5 期, 頁 20 。

林子基 1956 ，〈傷〉，《蕉風》第 5 期, 頁 20 。 
林我 1956, 〈記打西乳咯村〉, 《蕉風》第 10 期, 頁 31-32。

林春美 2012, 〈獨立前的《蕉風》與馬來亞之國族想像〉, 《南方華裔研究雜誌》第 5 期, 頁 201-

208 。

林春美 2016 , 〈非左翼的本邦：《蕉風》及其「馬来亞化」主張〉，《世界華文文學論壇》第 1 期，

頁 71-79。

林風 2011 , 〈追憶《虎報》到《南洋商報》歷程〉, 《東方日報》電子版, 11 月 8 日。

http://www2.orientaldaily.com.my/fread/27sC0J5M11OZ1HfC1b551SrG0zD68126

林風 1955 ，〈漫步〉，《蕉風》第 3 期，頁 9 。

林風 1956 ，〈明天〉，《蕉風》第 5 期，頁 4-5。

林間 (白圭) 1958 , 〈老屋〉, 《蕉風》第 73 期, 頁 13 。

林間（白圭）1958，〈晨舞〉，《蕉風》第 74 期，頁 23 。

知微 1956 ，〈文藝與現實〉，《蕉風》第 21 期，頁 3-4。

邵有民口述, 周奕韵採訪整理 2009 , 〈黎明前的獄中鬥争歲月〉, 《上海黨史與黨建》3 月號, 頁 1416 。

金北鳴著，端木鈴譯 $1956 ， 〈$ 帶來死亡的人〉，《蕉風》第 28 期，頁 8-9。

金然（方天）1956，〈我的博士論文〉，《蕉風》第 28 期，頁 21-23。

金榜居士 1953 ，〈馬大中文學系門庭冷落〉，《南洋商報》，10月 17 日，商餘版。

阿姆魯拉著, 吕卓翻譯 1957 , 〈失蹤的兒子〉, 《蕉風》第 42 期, 頁 7-9。

阿瑍 1956 ，〈排字女工的日記〉第 21 期, 頁 6-8。

阿瓊 1956，〈排字女工的日記〉第 23 期，頁 9-11。

柯思仁 2012 , 〈想像馬來亞, 操演多元文化一一五 $\bigcirc$ 年代新加坡華文知識界的馬來亞意識〉, 《人間 思想》第 1 期, 頁 170-190。

南洋商報 1936 ，〈梁宇鼻抵成都將轉赴雲南重開中緬勘界工作〉，《南洋商报》11月 21 日，頁 2 。

侯作珍 2003 , 〈藍星詩社對現代詩發展的貢獻——以五 $\bigcirc$ 年代三次論戰為探討中心〉, 《文學新錀》 創刊號, 頁 51-72。

重陽 1955 ，〈教師節〉（上），《蕉風》第 3 期，頁 10-13。

重陽 1955 ，〈教師節〉（下），《蕉風》第 4 期，頁 11-13。

常夫 1955 ，〈劇本的創作與戲劇批評〉，《蕉風》第 22 期，頁 5。

零丁 1956 , 〈宋伯- - 甘傍依干的大人物〉, 《蕉風》第 8 期, 頁 30-31。 
吕朗 1957 , 〈暗流〉, 《蕉風》第 30 期, 頁 6-9。

紅蕉 1957 ，〈教師日記〉，《蕉風》第 32 期, 頁 15-16。

黃山 1957 , 〈萬世師表〉, 《蕉風》第 45 期, 頁 14-15。

姚拓 1957 ，〈小貓〉，《蕉風》第 39 期, 頁 12-15。

姚拓 1957 , 〈七個世紀以後〉, 《蕉風》第 47 期, 頁 8-11。

姚拓 1958 , 〈最不能忘記的一張臉〉, 《蕉風》第 55 期, 頁 4-7。

姚拓 1958 , 〈意外的結局〉, 《蕉風》第 74 期, 頁 7 。

姚拓 1959 , 〈石縫中的一朵小花〉, 《蕉風》第 84 期, 頁 8-11。

姚拓 1960 , 〈丘陵上〉, 《蕉風》第 87 期, 頁 10-13。

姚拓 1960 , 〈走死運的人〉, 《蕉風》第 93 期, 頁 $15-17$ 。

姚拓 1960 , 〈美麗的童年回憶——殺猪似的剔頭滋味〉, 《蕉風》第 98 期, 頁 15 。

姚拓 1961 , 〈永刻在心裡面的——張張純潔而微笑的臉孔〉, 《學生周報》第 234 期, 我們的馬來 亞版。

姚拓 1979 , 〈二十年來的新馬華文文學〉, 載香港中國筆會編, 《二十年來的中國文學》, 香港 : 香 港中國筆會, 頁 78-82。

姚拓 1999 , 〈四十二年來的蕉風〉, 載江洺輝主編, 《馬華文學的新解讀》, 八打靈 : 馬來西亞留台 校友會聯合總會, 頁 76-81。

姚金果、蘇杭 2004 ，〈張國壽叛逃後的生活〉，《中國地名》第 116 期，頁 23-24。

姚金果、蘇杭 2013 , 〈張國壽叛變投敵後的狼狽境遇〉, 《北京農業》3 月中旬, 頁 39-43。

柯坎 1957 , 〈亦莊亦諧的《集愚集》〉, 《蕉風》第 37 期, 頁 10-11。

洛萍 1955 , 〈小說題材的處理與運用〉, 《蕉風》第 3 期, 頁 2 。

洛萍 1956 , 〈創作的動機與目的〉, 《蕉風》第 28 期, 頁 3-4。

秋貞理 1958 ，〈北國的春天〉，《蕉風》第 66 期，頁 8-9。

陳中和 2014 , 〈梁宇鼻〉, 何啟良主編, 《馬來西亞華人人物誌》, 八打靈：拉曼大學中華研究中 心，頁 754-757。

凌冷（白圭） 1959 , 〈新詩的再革命〉, 《蕉風》第 78 期, 頁 19 。

凌冷（白圭） 1959 , 〈新詩的道路〉, 《蕉風》第 79 期, 頁 7 。

孫達尼（Utuy T. Sontani）著, 吕卓譯 1956 , 《沙末的商品》, 《蕉風》第 21 期, 頁 17-18。 
孫達尼(Utuy T. Sontani)著，呂卓譯 1956，《女招待》，《蕉風》第 32 期，頁 17-20。

孫達尼(Utuy T. Sontani)著，呂卓譯 1956，《女招待》，《蕉風》第 33 期，頁 20-23+8、9。

徐速 1960 ，〈新詩派平議〉，《蕉風》第 96 期，頁 23-24+22。

馬來西亞中華大會堂總會 2011 , 〈馬來西亞華團總名冊 〉, 《馬來西亞中華大會堂總會》。

http://huazong.my/HuaTuanDIR/Johor.pdf 。

馬崙 $1982 ， 〈$ 方天的寫實作風〉，《南洋商報》，4 月 16 日，寫作人版。

馬博忠 $2012 ， 〈$ 近現代中國留埃回族學生歷史簡述〉，《回族研究》第 1 卷第 85 期，頁 67 。

馬森 2015 ，〈從寫實主義到現實主義：擬寫實主義與革命文學〉，《西潮東漸：第一度西潮與現實主

義》, 臺北：印刻, 頁 498-510。

馬漢 2012 , 〈正經 800 ：報社舉辦的徵文比賽〉, 《南洋商報》，6月16日，商餘版。

馬泰卡林內斯庫(Matei Calinescu)著, 李瑞華譯, 〈現代性, 現代主義, 現代化一一現代主題的變奏

曲〉，載周憲編，《文化現代性讀本》，南京：南京大學，2010，頁 98-117。

馬歇爾伯曼(Marshall Berman) 2010 , 〈現代性一昨天, 今天和明天〉, 周憲編, 《文化現代性讀

本》, 南京：南京大學，頁 27-52。

馬摩西 1955 ，〈沙漠的邊緣〉，《蕉風》第 1 期，頁 3-5。

馬摩西 1955 , 〈馬來亞頌〉, 《蕉風》第 2 期, 頁 10-11。

馬摩西 1955 ，〈旅行的生機〉，《蕉風》第 4 期，頁 4-6。

馬興周（馬摩西）1956，〈蘇彝士運河種種〉，《學生周報》第 4 期，綜合版。

馬摩西 1956 ，〈獅城與馬來散記一評魯白野的創作〉，《蕉風》第 5 期，頁 30-32。

馬摩西 1956 , 〈淡寫新山〉, 《蕉風》第 6 期, 頁 29-32。

馬摩西 1956 ，〈淡寫新山〉，《蕉風》第 7 期，頁 22-25。

馬摩西 1956 ，〈淡寫新山〉，《蕉風》第 9 期，頁 28-31。

馬摩西 1956 , 〈牛鼻子寫真記〉, 《蕉風》第 16 期, 頁 16 。

馬摩西 1956 ，〈馬來亞化問題〉，《蕉風》第 18 期，頁 1-3。

馬摩西 1956 , 〈海外詩人燕歸來〉, 《蕉風》第 19 期, 頁 $22-23$ 。

馬摩西 1956 ，〈雞的幻想曲〉，《蕉風》第 28 期，頁 14-16+12。

馬摩西 1957 ，〈文藝的新使命〉，《蕉風》第 36 期，頁 5-6。

高峯 1957 , 〈酒逢知已千杯少——謹以此文作為本刊二周年的賀禮〉, 《蕉風》第 48 期, 頁 4-5。 
區志堅 2009 , 〈以人文主義之教育為宗旨, 溝通世界中西文化：錢穆先生籌辦新亞教育事業的宏願及 實踐〉, 載王宏志、梁元生、羅炳良主編, 《中國文化的傳承與開拓：香港中文大學四十周年校慶 國際研討會論文集》，香港：香港中文大學，頁 85-180。

崔貴強 2001，〈從“中國化”走向“馬來亞化” 新加坡華文教科書的嬗變. 1946-1965〉，《第四屆世界 海外華人國際學術研討會論文集 I》，臺北：中央研究院，頁 271-286。

康如也 1953 ，〈祝馬大中文系〉，《南洋商報》，10月 19 日，商餘版。

張兆 1958 , 〈田園作家喬治桑〉, 《蕉風》第 74 期, 頁 6 。

張兆 $1960 ， 〈$ 美麗的童年回憶——走親戚〉，《蕉風》第 94 期，頁 $11 。$

張兆 $1960 ， 〈$ 美麗的童年回憶——不曾掏露的秘密〉，《蕉風》第 88 期，頁 23-24。

張錦忠 2004 , 〈重寫馬華文學史, 或, 離散與流動：從馬華文學到新興華文文學〉, 張錦忠編, 《重 寫馬華文學史論文集》，南投：國立暨南大學東南亞研究中心，頁 55-67。

張錦忠 2015 ，〈文學史料匱乏之窘境——方天为例〉，《南洋商報》，9月 28 日，商餘版。

張錦忠 $2010 ， 〈$ 亞洲現代主義的離散路徑：白圭與馬華文學的第一波現代主義風潮〉，《江湖、家國 與中文文學》，吉隆坡：博大現代語言與溝通學院，頁 219-232。

楊向榮 2005 , 〈距離〉, 周憲編, 《文化現代性與美學問題》, 北京 : 中國人民社會大學, 頁 315-

357 。

梅占魁 1960 ，《生命之歌》，《蕉風》第 92 期，頁 7 。

莊華興 2016 , 〈戰後馬華 (民國) 文學遺址 : 文學史再勘察〉, 《台灣東南亞學刊》第 11 卷第 1 期， 頁 7-30。

莊華興 2015 , 〈語言、文體、精神基調 : 思考馬華文學〉, 《思想：大馬華人與族群政治》第 28 期， 頁 $199-220$ 。

莊華興 2013 ，〈黄潤岳在（後）大分裂时代的家國想象〉，《當今大馬》，11月 14 日 https://www.malaysiakini.com/columns/246566

許文堂 2014 , 〈越南華人公民地位的變遷〉, 陳鴻瑜主編, 《海外華人之公民地位與人權》, 臺北 : 華僑協會總會。

許紀霖 $1997 ＼mathrm{~ 〈 現 代 中 國 的 自 由 主 義 傳 統 〉 ， 《 二 十 世 紀 雙 月 刊 》 第 ~} 42$ 期，頁 27-35。

陳以愛 $2015 ， 〈$ 錢穆論人文主義教育的失落與重建〉，《國史館館刊》第 45 期，頁 153-198。

傅清 1957 ，〈讀「集愚集」〉，《蕉風》第 41 期，頁 16-17。

童蒙 1960 ,〈站住吧, 詩人們〉, 《蕉風》第 95 期, 頁 $24-26$ 。

紫燕 1956 ，〈馬來亞去來〉，《蕉風》第 11 期，頁 9-12。 
紫燕 1956 , 〈馬來亞去來〉, 《蕉風》第 12 期, 頁 16-18。

紫燕 1956 , 〈馬來亞去來〉, 《蕉風》第 13 期, 頁 20-22。

華卿 1956 ，〈理髮椅上〉，《蕉風》第 13 期, 頁 23-24。

覃子豪 1957 ，〈新詩向何處去？〉，《藍星詩選》第 1 期。

覃子豪 1959 , 〈台灣十年來的新詩〉，《蕉風》第 76 期，頁 10-11。

覃子豪 1959 , 〈象徵與比喻〉, 《蕉風》第 83 期, 頁 5-7。

覃子豪 1960 ，〈由抽象到具象〉，《蕉風》第 88 期。頁 3-5。

賀淑芳 2016 , 〈關於在地書寫的翻譯〉, 《備忘錄 新加坡華文小說讀本》，新加坡：八方，頁 $40 。$

黃克武 2006 , 〈西方自由主義在現代中國〉, 黃俊傑編, 《中華文化與域外文化的互動與融合》, 臺 北市：喜瑪拉雅研發基金，頁 341-378。

黃克武 $2004,\langle\ulcorner$ 個人主義」的翻譯問題一從嚴復談起 〉, 《二十一世紀雙月刊》第 84 期, 頁 4051 。

黃秀玲 2010 , 〈去國家化之再探：理論十字路口的亞美文化批評〉, 載李有成、張錦忠主編, 《離散 與家國想像》，頁 47-94。

黃昌虎 1956 ，〈美麗的小鬥士〉，《蕉風》第 26 期，頁 18 。

黃思騁 1957 , 〈荒唐的事〉, 《蕉風》第 44 期, 頁 10-11。

黃思騁 1958 ，〈大樹的故事〉，《蕉風》第 66 期，頁 16-17。

黃思騁 1959 ，〈小說是怎樣完成的〉，《蕉風》第 78 期，頁 8-9。

黃思騁 $1960 ， 〈$ 空葬〉，《蕉風》第 91 期，頁 18-20。

黃思騁 1960 ，〈莫泊桑談小說〉，《蕉風》第 90 期，頁 3-5。

黃庭康 2007 , 〈國家權力形構與華文學校課程改革一戰後新加坡及香港的個案比較〉, 《教育與社會 研究》第 4 期, 頁 111-133。

黃崇憲 $2010 ， 〈 「$ 現代性」的多義性/多重向度〉, 黃金麟、汪宏倫、黃崇憲編， 《帝國邊緣：台灣現 代性的考察》，臺北：群學，頁 23-62。

黃崖 1957 ，〈秋情曲〉，《蕉風》第 50 期，頁 18-22。

黃崖 1957 ，〈秋情曲〉，《蕉風》第 51 期，頁 20-22。

黃崖 1957 ，〈秋情曲〉，《蕉風》第 52 期，頁 20-22。

黃錦樹 1997 , 〈中國性與表演性：論馬華文化與文學的限度〉，《馬來西亞華人研究學刊》第 1 期， 頁 59-96。 
黃錦樹 2015 , 〈香港一馬來亞：熱帶華文小說的兩種生成，及一種香港文學身分〉，《香港文學》5 月號，頁 8-15。

黃錦樹 2015 , 〈别一个盗火者〉, 《星洲日報》, 7 月 5 日，文藝春秋版。

黄錦樹 2016 , 〈地方特色與南洋色彩〉, 《聯合早報》，6月 24 日。

微鹿 1956 ，〈關於用方言寫作的商榷〉，《蕉風》第 16 期，頁 32 。

瘂弦 $1960 ， 〈$ 舵邊〉，《蕉風》第 92 期，頁 20 。

瘂弦 $1960 ， 〈$ 懷古〉，《蕉風》第 93 期，頁 19 。

瘂弦 $1960 ， 〈$ 遠洋感覺〉，《蕉風》第 96 期，頁 18 。

瘂弦 $1960 ， 〈$ 邊疆小夜〉，《蕉風》第 97 期，頁 4 。

萬景添 1956，〈神經病患者之鄉一紅毛丹〉，《蕉風》第 26 期，頁 8-9。

雷内・韋勒克(René Wellek) 著, 張今言譯 1999 , 〈文學研究中的現實主義概念〉, 《批評的概念》, 杭州：中國美術學院，頁 214-250。

韋勒克(René Wellek)著, 劉象愚編 1999 , 〈文學史上象徵主義的概念〉, 《文學思潮和文學運動的概 念》，北京：中國社會科學，頁 124-191。

廖伯源 2015 , 〈第三章 錢穆先生與新亞研究所〉, 載鮑紹霖、黃兆強、區志堅主編, 《北學南移：港 台文史哲溯源（文化卷）》，臺北：秀威，頁 89-104。

趙綺娜 2005, 〈一九五 $\bigcirc$ 年代的香港美國新聞處：美國在亞洲之反共宣傳政策研究〉, 行政院國家科 學委員會專題研究計劃。

趙綺娜 1994 ，〈冷戰與難民援助：美國「援助中國知識人士協會」，一九五二年至一九五九年〉，

《歐美研究》第 27 卷第 2 期, 頁 65-108。

劉放 $2010 ， 〈$ 虛擬認同：早期星馬文藝與歌唱〉，《星洲日報》，2 月 21 日，文藝春秋版。

慕娜桑 1960 ，〈楓〉，《蕉風》第 93 期，頁 11 。

潘碧華 2000，〈五、六十年代香港文學對馬華文學傳播的影響（1949－1975）〉，載黃維樑編，

《活潑紛繁的香港文學——九九九年香港文學國際研討會論文集》（下冊），香港：香港中文

大學、香港中文大學新亞書院，頁 747-762。

潘碧華 2002 , 〈取經的故事一一馬華文壇與外來影響 $(1950-1969)\rangle$, 載何國忠編, 《社會變遷與

文化詮釋》，吉隆坡：華社研究中心，頁 277-292。

潘碧華 2008 ，〈馬華文學中的國家認同與文化反思〉，《河南科技大學學報（社會科學版）》第 26 卷 第 5 期, 頁 62-67。 
潘碧華 2009，〈中國現代文學與馬華文學的關係〉, 載潘碧華編, 《馬華文學的現代詮釋》, 吉隆 坡：馬來西亞華文作家協會，頁 72-79。

編者 1957 ，〈一張新的菜單〉，《蕉風》第 37 期，頁 4 。

編者 $1958 ， 〈$ 發刊詞〉，《監星詩頁》創刊號。

蔡明彥 $2010 ， 〈$ 九五 $\bigcirc$ 年代台灣現代詩的幾個面向〉，《臺灣文學研究學報》第 11 期，頁 89-112。 蔡淑玲 1994 , 〈德希達與白朗修對「空無」看法之義同：符號與現實之間的關係〉，《中外文學》第 22 卷第 10 期, 頁 $99-115$ 。

鄭昭賢 2011 , 〈啟智夜學的貢獻〉, 《東南亞華人一鄭昭賢部落客》 http://southeastasiachinese.blogspot.my/2011/07/blog-post_02.html。

鄭蕾 $2014 ， 〈$ 葉維廉與香港現代主義文學思潮〉，《東華漢學》第 19 期，頁 449-476。

魯文 1959 ，〈文藝的個體主義〉，《蕉風》第 78 期，頁 4-5。

魯文 1959 ，〈短篇小說之王的短篇〉，《蕉風》第 75 期，頁 11 。

黎青 1956 ，〈母土的呼喊——記巫統婦女部遊藝會〉，《蕉風》第 6 期，頁 16-17。

興周〔馬摩西〕1956, 〈難忘的遊踪〉, 《蕉風》第 24 期, 頁 17-19。

蕉風 1963 ，〈我們對馬華文壇的看法〉，《蕉風》第 133 期，頁 3-4。

蕉風 1960 ，〈編者的話〉，《蕉風》第 95 期，首頁。

蕉風 $1960 ， 〈$ 蕉風對新詩創作所採的立場〉，《蕉風》第 94 期，頁 25 。

蕉風 1960 , 〈新詩的前途——摘自名詩論家林以亮的詩論〉, 《蕉風》第 94 期, 頁 25 。

蕉風 1957 ，〈論小說創作問題——文藝座談之六〉，《蕉風》第 31 期，頁 3-6。

蕉風 1957 , 〈九五七年馬華文壇的展望一文藝座談之五〉, 《蕉風》第 29 期, 頁 3-5 - 20。

蕉風 1956 ，〈再談馬華文藝〉，《蕉風》第 22 期，頁 3-5。

蕉風 1956 ，〈漫談馬華文藝—文藝座談之一〉，《蕉風》第 20 期，頁 3-4。

蕉風 1955 ，〈讀者作者編者〉，《蕉風》第 4 期，頁 32 。

蕉風 1955 , 〈創刊詞：春風吹遍綠洲〉, 《蕉風》第 1 期, 頁 2 。

蕭遙天 1955 , 〈馬來亞的天氣〉, 《蕉風》第 4 期, 頁 7-11。

蕭遙天 1956 , 〈食風與沖涼〉, 《蕉風》第 5 期, 頁 19-20。

蕭遙天 1956，〈熱帶女兒〉，《蕉風》第 6 期，頁 18-21。

蕭遙天 1957 , 〈蕃茉莉與蕃拓榴〉, 〈第二個夢〉, 《蕉風》第 29 期, 頁 13 。 
謝冰瑩 1957 〈漫談文學批評〉，《蕉風》第 75 期，頁 4-5。

謝冰瑩 1958，〈寫作必經道路〉系列一至七，《學生周報》第 105-111 期，讀書樂版。

鍾怡雯 2009 , 〈遮蔽的抒情一論馬華詩歌的浪漫主義傳統〉, 載潘碧華編, 《馬華文學的現代詮

釋》，吉隆坡：馬來西亞華文作家協會，頁 151-178。

羅紫 1957 , 〈寶寶真累人〉, 《蕉風》第 52 期, 頁 $16-18$ 。

羅蘭巴特著, 懷宇譯 2010 , 〈關於羅伯-格里耶〉, 《文藝批評文集》, 北京：中國人民大學出版社，

頁 236-245。

蘇的亞蘇加馬(Rusman Sutiasumarga)著, 吕卓譯 1957, 〈布加西姑娘〉, 《蕉風》第 29 期, 頁 6-7。

蘇敏逸 2008 , 〈文學、政治與意識形態的多重敘述：中國三○年代左翼文藝理論及作品研究一以胡

風、馮雪峰、丁玲為中心〉，97 年度國科會結案報告 NSC 97-2410-H-006-080。

蘇燕婷 2006 , 〈跨出的步伐一從姚紫的小說看 1950 年代馬華「現代小說」〉, 《中文人》第 4 期, 加影：新纪元学院中文系, 頁 23-29。

鐵維英 1991 , 〈抗戰時期中國回族穆斯林在麥加的一段愛國鬥爭經歷〉, 《回族研究》 第 3 期, 頁 76-81。

三、檔案資料

《中國學生周報》1958, 中華民國 47 年 1 月 31 日, 第 289 期。「香港文學資料庫」網頁， http://hklit.lib.cuhk.edu.hk/pdf/journal/78/1958/177237.pdf

$\ulcorner$ 西安交通大學檔案館」網頁【《西安交通大學大事記 (1896 2000) 》抗戰勝利後的交通大學・1948 年】http://58.206.125.28/?p=4360

$\ulcorner$ 西安交通大學檔案館」網頁【《南洋公學一交通大學年譜》一1948 年一戊子年（民國三十七年）】 http://58.206.125.28/?p=4756 亦見路海江 2003 , 《張國濤傳記和年譜》, 北京：中共, 頁 $184 。$

新加坡國家檔案局 FCO 141/14394，1949，Singapore. Chinese Consular Representation in Singapore and

South East Asia after the Recognition of the Chinese Communist Government by the UK Government. 文件 編號 1177/41/49, 10 月 7 日。

新加坡國家檔案局 FCO 141/14536, Ag. Director of Special Branch Singapore to Secretary for Defence and Internal Security Singapore, Third Forces, Singapore: Special Branch, July 28, 1952.

新加坡國家檔案局 FCO 141/14536, Governor Hong Kong to Singapore, A Report on the State of "Third Forces" in Hong Kong as on the 10th September, Hong Kong: Special Branch, 1951.

新加坡國家檔案局 Record Reference 7/55. Public Relation Office(PRO), The Asia Foundation: A Statement of the Foundation's purposes and activities. 1954-1955. Singapore: Singapore National Archive reading room. 
新加坡國家檔案局 ROB 043, Record reference 27812： The Chinese Student Weekly (Malaya Office).

新加坡國家檔案局 ROB 048, Record reference 30700： Union Press Organisation.

馬來西亞檔案局（柔佛州分行）文件 P.A.J/KS 747，柔佛州宗教局檔案。

馬來西亞檔案局（柔佛州分行）SSJ 2048/52，1953，新山州秘書寄予新山總警察官的信件， 3 月 12 日。

馬來西亞檔案局 (柔佛州分行) PAJ 208/52, 柔佛州宗教局檔案, 題為「馬來亞吉隆坡電台戒嚴部要求 柔佛宗教司通過電台宣講以對抗馬共意識」(Radio Malaya Kuala Lumpur Bahagia Dharurat meminta tuan-tuan kampong , mufti johor bersyarah melalui radio melawan komunis)

馬來西亞檔案局 (柔佛州分行) P.A.J. 419/52, 柔佛州宗教局檔案, 題為「在華語源流社群裡擴展回教 影響以及為的依的華裔穆斯林設立特殊的地區」(Mengembangkan ugama Islam di dalam bahasa China and mengadakan satu kawasan untuk menempatkan orang china yang memeluk Islam)

Amconsul Hong Kong to Department of State 1962 Jul 24. "Hong Kong- Influnce of Hong Kong Publication in Southeast Asia."

Ching Pao 1961 December 28."United And Division In the Arab and Communist Bloc."

Division of Research for Far East 1956 April 27. "Reactions to Current Communist Tactics In Southeast Asia." Document No. 7243. p.1-5.

Sydney Liu, Jack Friedman 1962 July 11. "Memo of Conversation."

CSO 00128/49: "Forteenth Commissioner-General's Conference (Malaya-Borneo Territories): Establishment of Communist Chinese Consulates in British Territories in South East Asia."

CSO 00128/49: "From Officer Administering The Government to Secretary Of State (date 4.1.50)."

DTPILLAR, Jan 15, 1952. Database: The CIA Records Search Tool (CIA CREST). https://archive.org/details/DTPILLAR 